\title{
PROCESOS QUE REGULAN LA TRANSCRIPCIÓN EN EUCARIOTAS
}

\section{ALICIA GARCÍA MARTÍNEZ}

SALAMANCA 2012

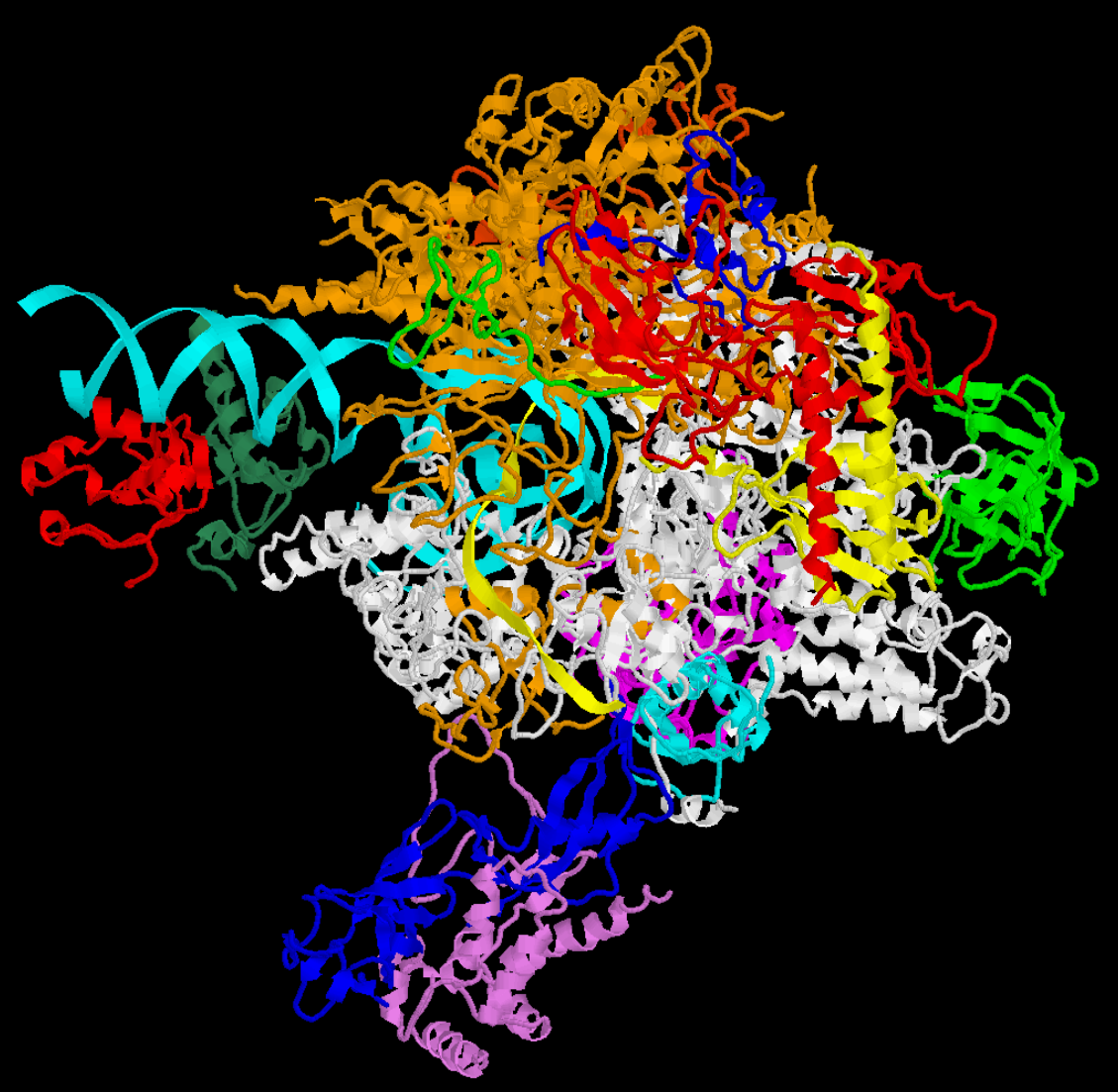

VNiVERSiDAD

DSALAMANCA
UNIVERSIDAD DE SALAMANCA

Departamento de Microbiología y Genética

Instituto de Biología Funcional y Genómica

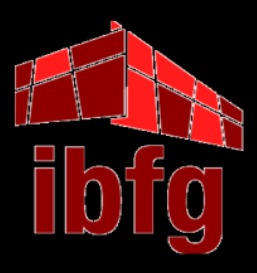




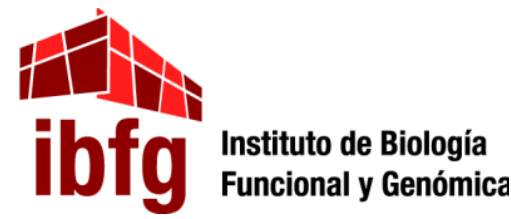

\section{DRA. OLGA MARÍA CALVO GARCÍA, CIENTÍFICO TITULAR DEL CONSEJO SUPERIOR DE INVESTIGACIONES CIENTÍFICAS,}

\section{CERTIFICA:}

Que la licenciada Alicia García Martínez ha realizado el trabajo titulado "Procesos que regulan la transcripción en eucariotas" bajo mi dirección, en el Instituto de Biología Funcional y Genómica (IBFG), centro mixto de la Universidad de Salamanca (Departamento de Microbiología y Genética) y del Consejo Superior de Investigaciones Científicas (CSIC), para optar al grado de Doctor en Biología.

Y para autorizar su presentación y evaluación por el tribunal correspondiente, expide el presente certificado en Salamanca, a 12 de Noviembre de 2012. 
DR. LUIS FERNÁNDEZ LAGO, PROFESOR TITULAR DE LA UNIVERSIDAD DE SALAMANCA y DIRECTOR del DEPARTAMENTO DE MICROBIOLOGÍA Y GENÉTICA de la UNIVERSIDAD DE SALAMANCA,

\section{CERTIFICA:}

Que la memoria titulada "Procesos que regulan la transcripción en eucariotas", presentada por la licenciada Alicia García Martínez para optar al grado de Doctor en Biología, ha sido realizada bajo la dirección de la Dra. Olga María Calvo García, en el Instituto de Biología Funcional y Genómica (IBFG), centro mixto de la Universidad de Salamanca (Departamento de Microbiología y Genética) y del Consejo Superior de Investigaciones Científicas (CSIC).

Y para autorizar su presentación y evaluación por el tribunal correspondiente, expide el presente certificado en Salamanca, a 12 de Noviembre de 2012.

Dr. Luis Fernández Lago 
DRA. MARÍA ÁNGELES SANTOS GARCÍA, PROFESORA TITULAR del DEPARTAMENTO DE MICROBIOLOGÍA Y GENÉTICA de la UNIVERSIDAD DE SALAMANCA,

\section{CERTIFICA:}

Que la memoria titulada "Procesos que regulan la transcripción en eucariotas", presentada por la licenciada Alicia García Martínez para optar al grado de Doctor en Biología, ha sido realizada bajo la dirección de la Dra. Olga María Calvo García, en el Instituto de Biología Funcional y Genómica (IBFG), centro mixto de la Universidad de Salamanca (Departamento de Microbiología y Genética) y del Consejo Superior de Investigaciones Científicas (CSIC).

Y para autorizar su presentación y evaluación por el tribunal correspondiente, expide el presente certificado en Salamanca, a 12 de Noviembre de 2012.

Dra. María Ángeles Santos García 
Esta tesis doctoral ha sido financiada por un contrato predoctoral del Programa de Ayudas para la Contratación del Personal Investigador de Reciente Titulación Universitaria (2008/2012) cofinanciado por la Junta de Castilla y León y el Fondo Social Europeo, y por proyectos del Plan Nacional de I+D y de la Junta de Castilla y León. 
Dedicado a la memoria de mis abuelos Jeremías y Ascensión, cuyo ejemplo y recuerdo me acompaña todos los días.

Salamanca, 2012 
La libertad no es un estado sino un proceso; sólo el que sabe es libre, y más libre el que más sabe. Sólo la cultura da libertad. No proclaméis la libertad de volar, sino dad alas; no la de pensar, sino dad pensamientos. La libertad que hay que dar al pueblo es la cultura. Sólo la imposición de la cultura lo hará dueño de sí mismo.

Miguel de Unamuno

Lucharé hasta mi último aliento y mi epitafio será "No estoy de acuerdo".

Joaquín Sabina 


\section{i. Agradecimientos}


Este es sin duda el momento más gratificante de estos cinco años, porque es cuando uno hace memoria y se da cuenta de cuantísima gente tiene a su alrededor a la que darle las gracias, y eso es ya todo un premio. Espero no olvidarme de nadie, y si es así ¡lo siento!

En primer lugar, y cómo no, me gustaría darle las gracias a Olga por un millón de razones... Por la oportunidad que me ha permitido comenzar a desarrollar una profesión que nunca pensé que me gustaría tanto, aunque me queje a todas horas. Por la confianza y por la disponibilidad para enseñarme. Por estar al otro lado casi 24 horas al día, 365 días al año. Por el ejemplo de luchadora incansable, y por haberme dejado ver esa "parte de la ciencia" que se suele ocultar a los que empezamos.

Gracias a María Gómez y Joana Sequeira por introducirme en el mundo de la realtime, que tanto me ha acompañado en estos años. A Sebastián Chávez, Alfonso Rodríguez y Gonzalo Millán por la ayuda con los ensayos GLAM y los experimentos de TRO. A Paco Navarro y sus chicas por la estupenda conexión Salamanca-Jaén.Y unas gracias generales a todo el IBFG, científicos y personal de apoyo, por hacer más fácil el trabajo.

Sin duda si a alguien le tengo que estar agradecida por algo en esta vida es a mis padres. No tanto por el apoyo incondicional que me han dado, sino por haberme dejado libertad para tomar mis propias decisiones, y haberlas respetado siempre. Sois lo mejor que tengo. Gracias a Irene porque, aun siendo la hermana pequeña, ha cuidado de mí durante estos cinco años, y algo me dice que lo va a seguir haciendo. A Juan, por haber entrenado la paciencia infinita en estos años (piensa que te he dado un súper-poder) y por el apoyo incondicional.

A todos los compañeros del IBFG que han contribuido y contribuyen al buen ambiente "becaril" y ayudan a la supervivencia pre y post-tesis. En especial a Sandrine Bonfils por ser mi amiga aquí y más allá de los Pirineos. A David Ontoso, por la ayuda prestada (extensible a todos los miembros y ex del grupo PSS, siempre dispuestos a echar una mano, Paco, Esther, Santi, Isa, gracias) y sobre todo por ser un buen amigo. A Rebeca Serrano, Laura Marín y José Sardina, por los buenos consejos. A Susana Velasco, por escuchar mis monólogos matutinos. A Dianis por esa "cadera latina". A Esther Cabañas por ser mi "media naranja”, gracias por TODO. A Ale Collin ¡Qué haría yo sin ti! Gracias por "ponerle onda" todos los días y por tu "optimismo demencial". 
Gracias por haber aguantado mis malos humores y perdón por no haber sido siempre la compañera que te merecías. A Raúl Alonso y Carlos Sacristán, por aguantar mi verborrea sobre todo estos últimos meses.

A mis amigas de "toda la vida". Gracias por "poneros debajo" para amortiguar los golpes. En especial, gracias a Lorena Hervada porque esta tesis es tan suya como mía. Sin nuestras reuniones semanales, y sin tu apoyo me hubiera rendido. No sé dónde me llevará la vida, pero espero que no sea muy lejos de ti. A Mada, Rosalía, Laura, Ana, Chus, Helena, Yeyus, Sara, Roci, y Raquel. Una reunión con todas vosotras equivale a una semana de sueño, y a dos cajas de complejos vitamínicos. Saber que estáis ahí lo hace todo más fácil.

Y finalmente, gracias a todos los que, aunque no os nombre, habéis contribuido al éxito de este trabajo. 
1. Introducción

1.1. Anatomía molecular de la RNAPII: Estructura y Función 2

1.1.1 Módulos estructurales centrales de la RNAPII 2

1.1.2 El tallo o stalk: un módulo estructural exclusivo de las RNAP de 3 arqueas y eucariotas

1.1.3 El dominio carboxi-terminal de la subunidad mayor de la RNAPII 4

1.2. Ciclo de transcripción de la RNAPII 4

1.2.1. Pre-iniciación: formación del PIC en el promotor 5

1.2.2 Iniciación de la transcripción: activación del PIC y escape del 6 promotor

1.2.3 Elongación: extensión del transcrito 6

1.2.3.1 Pausas de la RNAPII durante la elongación transcripcional $\quad 7$

1.2.4 Terminación: parada de la síntesis del transcrito y disociación de la 9 RNAPII

1.3. El complejo de elongación Spt4/5 10

1.4. La fosforilación de la RNAPII y la regulación de la expresión génica 13

$\begin{array}{ll}1.4 .1 \text { El código del CTD } & 14\end{array}$

1.4.2. Principales determinantes del código del CTD: la fosforilación de $\quad 16$ Ser 2,5 y 7

1.4.3. Otras dianas de fosforilación en el CTD: residuos de Tyr1 y Thr4 17

1.4.4 Moduladores de la fosforilación del CTD: CTD-quinasas y CTD- 18 fosfatasas

$\begin{array}{ll}\text { 1.4.4.1 CTD-quinasas } & 18\end{array}$

1.4.4.1.1. CTD-quinasas de pre-iniciación e iniciación $\quad 19$

1.4.4.1.2 CTD-quinasas de elongación 20

1.4.4.2 CTD-fosfatasas $\quad 22$

1.4.5 Modificaciones del CTD que afectan a su fosforilación 25

1.4.6 La fosforilación del CTD y el acoplamiento entre transcripción y 26 procesamiento

1.4.7 Acoplamiento entre el código del CTD y el código de las histonas $\quad 29$

1.4.8 Acoplamiento entre el código del CTD y el transporte del RNA 29

1.5. El factor de transcripción Sub1/PC4 30

1.5.1 Características generales del factor Sub1 $\quad 30$

1.5.2 Sub1 y la iniciación de la transcripción de la RNAPII 31

1.5.3 Sub1 y la terminación y procesamiento del extremo 3' del mRNA 32

1.5.4 Sub1 es un factor de transcripción ubicuo 32

1.5.5 Sub1 es un factor de reiniciación de la RNAPIII 33

1.5.6 Sub1 y la Fosforilación de la RNAPII $\quad 33$

2. Objetivos 34

3. Resultados 35

3.1. SUB1 regula negativamente a la CTD-quinasa de iniciación Kin28 35 
3.1.1 La deleción de SUB1 da lugar a un incremento en la actividad de Kin28

3.1.2 La deleción de $S U B 1$ conduce a un incremento en la asociación de Kin28 a los promotores génicos

3.1.3 La deleción de $S U B 1$ da lugar a un incremento de los niveles de polimerasa fosforilada en Ser5 asociada a las regiones 5' de los genes

3.1.4 La deleción de $S U B 1$ conduce a un ligero incremento de los niveles del complejo de capping

3.2. SUB1 regula positivamente a la CTD-quinasa Srb10 44

3.2.1 Interacción genética entre $S U B 1$ y $S R B 10$

3.2.2 La actividad quinasa de Srb10 se encuentra disminuida en el mutante $\quad 45$ subld

3.2.3 La deleción de SUB1 influye negativamente en la asociación de

Srb10 a los promotores

3.2.4 La deleción de $S R B 10$ da lugar a un incremento en la actividad quinasa de Kin28, consecuencia de un incremento en los niveles de la proteína y del transcrito

3.3. $S U B 1$ tiene un efecto negativo sobre la función de la quinasa Bur1

3.3.1 Interacción genética entre $S U B 1$ y BUR1 51

3.3.2 Actividad quinasa y asociación a los genes de Bur1 en el mutante 52 subld

3.3.2.1 La deleción de $S U B 1$ da lugar a un incremento en la actividad CTD-quinasa de Bur1

3.3.2.2 La deleción de $S U B 1$ afecta levemente a la asociación de Bur1 a los genes

3.4. SUB1 regula negativamente a la CTD-quinasa de elongación, Ctk1 56

3.4.1 Interacción genética entre $S U B 1$ y $C T K 1 \quad 56$

3.4.2 Actividad catalítica y asociación a los genes de Ctk1 en un mutante $\quad 57$ subld

3.4.2.1 La deleción de $S U B 1$ provoca un incremento en la actividad quinasa de Ctk1

3.4.2.2 La asociación de Ctk1 a los genes se encuentra incrementada en subla

3.5. Sub1 no se asocia a ningún complejo CTD-quinasa

3.6. La función de Sub1 no se relaciona con las CTD-fosfatasas de Ser5P 60

3.7. Interacciones genéticas específicas de alelo entre SUB1 y RPB1 61

3.8. Sub1 se asocia con la RNAPII vía el dímero disociable Rpb4/7 65

3.8.1 Purificación de complejos proteicos asociados a Sub1-TAP 65

3.8.2 Co-purificación de Sub1 con Rpb4/7 67

3.8.3. Interacción genética entre $S U B 1$ y RPB4 69

3.8.4. La deleción de $S U B 1$ no afecta al reclutamiento a la cromatina de $\quad 70$ $\mathrm{Rpb} 7$

3.8.5. Sub1 depende de Rpb4/7 para su reclutamiento a los genes 71

3.8.6. La RNAPII se encuentra hiperfosforilada en un mutante rpb4A $\quad 74$ 
3.9.1. Sub1 afecta a la eficiencia de la elongación de la transcripción de transcritos largos

3.9.2 Sub1 promueve la elongación de la transcripción y se asocia a las regiones codificantes de los genes

3.9.3 Sub1 influye en la asociación de Rpb1 a la cromatina durante la elongación de la transcripción

3.9.4 Sub1 influye en la tasa de elongación de la RNAPII

3.10. Sub1 regula la elongación de la transcripción a través de la interacción con el complejo Spt $4 / 5$

3.10.1 Interacción genética entre $S U B 1$ y el complejo $S P T 4 / 5$

3.10.2 La deleción de $S U B 1$ produce un incremento en la fosforilación de

Spt5, pero no afecta a su asociación con la cromatina

3.10.3 La deleción de SUB1 suprime el defecto en splicing de la mutación spt5-194

3.10.4 Sub1 y Spt5 forman parte del mismo complejo

3.10.5 Sub1 y Spt5 podrían coincidir asociados a las mismas regiones de la 104 cromatina durante la elongación temprana

3.10.6 La deleción de SUB1 afecta a la interacción entre Spt5-Rpb1 106

4. Discusión

4.1. Sub1 regula globalmente la fosforilación de la RNAPII 109

4.1.1 Efectos opuestos de Sub1 en la fosforilación del CTD 109

4.1.2 Sub1 influye en la fosforilación del CTD en los residuos de Ser5 y 113

Ser2 por distintas vías

4.1.3 ¿Cómo puede regular Sub1 la actividad y reclutamiento de todas las CTD-quinasas?

4.2.-Sub1 se asocia con Spt5 e influye en la tasa de elongación de la RNAPII

4.2.1 Sub1 afecta a la eficiencia de la elongación de la transcripción y a la tasa de elongación de la RNAPII

4.2.2. Para muestra un botón: Sub1 regula la iniciación y la elongación del gen IMD2

4.2.3. Sub1 está ligado funcionalmente al factor de elongación Spt5

4.2.4. ¿Cómo un componente del PIC puede ser a la vez un factor de elongación?

4.2.5. Sub1 funciona durante todo el ciclo de transcripción: un modelo de trabajo

5. Conclusiones

6. Materiales y Métodos 134

\begin{tabular}{ll} 
6.1. Cepas & 134 \\
\hline 6.11 Cepas de Saccharomyces cerevisiae & 134
\end{tabular}

6.1.1 Cepas de Saccharomyces cerevisiae 134

6.1.2 Cepas de Escherichia coli 134

6.2. Medios de cultivo 134

6.2.1 Medios de cultivo para levaduras $\quad 134$

$\begin{array}{ll}\text { 6.2.2 Medios de cultivo para bacterias } & 135\end{array}$ 
6.3. Condiciones de crecimiento

6.4. Técnicas Genéticas 136

6.4.1 Transformación de Saccharomyces cerevisiae 136

6.4.2 Modificación génica en levaduras 136

6.4.3 Conjugación, esporulación, y análisis de tétradas 137

6.4.4 Transformación de Escherichia coli 137

$\begin{array}{ll}\text { 6.5. Plásmidos } & 137\end{array}$

6.6. Métodos de manipulación y Análisis de Ácidos Nucleicos 138

$\begin{array}{ll}\text { 6.6.1 Aislamiento de DNA y RNA } & 138\end{array}$

6.6.1.1 Aislamiento de DNA plasmídico de E. coli 138

6.6.1.2 Aislamiento de DNA genómico de levadura 138

6.6.1.3 Aislamiento de RNA total de levadura 138

6.6.2 Electroforesis de ácidos nucleicos $\quad 139$

6.6.3 Reacción en cadena de la polimerasa (PCR) y transcripción reversa $\quad 140$ (RT)

$\begin{array}{ll}\text { 6.6.3.1 PCR } & 140\end{array}$

$\begin{array}{ll}\text { 6.6.3.2 PCR cuantitativa (qPCR) } & 140\end{array}$

6.6.3.3 Transcripción reversa o retrotranscripción (RT) 141

6.6.4 Marcaje in vivo de RNA naciente por RNA polimerasa II elongante 141

(Transcriptional run-on ó TRO)

6.6.4.1 Run-on y extracción de RNA 141

6.6.4.2 Hibridación, exposición y análisis 142

6.6.4.3 Fijación de sondas de DNA mediante slot blot 142

$\begin{array}{ll}\text { 6.7. Oligonucleótidos } & 143\end{array}$

6.8. Métodos de Manipulación y Análisis de Proteínas 143

6.8.1 Obtención de extractos proteicos y cuantificación de proteínas $\quad 143$

6.8.2 Inmunoprecipitaciones y co-inmunoprecipitaciones de proteínas $\quad 144$

6.8.3 Análisis por Western Blot 144

6.8.4 Purificación por afinidad en tándem o Purificación TAP 145

6.8.5 Inmunoprecipitación de cromatina o ChIP 146

6.8.5.1 Preparación y fijación del cultivo 146

6.8.5.2 Preparación del extracto celular y fragmentación del DNA 147

$\begin{array}{ll}\text { 6.8.5.3 Inmunoprecipitación } & 147\end{array}$

6.8.5.4 Procesamiento del INPUT y del PRECIPITADO 148

$\begin{array}{ll}\text { 6.8.6 Anticuerpos } & 148\end{array}$

6.8.7 Expresión de proteínas recombinantes desde Escherichia coli $\quad 148$

6.9. Ensayos de Actividades Enzimáticas 149

6.9.1 Ensayos de actividad quinasa in vitro 149

6.9.2 Ensayo de actividad fosfatasa ácida y cálculo de ratio GLAM 150

6.10. Antibióticos, Drogas, Inhibidores y Enzimas 150

6.10.1 Antibióticos 150

$\begin{array}{ll}\text { 6.10.2 Drogas e inhibidores } & 151\end{array}$ 
6.10.3 Enzimas y otros reactivos

Tablas

153

7. Bibliografía

161

8. Abreviaturas

198

9. Anexos 


\section{INTRODUCCIÓN}


La transcripción o biogénesis de RNA constituye la primera y la más regulada de las etapas de la expresión génica. Las enzimas que catalizan la síntesis de RNA a partir de un molde de DNA reciben el nombre de RNA polimerasas (RNAP). Mientras que en arqueobacterias y eubacterias una única enzima con actividad RNA polimerasa cataliza la síntesis de todos los tipos de RNA celulares, en eucariotas esta función la realizan varias RNA polimerasas nucleares especializadas en la transcripción de las diferentes clases de RNA (revisado por (Werner and Grohmann, 2011). Así, la RNAPI se encarga principalmente de la transcripción de los RNA ribosomales (rRNAs) 18S, 28S (25S en levaduras) y 5,8S; la RNAPII transcribe los RNA mensajeros (mRNAs) y algunos RNA de pequeño tamaño (snRNAs y snoRNAs); y la RNAPIII es la responsable de la síntesis del rRNA 5S, de los RNA de transferencia (tRNAs) y de algunos RNA pequeños. Además, en plantas existen otras dos RNAP nucleares, la RNAPIV y la RNAPV, que sintetizan pequeños RNAs de interferencia (siRNA) que regulan la metilación de las secuencias de DNA complementarias, participando en el silenciamiento génico (Haag and Pikaard, 2011). La estructura de todas las RNAP nucleares eucariotas se encuentra altamente conservada, de modo que algunas subunidades son comunes a todas las polimerasas y otras, aunque son específicas de cada polimerasa, comparten homología entre ellas e incluso, en algunos casos, con subunidades de la RNAP bacteriana. Este es el caso de las subunidades mayores, en las que se encuentran los centros catalíticos de las enzimas. No obstante, a pesar de la conservación y la homología, la subunidad mayor de la RNAPII, Rpb1, posee en exclusividad un dominio carboxilo terminal muy conservado denominado CTD. Dicho dominio está sujeto a numerosas modificaciones postraduccionales durante toda la transcripción, modificaciones que son de una extraordinaria importancia en la regulación de la expresión génica (revisado por (Heidemann et al., 2012).

Con el trabajo que se presenta a continuación, hemos contribuido al conocimiento de la regulación de la transcripción de la RNAPII eucariota mediada por el factor de transcripción Sub1. En concreto, hemos demostrado que Sub1 regula la fosforilación del CTD a lo largo de todo el ciclo de transcripción y que, además, podría funcionar como un factor de elongación de la trancripción. Para ello, hemos utilizado como organismo modelo la levadura Saccharomyces cerevisiae. Dado que es un microorganismo sencillo, de fácil manipulación y muy bien caracterizado, y sobre todo dada la alta conservación de la maquinaria de transcripción en todos los organismos eucariotas, $S$. cerevisiae se ha convertido en uno de los organismos modelo de estudio por excelencia para elucidar los complejos mecanismos moleculares que gobiernan la expresión génica. 


\subsection{Anatomía molecular de la RNAPII: Estructura y Función}

La RNAPII es un complejo enzimático formado por doce subunidades denominadas Rpb1-Rpb12 (Figura 1A), numeradas de mayor a menor peso molecular (Cramer et al., 2008; Young, 1991). Todas las subunidades, excepto Rpb4 y Rpb9, son esenciales para la viabilidad celular. Cuatro de ellas (Rpb1, Rpb2, Rpb3 y Rpb11) presentan homología de secuencia con las correspondientes subunidades de las RNAPI y III y cinco (Rpb5, Rpb6, Rpb8, Rpb10 y Rpb12) son compartidas con las RNAPI y III (Carles et al., 1991; Hampsey, 1998; Woychik et al., 1990; Young, 1991). Rpb4, Rpb7 y Rpb9, junto con el CTD de Rpb1, son exclusivas de la RNAPII. Además, las subunidades Rpb4 y Rpb7 constituyen un heterodímero, disociable del resto del complejo enzimático en levaduras (Cramer et al., 2001; Kwapisz et al., 2008a; RuprichRobert and Thuriaux, 2010). La estructura de la RNAPII se resolvió mediante cristalografía de rayos $\mathrm{X}$, inicialmente a partir de un cristal que contenía únicamente el núcleo del complejo (sin el dímero Rpb4/7) (Cramer et al., 2000, 2001; Gnatt et al., 2001) y posteriormente conteniendo las 12 subunidades (Armache et al., 2003, 2005; Bushnell and Kornberg, 2003). El conocimiento de la estructura de la polimerasa ha contribuido significativamente a la comprensión del mecanismo de transcripción (Cheung and Cramer, 2012).

\subsubsection{Módulos estructurales centrales de la RNAPII}

La RNAPII presenta una morfología que se asemeja a una pinza de cangrejo. Contiene cuatro módulos estructurales distintos, que pueden moverse de forma relativa unos respecto de los otros (Figura 1B; Cramer et al., 2000, 2001; Gnatt et al., 2001). Estos módulos son: el "núcleo" o core, donde reside el centro activo de la enzima; el módulo "mandíbula-lóbulo" o jaw-lobe que, junto con el módulo "plataforma" o shelf, contribuye a la entrada del DNA promotor al centro activo; y el módulo "cepo" o clamp que, a través de un cambio de conformación, pasa de un estado abierto, que permite el acceso del dsDNA al centro activo, a un estado cerrado, que posiciona el ssDNA en el centro activo. Esto facilita la separación del híbrido DNA-RNA en el extremo de la burbuja de transcripción, favoreciendo la procesividad durante la elongación (Cramer, 2002a, 2004; Cramer et al., 2000, 2001; Gnatt et al., 2001). 
A

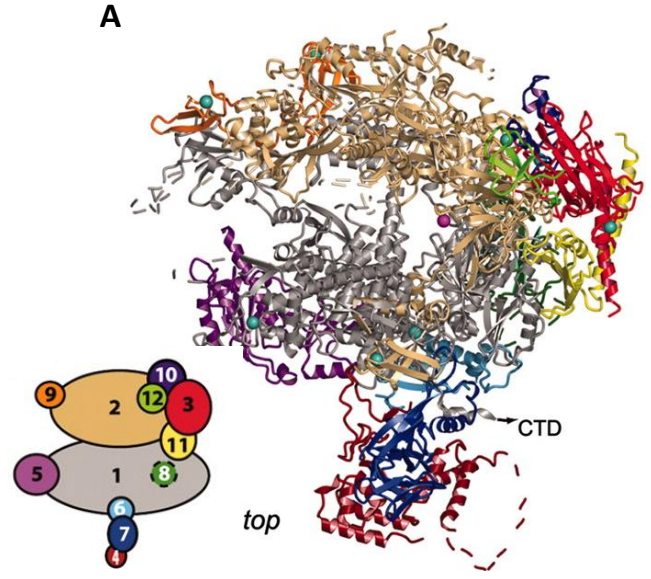

B

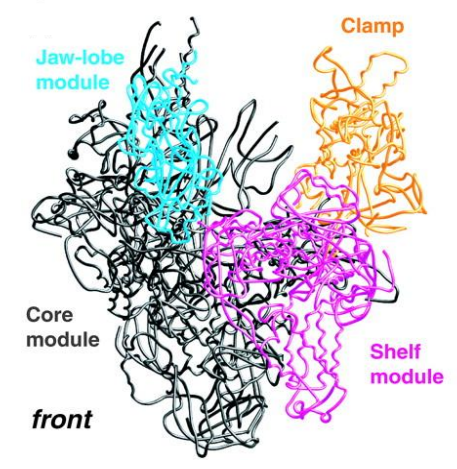

Figura 1. Estructura de la RNA polimerasa II completa: Rpb1-Rpb12. (A) Representación mediante diagrama de cintas de la estructura completa de la RNAPII. La imagen representa una vista superior (top). Las 12 subunidades están coloreadas siguiendo el patrón de colores del esquema situado a la izquierda. Las líneas discontinuas representan zonas de estructura desordenada. Imagen extraída de (Armache et al., 2005). (B) Núcleo de la RNAPII (10 subunidades, sin Rpb4/7). Los módulos core, jaw-lobe, shelf y clamp, se muestran en negro, azul, rosa y naranja, respectivamente. El módulo core está compuesto por las subunidades Rpb1 y Rpb2, entre las que se sitúa la "hendidura" o cleft con el centro activo, y las subunidades Rpb3, 10, 11 y 12, implicadas en el ensamblaje del complejo. El módulo jaw-lobe está formado por regiones de Rpb1 y Rpb9 que forman el dominio upper jaw y por el dominio lobe de Rpb2. El módulo shelf contiene los dominios lower jaw y assembly formado por regiones de Rpb5 y 6, regiones de Rpb1 pertenecientes al cleft y al dominio "pie" o foot. El módulo clamp está formado por las subunidades Rpb1 y 6 y por la región C-terminal de Rpb2. Imagen extraída de (Cramer et al., 2001).

\subsubsection{El tallo o stalk: un módulo estructural exclusivo de las RNAP de arqueas y eucariotas}

La RNAP de arqueas y todas las polimerasas eucariotas presentan un módulo estructural que no está conservado en eubacterias, el "tallo" o stalk (Werner and Grohmann, 2011). En el caso de la RNAPII, este módulo está constituido por las subunidades Rpb4 y Rpb7 que, juntas, forman un heterodímero capaz de disociarse del núcleo del complejo (Edwards et al., 1991). No obstante, in vivo se ha demostrado que la polimerasa asociada a lo largo de los genes durante la transcripción activa contiene las 12 subunidades (Jasiak et al., 2008; Verma-Gaur et al., 2008). La mayor parte del dímero Rpb4/7 se dispone en la estructura de la polimerasa fuera del core, sobresaliendo de la base del clamp con el que interacciona Rpb7 (Armache et al., 2005; Bushnell and Kornberg, 2003; Choder, 2004). La RNAPII sin un dímero Rpb4/7 asociado presenta defectos en iniciación de la transcripción in vitro (Edwards et al., 1991; Orlicky et al., 2001) y, además, fenotipos relacionados con problemas en la elongación in vivo (Verma-Gaur et al., 2008). El dímero Rpb4/7 participa también en procesos exonucleares relacionados con la regulación de la expresión génica. De hecho, existe un tránsito de dímeros Rpb4/7 que van y vienen del núcleo al citoplasma (Selitrennik et al., 
2006). Rpb7 posee dos dominios de unión a RNA, a través de los cuales puede asociarse al mensajero maduro y viajar con él al citoplasma donde se acumula en los cuerpos de procesamiento o P-bodies para, por un lado, estimular las dos rutas celulares de degradación de mensajeros (Lotan et al., 2005, 2007) y, por otro, asociarse a la maquinaria de iniciación de la traducción, estimulando la biosíntesis de proteínas (Harel-Sharvit et al., 2010). Por lo tanto, el dímero Rpb4/7 funciona como un auténtico coordinador del mRNA, participando a lo largo de todas las etapas de la vida del mensajero, desde la iniciación de la transcripción en el núcleo, hasta su degradación citoplasmática.

\subsubsection{El dominio carboxi-terminal de la subunidad mayor de la RNAPII}

La expresión génica en eucariotas está compuesta por múltiples eventos que se encuentran altamente coordinados, ligados y co-regulados en una compleja red de conexiones (por ejemplo, la transcripción y el procesamiento de los mRNAs (Maniatis and Reed, 2002; Proudfoot et al., 2002). El coordinador central de esta red es el dominio exclusivo de la subunidad mayor de la RNAPII, Rpb1, que se localiza en su extremo C-terminal, y que se conoce comúnmente como CTD (Figura 1A). El CTD está sometido a distintas modificaciones post-traduccionales durante todo el ciclo de transcripción, siendo la fosforilación la mejor conocida de todas ellas (Buratowski, 2009; Perales and Bentley, 2009; Phatnani and Greenleaf, 2006). El CTD se extiende desde el core de la RNAPII hasta las proximidades del canal de salida del RNA (Cramer et al., 2001), donde tiene una disposición ideal para regular el acceso de distintos factores de transcripción y procesamiento al transcrito naciente (Figura 1). El dominio CTD no interviene en la actividad catalítica de la RNAPII y aunque la transcripción in vitro puede llevarse a cabo con una polimerasa sin CTD, no así el procesamiento de los pre-mRNAs (Hirose and Manley, 2000; McCracken et al., 1997b). De hecho, el CTD es un dominio esencial para la viabilidad celular, así su deleción completa es letal en ratones, Drosophila y levaduras y truncaciones parciales en el mismo o mutaciones específicas de sitio causan defectos severos de crecimiento (Corden, 1990; McCracken et al., 1997b).

\subsection{Ciclo de transcripción de la RNAPII}

El ciclo de transcripción de la RNAPII se lleva a cabo en cuatro etapas distintas: pre-iniciación, iniciación, elongación y terminación (Shandilya and Roberts, 2012). 


\subsubsection{Pre-iniciación: formación del PIC en el promotor}

Una característica común a todas las RNAP eucariotas es su incapacidad para reconocer, por sí solas, la secuencia específica que determina el inicio de la transcripción. Por lo tanto, es necesaria la participación de otras proteínas para reclutar a la RNAPII a los promotores génicos y formar así un complejo competente (PIC) para iniciar la transcripción (Sikorski and Buratowski, 2009; Thomas and Chiang, 2006). Los componentes del PIC, además de reconocer las secuencias promotoras, reclutar y posicionar a la polimerasa en el promotor, son necesarios para la formación y estabilización de la burbuja de transcripción, para la selección del sitio de inicio de la transcripción (TSS) y para facilitar posteriormente la salida del promotor del complejo de transcripción. La formación del PIC normalmente comienza con la unión del factor general de la transcripción (GTF) TFIID a la caja TATA y/o a otros elementos consenso que se encuentran en la mayoría de los promotores eucariotas, seguido por la entrada del resto de GTFs y de la RNAPII. El ensamblaje de estos factores puede ocurrir de forma secuencial (Figura 2) o bien asociarse pre-ensamblados en el complejo conocido como holoenzima. La formación del PIC asociado al promotor es suficiente para que se lleve a cabo la transcripción basal in vitro; sin embargo, la transcripción dependiente de activadores in vivo requiere de la asociación de factores reguladores adicionales, como por ejemplo los coactivadores (revisado en (Thomas and Chiang, 2006).

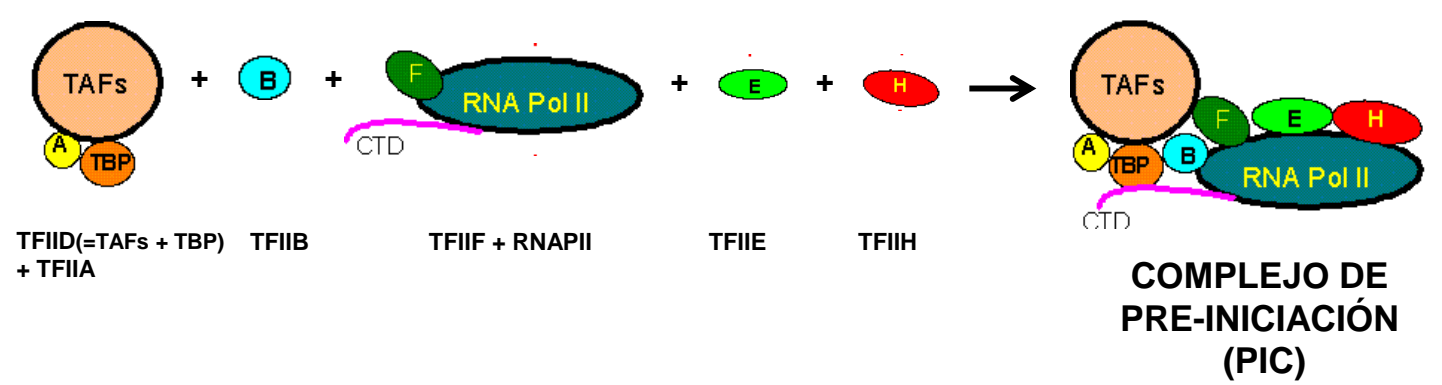

Figura 2. Formación del PIC. Representación esquemática, según el modelo de ensamblaje secuencial de los GTFs. El primer componente del PIC que se asocia al promotor es la proteína TBP, que será reclutada por el complejo SAGA o como integrante de TFIID, junto con las proteínas TAFs, dependiendo de las secuencias consenso presentes en el promotor del gen transcrito. Después se asocian TFIIA y TFIIB. TFIIA estabiliza la unión de TFIID al promotor e interacciona con activadores. Por su parte, la asociación de TFIIB determina la formación de un complejo ternario estable TBP-TFIIB-DNA. TFIIB participa en el reclutamiento de la RNAPII junto con TFIIF, además de ser necesario para la formación de la burbuja de transcripción y la selección del TSS. Tras la iniciación, TFIIB promueve el escape del promotor. Posteriormente, se ensambla en el complejo la RNAPII asociada al factor TFIIF que, a su vez, colabora con TFIIB en la formación del complejo abierto y en la selección del TSS. El siguiente factor reclutado es TFIIE que, gracias a su capacidad de unión a ssDNA, estabiliza la burbuja de transcripción, favoreciendo la transición iniciación-elongación. Por último, TFIIE recluta a TFIIH. Este factor es necesario para la formación de la burbuja de transcripción y para el acoplamiento entre la iniciación y el procesamiento del extremo 5' de los mRNAs. Revisado en (Thomas and Chiang, 2006). 


\subsubsection{Iniciación de la transcripción: activación del PIC y escape del promotor}

El PIC posicionado en el promotor es un complejo estable, pero inactivo, denominado complejo de transcripción cerrado. La transición del PIC del estado cerrado al abierto implica un cambio de conformación durante el cual el dsDNA del promotor accede al centro activo de la polimerasa a través del dominio cleft (Cramer et al., 2001; Wang et al., 1992). Gracias a la actividad ATPasa y helicasa del factor TFIIH, se produce la separación de las dos hebras del DNA unas $\sim 15$ pb alrededor del TSS, posicionándose la cadena molde en el centro activo (Dvir et al., 1997; Holstege et al., 1997; Wang et al., 1992; Yan and Gralla, 1997). La conformación cerrada del clamp, promovida por el dímero Rpb4/7, favorece la formación del enlace fosfodiéster entre los dos primeros NTPs (Armache et al., 2003; Bushnell and Kornberg, 2003). Durante la extensión inicial del RNA naciente, cuando la cadena consta solamente de 2-3 nt, puede producirse la terminación prematura, liberándose pequeños transcritos que serán degradados rápidamente. Este fenómeno se conoce como iniciación abortiva y, hasta el momento, solamente ha sido observado in vitro e in vivo en bacterias (Holstege et al., 1997; Liu et al., 2011; Luse and Jacob, 1987).

El escape del promotor supone que la polimerasa rompa sus contactos con la secuencia promotora, se desensamble de al menos algunos de los componentes del PIC, y establezca una unión más fuerte y estable con el RNA naciente. Así, cuando el transcrito alcanza una longitud de 8-9 nts, es lo suficientemente largo como para establecer contactos fuera del canal de salida del RNA que determinan la separación RNA-DNA molde y un cambio conformacional en la polimerasa, que pasará a contener un híbrido RNA-DNA estable en su centro activo (Westover et al., 2004). Además, la liberación del factor TFIIB produce el colapso de la burbuja de transcripción, de manera que se reanillan las dos hebras del DNA en su extremo aguas arriba, favoreciéndose así la salida de la polimerasa del promotor (Kostrewa et al., 2009; Pal et al., 2005), e iniciándose la elongación.

\subsubsection{Elongación: extensión del transcrito}

La elongación de la transcripción puede definirse como la etapa durante la cual la polimerasa extiende la cadena del transcrito naciente mientras atraviesa las regiones codificantes del DNA molde, tras haber iniciado su síntesis en el promotor. La polimerasa transcribiendo activamente posee dos cualidades muy importantes: una alta procesividad y una tasa de elongación constante, que se ven comprometidas con 
frecuencia durante la elongación y cuya garantía es imprescindible para la producción del transcrito maduro (Nechaev and Adelman, 2011). La procesividad puede definirse como la capacidad de la polimerasa para viajar a lo largo del gen molde sin disociarse, mientras que la tasa de elongación puede considerarse como la velocidad a la que la polimerasa viaja a lo largo del gen transcrito (Mason and Struhl, 2005). Aunque menos estudiada que la fase de iniciación, en los últimos años se han realizado muchos avances en el conocimiento de los mecanismos que regulan la elongación y en el descubrimiento de numerosos factores que directa o indirectamente favorecen la misma (Brannan and Bentley, 2012; Selth et al., 2010; Zhou et al., 2012). En la Tabla 1 se describen algunos de ellos. De todos estos factores, merece especial mención Spt5, del que hablaremos más adelante en detalle.

\begin{tabular}{|c|c|c|}
\hline FACTOR & ACTIVIDADES & REFERENCIAS \\
\hline $\begin{array}{l}\text { DSIF } \\
(\text { Spt } 4 / 5)\end{array}$ & $\begin{array}{l}\text { Evolutivamente conservado de bacterias a } \\
\text { eucariotas. Colabora en el establecimiento de la } \\
\text { pausa, junto con NELF, en eucariotas superiores. } \\
\text { Contribuye a la procesividad de la RNAPII. }\end{array}$ & $\begin{array}{l}\text { (Martinez-Rucobo } \text { et al., 2011; } \\
\text { Mayer } \text { et al., 2010; Peterlin and } \\
\text { Price, 2006; Venters } \text { et al., 2011; } \\
\text { Yamada } \text { et al., 2006) }\end{array}$ \\
\hline NELF & $\begin{array}{l}\text { Exclusivo de humanos y Drosophila. } \\
\text { Participa en el establecimiento de la pausa. }\end{array}$ & $\begin{array}{l}\text { (Narita et al., 2003; Renner et al., } \\
\text { 2001; Yamaguchi } \text { et al., 2002) }\end{array}$ \\
\hline $\begin{array}{l}\text { TFIIS } \\
\text { (Dst1) }\end{array}$ & $\begin{array}{l}\text { Principal factor regulador del backtracking de la } \\
\text { RNAPII. Estimula su actividad endonucleasa y } \\
\text { favorece la procesividad. }\end{array}$ & $\begin{array}{l}\text { (Awrey et al., 1997; Fish and Kane, } \\
\text { 2002; Izban and Luse, 1992; } \\
\text { Komissarova and Kashlev, 1997) }\end{array}$ \\
\hline PAF & $\begin{array}{l}\text { Favorece una conformación accessible de la } \\
\text { cromatina al complejo de elongación, actuando } \\
\text { como plataforma para el reclutamiento de } \\
\text { modificadores epigenéticos. }\end{array}$ & $\begin{array}{l}\text { (Jaehning, 2010; Kim and } \\
\text { Buratowski, 2009; Laribee et al., } \\
\text { 2005; Wood et al., 2003; Xiao et } \\
\text { al., 2005; Zhu et al., 2005) }\end{array}$ \\
\hline FACT & $\begin{array}{l}\text { Remodelador de la cromatina. } \\
\text { Contribuye a la procesividad facilitando el } \\
\text { ensamblaje/desensamblaje de los nucleosomas } \\
\text { durante la transcripción. }\end{array}$ & $\begin{array}{l}\text { (Jimeno-Gonzalez et al., 2006; } \\
\text { Kaplan et al., 2003; Mason and } \\
\text { Struhl, 2003; Orphanides et al., } \\
\text { 1998; Orphanides et al., 1999) }\end{array}$ \\
\hline Spt6 & $\begin{array}{l}\text { Remodelador de la cromatina. } \\
\text { Se asocia a la histona } \mathrm{H} 3 \text {, es capaz de ensamblar } \\
\text { nucleosomas in vitro, y su mutación altera la } \\
\text { estructura de la cromatina in vivo. }\end{array}$ & $\begin{array}{c}\text { (Bortvin and Winston, 1996; } \\
\text { Kaplan } \text { et al., 2003; Swanson and } \\
\text { Winston, 1992; Winston } \text { et al., } \\
\text { 1984) }\end{array}$ \\
\hline Ccr4-Not & $\begin{array}{l}\text { Favorece la activación de una polimerasa pausada } \\
\text { contribuyendo a la resolución de un estado de } \\
\text { backtracking. }\end{array}$ & (Kruk et al., 2011) \\
\hline
\end{tabular}

Tabla 1. Factores de elongación. Se listan algunos de los más conocidos y estudiados hasta el momento.

\subsubsection{Pausas de la RNAPII durante la elongación transcripcional}

La elongación es un proceso discontinuo, en el que el complejo de transcripción sufre etapas de pausa seguidas de pequeños avances (Darzacq et al., 2007). De hecho, la polimerasa elongante tiene que superar numerosos obstáculos a lo largo de las regiones 
codificantes génicas. Las pausas de la polimerasa pueden estar determinadas por diversas causas como son: (1) la propia estructura de la cromatina, esto es, el posicionamiento de los nucleosomas, que actúa como una barrera física al paso del complejo de transcripción (Fish and Kane, 2002); (2) una baja disponibilidad de nucleótidos, por ejemplo, como consecuencia de tratamiento con drogas que disminuyen la concentración intracelular de nucleótidos, como el 6-azauracilo (6AU) y el micofenolato (MPA) (Mason and Struhl, 2005; Powell and Reines, 1996); (3) superenrrollamientos causados por tensiones topológicas en el DNA durante la elongación (Brill and Sternglanz, 1988; Joshi et al., 2012); (4) lesiones en el DNA molde (Daulny and Tansey, 2009); y (5) secuencias ricas en AT en la cadena molde que debilitan las interacciones RNA-DNA en el centro activo de la enzima (GomezHerreros et al., 2012; Komissarova and Kashlev, 1997; Landick, 2006). Todas estas pausas se deben resolver durante el ciclo transcripcional y para ello recurren a distintos mecanismos que implican numerosos factores (algunos descritos en la tabla 1). Así, según su resolución, las pausas se han clasificado en tres grandes grupos: aquellas que implican backtracking (A), las que no implican backtracking (B) y las que conllevan la ubiquitinación y posterior degradación de la RNAPII (C).

(A) En el fenómeno del backtracking, la presencia de un híbrido RNA-DNA inestable en el centro activo de la polimerasa implica un movimiento de deslizamiento retrógrado de la misma sobre el molde, hasta alcanzar una región del DNA termodinámicamente estable. Como consecuencia, el extremo 3'-OH del transcrito naciente queda fuera del sitio catalítico (Komissarova and Kashlev, 1997). La propia actividad endonucleasa intrínseca de la polimerasa, estimulada por el factor TFIIS resuelve esta situación, cortando el RNA y generando un extremo 3'-OH nuevo (Awrey et al., 1997; Fish and Kane, 2002; Izban and Luse, 1992; Mason and Struhl, 2005).

(B) Las pausas que no implican backtracking se han descrito en bacterias (Artsimovitch and Landick, 2000; Wang et al., 1995). En éstas, durante la elongación puede producirse un cambio conformacional en el centro activo de la polimerasa. Dicho cambio determina el bloqueo del ciclo de adición de NTPs (Kireeva and Kashlev, 2009) y la formación de horquillas en el RNA naciente, estimulando la parada del complejo (Chan and Landick, 1993). En eucariotas, durante la transcripción del genoma del virus HIV-1, el RNA naciente también forma estructuras secundarias que han sido 
relacionadas con el establecimiento de la pausa (Palangat and Landick, 2001; Palangat et al., 1998).

(C) Si durante la transcripción se produce una lesión en la cadena de DNA molde, esto causa la parada de la polimerasa y un bloqueo transcripcional, activando los mecanismos de TCR ( Transcription Coupled Repair) para reparar la lesión. Si ésta es irreversible, se lleva a cabo la ubiquitinación y posterior proteólisis de la subunidad mayor de la polimerasa, Rpb1 (Somesh et al., 2005, 2007; Svejstrup, 2003; Woudstra et $a l ., 2002)$, con el objetivo de que una posterior iniciación restablezca la transcripción del gen correspondiente (Svejstrup, 2007).

\subsubsection{Terminación: parada de la síntesis del transcrito y disociación de la RNAPII.}

La terminación tiene lugar cuando la RNAPII cesa la síntesis del RNA y ambos, polimerasa y RNA naciente, se disocian del DNA molde. Se trata de un proceso dinámico, no limitado a las secuencias 3 'de los genes, ya que puede tener lugar a lo largo de toda la ORF (Kuehner et al., 2011). Dos vías de terminación han sido descritas, una para la mayoría de los genes codificantes de proteínas y acoplada a la poliadenilación (Proudfoot et al., 2002) y otra, para los snRNAS y los snoRNAs, cuyo extremo 3' se genera por corte endonucleolítico y/o exonucleolítico y carece de cola poli(A). Esta vía es dependiente de la helicasa Sen1 y, en S. cerevisiae, separa el híbrido RNA-DNA en el centro activo, facilitando la disociación de la polimerasa (Steinmetz and Brow, 1996). Sen1 participa también en la terminación de la transcripción de los llamados trancritos crípticos (CUTs, Cryptic Unstable Transcripts) (Arigo et al., 2006; Thiebaut et al., 2006) y en la resolución de estructuras secundarias en el RNA, R-loops, que se forman durante la transcripción y que son fuente de inestabilidad genómica (Mischo et al., 2011).

El reclutamiento coordinado de la maquinaria de transcripción a los promotores para formar el PIC ha sido la etapa de la transcripción más estudiada y, además, durante mucho tiempo se ha considerado como el paso limitante en la regulación de todo el proceso. Sin embargo, recientes investigaciones han puesto de manifiesto que la fase de elongación, y en menor medida la terminación, se encuentran también altamente reguladas en células eucariotas y estrictamente coordinadas con otros procesos nucleares. De hecho, durante la elongación, se reclutan al complejo de transcripción, además de factores de elongación basales como el complejo Spt4/5, numerosos factores 
implicados en el procesamiento del mRNA, en el remodelamiento y modificación de la cromatina y en el transporte del mRNA, entre otros procesos (Saunders et al., 2006; Selth et al., 2010; Shilatifard et al., 2003). A su vez, todas las etapas de ciclo de transcripción se encuentran estrictamente coordinadas con el procesamiento de los transcritos (capping, splicing y poliadenilación). La regulación y coordinación de la transcripción con el procesamiento y de estos eventos con otros procesos nucleares, se realiza a través del dominio CTD de Rpb1 (Hsin and Manley, 2012). Del complejo de elongación Spt4/5 y de la fosforilación del CTD, hablaremos a continuación en más detalle, dado el propósito del trabajo que se presenta.

\subsection{El complejo de elongación Spt4/5}

Desde que la polimerasa abandona el promotor, hasta que se encuentra transcribiendo activamente a una tasa más o menos constante, sufre un período de transición durante el cual el complejo de elongación, denominado temprano, no es completamente estable y tiende a realizar pausas (Darzacq et al., 2007). El fenómeno de la pausa de la polimerasa se describió inicialmente en Drosophila melanogaster. En este organismo, en genes de respuesta a choque térmico, como HSP70, y en condiciones de no inducción, la polimerasa que ha iniciado la transcripción se para, quedándose en estado inactivo y acumulándose en regiones 5' próximas al TSS. Estas polimerasas se reactivan rápidamente tras la inducción de la expresión (Gilmour and Lis, 1986; Lis, 1998; Rougvie and Lis, 1988). Una situación similar fue descrita posteriormente en células de ratón, para genes de inducción rápida, como c-fos (Collart et al., 1991; Coulon et al., 1999). En S. cerevisiae la transición iniciación-elongación es más rápida que en eucariotas superiores, aunque también se han observado ejemplos de genes inactivos con polimerasa pausada en 5', especialmente durante el crecimiento en fase estacionaria (Kuras and Struhl, 1999; Martens et al., 2001; Radonjic et al., 2005).

Para el establecimiento de la pausa de la polimerasa es necesaria la acción de factores reguladores negativos, como son los complejos humanos DSIF (Spt4/5 en levaduras) y NELF (no conservado en levaduras). Los dos complejos se aislaron como promotores de la represión transcripcional in vitro en presencia del inhibidor de la elongación DRB. In vivo, ambos interaccionan entre sí y con la RNAPII, cooperando en el mantenimiento de la pausa en eucariotas superiores (Wada et al., 1998a; Yamaguchi et al., 1999). En concreto, NELF, un complejo exclusivo de humanos y Drosophila, se une al RNA naciente y a la propia polimerasa, incrementando su tendencia a pausarse y 
aumentando el tiempo de las pausas (Narita et al., 2003; Renner et al., 2001; Yamaguchi et al., 2002). La fosforilación de NELF por la quinasa Cdk9 promueve su disociación y favorece la salida de la pausa de la polimerasa (Fujinaga et al., 2004).

Por su parte, el complejo DSIF posee una naturaleza dual ya que, por un lado, colabora en la represión y establecimiento de la pausa, junto con el complejo NELF en eucariotas superiores, pero, además, tras la restauración post-pausa de la actividad de la polimerasa, viaja con el complejo de transcripción, promoviendo su procesividad (Peterlin and Price, 2006; Yamada et al., 2006). En levaduras, se ha demostrado que el complejo homólogo de DSIF, Spt4/5, es un componente general y esencial del complejo de elongación de la RNAPII (Mayer et al., 2010; Venters et al., 2011) que, además, regula la transcripción de la RNAPI (Schneider et al., 2006; Viktorovskaya et al., 2011). Spt5 interacciona con la maquinaria de capping tanto en levaduras (Pei and Shuman, 2002), como en humanos, cuya asociación al complejo de transcripción es coincidente con la pausa de la polimerasa (Wen and Shatkin, 1999). De este modo, la pausa de la polimerasa puede considerarse un verdadero punto de control o checkpoint, que garantiza el correcto procesamiento del extremo 5' del transcrito. Además, se ha propuesto que el capping puede ser un evento determinante para la salida de la pausa (Glover-Cutter et al., 2008; Pei and Shuman, 2002).

El complejo de elongación Spt4/5 es un complejo heterodimérico, tanto en eucariotas como en arqueas, y está constituido por dos subunidades: Spt4 y Spt5 (Figura 3A). En bacterias, sin embargo es un monómero, consistente en la proteína NusG, homóloga de Spt5. En levaduras, SPT5 es esencial para la viabilidad celular, pero no así SPT4 (Hartzog et al., 1998; Malone et al., 1993; Swanson et al., 1991; Swanson and Winston, 1992). Estructuralmente, el factor Spt5-NusG está formado por un dominio NGN muy conservado, a través del cual la proteína interacciona con la polimerasa y con la subunidad Spt4 en arqueas y eucariotas y por un número variable de dominios de unión a RNA tipo KOW (1 en bacterias y arqueas; 5-6 en eucariotas). La proteína de eucariotas es más compleja y posee además un dominio ácido $\mathrm{N}$-terminal y un dominio C-terminal formado por varias repeticiones de una secuencia consenso (en S. cerevisiae, 15 repeticiones del consenso S[T/A]WGG[A/Q]) (Ponting, 2002; Steiner et al., 2002; Swanson et al., 1991). 


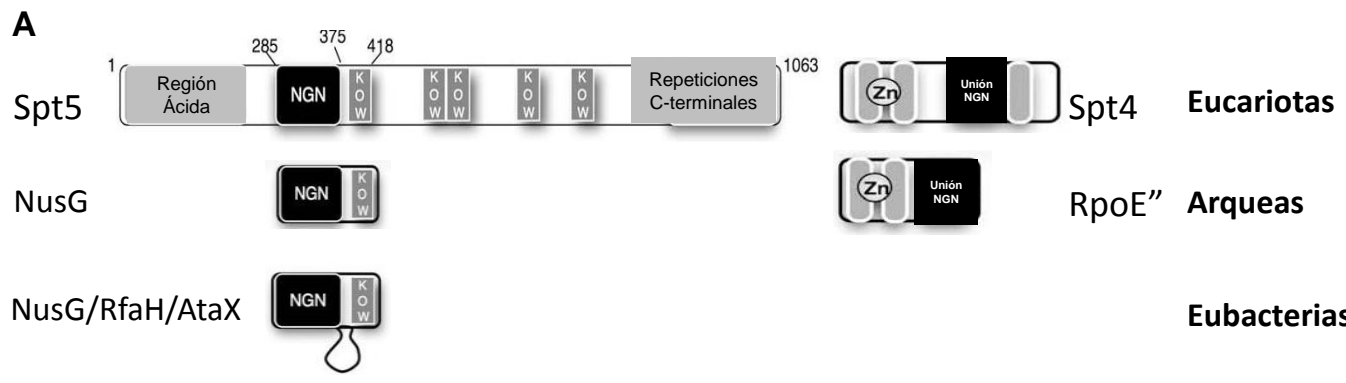

B
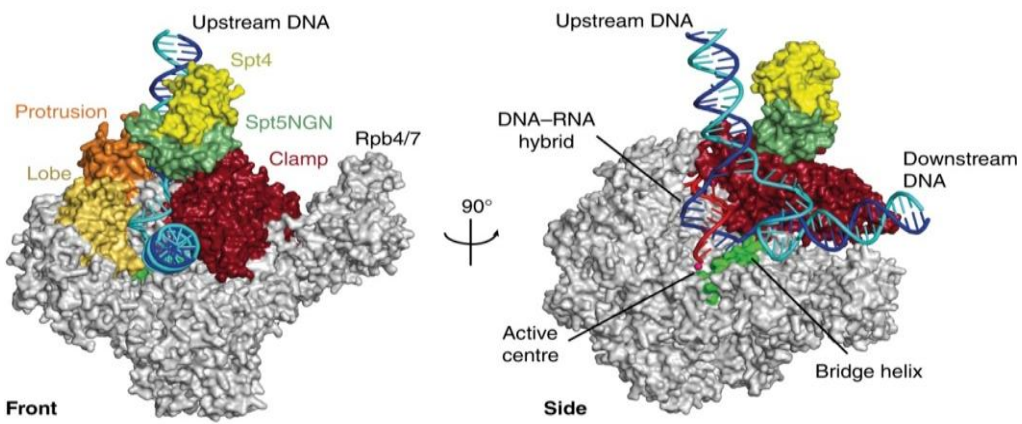

Figura 3. El complejo de elongación Spt4/5. (A) Mapa lineal de los complejos Spt4/5 de eucariotas y NusG/RpoE" de arqueobacterias, y del factor NusG de eubacterias. Aparecen representados los motivos conservados. Para el caso de Spt5, una región rica en aminoácidos ácidos N-terminal, el dominio NGN de interacción con Rpb1 y Spt4, los dominios KOW de interacción con ácidos nucleicos y el dominio Cterminal. Para los factores NusG bacteriano, el dominio NGN y el dominio KOW; y para Spt4 y RpoE" el dominio de unión a NGN. Los números sobre el dominio NGN de Spt5 indican la posición en la secuencia de aminoácidos. Modificado desde (Guo et al., 2008). (B) Modelo estructural del complejo RNAPII-Spt4/5. El modelo muestra la posición de Spt4/5 en el complejo de elongación: los ácidos nucleicos, en concreto, el híbrido DNA-RNA y las cadenas de DNA que forman la burbuja de transcripción, se encuentran en el centro activo de la polimerasa. El complejo Spt $4 / 5$ mantiene separados el DNA aguas arriba y el DNA aguas abajo de la burbuja, gracias a la interacción de Spt5 con el dsDNA aguas arriba y con la cadena no-molde. Spt5 aparece representado en verde, Spt 4 en amarillo, el dominio clamp de la RNAPII, con el que interacciona Spt5, en rojo oscuro y el resto de la polimerasa en gris. La cadena no molde del DNA se muestra en azul claro, la cadena molde en azul oscuro y el RNA en color rojo claro. Imagen extraída de (Martinez-Rucobo et al., 2011).

Spt5-NusG se asocia al complejo de elongación, interaccionando con el módulo clamp de la RNAPII (Figura 3B). A través del dominio NGN se une a la cadena no molde del DNA y también a una región de DNA dúplex adyacente a la formación de la burbuja de transcripción. Gracias a esta disposición espacial, Spt5-NusG garantiza la procesividad de la polimerasa, al ayudar a mantener al híbrido RNA-DNA estable en el centro activo, evitando la disociación del RNA y el reanillamiento de las dos cadenas del DNA (Klein et al., 2011; Martinez-Rucobo et al., 2011). Por otro lado, el/los dominio/s KOW podría/n actuar como una plataforma para la interacción con múltiples factores reguladores y con el transcrito naciente fuera de la polimerasa, incrementando así la estabilidad del complejo (Klein et al., 2011; Martinez-Rucobo et al., 2011; Missra and Gilmour, 2010; Steiner et al., 2002). Por su parte, la subunidad Spt4 no interacciona directamente con la polimerasa, pero estabiliza la unión de Spt5 (Guo et al., 2008). 
La función de Spt5 se regula mediante la fosforilación de su dominio C-terminal por una quinasa tipo CDK (Cdk9 en humanos; Bur1 en S. cerevisiae). En metazoos, cuando Spt5 se encuentra no fosforilada tiene función negativa, promotora de la pausa, mientras que cuando está fosforilada favorece la procesividad de la polimerasa (Wada et al., 1998b; Yamada et al., 2006; Yamaguchi et al., 1999). Además, en levaduras se ha descrito que la fosforilación de Spt5 estimula el reclutamiento del complejo de

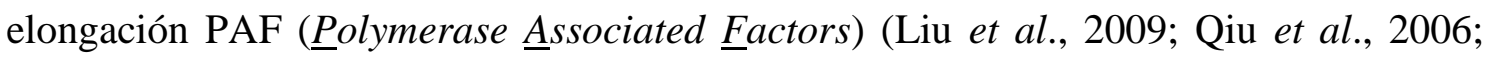
Zhou et al., 2009). Éste, a su vez, regula modificaciones epigenéticas en las histonas, que son marca de una conformación accesible de la cromatina para el complejo de transcripción (Jaehning, 2010). Así, el complejo PAF sirve de plataforma para el reclutamiento de las enzimas Rad6/Bre1 que ubiquitinan a la histona H2B (Kim et al., 2009a; Laribee et al., 2005; Wood et al., 2003; Xiao et al., 2005; Zhu et al., 2005). Esta modificación es necesaria para la asociación del complejo COMPASS (Chu et al., 2007; Krogan et al., 2003a; Ng et al., 2003) que, a través de la subunidad metil-transferasa Set1, media la metilación de la histona 3 en la lisina en posición 4 (meH3K4) en las regiones 5' de los genes activos (Shilatifard, 2008). Asimismo, esta marca facilita el reclutamiento de un complejo histona deacetilasa, que promueve la elongación e inhibe la transcripción críptica (Chu et al., 2007; Kim and Buratowski, 2009). Por otro lado, el complejo PAF estimula el reclutamiento de la enzima metil-transferasa Set2 (Kizer et al., 2005; Krogan et al., 2003b; Xiao et al., 2003), que metila la lisina 36 de la histona 3 (meH3K36), marca que se acumula en las regiones codificantes de los genes activos (Li et al., 2007).

Por lo tanto, Spt5 facilita la procesividad de la RNAPII por dos vías distintas: (1) mediante interacción directa con la polimerasa, estabilizando la burbuja de transcripción en el centro activo y (2) favoreciendo una conformación de la cromatina accesible durante la transcripción.

\subsection{La fosforilación de la RNAPII y la regulación de la expresión génica.}

El CTD de la subunidad mayor de la RNAPII, Rpb1, es un dominio muy conservado en la evolución y está compuesto por repeticiones en tándem del heptapéptido consenso: Tyr1-Ser2-Pro3-Thr4-Ser5-Pro6-Ser7 $\left(\mathrm{Y}_{1} \mathrm{~S}_{2} \mathrm{P}_{3} \mathrm{~T}_{4} \mathrm{~S}_{5} \mathrm{P}_{6} \mathrm{~S}_{7}\right)$, que varían en número según las especies (Allison et al., 1985; Corden et al., 1985; Cramer, 
2002a, b). Se ha propuesto que la estructura del CTD podría haberse originado a través de amplificaciones de una secuencia de DNA repetitivo y que el número de repeticiones incrementa en relación al incremento de la complejidad genómica de las especies (Chapman et al., 2008). Así, el CTD de ratón y humanos consta de 52 repeticiones (Figura 4B; (Corden et al., 1985; Prelich, 2002; Wintzerith et al., 1992), el de Drosophila de 45 (Allison et al., 1988), el de S. cerevisiae tiene 25-27 repeticiones (Figura 5B) (Allison et al., 1985) y el CTD de protozoos, 15 (Corden, 1990; Chapman et al., 2008).

A

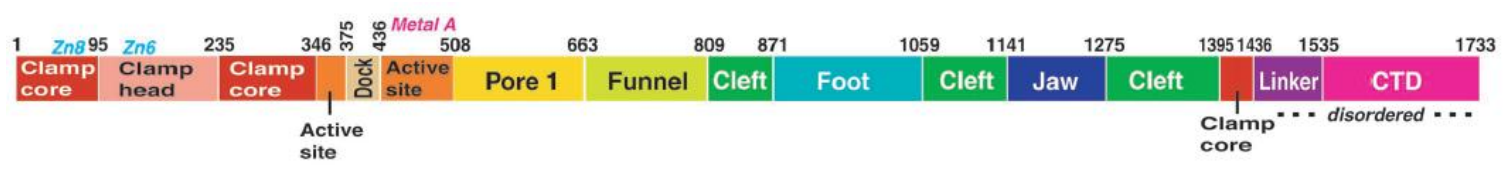

B

\begin{tabular}{ll} 
& \multicolumn{1}{c}{ CTD hum } \\
1 & YSPTSPA \\
2 & YEPRSPGG \\
3 & YTPQSPS \\
4 & YSPTSPS \\
5 & YSPTSPS \\
6 & YSPTSPN \\
7 & YSPTSPS \\
8 & YSPTSPS \\
9 & YSPTSPS \\
10 & YSPTSPS \\
11 & YSPTSPS \\
12 & YSPTSPS \\
13 & YSPTSPS \\
14 & YSPTSPS \\
15 & YSPTSPS \\
16 & YSPTSPS \\
17 & YSPTSPS \\
18 & YSPTSPS \\
19 & YSPTSPS \\
20 & YSPTSPS \\
21 & YSPTSPS \\
22 & YSPTSPN \\
23 & YSPTSPN \\
24 & YTPTSPS \\
25 & YSPTSPS \\
26 & YSPTSPN \\
27 & YTPTSPN \\
& \\
&
\end{tabular}

\section{CTD de \\ Saccharomyces cerevisiae}

28 YSPTSPS

29 YSPTSPS

30 YSPTSPS

31 YSPSSPR

32 YTPQSPT

33 YTPSSPS

34 YSPSSPS

35 YSPTSPK

36 YTPTSPS

37 YSPSSPE

38 YTPTSPK

39 YSPTSPK

40 YSPTSPK

41 YSPTSPT

42 YSPTTPK

43 YSPTSPT

44 YSPTSPV

45 YTPTSPK

46 YSPTSPT

47 YSPTSPK

48 YSPTSPT

49 YSPTSPKGST

50 YSPTSPG

51 YSPTSPT

52 YSLTSPAISPDDSDEEN
YSPTSPA

YSPTSPS

YSPTSPS

YSPTSPS

YSPTSPS

YSPTSPS

YSPTSPS

YSPTSPS

YSPTSPS

YSPTSPS

YSPTSPS

YSPTSPS

YSPTSPS

YSPTSPS

YSPTSPS

YSPTSPA

YSPTSPS

8 YSPTSPS

9 YSPTSPS

0 YSPTSPS

1 YSPTSPN

2 YSPTSPS

YSPTSPG

YSPGSPA

5 YSPKQDEQKHNENENSR

\footnotetext{
Heptapéptido conservado: $\quad \mathbf{Y}_{1} \mathbf{S}_{2} \mathbf{P}_{3} \mathbf{T}_{4} \mathbf{S}_{5} \mathbf{P}_{6} \mathbf{S}_{7}$

Principales sitios de fosforilación: $\mathrm{Y}_{1} \mathrm{~S}_{2} \mathrm{P}_{3} \mathrm{~T}_{4} \mathrm{~S}_{5} \mathrm{P}_{6} \mathrm{~S}_{7}$
}

Figura 4. La subunidad mayor de RNAPII, Rpb1, y su dominio C-terminal. (A) Representación lineal de la estructura de Rpb1. Se indican los distintos dominios y los residuos de aminoácidos correspondientes a los límites entre dominios. Imagen extraída de (Cramer et al., 2001). (B) CTD humano y CTD de S. cerevisiae. Imagen modificada desde (Calvo and Garcia, 2012).

\subsubsection{El código del CTD}

Los primeros estudios de biología molecular realizados sobre la fosforilación de la RNAPII permitieron distinguir dos formas distintas, en base a la diferente movilidad de Rpb1 cuando se sometía a electroforesis en geles SDS-PAGE: la RNAPIIA, forma 
hipofosforilada y la RNAPIIO, forma hiperfosforilada (Schwartz and Roeder, 1975). Ambas formas son funcionalmente distintas: la RNAPIIA se asocia preferentemente a los promotores génicos y a los complejos de preiniciación; mientras que la RNAPIIO funciona durante la elongación y su defosforilación es necesaria para la reiniciación de una nueva ronda de transcripción (Cadena and Dahmus, 1987; Lu et al., 1991; Zhang and Corden, 1991). A lo largo de los últimos años se ha demostrado que este modelo es demasiado simple. Diferentes formas fosforiladas de la polimerasa son específicas y características de los distintos pasos que componen un ciclo de transcripción y, asimismo, la progresión de la polimerasa a través del ciclo es dependiente de los cambios en el estatus de fosforilación del CTD (Kim et al., 2004b). Así, la fosforilación diferencial del CTD promueve el intercambio de factores de iniciación y elongación durante el escape del promotor (Pokholok et al., 2002), el intercambio entre factores de elongación y de procesamiento en 3' (Kim et al., 2004b), así como el reciclaje de la RNAPII (Zhang et al., 2012) y, además, sirve de nexo entre el procesamiento y otros eventos nucleares con la transcripción (Hirose and Manley, 2000; McCracken et al., 1997b).

Las principales dianas de regulación por fosforilación son las tres serinas (Ser2, Ser5 y Ser7) (Corden, 2007; Palancade and Bensaude, 2003), la tirosina (Tyr1) (Baskaran et al., 1997; Mayer et al., 2012b) y la treonina (Thr4) (Hintermair et al., 2012; Hsin et al., 2011). Las serinas y treonina también pueden ser glicosiladas (Egloff and Murphy, 2008a) y las prolinas (Pro3 y Pro6) isomerizadas (Wu et al., 2000). Además, en células humanas, el CTD puede ser metilado en algunas repeticiones degeneradas (Sims et al., 2011). La multitud de posibles modificaciones del CTD, especialmente la fosforilación de las serinas, en combinación con el número de repeticiones del consenso, suponen una amplia variedad de patrones del CTD, que constituyen en su conjunto el denominado código del CTD, que gobierna los distintos pasos de la expresión génica (Figura 5) (Buratowski, 2003; Corden, 2007; Egloff and Murphy, 2008a). Este código determina el reclutamiento secuencial y coordinado de los factores específicos requeridos durante el ciclo de transcripción. Por lo tanto, el CTD es una plataforma que coordina los distintos procesos de la expresión génica, regulando la asociación de factores específicos cuando se requieren durante la transcripción activa. 


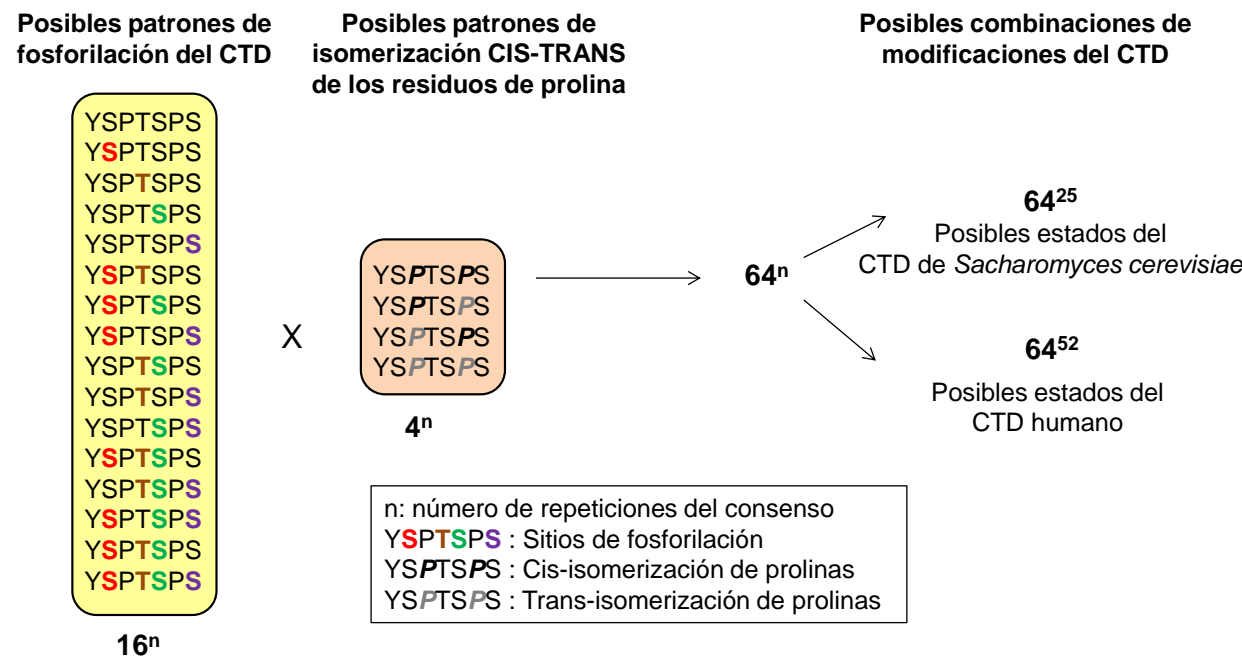

Figura 5. El código del CTD. Posibles estados del CTD humano y de $S$. cerevisiae, resultado de la combinación de la fosforilación e isomerización (cis-trans), que pueden sufrir los residuos conservados del consenso. Imagen modificada desde (Calvo and Garcia, 2012).

\subsubsection{Principales determinantes del código del CTD: la fosforilación de Ser2, 5 y 7.}

La técnica de inmunoprecipitación de cromatina (ChIP), junto con el uso de anticuerpos monoclonales específicos, ha permitido descubrir los distintos patrones de fosforilación del CTD a lo largo de todo el ciclo de transcripción, así como los factores específicos que se asocian a la polimerasa, dependiente de los patrones de fosforilación (Chapman et al., 2007; Egloff and Murphy, 2008a; Patturajan et al., 1998; Phatnani and Greenleaf, 2006). Los residuos Ser2 y Ser5 son las principales dianas de fosforilación del CTD, y las más estudiadas, mientras que la fosforilación en Ser7, la posición más degenerada del consenso, ha sido descrita recientemente (Heidemann et al., 2012; Hsin and Manley, 2012).

Durante un ciclo de transcripción, la fosforilación del CTD cambia de Ser5 a Ser2. Los niveles más altos de fosforilación en Ser5 se encuentran asociados a los promotores y regiones $5^{\prime}$ de los genes y se mantienen o van disminuyendo hacia regiones 3'. Por el contrario, la fosforilación en Ser2 es la principal modificación en las secuencias codificantes y 3' de los genes (Bataille et al., 2012; Kim et al., 2010; Komarnitsky et al., 2000; Mayer et al., 2010; Rodriguez et al., 2000; Schroeder et al., 2000; Tietjen et al., 2010). Por otro lado, la defosforilación de los residuos Ser5 tiene lugar en la transición iniciación-elongación, mientras que la defosforilación en Ser2 ocurre al final de la transcripción, permitiendo el reciclaje de la polimerasa y la reiniciación (Figura 6) (Buratowski, 2009; Phatnani and Greenleaf, 2006). 


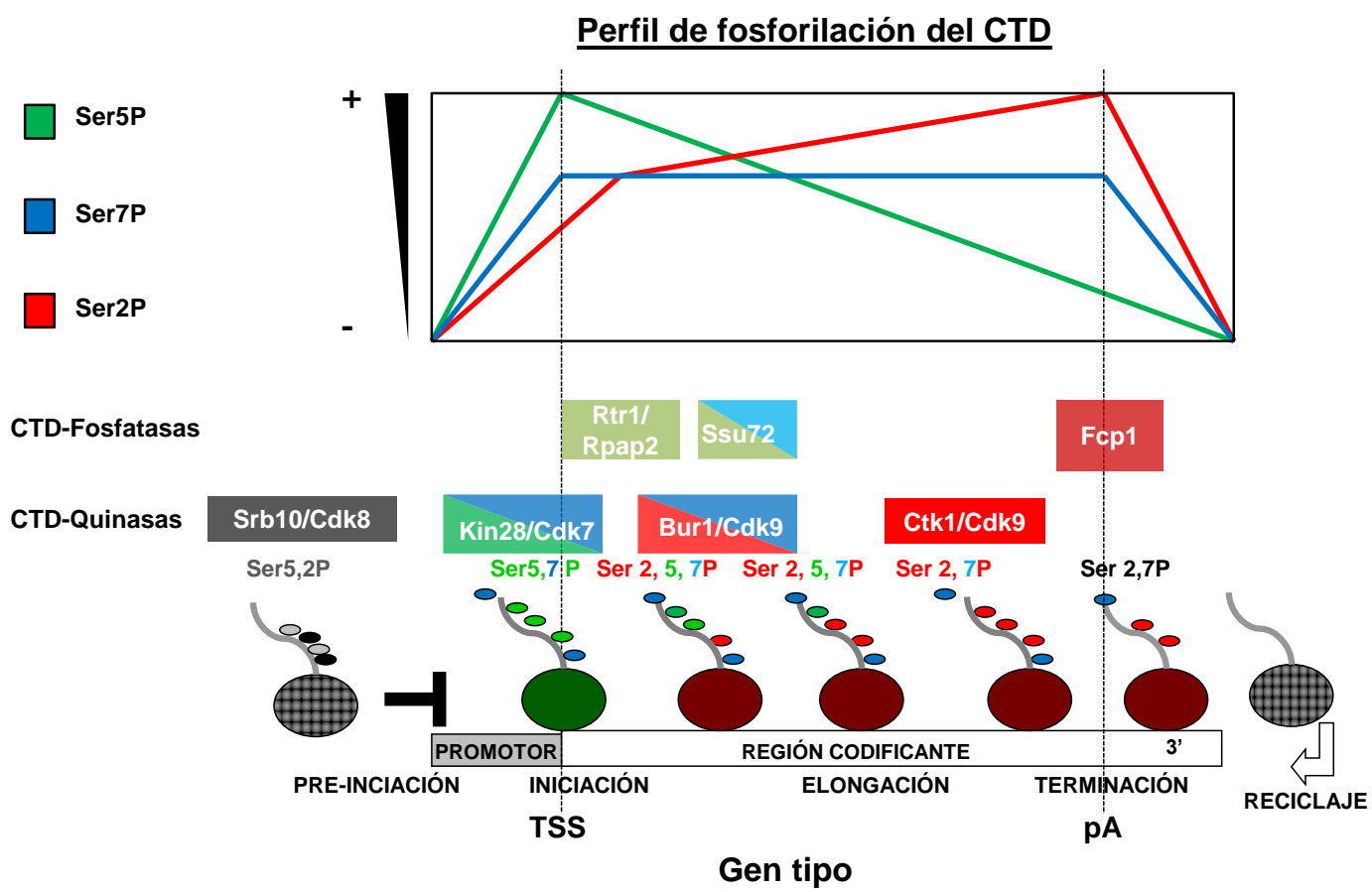

Figura 6. Perfil de fosforilación del CTD de $S$. cerevisiae. Durante la iniciación de la transcripción y el escape del promotor, la polimerasa se fosforila en Ser5 (en verde). Al mismo tiempo, la polimerasa se fosforila en Ser7 (en azul), estableciéndose una marca bivalente tanto en genes codificantes de proteínas, como en no codificantes. Poco después de la disociación del promotor, la marca de Ser5P se elimina rápidamente, mientras que van acumulándose marcas de Ser2P (en rojo) y continúa la fosforilación en Ser7. Por último, todas las marcas de fosforilación del CTD se eliminan al final de la transcripción y la polimerasa hipofosforilada (en gris) está lista para ensamblarse de nuevo en el PIC y reiniciar la transcripción. Los círculos pequeños coloreados representan los residuos fosforilados del consenso. Los círculos grandes, las distintas formas fosforiladas de la RNAPII durante la iniciación, la elongación y la terminación. Además, se indican las CTD-quinasas y CTD-fosfatasas de $S$. cerevisiae y sus homólogos en humanos. Imagen modificada desde (Calvo and Garcia, 2012).

La fosforilación de los residuos Ser7 ocurre en todos los genes codificantes de proteínas y también en los snRNAs (Akhtar et al., 2009; Chapman et al., 2007; Egloff et al., 2007). En células humanas, la fosforilación de este residuo se ha detectado en los promotores de los genes snRNAs, incrementándose hacia 3'. De hecho, se ha propuesto que pueda ser de especial importancia para la transcripción y el procesamiento de estos transcritos (Chapman et al., 2007; Egloff and Murphy, 2008a; Egloff et al., 2007). En S. cerevisiae, mediante análisis de ChIP on chip, se ha detectado la fosforilación en Ser7 en los promotores de los genes codificantes de proteínas, fosforilación que se manteniene a lo largo de toda la transcripción (Figura 6). Además, se ha propuesto que la fosforilación de Ser7 facilita la elongación y suprime la transcripción críptica (Tietjen et al., 2010).

\subsubsection{Otras dianas de fosforilación en el CTD: residuos de Tyr1 y Thr4}

La Tyr1 constituye una posición muy conservada en el consenso, presente en todas las repeticiones del CTD humano y de levaduras. Inicialmente se describió su 
fosforilación en humanos, aunque se desconocía su función (Baskaran et al., 1993, 1997, 1999). Recientemente, se ha descrito que este residuo se fosforila también en levaduras, en las regiones codificantes y en paralelo a la fosforilación en Ser2. Al parecer, los residuos Tyr-P impiden el reclutamiento prematuro de los factores de terminación, pero no de factores de elongación como Spt6 (Baskaran et al., 1993, 1997; Mayer et al., 2012a).

La Thr4 también está sometida a fosforilación (Hintermair et al., 2012; Hsin et al., 2011; Mayer et al., 2012a). En levaduras, esta fosforilación se localiza en el cuerpo de los genes y disminuye en las regiones próximas al sitio de poliadenilación (Mayer et $a l ., 2012 \mathrm{a}$ ), mientras que en células humanas se localiza en las regiones 3' (Hintermair et al., 2012). En estas últimas, recientemente se ha demostrado que la mutación de este residuo del consenso provoca un defecto global en la elongación. Además, se ha identificado a la quinasa responsable de su modificación, Plk3 (Hintermair et al., 2012) y se ha descrito que es necesaria para el procesamiento en 3' de los transcritos codificantes de histonas (Hsin et al., 2011; Zhang and Corden, 1991).

Por último, en mamíferos, las posiciones más C-terminales del CTD son muy degeneradas y podrían estar sometidas a modificaciones post-traduccionales adicionales. Esto, unido a que también se podrían modificar los residuos no canónicos del consenso, incrementa considerablemente los posibles estados del CTD (Chapman et al., 2004; Munoz et al., 2010) y, por lo tanto, incrementa, si cabe aún más, la complejidad del mismo y, en consecuencia, su regulación.

\subsubsection{Moduladores de la fosforilación del CTD: CTD-quinasas y CTD-fosfatasas}

Las enzimas modificadoras del CTD durante la transcripción, fundamentalmente CTD-quinasas y CTD-fosfatasas, se encuentran altamente conservadas y, aunque se conoce el mecanismo catalítico de las mismas, se desconocen las bases de su especificidad.

\subsubsection{CTD-quinasas}

Las enzimas que fosforilan al CTD son quinasas tipo CDK ( $\underline{\text { Cyclin-Dependent- }}$ Kinases), constituidas normalmente por una subunidad catalítica quinasa y una subunidad reguladora ciclina. En mamíferos se han descrito cuatro complejos con actividad CTD-quinasa: Cdk7/CycH, Cdk8/CycC, Cdk9/CycT y Cdk12/CycK, que se 
encuentran conservados en $S$. cerevisiae: Kin28/Cc11, Srb10/Srb11, Bur1/Bur2 y Ctk1/Ctk2. Dichos complejos son específicos de las distintas fases del ciclo de transcripción.

\subsection{CTD-quinasas de preiniciación e iniciación}

\section{Cdk8/CycC y Srb10/Srb11}

El complejo Cdk8/CycC en humanos y su homólogo en levaduras, Srb10/Srb11, forman parte del llamado módulo CDK del complejo Mediador (Liao et al., 1995). El Mediador es requerido para la transcripción de prácticamente todos los genes transcritos por la RNAPII (Holstege et al., 1998). Está constituido por 25-30 proteínas estructuradas en 4 módulos y actúa como puente molecular entre factores de transcripción y la RNAPII (Kornberg, 2005; Taatjes, 2010).

Cdk8/Srb10 fosforila in vitro los residuos Ser2 y Ser5 del CTD (Akoulitchev et al., 2000; Larschan and Winston, 2005; Liu et al., 2004; Ramanathan et al., 2001), aunque la función in vivo de esta fosforilación no está clara. En levaduras, a Srb10/Srb11 se le han otorgado efectos positivos y negativos sobre la expresión génica (Carlson, 1997; Holstege et al., 1998). Así, Srb10 es capaz de fosforilar al CTD antes del ensamblaje del PIC, regulando negativamente la iniciación (Hengartner et al., 1998). En humanos, Cdk8 reprime la transcripción vía la fosforilación de la subunidad ciclina del factor TFIIH (Cdk7/CycH) (Akoulitchev et al., 2000). Por otro lado, se ha demostrado que Srb10, junto con Kin28, promueve la reiniciación de la transcripción, favoreciendo la formación del complejo scaffold, compuesto por una serie de GTFs y componentes del Mediador, que se mantienen asociados a los promotores tras el escape del promotor y facilitan la reiniciación (Liu et al., 2004). Además, Srb10 fosforila a dos subunidades del TFIID, aunque se desconoce la función de esta fosforilación, y a algunos factores de transcripción, incrementando su actividad (Galbraith et al., 2010; Hirst et al., 1999; Vincent et al., 2001) o activando su transporte fuera del núcleo y su degradación (Chi et al., 2001; Nelson et al., 2003).

\section{Cdk7/CycH y Kin28/Ccl1-Tfb3}

El complejo $\mathrm{Cdk} 7 / \mathrm{CycH}$ en humanos y su homólogo en levaduras Kin28/Ccl1 forman parte del GTF, TFIIH. En S. cerevisiae, Kin28 además se encuentra asociado con una tercera subunidad, Tfb3, formando un trímero llamado TFIIK (Kin28-Ccl1Tfb3), componente de TFIIH (Keogh et al., 2002). Cdk7 posee también actividad CAK (ㅁDK-Áctivating-Kinase, (Roy et al., 1994; Serizawa et al., 1995; Shiekhattar et al., 
1995), mientras que en levaduras, ésta recae sobre una enzima independiente, Cak1 (Cismowski et al., 1995; Espinoza et al., 1998; Kaldis et al., 1996). Tanto Cdk7 como Kin28 son esenciales para la viabilidad celular (Simon et al., 1986). Cdk7/Kin28 fosforilan in vitro e in vivo los residuos Ser5 y Ser7 (Akhtar et al., 2009; Cho et al., 2001; Glover-Cutter et al., 2009; Hengartner et al., 1998; Kim et al., 2009b). Se ha propuesto que la fosforilación en Ser5 contribuye al escape del promotor, pudiendo modificar las interacciones estables entre algunos componentes del PIC y el CTD (Akoulitchev et al., 2000; Hengartner et al., 1998; Jiang et al., 1996). Además, la fosforilación mediada por $\operatorname{Cdk} 7 / \operatorname{Kin} 28$ es necesaria para el reclutamiento de la maquinaria de capping (Cho et al., 1997; Ho and Shuman, 1999; McCracken et al., 1997b; Rodriguez et al., 2000), del complejo de unión al cap (CBC) (Wong et al., 2007), del complejo de elongación PAF1 (Qiu et al., 2006), del complejo metiltransferasa de histonas SET1/COMPASS (Ng et al., 2003) y del complejo SAGA (Govind et al., 2007). Adicionalmente, la fosforilación llevada a cabo por Kin28 estimula el reclutamiento y la actividad de la CTD-quinasa de Ser2, Bur1/Bur2, cerca de los promotores (Qiu et al., 2009). Por último, recientemente se ha demostrado que Kin28 fosforila al CTD en Ser7 durante la iniciación (Akhtar et al., 2009; Glover-Cutter et al., 2009).

Kin28 es la principal CTD-quinasa durante la iniciación y, como acabamos de ver, tiene un papel esencial regulador en el procesamiento del extremo 5', que no tiene Srb10 (Komarnitsky et al., 2000; Liu et al., 2004; Schroeder et al., 2000; Valay et al., 1995). De hecho, Kin28 es esencial, mientras que la deleción de SRB10 es viable (Borggrefe et al., 2002). Sin embargo, al menos en levaduras, la disociación del PIC es dependiente de la actividad de ambas enzimas (Guidi et al., 2004; Liu et al., 2004).

\subsection{CTD-quinasas de elongación}

\section{Cdk9/CycT y Cdk12/CycK}

Cdk9 es la subunidad catalítica del factor de elongación P-TEFb ( PositiveTranscription Elongation Factor b) en mamíferos y Drosophila (Saunders et al., 2006). Es la principal CTD-quinasa de Ser2, aunque también contribuye a la fosforilación en Ser5 durante la transición iniciación-elongación y a la salida de la pausa de la polimerasa (Ramanathan et al., 2001; Wada et al., 1998b). La actividad de Cdk9 se requiere para un acoplamiento eficiente de la transcripción con el procesamiento del 
pre-mRNA (Ni et al., 2004) y recientemente se ha descrito que la inhibición de la actividad de Cdk9 contribuye a una disminución en la fosforilación de los residuos Thr4 (Hsin et al., 2011). Además de fosforilar al CTD, Cdk9 promueve la elongación de la transcripción, gracias a la actividad que ejerce sobre los represores transcripcionales que determinan la pausa de la polimerasa en eucariotas superiores: DSIF y NELF (Wada et al., 2000, 1998b; Yamaguchi et al., 1999).

Durante mucho tiempo, se ha considerado que Cdk9 era la única CTD-quinasa de Ser2 de eucariotas superiores, mientras que en levaduras esta función recae sobre dos complejos CTD-quinasa distintos: Bur1/Bur2 y Ctk1/Ctk2 en S. cerevisiae; y Cdk9 y Lsk1 en S. pombe (Viladevall et al., 2009). Sin embargo, recientemente se ha encontrado un complejo quinasa ortólogo de Ctk1 en Drosophila, Cdk12, y dos en humanos, Cdk12 y Cdk13. Estas últimas poseen actividad quinasa sobre Ser2 in vitro y, además, se ha propuesto que Cdk12 podría contribuir a la mayor parte de la fosforilación de estos residuos en la RNAPII elongante (Bartkowiak and Greenleaf, 2011; Bartkowiak et al., 2010). Por su parte, se desconoce la función de Cdk13 durante la transcripción (Blazek et al., 2011; Kohoutek and Blazek, 2012).

\section{Bur1/Bur2}

La CTD-quinasa Bur1 y su par ciclina Bur2 forman un complejo CDK esencial en S. cerevisiae, implicado en la elongación de la transcripción (Keogh et al., 2003; Yao and Prelich, 2002). Bur1 puede fosforilar a los residuos Ser2, Ser5 y Ser7 del CTD (Keogh et al., 2003; Lindstrom and Hartzog, 2001; Murray et al., 2001; Qiu et al., 2009; Tietjen et al., 2010). A pesar de que la fosforilación en Ser5 es la más eficiente in vitro (Keogh et al., 2003), Bur1 fosforila preferentemente el residuo Ser2 in vivo y con más eficiencia las repeticiones previamente fosforiladas en Ser5 (Jones et al., 2004). Esta fosforilación se localiza en regiones génicas próximas a los promotores. De hecho, la actividad quinasa de Kin28 estimula la actividad de Bur1 y ésta, a su vez, estimula la de Ctk1 (Qiu et al., 2009). De este modo, cuando Ctk1 se inactiva, Bur1 contribuye en exclusiva a la fosforilación en Ser2 (Chu et al., 2007). Además, Bur1 fosforila al CTD en Ser7 en las regiones codificantes génicas (Tietjen et al., 2010).

La función de Bur1 en la regulación de la elongación viene determinada, además de por su actividad CTD-quinasa, por la capacidad de fosforilar al factor de elongación Spt5 y regular a través de esta fosforilación la actividad de enzimas modificadoras de histonas, como Rad6/Bre1 (Liu et al., 2009; Zhou et al., 2009). 


\section{Ctk1/Ctk2-Ctk3}

Ctk1 es la subunidad catalítica del complejo CTDK-I, formado además por la ciclina Ctk2 y la proteína Ctk3, cuya función es desconocida (Sterner et al., 1995). Ctk1 es la principal CTD-quinasa de Ser2 durante la elongación de la transcripción, que se asocia a la polimerasa elongante (Cho et al., 2001; Jones et al., 2004). No obstante, Ctk1 no participa directamente en la regulación de la elongación (Ahn et al., 2004; Mason and Struhl, 2005; Skaar and Greenleaf, 2002), pero su actividad sí es necesaria para el reclutamiento al complejo de transcripción de los factores de terminación y poliadenilación (Ahn et al., 2004) y de factores modificadores de histonas, como Set2 (Xiao et al., 2007). Además, se ha descrito que Ctk1 promueve la disociación de los factores de transcripción basal de la polimerasa elongante, aunque al parecer, su actividad catalítica no es necesaria para esta función (Ahn et al., 2009). Adicionalmente, Ctk1 interacciona genética y bioquímicamente con el complejo TREX, que acopla la elongación de la transcripción al transporte del mRNA (Hurt et al., 2004; Jimeno et al., 2002). Por otro lado, participa también en la regulación de la transcripción mediada por la RNAPI (Bouchoux et al., 2004; Grenetier et al., 2006), en la transcripción inducida por daño a DNA (Ostapenko and Solomon, 2003) y tiene un papel en la fidelidad de elongación de la traducción en el citoplasma (Hampsey and Kinzy, 2007; Rother and Strasser, 2007).

\subsubsection{CTD-fosfatasas}

La defosforilación dinámica y regulada del CTD es imprescindible para regular los patrones de fosforilación que orquestan la asociación temporal y espacial de distintos factores reguladores. En levaduras, se han descrito las CTD-fosfatasas Ssu72, Fcp1 y Rtr1, y en mamíferos, Fcp1, y dos fosfatasas pequeñas, SCP1y RAP2 (homóloga de Rtr1). Al contrario de lo que ocurre para las CTD-quinasas, no existe una separación espacial y/o temporal exacta de las CTD-fosfatasas en las distintas etapas del ciclo de transcripción. Así, todas las CTD-fosfatasas, a excepción de Rtr1, viajan con el complejo de transcripción durante todo el ciclo. Por último, recientemente se ha demostrado que la fosfatasa de ciclo celular Cdc14 defosforila a la RNAPII durante la mitosis.

\section{$\underline{\text { Ssu72 }}$}

Ssu72 es una CTD-fosfatasa capaz de defosforilar residuos de Ser5P y Ser7P (Bataille et al., 2012; Krishnamurthy et al., 2004; Zhang et al., 2012). Inicialmente se 
aisló como un factor capaz de interaccionar con el factor TFIIB (Sun and Hampsey, 1996; Wu et al., 1999) y después se ha identificado como componente del complejo CPF (Cleveage-Polyadenylation-Factor), con un papel en terminación y procesamiento del extremo 3' de los mRNAs (Dichtl et al., 2002; He et al., 2003; Krishnamurthy et al., 2004; Steinmetz and Brow, 2003; Xiang et al., 2010). Mediante análisis de localización a escala genómica, se ha demostrado que Ssu72 presenta dos picos de asociación en los genes: uno en una región 5' y otro, de mayor intensidad, en torno al sitio de corte y poliadenilación en 3' (Zhang et al., 2012). Así, contribuye a la defosforilación de la polimerasa en 3' y participa en su reciclaje. De hecho, ciertas mutaciones en Ssu72 que abolen su actividad catalítica, provocan una acumulación de Ser7P, que impide la reiniciación de la transcripción y conduce a la muerte celular (Zhang et al., 2012). Ssu72 también tiene un papel en el gene looping (Ansari and Hampsey, 2005).

En células humanas también se ha identificado una proteína homóloga de Ssu72, que al igual que la proteína de levaduras, interacciona con TFIIB y con la maquinaria de corte y poliadenilación. Tiene actividad CTD-fosfatasa y participa en el acoplamiento de la transcripción y el procesamiento del extremo 3' de los mRNAs (St-Pierre et al., 2005; Xiang et al., 2010).

\section{Fcp1/SCP1}

Fcp1 fue la primera CTD-fosfatasa descrita. Se encuentra altamente conservada entre todos los eucariotas (Archambault et al., 1997; Chambers and Dahmus, 1994; Chambers and Kane, 1996; Kimura and Ishihama, 2004). In vitro, su actividad catalítica es estimulada por TFIIF e inhibida por TFIIB (Archambault et al., 1997; Cho et al., 2001; Kobor et al., 1999). En levaduras, es esencial para la viabilidad celular y la transcripción (Archambault et al., 1997; Kobor et al., 1999). Fcp1 defosforila preferentemente los residuos Ser2P, por lo que comúnmente se le conoce como la fosfatasa de elongación (Cho et al., 2001; Hausmann and Shuman, 2002). En eucariotas superiores, además, existen CTD-fosfatasas pequeñas como SCP1 ( $\underline{\text { Small-C}}$ TDPhosphatases 1), que comparten homología con un dominio concreto de Fcp1, pero con especificidad por residuos Ser5P (Yeo et al., 2003).

En células en las que la función de Fcp1 se encuentra comprometida, como en algunos mutantes $f c p l$, la transcripción se encuentra disminuida y en los genes se acumulan formas hiperfosforiladas de la polimerasa (Kobor et al., 1999). Fcp1 estimula in vitro la elongación de la transcripción (Mandal et al., 2002) y se asocia in vivo a lo 
largo de toda la secuencia de los genes transcritos, desde los promotores a las regiones 3', siendo mayor su asociación en torno a los sitios de corte y poliadenilación, donde ésta solapa con la de Ssu72 (Cho et al., 2001). De hecho, se ha propuesto que existe una cooperación entre Fcp1 y Ssu72 en las regiones 3' de los genes, de modo que la función de Ssu72 es importante para la de Fcp1 y que, por lo tanto, la defosforilación en Ser2P del CTD se acopla a la de Ser5P y Ser7P (Bataille et al., 2012). Así, Fcp1 contribuye también al reciclaje de la RNAPII, una vez que las quinasas Bur1 y Ctk1 se han disociado del complejo de transcripción (Zhang et al., 2012). Además, Fcp1 es responsable de la defosforilación de la polimerasa una vez que se ha disociado del DNA molde (Kong et al., 2005).

\section{$\underline{\text { Rtr1/RPAP2 }}$}

En la dinámica de fosforilación del CTD a lo largo de un gen transcrito, el punto de máxima fosforilación de los residuos Ser5 se localiza en las regiones 5' de los genes y va descendiendo a la par que la fosforilación de Ser2 incrementa en la secuencia codificante. Se ha propuesto que la proteína Rtr1 de S. cerevisiae forma parte de una nueva familia de fosfatasas, capaz de defosforilar específicamente el CTD en Ser5P durante la transición Ser5P-Ser2P. De hecho, su deleción provoca un incremento de los niveles de fosforilación en Ser5 en las regiones codificantes de los genes (Gibney et al., 2008; Mosley et al., 2009). Sin embargo, recientemente se ha resuelto la estructura cristalográfica de la proteína Rtr1 de Kluiveromyces lactis y no se ha encontrado sitio activo alguno, ni se ha podido demostrar su actividad catalítica. Este resultado sugiere que Rtr1 puede influir en la defosforilación de la polimerasa de una manera no catalítica (Xiang et al., 2012).

La eliminación de la CTD-fosfatasa humana RPAP2 provoca también un incremento en los niveles de Ser5P en el cuerpo de los genes. RPAP2 tiene además una función en la transcripción de los snRNAs. Al parecer, los residuos Ser7P reclutan a esta fosfatasa, desencadenándose una cascada de eventos que son críticos para una adecuada expresión génica (Egloff et al., 2007, 2012; Ni et al., 2011).

\section{Cdc14}

La fosfatasa Cdc14 es un regulador esencial de ciclo celular necesario para la salida de mitosis, presente en levaduras y con ortólogos conservados en eucariotas superiores (por ejemplo (Stegmeier and Amon, 2004; Vazquez-Novelle et al., 2005). En S. cerevisiae, la actividad CTD-fosfatasa de Cdc14 durante mitosis es necesaria para la 
represión de la transcripción de la RNAPII en regiones repetitivas del genoma de la levadura, lo que se ha postulado que podría contribuir a la segregación telomérica (Clemente-Blanco et al., 2011). Un ortólogo humano, Cdc14b defosforila residuos de Ser5P y reprime la transcripción de reguladores de ciclo celular (Guillamot et al., 2011).

\subsubsection{Modificaciones del CTD que afectan a su fosforilación}

\section{La isomerización de las prolinas}

Los residuos de prolina presentes en la secuencia del CTD pueden adoptar distintas conformaciones espaciales, cis o trans, que afectan a la fosforilación. Las enzimas prolil-isomerasas aceleran la rotación del enlace peptídico que precede a un residuo de prolina (Lu et al., 2007; Lu and Zhou, 2007). Pin1, en mamíferos, y Ess1, en S. cerevisiae, son enzimas con actividad CTD-prolil-isomerasa. Pin1 tiene especificidad por residuos fosforilados de Ser/Thr-Pro y modula la actividad de la RNAPII durante el ciclo celular, al menos en parte, modulando los niveles de fosforilación del CTD (Xu et al., 2003). La proteína Ess1 de levaduras interacciona con el CTD (Morris et al., 1999; Wu et al., 2000) y, al menos in vitro, presenta preferencia por residuos Ser5P (Gemmill et al., 2005). Se ha propuesto que Pin1 estimula la hiperfosforilación del CTD, lo que tiene como consecuencia la represión de la transcripción y del splicing (Xu et al., 2003; $\mathrm{Xu}$ and Manley, 2007). Por el contrario, parece ser que Ess1 promueve la defosforilación de la polimerasa, gracias a que favorece una conformación del CTD adecuada para que sea reconocida por la fosfatasa Ssu72 (Bataille et al., 2012; Krishnamurthy et al., 2009). De cualquier modo, ambas enzimas, influyen en la fosforilación del CTD y desempeñan funciones importantes en la regulación de la transcripción.

\section{La glicosilación de las serinas}

La O- y N-glicosilación de residuos de serina y treonina del CTD se describió hace bastante tiempo, aunque hasta la fecha su función era desconocida (Kelly et al., 1993). Se trata de una modificación mutuamente excluyente con la fosforilación (Comer and Hart, 2001). Estudios recientes en eucariotas superiores proponen que durante la formación del PIC tiene lugar una O-glicosilación dinámica de los residuos Ser5 y Ser7, cuya inhibición produce un descenso de la transcripción y de la densidad de polimerasa asociada a varios promotores (Ranuncolo et al., 2012). 


\subsubsection{La fosforilación del CTD y el acoplamiento entre transcripción y procesamiento}

El CTD es un dominio esencial para la viabilidad celular, pese a no estar involucrado en la actividad catalítica de la RNAPII, debido a la función de coordinación que realiza entre procesos nucleares. Así, el acoplamiento entre transcripción y procesamiento mediado por el CTD supone un incremento en la eficiencia del procesamiento y garantiza que solamente los mensajeros que han sido procesados correctamente, se transporten. La función del CTD como coordinador de procesos nucleares viene determinada por: (1) su posición estratégica en el conjunto de la RNAPII, situado próximo al canal de salida del RNA, donde puede interaccionar con una plétora de factores implicados en distintos procesos nucleares; y (2) su capacidad para adoptar numerosas conformaciones, que permiten la asociación de diferentes factores al mismo tiempo y que dependen del estado de fosforilación del CTD.

\section{Fosforilación del CTD y capping}

El capping es el primer evento de procesamiento que ocurre durante la elongación temprana, cuando el transcrito consta de unos 20 nucleótidos (Coppola et al., 1983; Chiu et al., 2002; Moteki and Price, 2002; Rasmussen and Lis, 1993). Consiste en la adición de un residuo de 7-metil-guanosina conocido como caperuza o cap en el extremo 5' del RNA naciente. La formación del cap estabiliza al transcrito frente a la degradación exonucleolítica $5^{\prime} \rightarrow 3^{\prime}$, promueve la eliminación de intrones y el procesamiento del extremo 3' y facilita su transporte al citoplasma y su posterior traducción (Lewis and Izaurralde, 1997).

La maquinaria de capping se recluta al complejo de transcripción asociándose específicamente a la RNAPII fosforilada en Ser5 por el TFIIH (Kin28, en S. cerevisiae) (Fabrega et al., 2003; Ghosh et al., 2011; Komarnitsky et al., 2000; McCracken et al., 1997a; Schroeder et al., 2000). La interacción del CTD fosforilado con el complejo de capping estimula alostéricamente la actividad de las enzimas del capping y, en respuesta a ello, se incrementa la transcripción (Cho et al., 1998; Ho and Shuman, 1999). La cercanía del CTD respecto del canal de salida del RNA facilita el procesamiento del extremo 5' del transcrito tan pronto como emerge de la polimerasa, de modo que se evita su degradación prematura y promueve la elongación productiva (Cho et al., 1998; Kim et al., 2004a; McCracken et al., 1997a; Schroeder et al., 2000). De hecho, el complejo de capping también interacciona con el factor de elongación 
Spt5, tanto en levaduras como en humanos (Pei and Shuman, 2002; Wen and Shatkin, 1999).

\section{Fosforilación del CTD y splicing}

La eliminación de intrones o splicing es un proceso catalizado por un complejo macromolecular formado por cinco snRNAs y al menos 150 proteínas, llamado madurosoma o espliceosoma (Adams et al., 1996; Kramer, 1996). Reconoce secuencias consenso en los extremos 5' y 3' del intrón, se ensambla a ambos y escinde la secuencia intermedia, favoreciendo el empalme entre exones. Los genes de los metazoos están formados por pequeños exones (de $\sim 140$ nucleótidos) separado por intrones de tamaño muy superior, que constituyen el 25\% del genoma (Lander et al., 2001; Venter et al., 2001). Por su parte, en S. cerevisiae solamente el $\sim 5 \%$ de los genes contiene intrones, que son de pequeño tamaño y se sitúan en las regiones 5' génicas (Clark et al., 2002; Kellis et al., 2003; Juneau et al., 2007).

El splicing puede ocurrir co-transcripcional y post-transcripcionalmente. Con frecuencia puede iniciarse de manera co-transcripcional y finalizar posttranscripcionalmente, como consecuencia de un desfase entre la velocidad de procesamiento del espliceosoma y la velocidad de síntesis de la polimerasa (Beyer and Osheim, 1988). El acoplamiento co-transcripcional del splicing ocurre a través de la asociación del espliceosoma con la fosforilación del CTD (David and Manley, 2011). El CTD influye en el splicing in vitro (McCracken et al., 1997b) e in vivo y su fosforilación es necesaria para que el splicing ocurra de forma eficiente (Hirose et al., 1999; Millhouse and Manley, 2005). Así, se han identificado numerosos factores de splicing que interaccionan con el CTD hiperfosforilado (por ejemplo el factor Prp40 de S. cerevisiae) (Morris and Greenleaf, 2000), y se ha demostrado que la unión directa de la maquinaria de splicing con el RNA naciente es responsable en gran medida del splicing co-transcripcional en levaduras y humanos (Listerman et al., 2006; Moore et al., 2006). Los residuos de Ser2P son los principales responsables de la coordinación entre transcripción y splicing (Hargreaves et al., 2009). Además, se ha propuesto que la interacción de ciertos factores de splicing con el CTD favorece el ensamblaje del espliceosoma (David et al., 2011; David and Manley, 2011). Por último, la fosforilación del CTD podría regular el splicing alternativo, modulando la concentración local de factores de splicing (de la Mata et al., 2003; Munoz et al., 2010). 


\section{Fosforilación del CTD y procesamiento del extremo 3',}

El procesamiento del extremo 3' de los mRNAs consiste en un corte endonucleolítico del transcrito y en la posterior adición de una cola de poliadeninas. En mamíferos, el sitio de corte está definido por unas secuencias consenso a las que se asocian los complejos CPSF (factor específico de corte y poliadenilación) y CstF (factor de estimulación del corte), respectivamente. La asociación de estos complejos determina el ensamblaje posterior de los factores CFI y CFII (factores de corte I y II) que llevan a cabo el corte endonucleolítico del transcrito. En S. cerevisiae los procesos y factores que gobiernan la terminación y el procesamiento en 3 ' son muy similares a los de eucariotas superiores, pero las secuencias que los dirigen son degeneradas y redundantes (Keller and Minvielle-Sebastia, 1997; Mandel et al., 2008; Proudfoot, 2011). Tras el corte, en ambos sistemas, la enzima poli(A)-polimerasa (PAP) sintetiza una cola de poli-adeninas en el extremo 3' libre del RNA cortado, de una longitud de 250 bases en células humanas (Brawerman, 1981) y 70-90 bases en S. cerevisiae (Brown and Sachs, 1998; Groner et al., 1974).

La asociación de la maquinaria de terminación y procesamiento al complejo de transcripción se produce gracias a las interacciones específicas de muchos de estos factores con la polimerasa fosforilada. Así, las reacciones de procesamiento del extremo 3' de los mRNA, corte y poliadenilación, requieren un CTD funcional (Hirose and Manley, 1998; McCracken et al., 1997b). De hecho, la deleción del CTD, o la ausencia de su fosforilación, afectan negativamente al procesamiento en 3' (Ahn et al., 2004; Fong and Bentley, 2001; Licatalosi et al., 2002; Proudfoot et al., 2002; Skaar and Greenleaf, 2002). Los factores de procesamiento en 3' se asocian al CTD y éste estimula el corte y la poliadenilación de los transcritos in vitro e in vivo (Hirose and Manley, 1998; McCracken et al., 1997b). En levaduras, la maquinaria de procesamiento en 3' se recluta dependiendo de los niveles de fosforilación en Ser2 determinados por Ctk1 (Ahn et al., 2004). Por su parte, el procesamiento en 3' de los RNAs pequeños (snRNAs), se asocia a la fosforilación en Ser7 tanto en levaduras (Akhtar et al., 2009), como en eucariotas superiores (Baillat et al., 2005; Egloff and Murphy, 2008b; Egloff et al., 2007, 2010). 


\subsubsection{Acoplamiento entre el código del CTD y el código de las histonas}

Durante la transcripción, las histonas están sometidas a diversas modificaciones post-traduccionales dinámicas, que tienen lugar fundamentalmente en sus colas amino y carboxi-terminales y, en menor medida, en los dominios globulares. Como ocurre para la fosforilación del CTD, algunas marcas epigenéticas marcan la deposición de otras, creándose un complejo código de señales, el código de las histonas, que gobierna la organización de la cromatina y los procesos dependientes de DNA, entre ellos la transcripción (Jenuwein and Allis, 2001; Strahl and Allis, 2000). Entre las modificaciones más importantes encontramos la metilación de H3K4 y H3K36, cuya función está ligada directamente a la fosforilación del CTD (Kouzarides, 2002). La trimetilación de H3K4, llevada a cabo por el complejo SET1/COMPASS, se acumula en los promotores génicos, coincidiendo con el pico de polimerasa hiperfosforilada en Ser5, depende de la actividad de Cdk7/Kin28 y del complejo PAF, e influye en la iniciación, elongación y el procesamiento del RNA (Krogan et al., 2003a; Ng et al., 2003; Pinskaya and Morillon, 2009). Por su parte, la metilación de H3K36, mediada por el complejo Set2, se distribuye a lo largo de la secuencia codificante de los genes y depende de la doble marca Ser5P/Ser2P en el CTD y, por lo tanto, de la actividad de Ctk1 (Kizer et al., 2005; Xiao et al., 2007). Además, Bur1/Bur2 promueve la ubiquitinación de $\mathrm{H} 2 \mathrm{~B}$, que facilita esta metilación en regiones cercanas a los promotores (Chu et al., 2007; Laribee et al., 2005; Wood et al., 2005). Por otro lado, la acetilación/deacetilación de $\mathrm{H} 3$ es también relevante durante la transcripción (Drouin et al., 2010; Govind et al., 2010; Spain and Govind, 2011) y asimismo es un proceso asociado a la fosforilación del CTD. Por ejemplo, la fosforilación en Ser5 por Cdk7/Kin28 es importante para el reclutamiento a las regiones codificantes de los complejos con actividad HDACs, Set3C y Rpd3(S) (Govind et al., 2010).

\subsubsection{Acoplamiento entre el código del CTD y el transporte del RNA}

Tan pronto como el RNA naciente emerge a partir del canal de salida de la polimerasa, se asocian a él numerosos factores, de procesamiento y de transporte, que lo empaquetan en una verdadera ribonucleopartícula (mRNP). A diferencia de los factores de procesamiento, los factores de transporte no interaccionan con el CTD, sin embargo, el transporte del RNA está acoplado a la transcripción, ya que errores en la elongación, el splicing o el procesamiento del extremo 3', afectan al transporte (Brodsky and Silver, 
2000). En levaduras, el transporte del mRNA está ligado a la transcripción a través del complejo TREX (Transcription Export), que está compuesto por el complejo THO (Tho2, Hpr1, Mft1, y Thp2) y las proteínas Sub2, Yra1 y Tex1 (Rondon et al., 2010; Strasser et al., 2002). La deleción de componentes del complejo THO causa defectos en transcripción, fenotipos de hiper-recombinación asociada a la transcripción y altera el transporte (Jimeno et al., 2002; Rondon et al., 2003). El complejo Sub2/Yra1 se recluta a las secuencias codificantes génicas por el complejo THO (Strasser et al., 2002; Zenklusen et al., 2002). Aunque se ha descrito que el complejo TREX y Ctk1 están funcionalmente relacionados (Hurt et al., 2004), el reclutamiento de TREX a los genes es independiente de Ctk1 (Ahn et al., 2004) y en células humanas es dependiente de splicing (Masuda et al., 2005). Se desconoce la implicación real del CTD y de su fosforilación en el proceso de transporte. Sin embargo, recientemente se ha identificado al factor Yra1 como una proteína de unión al CTD fosforilado, lo que supone una fuerte evidencia de un reclutamiento co-transcripcional de los factores de transporte, mediado por el CTD (MacKellar and Greenleaf, 2011).

\subsection{El factor de transcripción Sub1/PC4}

\subsubsection{Características generales del factor Sub1}

Sub1 ( Suppressor of TFII $\underline{B}$ mutations) es una proteína de unión a DNA, que se describió originalmente como un co-activador transcripcional por su alta homología con el coactivador humano PC4 ( Positive Coactivator 4) y por su capacidad de estimular la transcripción in vitro y de interaccionar con el factor general de transcripción TFIIB (Henry et al., 1996; Knaus et al., 1996). Consta de 292 aminoácidos y está formada por dos dominios: el dominio N-terminal, que comprende aproximadamente los primeros 107 aminoácidos y un dominio C-terminal con los restantes 185 aminoácidos. El dominio N-terminal, que contiene un dominio de unión a ssDNA, comparte homología de secuencia con el dominio C-terminal del coactivador humano PC4 (48\% de identidad; 70\% de similitud (Henry et al., 1996; Knaus et al., 1996). El dominio Cterminal no está presente en la proteína humana y por el momento se desconoce su función. La deleción de $S U B 1$ es viable y no produce un fenotipo aparente de crecimiento, a excepción de la auxotrofía al inositol. La regulación de la actividad de la proteína por fosforilación se ha demostrado in vitro. Al parecer, la proteína no fosforilada tiene alta afinidad por el ssDNA y dsDNA, afinidad que se ve reducida 
cuando es fosforilada (Henry et al., 1996). Aunque en un principio sólo se propusieron funciones para Sub1 relacionadas con la iniciación de la transcripción, estudios posteriores han demostrado que está implicado en diversos etapas del ciclo de transcripción (Conesa and Acker, 2010).

\subsubsection{Sub1 y la iniciación de la transcripción de la RNAPII}

Inicialmente, Sub1 se aisló en un ensayo genético que buscaba supresores para mutaciones en el GTF TFIIB (Knaus et al., 1996). Se encontró que SUB1 expresado en alto número de copia era capaz de suprimir los defectos de crecimiento de varios mutantes del factor TFIIB, codificado por el gen SUA7 (Knaus et al., 1996; Wu et al., 1999). Asimismo, la deleción de $S U B 1$, en combinación con estas mutaciones, producía letalidad sintética. Posteriormente se demostró in vitro (Henry et al., 1996; Knaus et al., 1996) que ambos factores interaccionaban físicamente y que su interacción es excluyente de la interacción entre TFIIB y TBP. Además, se mostró que la interacción Sub1-TFIIB es más fuerte cuando la proteína está defosforilada, es decir, cuando también es más fuerte su afinidad por el DNA (Henry et al., 1996). En base a esto, se propuso un modelo según el cual Sub1 podría actuar como un factor que podría promover la salida del TFIIB del complejo de transcripción, tras la iniciación, al interrumpir la unión de éste con la proteína TBP (Knaus et al., 1996).

Sub1 forma parte de la maquinaria de transcripción basal asociada a los promotores durante la iniciación. Así, mediante ensayos de ChIP se ha demostrado la asociación de Sub1 a los promotores de genes de clase II de expresión constitutiva (Calvo and Manley, 2005) y a genes de expresión inducible en respuesta a estrés osmótico (Rosonina et al., 2009). Al parecer, en genes de expresión constitutiva, Sub1 se asocia después de los GTFs. Tras la exposición celular a un estrés osmótico, la asociación de Sub1 a estos genes disminuye y se recluta rápidamente a genes de respuesta a estrés, donde promueve la unión de los GTFs, lo que sugiere que Sub1 podría participar en el ensamblaje del PIC (Rosonina et al., 2009). De hecho, recientemente se ha demostrado in vitro que Sub1 es un componente del PIC (Sikorski et al., 2011).

Por su parte, PC4 también tiene función de co-activador en sistemas de transcripción in vitro ( $\mathrm{Wu}$ and Chiang, 1998). Así, interacciona con numerosos activadores como Gal4-VP16 (Ge and Roeder, 1994), con GTFs como TFIIA (Ge and Roeder, 1994) y TFIIH (Fukuda et al., 2004) y con la propia polimerasa (Malik et al., 
1998). Actúa como un puente molecular que facilita la transcripción dependiente de activadores, incrementando el ensamblaje del PIC en la región promotora o promoviendo la actividad de unión a DNA de algunos activadores como p53 (Banerjee et al., 2004). Además, PC4 puede reprimir la transcripción previamente al ensamblaje del PIC (Wu and Chiang, 1998), represión que se alivia cuando es fosforilado por las quinasas del PIC (Malik et al., 1998).

\subsubsection{Sub1 y la terminación y procesamiento del extremo 3' del mRNA}

La coordinación de la transcripción con otros procesos nucleares está mediada en gran parte por las modificaciones post-traduccionales que sufre el dominio CTD de la RNAPII, pero también por la acción de factores de transcripción que intervienen en entre procesos, a priori, temporal y espacialmente distantes. En el año 2001 se demostró que Sub1 interaccionaba con un factor de poliadenilación, Rna15, y que esta interacción estaba evolutivamente conservada en las proteínas homólogas humanas (PC4 y CstF64, respectivamente). De esta manera, Sub1 fue uno de los primeros factores identificados, a parte de la polimerasa, que participan en la conexión de distintos etapas y constituyen un nexo entre procesos que tienen lugar en el promotor con aquellos que ocurren en las regiones 3' de los genes (Calvo and Manley, 2001).

La función de Sub1/PC4 en la terminación y el procesamiento en 3' de los mRNAs inicialmente se determinó por su interacción con el factor de terminación Rna15/CstF64 (Calvo and Manley, 2001), componente del complejo de poliadenilación CFIA/CstF, respectivamente (Minvielle-Sebastia et al., 1994). Ambas proteínas, Sub1 y Rna15 se asocian a los promotores y viajan con el complejo de transcripción a lo largo de los genes (Calvo and Manley, 2005). Se ha propuesto una función de antiterminación para Sub1, probablemente impidiendo la terminación/poliadenilación temprana durante la transcripción (Calvo and Manley, 2001). Más tarde, se demostró que Sub1 también interacciona con otro factor de terminación/poliadenilación, Pta1, componente del complejo CPF (He et al., 2003). Por lo tanto, ambas interacciones ponen de manifiesto la participación de Sub1 en la terminación y el procesamiento del extremo 3' de los mRNAs.

\subsubsection{Sub1 es un factor de transcripción ubicuo}

Mediante análisis de localización a escala genómica se ha comprobado que Sub1 es un factor de transcripción que no es exclusivo de un tipo de RNAP concreto, ya que se detecta asociado a todos los genes transcritos por la RNAPIII y a la mayoría de los 
transcritos por la RNAPII. La mayor parte de los genes a los que se asocia Sub1 son de expresión alta y están englobados en la regulación de funciones celulares específicas como la traducción, la estructura de la cromatina y las modificaciones del RNA. (Tavenet et al., 2009). Para el caso de PC4, la eliminación de la proteína mediante el uso de iRNA incrementa la expresión de genes implicados en la biogénesis de proteínas o codificantes de factores asociados a la cromatina (Das et al., 2006).

\subsubsection{Sub1 es un factor de reiniciación de la RNAPIII}

Al igual que para los genes de clase II, Sub1/PC4 también se asocia a los complejos PIC en los genes transcritos por la RNAPIII. Así, Sub1 interacciona con los factores TFIIIB y TFIIIC, y PC4 con TFIIIC. Mediante el uso de sistemas de transcripción in vitro, se ha demostrado que ambas proteínas estimulan la transcripción y promueven la reiniciación de la RNAPIII (Tavenet et al., 2009; Wang and Roeder, 1998). Es posible que también sea un factor de reiniciación de la RNAPII, puesto que regula los niveles de la fosfatasa Fcp1 (Calvo and Manley, 2005) y está relacionado funcionalmente con un factor esencial para la iniciación y el gene looping, como es TFIIB (Henry et al., 1996; Knaus et al., 1996; Singh and Hampsey, 2007).

\subsubsection{Sub1 y la Fosforilación de la RNAPII}

En los últimos años se han ido acumulando evidencias que indican que los coactivadores transcripcionales, Sub1, en levaduras, y PC4, en humanos, tienen una función relacionada con la fosforilación de la RNAPII. Así, por ejemplo, en 2005, se describieron una serie de interacciones genéticas alelo-específicas entre SUB1, KIN28 y FCP1 y se demostró que en el mutante subl $\triangle$ hay una menor densidad de polimerasa asociada a los genes, pero que ésta se encuentra hiperfosforilada en Ser2. Asimismo, se demostró que la presencia de Sub1 es necesaria para mantener niveles adecuados de la fosfatasa de elongación Fcp1 (Calvo and Manley, 2005). Por otra parte, en el caso de PC4, previamente se había demostrado que este factor es capaz de reprimir la fosforilación de la RNAPII in vitro, actuando como un inhibidor de la CTD-quinasa Cdk7 y de las quinasas Cdk1 y Cdk2 (Schang et al., 2000).

En conjunto, todos estos datos sugerían que Sub1 podría tener un papel más general, del que en un principio cabría esperarse de un simple coactivador de la transcripción, y que éste podría incluir la regulación de la fosforilación y la elongación de la transcripción. Por lo tanto, en base a los mismos, se planteó el estudio que se presenta a continuación. 


\section{Objetivos}


1. Estudiar el papel del coactivador transcripcional Sub1 en la regulación de la fosforilación de la RNAPII.

2. Investigar si Sub1 tiene un papel en la elongación de la transcripción y, de ser así, si éste lo ejerce directamente e independientemente de su función en la regulación de la fosforilación de la RNAPII. 
3. Resultados 
1.- Papel del factor Sub1 en la regulación de la fosforilación de la RNA polimerasa II 


\subsection{SUB1 regula negativamente a la CTD-quinasa de iniciación Kin28}

Hace unos años, Calvo y Manley (2005) describieron una interacción genética específica de alelo entre $S U B 1$ y varios mutantes de la CTD-quinasa de iniciación KIN28. Así, mostraron que la deleción de SUB1 causa letalidad sintética en un mutante kin28, kin28-T17D, carente de actividad quinasa, agrava los fenotipos de crecimiento lento y termosensibilidad de un mutante con actividad catalítica reducida, kin28-K36A, mientras que no provoca ningún efecto en el mutante kin28-T162A, cuya mutación no afecta a la actividad quinasa de Kin28. Por otra parte, en el mismo estudio se describió la interacción genética entre SUB1 y la CTD-fosfatasa de elongación Fcp1. En este caso, observaron que la deleción de $S U B 1$ agrava el fenotipo de un mutante $f c p l-1$ con actividad fosfatasa reducida, pero que no tiene efecto sobre el mutante $f c p 1-3$, cuya mutación no afecta a la actividad catalítica. Además, demostraron que en células carentes de SUB1 los niveles de Fcp1 y su reclutamiento a los genes se encuentran reducidos, mientras que tiene lugar un incremento en los niveles de RNAPII fosforilada en Ser2. Todos estos resultados, en su conjunto, sugerían una posible relación funcional entre Sub1 y la fosforilación del CTD.

Con el fin de determinar si Sub1 podría tener un papel general o específico en la fosforilación de la RNAPII y si este se podría ejercer a través de las quinasas, o sólo regulando los niveles de Fcp1, nos planteamos el estudio que se presenta a continuación. En primer lugar, decidimos investigar el significado funcional de la relación genética entre $S U B 1$ y KIN28 y, en segundo lugar, quisimos extender nuestro estudio al resto de las quinasas del CTD, Srb10, Bur1 y Ctk1.

\subsubsection{La deleción de $S U B 1$ da lugar a un incremento en la actividad de Kin28}

Con el objetivo de profundizar en el significado biológico de la interacción genética entre SUB1 y KIN28, decidimos estudiar si Sub1 afectaba a la actividad quinasa de Kin28 y/o a su reclutamiento a los promotores génicos durante la transcripción. Para ello, llevamos a cabo dos estrategias distintas: ensayos de actividad quinasa in vitro y ensayos de inmunoprecipitación de cromatina o ChIP.

Para los ensayos de actividad quinasa in vitro se utilizaron cepas que expresaban Kin28 marcada en su extremo C-terminal con tres copias del epítopo hemaglutinina (HA) en una cepa silvestre (wt) y en el mutante de deleción de SUB1 (subl $\Delta$ ). Se prepararon extractos totales y se inmunoprecipitó Kin28-HA utilizando el anticuerpo 
anti-HA. Los complejos quinasa así purificados se utilizaron para ensayar la actividad enzimática utilizando como sustrato la proteína recombinante GST-CTD. Las reacciones se realizaron por duplicado, incubándose una réplica en presencia de ATP y la otra sin ATP. Posteriormente, la fosforilación del sustrato GST-CTD se analizó por Western Blot (Figura 7). Primero se analizó la fosforilación en serina 5 con el anticuerpo monoclonal H14 (CTD-Ser5P) y, en una segunda incubación, con el anticuerpo 8WG16 (anti-Rpb1CTD) se analizaron los niveles correspondientes al CTD no fosforilado (Bregman et al., 1995; Thompson et al., 1989). Como se observa en la Figura 7A, sólo en presencia de ATP, Kin28-HA es capaz de fosforilar eficientemente en Ser5 a la proteína GST-CTD y, además, su actividad quinasa se encuentra aumentada en ausencia de Sub1. Realizamos un segundo ensayo (Figura 7B) en el que además se llevó a cabo una inmunoprecipitación paralela para analizar los niveles de Kin28-HA en ambas cepas, wt y subl $\Delta$, utilizando el anticuerpo anti-HA, y en el que se analizaron los niveles de la proteína PGK como control de cantidad de proteína total en los extractos utilizados en las inmunoprecipitaciones. En este caso, analizamos la fosforilación en Ser5 con el anticuerpo monoclonal CTD4H8, que reconoce específicamente la fosforilación en serina 5 (anti-CTDSer5P, Figura 7B, panel superior; (Stock et al., 2007). El anticuerpo H14, usado en el ensayo anterior (Figura 7A), se ha utilizado comúnmente para analizar fosforilación en Ser5, aunque su especificidad ha sido cuestionada en algunos trabajos. Al parecer, el anticuerpo H14 reconoce un patrón de fosforilación del CTD que se corresponde con el de la polimerasa asociada a las regiones 5' de los genes, reaccionando indistintamente con residuos fosforilados en serina 5 y con residuos fosforilados a la vez en serina 5 y serina 2 (Jones et al., 2004). Como se muestra en la figura 7B, la fosforilación del GST-CTD mediada por Kin28HA es mayor en ausencia de Sub1 y esto no es debido a una alteración en los niveles de la quinasa. Este resultado es similar al mostrado en la figura 7A y las diferencias en el patrón de fosforilación del sustrato GST-CTD observables entre ambos ensayos se deben a las diferencias de especificidad de los anticuerpos. En cualquier caso, estos resultados sugieren que Sub1 ejerce un efecto negativo sobre la actividad de Kin28. 
A

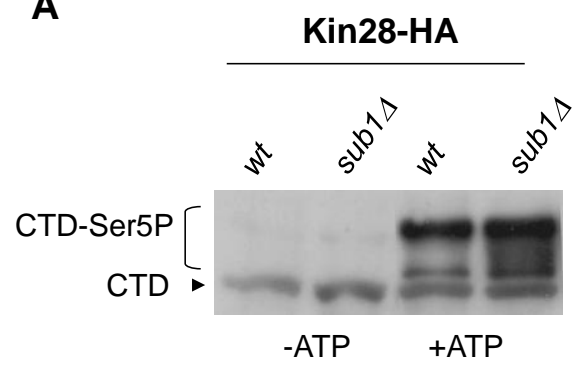

B

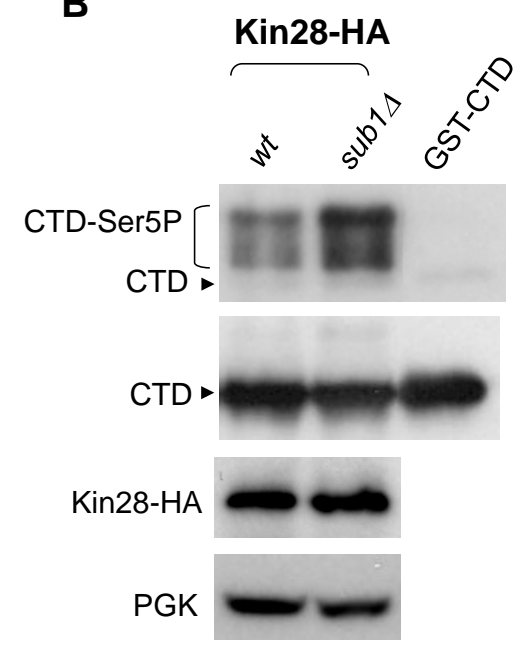

Ensayos de actividad quinasa in vitro

Figura 7. La deleción de $S U B 1$ da lugar a un incremento en la actividad CTD-quinasa de Kin28. (A) Ensayo de actividad quinasa in vitro. Se prepararon extractos totales de células $w t$ y sublu expresando Kin28-HA. Los complejos proteicos asociados a la quinasa se purificaron por inmunoprecipitación con el anticuerpo 12CA5 (anti-HA) acoplado a bolitas de proteína A-sefarosa, y la actividad catalítica se ensayó en ausencia y presencia de $2.5 \mathrm{mM}$ de ATP y de la proteína recombinante GST-CTD, utilizada como sustrato. Para analizar la fosforilación del CTD, las mezclas de reacción se sometieron a electroforesis en gel SDS-PAGE y posterior inmunoblot, usando los siguientes anticuerpos: H14 (anti-CTD Ser5P) y 8WG16 (anti-CTD). (B) Ensayo de actividad quinasa in vitro para cepas Kin28HA $w t$ y subl $\Delta$, realizado según se detalla en (A). Además, se realizó una inmunoprecipitación adicional con anti-HA para comprobar que los niveles de inmunoprecipitación de Kin28-HA eran similares en ambas cepas, $w t$ y subla. Como control de niveles similares de proteína total se analizaron los niveles de la proteína 3-fosfoglicerato quinasa, Pgk1 (PGK). En este caso el anticuerpo anti-CTD Ser5P fue CTD4H8.

A continuación, para verificar la especificidad de los ensayos de actividad quinasa in vitro, realizamos varios experimentos control. En primer lugar, para descartar una posible actividad quinasa inespecífica asociada a la inmunoprecipitación con el anticuerpo anti-HA, y no debida a Kin28, realizamos un ensayo utilizando extractos procedentes de las siguientes cepas: dos cepas que expresan Kin28-HA, wt y kin28K36A (mutante con actividad quinasa reducida (Rodriguez et al., 2000), una cepa que expresa Sub1-HA, otra que expresa Cdc5-HA (una quinasa de mitosis y citoquinesis no relacionada con la fosforilación del CTD (Alexandru et al., 2001) y, por último, las cepas $w t$ y $s u b 1 \Delta$, que no expresan ninguna proteína marcada con el epítopo HA (Figura 8A). En segundo lugar, realizamos otro ensayo quinasa inmunoprecipitando Kin28-HA y Cdc5-HA a partir de extractos de las cepas $w t$ y subl $\Delta$ con la intención de descartar un aumento inespecífico de la fosforilación residual en general, debido a la ausencia de SUB1. Como se aprecia en la figura 8A, solamente Kin28-HA wt es capaz de fosforilar eficientemente en Ser5 al sustrato GST-CTD y, además, de nuevo corroboramos que la 
actividad quinasa de Kin28 es específicamente mayor en el mutante $\operatorname{subl} \Delta$ que en la cepa $w t$ (Figura 8B).

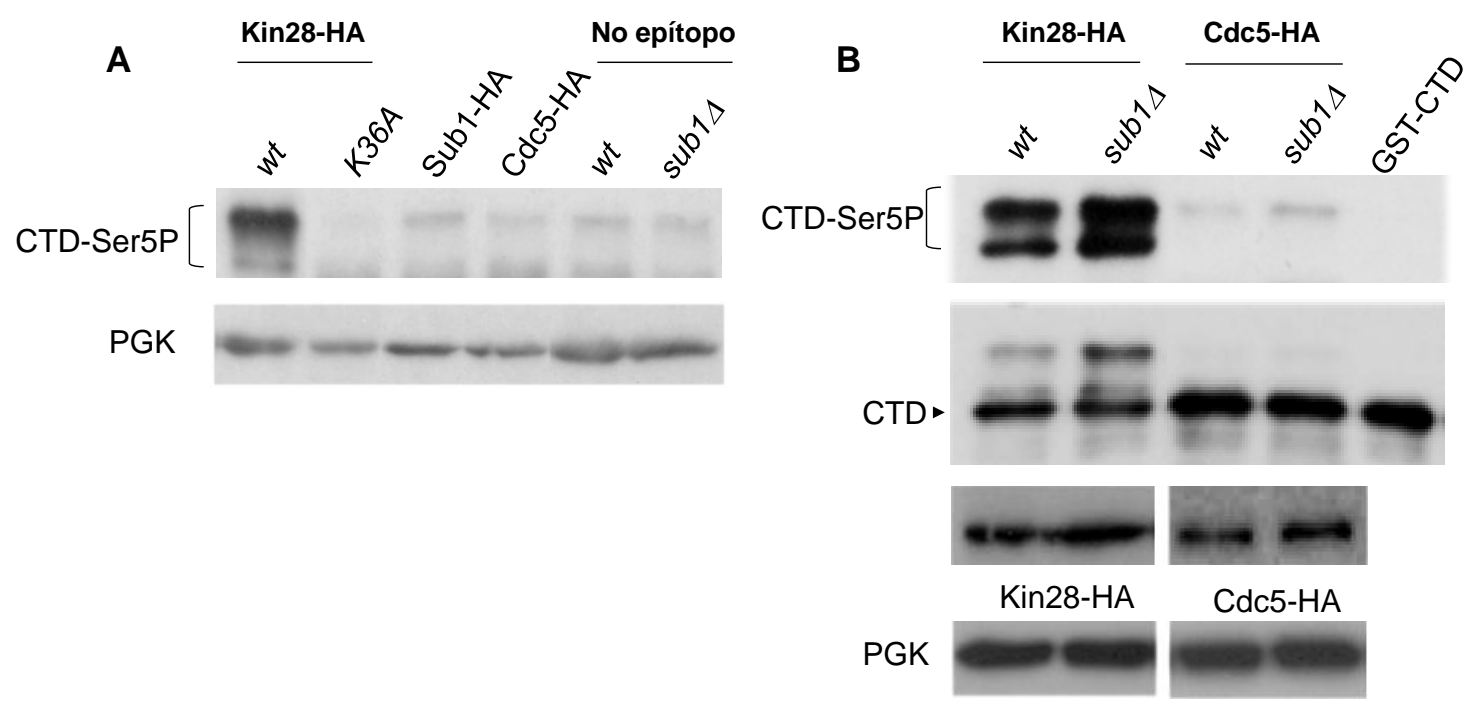

\section{Ensayos de actividad quinasa in vitro}

Figura 8. Especificidad de los ensayos de actividad quinasa in vitro. (A) Se prepararon extractos totales de las siguientes cepas: Kin28-HA (wt y kin28-K36A), Sub1-HA, Cdc5-HA y cepas sin ningún epítopo ( wt y sub1 $\Delta$ ). Con ellos se realizó un ensayo de actividad quinasa in vitro, como el detallado en la leyenda de la figura 7, y la fosforilación del CTD en Ser5 se analizó usando el anticuerpo CTD4H8. Como control de niveles totales de proteínas se analizaron los niveles de PGK en todas las cepas utilizadas. (B) Se prepararon extractos totales de las cepas wt y sub1 $\Delta$, expresando Cdc5-HA, y extractos de cepas wt y sub1 1 , expresando Kin28-HA. Se llevó a cabo un ensayo de actividad quinasa in vitro para analizar la fosforilación del CTD en Ser5, como en (A). Además se comprobó la purificación equivalente de ambas quinasas entre las cepas wt y subla mediante una inmunoprecipitación adicional, usando el anticuerpo anti-HA.

Asimismo, se estudió la posibilidad de que otra proteína quinasa del complejo de la RNAPII co-purificase con Kin28-HA en nuestros ensayos y que el incremento en la fosforilación en Ser5 observada no se debiera solamente a Kin28. Para ello, preparamos extractos totales de las cepas Kin28-HA, wt y subla, e inmunoprecipitamos Kin28 con el anticuerpo anti-HA y la RNAPII con un anticuerpo específico frente a la subunidad Rpb3 (anti-Rpb3). En la figura 9, se observa que solamente Kin28-HA es capaz de fosforilar al GST-CTD y, de nuevo, que lo hace de manera más eficiente en ausencia de SUB1. 


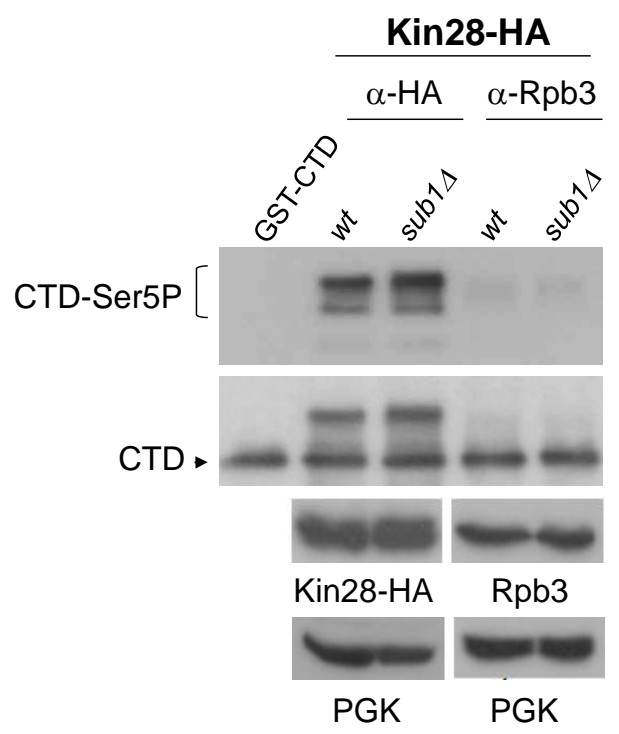

Ensayos de actividad quinasa in vitro

Figura 9. El incremento de la fosforilación en Ser5, en ausencia de $S U B 1$, es específico de Kin28 e independiente del complejo RNAPII. Se realizó un ensayo de actividad quinasa in vitro para analizar la fosforilación del CTD en Ser5, inmunoprecipitando Kin28-HA y Rpb3 desde extractos de cepas Kin28HA wt y sub14. La fosforilación en Ser5 se analizó usando el anticuerpo CTD4H8, y los niveles de GSTCTD en cada reacción con el anticuerpo 8WG16. Mediante una inmunoprecipitación adicional se comprobó que los niveles de inmunoprecipitación, tanto de Kin28-HA, como de Rpb3, eran similares en ambas cepas, wt y subl $\Delta$. Como control de niveles de proteína equivalentes en ambas cepas se analizaron los niveles de PGK.

Por último, realizamos un ensayo de complementación, transformando la cepa Kin28-HA sub1 $\Delta$ con un plásmido centromérico que contiene clonado el gen SUB1 bajo el control de su propio promotor. La cepa resultante se utilizó en un ensayo quinasa. Como cabía esperar, la presencia de $S U B 1$ rescataba los niveles de fosforilación de Kin28 en la cepa sub1 $\Delta$ (Figura 10). No obstante, este resultado no dilucidaba si el efecto de Sub1 sobre la actividad de Kin28 era directo o indirecto. Para resolver esta cuestión, se intentó la producción de una proteína Sub1 recombinante para utilizarla en un ensayo quinasa in vitro y determinar si la adición de la misma en un ensayo realizado con extractos de la cepa subla reduciría los niveles de fosforilación del CTD a los niveles observados en la cepa $w t$. Sin embargo, todos los intentos de expresión y purificación de Sub1 recombinante fracasaron y, por el momento, queda sin resolver si Sub1 afecta a la actividad quinasa de Kin28, directa o indirectamente. 


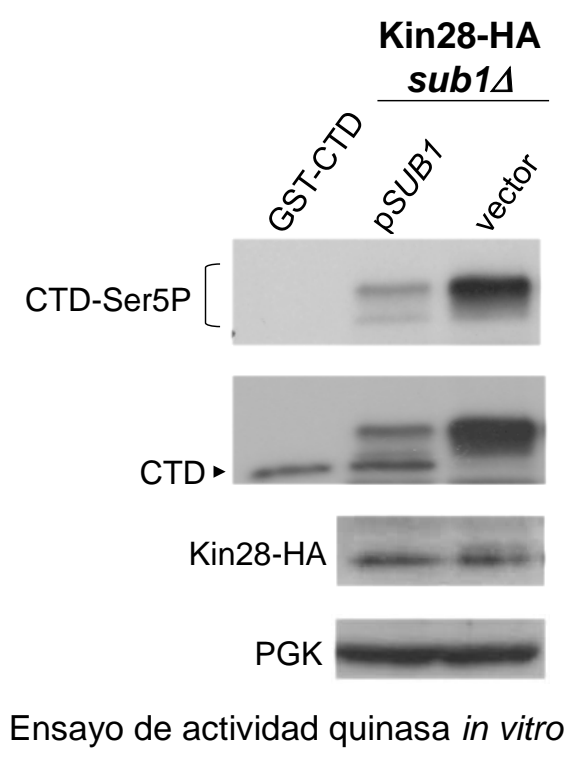

Figura 10. La ausencia de $S U B 1$ es responsable de los efectos observados en la actividad de Kin28 sobre el sustrato GST-CTD in vitro. La cepa Kin28-HA subla se transformó con un plásmido vacío (vector) o con un plásmido centromérico (pRS315) conteniendo el gen SUB1 bajo su propio promotor (pSUB1). Se prepararon extractos totales de las cepas transformantes y se llevó a cabo un ensayo quinasa in vitro, analizándose la fosforilación del CTD en Ser5 tal y como se detalla en la figura 9.

\subsubsection{La deleción de $S U B 1$ conduce a un incremento en la asociación de Kin28 a los promotores génicos.}

Dado que Kin28 fosforila los residuos Ser5 del CTD de la RNAPII cuando ésta se encuentra asociada a las regiones próximas a las secuencias promotoras (Rodriguez et al., 2000), decidimos estudiar si SUB1 afectaba también al reclutamiento de la misma a los promotores. Para ello, realizamos ensayos de inmunoprecipitación de cromatina (ChIP) utilizando las mismas cepas que en el ensayo quinasa: wt y subl $\Delta$, expresando Kin28-HA, y mediante qPCR analizamos la asociación de Kin28-HA a los promotores de varios genes de expresión constitutiva ( $A D H 1, A C T 1, P Y K 1$ y PMA1). En la figura 11A, se representa la asociación relativa de Kin28-HA a los promotores en el mutante $s u b 1 \Delta$ respecto a su asociación en la cepa $w t$, que se considera del $100 \%$. En ausencia de $S U B 1$ se produce un incremento del reclutamiento de Kin28 para todos los genes analizados, con valores que van desde el $125 \%$ para $A D H 1$, hasta el $225 \%$ para $A C T 1$.

Por otra parte, trabajos anteriores habían demostrado que en el mutante subl $\Delta$ disminuía el reclutamiento de la RNAPII a los genes a lo largo de todo un ciclo transcripcional (Calvo and Manley, 2005; Rosonina et al., 2009). Por lo tanto, esto sugería que los niveles de ocupación de Kin28-HA en el mutante subl $\Delta$ podrían ser aún mayores si teníamos en cuenta los valores de ocupación de su sustrato, Rpb1. 
A

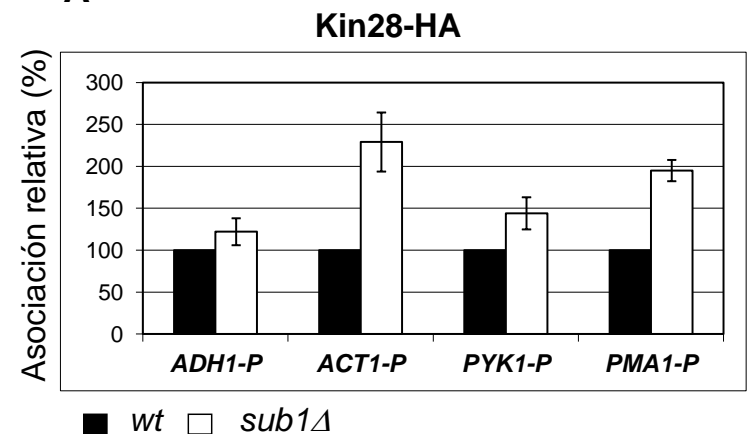

B

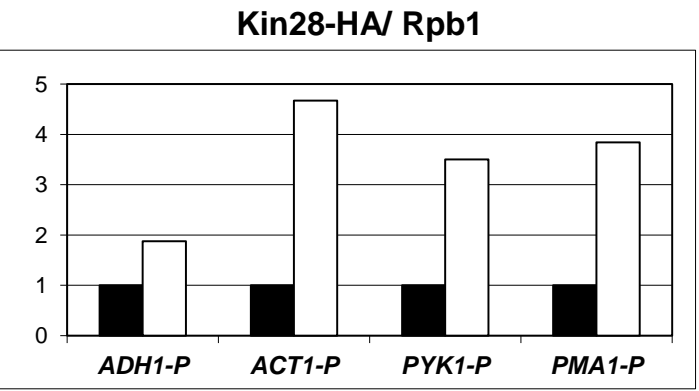

wt $\square$ sub1s

ChIP

Figura 11. La deleción de $S U B 1$ conduce a un aumento en la asociación de Kin28 a los promotores génicos. Análisis de los ensayos de ChIP. (A) La unión de Kin28-HA a los promotores de cuatro genes de expresión constitutiva (ADH1-P, ACT1-P, PYK1-P, PMA1-P) se analizó y cuantificó por qPCR (ver Materiales y Métodos). En el eje $y$ se representa el porcentaje de Kin28 asociada a los promotores (asociación relativa) en el mutante $s u b 1 \Delta$ respecto a la estirpe $w t$, donde éste se considera del $100 \%$. Las barras de error indican la desviación estándar. (B) Cociente Kin28-HA/Rpb1. Los porcentajes de asociación de Kin28-HA y Rpb1 en el mutante sub1 1 respecto a los del wt se cuantificaron independientemente, después se calculó el cociente de ambos y se representó como en (A). Los ensayos se realizaron al menos 3 veces de manera independiente.

Decidimos entonces analizar por ChIP los niveles de polimerasa total asociada a los promotores génicos (medidos a través de Rpb1) en las cepas wt y subl $\Delta$, que expresan Kin28-HA. Para ello, usamos el anticuerpo 8WG16 que, aunque inicialmente se describió como específico frente a las formas no fosforiladas de Rpb1 (Bregman et al., 1995; Thompson et al., 1989), se ha usado frecuentemente para medir polimerasa total, incluso en análisis de asociación a escala genómica (ChIP on chip (Drouin et al., 2010). De hecho, se ha observado que el patrón de distribución de la polimerasa a lo largo de los genes, usando el anticuerpo 8WG16, es similar al patrón obtenido usando el anticuerpo anti-Rpb3 (Bataille et al., 2012). Esto se debe probablemente a que a lo largo de la transcripción la polimerasa mantiene en su CTD repeticiones del consenso no fosforiladas. En el caso del mutante subla, se ha demostrado que la disminución de la asociación de la polimerasa a los genes es similar usando ambos anticuerpos (8WG16 y anti-Rpb3 (Calvo and Manley, 2005; Rosonina et al., 2009).

Preparamos cromatina a partir de las cepas Kin28-HA wt y subld, inmunoprecipitamos Rpb1 y analizamos su asociación a los mismos promotores que en el análisis del reclutamiento de Kin28. Se calculó el cociente entre las asociaciones de Kin28 y Rpb1 de forma independiente para las cepas $w t$ y $s u b 1 \Delta$, después se calculó el ratio $s u b 1 \Delta / w t$ para dicho cociente y se representó. En la figura 11B se representan, por lo tanto, las asociaciones relativas de Kin28 y Rpb1 para el mutante $s u b 1 \Delta$ frente a las de la estirpe $w t$, consideradas como 1. La asociación relativa de Kin28 respecto de Rpb1 
es mayor en el mutante sub1 $\Delta$ para todos los genes estudiados, con valores hasta casi cinco veces superiores a la asociación relativa de la estirpe wt en genes como ACT1.

En su conjunto, los resultados descritos hasta ahora muestran que la deleción de SUB1 conduce a un incremento en la actividad catalítica de Kin28 y a su asociación a los genes, sugiriendo que Sub1 podría estar modulando la fosforilación del CTD en Ser5 por Kin28.

\subsubsection{La deleción de $S U B 1$ da lugar a un incremento de los niveles de polimerasa} fosforilada en Ser5 asociada a las regiones 5' de los genes

La fosforilación de la RNAPII en los residuos Ser5 llevada a cabo por Kin28 tiene lugar en las regiones 5' de los genes y es progresivamente sustituida por la fosforilación en Ser2 durante la elongación transcripcional (Komarnitsky et al., 2000). Como la deleción de $S U B 1$ produce un incremento en la asociación a los genes y en la actividad de Kin28, quisimos estudiar si estos efectos, en consecuencia, conducían a un incremento en la presencia de polimerasa fosforilada en Ser5 asociada a los promotores. Así, realizamos ensayos de ChIP en las cepas Kin28-HA wt y sub1 $\Delta$, para analizar la unión de polimerasa, total y fosforilada específicamente en Ser5, a los promotores de los genes ACT1, PMA1 y PYK1. Como se observa en la figura 12, en ausencia de $S U B 1$, a pesar de que los niveles de polimerasa total asociada se encuentran disminuidos, hay un incremento de la polimerasa fosforilada en Ser5 en los promotores analizados, corroborando que, en efecto, la deleción de $S U B 1$ provoca un incremento en la actividad CTD-quinasa de Kin28 sobre la polimerasa in vivo.

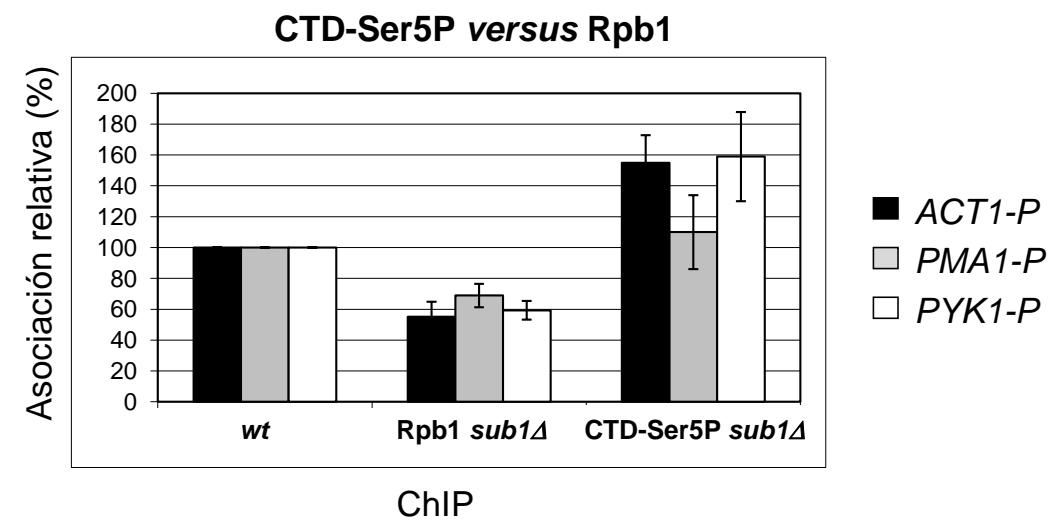

Figura 12. La deleción de $S U B 1$ produce un aumento en los niveles de polimerasa fosforilada en Ser5 asociada a los promotores génicos. Se realizaron ensayos de ChIP para Rpb1 total y Rpb1 fosforilada en Ser5 (CTD-Ser5P) en las cepas $w t$ y sub1 $\Delta$, usando los anticuerpos 8WG16 (antiRpb1CTD) y CTD4H8 (anti-CTDSer5P), respectivamente. La unión de Rpb1 y CTD-Ser5P a los promotores de ACT1, PMAl y PYK1 se cuantificó por qPCR. En el eje y se representa la ocupación relativa de Rpb1 asociada a los promotores en el mutante subl $\Delta$ respecto a los niveles en la estirpe $w t$, donde la asociación se considera de $100 \%$. Las barras de error representan la desviación estándar. 


\subsubsection{La deleción de $S U B 1$ conduce a un ligero incremento de los niveles del complejo de capping}

Durante el proceso de iniciación de la transcripción, cuando el transcrito consta tan solo de unos 25 nucleótidos de longitud, sufre la adición en su extremo 5' de una 7metilguanosina o cap (Shuman, 2001). En S. cerevisiae, la adición del cap se lleva a cabo gracias a la acción de tres enzimas distintas: el heterodímero formado por la trifosfatasa Cet1 más la guanilil-transferasa Ceg1 y la metil-transferasa Adb1. El capping es un procesamiento restringido a los transcritos de la RNAPII y la maquinaria que lo lleva a cabo se asocia específicamente al CTD fosforilado durante la iniciación (Komarnitsky et al., 2000; Schroeder et al., 2000). En concreto, la subunidad Ceg1 se asocia al CTD fosforilado en Ser5 por Kin28 (Rodriguez et al., 2000). Curiosamente, hace tiempo, se describieron interacciones genéticas específicas de alelo de un mutante ceg1, ceg1-250, con los mutantes kin28, kin28-T17D, kin28-K36A y kin28-T162A, con los que también se había observado una interacción específica de alelo con SUB1 (Calvo and Manley, 2005) y con resultados similares (Rodriguez et al., 2000). Sin embargo, la deleción de SUB1 no afecta al fenotipo del mutante ceg1-250 (Calvo and Manley, 2005). No obstante, como los niveles de polimerasa fosforilada en Ser5 se encuentran aumentados en células subla (Figura 12), decidimos estudiar si el reclutamiento de la maquinaria de capping, medido a través de la asociación a la cromatina de su subunidad Ceg1, se encontraba también incrementado. Para ello, delecionamos $S U B 1$ en una cepa que expresa Ceg1-HA y la usamos, junto con su isogénica silvestre, en un ensayo de ChIP para analizar la asociación de Ceg1-HA a varios promotores génicos (ACT1, PMA1 y PYK1). Como puede observarse en la figura 13, en el mutante sub1 $\Delta$ la asociación de Ceg1-HA se encuentra disminuida respecto a la situación de la cepa wt. Sin embargo, si comparamos el reclutamiento de Ceg1-HA con el de la polimerasa total en ambas cepas, wt y subl $\Delta$, comprobamos que, en efecto, en ausencia de Sub1 hay un ligero aumento de los niveles de Ceg1-HA, al menos en el caso de los genes PMA1 (75.36\% versus 56.5\%) y PYK1 (79.12\% versus $50.15 \%)$. 


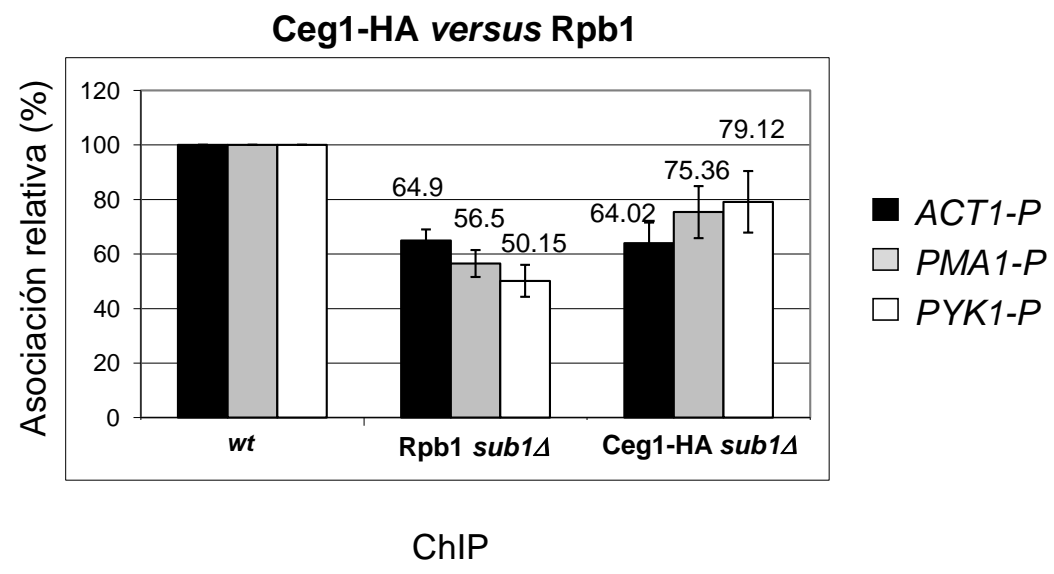

Figura 13. La deleción de $S U B 1$ da lugar a un incremento en el reclutamiento del complejo de capping, medido a través de su subunidad Ceg1. Se analizó la unión de Rpb1 y Ceg1-HA a los promotores de los genes ACT1, PMAl y PYKl en células wt y subla, utilizando los anticuerpos 8WG16 (Rpb1) y anti-HA, respectivamente. Los números en el eje $y$ representan los porcentajes de Rpb1 y Ceg1HA asociados a los promotores en el mutante $s u b 1 \Delta$ relativos a los niveles en la cepa $w t$, donde el nivel de asociación se considera del 100\%. Las barras de error representan la desviación estándar.

En resumen, nuestros resultados muestran que la deleción de $S U B 1$ da lugar a un incremento en la actividad y el reclutamiento de la CTD-quinasa Kin28 y, en consecuencia, a un incremento in vivo de la fosforilación en Ser5 de la RNAPII asociada a las regiones $5^{\prime}$ de los genes y, en menor medida, a un aumento en el reclutamiento del complejo de capping. Además, estos resultados sugieren un papel negativo de Sub1 durante la iniciación de la transcripción.

\section{2. $S U B 1$ regula positivamente a la CTD-quinasa Srb10}

A la fosforilación del CTD llevada a cabo por Srb10 se le han atribuido efectos contrapuestos sobre la transcripción. Por un lado, se ha propuesto que fosforila a la polimerasa, inhibiendo el reclutamiento de la misma a los promotores antes de la formación del PIC (Hengartner et al., 1998). Por otro lado, estudios más recientes han mostrado que su actividad quinasa, junto con la de Kin28, promueve la salida de la RNAPII del promotor y la formación del complejo scaffold (Liu et al., 2004). Puesto que las funciones de Kin28 y Srb10 están íntimamente ligadas, decidimos estudiar si Sub1 podía afectar también a la fosforilación mediada por Srb10.

\subsubsection{Interacción genética entre $S U B 1$ y $S R B 10$}

Para estudiar una posible relación entre Sub1 y Srb10 realizamos en primer lugar un ensayo genético. $S R B 10$ es un gen no esencial cuya deleción produce un ligero 
retraso en el crecimiento a $30^{\circ} \mathrm{C}$ y $37^{\circ} \mathrm{C}$, mientras que el mutante subl $\Delta$ no tiene fenotipo aparente en condiciones normales de crecimiento (Figura 14A). Construimos el doble mutante srb10 $\operatorname{sub1\Delta }$ por reemplazamiento génico y analizamos su crecimiento en placa mediante ensayos de diluciones seriadas, junto con las cepas controles isogénicas. Como se muestra en la figura 14A, la deleción de SUB1 rescata parcialmente los defectos en el crecimiento del mutante sencillo $\operatorname{srb} 10 \Delta$, tanto a $30^{\circ} \mathrm{C}$, como a $37^{\circ} \mathrm{C}$. Por el contrario, al transformar el doble mutante $s r b 10 \Delta$ con un plásmido multicopia que sobre-expresa $S U B 1$ bajo el control del promotor constitutivo $A D H 1$, el fenotipo del mutante sencillo se agrava considerablemente. Observamos este mismo fenotipo cuando transformamos el doble mutante $\operatorname{srb} 10 \Delta s u b 1 \Delta$ con un plásmido que sobre-expresa $S U B 1$ bajo el control del promotor inducible GAL1 y se crecieron las células en presencia de galactosa (Figura 14B). Por lo tanto, SUB1 también interacciona genéticamente con SRB10, aunque con efectos opuestos a los observados para la interacción genética entre SUB1 y KIN28 (Calvo and Manley, 2005).

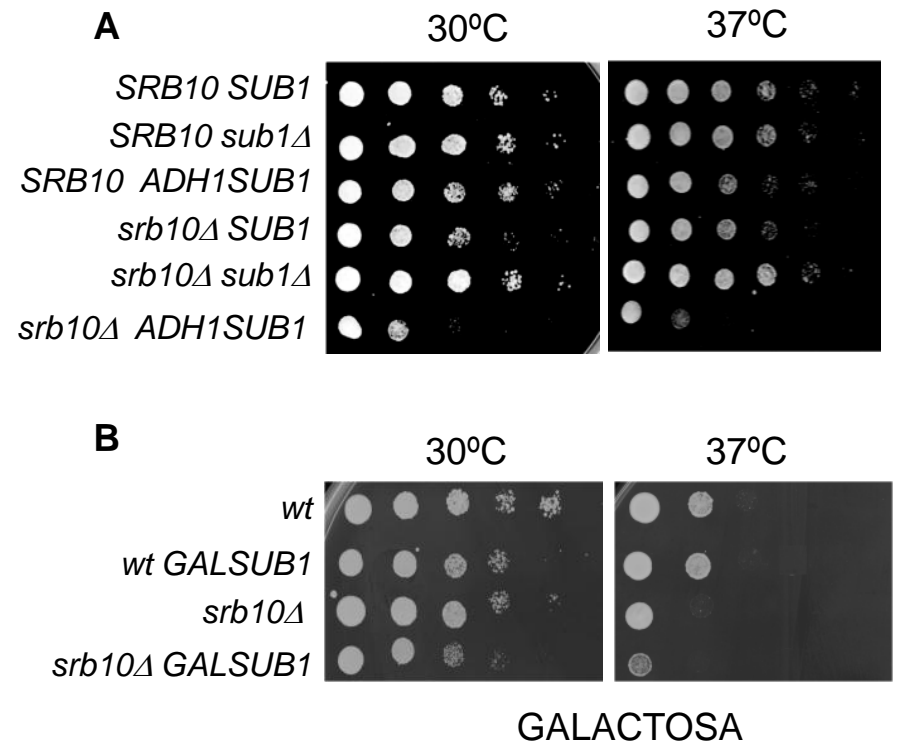

Figura 14. SUB1 interacciona genéticamente con $S R B 10$. (A) Ensayo de diluciones seriadas en placa que muestra que la deleción de $S U B 1$ rescata parcialmente el fenotipo de crecimiento lento del mutante srb10A, mientras que su sobreexpresión lo agrava. Para sobre-expresar SUB1, se clonó su ORF en un plásmido multicopia bajo el control del promotor constitutivo $A D H 1$ (ADH1SUB1) y se utilizó para transformar las cepas $w t$ y srb10 4 . Las cepas con los genotipos indicados se crecieron en placas de medio $\mathrm{SC}$ a $30^{\circ} \mathrm{C}$ y $37^{\circ} \mathrm{C}$ durante 2 días. (B) Ensayo de diluciones seriadas en placa de las cepas wt y $s r b 10 \Delta$, transformadas con un plásmido que sobre-expresa $S U B 1$ bajo el control del promotor inducible GAL1 Para la inducción del promotor GALl las cepas se crecieron en medio YEP con Galactosa.

\subsubsection{La actividad quinasa de Srb10 se encuentra disminuida en el mutante sub1 $\Delta$}

Con el objeto de estudiar si Sub1 podía estar afectando a la actividad catalítica de Srb10 se realizaron ensayos de actividad quinasa in vitro similares a los detallados para 
Kin28. Generamos una cepa que expresa Srb10 marcada en su extremo C-terminal con 13 copias del epítopo MYC, en la que delecionamos SUB1. Inmunoprecipitamos Srb10 vía el epítopo MYC, ensayamos su actividad quinasa sobre el sustrato GST-CTD y analizamos la fosforilación tanto en Ser5, como en Ser2, con anticuerpos específicos. Mediante una inmunoprecipitación paralela con el anticuerpo anti-MYC comprobamos que los niveles de Srb10-MYC eran similares en ambas cepas, wt y subla. Como se aprecia en la figura 15, y de acuerdo con resultados publicados previamente (Borggrefe et al., 2002; Hengartner et al., 1998; Ramanathan et al., 2001), Srb10 es capaz de fosforilar al CTD en ambos residuos, aunque con una mayor eficiencia en Ser5. En el mutante $\operatorname{sub1} \Delta$, dicha fosforilación se encuentra disminuida, mientras que los niveles totales de la quinasa no varían respecto a los niveles en la cepa wt. Este resultado sugiere que Sub1 influye positivamente sobre la actividad de Srb10, al contrario de lo que ocurre en el caso de Kin28.

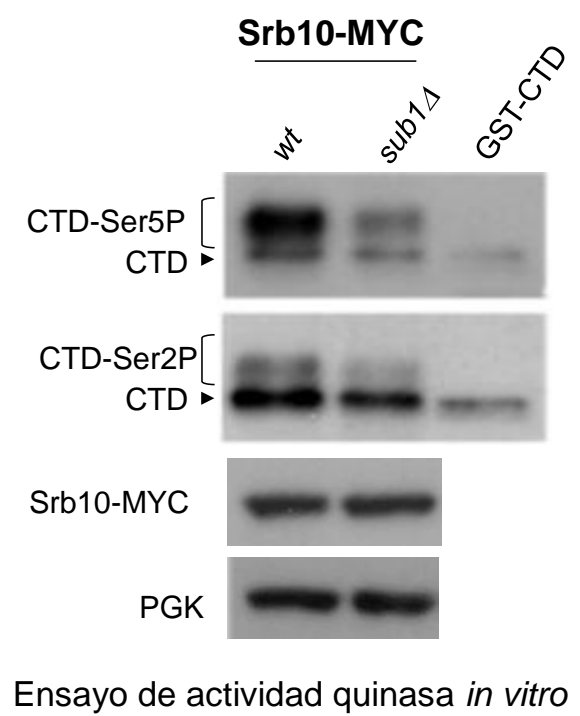

Figura 15. La actividad quinasa de Srb10 se encuentra disminuida en el mutante sub1 $\Delta$. Los resultados del ensayo de actividad CTD quinasa in vitro muestran que la deleción de SUB1 causa un descenso en la fosforilación del CTD por Srb10. Se prepararon extractos totales de células wt y subla expresando Srb10-MYC. El ensayo de actividad quinasa in vitro y el análisis de la fosforilación se realizaron como se detalla en la Figura 7. La fosforilación en Ser5 y Ser2 se analizó usando los siguientes anticuerpos: CTD4H8 (anti-CTDSer5P) y ab5095 (anti-CTDSer2P). Los niveles totales de GST-CTD presentes en las mezclas de reacción se analizaron con el anticuerpo 8WG16 (anti-CTD). Mediante inmunoprecipitación con anti-MYC se confirmó que los niveles de Srb10-MYC eran similares para ambas cepas. Como control de niveles de proteína equivalentes se analizaron los niveles de PGK.

\subsubsection{La deleción de $S U B 1$ influye negativamente en la asociación de Srb10 a los promotores}

Como en el caso de Kin28, ensayamos mediante ChIP la asociación de Srb10 a los promotores de varios genes de expresión constitutiva, sin embargo, ésta no fue lo 
suficientemente eficiente. Los valores de asociación obtenidos no alcanzaron niveles de enriquecimiento (IP/INPUT) muy significativos (por encima de 2), salvo para el caso del gen PYK1. Por lo tanto, decidimos analizar la unión de Srb10 a genes inducibles, cuya expresión depende de esta quinasa. Por ejemplo, se ha descrito que la actividad de Srb10 sobre el regulador Gal4 es necesaria para la activación de la transcripción del gen inducible GAL1 y que el complejo Srb8-11 se asocia a las secuencias UAS (Upstream Activating Sequences) del promotor de GAL1 tras su activación (Larschan and Winston, 2005). Así, para estudiar el efecto de la deleción de SUB1 sobre el reclutamiento de Srb10, realizamos ensayos de ChIP analizando la asociación de Srb10-MYC a la secuencia $U A S$ del gen $G A L 1$ en las cepas wt y sub1 $\Delta$. Para ello, crecimos las células en medio con rafinosa (expresión de GAL1 reprimida) hasta una densidad óptica de 1,0 a $600 \mathrm{~nm}$. En este momento las células se recogieron por centrifugación, se lavaron y se dividieron en dos mitades. Una de ellas se transfirió a medio con rafinosa y la otra a medio con galactosa (expresión de GAL1 activada) y se incubaron durante 20 minutos, para permitir la inducción de los genes $G A L$ (ver Materiales y Métodos). Se comprobó la inducción del gen GAL1 mediante RT-PCR que, como puede observarse en la figura 16 (panel superior), solamente tiene lugar en presencia de galactosa. También se analizaron los niveles de $S U B 1$ y $S R B 10$, así como los del gen $P Y K 1$, de expresión constitutiva e independiente de la fuente de carbono, como control de carga. La deleción de SUBI no afecta a la transcripción de SRB10 (Figura 16, panel inferior), aunque, curiosamente, se observa un incremento en los niveles de $S U B 1$ durante la inducción con galactosa (Figura 16, panel medio), sugiriendo una posible función de Sub1 en la transcripción dependiente de esta fuente de carbono.

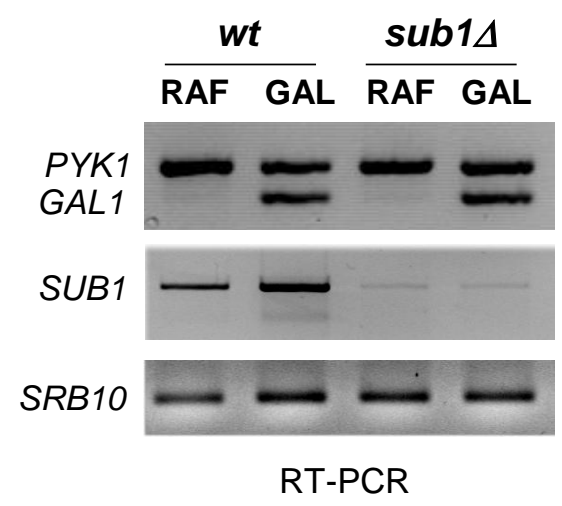

Figura 16. Inducción de la expresión de $\boldsymbol{G A L 1}$. Ensayo de RT-PCR para comprobar la inducción de la transcripción del gen GAL1. Se aisló RNA total de las cepas wt y subl $\Delta$ crecidas en condiciones de no inducción (rafinosa 2\%, RAF) y en condiciones de inducción (galactosa 2\%, GAL). Se sintetizó cDNA y se utilizó como molde en una PCR en la que se usaron oligonucleótidos específicos para los genes $P Y K 1$, GAL1, SUB1 y SRB10. Los productos de PCR se sometieron a electroforesis en gel de agarosa teñido con bromuro de etidio. 
A continuación, preparamos cromatina de las células Srb10-MYC wt y subla crecidas en las condiciones de represión e inducción para GAL1 detalladas más arriba. Analizamos mediante qPCR la asociación de Srb10-MYC a la secuencia UAS del gen GAL1 y al promotor del gen PYK1. Como puede observarse en la figura 17, Srb10MYC se asocia solamente a GAL1 en condiciones de inducción (galactosa) y a PYK1 en ambas condiciones de crecimiento (rafinosa y galactosa), aunque de modo menos eficiente. Curiosamente, la asociación de Srb10-MYC es menor en el mutante sub1A para ambos genes (aproximadamente un 50\% menor; Figura 17). Este resultado concuerda con el obtenido para los ensayos de actividad quinasa in vitro (Figura 15) y sugiere un papel positivo de Sub1 en la asociación de Srb10 a la cromatina.

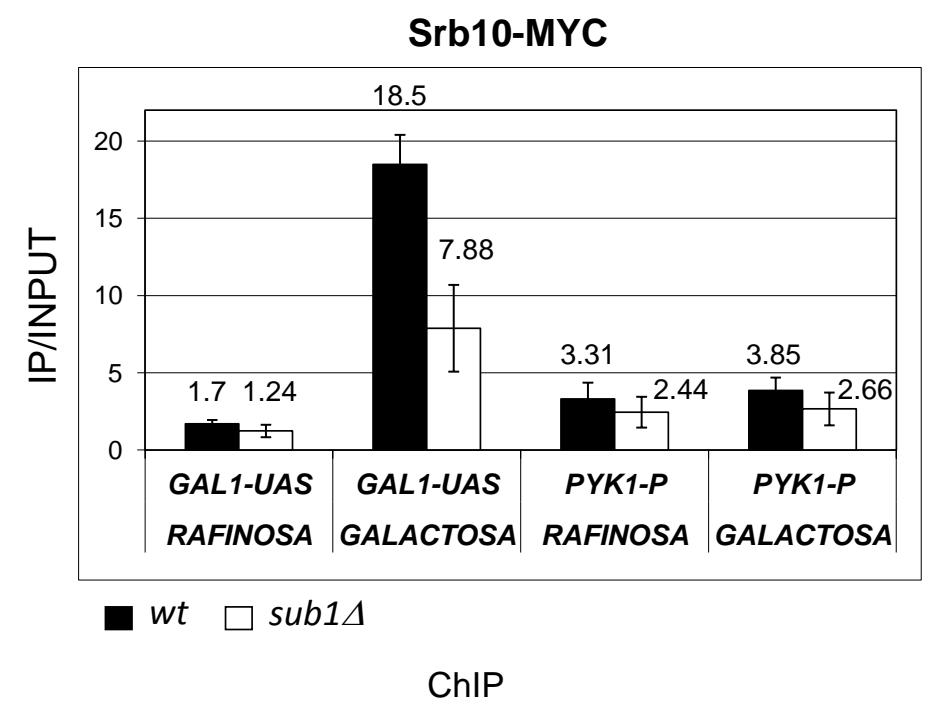

Figura 17. La deleción de $S U B 1$ influye negativamente en la asociación de Srb10 a los promotores génicos. Análisis de los ensayos ChIP para comparar la asociación de Srb10-MYC al promotor del gen PYKl (PYK1-P) y a la secuencia UAS del gen GALl (GAL1-UAS) en cepas wt y subl , crecidas en condiciones de no inducción (Rafinosa) y en condiciones de inducción (Galactosa). La cuantificación se realizó por qPCR. En la gráfica, los números del eje y representan el cociente entre los valores de amplificación obtenidos para cada par de oligonucleótidos específicos respecto al control negativo (región intergénica del cromosoma VII), utilizando como molde la cromatina inmunoprecipitada (IP) y normalizado para las muestras input. Las barras de error indican desviación estándar.

\subsubsection{La deleción de $S R B 10$ da lugar a un incremento en la actividad quinasa de} Kin28, consecuencia de un incremento en los niveles de la proteína y del transcrito

En humanos existe una co-regulación entre las proteínas homólogas de Srb10 y Kin28 (Cdk8 y Cdk7, respectivamente). De hecho, se ha descrito que Cdk8 es capaz de fosforilar al par ciclina de Cdk7/Ccl1 e inactivarlo (Akoulitchev et al., 2000). Aunque una situación similar no ha sido descrita para levaduras, se ha observado que durante el ciclo de división celular meiótica Srb10 es capaz de inhibir la transcripción de KIN28 (Ohkuni and Yamashita, 2000). Estos datos nos llevaron a plantear la hipótesis de que la 
disminución de la actividad catalítica y del reclutamiento a la cromatina de Srb10 observada en el mutante subl $\Delta$ pudiese estar contribuyendo a los efectos observados para Kin28. Por lo tanto, decidimos construir el mutante de deleción sencillo srb10 4 y doble $\operatorname{srb} 10 \Delta$ sub1 $\Delta$ en la cepa Kin28-HA y realizar un ensayo de actividad quinasa in vitro sobre el sustrato GST-CTD. Al analizar los niveles de inmunoprecipitación de Kin28-HA en las cepas $w t, \operatorname{srb} 10 \Delta$ y srb10 $\Delta$ sub1 $\Delta$ encontramos que estos son mucho mayores en el mutante de deleción de SRB10 (Figura 18A) y, en consecuencia, la actividad quinasa de Kin28 sobre GST-CTD se encontraba significativamente incrementada en la cepa srb10 $\Delta$ (Figura 18A). En el doble mutante srb10 $\Delta$ subl $\Delta$ los niveles y la actividad de Kin28-HA son similares a los del mutante sencillo srb10 (Figura 18A, B). Además, mediante RT-PCR comprobamos que el efecto de la deleción de $S R B 10$ sobre los niveles de Kin28 es debido a un incremento de la transcripción del gen codificante de la quinasa (Figura 18C).

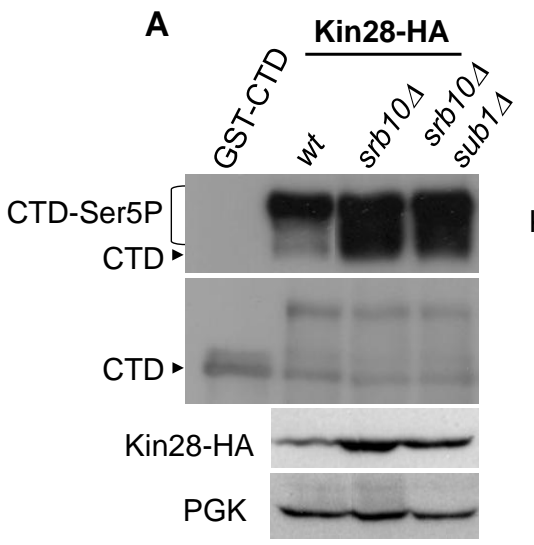

Ensayo de actividad quinasa in vitro
B

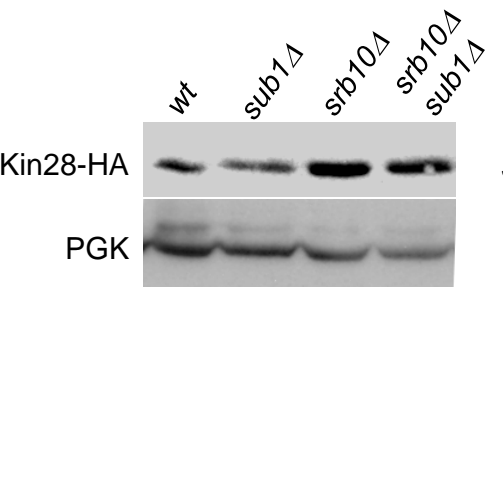

Western Blot
C

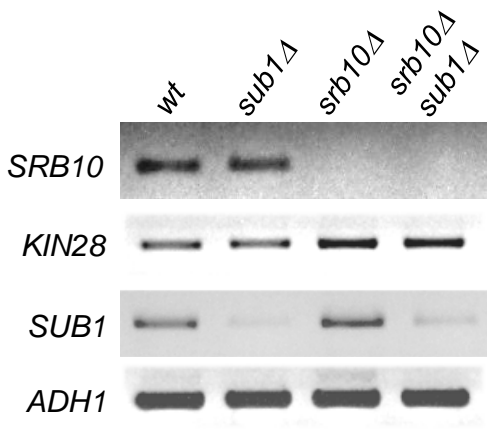

RT-PCR

Figura 18. La deleción de $S R B 10$ da lugar a un incremento en la actividad quinasa de Kin28, consecuencia de un incremento en los niveles de la proteína y del transcrito. (A) Ensayo de actividad CTD-quinasa in vitro, realizado con extractos procedentes de las cepas $w t, \operatorname{srb} 10 \Delta$ y $\operatorname{srb} 10 \Delta \operatorname{sub} 1 \Delta$, que expresan Kin28-HA. La fosforilación en Ser5 se analizó utilizando el anticuerpo CTD4H8. Los niveles totales de GST-CTD en cada reacción se midieron con el anticuerpo 8WG16 (anti-CTD). Se realizó una inmunoprecipitación paralela con anti-HA para corroborar la purificación de Kin28-HA en todas las cepas, $w t$, srb10 4 y $\operatorname{srb} 10 \Delta \operatorname{sub} 1 \Delta$. Los niveles totales de proteína se analizaron con anti-PGK. (B) Análisis mediante Western Blot de los niveles de Kin28-HA en las cepas wt, sub14, srb104 y srb10 $\Delta$ subl $\Delta$. Como control de la cantidad total de proteína presente en los extractos se analizaron los niveles de PGK. (C) RT-PCR para analizar la expresión de SRB10, KIN28 y SUB1 en las cepas wt, subla, srb104 y srb104 sub14, expresando Kin28-HA. Se purificó el RNA total y a partir de él se sintetizó el cDNA correspondiente, que se utilizó como molde en una PCR con oligonucleótidos específicos para SRB10, KIN28 y SUB1. Los niveles de ADH1 se analizaron como control de carga. Los productos de la reacción se resolvieron por electroforesis en gel de agarosa teñido con bromuro de etidio. 
Por otro lado, estudiamos si Srb10 podría estar regulando, además de los niveles de Kin28, los de otras proteínas relacionadas con la fosforilación del CTD. Así, delecionamos SRB10 en las siguientes cepas: Sub1-HA, Bur1-HA, Ctk1-HA y Ceg1HA. Preparamos extractos totales y analizamos por Western Blot los niveles de estas proteínas, junto con los de Kin28-HA, en las cepas wt y srb104. Como puede observarse en la figura 19, la deleción de SRB10 afecta específicamente a los niveles de Kin28-HA.

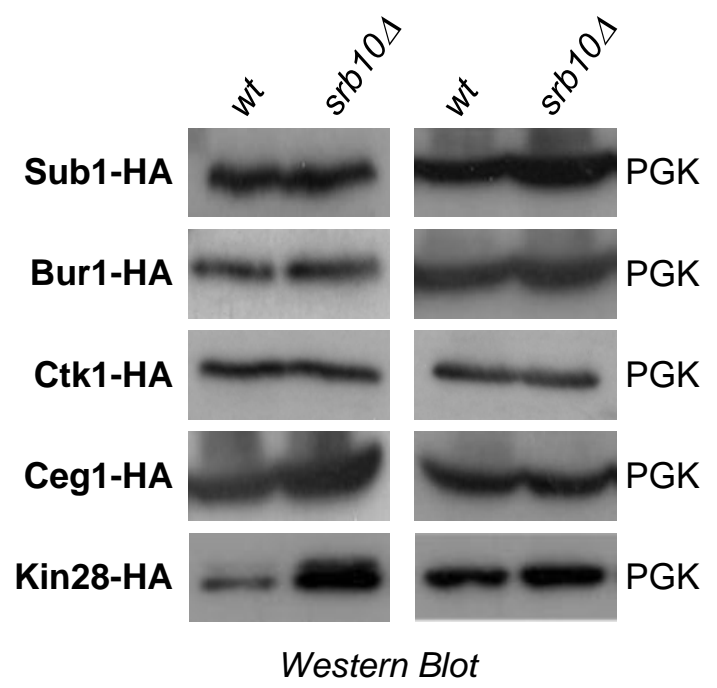

Figura 19. La deleción de $S R B 10$ afecta específicamente a los niveles de Kin28. Western Blot para analizar los niveles de Sub1-HA, Bur1-HA, Ctk1-HA, Ceg1-HA y Kin28-HA en células wt y srb104. Se prepararon extractos totales de las cepas $w t$ y $\operatorname{srb} 10 \Delta$ correspondientes y se analizaron con el anticuerpo anti-HA y PGK, como control de carga.

En las figuras 18 y 19 se muestra que la deleción de $S R B 10$ produce un aumento en los niveles de Kin28, lo que tiene como consecuencia un incremento en su actividad. Asimismo, si al igual que ocurre en eucariotas superiores, Srb10 reprime la actividad de Kin28, la deleción de $S R B 10$ no solamente alteraría los niveles de Kin28, sino que además aliviaría su efecto represor a nivel de actividad catalítica. Por otro lado, la deleción de SUB1 produce un aumento de la actividad de Kin28 y a la vez una disminución de la actividad de Srb10 sin afectar a los niveles de ambas proteínas (Figuras 7 y 15). Es posible que el incremento en la actividad CTD-quinasa de Kin28 producido por la deleción de SUB1 sea consecuencia, al menos en parte, del alivio del efecto represor de Srb10, al encontrarse su actividad y reclutamiento disminuidos en células subl $\Delta$ (Figuras 15 y 17). 


\subsection{SUB1 tiene un efecto negativo sobre la función de la quinasa Bur1}

Como demuestran los resultados presentados anteriormente, Sub1 está relacionado funcionalmente con las dos CTD-quinasas de iniciación, Kin28 y Srb10, influyendo de manera diferencial en su reclutamiento y actividad. Para completar nuestro análisis sobre la conexión entre Sub1 y la fosforilación del CTD, decidimos ampliar nuestro estudio a la CTD-quinasa de elongación Bur1.

\subsubsection{Interacción genética entre $S U B 1$ y BUR1}

Iniciamos el estudio con la búsqueda de una posible interacción genética entre $S U B 1$ y $B U R 1$. Puesto que BURl es un gen esencial, utilizamos los siguientes mutantes bur1: bur1-23 (Keogh et al., 2003) y bur1-2 (Prelich and Winston, 1993; Yao and Prelich, 2002). Ambas mutaciones alteran la actividad quinasa in vitro de Bur1. El mutante burl -23 presenta crecimiento lento a $28^{\circ} \mathrm{C}$, es termosensible a $37^{\circ} \mathrm{C}$ y sensible a la droga 6-azauracilo (6AU). Esta droga se ha utilizado muy a menudo para detectar defectos en la elongación (Desmoucelles et al., 2002; Escobar-Henriques et al., 2001; Riles et al., 2004; Shaw and Reines, 2000). Además, en la cepa bur1-23 los niveles totales de polimerasa asociada a los genes, analizados mediante ChIP, se encuentran disminuidos, aunque no se ve alterada su fosforilación (Keogh et al., 2003). En cuanto al mutante bur 1-2, muestra un ligero retraso en el crecimiento a $37^{\circ} \mathrm{C}$ y sensibilidad a 6AU (Prelich and Winston, 1993; Yao and Prelich, 2002).

Construimos el mutante doble burl-2 subl $\Delta$ mediante reemplazamiento génico y analizamos su fenotipo de crecimiento, junto con el de las cepas isogénicas, a $28^{\circ} \mathrm{C} \mathrm{y}$ $37^{\circ} \mathrm{C}$ y en presencia de $6 \mathrm{AU}$ a $28^{\circ} \mathrm{C}$. En la figura 20 (panel superior) se aprecia como la deleción de $S U B 1$, aunque no afecta al fenotipo de crecimiento del mutante burl-2, incrementa drásticamente su sensibilidad a 6AU. En el caso del mutante bur1-23,

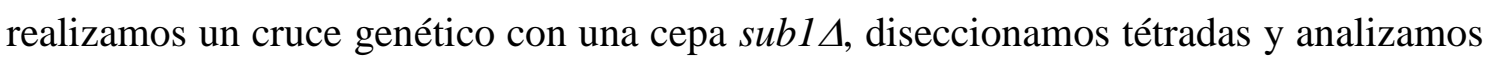
el fenotipo de los dobles mutantes a $28^{\circ} \mathrm{C}$ y $37^{\circ} \mathrm{C}$ y en presencia de $6 \mathrm{AU}$ a $28^{\circ} \mathrm{C}$. En este caso, la deleción de $S U B 1$ incrementa ambos fenotipos, crecimiento lento y sensibilidad a 6AU (Figura 20, panel inferior). Estos resultados confirman la existencia de una interacción genética entre SUB1 y BUR1. Además, el hecho de que la deleción de SUB1 solamente afecte al fenotipo de sensibilidad a 6AU del mutante burl-2, podría indicar que su efecto principal se produce sobre los defectos en elongación de los mutantes 
burl, sobre todo si tenemos en cuenta que el mutante subl $\Delta$ no presenta sensibilidad a la droga por sí mismo, al menos en medio sólido (Figura 20).

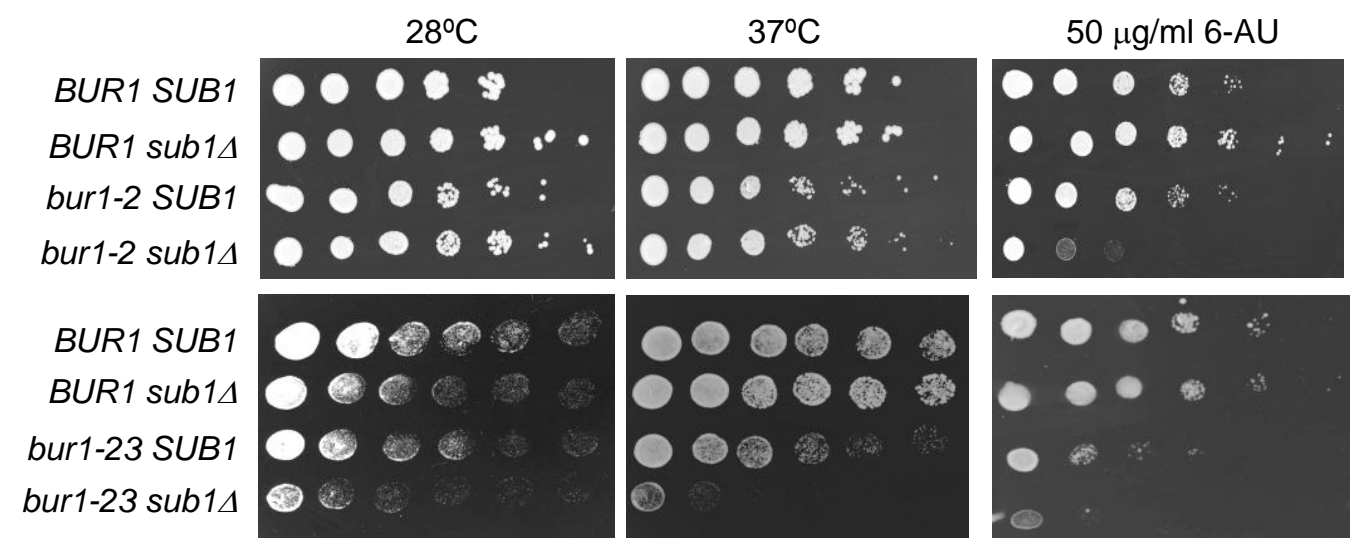

Figura 20. SUB1 y BUR1 interaccionan genéticamente. Análisis fenotípico de la interacción genética SUB1-BUR1. La deleción de SUB1 incrementa la sensibilidad a 6AU de los mutantes burl. Se delecionó $S U B 1$ en un mutante burl-2 (panel superior). En el caso del mutante burl-23, generamos un diploide heterozigótico cruzando el mutante burl-23 con una cepa subl $\Delta$. Se indujo la esporulación del diploide y se realizó la disección de tétradas. En el panel inferior se muestra el fenotipo de crecimiento de una tétrada. El análisis genético se realizó en placas de medio SC sin uracilo, que se incubaron durante 2 días a $28^{\circ} \mathrm{C}$ y $37^{\circ} \mathrm{C}$, y en medio $\mathrm{SC}$ sin uracilo y con $6 \mathrm{AU}$ a concentración de $50 \mu \mathrm{g} / \mathrm{ml}$, durante 3días a $28^{\circ} \mathrm{C}$.

\subsubsection{Actividad quinasa y asociación a los genes de Bur1 en el mutante sub1 $\Delta$}

La interacción genética entre $S U B 1$ y $B U R 1$ podría explicarse en base a un efecto en la fosforilación de la RNAPII o a un efecto de la elongación. Es posible que la deleción de $S U B 1$ incremente los defectos en elongación de los mutantes burl, como sugieren los resultados de crecimiento en presencia de la droga 6AU y de acuerdo con el hecho de que en el mutante subl $\Delta$ el reclutamiento de la polimerasa a los genes y su reciclaje tras la fosforilación se encuentran disminuidos (Calvo and Manley, 2005).

\subsubsection{La deleción de $S U B 1$ da lugar a un incremento en la actividad CTD-quinasa} de Bur1

Realizamos ensayos de actividad quinasa in vitro utilizando una cepa que expresa Bur1 marcada en su extremo C-terminal con 3 copias del epítopo HA (Keogh et al., 2003) y en la que delecionamos SUB1. Preparamos extractos totales de las cepas wt y sub1 1 , purificamos Bur1-HA con anti-HA y realizamos el ensayo in vitro, utilizando como sustrato de la reacción la proteína recombinante GST-CTD. Analizamos la fosforilación tanto en Ser5, como en Ser2 con anticuerpos específicos. En la figura 21, se observa que Bur1 fosforila ambos residuos de serina, aunque con mayor eficiencia los residuos Ser5, como se había descrito previamente (Murray et al., 2001), y que su 
actividad se encuentra incrementada en ausencia de $S U B 1$, mientras que no hay variación en los niveles totales de quinasa.

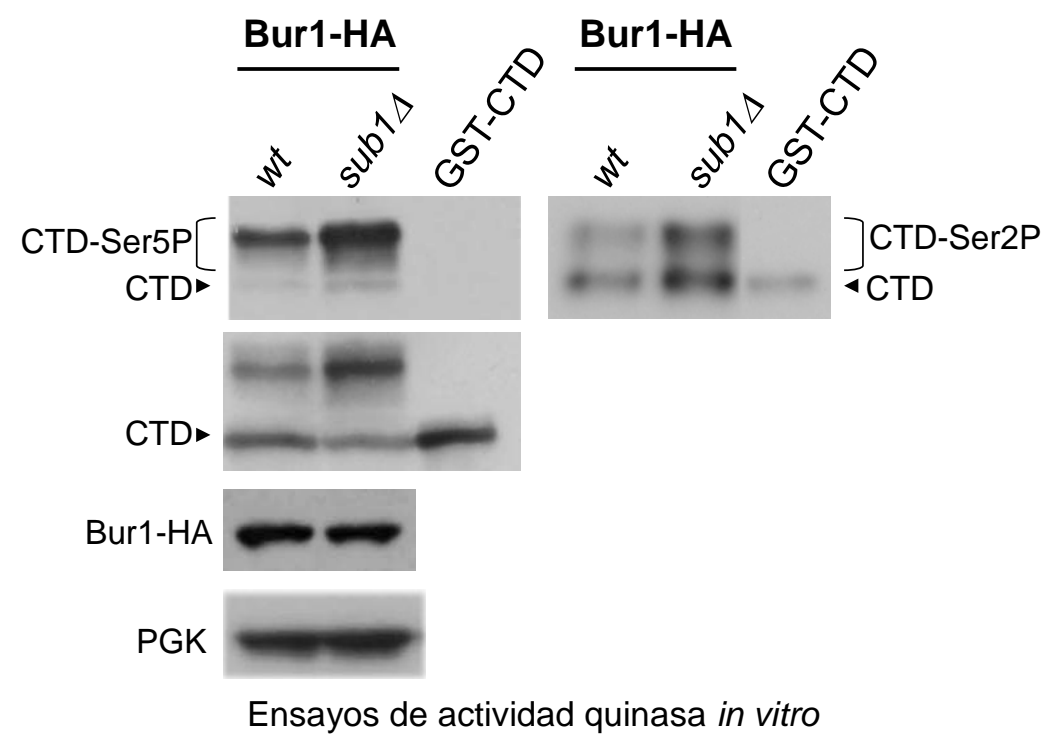

Figura 21. La deleción de SUB1 da lugar a un incremento en la actividad CTD-quinasa de Bur1. Ensayo de actividad CTD-quinasa in vitro. Se prepararon extractos totales de células wt y subl $\Delta$ que expresan Bur1-HA. Se inmunoprecipitó Bur1-HA con anti-HA y se ensayó su actividad quinasa sobre la proteína recombinante GST-CTD. La fosforilación del CTD en Ser5 y Ser2 se analizó por Western Blot utilizando los anticuerpos CTD4H8 (anti-CTDSer5P) y ab5095 (anti-CTDSer2P). Los niveles totales de GST-CTD en cada reacción se analizaron con el anticuerpo 8WG16 (anti-Rpb1CTD). Mediante una inmunoprecipitación adicional se analizaron los niveles de Bur1-HA en las dos cepas, wt y subla. Niveles de proteínas similares en ambas cepas se comprobaron analizando los niveles de la PGK.

Bur1 es una quinasa capaz de autofosforilarse y su fosforilación promueve la fosforilación del CTD (Murray et al., 2001; Yao and Prelich, 2002). Por esta razón, decidimos comprobar si la actividad de Bur1 sobre sí misma se incrementa también en un mutante sub1 $\Delta$. Para ello, realizamos un ensayo quinasa in vitro inmunoprecipitando Bur1-HA a partir de extractos totales de las cepas $w t$ y subl $\Delta$ y ensayando su actividad en presencia de ATP. Las mezclas de reacción se resolvieron por Western Blot, analizándose, además de la fosforilación de Bur1, los niveles de Rpb1 fosforilada en Ser5 co-purificada en la inmunoprecipitación. Como se aprecia en la figura 22, Bur1 es capaz de autofosforilarse en nuestro ensayo y de co-inmunoprecipitar con la polimerasa fosforilada en Ser5. Además, observamos que la deleción de SUB1 también da lugar a un incremento en la autofosforilación de Bur1, lo que se corresponde con un incremento en los niveles de polimerasa fosforilada en Ser5 co-purificando con la enzima. Este resultado sugiere que en el mutante $\operatorname{subl} \Delta$, y de acuerdo con trabajos anteriores (Murray 
et al., 2001; Yao and Prelich, 2002), el incremento de la actividad de Bur1 podría contribuir a un aumento en la fosforilación de la polimerasa.

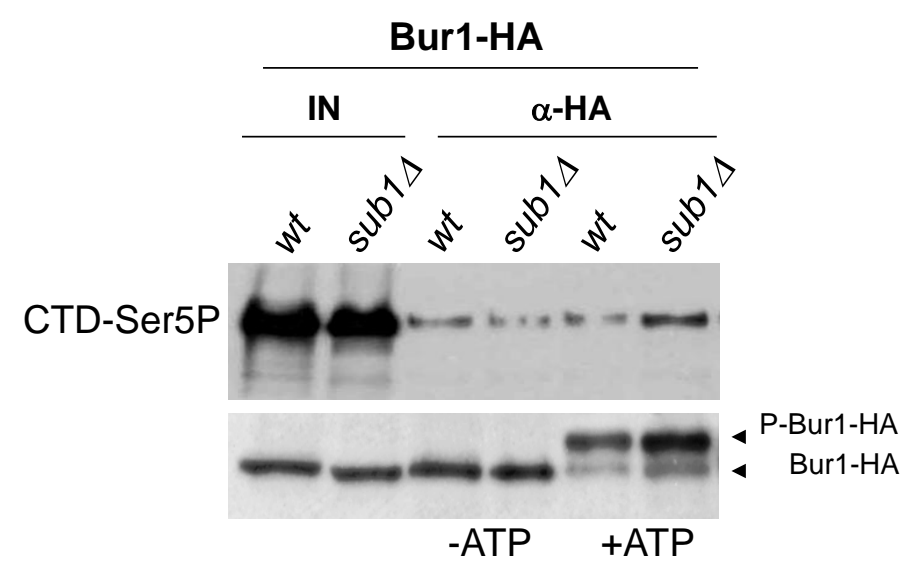

Ensayos de actividad quinasa in vitro y Co-IP

Figura 22. La deleción de SUB1 da lugar a un incremento en la autofosforilación de Bur1 y en su interacción con Rpb1-CTD. Se prepararon extractos totales de cepas wt y subla expresando Bur1-HA. Los complejos asociados a la quinasa se inmunoprecipitaron con el anticuerpo anti-HA acoplado a bolitas de proteína A-sefarosa y se ensayó la actividad quinasa en presencia y ausencia de ATP. Las mezclas de reacción se analizaron por Western Blot con los anticuerpos anti-HA y CTD4H8 (anti-CTDSer5P).

\subsubsection{La deleción de $S U B 1$ afecta levemente a la asociación de Bur1 a los genes}

Bur1 se recluta al complejo de transcripción en las secuencias codificantes cercanas a los promotores y se mantiene asociada a las mismas hasta las regiones 3' durante todo el ciclo transcripcional (Keogh et al., 2003). Para estudiar si Sub1 podría afectar al reclutamiento de Bur1 a la cromatina, analizamos por ChIP la distribución de Bur1-HA a lo largo de la secuencia de tres genes de expresión constitutiva (PMA1, PYK1 y ACT1: Figura 23B) en las cepas wt y sub1A. Asimismo, analizamos la distribución de la polimerasa total en estos mismos genes. Como puede observarse en la figura 23A (panel izquierdo), la deleción de SUB1 no afecta de forma significativa a la asociación de Bur1 a los genes estudiados. No obstante, detectamos un incremento medio de entre 1,5-2 veces, si comparamos el reclutamiento de Bur1 frente al de Rpb1 en el mutante (Figura 23A, panel derecho). De cualquier manera, este incremento no es comparable al que se produce en la asociación de Kin28 a los promotores génicos en ausencia de Sub1 (Figura 11). 
A
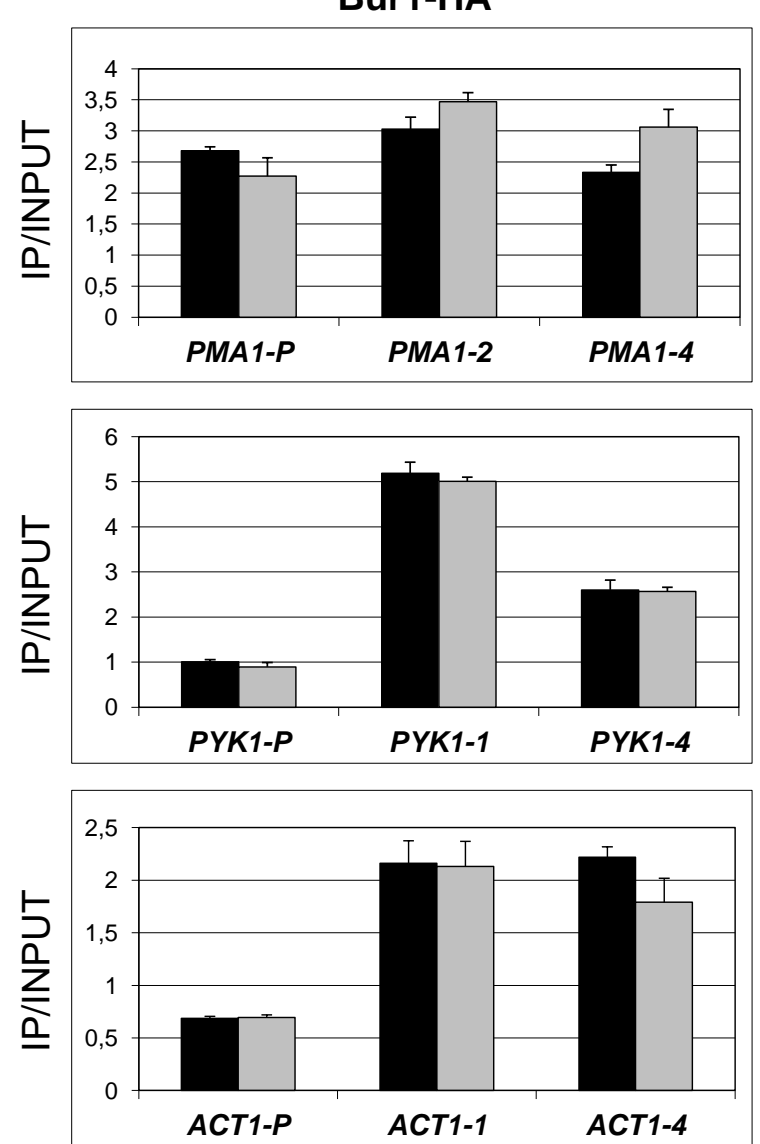

wt $\square \operatorname{sub1\Delta }$
Bur1-HA/Rpb1
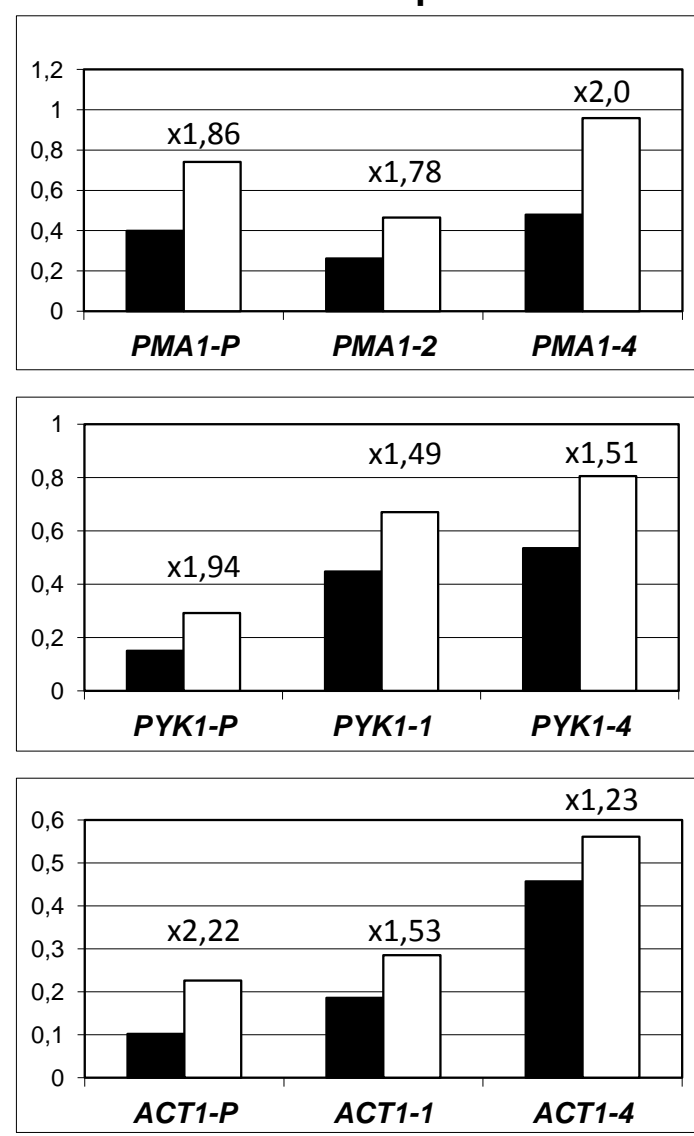

wt $\square$ sub1

ChIP

B
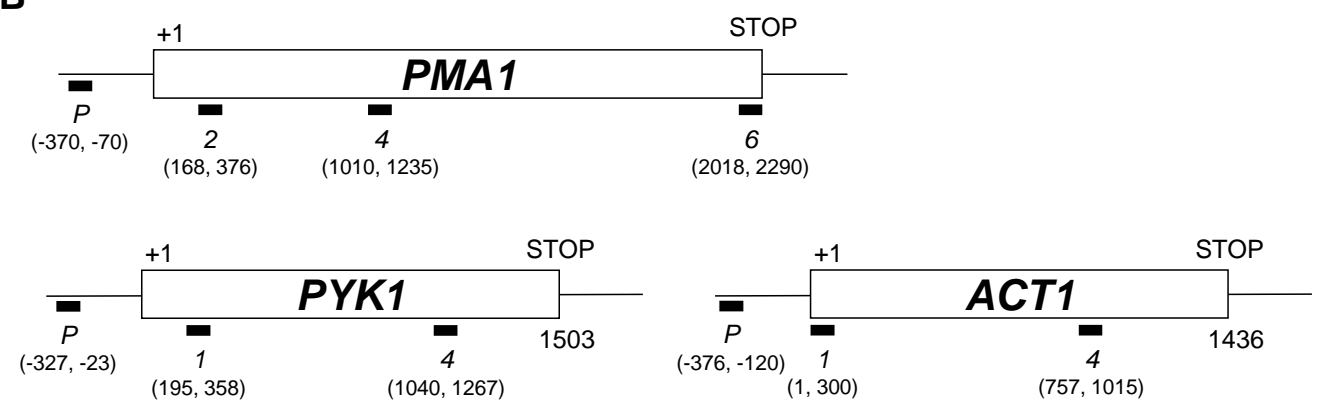

Figura 23. La deleción de SUB1 provoca un ligero incremento de la asociación del cociente Bur1/Rpb1. (A) Análisis de ChIP para Bur1-HA y Rpb1 en cepas wt y sub1 $\Delta$. Panel izquierdo: se analizó por qPCR la asociación de Bur1-HA a los genes de expresión constitutiva PMA1, PYKl y ACT1. En la gráfica, los números del eje $y$ representan el cociente entre los valores de amplificación obtenidos para cada par de oligonucleótidos específicos, respecto al control negativo (región intergénica del cromosoma VII), utilizando como molde la cromatina inmunoprecipitada (IP) y normalizado para las muestras input. Panel derecho: cociente Bur1/Rpb1. Se cuantificaron las asociaciones de Bur1-HA y de Rpb1 de forma independiente en células $w t$ y subl $\Delta$. Posteriormente se calculó el cociente Bur1/Rpb1 y se representó. Los valores sobre las barras correspondientes a la cuantificación para subl $\Delta$ indican el incremento de la asociación de Bur1-HA relativo al wt, considerado 1. Las barras de error indican desviación estándar. (B) Representación esquemática de los genes PMA1, PYKl y ACT1. Los recuadros negros indican la posición de anillamiento de los oligonucleótidos utilizados en las qPCR para el análisis de los experimentos de ChIP. Bajo los recuadros se indican las coordenadas de anillamiento de los oligonucleótidos en el gen, respecto del TSS $(+1)$. 
Aunque inicialmente se describió que Bur1 fosforila a la polimerasa tanto en los residuos Ser5 como Ser2 (Jones et al., 2004; Keogh et al., 2003), recientemente se ha mostrado que esta quinasa fosforila principalmente los residuos Ser2 en las regiones codificantes de los genes próximas a los promotores, lo que a su vez promueve la actividad de la CTD-quinasa, Ctk1 (Qiu et al., 2009). Aún más, se ha mostrado que la actividad de Kin28 estimula dicha fosforilación. Así, es posible que el efecto de Sub1 sobre la asociación de Bur1 sea consecuencia de su efecto sobre la actividad y reclutamiento de Kin28 de acuerdo con los resultados de (Qiu et al., 2009).

\subsection{SUB1 regula negativamente a la CTD-quinasa de elongación, Ctk1}

A continuación, decidimos ampliar nuestro estudio a la CTD-quinasa de elongación Ctk1, responsable de la fosforilación de la RNAPII en los residuos de Ser2 durante la elongación (Cho et al., 2001), por varias razones: 1) la deleción de SUB1 produce un incremento en los niveles de polimerasa fosforilada en Ser2 asociada a los genes, probablemente debido a una disminución en los niveles de la fosfatasa de Ser2, Fcp1 (Calvo and Manley, 2005). No obstante, no podemos descartar un efecto opuesto sobre Ctk1. De hecho, se sabe que Fcp1 y Ctk1 tienen funciones opuestas durante la transcripción (Cho et al., 2001). 2) En el mutante sub1 $\Delta$ los niveles de polimerasa fosforilada en Ser5 se encuentran aumentados (Figura 12). La fosforilación del CTD en Ser5 es el sustrato sobre el que tiene lugar la fosforilación en Ser2 por Ctk1 (Jones et al., 2004). 3) Por último, en el mutante sub1 $\Delta$ la actividad de Kin28 se encuentra incrementada (Figuras 7-10). Como ya hemos mencionado, coincidente con el desarrollo de nuestro estudio, se ha demostrado que la actividad quinasa de Kin28 estimula la fosforilación en Ser2 llevada a cabo por la quinasa Bur1, promoviendo, a su vez, la actividad de Ctk1 (Qiu et al., 2009).

\subsubsection{Interacción genética entre $S U B 1$ y CTK1}

Para analizar si SUB1 y CTK1 interaccionan genéticamente, se realizó un cruce entre las cepas $c t k 1 \Delta$ y subla en el laboratorio del doctor James Manley (Columbia University, Nueva York). El mutante $c t k 1 \Delta$, caracterizado por la ausencia de fosforilación en Ser2 de la polimerasa durante la elongación y terminación (Cho et al., 2001), presenta un fenotipo de severo retraso en el crecimiento. Para el estudio genético, se generó una cepa diploide $C T K 1 / \operatorname{ctk} 1 \Delta S U B 1 / \operatorname{sub1} \Delta$, se indujo su esporulación y se 
diseccionó. En el análisis de la disección de tétradas se observó que la deleción de SUB1 es letal sintética en combinación con la deleción de CTK1 (Figura 24). Este resultado muestra una clara interacción genética entre $S U B 1$ y $C T K 1$, siendo comparable a la observada para el caso de SUB1 y kin28-T17D (Calvo and Manley, 2005), un mutante que carece totalmente de actividad quinasa (Rodriguez et al., 2000).

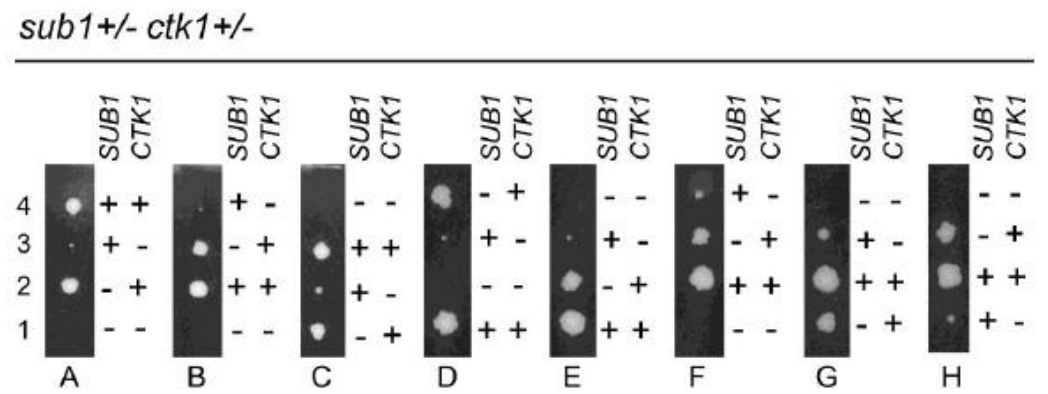

Figura 24. La deleción de SUB1 es letal sintética en combinación con la deleción de CTK1. Se construyó un diploide heterozigótico para SUB1 y CTK1 (sub1 $1:: U R A 3 / S U B 1$ ctk1 $1:: k a n M X / C T K 1$ ), se indujo su esporulación y se llevó a cabo la disección de tétradas correspondiente, siguiéndose su crecimiento en placa durante 3 días. En la figura se muestran 8 tetratipos, donde se señala la presencia o ausencia del gen correspondiente mediante $(+)$ o $(-)$, respectivamente.

\subsubsection{Actividad catalítica y asociación a los genes de Ctk1 en un mutante sub1 $\Delta$}

Estudios previos demostraron que en el mutante $\operatorname{subl} \Delta$ los niveles de polimerasa fosforilada en Ser2 asociada a los genes se encuentran incrementados (Calvo and Manley, 2005). Como ya hemos mencionado en repetidas ocasiones, esta situación podría ser consecuencia directa de la bajada que se produce en este mutante en los niveles de la CTD-fosfatasa Fcp1 y de su reclutamiento a los genes (Calvo and Manley, 2005). No obstante, por las razones que hemos indicado más arriba, es posible también que en un mutante $\operatorname{sub1} 1 \Delta$, la actividad y/o el reclutamiento de Ctk1 se encuentren alterados.

\subsubsection{La deleción de $S U B 1$ provoca un incremento en la actividad quinasa de} Ctk1

Con el objetivo de analizar la actividad catalítica de Ctk1 en un mutante subl $\Delta$, construimos una cepa doblemente marcada Srb10-MYC/Ctk1-HA, que nos ha permitido determinar en las mismas células el efecto de la deleción de $S U B 1$ sobre la actividad quinasa de Srb10 y Ctk1, además de confirmar la especificidad de los ensayos quinasa y descartar posibles artefactos. Así, preparamos extractos totales, inmunoprecipitamos Ctk1-HA y Srb10-MYC con anti-HA y anti-MYC, respectivamente, y ensayamos la 
actividad quinasa in vitro de ambas enzimas sobre el sustrato GST-CTD. Mediante análisis por Western Blot, observamos que en ausencia de $S U B 1$ la fosforilación en Ser2 por Ctk1 se encuentra incrementada (Figura 25, panel derecho), sugiriendo que Sub1 afecta negativamente a la actividad de Ctk1. Por otro lado, corroboramos que la actividad de Srb10 disminuye en el mutante sub1 $\Delta$ (Figura 25, panel izquierdo), como ya habíamos mostrado anteriormente (Figura 15).

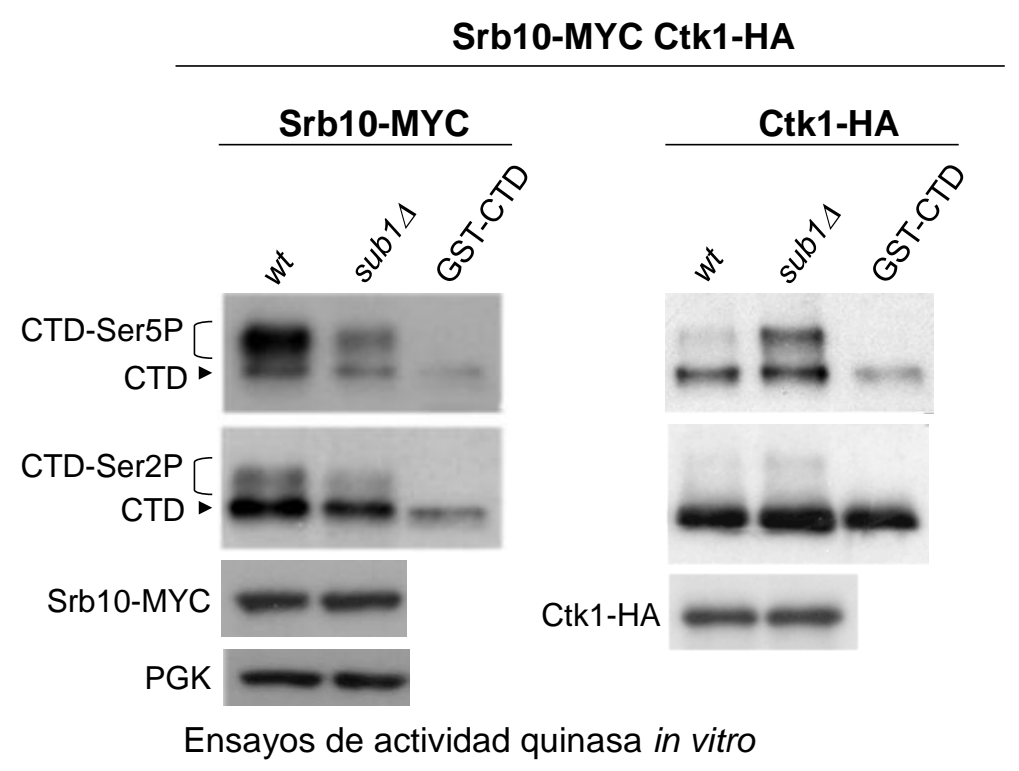

Figura 25. La deleción de SUB1 da lugar a un incremento en la fosforilación del CTD en Ser2 llevada a cabo por Ctk1. Ensayo de actividad quinasa in vitro para Srb10-MYC y Ctk1-HA a partir de los mismos extractos celulares. Se prepararon extractos totales de una cepa que expresaba Srb10-MYC y Ctk1-HA. Srb10 y Ctk1 se inmunoprecipitaron con anti-MYC y anti-HA, respectivamente, y se ensayó su actividad sobre el sustrato GST-CTD. La fosforilación se analizó por Western Blot utilizando en la inmuno-detección los anticuerpos CTD4H8 (anti-CTDSer5P) y ab5095 (anti-CTDSer2P). Los niveles de GST-CTD presentes en cada reacción se analizaron con el anticuerpo 8WG16 (anti-Rpb1CTD). Como en casos anteriores, se comprobó mediante inmunoprecipitaciones adicionales que los niveles de Srb10 y Ctk1 eran similares, así como los niveles de una proteína control (PGK).

\subsubsection{La asociación de Ctk1 a los genes se encuentra incrementada en sub1 $\Delta$}

Ctk1 se recluta a las regiones 5' de los genes y se mantiene asociada a los mismos durante todo el ciclo transcripcional hasta las regiones 3' (Cho et al., 2001). Para determinar si SUB1 afecta a dicha asociación, realizamos ensayos de ChIP en las cepas Ctk1-HA wt y sub1 $\Delta$ y analizamos por qPCR la distribución de Ctk1 en varios genes de expresión constitutiva (PMA1, PYK1 y ACT1, Figura 23B). En la figura 26, podemos observar que la asociación de Ctk1 a la cromatina se encuentra incrementada en ausencia de $S U B 1$, en una media de dos veces por encima de sus niveles de asociación en la cepa $w t$ (Figura 26, panel izquierdo). 

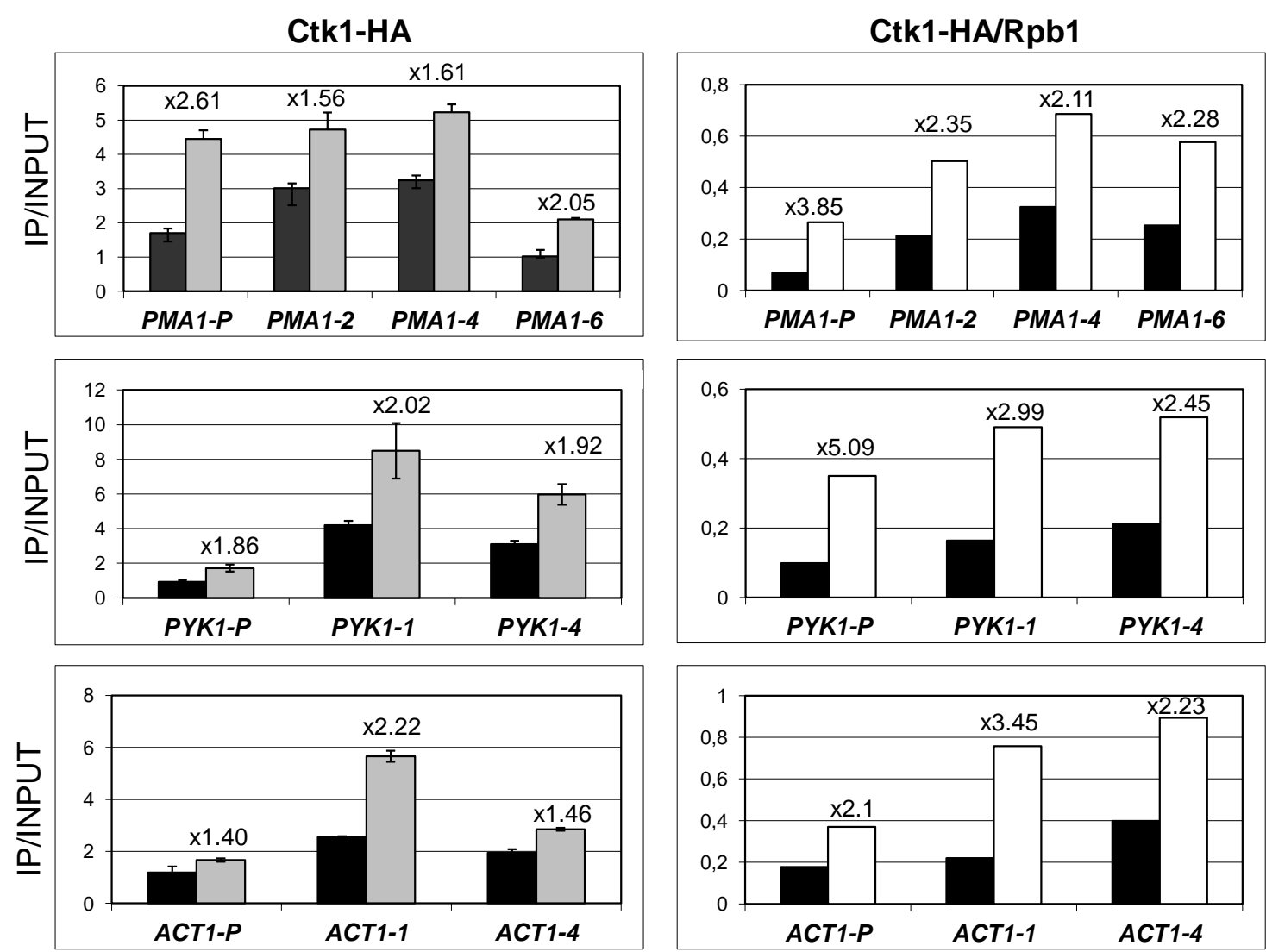

wt $\square$ sub1A

- wt $\square$ sub1A

ChIP

Figura 26. La asociación de Ctk1 a los genes se encuentra incrementada en sub1 $\Delta$. Panel izquierdo: análisis de experimentos de ChIP para Ctk1-HA en células wt y sub1 $\Delta$ La asociación de Ctk1-HA se analizó por qPCR para los genes PMA1, PYK1 y ACT1. La cuantificación se realizó según se detalla en la Figura 23 y en Materiales y Métodos. Panel derecho: cociente Ctk1-HA/Rpb1. Se cuantificaron las asociaciones de Ctk1-HA y de Rpb1 de forma independiente en células wt y sublu. Posteriormente se calculó el cociente Ctk1/Rpb1 y se representó. Los valores sobre las barras, correspondientes a la cuantificación para subld, indican el incremento de la asociación de Ctk1-HA en relación al wt. Las barras de error indican desviación estándar.

Si analizamos la distribución de Rpb1 en estos mismos genes y calculamos el cociente entre la asociación de Ctk1 respecto a la de Rpb1 (Figura 26, panel derecho), observamos que este efecto se asevera. Estos resultados indican que el aumento en la fosforilación en Ser2 que se produce en un mutante sub1 $\Delta$ se debe al menos a tres hechos: al descenso en la asociación de Fcp1 a la cromatina durante la transcripción (Calvo and Manley, 2005), al incremento en la actividad de Ctk1 (Figura 25) y a su reclutamiento a los genes (Figura 26).

En su conjunto, todos los resultados mostrados hasta ahora indican que Sub1 afecta clara y diferencialmente a la quinasa de pre-iniciación Srb10 (Figuras 15, 17 y 25), frente a la quinasas Kin28 (Figuras 7-11), Bur1 (Figuras 21-23) y Ctk1 (Figuras 25- 
26). Así, la deleción de SUB1 disminuye la fosforilación mediada por Srb10 e incrementa la fosforilación debida a las quinasas de iniciación, Kin28, y de elongación, Bur1 y Ctk1. En el mismo sentido, en el mutante $s u b 1 \Delta$, el reclutamiento a la cromatina de Srb10 se encuentra disminuido, mientras que incrementan las asociaciones de Kin28 y Ctk1 y, en menor medida, de Bur1. Así pues, Sub1 regula la fosforilación del CTD a distintos niveles, durante todas las etapas del ciclo de transcripción, incluyendo la preiniciación, iniciación, elongación y terminación. Por lo tanto, Sub1 parece tener un papel regulador de la transcripción por la RNAPII más complejo de lo que cabría esperar de un simple coactivador transcripcional.

\subsection{Sub1 no se asocia a ningún complejo CTD-quinasa}

Como se ha mostrado hasta ahora, Sub1 regula globalmente la fosforilación de la RNAPII, afectando a la actividad y al reclutamiento de todas las CTD-quinasas que se conocen hasta el momento. Un posible mecanismo de acción para modular la actividad de las quinasas podría ser la interacción directa entre Sub1 y la/s propia/s enzima/s o entre Sub1 y alguno de los factores reguladores íntimamente asociados con ella/s, como por ejemplo, el par ciclina o la Cdk activadora de kinasas, Cak1. Así, realizamos varios ensayos de co-inmunoprecipitación para investigar si Sub1 podría formar parte de alguno o todos los complejos CTD-quinasa. Los resultados obtenidos en todos los casos fueron negativos (datos no mostrados). Sub1 no co-inmunoprecipita con ninguna de las CTD-quinasas, ni con Cak1, al menos en las condiciones utilizadas en nuestros experimentos, lo que indicaría que Sub1 no parece formar parte de ninguno de los complejos constituidos por las CTD-quinasas. Sin embargo, es posible que interaccione lábil o transitoriamente con alguno/s o todos los complejos (dependiendo del estadio del ciclo de transcripción), de manera que, en nuestras condiciones experimentales, somos incapaces de detectar tales interacciones.

\subsection{La función de Sub1 no se relaciona con las CTD-fosfatasas de Ser5P}

De la misma manera que el aumento en la fosforilación Ser2 en el mutante sub1 $\Delta$ se produce en parte por un defecto en la defosforilación mediada por Fcp1 (Calvo and Manley, 2005), es posible que el aumento en la fosforilación en Ser5 pueda deberse, además de a los efectos sobre Kin28 (Figuras 7-11), a un defecto adicional en la defosforilación de este residuo. Así, por ejemplo, mutaciones en Ssu72 que afectan a su 
actividad fosfatasa, o la deleción de $R T R 1$, provocan un incremento de la polimerasa fosforilada en Ser5P (Krishnamurthy et al., 2004; Mosley et al., 2009), similar al fenotipo que hemos descrito anteriormente para el mutante subl $\Delta$. Por esta razón, también investigamos si la deleción de $S U B 1$ alteraba la defosforilación del CTD en Ser5P a través de las fosfatasas Rtr1 y Ssu72. Sin embargo, hasta el momento no hemos encontrado ninguna relación genética, ni funcional, que relacione a Sub1 con la defosforilación de los residuos Ser5P (datos no mostrados).

\subsection{Interacciones genéticas específicas de alelo entre $S U B 1$ y $R P B 1$}

Ensayos de co-inmunoprecipitación entre Sub1 y las subunidades Rpb1 y Rpb2, han generado resultados negativos o no concluyentes (datos no mostrados). De manera que parece que Sub1 tampoco se asociaría a Rpb1, al menos directamente, para realizar sus funciones de regulación de la fosforilación del CTD. Sin embargo, Sub1 no es el primer caso de un factor que afecta a la fosforilación del CTD y que no se asocia directamente a Rpb1. Así por ejemplo, en $S$. pombe, la CTD- fosfatasa Fcp1 se asocia a la polimerasa a través de su interacción con Rpb4 (Kimura et al., 2000) y, en el caso de $S$. cerevisiae, se ha demostrado que al menos in vitro esta fosfatasa no se asocia a la RNAPII si el dímero Rpb4/7 no está asociado al complejo (Kamenski et al., 2004).

Por otra parte, las interacciones específicas de alelo son de gran ayuda a la hora de relacionar la función de un factor con una región determinada de la polimerasa. Por ejemplo, se han descrito una serie de interacciones genéticas específicas de alelo entre el mutante del complejo capping, ceg1-250, y una serie de alelos mutantes de RPB1 cuyas mutaciones se localizan en el dominio CTD. Sin embargo, este no ha sido el caso para mutantes en otras regiones de Rpb1 (Rodriguez et al., 2000). En base a esto, decidimos investigar un poco más las relaciones genéticas de $S U B 1$ con distintos mutantes $r p b 1$, cuyas mutaciones se localizan estratégicamente en la estructura del complejo RNAPII y que nos podrían ayudar en la búsqueda del mecanismo por el que Sub1 regula la fosforilación del CTD. Para ello, utilizamos tres mutantes de RPB1 localizados en los dominios clamp y foot y un mutante en el dominio core, situado en la región cleft de la polimerasa. Los dominios clamp y foot están relacionados con las funciones del dímero Rpb4/7 y con el CTD, respectivamente. Sin embargo, el cleft se sitúa topológicamente en el contexto del complejo de la polimerasa, pero lejos del CTD y, a priori, podría no estar relacionado funcionalmente con la fosforilación de la polimerasa (Figura 27). 


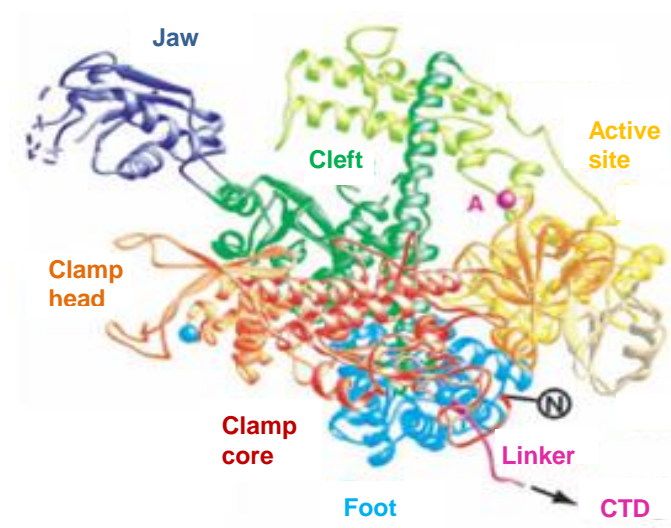

Figura 27. Dominios estructurales de Rpb1, se muestran el dominio clamp en color rojo/naranja, el dominio jaw en azul oscuro, el dominio foot en azul claro y el cleft en verde. Se puede observar la disposición espacial de estos dominios respecto al CTD, que aparece en morado en la imagen. Modificado de (Cramer et al., 2001).

\section{Interacción genética entre $S U B 1$ y el dominio clamp de Rpb1}

La unión del dímero Rpb4/7 con el núcleo central de la RNAPII (o core) se produce a través de los contactos directos de Rpb7 con las subunidades Rpb6, Rpb2 y Rpb1 (Bushnell and Kornberg, 2003; Tan et al., 2003). Curiosamente, la región de interacción de Rpb1 con Rpb7 corresponde al dominio estructural clamp (Armache et al., 2003; Bushnell and Kornberg, 2003; Martinez-Rucobo et al., 2011), topológicamente situado próximo al canal de salida del mensajero y al CTD (Figura 27). De hecho, se han descrito interacciones entre Rpb7 y la región linker, que une el CTD al resto de Rpb1 (Armache et al., 2003). Para determinar si existe una relación de la función de Sub1 con esta región de la polimerasa, investigamos la posible relación genética entre SUB1 y el mutante del dominio clamp de RPB1, rpb1-L1397S (Kwapisz et al., 2008b). La mutación de este alelo reside en la región del clamp denominada "Switch 1 loop" que se localiza, en la estructura de la polimerasa, en la región que interacciona con el DNA en un extremo de la burbuja de transcripción (Cramer et al., 2001, Gnatt et al 2001). El mutante rpb1-L1397S presenta un fenotipo severo de crecimiento lento a $30^{\circ} \mathrm{C}$, sensibilidad al frío $\left(16^{\circ} \mathrm{C}\right)$, al calor $\left(37^{\circ} \mathrm{C}\right)$ y a drogas como el MPA y el 6AU. Además, esta mutación afecta a la asociación de la RNAPII a los genes. Realizamos entonces un cruce genético entre un mutante subl $\Delta$ y el mutante rpblL1397S. Tras la disección de tétradas y el análisis posterior de la progenie, comprobamos que la deleción de $S U B 1$ causa letalidad sintética en combinación con la mutación del dominio clamp (Figura 28). Es decir, la función de Sub1 es esencial en 
presencia de la mutación rpbl-L1397S, lo que sugiere una relación funcional entre Sub1 y el dominio clamp de la polimerasa.

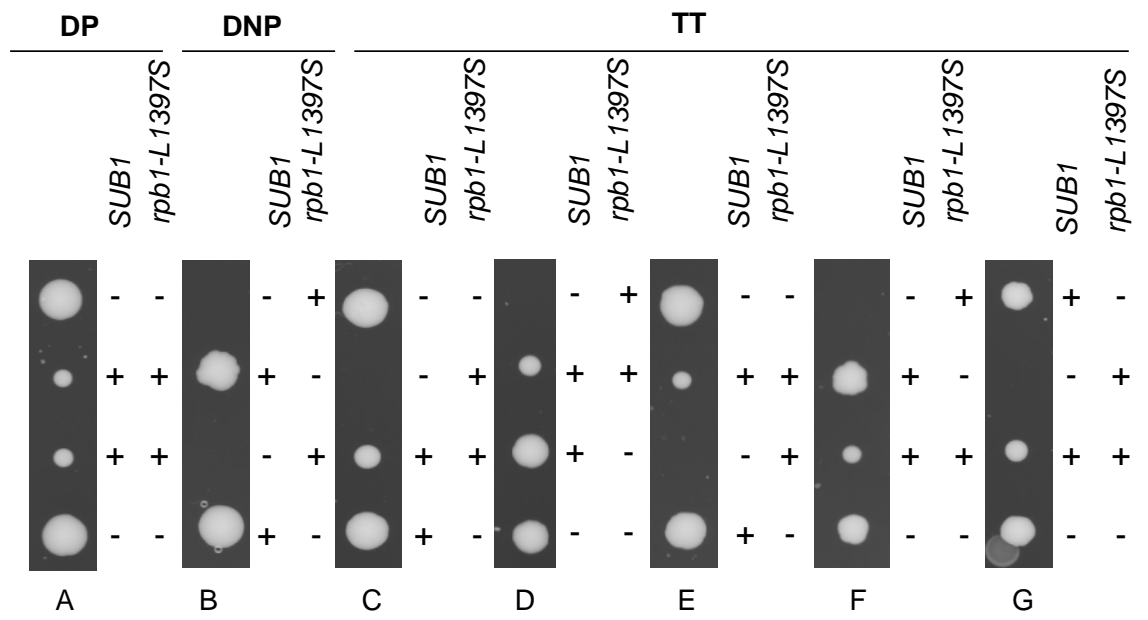

Figura 28. La deleción de $S U B 1$ es letal sintética en combinación con una mutación en el dominio clamp de Rpb1, rpb1-L1397S. Se construyó un diplodide heterozigótico para SUB1 y RPB1 (sub1 $\triangle:: H I S 3 / S U B 1$ rpb1-L1397S/RPB1). A continuación, se esporuló, se diseccionaron las tétradas correspondientes y se siguió su crecimiento en placa durante 3 días. Se diseccionaron 46 tétradas, de las cuales 7 mostraron un patrón de ditipo no parental, 9 de ditipo parental y 30 de tetratipo. En la imagen, A es un ditipo parental (DP), B un ditipo no parental (DNP) y C-G son tetratipos (TT). (-) y (+) indican la ausencia o presencia SUB1 o de la mutación rpb1-L1397S.

\section{Interacción genética entre $S U B 1$ y el dominio foot de la RNAPII}

El dominio del pie o foot de la subunidad Rpb1 es una región muy conservada y específica de la RNAPII que no está presente ni en la RNAPI, ni en la RNAPIII, ni tampoco en las polimerasas de bacterias y arqueas. Se dispone en la superficie del complejo, próximo al CTD. De hecho se ha demostrado que es necesario, junto con el CTD, para la interacción de la enzima de capping Ceg1 con la RNAPII (Suh et al., 2010). Además, se ha descrito que este dominio foot podría constituir una plataforma para la interacción de factores de transcripción con la polimerasa (Garcia-Lopez et al., 2011). Por lo tanto, nos pareció que el análisis de la interacción genética de SUB1 con dicho dominio podría ser interesante. Así, analizamos una posible relación genética entre la deleción de SUB1 y la mutación rpol-24 localizada en el dominio foot, (Archambault et al., 1998) y para ello construimos el doble mutante rpol-24 subl $\Delta$ por reemplazamiento génico. Como puede observarse en la figura 29, el mutante rpol-24 presenta un fenotipo severo de termosensibilidad y sensibilidad extrema a 6AU y, curiosamente, la deleción de SUB1 suprime muy parcialmente el fenotipo de termosensibilidad y bastante bien el de sensibilidad a 6AU. 


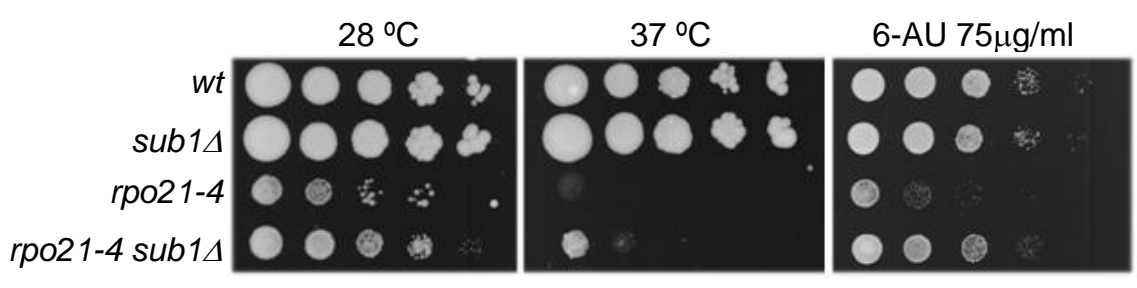

Figura 29. Interacción genética entre $s u b 1 \Delta$ y el mutante del dominio foot de Rpb1, rpo21-4. Se llevó a cabo la deleción de SUB1 mediante reemplazamiento génico en la cepa mutante rpo21-4. El crecimiento del doble mutante, junto con las cepas controles isogénicas, se siguió mediante ensayo de diluciones seriadas en placa de medio SC sin uracilo, incubadas a $28^{\circ} \mathrm{C}$ y $37^{\circ} \mathrm{C}$ durante 2 días. Para analizar la sensibilidad a 6AU se utilizaron placas de medio SC sin uracilo suplementadas con la droga a una concentración de $75 \mu \mathrm{g} / \mathrm{ml}$, y se incubaron a $28^{\circ} \mathrm{C}$ durante $2-3$ días.

La deleción de $S U B 1$ produce un incremento en el reclutamiento y la actividad de la CTD-quinasa Kin28, así como un aumento en la asociación a la cromatina de la enzima de capping Ceg1 (Figuras 7,11 y 13). Por su parte, en el mutante del dominio foot, rpo21-4, la asociación de Ceg1 a la RNAPII podría verse comprometida. Es posible que la deleción de SUB1 suprima parcialmente el fenotipo de este mutante debido a los efectos que produce sobre Kin28 y Ceg1.

\section{Análisis genético entre $S U B 1$ y la región cleft de la RNAPII}

La región cleft de la RNAPII se sitúa dentro del dominio estructural core, sobre el centro activo, y constituye una hendidura que aloja el DNA durante la transcripción (Cramer et al., 2000; 2001; Gnatt et al., 2001). Para el estudio de la posible relación genética entre SUB1 y esta región de la polimerasa, utilizamos el mutante rpb1-19 (Scafe et al., 1990a, 1990b). Este mutante contiene una mutación puntual en RPBI $(\mathrm{G} 4031 \mathrm{~A})$ que otorga a las células un fenotipo de ligero retraso en el crecimiento a $28^{\circ} \mathrm{C}$ y termosensibilidad a $37^{\circ} \mathrm{C}$. La mutación G4031A se halla en la estructura de la polimerasa en una zona alejada del CTD (Cramer et al., 2001). De hecho, se ha mostrado que esta mutación no afecta al fenotipo de un mutante de capping, ceg 1-250, que es letal sintético en combinación con mutaciones en el CTD (Rodriguez et al., 2000). Construimos el doble mutante rpb1-19 subla por reemplazamiento génico $\mathrm{y}$, posteriormente, analizamos su crecimiento a diferentes temperaturas. Como puede observarse en la figura 30, la deleción de SUB1 no altera el fenotipo del mutante sencillo $r p b 1-19$, por lo que podemos afirmar la ausencia de una interacción genética de SUB1 con una región de la polimerasa no relacionada funcionalmente con el complejo capping, cuya función está íntimamente ligada a la fosforilación del CTD. 


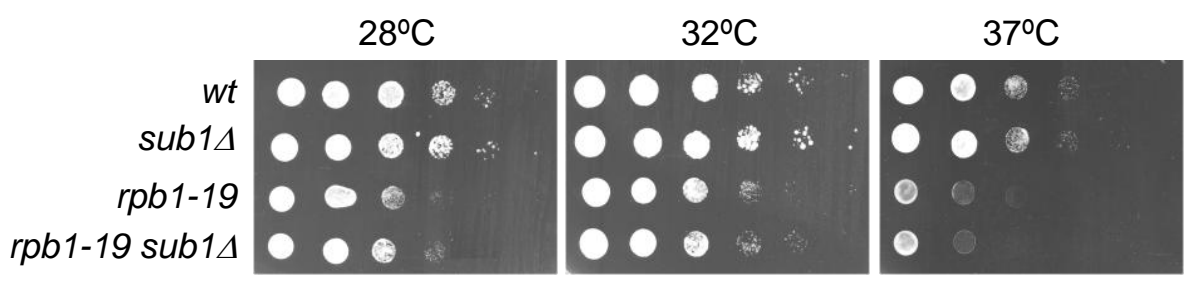

Figura 30. Análisis genético de la deleción de $S U B 1$ en el mutante rpb1-19 de la región cleft de la RNAPII. Se llevó a cabo la deleción de SUB1 mediante reemplazamiento génico en la cepa mutante rpb1-19. El crecimiento del doble mutante, junto con sus controles isogénicos, se siguió mediante ensayo de diluciones seriadas en placa, incubadas a diferentes temperaturas, $28^{\circ} \mathrm{C}, 32^{\circ} \mathrm{C}$ y $37^{\circ} \mathrm{C}$, durante $2-3$ días .

En conjunto, nuestros resultados sugieren que la función moduladora de Sub1 en la fosforilación de Rpb1 podría ser indirecta y ejercerse a través de una región concreta del complejo. Región que posiblemente comprende los dominios clamp y/o foot de Rpb1, todos ellos relacionados física y funcionalmente con el CTD. Por otra parte, como Sub1 no se asocia a ninguno de los complejos quinasa, ni a las fosfatasas, ¿cómo es posible que regule globalmente la fosforilación de la RNAPII? Una posibilidad es que Sub1 se asocie a un regulador común conocido, o aún por identificar, de las CTDquinasas y/o la CTD-fosfatasa Fcp1. Además, los datos genéticos sugieren que Sub1 podría interaccionar con el complejo RNAPII a través de algún factor o alguna de las subunidades de la RNAPII que se localicen probablemente en las regiones que comprenden los dominios clamp y/o foot de la polimerasa.

\subsection{Sub1 se asocia con la RNAPII vía el dímero disociable Rpb4/7}

Para investigar si efectivamente Sub1 podría asociarse a algún factor, conocido o desconocido, para realizar sus funciones en relación a la fosforilación de la RNAPII, decidimos purificar los complejos proteicos asociados a Sub1 in vivo, mediante la técnica de Purificación por Afinidad en Tándem (o TAP) (Rigaut et al., 1999; Rodriguez-Navarro et al., 2004).

\subsubsection{Purificación de complejos proteicos asociados a Sub1-TAP}

Para llevar a cabo la purificación TAP de los complejos proteicos asociados a Sub1 construimos una cepa que expresaba Sub1 marcada en su extremo C-terminal con el epítopo TAP. Como control de purificación inespecífica utilizamos una cepa $w t$ sin ningún epítopo. Un 10\% del material purificado se analizó por Western Blot para comprobar la eficiencia del proceso (Figura 31). El 90\% restante del material obtenido se digirió con tripsina. Las mezclas heterogéneas de péptidos así obtenidas se analizaron 
por espectrometría de masas acoplada a trampa iónica. Realizamos tres purificaciones y tres identificaciones por espectrometría de masas independientes. Los péptidos secuenciados se contrastaron con aquéllos presentes en las bases de datos Swiss-Prot y NCBInr.

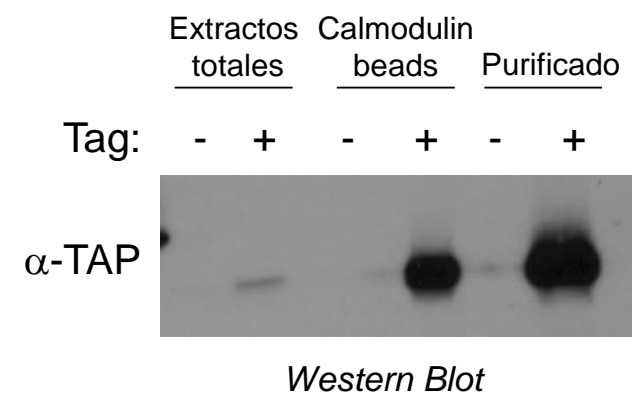

Figura 31. Purificación de Sub1-TAP. Mediante Western Blot se analizó un $10 \%$ del material purificado, junto con un 10\% de la fracción previa a la purificación final (Calmodulin-beads) y de los extractos totales. Para la inmuno-detección se utilizó el anticuerpo anti-TAP.

Las proteínas asociadas a Sub1-TAP identificadas por espectrometría de masas componían una lista muy extensa, con numerosas proteínas contaminantes identificadas con un alto score y que aparecen normalmente en este tipo de experimentos (Gavin et $a l ., 2002)$. Sin embargo, identificamos varios péptidos comunes a los tres experimentos (Tabla 2) y algunos que sólo identificamos en dos de ellos (por ejemplo, Npl3, proteína de unión a RNA que participa en la elongación, terminación y transporte de los transcritos, y en la coordinación de transcripción y traducción (Dermody et al., 2008; Kress et al., 2008; Rajyaguru et al., 2012; Wong et al., 2007); Efb1, factor de elongación de la traducción beta 1 (Hiraga et al., 1993; Kinzy and Woolford, 1995; Pittman et al., 2009); y Eft1, factor de elongación de la traducción 2 (Justice et al., 1998). Además, en uno de los experimentos identificamos Rfa1, consistente con la relación genética y funcional recientemente descrita para ambas proteínas (Sikorski et al., 2011). Curiosamente, entre las pocas proteínas que aparecían asociadas a Sub1-TAP en los tres experimentos, identificamos a la subunidad Rpb7 de la RNAPII (Tabla 2), que consideramos el candidato más interesante para seguir investigando el mecanismo por el cual Sub1 podría regular la fosforilación de la RNAPII. 


\begin{tabular}{|c|l|}
\hline $\begin{array}{l}\text { Proteína identificada por } \\
\text { espectrometría de masas }\end{array}$ & \multicolumn{1}{c|}{ Función } \\
\hline Rpb7 & $\begin{array}{l}\text { Subunidad de la RNAPII. Forma un heterodímero disociable con la } \\
\text { subunidad Rpb4 (Armache } \text { et al., 2003; Bushnell and Kornberg, } \\
\text { 2003; Edwards } \text { et al., 1991; Ruet } \text { et al., 1980). }\end{array}$ \\
\hline Rim1 & $\begin{array}{l}\text { Proteína de unión a ssDNA, esencial para la replicación del genoma } \\
\text { mitocondrial (Van Dyck } \text { et al., 1992). }\end{array}$ \\
\hline Fpr4 & $\begin{array}{l}\text { Peptidil-prolil cis-trans isomerasa de las histonas H3 y H4 (Davey et } \\
\text { al., 2000; Dolinski } \text { et al., 1997). }\end{array}$ \\
\hline Tef2 & $\begin{array}{l}\text { EF1-alpha, Factor de elongación de la traducción 1 (Murthi } \text { et al., } \\
\text { 2010; Schirmaier and Philippsen, 1984). }\end{array}$ \\
\hline
\end{tabular}

Tabla 2. Proteínas asociadas a Sub1-TAP, identificadas en tres experimentos independientes.

La RNAP de arqueas y todas las polimerasas eucariotas presentan un módulo estructural que no está conservado en eubacterias, el "tallo" o stalk. Dicho módulo se sitúa en el complejo próximo al canal de salida del RNA naciente, junto a los últimos residuos ordenados de Rpb1. Estos residuos que forman el inicio de una región linker que conecta con la estructura desordenada del CTD (Armache et al., 2003; Bushnell and Kornberg, 2003). En el caso de la RNAPII, el modulo está formado por las subunidades Rpb4 y Rpb7. Estas dos subunidades constituyen un heterodímero disociable del núcleo del complejo en levaduras (Armache et al., 2003; Bushnell and Kornberg, 2003; Edwards et al., 1991; Ruet et al., 1980) que, por su disposición en la estructura de la RNAPII (Figura1A), se ha propuesto que podría influir en el reclutamiento y/o la accesibilidad de algunas enzimas modificadoras al CTD (Armache et al., 2003, 2005; Bushnell and Kornberg, 2003; Cai et al., 2009, 2010; Kamenski et al., 2004; Sampath et al., 2008).

\subsubsection{Co-purificación de Sub1 con Rpb4/7}

Para corroborar la interacción entre Sub1 y Rpb7 y la validez de la identificación de Rpb7 por espectrometría de masas, llevamos a cabo dos aproximaciones distintas. En primer lugar, realizamos una purificación TAP de dos cepas: una cepa $w t$ sin marcar con ningún epítopo (No TAP, Figura 32) y una cepa doblemente marcada Sub1-TAP/Rpb7HA (TAP, Figura 32). Un 10\% del material total obtenido se sometió a electroforesis en gel SDS-PAGE y posterior inmunnoblot. La membrana se hibridó primero con anti- 
TAP, para corroborar la purificación de Sub1-TAP y después con anti-HA, para comprobar la co-purificación de Rpb7. En la figura 32, se observa perfectamente la copurificación de Rpb7-HA con Sub1-TAP, por lo tanto, corroborando los datos obtenidos por espectrometría de masas.

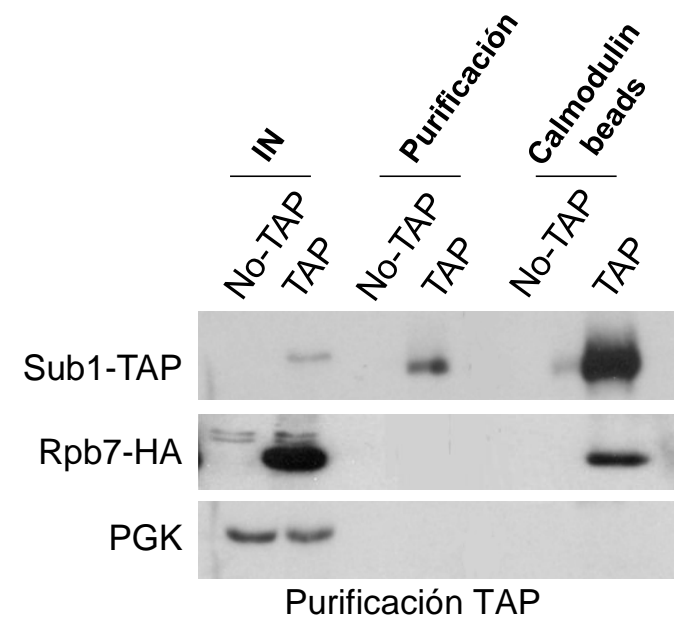

Figura 32. Rpb7 co-purifica con Sub1. Se prepararon extractos totales de dos cepas: una cepa sin marcar con ningún epítopo (No-TAP) y otra Sub1-TAP/Rpb7-HA (TAP). Los extractos se sometieron a dos purificaciones sucesivas (Materiales y Métodos) y las proteínas presentes en la mezcla final de purificación se precipitaron con ácido tricloroacético. Un 10\% del precipitado se analizó por Western Blot, utilizando los anticuerpos anti-TAP, anti-HA y anti-PGK (control de niveles proteínas en los extractos totales).

En segundo lugar, realizamos un ensayo de co-inmunoprecipitación en el que usamos extractos totales de la cepa Sub1-TAP/Rpb7-HA y de la cepa Sub1-TAP, como control negativo de la purificación inespecífica asociada al anticuerpo anti-HA. Inmunoprecipitamos Sub1-TAP, mediante incubación de los extractos con bolitas de inmunoglobulina $G$, y Rpb7-HA, utilizando anti-HA. Las mezclas de reacción se resolvieron por Western Blot y se analizaron con el anticuerpo anti-TAP. En la figura 33, se aprecia como en la cepa doblemente marcada, Sub1-TAP co-purifica con Rpb7HA, mientras que en la muestra correspondiente a la cepa Sub1-TAP sólo detectamos una ligera señal de reacción inespecífica.

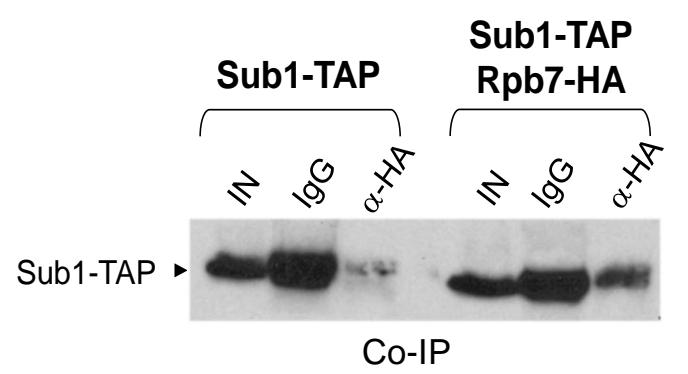

Figura 33. Sub1 co-inmunoprecipita con Rpb7. Se prepararon extractos totales de dos cepas: Sub1TAP y Sub1-TAP/Rpb7-HA. Se purificó Sub1-TAP por incubación de los extractos con bolitas acopladas a inmunoglobulina-G y Rpb7-HA por inmunoprecipitación con anti-HA. Las mezclas de reacción se analizaron por Western Blot con anti-TAP. 
Puesto que Rpb7 se asocia a Rpb4 in vivo, formando un heterodímero disociable del núcleo central de la RNAPII (Armache et al., 2003; Bushnell and Kornberg, 2003; Edwards et al., 1991; Ruet et al., 1980), decidimos investigar si Sub1 también copurifica con Rpb4, a pesar de que no habíamos identificado esta subunidad en las purificaciones de Sub1-TAP. Para ello, preparamos extractos totales de la cepa Sub1HA y realizamos varias inmunoprecipitaciones, usando el anticuerpo anti-HA para Sub1 y dos anticuerpos distintos para la RNAPII: 8WG16 (para la subunidad Rpb1) y antiRpb4. Además, inmunoprecipitamos la proteína Pgk1 como control de purificación inespecífica (mock). Como puede observarse en la figura 34, Rpb4 co-purifica con Rpb1 y también con Sub1-HA. Este resultado confirma, por lo tanto, la asociación de Sub1 con el heterodímero Rpb4/7.

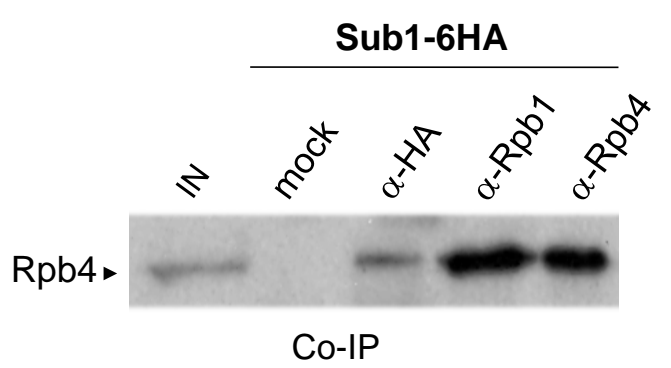

Figura 34. Sub1 y Rpb4 co-inmunoprecipitan. Se prepararon extractos totales de la cepa Sub1-6HA y se utilizaron para realizar varias inmunoprecipitaciones con los siguientes anticuerpos: anti-HA, antiRpb1 (8WG16) y anti-Rpb4. Además se realizó una inmunoprecipitación con anti-PGK, como control negativo (mock). Las mezclas de reacción se analizaron por Western blot con anti-Rpb4.

\subsubsection{Interacción genética entre $S U B 1$ y RPB4}

Los resultados mostrados sugieren que Sub1 podría asociarse al complejo de la RNAPII a través de su interacción con Rpb4/7. Decidimos realizar un ensayo genético para profundizar un poco más en la relación de Sub1 con este heterodímero. Como $R P B 7$ es un gen esencial, pero la deleción de $R P B 4$ es viable, utilizamos un mutante rpb4 4 sobre el que eliminamos SUB1 mediante reemplazamiento génico. Como puede observarse en la figura 35, el mutante sencillo rpb4A presenta un retraso en el crecimiento a $28^{\circ} \mathrm{C}$, que se acusa a $34^{\circ} \mathrm{C}$ y es letal a $37^{\circ} \mathrm{C}$. La deleción de SUB1 no afecta al crecimiento del mutante sencillo a la temperatura permisiva, pero produce una supresión parcial del fenotipo a $34^{\circ} \mathrm{C}$, mientras que la sobre-expresión lo agrava severamente. Estos datos sugieren que Sub1 podría ejercer un efecto negativo sobre la función de $R P B 4 / 7$. 


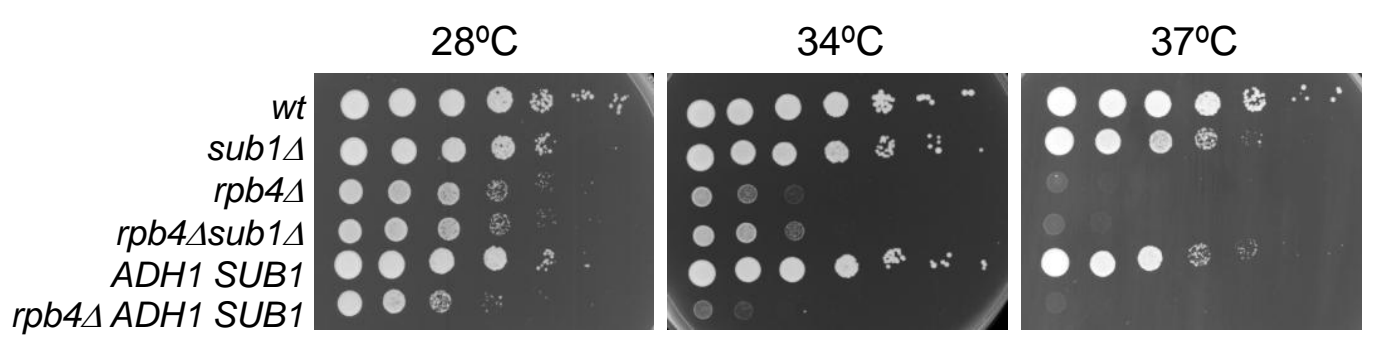

Figura 35. SUB1 interacciona genéticamente con $R P B 4$. Como se muestra en el ensayo de diluciones seriadas en placa, la deleción de $S U B 1$ afecta ligeramente al fenotipo del mutante $r p b 4 \Delta$, mientras que su sobreexpresión lo agrava. SUB1 se sobreexpresó bajo el control del promotor constitutivo ADHI $(A D H 1 S U B 1)$. Las cepas con los genotipos indicados se crecieron en placas de medio SC sin uracilo a $28^{\circ} \mathrm{C}, 34^{\circ} \mathrm{C}$ y $37^{\circ} \mathrm{C}$ durante $2-3$ días.

En conjunto, los resultados mostrados, es decir, la asociación entre Sub1 y el dímero Rpb4/7 y las interacciones genéticas entre SUB1 y los dominios clamp y foot de Rpb1, podrían ser el primer indicio del mecanismo por el cual Sub1 regula la fosforilación del CTD (ver Discusión). Así, dichas interacciones sugieren que la función de Sub1 está asociada a una región estructural de la RNAPII concreta, que comprende el dímero Rpb4/7 y los dominios clamp y foot de Rpb1, todos ellos relacionados a su vez con el CTD. En este sentido, por ejemplo, no hemos encontrado una interacción genética entre $S U B 1$ y el mutante rpb1-19, cuya mutación no afecta a la función del CTD. Además, como ya hemos adelantado, curiosamente, para el módulo Rpb4/7 con el que Sub1 se asocia físicamente, existen varios indicios que lo relacionan con las modificaciones postraduccionales del CTD. Por ejemplo, en S. cerevisiae, se ha descrito una interacción genética entre la prolil-isomerasa Ess1 y Rpb7 en S. cerevisiae, mientras que en $S$. pombe se ha identificado una interacción física entre la fosfatasa Fcp1 y Rpb4 (Kamenski et al., 2004; Kimura et al., 2002; Wu et al., 2000). Además, se sabe que, en $S$. cerevisiae, in vitro, Fcp1 solamente se asocia a la RNAPII que contiene las doce subunidades y no al complejo sin Rpb4/7 (Kamenski et al., 2004). A todas estas evidencias tenemos que añadir la interacción genética y funcional de Sub1 con Fcp1 en S. cerevisiae (Calvo and Manley, 2005).

\subsubsection{La deleción de $S U B 1$ no afecta al reclutamiento a la cromatina de $R p b 7$}

Como ya se ha mencionado anteriormente, la deleción de SUB1 provoca un descenso en el reclutamiento de la RNAPII a los genes, medido mediante ChIP de las subunidades Rpb1 (Calvo and Manley, 2005) y Rpb3 (Rosonina et al., 2009) y, puesto que Sub1 interacciona específicamente con Rpb4/7, decidimos investigar si su ausencia podría afectar también a la carga de este complejo a la cromatina. Para ello utilizamos 
las cepas $w t$ y subl $\Delta$ que expresan Rpb7-HA. En primer lugar, analizamos los niveles totales del complejo Rpb4/7 y observamos que éstos son similares en ambas cepas (Figura 36A). En segundo lugar, mediante ChIP analizamos la asociación de Rpb7-HA y Rpb1 a lo largo de los genes PMA1 y PYK1. Sorprendentemente, aunque la deleción de SUB1 disminuye la densidad de Rpb1 asociada a ambos genes (Figura 36B, panel superior), no tiene efecto sobre la asociación de Rpb7 (Figura 36B, panel inferior), de manera que si hiciéramos la relación Rpb7/Rpb1, podríamos inferir que hay más Rpb7 asociada a los genes en el mutante subl $\Delta$.

A

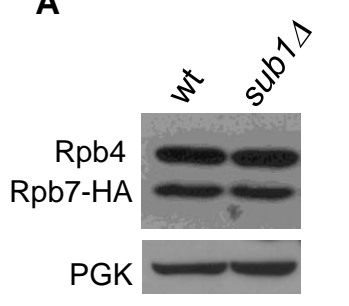

Western Blot
B

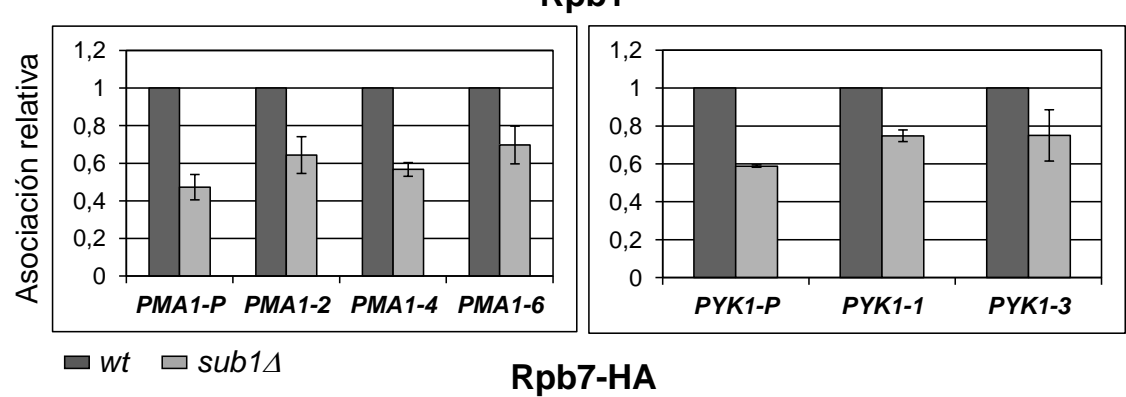

Rpb1

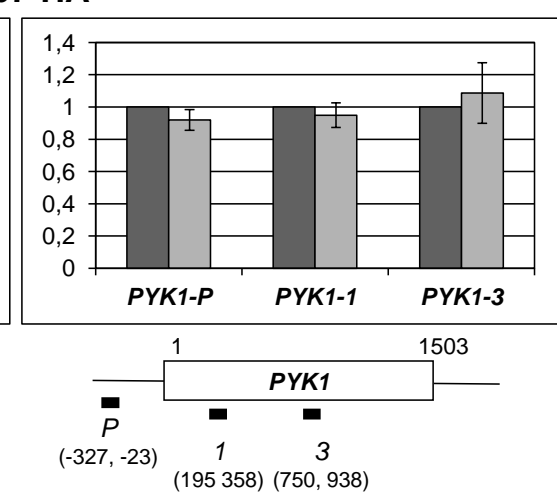

ChIP

Figura 36. La deleción de $S U B 1$ no altera los niveles ni el reclutamiento de Rpb7. (A) Análisis de los niveles totales de Rpb4/7. Se prepararon extractos totales de dos cepas: wt y sub1 $\Delta$, expresando Rpb7-HA y se analizaron mediante Western Blot los niveles de Rpb4 y Rpb7-HA con anti-Rpb4 y anti-HA, respectivamente. Como control de carga se analizaron los niveles de PGK. (B) Análisis de experimentos de ChIP para Rpb1 y Rpb7-HA en las cepas analizadas en (A). ChIP de Rpb1 (panel superior) con el anticuerpo 8WG16. ChIP de Rpb7-HA con anti-HA. En las gráficas se representan las cuantificaciones relativas derivadas del análisis por qPCR de la unión de Rpb1 y Rpb7-HA a los genes PMA1 y PYK1. La posición de anillamiento de los oligonucleótidos respecto al sitio de inicio de la transcripción se representa entre paréntesis. Los números en el eje y representan la asociación relativa de Rpb1 y Rpb7 en el mutante sub1 $\Delta$ respecto a la cepa $w t$, donde el nivel de asociación se considera 1. Las barras de error representan la desviación estándar.

\subsubsection{Sub1 depende de Rpb4/7 para su reclutamiento a los genes}

Aunque Rpb4/7 pueden disociarse del resto del complejo de la RNAPII, la polimerasa que se encuentra asociada a los genes transcribiendo activamente contiene las doce subunidades (Jasiak et al., 2008; Verma-Gaur et al., 2008). Dado que Sub1 co- 
purifica con el dímero Rpb4/7, quisimos estudiar si esta asociación era necesaria para el reclutamiento de Sub1 a la cromatina. Para ello trabajamos con el mutante de deleción $r p b 4 \Delta$, ya que $R P B 7$ es un gen esencial. Las células $r p b 4 \Delta$ presentan disminuidos los niveles totales de Rpb7 y su asociación al complejo RNAPII (Kolodziej et al., 1990; Runner et al., 2008; Sheffer et al., 1999). Además, se ha descrito que la polimerasa sin Rpb4/7 presenta defectos en iniciación in vitro y que la deleción de $R P B 4$ produce fenotipos relacionados con problemas en la elongación. Por su parte, Runner et al (2008) encontraron que Rpb4 participa en el reclutamiento de la maquinaria de procesamiento del extremo 3' de los mRNAs y describieron que su deleción produce un defecto en la asociación de la RNAPII, medida a través de la subunidad Rpb3, especialmente en las regiones 3'. Curiosamente, observaron que los niveles de Rpb1 se encuentran incrementados en el mutante $r p b 4 \Delta$.

Para analizar los niveles de asociación de Sub1 a la cromatina en ausencia de $R P B 4$, utilizamos la cepa Sub1-HA y realizamos experimentos de ChIP para Rpb3, Rpb1 y Sub1. Así, analizamos la asociación de todas estas proteínas a los promotores de varios genes de expresión constitutiva ( $P G K 1, A D H 1, P M A 1$ y YEF3). Como puede observarse en la figura 37, y de acuerdo con los resultados publicados previamente, la deleción de $R P B 4$ provoca una disminución en la asociación de Rpb3 a los promotores (Figura 37A y (Runner et al. 2008). Además, observamos que también se encuentra reducida la asociación de Rpb1 (B). En nuestro caso, observamos un defecto mayor para Rpb3 que la encontrada por estos autores, que podríamos achacar a diferencias en las condiciones de experimentación (temperatura de crecimiento de las células, $30^{\circ} \mathrm{C}$ versus $23^{\circ} \mathrm{C}$; qPCR frente a PCR radiactiva). Por su parte, y de forma análoga a lo que ocurre para la polimerasa, la asociación de Sub1-HA a estos mismos promotores se encuentra significativamente comprometida en el mutante rpb4 (Figura 37C). Es más, el efecto que la ausencia de $R P B 4$ causa sobre el reclutamiento de Sub1 a los promotores es más drástico que el que produce sobre Rpb3 y Rpb1. Así, por ejemplo, para el caso del gen ADH1 se observa un 35,5\% de asociación de Rpb3 y un 48,7\% de Rpb1, frente a un 22,22\% para Sub1-HA, cuando se comparan con los valores del silvestre, considerados como $100 \%$. 
A

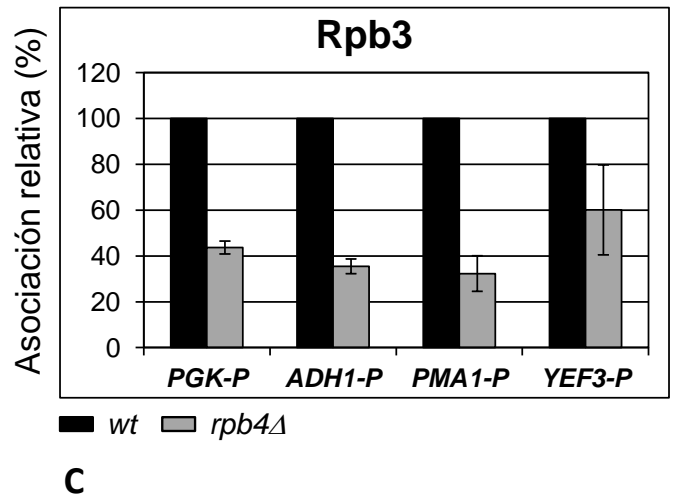

B

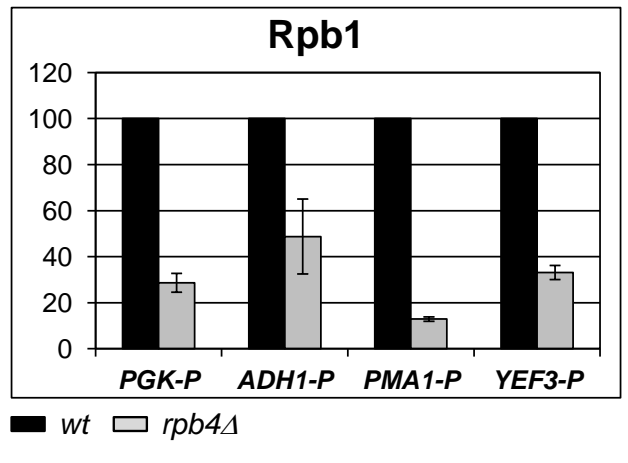

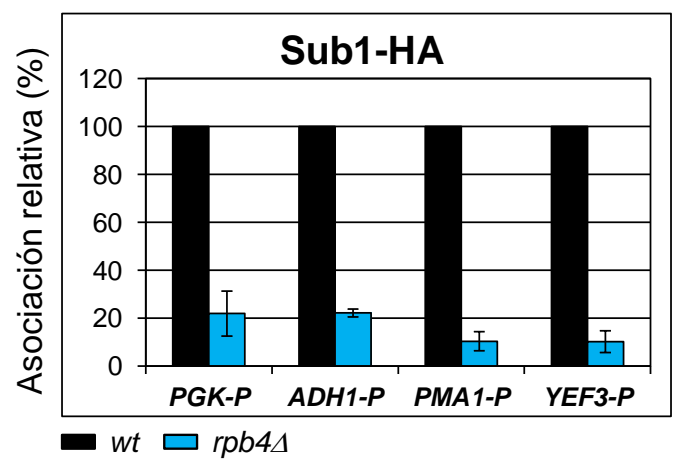

ChIP

Figura 37. La deleción de $R P B 4$ produce una disminución en la asociación a los genes de la RNAPII y de Sub1. (A) Análisis mediante ChIP del reclutamiento de Rpb3 a los promotores de los genes de expresión constitutiva $P G K 1, A D H 1, P M A 1$ y YEF3. Se utilizaron dos cepas wt y rpb4A que expresan Sub1-HA. Rpb3 se inmunoprecipitó utilizando un anticuerpo monoclonal específico anti-Rpb3. En la gráfica, los números en el eje $y$ representan la asociación relativa de $\mathrm{Rpb} 3$ en el mutante $r p b 4 \Delta$ respecto a la cepa $w t$, donde el nivel de asociación se considera $100 \%$. Las barras de error representan la desviación estándar. (B) ChIP de Rpb1 en las cepas wt y rpb4A con el anticuerpo 8WG16. La cuantificación se realizó como en (A). (C) ChIP de Sub1-HA en las cepas wt y rpb4A, utilizando el anticuerpo anti-HA. El análisis se realizó como en (A).

Como se acaba de mostrar, la asociación de la polimerasa a los genes se encuentra disminuida en el mutante $r p b 4 \Delta$ (Figura 37A y B), pese a que la expresión y los niveles de Rpb1 se encuentran incrementados (Runner et al., 2008). Por lo tanto, a continuación investigamos si la deleción de $R P B 4$ también afectaría a la expresión y a los niveles de Sub1. En la figura 38A se muestra que los niveles de transcripción de SUB1 no se alteran de forma significativa en el mutante $r p b 4 \Delta$, de manera similar a lo que ocurre para otro transcrito de expresión constitutiva de la RNAPII como ADH1 y para un transcrito de la RNAPI, como el gen codificante del rRNA 18S. Sin embargo la transcripción de RPB1 incrementa notablemente en ausencia de RPB4. Por otro lado, mediante Western Blot comprobamos que la deleción de RPB4 no afecta a los niveles totales de Sub1, pero sí provoca un incremento de los de Rpb1 (Figura 38B), de acuerdo con lo que se había descrito previamente (Runner et al., 2008). Este resultado demuestra 
que en el mutante $r p b 4 \Delta$, pese a que los niveles de Sub1 son similares a los de una cepa $w t$, Sub1 no es capaz de reclutarse a la cromatina y que, por lo tanto, la asociación de Sub1 a los genes requiere de un dímero Rpb4/7 funcional. Sin embargo, merece la pena destacar que cuando el mutante rpb4 $\Delta$ se mantiene en cultivo a lo largo del tiempo, aunque los niveles de Rpb1 siguen siendo elevados, los niveles de Sub1 caen drásticamente, probablemente debido a un problema de degradación de este factor cuando no se puede reclutar al complejo de la RNAPII (Figura 38C).

A

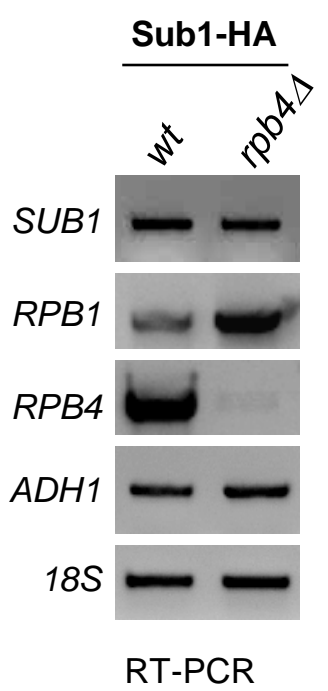

B

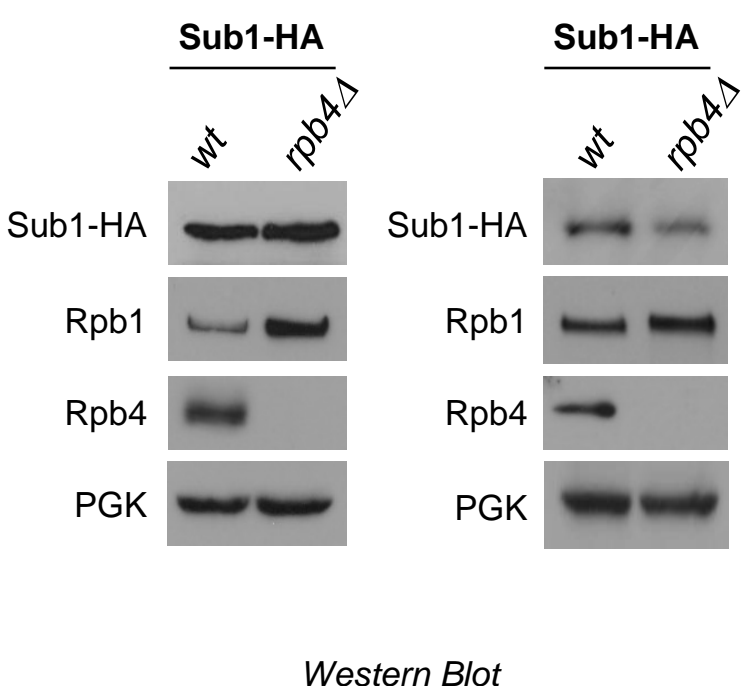

Figura 38. La deleción de RPB4 no afecta a la expresión de Sub1, al menos en fase logarítimica temprana. (A) RT-PCR para analizar la expresión de $S U B 1, R P B 1, R P B 4, A D H 1$ y $18 S$ en las cepas Sub1-HA wt y $r p b 4 \Delta$. Se purificó el RNA total y a partir de él se sintetizó el cDNA correspondiente, que se utilizó como molde en una PCR con oligonucleótidos específicos para los genes correspondientes. Los productos de la reacción se resolvieron por electroforesis en gel de agarosa teñido con bromuro de etidio. (B) Análisis de los niveles de proteína de Sub1-HA y Rpb1 en el mutante rpb44. Se prepararon extractos totales y se analizaron mediante Western Blot los niveles de Sub1-HA, Rpb1 y Rpb4, utilizando los anticuerpos anti-HA, 8WG16 y anti-Rpb4. Como control de carga se analizaron los niveles de la proteína PGK. (C) Análisis de los niveles de Sub1-HA y Rpb1 en el mutante rpb4 4 en extracto celulares totales procedentes de cultivos crecidos hasta fase estacionaria.

\subsubsection{La RNAPII se encuentra hiperfosforilada en un mutante $r p b 4 \Delta$}

Como se ha mencionado anteriormente, el dímero Rpb4/7 se dispone en el complejo de la RNAPII en una situación estratégica, cercano al CTD, y existen algunas evidencias que sugieren que podría estar implicado en la regulación de su fosforilación. Puesto que los niveles totales de proteína Rpb1 se incrementan en la deleción de RPB4, decidimos investigar qué ocurre con las formas hiperfosforiladas, tanto en Ser5 como en Ser2. En la figura 39 se observa que en el mutante $r p b 4 \Delta$ los niveles totales de Rpb1 hiperfosforilado en ambas serinas también se encuentran incrementados. Sin embargo, los niveles de Rpb3, otra de las subunidades de la RNAPII perteneciente al core, son 
similares en el mutante y en la cepa $w t$. Estos resultados concuerdan con los de Runner et al (2008), aunque estos autores solamente describieron un aumento en los niveles de Ser2P. En cualquier caso, el aumento de los niveles de polimerasa hiperfosforilada, tanto en Ser5P como en Ser2P, en ausencia de $R P B 4$, puede ser consecuencia del incremento en la transcripción del gen $R P B 1$ y de los niveles totales de proteína Rpb1 (Figuras 38 y 39; (Runner et al., 2008).

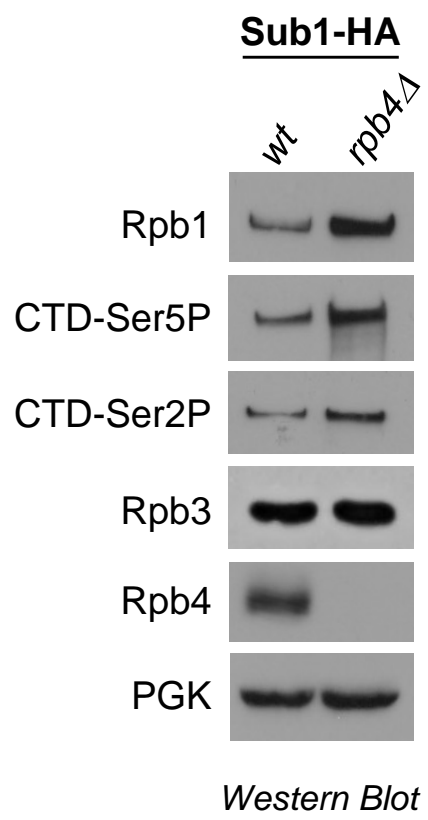

Figura 39. La deleción de RPB4 produce un aumento de los niveles totales de la RNAPII hiperfosforilada. Se prepararon extractos totales de dos cepas wt y rpb4A, expresando Sub1-HA, y se sometieron a electroforesis en geles SDS-PAGE y posterior inmunoblot. Los niveles de polimerasa total (Rpb1-CTD) se analizaron con el anticuerpo 8WG16, la fosforilación en Ser5 (CTD-Ser5P) con el anticuerpo CTD4H8 y la fosforilación en Ser2 (CTD-Ser2P) con el anticuerpo ab5095. Además se analizaron los niveles de Rpb3 y Rpb4, y como control de carga, PGK.

A continuación, decidimos investigar si la polimerasa asociada a los genes se encuentra también hiperfosforilada. Para lo cual, llevamos a cabo ChIP en las cepas $w t$ y rpb4A, expresando Sub1-HA, y analizamos la asociación de Rpb3, Rpb1 no fosforilada, Rpb1-CTDSer5P y Rpb1-CTDSer2P a lo largo de la secuencia de varios genes de expresión constitutiva de distinto tamaño (de menor a mayor, ADH1, PGK1, PMA1 y $Y E F 3)$. Como puede observarse en la figura 40A, la deleción de RPB4 produce una disminución en el reclutamiento de Rpb3, que es especialmente observable a lo largo de toda la secuencia del gen largo $Y E F 3$, de aproximadamente $3.2 \mathrm{~Kb}$, en menor medida de del gen PMAl (de $2.7 \mathrm{~Kb}$ ), mientras que no afecta de manera significativa a la asociación en dos genes cortos como $A D H 1$ y $P G K 1$, de aproximadamente 1,2-1,3 Kb, respectivamente. Estos resultados concuerdan perfectamente con los publicados por 
Runner et al. (2008). Sin embargo, los niveles de Rpb1 sí disminuyen de 5' a 3' para los cuatro genes analizados, con independencia de su longitud (Figura 40B). La inmunoprecipitación de Rpb1 se realizó usando el anticuerpo 8WG16, que reconoce preferentemente la forma no fosforilada del CTD, aunque es capaz de reconocer polimerasas elongantes, que en principio están hiperfosforiladas, ya que, como hemos indicado anteriormente, el CTD mantiene repeticiones del consenso no fosforiladas durante toda la transcripción. Por otra parte, se ha demostrado que la fosforilación en Ser2 compromete la detección del CTD por el anticuerpo 8WG16 (Stock et al., 2007). Así, es posible especular que a mayor fosforilación en Ser2, menor detección de Rpb1 en las secuencias codificantes cuando se utiliza el anticuerpo $8 \mathrm{~W} 16 \mathrm{G}$ en los ensayos de ChIP. Esto podría explicar la diferencia observada en los niveles de asociación de Rpb3 frente a los de Rpb1 (Figuras 40A y B). Por otra parte, en la deleción de RPB4 los niveles totales de Rpb1, medidos a partir de extractos celulares, son mayores que en una cepa $w t$, aunque la polimerasa asociada a los genes es menor. Esto podría indicar que hay un exceso de polimerasa libre que no se está reclutando a los genes, lo que está totalmente de acuerdo con el defecto en iniciación descrito para este mutante in vitro (Edwards et al., 1991). Además, es posible que aquellas polimerasas que consiguen ensamblarse completa y correctamente, aunque en un porcentaje menor, sean lo suficientemente eficientes como para elongar y que el defecto en elongación que se ha descrito para el mutante $r p b 4 \Delta$ (Verma-Gaur et al., 2008) no sea tan limitante como el defecto en iniciación. De hecho, nuestros experimentos de ChIP muestran que los niveles de fosforiación en Ser5P no se alteran significativamente (salvo en el caso del gen más largo, YEF3) y que sólo en los extremos 3' de los genes observamos claramente un aumento en la fosforilación en Ser2P, de acuerdo con (Runner et al., 2008).

Figura 40. La RNAPII se encuentra hiperfosforilada en un mutante rpb4 . (A) ChIP de Rpb3 en las cepas $w t$ y $r p b 4 \Delta$, expresando Sub1-HA. La asociación de Rpb3 se analizó por qPCR para los genes PGK1, ADH1, PMA1 y YEF3. La cuantificación se realizó según se detalla en Figura 17 y en Materiales y Métodos. Las barras de error indican desviación estándar. (B) Chip de Rpb1 con el anticuerpo 8WG16. (C) ChIP de Rpb1 hiperfosforilada en Ser5 usando el anticuerpo CTD4H8. (D) ChIP de Rpb1 hiperfosforilada en Ser2 usando el anticuerpo ab70324. Bajo cada gráfica se muestra un esquema con la posición de anillamiento de los oligonucleótidos utilizados. Se muestra el inicio y el final de la transcripción con una barra vertical. 
A

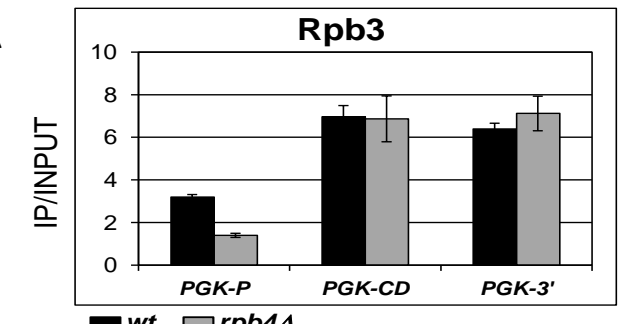

B

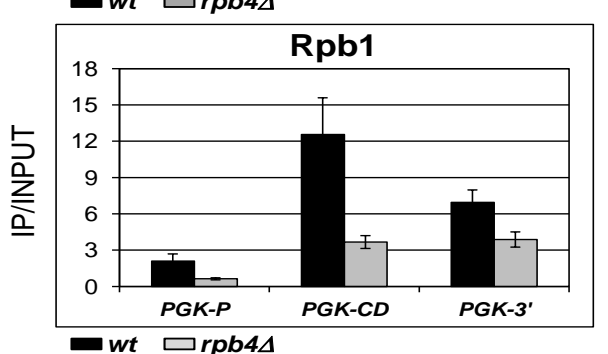

C

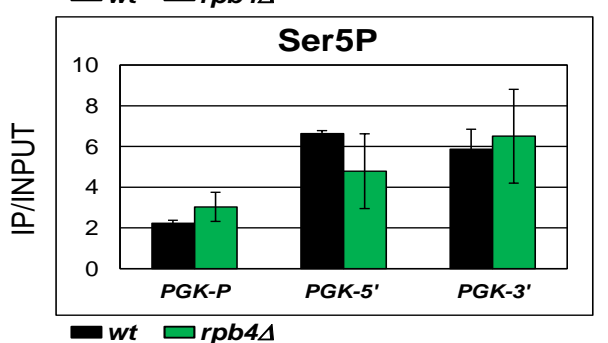

D

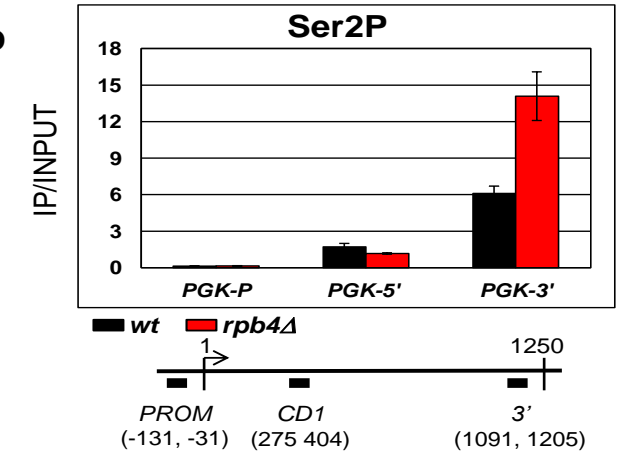

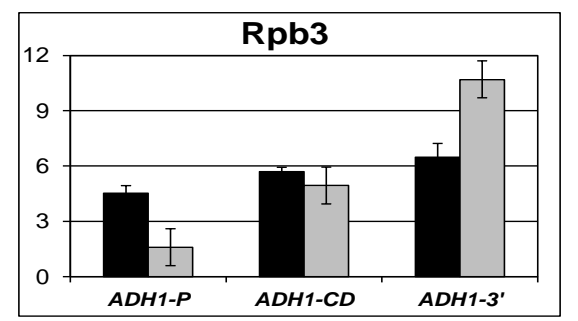
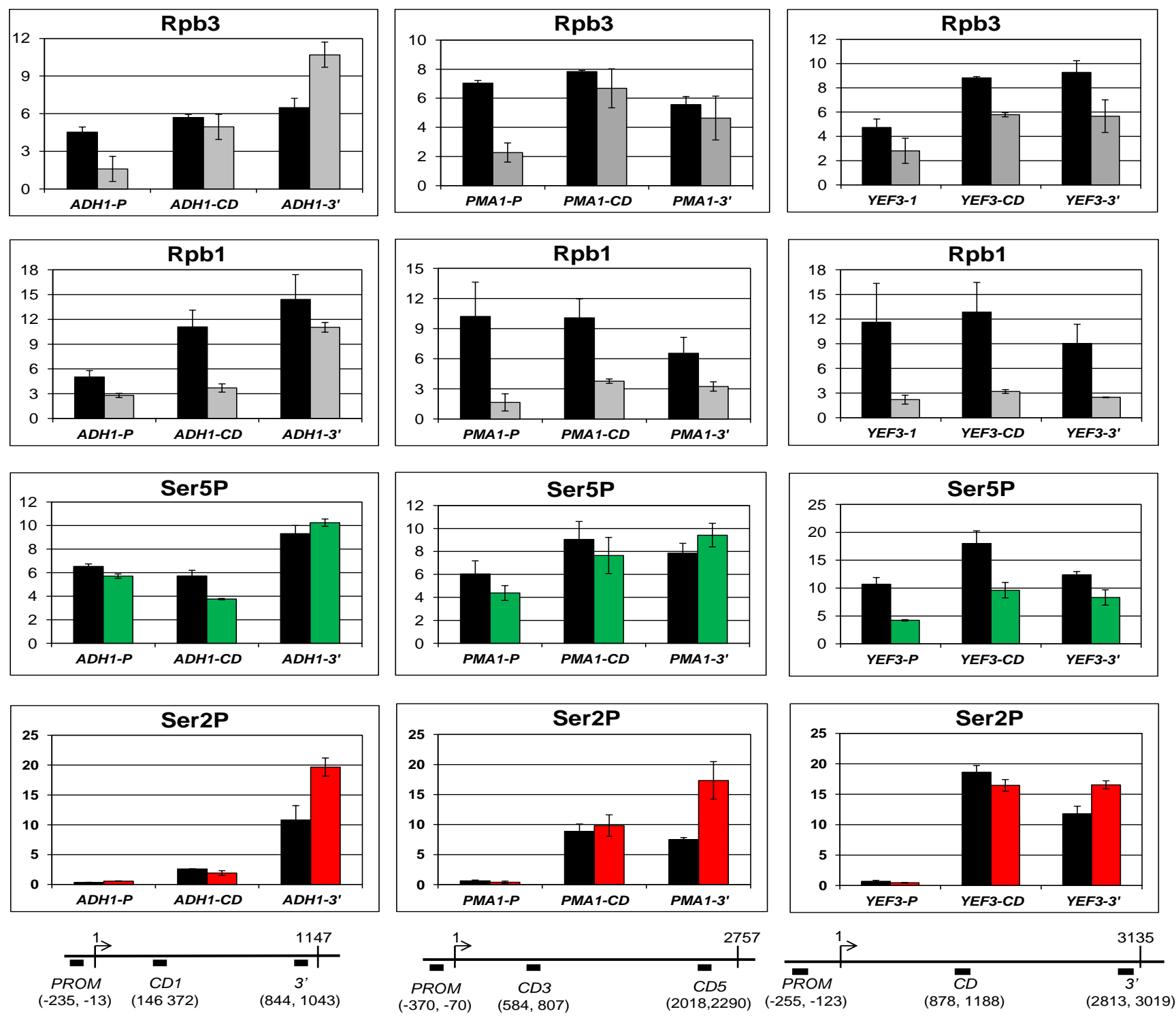
El aumento específico de los niveles de fosforilación en Ser2 en el mutante rpb4 $\Delta$ puede ser consecuencia directa de un incremento en su fosforilación y/o de defectos en su defosforilación. En este sentido, es posible que la ausencia de un dímero Rpb4/7 funcional altere los niveles y/o la asociación de las CTD-quinasas de Ser2, Bur1 y Ctk1. Puesto que la acumulación de Ser2 se produce fundamentalmente en regiones 3' génicas y Bur1 fosforila fundamentalmente en regiones cercanas a los promotores, parece más plausible que pudiera modular a Ctk1. Sin embargo, Runner et al (2008) demostraron por ChIP que el reclutamiento a la cromatina de Ctk1 no se altera, o se incrementa ligeramente. Así bien, si a priori no hay defectos en la fosforilación, es posible que se produzcan en la defosforilación mediada por Fcp1, debido a que esta enzima es la principal CTD-fosfatasa de los residuos de Ser2 y a que está funcionalmente relacionada con Rpb4/7. Además, hay que tener en cuenta que la asociación de Sub1 a la cromatina se encuentra reducida de forma severa en el mutante $r p b 4 \Delta$, de manera que la ausencia de niveles adecuados de Sub1 podría contribuir al incremento en la fosforilación, de acuerdo con los fenotipos descritos anteriormente para el mutante subl $\Delta$. En conclusión, la situación topológica de Rpb7 en el complejo de la RNAPII próxima al CTD (Armache et al., 2003; Bushnell and Kornberg, 2003), así como las relaciones genéticas descritas en la literatura entre $\mathrm{Rpb} 7 \mathrm{y}$ algunas enzimas modificadoras del CTD, como Ess1 o Fcp1 (Kimura et al., 2002; Wu et al., 2000) y los datos que acabamos de presentar, nos llevan a plantear la hipótesis de que Sub1 podría estar regulando la fosforilación de la RNAPII a través de su interacción con Rpb4/7. Evidentemente, queda trabajo por realizar para demostrar esta hipótesis, como por ejemplo, investigar el estado de la asociación a la cromatina de Fcp1 y/o sus niveles celulares en el mutante $r p b 4 \Delta$. Alternativamente, nos gustaría estudiar si se producen alteraciones estructurales en el complejo RNAPII en ausencia de Sub1, alteraciones que impliquen al dímero Rpb4/7 y/o a otros dominios de la polimerasa, como, por ejemplo, el clamp, y que podrían contribuir a los defectos en fosforilación observados en el mutante subl $\Delta$. 
2.- Papel del factor Sub1 en la regulación de la elongación de la RNA polimerasa II 


\subsection{Sub1 promueve la elongación transcripcional}

Sub1 se describió inicialmente como un coactivador transcripcional, relacionado funcionalmente con el factor de transcripción TFIIB (Henry et al., 1996; Knaus et al., 1996) y más tarde se demostró que se encuentra preferentemente asociado a las regiones promotoras durante la transcripción (Nedea et al., 2003; Rosonina et al., 2009). No obstante, una serie de evidencias experimentales sugerían que Sub1 podría tener un papel regulador durante la elongación transcripcional e, incluso, ser en sí mismo un verdadero factor de elongación. Las evidencias son las siguientes:

1) Sub1 está relacionado genética y funcionalmente con las CTD-quinasas de elongación Bur1 y Ctk1.

2) Regula los niveles de proteína de la fosfatasa de elongación Fcp1, además de influir en su interacción con la cromatina durante todo el ciclo de transcripción (Calvo and Manley, 2005).

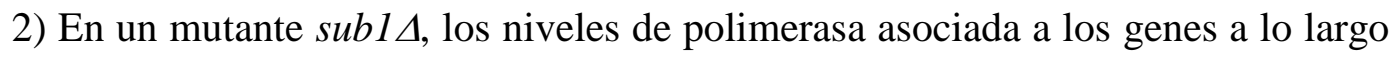
de todo el ciclo transcripcional se encuentran disminuidos (Calvo and Manley, 2005; Rosonina et al., 2009; Sikorski et al., 2011).

4) Sub1 se asocia a las secuencias codificantes a lo largo de toda la transcripción (Calvo and Manley, 2005), aunque hay algunas discrepancias al respecto (Rosonina et al., 2009; Sikorski et al., 2011).

Teniendo en cuenta todos estos datos, decidimos realizar un estudio con el objetivo de determinar si, en efecto, Sub1 juega un papel en la elongación de la transcripción y, de ser así, si éste es directo o no. Para ello, hemos seguido diferentes estrategias: análisis de la eficiencia de la elongación transcripcional usando el ensayo GLAM, análisis de la expresión del gen IMD2 por RT-PCR, análisis de la distribución de la RNAPII a lo largo de genes tanto de expresión constitutiva, como inducible o regulable, mediante ChIP, y por último, análisis de los niveles de polimerasa activa y competente para elongar, por ensayo de Run-On Transcripcional (TRO).

\subsubsection{Sub1 afecta a la eficiencia de la elongación de la transcripción de transcritos largos}

El ensayo GLAM (gene lenght-dependent accumulation of $m R N A$ ) se utiliza para detectar específicamente defectos en elongación y permite determinar la eficiencia de la 
biosíntesis de mRNA en función de la longitud génica in vivo (Morillo-Huesca et al., 2006). Para ello, se mide la actividad fosfatasa ácida derivada de la actividad del gen PHO5, utilizando tres construcciones que difieren en la longitud del extremo 3'-UTR Estas tres construcciones contienen la $O R F$ de $P H O 5$, expresada bajo el control del promotor inducible GAL1 en los siguientes plásmidos: pSCh202, pSCh209 y pSCh212 (Figura 41A). El plásmido pSCh202 sólo contiene la secuencia codificante de PHO5, mientras que las otras dos construcciones presentan una región 3'-UTR de igual longitud, pero que difieren entre sí en su origen, en su contenido en $\mathrm{G}+\mathrm{C}$ y en la estructura de la cromatina. Así, pSCh209 contiene el gen PHO5 fusionado al gen LAC4 de Kluyveromyces lactis y pSCh212 el gen PHO5 fusionado al gen lacZ de Escherichia coli. Además, en el ensayo GLAM, se utiliza el plásmido YCplac33, como control para evaluar la actividad fosfatasa producida por el gen PHO5 endógeno en el ensayo enzimático (Morillo-Huesca et al., 2006).

Realizamos el ensayo con las cepas wt y subla y, como control positivo del experimento, utilizamos un mutante del factor de elongación Spt5, spt5-194, y su correspondiente cepa isogénica silvestre. La cepa spt5-194 es un mutante bien caracterizado que presenta defectos en elongación (Hartzog et al., 1998; Swanson et al., 1991; Swanson and Winston, 1992; Winston et al., 1984). Las dos cepas mutantes, sub1 $\Delta$ y spt5-194, y las cepas silvestres correspondientes $(w t)$ se transformaron con los plásmidos mencionados arriba (pSCh202, pSCh209, pSCh212 y YCplac33). En los transformantes obtenidos se cuantificó la actividad fosfatasa ácida en las condiciones descritas para el ensayo (Materiales y Métodos y (Morillo-Huesca et al., 2006). La medida de la eficiencia de la elongación se obtiene a partir del cálculo del ratio GLAM, que es la cuantificación de la actividad fosfatasa ácida debida a las unidades transcripcionales largas, respecto a la actividad debida a la unidad transcripcional corta. Como se observa en la figura 41B (panel izquierdo), el mutante spt5-194 presenta un ratio GLAM reducido para las dos unidades transcripcionales largas $\mathrm{P}_{\mathrm{GAL1}}$-PHO5-LAC4 (LAC4) y $\mathrm{P}_{\mathrm{GAL1}}-\mathrm{PHO5-lacZ}$ (LACZ), si lo comparamos con el correspondiente a la cepa $w t$. Este resultado era esperable, al tratarse Spt5 de un factor de elongación esencial, y es similar al descrito previamente para otros mutantes de elongación, como spt4 $\Delta$ y mutantes del complejo PAF (Gaillard et al., 2009; Morillo-Huesca et al., 2006). Curiosamente, el mutante subla también presenta un ratio GLAM disminuido en relación a la cepa $w t$, para ambas unidades transcripcionales (Figura 41C, panel 
izquierdo), aunque la disminución es menor que la observada en el mutante spt5-194 (Figura 41B, panel izquierdo).

A continuación, mediante RT-PCR, analizamos la expresión del gen PHO5 en las cepas $w t$, subl $\Delta$ y spt5-194, transformadas con los cuatro plásmidos del ensayo GLAM, para corroborar que la reducción en la actividad fosfatasa se debía a una disminución en la síntesis del mensajero correspondiente. Como puede apreciarse en las figuras 41B (panel derecho) y 41C (panel derecho), la reducción del ratio GLAM que se produce en los mutantes spt5-194 y subla se corresponde con una disminución de la transcripción del gen $\mathrm{PHO5}$, expresado desde las unidades transcripcionales largas conteniendo las regiones 3'-UTR de los genes LAC4 y lacZ, mientras que no se ve afectada la transcripción desde la unidad de longitud corta. Este resultado sugiere que la deleción de $S U B 1$ conduce a defectos en la elongación de la transcripción in vivo.

A

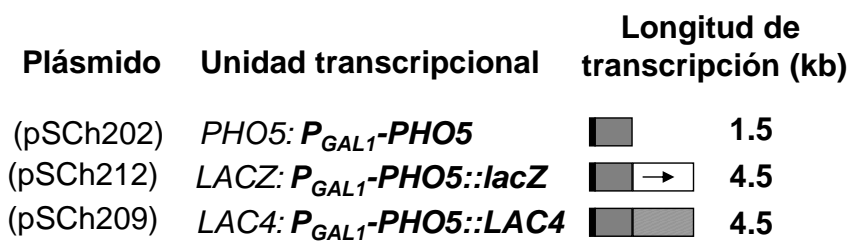

B

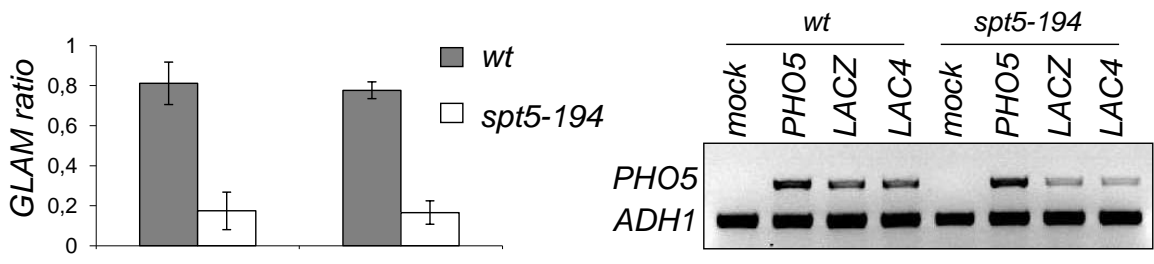

C
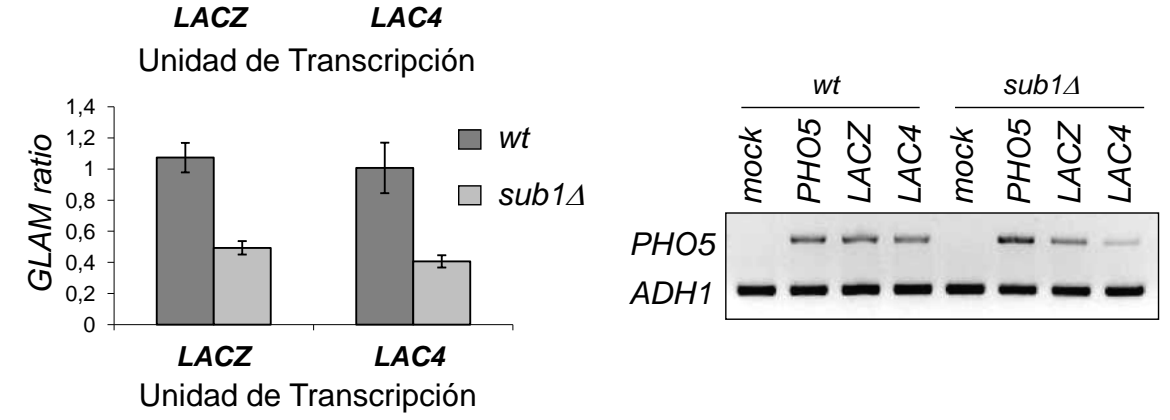

\section{Ensayo GLAM}

RT-PCR

Figura 41. Sub1 influye en la eficiencia de la elongación transcripcional de transcritos largos. (A) Representación esquemática de las tres unidades de transcripción usadas en los ensayos GLAM. (B) Las cepas $w t$ y spt5-194 se transformaron con los plásmidos que contenían las tres unidas transcripcionales mostradas en (A). Los ratio GLAM se calcularon como los niveles relativos de actividad fosfatasa ácida expresada por la unidad de transcripción indicada (GAL1-PHO5 lacZ o GAL1-PHO5 LAC4), con respecto a la actividad fosfatasa ácida de la unidad de transcripción más corta (GAL1-PHO5). El panel de la izquierda contiene una representación de los ratio GLAM y el de la derecha muestra los resultados de la expresión de PHO5 analizados por RT-PCR, para las tres unidades transcripcionales y para la cepa control transformada con el plásmido vacío. El gen $A D H 1$ se usó como control de carga. Los productos de PCR se analizaron por electroforesis en gel de agarosa teñido con bromuro de etidio. (C) Resultados del ensayo GLAM para las cepas wt y subl 1 (ratio GLAM y RT-PCR). 
Puesto que la fosforilación del CTD tiene un papel esencial en la regulación del procesamiento de los pre-mRNAs y que mutantes que afectan al procesamiento también tienen ratios GLAM reducidos (Morillo-Huesca et al., 2006), nos preguntamos si defectos en la fosforilación darían lugar a defectos en la eficiencia de la elongación. Para estudiar esta posibilidad, decidimos realizar un ensayo GLAM para dos mutantes kin28: kin28-K36A, con actividad CTD-quinasa reducida, y kin28-T162A, cuya mutación no afecta a su actividad catalítica, ni a la fosforilación de la polimerasa in vivo, pero sí a la activación de la enzima (Rodriguez et al., 2000). Transformamos las dos cepas con los plásmidos del ensayo, medimos la actividad fosfatasa ácida y calculamos los ratio GLAM. Como puede observarse en la figura 42 (panel izquierdo), ambos mutantes kin28 presentan una reducción del ratio GLAM, aunque el efecto es mucho más drástico para el mutante kin28-K36A. Resultado que corroboramos por RTPCR, analizando la síntesis del transcrito PHO5 en las cepas correspondientes (panel derecho).
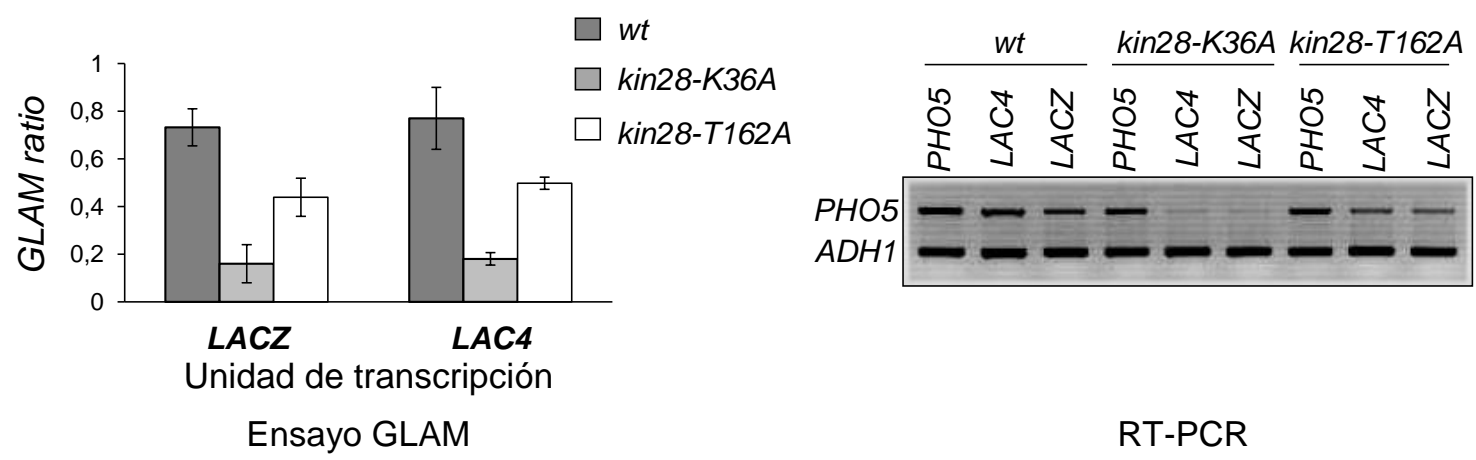

Figura 42. La fosforilación de la RNAPII afecta a la eficiencia de la elongación transcripcional. Ensayo GLAM en las cepas wt, kin28-K36A y kin28-T162A transformadas con los plásmidos YCplac33, pSCh202, pSCh209 y pSCh212. Los ratio GLAM se calcularon tal y como se detalla en la figura 41. El panel de la izquierda contiene una representación de los ratio GLAM y el de la derecha muestra los resultados de la expresión de $P H O 5$ analizados por RT-PCR, para las tres unidades transcripcionales (PHO5, LAC4 y LACZ). El gen ADH1 se usó como control de carga. Los productos de PCR se analizaron por electroforesis en gel de agarosa teñido con bromuro de etidio.

Este resultado indica que defectos en la fosforilación del CTD, aunque tengan lugar durante la iniciación de la transcripción, dan lugar a ratios GLAM bajos. Es decir, defectos en la fosforilación de la RNAPII conducen a defectos en la eficiencia de la elongación, de acuerdo con el papel esencial de Kin28 en el procesamiento del extremo 5' de los pre-mRNAs (Komarnitsky et al., 2000; Rodriguez et al., 2000). Por lo tanto, puesto que Sub1 influye en la función de Kin28 y la fosforilación del CTD, no podemos descartar que los defectos en la eficiencia de la elongación observados en la cepa subl $\Delta$ 
sean indirectos, como consecuencia de su defecto en la fosforilación de la RNAPII y, por lo tanto, en el procesamiento de los mRNAs.

\subsubsection{Sub1 promueve la elongación de la transcripción y se asocia a las regiones codificantes de los genes}

Durante los últimos años se han descrito numerosos factores que influyen en la elongación (Selth et al., 2010), muchos de los cuales no actúan directamente sobre este proceso (Mason and Struhl, 2005). No obstante, todos ellos cumplen una serie de criterios que se han utilizado frecuentemente para definirlos como factores de elongación. Estos criterios incluyen la capacidad que tienen para asociarse a las regiones codificantes de los genes in vivo dependiente de la transcripción, viajando con la polimerasa elongante de 5' a 3' (por ejemplo, (Krogan et al., 2002; Kruk et al., 2011; Mason and Struhl, 2003; Pokholok et al., 2002). Además, muchos de ellos se han caracterizado a partir de los defectos que provocan mutaciones en los mismos en la expresión del gen IMD2, que codifica para la enzima IMP deshidrogenasa 2, de la ruta de síntesis de novo de GTP. En este sentido, se han utilizado comúnmente drogas que afectan a los niveles intracelulares de GTP y UTP, como son el MPA o el 6AU (Escobar-Henriques et al., 2001; Shaw and Reines, 2000). Aunque su mecanismo concreto de acción no se conoce bien, se sabe que provocan la inducción de la expresión del gen IMD2 (Escobar-Henriques et al., 2001; Jenks et al., 2008; Kuehner and Brow, 2008; Shaw and Reines, 2000). Así, mutaciones en componentes de la maquinaria de elongación confieren sensibilidad a estas drogas debido a su incapacidad para inducir la expresión del gen IMD2 (Riles et al., 2004; Shaw and Reines, 2000).

La transcripción de IMD2 está regulada por la selección de diferentes sitios de inicio (TSS). En el promotor de este gen hay varios sitios en posiciones distales aguas arriba del codón de inicio, que lideran la transcripción de transcritos cortos no codificantes que son degradados rápidamente. Adicionalmente, hay un sitio más próximo al ATG, que se selecciona por limitación de la concentración de nucleótidos, permitiendo la expresión del gen IMD2 (Jenks et al., 2008; Kuehner and Brow, 2008) (Figura 43A). Curiosamente, se ha propuesto que Sub1 funciona como un represor de la expresión de IMD2, en condiciones de no inducción (Koyama et al., 2008), condiciones en las que solamente se utilizan los sitios de inicio aguas arriba, se sintetizan los transcritos cortos y la ORF de IMD2 no se transcribe. Así, en el mutante subl $\Delta$ hay una 
expresión constitutiva del gen IMD2 en condiciones normales de crecimiento, mientras que su expresión está reprimida en células wt (Koyama et al., 2008). No obstante, los efectos de Sub1 sobre la expresión del gen IMD2 podrían ser explicados por un mecanismo distinto que implica la selección de TSS, de acuerdo con datos recientes que demuestran que la deleción de SUB1 altera la selección de TSS en el gen $A D H 1$ (comunicación personal del Dr. NJ. Krogan, University of California-San Francisco). Así, probablemente, en ausencia de Sub1 y en condiciones de no-inducción, la transcripción se lleva a cabo utilizando preferentemente el sitio de inicio aguas abajo y, como resultado, tiene lugar la expresión constitutiva del gen IMD2. Esto explicaría porque el mutante subl $\Delta$ es resistente a MPA (Koyama et al., 2008) o a 6AU en medio sólido (Figura 20). Sin embargo, al analizar el crecimiento de subl $\Delta$ en medio líquido con 6AU, observamos que las células presentan un acusado retraso en el crecimiento en estas condiciones (Figura 43B).

A

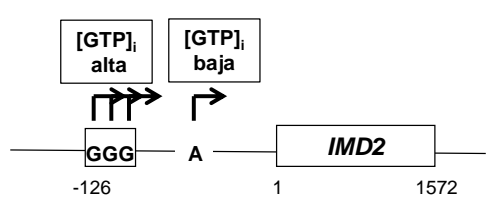

B

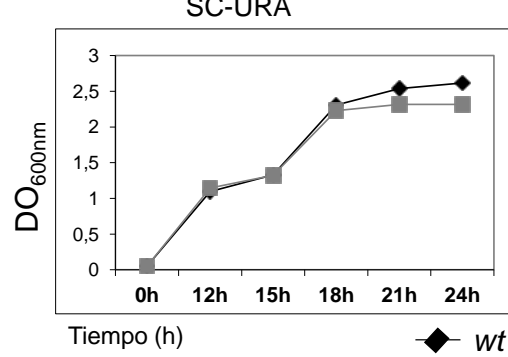

SC-URA $+75 \mu \mathrm{g} / \mathrm{ml} 6 \mathrm{AU}$

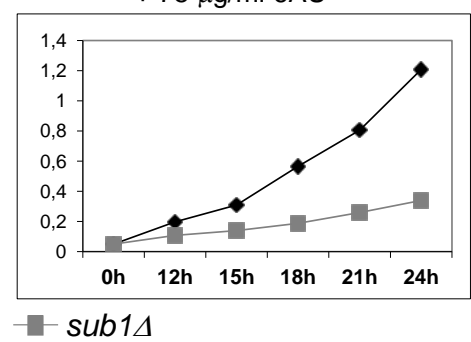

Figura 43. La deleción de SUB1 produce sensibilidad a la droga 6AU en medio líquido. (A) Modelo esquemático del gen $I M D 2$ en el que aparecen indicados los distintos sitios de inicio de la transcripción. Los sitios G, aguas arriba, se utilizan cuando hay una alta disponibilidad de GTP intracelular $\left([\mathrm{GTP}]_{\mathrm{i}}\right.$ alta), y a partir de ellos se sintetizan transcritos cortos que se degradan rápidamente El sitio A, aguas abajo, se utiliza cuando hay una baja disponibilidad de GTP intracelular ([GTP $]_{\mathrm{i}}$ baja), y a partir de él se transcribe el mRNA de IMD2. (B) Curva de crecimiento de las cepas $w t$ y $s u b 1 \Delta$, a $28^{\circ} \mathrm{C}$, en medio SCURA, con o sin $6 \mathrm{AU}$ a una concentración final de $75 \mu \mathrm{g} / \mathrm{ml}$. El crecimiento de las cepas indicadas se siguió durante 24 horas, midiéndose la D.O. a 600nm de los cultivos cada 3 horas.

Además, la deleción de SUB1 incrementa el fenotipo de sensibilidad a 6AU de dos mutantes burl (Figura 20) y, como veremos más adelante, provoca sensibilidad extrema a esta droga en cepas mutantes para dos factores de elongación, Spt4 y Spt5. Estos datos sugerían que Sub1 podría tener también un papel durante la elongación de la transcripción. Más aún, sugerían que su función podría ser particularmente importante para la expresión del gen IMD2, tanto a nivel de su iniciación, como de su elongación.

Para estudiar si Sub1 participa en la expresión del gen IMD2, las cepas wt y sublA se cultivaron en medio SC sin uracilo. Los cultivos se crecieron hasta una densidad 
óptica de 0,5 a $600 \mathrm{~nm}$, momento en el que se dividieron en dos mitades, a una de ellas se le añadió $6 \mathrm{AU}$ a una concentración final de $50 \mu \mathrm{g} / \mathrm{ml}$, y ambas se continuaron creciendo durante una hora más, tras lo cual las células se recogieron y se procesaron. Se extrajo el RNA total y se sintetizó el cDNA correspondiente. Finalmente, por qPCR se analizó la expresión de IMD2 y se normalizó frente a los valores de la expresión del $18 \mathrm{~S}$ rRNA. Como puede apreciarse en la figura 44A, en condiciones normales de crecimiento, la expresión del gen IMD2 se encuentra incrementada en más de 10 veces en $\operatorname{sub1} 14$, si se compara con la expresión en el $w t$. Sin embargo, cuando las células se tratan con 6AU, los niveles de IMD2 aumentan significativamente en la cepa $w t$, como era de esperar (Figura 44A), sin que ocurra lo mismo en sub1 $\Delta$. Parece ser que no hay síntesis de novo del transcrito. Hecho que es mucho más evidente cuando calculamos el cociente de la expresión de IMD2 en presencia y ausencia de 6AU para ambas cepas (+6AU/-6AU, Figura 44B). Claramente, estos resultados indican que la deleción de SUB1 tiene un efecto epistático sobre la activación del gen IMD2 por 6AU.

A

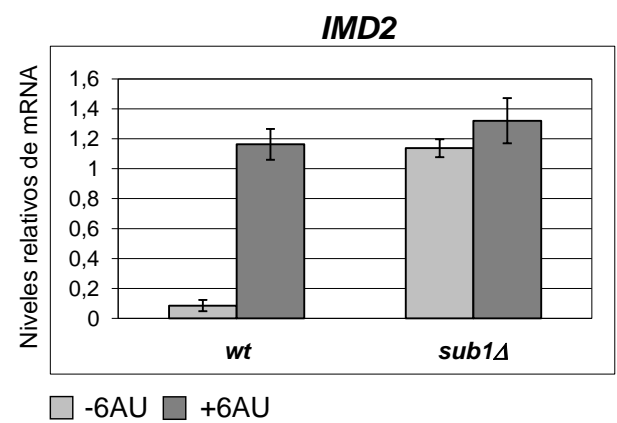

B

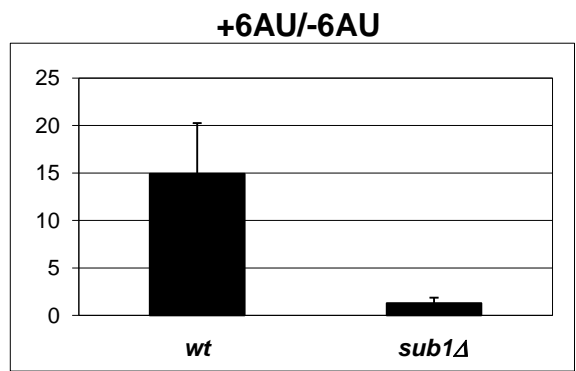

RT-qPCR

Figura 44. En el mutante sub1 4 no tiene lugar la síntesis de novo del gen IMD2 en condiciones de inducción. (A) Análisis de la expresión de IMD2 por RT-PCR. Se aisló RNA total de cepas wt y subl $\Delta$ crecidas en medio SC sin uracilo y con o sin $6 \mathrm{AU}$ a una concentración final de $50 \mu \mathrm{g} / \mathrm{ml}$. Se sintetizó cDNA y posteriormente se analizaron por qPCR los niveles de IMD2 y $18 S$ rRNA. Los valores de expresión de IMD2 se normalizaron frente a los valores de $18 S$ rRNA en tres experimentos independientes. (B) Cociente de expresión de IMD2 en presencia de 6AU (+6AU), frente a la expresión en ausencia de $6 \mathrm{AU}$ (-6AU). Se calcularon de forma independiente los cocientes de la cuantificación de la expresión de IMD2 en +6AU, frente a la expresión en $-6 \mathrm{AU}$, para las cepas wt y subl $\Delta$ y se representaron los valores. Las barras de error representan los datos de desviación estándar.

Por otra parte, la ausencia de activación de IMD2 en presencia de 6AU en células subl $\Delta$ concuerda con el hecho de que estás células sean sensibles a esta droga en medio líquido y que la deleción de $S U B 1$ incremente la sensibilidad de los mutantes burl en medio sólido. No obstante, no podemos descartar que el efecto sobre las células burl sea específico de gen, ya que no hemos analizado los niveles de expresión de IMD2 en 
los mutantes burl y burlsubl $\Delta$. En cualquier caso, nuestros datos sugieren que la expresión completa de IMD2, tras la inducción con 6AU, depende de la función de Sub1 durante la elongación, además de depender de su posible papel en la selección del sitio de inicio, cuando se une al promotor en condiciones de no-inducción. Es decir, Sub1 podría desempeñar también un papel en la elongación de IMD2 tras la inducción. De hecho, durante la finalización de esta tesis, se ha publicado un trabajo, en el que se ha demostrado que ciertas mutaciones en el bucle de activación o trigger loop de Rpb1 causan sensibilidad o resistencia a MPA, lo que se correlaciona con un desplazamiento del uso preferente del TSS aguas arriba o aguas abajo de IMD2 y con un incremento o reducción de las tasas de elongación, respectivamente (Kaplan et al., 2012).

Como ya hemos anticipado previamente, uno de los criterios que se ha utilizado comúnmente para definir un factor de elongación es su capacidad de unirse a las secuencias codificantes de los genes durante la transcripción activa. Calvo y Manley (2005) demostraron que Sub1-HA se asocia de forma similar a lo largo de toda la secuencia de varios genes de expresión constitutiva cuando se expresa desde un plásmido centromérico bajo el control de un promotor fuerte. Sin embargo, en trabajos posteriores (Rosonina et al., 2009), cuando se analizó la asociación de Sub1-HA expresado desde su locus endógeno, se encontró que los niveles más altos de unión se hallaban en las regiones $5^{\prime}$ y se sugirió que los resultados obtenidos anteriormente podían ser consecuencia del exceso de moléculas de Sub1, al expresarse desde un promotor fuerte y siendo Sub1 una proteína de gran afinidad por el DNA (Henry et al., 1996). Por ello, decidimos repetir los experimentos de ChIP y analizar la asociación de Sub1-HA, expresado desde su locus endógeno, a dos clases de genes distintos: uno de expresión constitutiva, PMA1, y otro regulable, IMD2. Así, realizamos los ensayos en presencia y ausencia de 6AU. La droga induce la expresión del gen IMD2 (EscobarHenriques et al., 2001; Hyle et al., 2003; Shaw and Reines, 2000) y disminuye la asociación de la RNAPII al gen PMAl (Keogh et al., 2003). Realizamos el tratamiento con 6AU, de forma similar al detallado más arriba, para analizar la expresión de IMD2, pero utilizando una concentración mayor de la droga, $100 \mu \mathrm{g} / \mathrm{ml}$, con el objetivo de agravar sus efectos. Como era de esperar, Sub1 se asocia al promotor del gen IMD2 en condiciones de no inducción (Figura 45A; (Koyama et al., 2008), mientras que no lo hace en las regiones codificantes, lo que concuerda con su papel regulador a nivel de promotor (Koyama et al., 2008). Sin embargo, tras el tratamiento con 6AU, la 
asociación de Sub1 al promotor del gen IMD2 aumenta y, además, observamos que se asocia de manera significativa a lo largo de toda la secuencia codificante con valores entre 4 y 6,5 veces superiores a los obtenidos en condiciones de no inducción (Figura 45A). Este resultado sugiere que Sub1 podría participar en la elongación del gen IMD2 en condiciones de inducción y concuerda perfectamente con los resultados del análisis de expresión en el mutante subld (Figura 44). Para el caso del gen de expresión constitutiva PMA1, encontramos asociación de Sub1 desde el promotor a la región 3' del gen en ausencia de 6AU (Figura 45B). En las células sometidas a tratamiento con 6AU, la asociación de Sub1 con el promotor y las secuencias codificantes de PMA1 disminuye (Figura 45B), indicando que Sub1 podría participar también en la regulación de la elongación de PMAl.

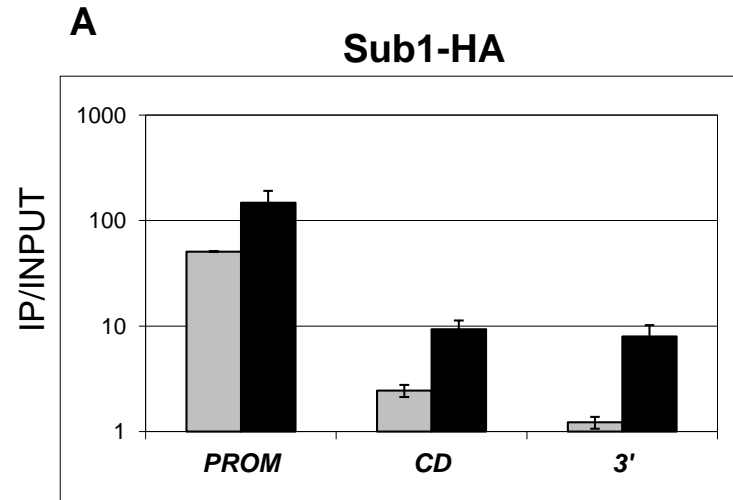

$\square-6 \mathrm{AU} \mathbf{\square}+6 \mathrm{AU}$

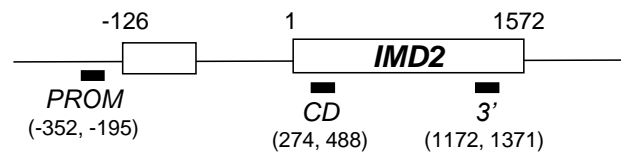

B

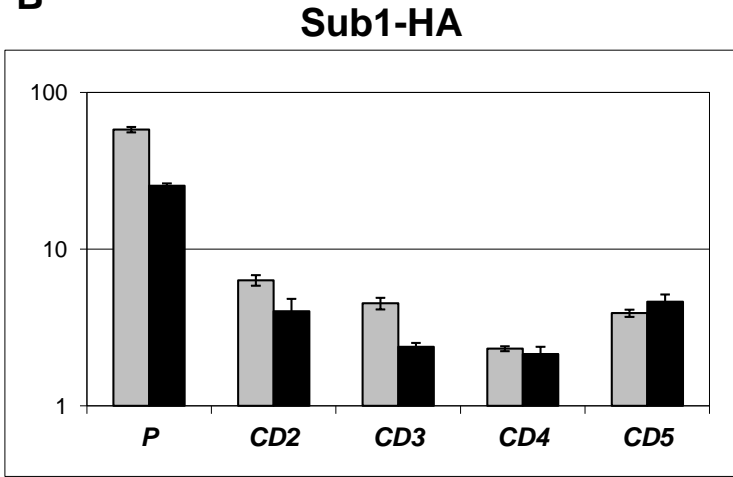

$\square-6 A U \square+6 A U$

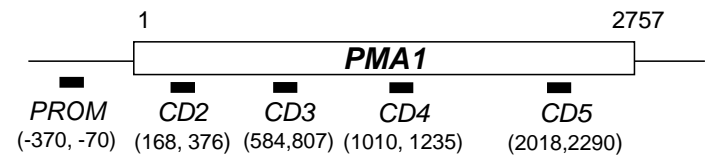

ChIP

Figura 45. Sub1 se asocia con las regiones codificantes de los genes dependiente de transcripción. (A) ChIP de Sub1 para el gen inducible IMD2 en la cepa silvestre Sub1-6HA. Se crecieron las células en medio SC sin uracilo, con o sin $6 \mathrm{AU}$ a una concentración final de $100 \mu \mathrm{g} / \mathrm{ml}$. La inmunoprecipitación se realizó con el anticuerpo anti-HA y se analizó por qPCR la asociación de Sub1-HA al gen IMD2 en la zona promotora $(P R O M)$, codificante $(C D)$ y $3^{\prime}$. El esquema de las regiones de anillamiento de los oligonucleótidos utilizados se muestra debajo de la gráfica, indicándose entre paréntesis la posición relativa de anillamiento de cada par de oligonucleótidos respecto del sitio de inicio de la transcripción. En el caso del gen $I M D 2$, la caja de color blanco aguas arriba del nucleótido +1 representa la región del promotor a partir de la que se transcriben pequeños transcritos no codificantes (Jenks et al., 2008). Las cuantificaciones de los resultados se muestran en la gráfica, donde los números del eje $y$ representan los valores obtenidos para cada producto específico de PCR respecto del control negativo (región intergénica del CVII) y, a su vez, normalizados frente a los controles input. (B) ChIP de Sub1-HA y análisis en el gen $P M A 1$, con o sin 6AU. Tanto en (A) como en (B) los valores de cuantificación se representan en escala logarítmica. Las barras de error indican desviación estándar. 
Paralelamente, analizamos la asociación a la cromatina del factor general de transcripción TFIIB, como control negativo (Figura 46A y B), ya que es un componente del PIC bien caracterizado, sin función en la elongación y que presenta conexiones genéticas y funcionales con Sub1 (Knaus et al., 1996; Rosonina et al., 2009; Wu et al., 1999). Para este propósito, utilizamos una cepa que expresa el gen $S U A 7$, que codifica para TFIIB, marcado con 13 copias del epítopo MYC. Como era de esperar, TFIIB solamente se asocia de forma eficiente al promotor del gen IMD2, en ausencia y presencia de 6AU, aunque también se detecta un ligero enriquecimiento en la región 3' del gen en condiciones de inducción (Figura 46A), probablemente debido al papel de este factor en el fenómeno de gene looping (Singh and Hampsey, 2007). Para el caso del gen PMA1, tanto Sub1 como TFIIB se asocian a su promotor, pero solamente Sub1 es capaz de asociarse de forma significativa con las secuencias codificantes del gen (Figura 46B).

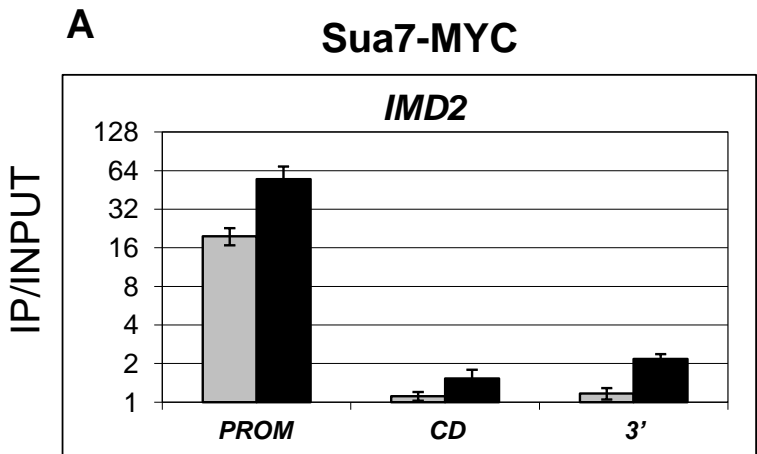

$-6 A U$ $+6 \mathrm{AU}$
B

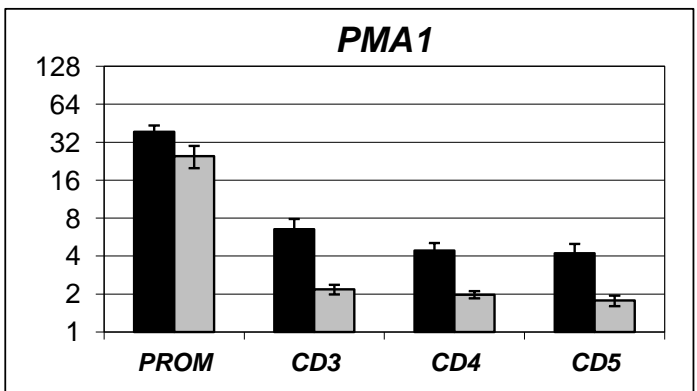

Sub1-6HA $\square$ Sua7-MYC

ChIP

Figura 46. Sub1 se asocia con las regiones codificantes de los genes dependiente de transcripción. (A) Ensayo de ChIP para analizar la asociación de Sua7-MYC al gen IMD2, como en la Figura 45. (B) Análisis mediante ChIP de la asociación de Sub1-HA y Sua7-MYC al gen PMA1.

Por otra parte, analizamos la asociación de Sub1 al gen largo YLR454w (8 Kb) expresado bajo el control del promotor inducible GAL1 (Mason and Struhl, 2005). Con este experimento pretendíamos estudiar si los valores de asociación de Sub1 obtenidos para las regiones codificantes de los genes examinados hasta el momento son realmente significativos, o si podría tratarse de valores de asociación residual o de contaminación, debido a la fuerte asociación de Sub1 a las zonas promotoras y como consecuencia del tamaño medio de los fragmentos de cromatina tras la sonicación (en nuestro caso, utilizamos cromatinas fragmentadas con un tamaño igual o menor a 300 pb, aproximadamente). La ventaja de la utilización del gen largo GAL1-YLR454w es que 
nos permite analizar regiones situadas a distancias mucho mayores (de 1,4 y $8 \mathrm{~Kb}$ ) del promotor. Además, permite separar la señal obtenida para la secuencia codificante de una posible señal residual correspondiente a un promotor situado adyacente a la región 3'. Como se observa en la figura 47 , Sub1 se asocia a las regiones codificantes en condiciones de inducción por galactosa y se disocia tras reprimir la transcripción con glucosa. La asociación de Sub1 con la cromatina se mantiene en niveles significativos hasta $4 \mathrm{~Kb}$ por debajo del promotor, mientras que la asociación a las regiones más 3' está ligeramente por encima del fondo.

Este resultado apoya de nuevo la hipótesis de que Sub1 podría tener un papel durante la elongación, especialmente si tenemos en cuenta que la mayoría de genes de levaduras tienen un tamaño medio que oscila entre 1,5 y $2 \mathrm{~Kb}$ y que genes del tamaño de YLR454w e, incluso, no tan largos, como PMAl, son minoritarios en el genoma de $S$. cerevisiae.

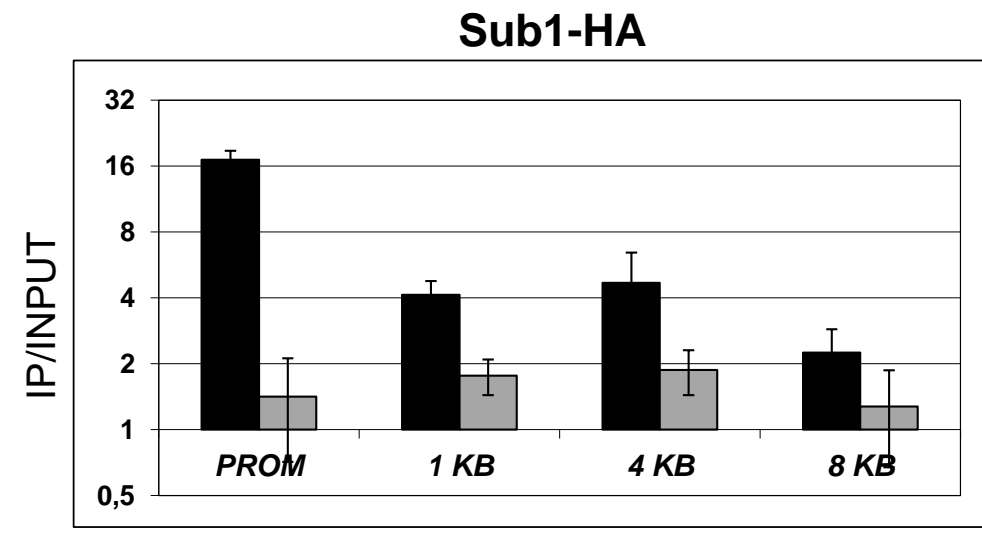

- Galactosa $\square$ Glucosa

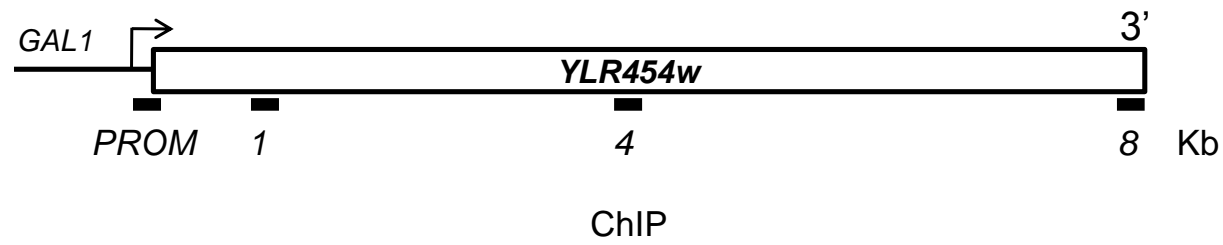

Figura 47. Sub1 se asocia a las regiones codificantes de los genes dependiente de transcripción. ChIP de Sub1-HA en el gen GAL1-YLR454w en presencia de galactosa y tras 4 minutos de tratamiento con glucosa al 5\%. El esquema de las regiones de anillamiento de los oligonucleótidos utilizados se muestra debajo de la gráfica. Las barras de error indican desviación estándar. 


\subsubsection{Sub1 influye en la asociación de Rpb1 a la cromatina durante la elongación de la transcripción}

Otro de los criterios frecuentemente utilizados para caracterizar los factores de elongación es que mutaciones en los mismos tienen efectos sobre la asociación de la polimerasa con la cromatina durante la transcripción activa. En estudios anteriores se describió que, en condiciones de crecimiento normal, Sub1 afecta a la asociación de la polimerasa a los genes (Calvo and Manley, 2005; Rosonina et al., 2009). Decidimos corroborar y ampliar estos datos, analizando la distribución de la RNAPII a lo largo de los genes IMD2 y PMA1, en presencia y ausencia de 6AU. Así, observamos que en el mutante subla la asociación de la polimerasa, analizada por ChIP se encuentra disminuida en el gen PMA1, respecto a la asociación en la estirpe $w t$, de acuerdo con los trabajos anteriores, y que, además, este efecto se agrava tras el tratamiento con 6AU (Figura 48A, paneles superior e inferior). Como era esperable, en ausencia de esta droga, en una cepa $w t$ no hay asociación significativa de Rpb1 a las regiones codificantes del gen IMD2, pero sí al promotor, como consecuencia de la transcripción de los RNAs no codificantes que se produce en condiciones de no inducción (Figura 48B, superior izquierdo). Tras la inducción con 6AU, Rpb1 se localiza a lo largo de todo el gen. Curiosamente, la situación opuesta se observa para el mutante sub1 $\Delta$. Hay un incremento en la asociación de Rpb1 a las secuencias codificantes del IMD2 en condiciones de no inducción, seguido de un descenso en condiciones de inducción (Figura 48B, superior derecho), resultado que concuerda con la expresión constitutiva del gen IMD2 en subl 4 y con su análisis por qRT-PCR (Figura 44). De hecho, cuando representamos el cociente de la asociación de Rpb1 en presencia de 6AU, frente a la asociación en ausencia de tratamiento (+6AU/-6AU), tal y como se hizo para el análisis de expresión (Figura 40), observamos que en el mutante subl $\Delta$ la asociación de Rpb1 al gen IMD2 se encuentra significativamente comprometida en condiciones de inducción (Figura 48B, panel inferior). 
A

$-6 A U$

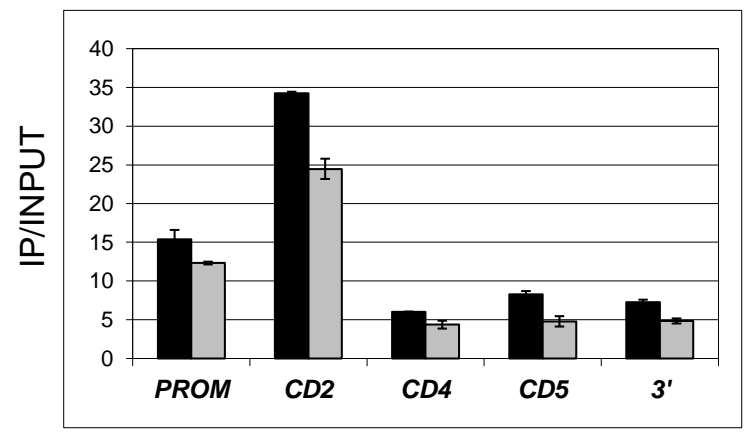

wt $\square$ sub1A

B

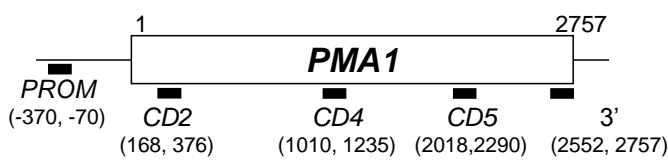

$w t$

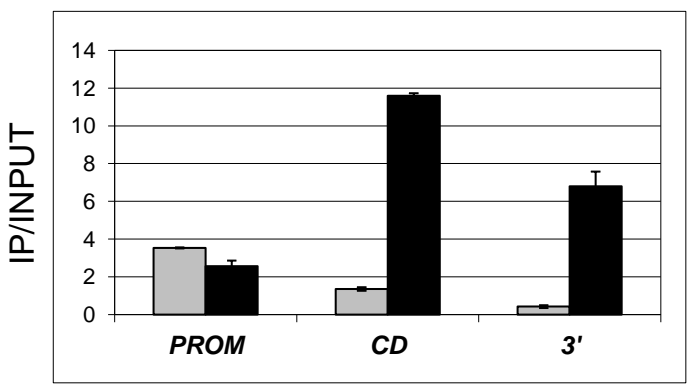

$-6 A U \boldsymbol{\square}+6 A U$

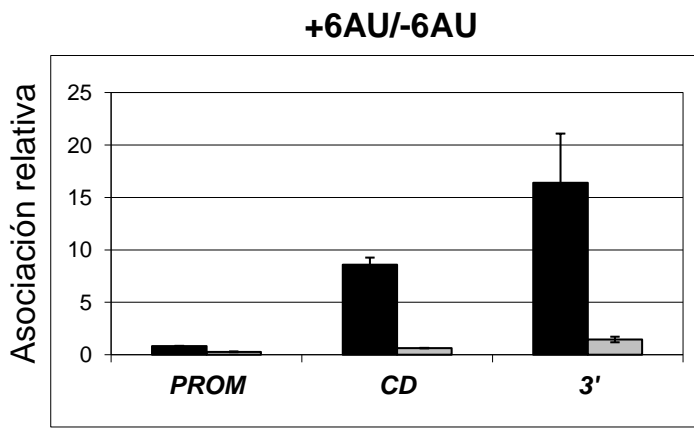

wt $\square$ sub1A
+6AU

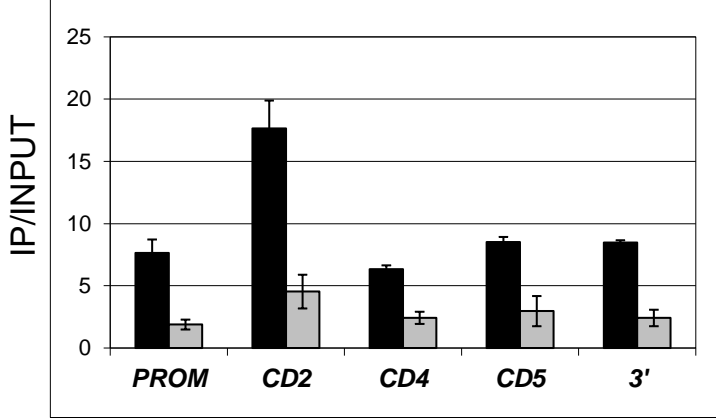

sub1A
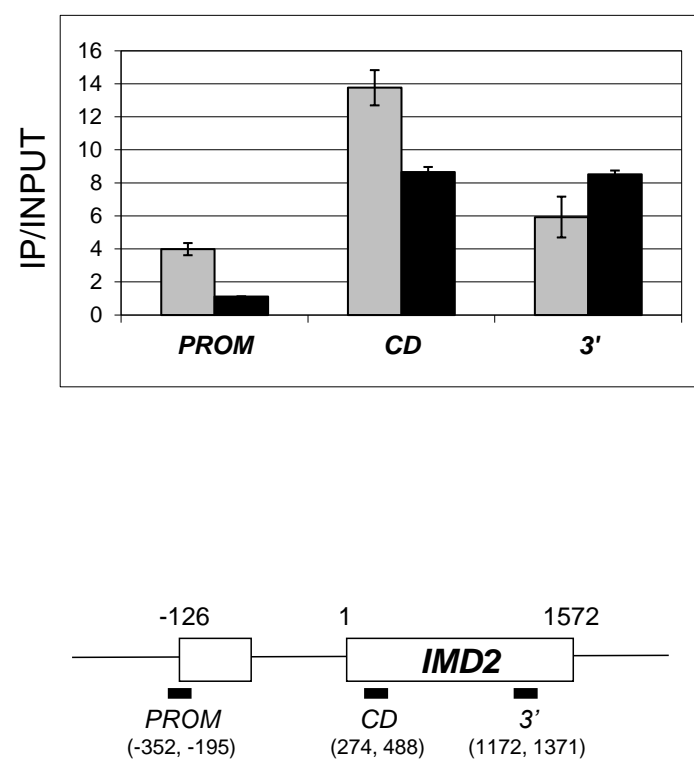

ChIP

Figura 48. Sub1 influye en la asociación de Rpb1 a la cromatina durante la elongación de la transcripción. (A) ChIP de Rpb1 en las cepas wt y subla para analizar su asociación al promotor y regiones codificantes $(C D)$ del gen PMAI. Los cultivos se crecieron en medio SC sin uracilo en presencia o ausencia de $6 \mathrm{AU}$ a una concentración final de $100 \mu \mathrm{g} / \mathrm{ml}$. La inmunoprecipitación de Rpb1 se llevó a cabo con el anticuerpo $8 \mathrm{WG} 16$. Las cuantificaciones se realizaron por qPCR y se representaron tal y como se indica en la figura 45. (B) ChIP de Rpb1 en cepas wt y subl $\Delta$ para analizar su asociación al gen inducible IMD2, en cultivos crecidos en presencia o ausencia de 6AU. Los resultados de las cuantificaciones por qPCR para las dos cepas se representan en dos gráficas independientes (paneles superior izquierdo y derecho). El panel inferior muestra el cociente +6AU/-6AU. La asociación de Rpb1 al promotor y regiones codificantes se cuantificó independientemente en células wt y subl $\Delta$, se calculó el cociente +6AU/-6AU y se representaron los valores. Las barras de error indican la desviación estándar. 
Los resultados que acabamos de presentar sugieren que la reducción en los niveles de nucleótidos intracelulares, que se produce tras el tratamiento con la droga 6AU, dan lugar a una situación en la que la elongación de la transcripción se vuelve más dependiente de la presencia de Sub1. Esta afirmación viene apoyada por el hecho de que Sub1-HA se asocia al gen IMD2 a lo largo de la secuencia codificante durante la elongación, y dependiente de transcripción activa, y que en las células subla la asociación de la polimerasa se encuentra reducida después de la inducción. Estos datos, en conjunto, apoyan la hipótesis de que Sub1 influye en la elongación de la transcripción, aunque no demuestran que Sub1 juegue un papel directo en este proceso. De hecho, la deleción de $S U B 1$ afecta a la expresión de IMD2 y, en consecuencia, los niveles de nucleótidos podrían ser más bajos en el mutante subl $\Delta$. Por lo tanto, en este punto, no podemos descartar que el papel de Sub1 sobre la elongación de la transcripción sea indirecto a través de su efecto sobre la expresión de IMD2.

\subsubsection{Sub1 influye en la tasa de elongación de la RNAPII}

Una característica importante de un defecto en elongación es la disminución en la asociación de la RNAPII a los genes transcritos a lo largo de todo el ciclo transcripcional, como consecuencia de un defecto en la tasa de elongación, en la procesividad o en ambos (Chanarat et al., 2011; Kruk et al., 2011; Mason and Struhl, 2005; Quan and Hartzog, 2010).

Mason y Struhl (2005) desarrollaron un ensayo ChIP para medir la tasa de elongación y la procesividad de la RNAPII, con el fin de determinar qué factores de elongación conocidos hasta el momento tenían en realidad un papel directo en este proceso. Muchos de ellos influyen en la elongación, pero no afectan directamente a la actividad de la RNAPII (por ejemplo, remodeladores de cromatina). En consecuencia, no pueden considerarse factores de elongación en sí mismos. Así, clasificaron los factores de elongación "verdaderos" en base a los efectos que provocan mutaciones en los mismos en la procesividad de la polimerasa: 1) mutaciones que reducen la procesividad; 2) mutaciones que reducen la procesividad solamente en presencia de 6AU. Además, describieron cómo muchas mutaciones en distintos factores de elongación afectaban a la procesividad de la polimerasa, sin alterar la tasa de elongación, mientras que mutaciones que afectaban a la tasa, afectaban siempre a la procesividad. Sin embargo, trabajos más recientes han puesto de manifiesto que esto no 
es cierto y que mutaciones en determinados factores, como el complejo Ccr4-Not, incrementan la procesividad a la vez que disminuyen la tasa de elongación (Kruk et al., 2011), e incluso se ha encontrado que una mutación en el factor de elongación Spt5 (spt5-242) afecta a la tasa de elongación, sin afectar a la procesividad de la polimerasa (Quan and Hartzog, 2010).

Hemos realizado el mismo ensayo que Mason y Struhl (2005) para analizar la procesividad de la polimerasa en el mutante subl $\Delta$. Para ello, hemos analizado la distribución de Rpb1 en las cepas wt y subla por ChIP, a lo largo del gen largo YLR454w $(8 \mathrm{~Kb})$, cuya expresión se encuentra regulada bajo el control del promotor inducible GAL1 (Figura 49A). Como puede observarse en la figura 49B, y de acuerdo con los resultados expuestos anteriormente (Figura 48), la deleción de SUB1 provoca una disminución en la asociación de la polimerasa a lo largo de todo el gen, aunque el mayor efecto se produce en la región promotora.

A

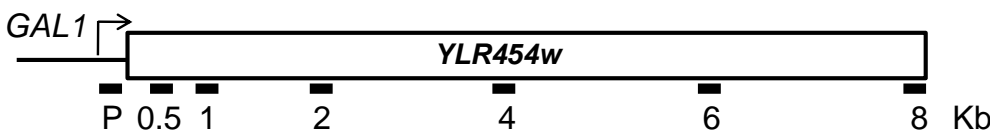

B

Rpb1

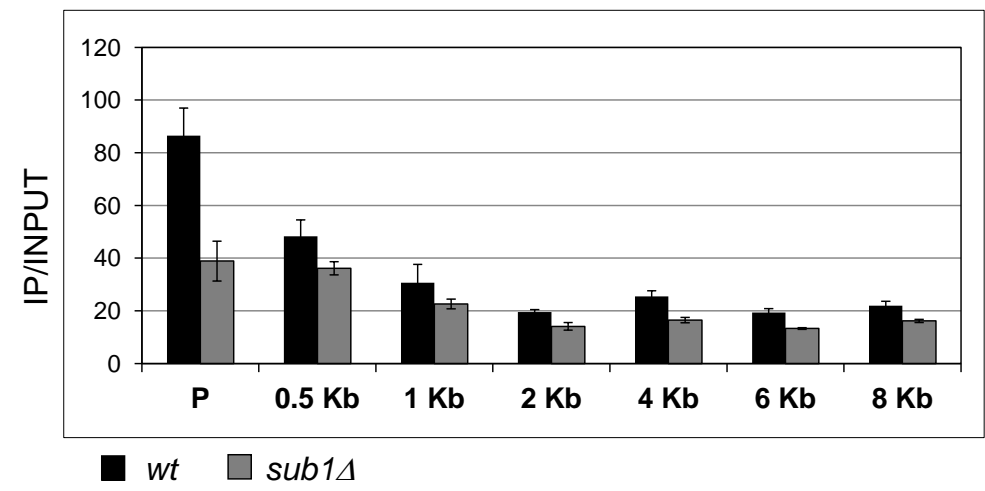

ChIP

Figura 49. La deleción de $S U B 1$ disminuye la asociación de Rpb1 al gen largo GAL1-YLR454w. (A) Representación esquemática del gen GAL1-YLR454w. Los pares de oligonucleótidos utilizados en las reacciones de PCR se indican con una barra negra y debajo de ellas las posiciones de anillamiento respecto del sitio de inicio de la transcripción. (B) Se analizó la ocupación total de Rpb1 en el promotor y regiones codificantes del gen GAL1-YLR454w por ChIP, utilizando el anticuerpo 8WG16, en las cepas $w t$ y subl $\Delta$ crecidas en medio con galactosa. Las cuantificaciones de las reacciones de qPCR se realizaron como se detalla en la figura 45. Las barras de error indican la desviación estándar

La representación de la asociación de Rpb1 a lo largo del gen GAL1-YLR454w mostrada en la figura 49 no permite apreciar defectos en procesividad de la polimerasa. Así, aunque una cepa mutante (como en este caso sub1 $\Delta$ ) presente una menor densidad 
de polimerasa asociada al gen en condiciones de transcripción activa, no quiere decir que la polimerasa asociada sea menos procesiva que en una cepa $w t$. Es posible que, aunque la asociación de la polimerasa se encuentre reducida a lo largo del gen, la polimerasa que se une en el promotor y es capaz de iniciar la transcripción, es lo suficientemente procesiva como para alcanzar las regiones 3' del gen.

Para analizar defectos en procesividad, Mason y Struhl (2005) representaron los datos de enriquecimiento de Rpb1 en la cepa de estudio para cada par de oligonucleótidos correspondiente a la secuencia codificante del gen, respecto al enriquecimiento obtenido en el promotor y, a su vez, relativos a los valores para la cepa $w t$. Utilizamos este mismo sistema de representación para los datos de la ChIP de Rpb1 para las cepas $w t$ y subl $\Delta \mathrm{y}$, como puede observarse en la figura 50A, la deleción de SUB1 produce un ligero incremento en la procesividad de la polimerasa, debido a que el descenso que se produce en las regiones 3' del gen es significativamente inferior al producido en el promotor. A continuación, quisimos comprobar si el descenso en los niveles de polimerasa asociada al gen GAL1-YLR454w, que encontramos en el mutante subl $\Delta$ (Figura 49B), era debido a un descenso en la tasa de elongación de la polimerasa. Analizamos para ello la asociación relativa de Rpb1 a la cromatina después de reprimir la transcripción de GAL1-YLR45w, mediante la adición al medio de cultivo de glucosa en una concentración final del 5\%, e incubación durante 4 minutos. Escogimos un tiempo de 4 minutos porque cinéticas de represión previas habían mostrado que es tiempo suficiente para determinar defectos en tasa de elongación (Mason and Struhl, 2005; Quan and Hartzog, 2010). Todas las regiones del gen GAL1-YLR454w presentaban mayor densidad de polimerasa en el mutante subl $\Delta$ tras la parada de la transcripción (Figura 50B). Este resultado es muy similar al obtenido para el mutante spt5-242, que presenta defectos en la tasa de elongación, sin afectar a la procesividad de la polimerasa (Quan and Hartzog, 2010). En conjunto, nuestros resultados apoyan la hipótesis de que la elongación de la transcripción, medida como la asociación de la RNAPII a lo largo del gen, está alterada en células $s u b 1 \Delta$, donde hay una mayor asociación de la RNAPII en regiones internas del gen, después de la última ola de transcripción. 


\section{A}

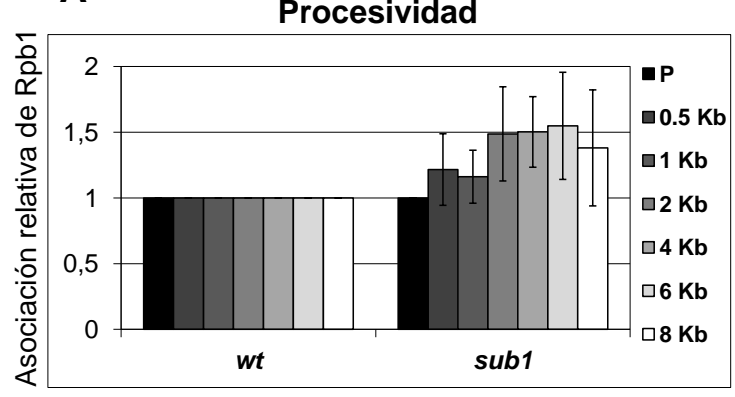

B

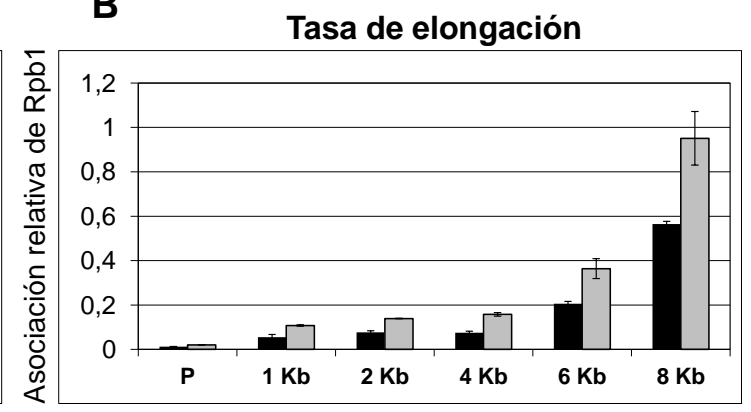

wt $\square$ sub14

ChIP

Figura 50. Sub1 influye en la tasa de elongación de la transcripción. (A) Medida de la procesividad de la RNAPII. Asociación relativa de Rpb1 a lo largo del gen GAL1-YLR454w, en las posiciones indicadas y en condiciones de inducción, en las cepas wt y subl $\Delta$. Los valores obtenidos por qPCR para cada par de oligonucleótidos se normalizaron primero a los valores obtenidos para el promotor $(\mathrm{P})$ y después respecto a los valores del wt, considerados 1 para cada posición (Mason and Struhl, 2005). (B) Medida de la tasa de elongación de la transcripción. Asociación relativa de Rpb1 a lo largo del gen GAL1-YLR454w en cepas wt y subl $\Delta$ crecidas en condiciones de inducción, tras 4 minutos de tratamiento con glucosa para parar la transcripción (cociente glucosa/galactosa). Las barras de error indican la desviación estádar.

Mediante los ensayos de ChIP medimos los niveles de polimerasa asociada a la cromatina durante la transcripción activa, pero no podemos distinguir si la polimerasa analizada está activa y es competente para elongar o si, por el contrario, se encuentra parada o pausada (Hirayoshi and Lis, 1999; Rodriguez-Gil et al., 2010). Sin embargo, puede usarse el ensayo de TRO (Transcriptional Runn-on), que mide la densidad de polimerasas transcribiendo activamente, mediante el marcaje y detección de los mensajeros nacientes (Birse et al., 1998; Hirayoshi and Lis, 1999; Rodriguez-Gil et al., 2010). Por consiguiente, realizamos ensayos de TRO en células wt y subl $\Delta$ para estudiar la distribución de polimerasas transcripcionalmente competentes a lo largo del gen GAL1-YLR454w. Para ello, diseñamos sondas de $300 \mathrm{pb}$ distribuidas a lo largo del gen (Figura 51A). En la figura 51B puede observarse que en el mutante subla la densidad de RNAPII activa es menor que en la cepa $w t$, en todas las regiones analizadas y, en especial, en la región 5', correspondiente al ATG. Este resultado concuerda perfectamente con los resultados de ChIP (Figura 49), en los que la mayor disminución de la densidad de polimerasa que se produce en células subl $\Delta$ tiene lugar a nivel de promotor. En la figura $51 \mathrm{C}$ se representan los valores de densidad relativa de polimerasa activa de cada región con respecto a la densidad en la región 5' (ATG). Esta normalización se llevó a cabo para determinar si el descenso de polimerasa activa en las secuencias codificantes del gen era consecuencia de una disminución progresiva desde 
las regiones $5, \mathrm{y}$, por lo tanto, de una polimerasa sufriendo paradas durante la transcripción o, si por el contrario, se trataba de una disminución general, consecuencia de la gran caída de polimerasa activa desde la iniciación. Como puede observarse, la deleción de $S U B 1$ produce una disminución de la polimerasa activa a lo largo de todo el gen, lo que indica que la mayor asociación de la RNAPII observada por ChIP a lo largo del gen GAL1-YLR454w en sub1 $\Delta$ se corresponde a polimerasas paradas e inactivas, que probablemente no pueden reanudar y finalizar eficientemente la transcripción. En conjunto, nuestros datos muestran que Sub1 influye en la elongación de la transcripción, y concretamente en la tasa de elongación de la RNAPII.

A

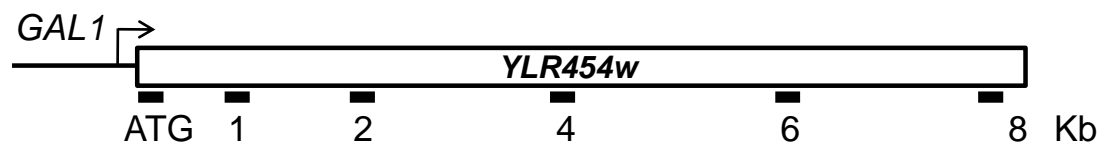

B

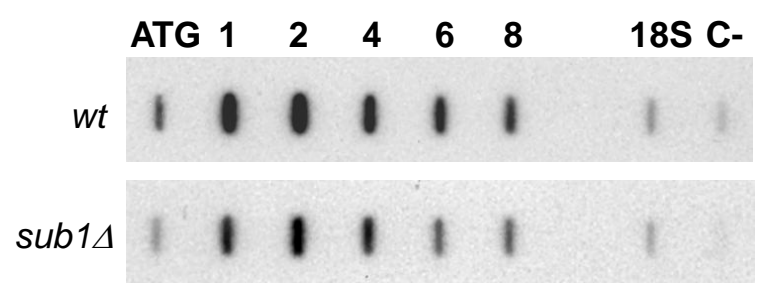

C

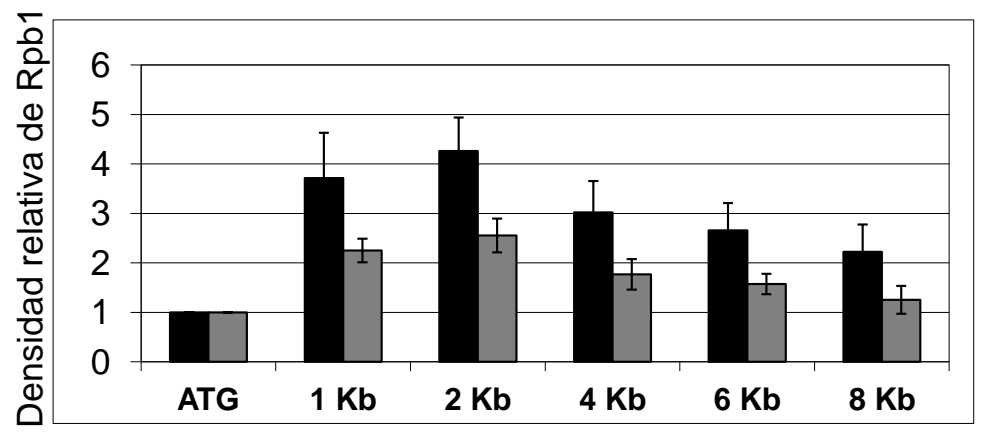

TRO

Figura 51. La deleción de $S U B 1$ disminuye los niveles de RNAPII activa, competente para elongar. (A) Diagrama del gen GAL1-YLR454w. Se indican las posiciones de las sondas utilizadas en el ensayo de run-on transcripcional (TRO). (B) Slot blot representativo de uno de los ensayos de TRO realizados para las cepas $w t$ y subl $\Delta$, crecidas en medio con galactosa como fuente de carbono. (C) Cuantificación de las hibridaciones de los slot blot. Las señales de hibridación se cuantificaron con un sistema PhosphorImager. Se utilizó DNA de bacteria como control negativo de la señal inespecífica (C-), y los valores obtenidos para el mismo se substrajeron del valor obtenido para cada sonda específica. Después se normalizó cada valor a un control positivo (la señal del $18 S$ rRNA) y, a su vez, a la señal de la sonda ATG, cuyo valor se consideró 1 . Se realizó la cuantificación de la señal correspondiente a cada sonda en tres experimentos independientes y después se calculó el valor medio. Las barras de error indican la desviación estándar. 


\subsection{Sub1 regula la elongación de la transcripción a través de la interacción con el complejo Spt4/Spt5}

\subsubsection{Interacción genética entre $S U B 1$ y el complejo $S P T 4 / S P T 5$}

Como hemos demostrado en la primera parte de los Resultados presentados, Sub1 regula globalmente la fosforilación de la RNAPII, afectando a la actividad y al reclutamiento de todas las CTD-quinasas, incluyendo las quinasas de elongación Ctk1 y Bur1. Aunque estas dos CTD-quinasas fosforilan a la polimerasa durante la elongación, sus funciones no son redundantes. La fosforilación por Ctk1 es necesaria para el reclutamiento al complejo de transcripción de los factores de terminación y de procesamiento del extremo 3' del transcrito (Ahn et al., 2009). Además, la deleción de CTK1 no afecta al reclutamiento de la polimerasa a los genes, lo que indica que la función principal de esta quinasa no es la regulación de la elongación (Ahn et al., 2004). En cuanto a Bur1, fosforila a la polimerasa en las regiones cercanas a los promotores génicos, estimulando la fosforilación por Ctk1 (Qiu et al., 2009) y es capaz de fosforilar al factor de elongación Spt5 en su extremo C-terminal. La fosforilación de Spt5 promueve el reclutamiento del complejo de elongación PAF y de factores remodeladores de la cromatina, favoreciendo la procesividad de la RNAPII (Liu et al., 2009; Zhou et al., 2009). Por lo tanto, los efectos de la deleción de SUB1 sobre las CTD-quinasas de elongación sugerían, como ya hemos dicho en varias ocasiones, que Sub1 podría influir en la elongación de la transcripción. No obstante, decidimos estudiar si Sub1 podría afectar a la regulación de este proceso, independientemente de su papel en la fosforilación de la RNAPII, dado que Sub1 se asocia a las regiones codificantes durante la transcripción (Figuras 45 y 47).

Para este propósito, decidimos, en primer lugar, analizar una posible interacción genética entre SUB1 y SPT5 por varias razones:

1) Spt5 es el único factor de transcripción evolutivamente conservado en los tres dominios de la vida: arqueobacterias, eubacterias y eucariotas (Werner, 2012).

2) Spt5 es fosforilado en su dominio C-terminal por la quinasa Bur1, cuya actividad está incrementada en el mutante subl $\Delta$ (Figuras 21-22).

3) Se ha descrito que el mutante spt5-242, cuya mutación reside en el dominio de interacción con la RNAPII (NGN, Figura 52A), presenta una alteración en la tasa de 
elongación medida por ChIP, sin que esto afecte a la procesividad (Quan and Hartzog, 2010). Dicho efecto es muy similar al encontrado para el mutante sub1 $\Delta$ (Figura 50).

Realizamos el análisis genético utilizando dos mutantes spt5 con defectos en la elongación de la transcripción, spt5-194 y spt5-242. El mutante spt5-194 contiene dos mutaciones localizadas en el dominio NGN, (S324F y G610D), aunque su fenotipo se debe exclusivamente a la mutación en el residuo S324 (Figura 52A; (Guo et al., 2008). Este mutante presenta un fenotipo de crecimiento lento a $37^{\circ} \mathrm{C}$ y sensibilidad moderada a 6AU, mientras que el mutante spt5-242 presenta una mutación única en el dominio NGN (V286A, Figura 52A), es sensible a bajas temperaturas y no presenta sensibilidad a 6AU (Hartzog et al., 1998; Swanson et al., 1991; Swanson and Winston, 1992; Winston et al., 1984). De acuerdo con lo que ya sabíamos, el mutante subl $\Delta$ crece de forma similar a la cepa $w t$ y no presenta sensibilidad a 6AU en medio sólido (Figura 20,

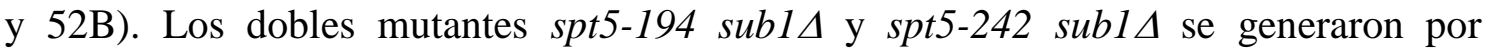
reemplazamiento génico de $S U B 1$ y se ensayaron sus fenotipos. La deleción de $S U B 1$ incrementa los fenotipos de los mutantes sencillos a ambas temperaturas $\left(28^{\circ} \mathrm{C} \mathrm{y} 37^{\circ} \mathrm{C}\right)$ y provoca sensibilidad extrema a 6AU (Figura 52B). Además, cuando sobreexpresamos SUB1 en un mutante spt5-194, se rescata, aunque sólo parcialmente, su fenotipo (Figura 52C).

Spt5 se asocia in vivo con Spt4 para formar un complejo heterodimérico, cuya función es necesaria para que la elongación de la RNAPII sea eficiente (Hartzog et al., 1998; Wada et al., 1998a). Por ello, investigamos si SUB1 también está relacionado genéticamente con SPT4. Como se observa en la figura 52D, la combinación de la deleción de SUB1 con la deleción de SPT4 da lugar a un fenotipo muy grave de retraso en el crecimiento y de extrema sensibilidad a 6AU. Por lo tanto, SUB1 está asociado genéticamente a ambos, SPT4 y SPT5, y podría estar funcionalmente relacionado con el complejo de elongación Spt4/5. 
A

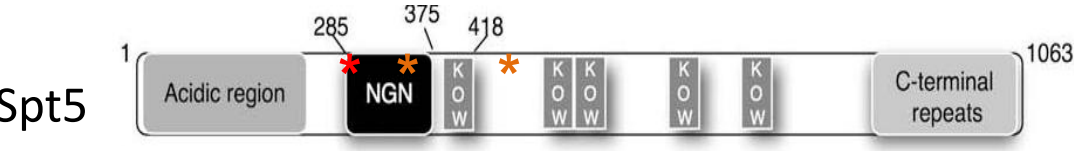

B
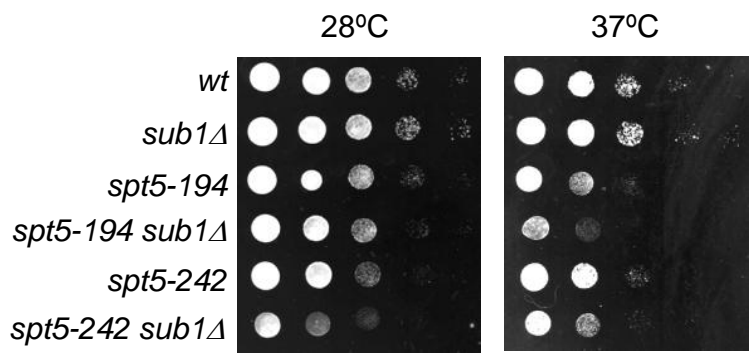

6-AU
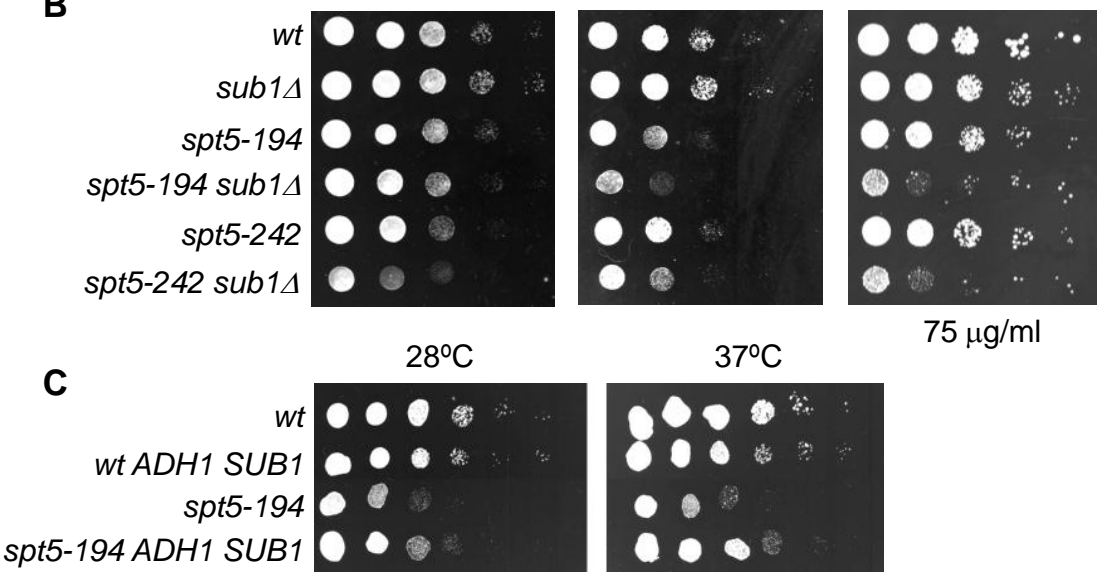

$75 \mu \mathrm{g} / \mathrm{ml}$
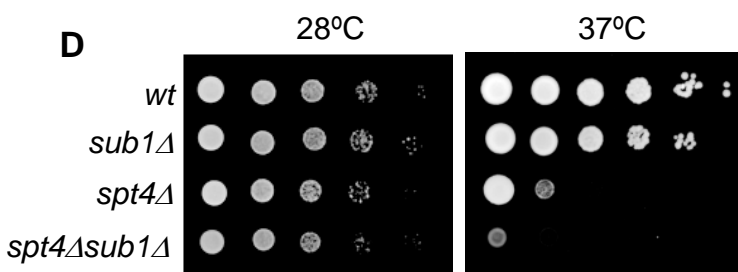

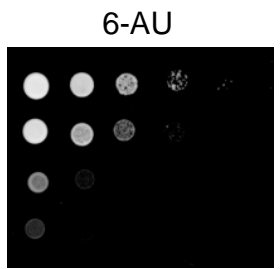

$25 \mu \mathrm{g} / \mathrm{ml}$
6-AU

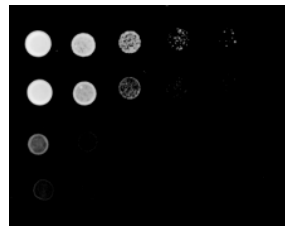

$50 \mu \mathrm{g} / \mathrm{ml}$

Figura 52. SUB1 está genéticamente asociado a SPT5 y SPT4. (A) Mapa lineal de Spt5 de eucariotas. Aparecen representados los motivos conservados: una región N-terminal rica en aminoácidos ácidos, el dominio NGN de interacción con Rpb1 y Spt4, los dominios KOW de interacción con ácidos nucleicos y el dominio C-terminal, con repeticiones susceptibles de fosforilación. El asterisco rojo indica la posición de la mutación spt5-242, mientras que en naranja se muestran las mutaciones correspondientes al alelo spt5-194. Imagen modificada desde (Guo et al., 2008). (B) La deleción de SUB1 incrementa los defectos de crecimiento en los mutante spt5-194 y spt5-242 y produce sensibilidad extrema a 6AU. (C) La sobreexpresión de $S U B 1$ suprime parcialmente el fenotipo de crecimiento del mutante spt5-194. Para sobreexpresar $S U B 1$, su $O R F$ fue clonada bajo el control del promotor constitutivo ADH1 (ADH1SUB1). (D) La deleción de $S U B 1$ incrementa el fenotipo de termosensibilidad y de sensibilidad a 6AU del mutante spt4A. Las cepas con los genotipos indicados se crecieron durante 2-3 días en los siguientes medios: SCURA y SC-URA con 6AU a concentraciones de 75,50 y $25 \mu \mathrm{g} / \mathrm{ml}$.

\subsubsection{La deleción de SUB1 produce un incremento en la fosforilación de Spt5, pero no afecta a su asociación con la cromatina}

La CTD-quinasa Bur1 fosforila a Spt5 en su extremo C-terminal, estimulando de este modo el reclutamiento del complejo PAF y de proteínas remodeladoras de cromatina al complejo de elongación (Liu et al., 2009). Puesto que Sub1 afecta a la actividad CTD-quinasa de Bur1, quisimos comprobar si, de igual modo, podría afectar a su actividad sobre Spt5. Así, llevamos a cabo ensayos de actividad quinasa in vitro, en presencia o ausencia de ATP, utilizando las cepas wt y sub14, que expresan Bur1-HA, 
y como sustrato una proteína Spt5 recombinante (rSpt5: 6xHIS-Spt5). El producto de la reacción se resolvió por Western Blot. Para la inmuno-detección se utilizó primero un anticuerpo fosfo-específico para Spt5 (anti-Spt5P) (Liu et al., 2009) y después un anticuerpo que reconoce la región C-terminal de Spt5. Como puede observarse en la figura 53A, Bur1-HA fosforila eficientemente a rSpt5 en presencia de ATP y la fosforilación de Spt5 se encuentra incrementada en ausencia de SUB1.

A continuación, realizamos un ensayo quinasa adicional para verificar la especificidad de la fosforilación de Bur1-HA sobre el sustrato rSpt5 en nuestro ensayo. Para ello, preparamos extractos totales de cepas expresando Bur1-HA (wt, subl $\Delta \mathrm{y}$ bur1-23 (con reducida actividad quinasa (Keogh et al., 2003) y cepas expresando Ctk1HA (wt y sub1 4 ). Inmunoprecipitamos Bur1-HA y Ctk1-HA y ensayamos sus actividades sobre el sustrato rSpt5. De nuevo, observamos que Bur1-HA es capaz de fosforilar a Spt5, siendo esta fosforilación más eficiente en células sub1 $\Delta$. Sin embargo, no detectamos fosforilación de Spt5 debida a la actividad del mutante burl-23 o de Ctk1 (Figura 53B).
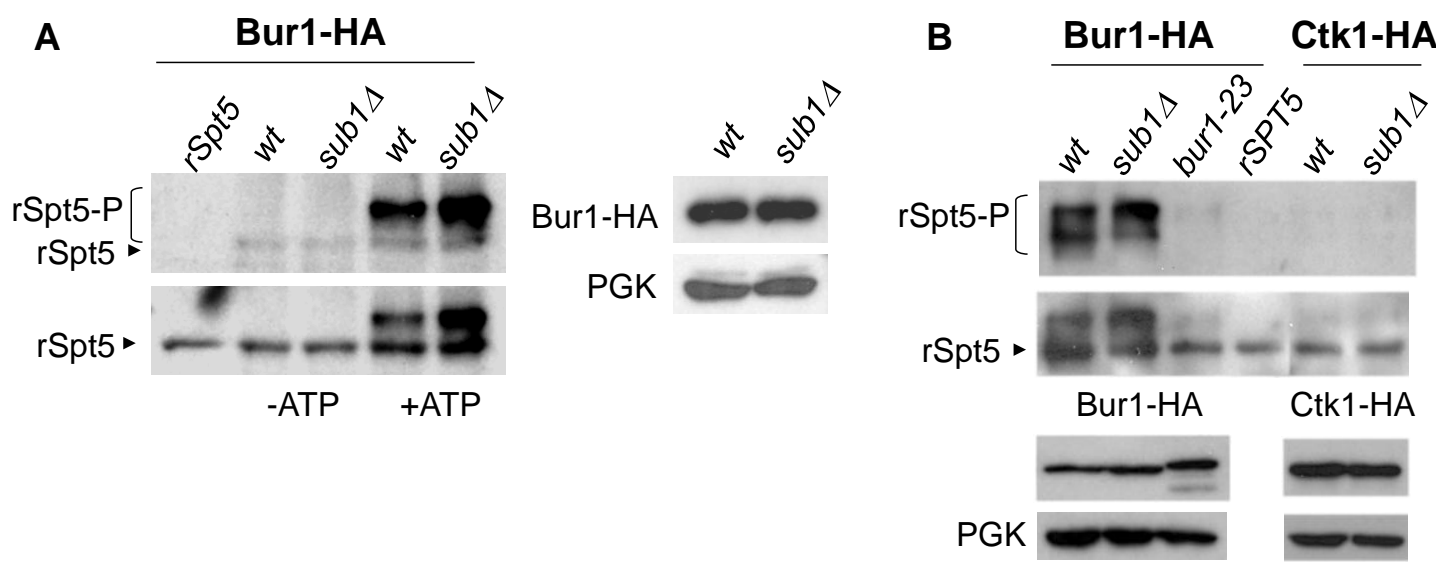

Ensayos de actividad quinasa in vitro

Figura 53. La deleción de SUB1 incrementa la fosforilación de Spt5 por Bur1. (A) Ensayo de actividad quinasa in vitro (panel izquierdo). Se prepararon extractos totales de cepas wt y sublu expresando Bur1-HA. Los complejos asociados a la quinasa se inmunoprecipitaron con anti-HA acoplado a bolitas de proteína-A sefarosa y se ensayó la actividad quinasa sobre una proteína recombinante 6 HisSpt5 (rSpt5), en ausencia y presencia de $2,5 \mathrm{mM}$ de ATP. Las mezclas de reacción se analizaron por Western Blot, utilizándose los siguientes anticuerpos: anti-Spt5P (Liu et al., 2009) y anti-Spt5 (panel derecho). Para comprobar que los niveles de inmunoprecipitación de Bur1-HA eran similares en ambas cepas, wt y subla, se llevó a cabo una inmunoprecipitación adicional con anti-HA. (B) Ensayo de actividad quinasa in vitro. Se prepararon extractos totales de cepas $w t$ y subld, expresando Bur1-HA y Ctk1-HA, y de una cepa mutante burl-23-HA. Para analizar la fosforilación de Spt5, el ensayo quinasa se realizó tal y como se describe en (A). Como control de niveles similares de proteína en todos los extractos se analizaron los niveles de PGK. 
Mediante experimentos de ChIP on chip se ha demostrado que Spt5 se asocia a la cromatina en la región de transición iniciación-elongación, situada unos 150 nucleótidos por debajo del sitio de inicio de la transcripción (Mayer et al., 2010). Por lo tanto, analizamos si Sub1, además de afectar a la fosforilación de Spt5, podría también alterar su asociación a la cromatina durante la transcripción. Para ello, llevamos a cabo experimentos de ChIP utilizando cepas wt y subld que expresan Spt5-Flag y analizamos por qPCR la asociación de Spt5 a genes de expresión constitutiva (ACT1, ADH1, PYK1 y PMA1). Así, analizamos una región comprendida entre los nucleótidos +150 y +400 , e incluimos en el análisis las regiones intermedias y 3'. Como se aprecia en la figura 54, la deleción de $S U B 1$ no afecta significativamente al reclutamiento de Spt5 a la cromatina para ninguno de los casos estudiados. En conjunto, nuestros datos apoyan la idea de que Sub1 se asocia al complejo de transcripción y modula la fosforilación de los CTDs de Rpb1 y de Spt5. Sin embargo, por el momento desconocemos los mecanismos por los que influye en la actividad quinasa de Bur1.

\section{Spt5-Flag}
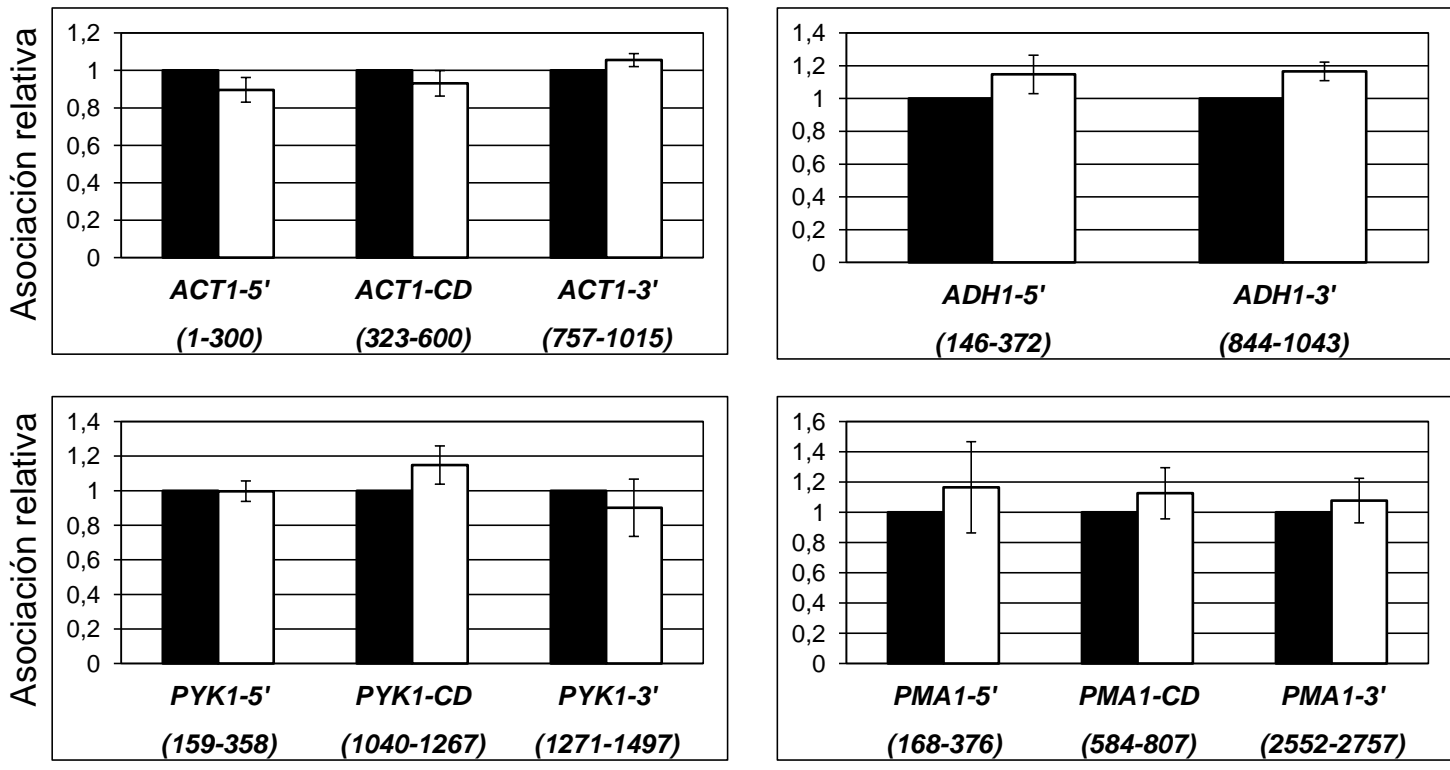

$w t$ sub14

ChIP

Figura 54. La deleción de $S U B 1$ no afecta a la asociación de Spt5 a la cromatina. ChIP de Spt5-Flag en las cepas $w t$ y subla. En las graficas se representa la asociación relativa de Spt5 a las regiones 5', codificante $(C D)$ y 3 ', de cuatro genes de expresión constitutiva (ACT1, ADH1, PYKl, y PMA1). La posición de anillamiento de los oligonucleótidos respecto al sitio de inicio de la transcripción se indica entre paréntesis. Los números en el eje y representan la asociación relativa de Spt5 en el mutante subla respecto a la cepa $w t$, donde el nivel de asociación se considera 1. Las barras de error representan la desviación estándar. 


\subsubsection{La deleción de $S U B 1$ suprime el defecto en splicing de la mutación spt5-194}

Varios trabajos han demostrado que la tasa de elongación influye en el splicing (de la Mata et al., 2003; Howe et al., 2003). Así, mutantes de la RNAPII, cuya tasa de elongación es lenta, o células que han sido tratadas con drogas como el MPA o el 6AU, que ralentizan la elongación, presentan alterada la inclusión de exones (Howe et al., 2003). Puesto que Sub1 influye en la tasa de elongación (Figura 50B), decidimos analizar si podría afectar también al splicing. Para estudiar esta posibilidad nos basamos en varios estudios que han puesto de manifiesto que Spt5 participa en el procesamiento de los intrones y que ambos, Sub1 y Spt5 parecen estar relacionados funcionalmente (Lindstrom et al., 2003; Xiao et al., 2005). Para ello, utilizamos las cepas wt, subla, spt5-194 y spt5-194 sub14, en las que analizamos los niveles de intrón no procesado presentes en el transcrito del gen RPL26 (Figura 55A). Aislamos RNA total de las cuatro cepas, sintetizamos el correspondiente cDNA y llevamos a cabo una RT-PCR para analizar los niveles de $R P L 26$, no procesado y procesado y del transcrito del gen $P Y K 1$, que no contiene intrones. Como puede observarse en la figura $55 \mathrm{~B}$, los niveles de mensajero de RPL26 maduro y no procesado son similares en las cepas wt y subl $\Delta$. Como ya se había descrito (Lindstrom et al., 2003) el mutante spt5-194 acumula la forma no procesada de RPL26. Sin embargo, cuando la deleción de SUB1 se combina con la mutación spt5-194, se produce una reducción significativa en la acumulación del transcrito no procesado, consistente con una reducción de la tasa de elongación en células subla (Figura 50B) y con el hecho de que la tasa de elongación influye en el splicing (de la Mata et al., 2003; Howe et al., 2003).
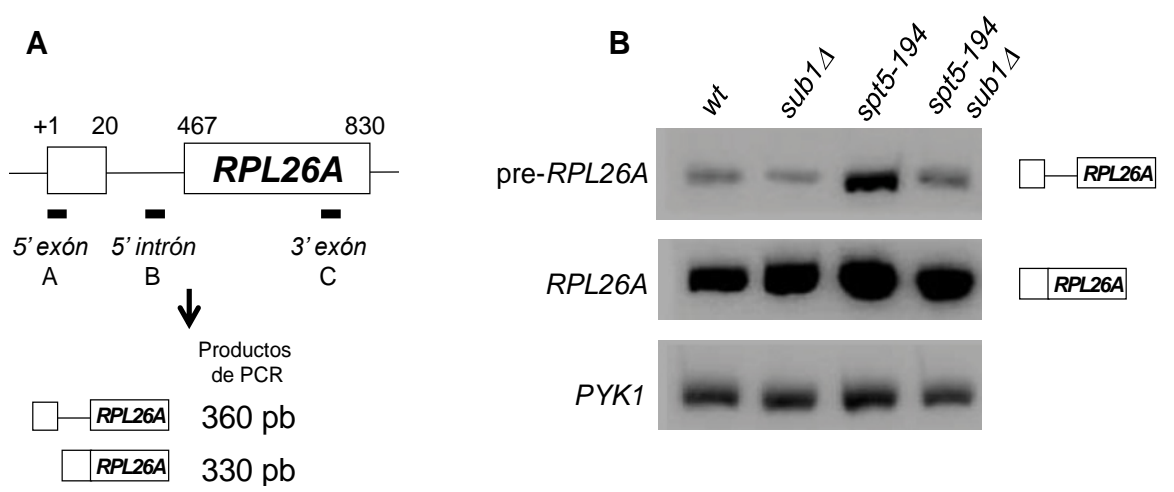

RT-PCR

Figura 55. La deleción de $S U B 1$ suprime los defectos en splicing del mutante spt5-194. (A) Esquema representativo del gen $R P L 26 A$. Se indican los oligonucleótidos utilizados en la PCR mediante barras negras. Además, se muestra el tamaño de los productos de amplificación con y sin intrón. (B) Análisis mediante RT-PCR de las formas no procesada y madura del transcrito RPL26 en las cepas $w t, s u b 1 \Delta$, spt5-194 y spt5-194sub1 $\Delta$. Los pre-mRNAs no procesados se amplificaron específicamente mediante PCR con el par de oligonucleótidos A-B, tal y como describieron (Lindstrom et al., 2003). El par A-C se utilizó para amplificar el mRNA procesado de RPL26. Como control negativo se analizó el gen $P Y K 1$, que no contiene intrones. 


\subsubsection{Sub1 y Spt5 forman parte del mismo complejo}

Lindstrom et al. (Lindstrom et al., 2003) llevaron a cabo una purificación por afinidad acoplada a espectrometría de masas para identificar los complejos proteicos asociados a Spt5. Identificaron hasta 92 proteínas, entre las que se encontraba Sub1 y otros factores del procesamiento de los pre-mRNAs. Sin embargo, no corroboraron la especificidad de la interacción Spt5-Sub1, ni tampoco estudiaron su significado biológico.

Para investigar si Spt5 co-purificaba con Sub1 decidimos aprovechar la ventaja del ensayo de purificación TAP, que previamente habíamos realizado para identificar los complejos proteicos asociados a Sub1 in vivo (apartado 3.8). Así, analizamos por Western Blot un décimo del material total purificado en el ensayo TAP. Como puede apreciarse en la figura 56A, y de acuerdo con los resultados publicados previamente (Lindstrom et al., 2003), Spt5 co-purifica con Sub1-TAP, lo que claramente sugiere que ambas proteínas pueden estar formando parte de un mismo complejo.

A continuación, decidimos confirmar la co-purificación por ensayos de coinmunoprecipitación. Utilizamos para ello una cepa doblemente marcada, Sub16HA/Spt5-3Flag, y las cepas Sub1-HA y Spt5-Flag como controles negativos del experimento. Preparamos extractos totales de todas ellas y realizamos las inmunoprecipitaciones de Sub1 con el anticuerpo anti-HA, que se analizaron por Western Blot. La misma membrana fue hibridada, en primer lugar, con el anticuerpo anti-HA para detectar Sub1-HA y posteriormente con anti-Spt5. Sub1-HA se inmunoprecipitó eficientemente en las cepas Sub1-HA y Sub1-HA/Spt5-Flag (Figura 56B, panel inferior) y comprobamos que efectivamente Spt5-Flag co-inmunoprecipita con Sub1-HA (Figura 56B, panel medio), corroborando los resultados del ensayo TAP. No obstante, si comparamos los niveles de Spt5 co-inmunoprecipitado con Sub1, con los niveles en las muestras input (Figura 56B, panel superior), observamos que solamente una pequeña fracción de Spt5 co-inmunoprecipita con Sub1, lo que podría deberse a una interacción lábil o transitoria entre ambas proteínas. 
A

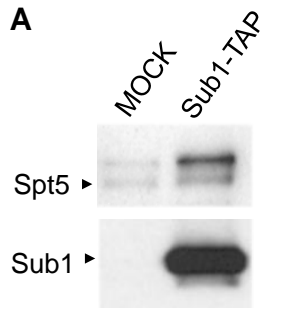

Purificación TAP

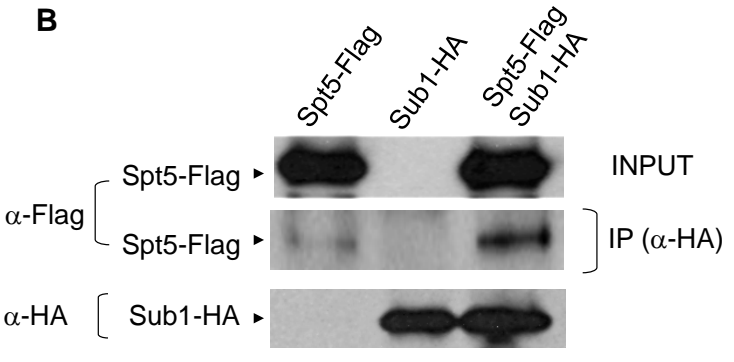

Co-IP

Figura 56. Sub1 y Spt5 forman parte de un mismo complejo. (A) Spt5 co-purifica con Sub1-TAP. Purificación por afinidad en tándem a partir de extractos totales de una cepa Sub1-TAP y de una cepa isogénica sin epítopo alguno, como control de purificación inespecífica (mock). Los complejos Sub1-TAP purificados se analizaron por Western Blot. La parte superior de la membrana se incubó con un anticuerpo policlonal anti-Spt5, para analizar la co-purificación, y la parte inferior con anti-TAP, para comprobar la purificación específica de Sub1-TAP. (B) Spt5-Flag co-inmunoprecipita con Sub1-HA. Se prepararon extractos totales de las cepas: Spt5-3Flag, Sub1-6HA y Spt5-3Flag/Sub1-6HA. Se inmunoprecipitó Sub1 con anti-HA (IP) y tras realizar exhaustivos lavados, inputs e IPs se analizaron por Western Blot. La parte superior de la membrana se incubó con anti-Flag y la parte inferior con anti-HA.

\subsubsection{Sub1 y Spt5 podrían coincidir asociados a las mismas regiones de la cromatina durante la elongación temprana}

Cuando analizamos la asociación de Sub1-HA y Spt5-Flag a la cromatina por ChIP, utilizando la cepa doblemente marcada, observamos que la distribución de ambas proteínas es claramente diferente, al menos para los genes de expresión constitutiva (ADH1, PGK1, PYK1, PMA1 y YEF3, (Figura 57). La asociación de Sub1-HA es predominante en el promotor, desciende rápidamente y se mantiene constante en niveles más bajos hacia las regiones 3' del gen. Sin embargo, Spt5-Flag no se detecta en los promotores (salvo en el caso de $P M A 1$ ) y su máxima asociación se produce en la zona de los 150-400 pb. Dicha asociación se mantiene en las regiones media y 3' de la secuencia codificante del gen, como ya se había descrito (Mayer et al., 2010), y con valores siempre superiores a los de Sub1-HA en las regiones codificantes. Sin embargo, y curiosamente, existe una pequeña región, concretamente la región comprendida entre los 150-400 nucleótidos por debajo del sitio de inicio de la transcripción, donde la asociación de Sub1 y Spt5 a la cromatina parece coincidir (el caso más claro es el del gen $P Y K 1)$. De manera que ésta podría ser la región, durante la elongación temprana, donde ambos factores interaccionarían directa o indirectamente formando parte del mismo complejo. Alternativamente, la detección de Sub1 por ChIP podría ser menos eficiente en las regiones codificantes, debido a los cambios conformacionales que se producen en el complejo de transcripción durante la elongación. Cambios que debilitarían la capacidad de Sub1 para unirse al DNA, pero permitirían su interacción con el complejo Spt4/5 (ver Discusión). 

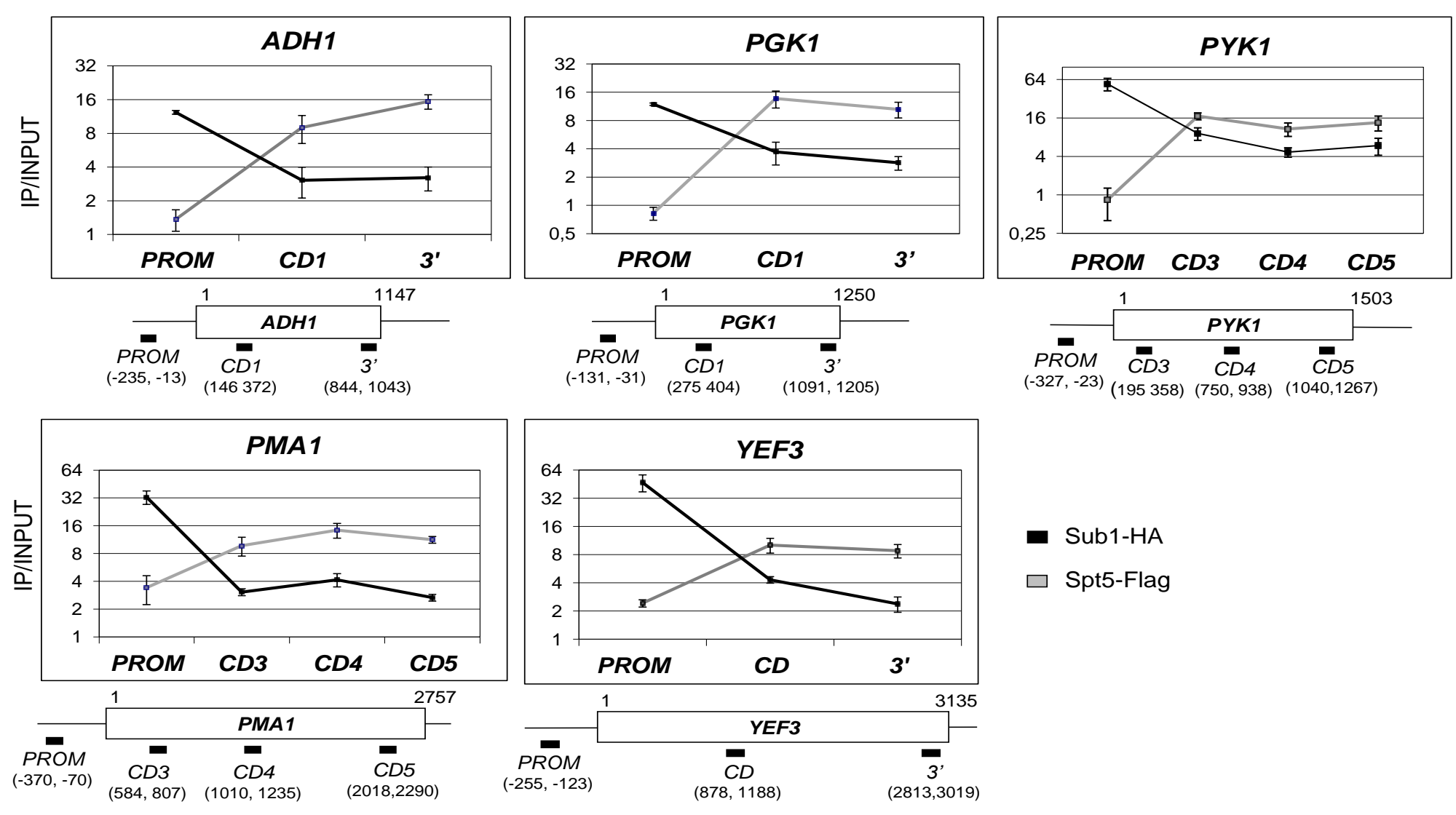

Sub1-HA

$\square$ Spt5-Flag

ChIP

Figura 57. Asociación a la cromatina de Sub1-HA y Spt5-Flag. Ensayo de ChIP para analizar la distribución de Sub1 y Spt5 a lo largo de varios genes de expresión constitutiva: ADH1, PGK1, PYK1, PMA1 y YEF3. Se utilizó la cepa Spt5-Flag/Sub1-HA, se preparó cromatina y se inmunoprecipitaron Spt5 y Sub1 usando los anticuerpos anti-Flag y anti-HA, respectivamente. La asociación de ambas proteínas al promotor, regiones codificantes y 3 ' de los genes se analizaron por qPCR. En cada gráfica, el eje $y$ (en escala logarítmica) representa el cociente de los valores obtenidos para la cuantificación de cada producto específico, respecto a un control negativo (región intergénica del cromosoma VII), después de normalizar a los resultados obtenidos para las muestras input. Debajo de cada gráfica se muestra una representación esquemática del gen correspondiente. Los números indican la posición relativa al sitio de inicio de la transcripción (1) y las barras por encima de ellos los productos de PCR analizados por ChIP. 


\subsubsection{La deleción de $S U B 1$ afecta a la interacción entre Spt5 y Rpb1}

Existen varias evidencias que sugieren que Sub1 podría estar afectando a la interacción entre Spt5 y Rpb1:

1) SUB1 interacciona genéticamente con las mutaciones spt5-194 y spt5-242 (Figura 52B). Ambas mutaciones están localizadas en el dominio NGN de Spt5 (Figura 52A), implicado en la interacción con la polimerasa y con Spt4 (Guo et al., 2008; Klein et al., 2011; Martinez-Rucobo et al., 2011). En el caso concreto del mutante spt5-194, se ha descrito que presenta dos mutaciones en el dominio NGN y concretamente su fenotipo se debe exclusivamente a una mutación que reside en el centro de la interfaz Spt4-Spt5NGN (Guo et al., 2008), participando directamente en la interacción con Spt4. Como hemos visto, la deleción de SUB1 asevera los fenotipos producidos por ambas mutaciones, spt5-194 y spt5-242 (Figura 52B) y, además, la sobreexpresión de SUB1 rescata parcialmente el fenotipo del mutante spt5-194 (Figura 52C).

2) Los niveles de polimerasa activa, competente para elongar, están reducidos en células sub1 $\Delta$ (Figura 51), afectando a la tasa de elongación, de manera similar a como lo hace la mutación spt5-242 (Quan and Hartzog, 2010).

3) Además, la deleción de $S U B 1$ incrementa drásticamente el fenotipo del mutante spt4A, especialmente en presencia de 6AU (Figura 52D). Spt4 es importante para la estabilidad de la RNAPII elongante, pero no para su tasa. Así, la deleción de SPT4 produce severos defectos en procesividad sin afectar a la tasa de elongación (Mason and Struhl, 2005). No obstante, la presencia de 6AU reduce la tasa y agrava los defectos en procesividad del mutante $s p t 4 \Delta$ y es posible que la deleción de $S U B 1$ produzca efectos aditivos sobre estos fenotipos, como reflejan nuestros resultados (Figura 52D).

Todas estas evidencias, en su conjunto, sugerían que Sub1 podría estar afectando a la formación del complejo Spt4/5-RNAPII y decidimos, por lo tanto, investigar el estado de la interacción de Spt5 con Rpb1 en las cepas wt, subld, spt5-194 y spt5-194 sub14, que expresan Spt5-Flag. Preparamos extractos totales y a partir de ellos inmunoprecipitamos Spt5. Posteriormente, analizamos por Western Blot los niveles de Rpb1 co-inmunoprecipitados con Spt5-Flag. Como muestra la figura 58A, los niveles totales de Spt5 no se alteran en las cepas sub1 4 y spt5-194, en comparación con los niveles correspondientes al $w t$. Sin embargo, se aprecia un ligero descenso en los niveles de Spt5 en el doble mutante spt5-194 sub1 $\Delta$. Sin embargo, cuando analizamos 
por RT-PCR la expresión de SPT5 (Figura 58B), comprobamos que este efecto no se debía a un descenso en la transcripción del gen. Por lo tanto, una posibilidad es que la deleción de SUB1 podría afectar a la estabilidad de la proteína mutante Spt5-194p. Cuando analizamos las inmunoprecipitaciones de Spt5-Flag (Figura 58A), observamos un descenso en los niveles del complejo Rpb1-Spt5, tanto en las células sub1 4 , como en spt5-194, efecto que se agrava drásticamente en el doble mutante.

Para corroborar este resultado, realizamos un experimento a la inversa, es decir, inmunoprecipitamos Rpb1 y analizamos los niveles de Spt5-Flag que coinmunoprecipitan con la polimerasa (Figura 58C). Los niveles de Rpb1 inmunoprecipitados son similares en las cuatro cepas, wt, sublA, spt5-194 y spt5-194 sub1 $\triangle$. Sin embargo, los niveles de Spt5 que co-purifican con Rpb1 disminuyen ligeramente en sub14; en el mutante spt5-194 esta disminución es más severa; y en el doble mutante spt5-194 sub1 $\Delta$, Spt5 es prácticamente indetectable (Figura 58C).

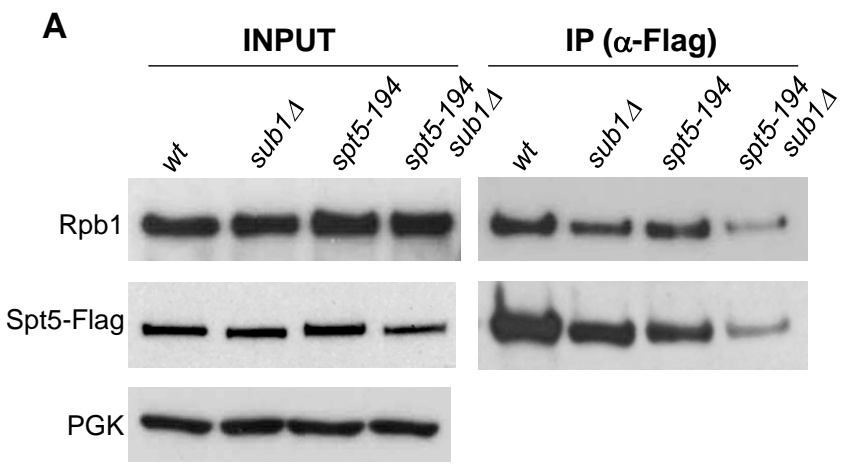

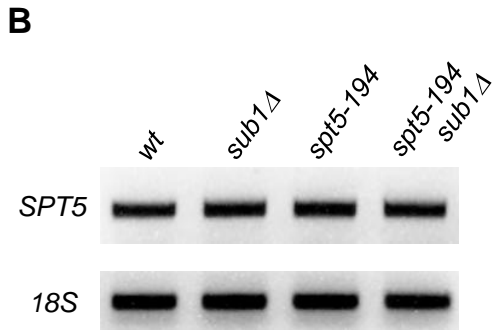

RT-PCR

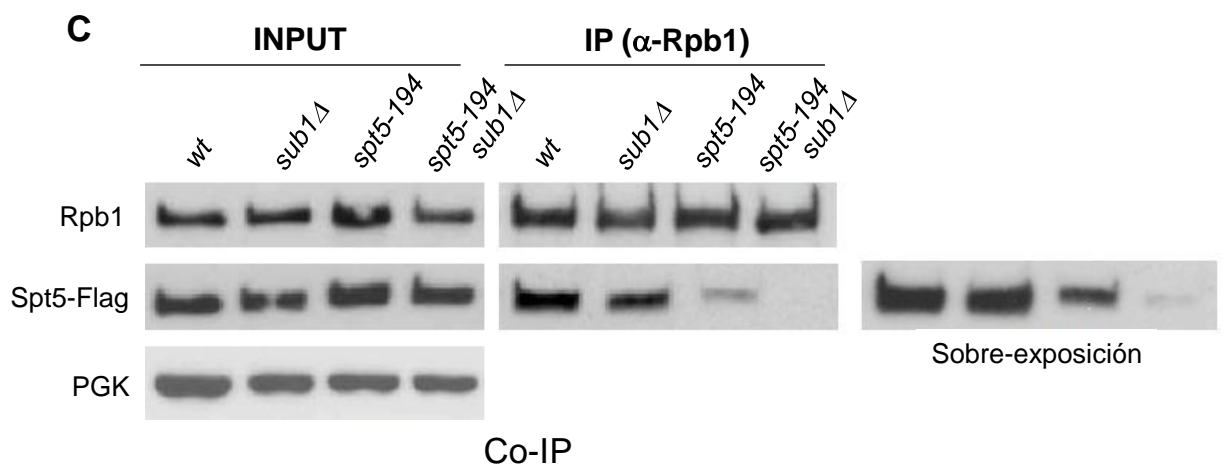

Figura 58. La deleción de $S U B 1$ afecta negativamente a la interacción entre Spt5 y Rpb1. (A) Coinmunoprecipitación de Spt5-Rpb1. Se prepararon extractos totales de cepas $w t$, sub1 4 , spt5-194 y spt5194 sub1 $\Delta$, expresando las proteínas correspondientes Spt5-Flag y spt5-194-Flag. Se utilizó el anticuerpo anti-Flag para inmunoprecipitar Spt5. Las mezclas de reacción se analizaron por Western Blot, utilizando los siguientes anticuerpos: 8WG16 para Rpb1 (panel superior), anti-Flag para Spt5-Flag (panel medio) y anti-PGK como control de carga (panel inferior). (B) Análisis de RT-PCR del gen SPT5. Se usó como control de carga el gen $18 S$ rRNA. Los productos de PCR se sometieron a electroforesis en gel de agarosa. (C) Co-inmunoprecipitación de Spt5-Rpb1 tal y como se realizó en (A), pero en este caso, las inmunoprecipitaciones se llevaron a cabo usando el anticuerpo anti-Rpb1 (8WG16). Los Western Blot para las muestras input y para los inmunoprecipitados se analizaron como en (A). 
Estos resultados indican que Sub1 podría ayudar a mantener niveles adecuados de Spt5 en la célula, incrementando directa o indirectamente su estabilidad, y especialmente en un fondo mutante spt5-194. Esto es consistente con el requerimiento de un dominio NGN funcional para garantizar la interacción Rpb1-Spt5 y con el hecho de que la sobre-expresión de $S U B 1$ suprima los defectos de crecimiento de un mutante spt5-194. Dicha supresión podría deberse a una mayor estabilidad del complejo en un contexto de mayores niveles de Sub1.

En conjunto, todos nuestros datos indican que Sub1 afecta a los niveles del complejo Rpb1-Spt5 y, en consecuencia, a la elongación de la transcripción, y concretamente a la tasa de elongación. 


\section{Discusión}


En el trabajo que se acaba de presentar, hemos mostrado evidencias de que el factor de transcripción Sub1 influye en la fosforilación de la RNAPII afectando a la función de las cuatro CTD-quinasas, Kin28, Srb10, Bur1 y Ctk1. Los efectos de Sub1 sobre estas quinasas los hemos observado genética y bioquímicamente, incluyendo efectos en la actividad catalítica y/o el reclutamiento a la cromatina. Nuestros resultados indican que Sub1 puede actuar a lo largo de todo el ciclo de transcripción como un regulador general de la fosforilación del CTD. Además, es posible que el mecanismo de regulación se encuentre en la relación Sub1-Rpb4/7.

Por otra parte, hemos demostrado que Sub1 no es solo un factor de pre-iniciación, como algunos autores han apuntado, sino que además es capaz de funcionar como un factor de elongación de la transcripción. Concretamente, regulando la tasa de elongación y posiblemente a través de su relación funcional con el factor Spt5. A continuación, se discuten las implicaciones de las relaciones funcionales de Sub1 con las CTD-quinasas y de cómo Sub1 puede influir en la fosforilación del CTD y en la elongación de la transcripción por la RNAPII.

\subsection{Sub1 regula globalmente la fosforilación de la RNAPII}

\subsubsection{Efectos opuestos de Sub1 en la fosforilación del CTD}

Durante la iniciación de la transcripción, dos son las enzimas con actividad CTDquinasa que fosforilan a la RNAPII: Srb10 y Kin28 (Cdk8 y Cdk7 en humanos, respectivamente). Se ha propuesto que ambas quinasas tienen efectos opuestos sobre la transcripción, aunque, como veremos, esto no es cierto del todo. Srb10 es capaz de fosforilar a la polimerasa antes de que se asocie a la cromatina en el PIC e inhibir de este modo la transcripción (Hengartner et al., 1998). Sin embargo, los análisis de arrays de expresión indican que esta quinasa puede comportarse como un factor positivo o negativo de la transcripción (Donner et al., 2010; Green and Johnson, 2004; Holstege et al., 1998; van de Peppel et al., 2005). En cuanto a Kin28, su actividad promueve la salida de la polimerasa del promotor (Akoulitchev et al., 2000; Hengartner et al., 1998; Jiang et al., 1996) y el procesamiento del extremo 5' del transcrito naciente (Cho et al., 1997; Ho and Shuman, 1999; McCracken et al., 1997b; Rodriguez et al., 2000). Además, estimula el reclutamiento y la actividad de la CTD-quinasa de elongación Bur1 (Qiu et al., 2009) y recientemente se ha demostrado que, en humanos, la actividad de Cdk7 es necesaria para la activación de Cdk9 (yBur1) y para mantener niveles adecuados de Ser2P (Larochelle et al., 2012). Por lo tanto, está claro que Kin28 posee 
un papel activador de la transcripción. Adicionalmente, la actividad quinasa de Srb10, junto con la de Kin28, promueve la formación del complejo scaffold (Liu et al., 2004). Dicho complejo está compuesto por una serie de factores de la maquinaria de transcripción basal (todos los componentes del PIC, excepto la RNAPII y los factores TFIIB y TFIIF) que, tras el inicio de la transcripción, permanecen asociados a los promotores, sirviendo de plataforma para el ensamblaje de nuevos complejos de transcripción y facilitando los eventos de reiniciación (Yudkovsky et al., 2000). Se ha demostrado que la inhibición química específica de Kin28 provoca un incremento en la contribución de la actividad quinasa de Srb10 a la formación de este complejo y que. Por lo tanto, Srb10, junto con Kin28, también es capaz de promover la transcripción facilitando la activación y disociación del PIC (Liu et al., 2004).

Nuestros resultados muestran claramente que el factor de transcripción Sub1 tiene efectos opuestos sobre estas dos CTD-quinasas. Así, mientras que la deleción de SUB1 afecta negativamente a la asociación a la cromatina in vivo y a la actividad in vitro de Srb10, efectos contrarios se observan en el caso de Kin28 y del resto de CTD-quinasas. Estos resultados sugieren que Sub1 podría desempeñar un papel inhibitorio sobre la transcripción, favoreciendo la función de Srb10 y regulando negativamente al resto de CTD-quinasas. Sin embargo, el análisis genético parece indicar lo contrario. La deleción de SUB1 rescata parcialmente el fenotipo del mutante $\operatorname{srb} 10 \Delta$, mientras que agrava los fenotipos de los mutantes kin28 con alterada actividad quinasa (Calvo and Manley, 2005). No obstante, aunque los resultados genéticos y bioquímicos parezcan contradictorios, no son incompatibles. Como ya se ha mencionado antes, cuando se inhibe la actividad de Kin28, Srb10 contribuye en mayor medida a la fosforilación de la polimerasa en el PIC y a promover la activación de la transcripción (Liu et al., 2004). Por otra parte, Srb10 es un regulador negativo de la transcripción de KIN28 durante la meiosis (Ohkuni and Yamashita, 2000) y durante el crecimiento vegetativo (Figura 18), de manera que en células srb10 1 los niveles y la actividad de Kin28 se encuentran incrementados. Así, en un mutante srb10A, la sobre-expresión de SUB1 produce un fenotipo tan severo probablemente porque niveles muy altos de Sub1 ejercen una fuerte inhibición sobre la actividad y el reclutamiento de Kin28 que, en este caso, no pueden ser compensados por la presencia de Srb10. En esta situación, la disociación del PIC, la formación del scaffold y la iniciación de la transcripción se encontrarían comprometidas. No obstante, aunque el fenotipo es muy grave, no se produce letalidad, ya que probablemente otras CTD-quinasas pueden suplir la función de Srb10 y Kin28, 
de acuerdo con resultados previamente publicados (Liu et al., 2004), en los que se muestra que la inhibición conjunta de ambas enzimas no abole completamente la fosforilación de la polimerasa en el PIC.

En cuanto a la interacción genética SUB1-KIN28, la deleción de SUB1 tiene efectos aditivos sobre el fenotipo de varios mutantes kin28 con severos defectos en la fosforilación (Calvo and Manley, 2005). Así por ejemplo, en el caso del mutante kin28$K 36 A$, con actividad quinasa reducida, la deleción de $S U B 1$ provoca efectos negativos porque, probablemente, pese a provocar un incremento en la actividad y el reclutamiento de Kin28, y en consecuencia favorecer la iniciación y parcialmente el capping (Figuras 7-13), es posible que este incremento no sea lo suficientemente significativo como para aliviar los efectos provocados en la activación de las quinasas Bur1 y Ctk1 (Qiu et al., 2009), a los que, adicionalmente, habría que sumarle los defectos en la tasa de elongación que produce la ausencia de SUB1. En el caso del mutante $\operatorname{kin} 28-T 17 D$, donde la actividad quinasa se encuentra abolida totalmente, la deleción de $S U B 1$ es letal. En este caso, ni siquiera existe la posibilidad de un rescate parcial de la actividad quinasa, por lo que a los efectos en iniciación, capping y activación de las quinasas de elongación, se suman deletéreamente los efectos en elongación de subla. Asímismo, los efectos de Sub1 sobre Bur1 (y en parte sobre Ctk1), se podrían explicar como efectos indirectos derivados de la relación Sub1-Kin28, aunque no podemos descartar otros mecanismos alternativos. Así, por ejemplo, la relación funcional de Sub1 con Bur1, alternativamente, podría llevarse a cabo a través del complejo de replicación RPA. El complejo Bur1/Bur2 interacciona física y genéticamente con Rfa1 (subunidad de RPA) y se ha propuesto que colabora en el mantenimiento de la estabilidad genómica durante el estrés replicativo (Clausing et al., 2010). Por otra parte, muy recientemente se ha descrito que la subunidad Rfa1 es un factor de elongación, que parece competir con Sub1 por la asociación a los promotores durante la transcripción (Sikorski et al., 2011). En realidad, Rfa1 solamente puede asociarse a los promotores durante la transcripción activa en ausencia de SUB1. Por lo tanto, es posible que el incremento de la asociación de Rfal en un mutante subla pudiera determinar el incremento en el reclutamiento de Bur1 y su actividad. Sin embargo, no hemos observado que el reclutamiento de Bur1 se altere de forma significativa en ausencia de SUB1. Aún así, no podemos descartar que Sub1 pueda influir indirectamente en la actividad quinasa de Bur1 durante la elongación, a través de Rfa1. 
En cuanto a los efectos de la deleción de $S U B 1$ sobre Ctk1 es posible que, al igual que se ha propuesto para Bur1, los efectos que Sub1 tiene sobre Kin28 afecten de manera indirecta a la función de Ctk1. Sin embargo, la deleción de SUB1 produce un defecto mucho mayor sobre el reclutamiento de esta quinasa que sobre el de Bur1, lo que sugiere un mecanismo distinto y/o adicional. Ctk1 fosforila a la RNAPII en Ser2 durante la elongación, permitiendo el reclutamiento de la maquinaria de procesamiento del extremo 3' de los mRNAs (Ahn et al., 2004). Además, Ctk1 promueve la disociación de la maquinaria de transcripción basal en el promotor y la formación del complejo scaffold de manera independiente de su actividad catalítica (Ahn et al., 2009). La actividad de esta quinasa es opuesta a la actividad de la fosfatasa Fcp1, de manera que mutaciones que afectan a la actividad fosfatasa de Fcp1 producen un incremento en los niveles de polimerasa fosforilada en Ser2 en los genes (Cho et al., 2001). Por su parte, la deleción de $S U B 1$ provoca un descenso en los niveles totales y en el reclutamiento de Fcp1 (Calvo and Manley, 2005) que, junto con el incremento en la asociación de Ctk1 (Figura 26), da lugar al aumento de polimerasa hiperfosforilada en Ser2 previamente descrito (Calvo and Manley, 2005). De la misma manera, los efectos de la deleción de SUB1 sobre Fcp1 podrían explicar por qué es letal el doble mutante

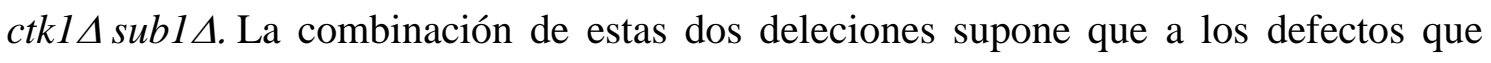
provoca la ausencia de CTKI en la activación y disociación del PIC y en el procesamiento del extremo 3' de los mRNAs (Ahn et al., 2004, 2009), habría que sumarle los defectos que la deleción de $S U B 1$ provoca sobre la tasa de elongación y sobre Fcp1, que podrían alterar el reciclaje de la RNAPII para reiniciar nuevas rondas de transcripción (Calvo and Manley, 2005).

De cualquier modo, nuestros resultados apoyan la hipótesis de que Sub1 regula positivamente la función de Srb10 y negativamente la de Kin28 durante la preiniciación, lo que sugiere un papel represor de Sub1 a este nivel. De acuerdo con esta interpretación, la proteína homóloga humana de Sub1, PC4, también actúa como un represor transcripcional durante la transición pre-iniciación-iniciación (Malik et al., 1998). En un sistema in vitro, PC4 es capaz de reprimir la transcripción cuando el PIC no está ensamblado correctamente (Malik et al., 1998) y de actuar como un inhibidor competitivo de la fosforilación específica de la RNAPII por Cdk7 (Schang et al., 2000). Al parecer, la función de PC4 se regula mediante fosforilación gradual, también por la propia Cdk7 y por otras quinasas del PIC (Jonker et al., 2006b; Schang et al., 2000). Así, se ha propuesto que: 1) PC4 defosforilado se recluta a los promotores a través de su 
interacción con activadores; 2) en un estado de fosforilación intermedio se asocia al dsDNA y favorece la formación de la burbuja de transcripción junto con los GTFs, en un contexto de PIC estable e inactivo; y 3) su fosforilación completa provoca la pérdida de su capacidad de unión a DNA y, por lo tanto, su disociación, aliviándose de esta manera su efecto represor (Jonker et al., 2006a, 2006b). En este sentido, Sub1 podría funcionar de la misma manera pues, al menos in vitro, su afinidad por el DNA también está regulada por fosforilación (Henry et al., 1996). Asimismo, se ha propuesto que Sub1 funciona como un factor que facilita la activación del PIC, promoviendo la disociación del factor TFIIB (Henry et al., 1996; Knaus et al., 1996). En un sistema in vitro, Sub1 defosforilado es capaz de asociarse al DNA y de interaccionar con TFIIB y su fosforilación supone su disociación del DNA y la pérdida de la interacción con TFIIB (Henry et al., 1996). En resumen, Sub1, al igual que PC4, podría tener un papel dual durante el inicio de la transcripción, papel que implica a las quinasas Srb10 y Kin28 y, en consecuencia afecta a la fosforilación de la RNAPII.

\subsubsection{Sub1 influye en la fosforilación de los residuos Ser5 y Ser2 por distintas vías}

La deleción de SUB1 produce un incremento en la fosforilación global de la RNAPII, influyendo de forma distinta en la fosforilación específica de los residuos Ser5 y Ser2 del consenso. Los altos niveles de polimerasa fosforilada en Ser5 asociada a los promotores génicos, en el mutante subl $\Delta$, son consecuencia directa de un incremento en la asociación y la actividad de Kin28 y no en una alteración en su defosforilación. Así, no hemos observado una relación genética y/o funcional de Sub1 con las fostatasas de Ser5, Ssu72 y Rtr1 (datos no mostrados). Tampoco hemos detectado formas hiperfosforiladas en Ser5 de la polimerasa que se vayan acumulando a lo largo de toda la secuencia codificante, indicando defectos en la defosforilación (datos no mostrados). Sin embargo, en el mutante subl $\Delta$, la fosforilación de la RNAPII en Ser2 se encuentra incrementada debido a que la ausencia de $S U B 1$ altera tanto la fosforilación, como la defosforilación de estos residuos. Relativo a la fosforilación, en un mutante subl $\Delta$ el reclutamiento a la cromatina de Ctk1 y su actividad se encuentran incrementados. Este fenotipo puede ser una consecuencia del efecto que la deleción de SUB1 tiene sobre la actividad de Kin28, incrementando los niveles de polimerasa fosforilada en Ser5, que es el sustrato de Ctk1 (Jones et al., 2004) y activando su reclutamiento (Qiu et al., 2009). En cuanto a la defosforilación, Sub1 altera la defosforilación de los residuos Ser2P, ya que su deleción disminuye la asociación de Fcp1 a los genes, así como los niveles 
totales de esta fosfatasa en la célula (Calvo and Manley, 2005). En conjunto, nuestros datos sugieren que la deleción de $S U B 1$ produce un incremento en la fosforilación en Ser5 que podría influir directamente en la fosforilación en Ser2, la cual a su vez también se encuentra incrementada como consecuencia de defectos en su defosforilación.

\subsection{3 ¿Cómo puede Sub1 regular la actividad y reclutamiento de todas las CTD- quinasas?}

Por el momento, desconocemos el mecanismo molecular por el cual Sub1 regula la fosforilación de la RNAPII a lo largo de todo el ciclo de transcripción. No hemos encontrado que Sub1 co-purifique con ninguna de las CTD-quinasas (datos no mostrados), ni que afecte a sus niveles. Por otro lado, Kin28, Bur1 y Ctk1, pero no Srb10, están reguladas por fosforilación por la quinasa activadora de CDKs, Cak1 (Espinoza et al., 1998; Ostapenko and Solomon, 2005; Yao and Prelich, 2002), con la que tampoco parece ser que Sub1 se relacione funcionalmente (datos no mostrados). No obstante, la conexión Sub1-Srb10 y/o la interacción Sub1-Rpb4/7 nos han llevado al planteamiento de dos hipótesis, no excluyentes, que podrían explicar cómo Sub1 es capaz de regular la función de las CTD-quinasas.

\section{Sub1-Srb10}

Como ya se ha mencionado, Srb10 y Kin28 se encuentran estrechamente relacionadas. Por un lado, en S. cerevisiae, Srb10 es un represor transcripcional de KIN28 (Ohkuni and Yamashita, 2000) y, además, un regulador negativo de su actividad catalítica (Figura 18). Asimismo, se ha descrito que Srb10, como parte del módulo quinasa del complejo Mediador, es capaz de fosforilar a otras subunidades del factor TFIIH, del que forma parte Kin28 y que, a su vez, Kin28 fosforila a otros componentes del Mediador, diferentes de Srb10 (Liu et al., 2004). Las funciones concretas de estas fosforilaciones se desconocen por el momento, pero suponen indicios adicionales que sugieren la regulación conjunta de ambas enzimas. Por su parte, en células humanas, Cdk8 (ySrb10) inactiva a Cdk7 (yKin28) mediante la fosforilación de su par ciclina (Akoulitchev et al., 2000). Además, el complejo Mediador participa en el ensamblaje del PIC, facilitando el reclutamiento de los factores TFIIH (Kin28) y TFIIE (Esnault et al., 2008), y se ha propuesto que $\mathrm{Cdk} 8$, en concreto, favorece su disociación promoviendo el escape del promotor (Knuesel et al., 2009). Asimismo, la actividad de Cdk7 es necesaria para la disociación de TFIIE tras la iniciación (Larochelle et al., 2012). Por último, Sub1 está relacionado genética y funcionalmente con el complejo 
Mediador, no solamente a través de Srb10, si no también a través de otras subunidades del complejo (Figura 14; (Dettmann et al., 2010).

Nuestros resultados muestran que la deleción de $S U B 1$ disminuye el reclutamiento de Srb10 al gen GAL1, así como su actividad quinasa in vitro (Figuras 15 y17). Una posible consecuencia de este fenotipo es que en células subl $\Delta$ los niveles de Kin28 se incrementen de la misma manera que ocurre en un mutante $s r b 10 \Delta$, sin embargo, esto no sucede así. En el mutante subla sólo hay un aumento en la actividad quinasa, sin aumentar los niveles de la misma. Es posible que la disminución de la actividad y el reclutamiento de Srb10 que se producen en ausencia de SUB1 no sea lo suficientemente drástico como para afectar a la expresión de KIN28, sobre todo, teniendo en cuenta que la expresión de $S R B 10$ y los niveles de proteína no varían en subl $\Delta$. No obstante, si al igual que ocurre en mamíferos, en levaduras, la actividad de Srb10 regula negativamente la actividad de Kin28 por fosforilación de su par ciclina, una reducción en la actividad de Srb10 podría aliviar su efecto represor sobre Kin28, contribuyendo a los fenotipos observados cuando se deleciona SUB1 (Figuras 7-11). Así, el efecto de la deleción de SUB1 sobre Srb10 contribuiría al incremento en la asociación de Kin28 a los genes, lo que a su vez contribuiría al incremento subsiguiente de los niveles de Bur1 y Ctk1 asociados (Larochelle et al., 2012; Qiu et al., 2009). De acuerdo con esto, en mamíferos, para un grupo de genes concreto, Cdk8 es capaz de interaccionar con el complejo P-TEFb y reclutarlo a la maquinaria de transcripción (Donner et al., 2010).

Teniendo en cuenta todas estas consideraciones, en conjunto, proponemos un modelo para explicar cómo Sub1 podría regular la fosforilación del CTD de la RNAPII de forma global (Figura 59). En células wt, Sub1 no-fosforilado se uniría al promotor a través de su dominio de unión a ssDNA durante la formación del PIC, probablemente reclutándose vía su interacción con TFIIB (Henry et al., 1996; Rosonina et al., 2009). En este punto, Sub1 interaccionaría con el complejo Srb10-Mediador, ayudando a mantener el PIC en una conformación estable pero inactiva. Cuando el PIC está perfectamente ensamblado, entonces Sub1 podría ser fosforilado (probablemente por la acción de alguna quinasa componente del PIC, de forma análoga a lo que sucede en células humanas para PC4 (Malik et al., 1998), perdiendo así su capacidad de unión a DNA, disociándose y facilitando la disociación de TFIIB (Ge et al., 1994; Henry et al., 1996). Tras ello, el PIC cambiaría a una conformación en la que Kin28 puede ser activada $\mathrm{y}$, con la ayuda de Srb10, promover la disociación del PIC al complejo 
scaffold, así como facilitar el reclutamiento de las CTD-quinasas de elongación Ctk1 y Bur1, desencadenándose la fosforilación de la polimerasa (Larochelle et al., 2012; Qiu et al., 2009, 2012). Por el contrario, en ausencia de SUB1 (sublA), la actividad y el reclutamiento de Srb10 se encuentran disminuidos, mientras que el reclutamiento y la actividad de Kin28 se incrementan, de acuerdo con la regulación negativa que Srb10 ejerce sobre la función de Kin28 (Akoulitchev et al., 2000; Ohkuni and Yamashita, 2000). Como resultado, los niveles de polimerasa fosforilada en Ser5 aumentan en las regiones promotoras de los genes y, consecuentemente, la asociación a la cromatina de Bur1 y Ctk1 (Donner et al., 2010; Larochelle et al., 2012; Qiu et al., 2009). Además, en el mutante subla se produce una reducción en los niveles y en la asociación a la cromatina de la fosfatasa Fcp1, lo que induce un incremento adicional de la fosforilación de la polimerasa en Ser2 (Calvo and Manley, 2005). A su vez, esto produciría un defecto en su reciclaje tras la terminación de la transcripción, lo que podría explicar la menor densidad de polimerasa total detectada por ChIP en células subla, sobre todo en los promotores (Figuras 12, 48-49; (Calvo and Manley, 2005; Rosonina et al., 2009; Sikorski et al., 2011).

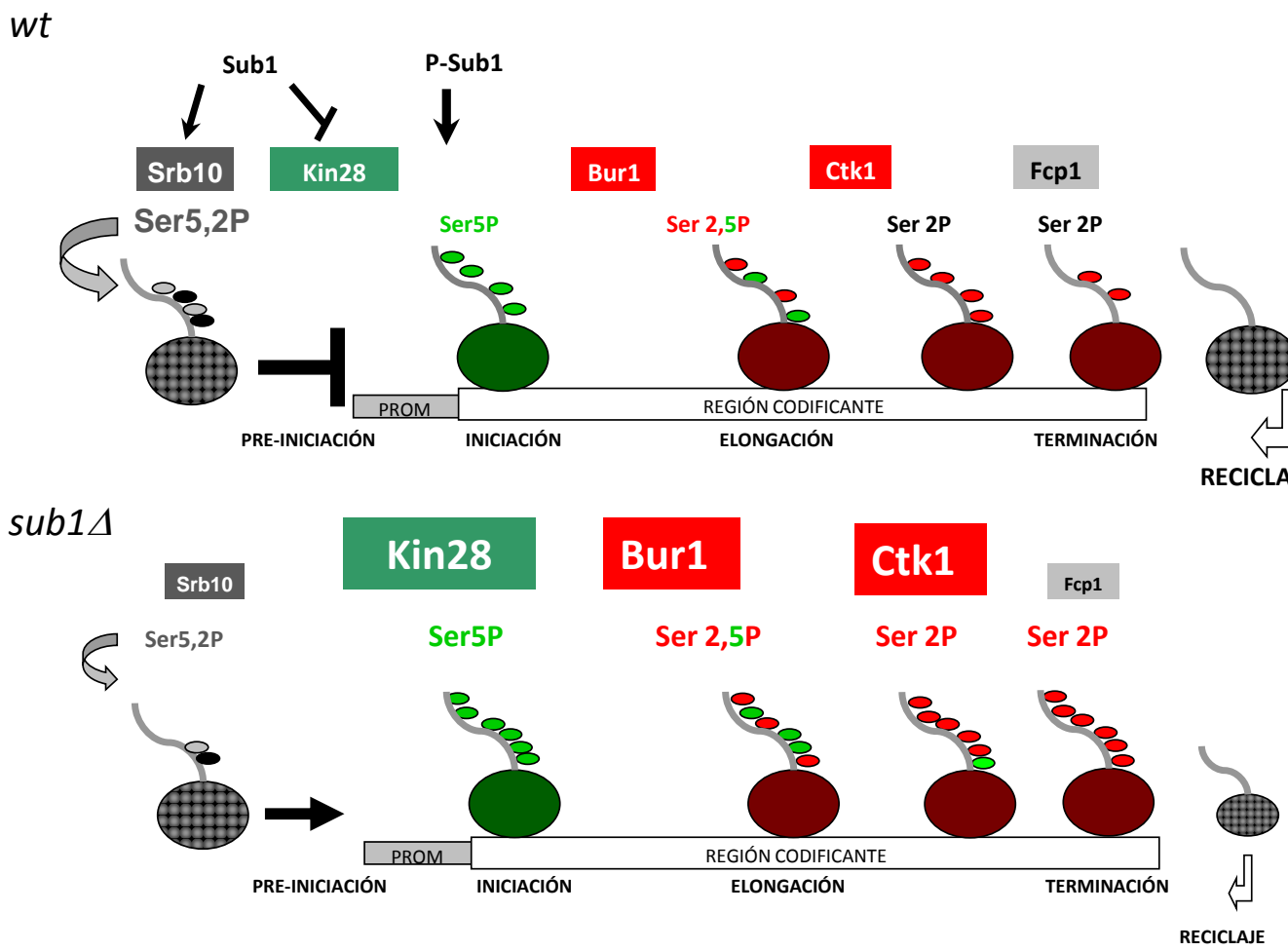

Figura 59. Modelo ilustrativo de como Sub1 podría regular globalmente la fosforilación de la RNAPII durante un ciclo de transcripción. El uso de diferentes tamaños de letra indican el incremento o la disminución de las correspondientes enzimas modificadoras del CTD en las células subl $\Delta$ versus wt. 
De acuerdo con la idea de que Sub1 podría participar en el reciclaje de la RNAPII a través de sus efectos sobre Fcp1, se sabe que, en sistemas in vitro, tanto Sub1 como PC4 facilitan la reiniciación de la transcripción de la RNAPIII, asociándose a componentes de la maquinaria basal, como el factor TFIIIC (Tavenet et al., 2009; Wang and Roeder, 1998). Se ha sugerido que Sub1 y PC4 podrían ayudar a la transferencia de la RNAPIII desde las regiones terminadoras hasta las regiones promotoras mediante la torsión del DNA o mediante gene looping (Conesa and Acker, 2010). Sin embargo, el fenómeno del gene looping solamente se ha descrito hasta el momento para genes transcritos activamente por la RNAPII y para el locus de rDNA mitocondrial humano (Ansari and Hampsey, 2005; Martin et al., 2005; O'Sullivan et al., 2004; Tan-Wong et $a l ., 2008)$. Este fenómeno consiste en la formación de un bucle de DNA entre regiones promotoras y regiones terminadoras génicas, tras la primera ronda de transcripción, para facilitar la reiniciación (Hampsey et al., 2011). Sin embargo, por el momento no se ha encontrado implicación directa de Sub1 en gene looping. De hecho, el mutante sub1 $\Delta$ no presenta fenotipos asociados a defectos en gene looping, como la incapacidad para crecer utilizando como fuente de carbono la galactosa (datos no mostrados).

\section{Sub1-Rpb4/7}

El efecto de la deleción de $S U B 1$ sobre el reclutamiento de todas las CTDquinasas podría explicarse según el modelo que acabamos de proponer, no así los efectos sobre la actividad quinasa de las mismas. Todavía no podemos explicar como la deleción de SUB1 puede afectar de forma diferencial a la actividad quinasa en un ensayo in vitro, máxime cuando no hemos encontrado que Sub1 interaccione con ninguno de los complejos CTD-quinasas asociados. Una posibilidad es que Sub1 regule el acceso de las enzimas a su sustrato, afectando de este modo a su accesibilidad al CTD, y/o que module la función de un regulador común de las CTD-quinasas. Un candidato excelente podría ser el dímero Rpb4/7, que hemos identificado en los complejos asociados a Sub1-TAP. Aunque desconocemos si éste interacciona directamente con las quinasas, sí que lo hace con la fosfatasa Fcp1 (Kamenski et al., 2004; Kimura et al., 2002).

Rpb4 y Rpb7 son dos subunidades de la RNAPII que constituyen un heterodímero, disociable en levaduras, asociado al resto del complejo mediante interacción con el dominio clamp y que está conservado en todas las polimerasas eucariotas y de arqueas (Werner and Grohmann, 2011). Las estructuras cristalográficas 
de Rpb4/7, en el contexto de la RNAPII, han localizado a este subcomplejo en la proximidad del CTD y del canal de salida del RNA (Armache et al., 2003; Bushnell and Kornberg, 2003). Además, algunos ensayos genéticos y bioquímicos sugieren que estas subunidades podrían influir en el reclutamiento de algunas enzimas modificadoras del CTD a la polimerasa. Así, se ha propuesto que podrían regular el acceso de las enzimas que modifican el CTD durante todo el ciclo de transcripción (Armache et al., 2003, 2005; Bushnell and Kornberg, 2003; Cai et al., 2009, 2010; Sampath et al., 2008), aunque hasta el momento no se ha demostrado. No obstante, en $S$. cerevisiae se ha descrito la interacción genética entre la prolil-isomerasa Ess1 y Rpb7 y se ha demostrado que, al menos in vitro, Rpb4/7 es necesario para la interacción de Fcp1 con la polimerasa (Kamenski et al., 2004; Kimura et al., 2002). Asimismo, en S. pombe, se ha identificado una interacción física entre Fcp1 y Rpb4 ( Wu et al., 2000).

Por otra parte, curiosamente, la resolución de la estructura del Mediador ha demostrado que la asociación de este complejo a la RNAPII se lleva a cabo a través de su interacción con el dímero Rpb4/7 (Cai et al., 2009, 2010). Mediante estudios de microscopía electrónica, se ha visto que el módulo estructural head del Mediador, y concretamente los factores Med18 y Med20, se asocian directamente con estas dos subunidades de la polimerasa. Se ha propuesto que Rpb4/7 podrían regular la movilidad del dominio clamp de la RNAPII, modulando el acceso del dsDNA al centro activo de la enzima, en respuesta a la interacción con el Mediador y con otros componentes de la maquinaria de transcripción (Cai et al., 2010). En este sentido, se han descrito una serie de interacciones genéticas negativas entre $R P B 4 / 7$ y distintas subunidades del Mediador, entre ellas $M E D 20$ y $M E D 16$, con las que sorprendentemente también interacciona genéticamente SUB1 (Dettmann et al., 2010).

Los estudios genéticos que hemos realizado con distintos mutantes de la polimerasa sugieren una relación funcional de Sub1 con una región estratégica de la misma, relacionada con Rpb4/7 y el CTD. Así, conviene recordar que SUB1 interacciona genéticamente con un mutante en el dominio foot. Este dominio, situado en la superficie de Rpb1, está relacionado funcionalmente con el CTD, al ser necesario para el reclutamiento de la maquinaria de capping (Suh et al., 2010). Además, la deleción de SUB1 es letal sintética con una mutación en el dominio clamp y su sobreexpresión agrava significativamente el fenotipo de la deleción de $R P B 4$. Sin embargo, no existe interacción genética entre SUB1 y un mutante del core, en principio no 
relacionado funcionalmente con el CTD (Rodriguez et al., 2000). Al mismo tiempo, los resultados de nuestros ensayos de ChIP indican que el dímero Rpb4/7 es necesario para el reclutamiento de Sub1 a la cromatina, de manera que en un mutante $r p b 4 \Delta$, la presencia de Sub1 en el complejo de transcripción se encuentra extraordinarimanete reducida. Estos datos concuerdan con el hecho de que la deleción de RPB4 produce un incremento de la polimerasa fosforilada asociada a la cromatina. Sin embargo, los fenotipos de fosforilación de los mutantes $\operatorname{subl} \Delta$ y $r p b 4 \Delta$ no son exactamente iguales. La deleción de SUB1 produce un incremento notable en la fosforilación en Ser5 y Ser2 presente en los genes, consecuencia de un incremento del reclutamiento de las CTDquinasas y de defectos en la defosforilación mediada por Fcp1. Por su parte, la deleción de RPB4 incrementa los niveles totales de $\mathrm{Rpb} 1$, tal vez como un mecanismo compensatorio a la disminución de los niveles de polimerasa transcribiendo activamente, que carece de Rpb4/7 (Runner et al., 2008), pero que se encuentra hiperfosforilada en Ser2P. Según los resultados de Runner et al (2008), la deleción de RPB4 no afecta al reclutamiento de Ctk1, por lo tanto, una posible hipótesis es que el incremento en Ser2P podría estar causado por un defecto en su defosforilación o sobre la actividad y/o el reclutamiento de las otras CTD-quinasas. En relación a los defectos en defosforilación, Fcp1 es capaz de asociarse a la polimerasa in vitro solamente cuando contiene las doce subunidades (Kamenski et al., 2004) y es posible que la asociación de Rpb4/7 al core de la polimerasa favorezca la asociación de Sub1 y en consecuencia la de Fcp1, de acuerdo con (Calvo and Manley, 2005).

En resumen, los datos genéticos y bioquímicos presentados en este trabajo sugieren que existe una conexión funcional entre Sub1, Rpb4/7, el Mediador (Srb10) y Fcp1. Así, una posible explicación al efecto que la deleción de SUB1 tiene sobre la fosforilación de la RNAPII es que se encuentre alterarada la interacción de Rpb4/7 con el complejo Mediador y con Fcp1. En ausencia de SUB1, la interacción del Mediador con la RNAPII se vería comprometida, lo que explicaría la disminución en la asociación a la cromatina de Srb10 en el mutante $s u b 1 \Delta$, así como los efectos sobre Kin28, Bur1 y Ctk1 expuestos anteriormente. 


\section{2.-Sub1 se asocia con Spt5 e influye en la tasa de elongación de la RNAPII}

Sub1 es un factor de transcripción, predominantemente asociado a los promotores de los genes (Henry et al., 1996; Knaus et al., 1996; Rosonina et al., 2009), que recientemente se ha aislado como un componente funcional del PIC en ensayos in vitro (Sikorski et al., 2011). Sin embargo, a pesar de que la función de Sub1 se ha relacionado fundamentalmente con procesos que tienen lugar en las regiones 5', en este trabajo hemos presentado numerosas evidencias que demuestran que Sub1 puede funcionar también como un factor de elongación. Se asocia a las regiones codificantes de los genes transcritos dependiente de transcripción activa y afecta a los niveles totales de polimerasa asociada a los genes durante todo el ciclo de transcripción. Además, Sub1 interacciona con el factor de elongación Spt5, probablemente durante la elongación temprana, influyendo sobre los niveles del complejo Spt5- RNAPII y afectando así a la tasa de elongación.

\subsubsection{Sub1 afecta a la eficiencia de la elongación de la transcripción y a la tasa de elongación de la RNAPII}

Las primeras evidencias de que Sub1 podría ser un factor de elongación, independientemente de su función en la fosforilación del CTD, surgen de los análisis genéticos y del hecho de que su deleción incrementa considerablemente la sensibilidad a la droga 6AU. Esta droga ralentiza la transcripción al disminuir la concentración intracelular de nucleótidos. Así, la deleción de SUB1 incrementa el fenotipo de crecimiento y sensibilidad a 6AU del mutante burl-23 y, notablemente, en el caso del mutante burl-2, que per sé no presenta sensibilidad a esta droga, causa una extremada sensibilidad a la misma (Figura 20). Asímismo, la deleción de $S U B 1$, en combinación con las mutaciones spt5-194 y spt5-242, también produce un fenotipo de gran sensibilidad a $6 \mathrm{AU}$ y, por su parte, el doble mutante $\operatorname{spt} 4 \Delta$ subl $\Delta$ es letal en presencia de concentraciones de la droga que son soportables para el mutante sencillo. Además, aunque en medio sólido con 6AU el crecimiento del mutante subla no se altera significativamente, sí lo hace en medio líquido.

Adicionalmente, el resultado del ensayo GLAM indicaba que Sub1 podría afectar a la eficiencia de la elongación de transcritos largos (Figura 41). Morillo-Huesca et al. (2006), utilizando este ensayo, demostraron que defectos en el ensamblaje, y/o 
formación del PIC, o en la iniciación de la transcripción, como los provocados por mutaciones en los factores TBP, TFIIA, TFIIB y TFIIE, no afectan a la eficiencia de la elongación. Por el contrario, nosotros hemos mostrado que Sub1, a pesar de ser un componente del PIC (Sikorski et al., 2011), su deleción provoca a una reducción significativa de los ratios GLAM, lo que indica un defecto en la eficiencia de la elongación. No obstante, este ensayo mide la extensión de transcritos largos de forma indirecta y así, por ejemplo, mutaciones en factores implicados en la fosforilación de la polimerasa o en el procesamiento de los mensajeros muestran ratios GLAM reducidos (Figura 42 y (Morillo-Huesca et al., 2006). Al tratarse Sub1 de un factor de transcripción que influye en la fosforilación de la RNAPII y que la función esencial de dicha fosforilación es la conexión de la transcripción con el procesamiento (Calvo and Manley, 2001; He et al., 2003), no podemos descartar que el efecto de Sub1 en la eficiencia de la elongación sea un efecto indirecto, si sólo tenemos en cuenta el resultado del ensayo GLAM.

Evidencias concluyentes de un efecto más directo de Sub1 en la elongación proceden de los ensayos de inmunoprecipitación de cromatina, cuyos resultados muestran que en el mutante subla se produce una disminución en la densidad de polimerasa asociada a los genes medida por ChIP (Figuras 12, 48-49 y (Calvo and Manley, 2005; Rosonina et al., 2009; Sikorski et al., 2011), aunque la procesividad de la misma no se altere o se encuentre ligeramente incrementada (Figura 50A). Por otro lado, aplicando el análisis diseñado por Mason y Struhl (2005), encontramos que la ausencia de $S U B 1$ provoca una acumulación de polimerasa asociada al gen largo GAL1$Y L R 454 w$ tras la última ronda de transcripción, lo que indica un defecto en la tasa de elongación de la polimerasa. Adicionalmente, los ensayos de TRO muestran que en el mutante $\operatorname{sub1} 1 \Delta$ hay una disminución de la polimerasa activa y competente para elongar. Estos resultados sugieren que la polimerasa que consigue salir del promotor es probablemente más lenta y sufre más paradas en el mutante subld durante la transcripción. Además, el defecto en la tasa de elongación es consistente con el hecho de que la deleción de SUB1 corrige los defectos en splicing que ocurren en el mutante spt5-194 (Figura 55), puesto que la tasa de elongación influye en la velocidad de procesamiento de intrones y en la selección de los sitios alternativos de splicing (de la Mata et al., 2003; Howe et al., 2003). De hecho, el grupo del Dr. N.J. Krogan ha demostrado que mutaciones en la RNAPII que disminuyen su velocidad de síntesis, así 
como la deleción de $S U B 1$, dan lugar a un aumento en la eficiencia del splicing (comunicación personal).

La tasa de elongación de la polimerasa se consideraba una característica intrínseca de la enzima. Cuando Mason y Struhl (2005) analizaron los defectos en tasa y procesividad de una batería de mutantes en factores de elongación (se trataba de factores que interaccionaban con la RNAPII in vitro y se asociaban a las secuencias codificantes de los genes in vivo, o cuyas mutaciones provocaban sensibilidad a 6AU), encontraron que ninguno de ellos afectaba a la tasa, aunque sí a la procesividad, exceptuando un mutante de la propia enzima (rpb2-10). Sin embargo, en trabajos posteriores, se han descrito defectos en tasa en mutantes del complejo Ccr4-Not (Kruk et al., 2011) y también en el mutante spt5-242 (Quan and Hartzog, 2010). Puesto que el complejo Spt4/5 afecta tanto a la procesividad como a la tasa de elongación de la RNAPII (Mason and Struhl, 2005; Quan and Hartzog, 2010) y que Sub1 se asocia a Spt5, es posible que los defectos en tasa que presenta el mutante subl $\Delta$ sean consecuencia de una alteración en los niveles y/o en la estabilidad del complejo Rpb1Spt5 (Figura 58). Sin embargo, no podemos descartar que el efecto de Sub1 sobre la tasa de elongación sea una consecuencia de su función a nivel de promotor y/o en un posible papel en gene looping, ligado a su relación funcional con el factor TFIIB (Knaus et al., 1996; Rosonina et al., 2009; Wu et al., 1999). De hecho, en algunos genes hay un incremento en la asociación de Sub1 con las regiones 3', en relación a su asociación con las regiones codificantes (por ejemplo, PMA1, Figura 45B; (Sikorski et al., 2011). De cualquier manera, merece la pena destacar que, a diferencia de TFIIB, que sólo se asocia a los promotores y regiones 3', Sub1 se asocia también a lo largo de toda la secuencia codificante de los genes transcripcionalmente activos y, como ya hemos adelantado, el mutante de sub1 $\Delta$ no presenta fenotipos asociados a defectos en el gene looping. Otra posibilidad es que los defectos en tasa del mutante subla sean consecuencia, en parte, de su efecto sobre el reclutamiento de Srb10, ya que en humanos, la ausencia de Cdk8 reduce la tasa de elongación de la RNAPII (Donner et al., 2010).

\subsubsection{Para muestra un botón: Sub1 regula la iniciación y elongación del gen IMD2}

La disminución de la concentración intracelular de nucleótidos como consecuencia, por ejemplo, del tratamiento con MPA o 6AU, induce la expresión del gen IMD2. Este gen codifica una enzima que participa en la síntesis de GTP y posee 
varios sitios de inicio en su promotor, que se seleccionan en función de los niveles de GTP disponibles. Así, la polimerasa es capaz de utilizar o bien varios sitios aguas arriba del nucleótido +1 (a partir de los que sintetiza transcritos cortos que se degradan rápidamente), o bien un sitio único aguas abajo, proximal al ATG (a partir del que se transcribe el mRNA). Esta selección del sitio de inicio se lleva a cabo en función de si la concentración de GTP en la célula es alta o baja, respectivamente (Figura 43A).

Koyama et al (2008) propusieron que Sub1 funciona como un represor del gen $I M D 2$, ya que su deleción provoca la expresión constitutiva del gen en condiciones de no inducción. Sin embargo, el mecanismo por el que Sub1 regula la expresión del gen IMD2 se puede explicar, en parte, por un mecanismo que implica la selección del TSS, de acuerdo con datos recientes obtenidos en el laboratorio del Dr. Krogan que muestran que la deleción de SUB1 altera la selección del TSS del gen ADH1 (comunicación personal). Consistente con esto, en ausencia de Sub1, en condiciones de no inducción, la transcripción a partir del sitio aguas abajo sería la preferida, dando lugar a la expresión constitutiva. Adicionalmente, nuestros datos sugieren que Sub1 también podría tener un papel durante la elongación de la transcripción de IMD2. Esta hipótesis viene corroborada por los resultados de nuestros ensayos ChIPs, en los que se observa que Sub1 se recluta al promotor del gen IMD2 en ausencia de inducción y que, en presencia de 6AU, también lo hace a lo largo de la secuencia codificante y con un patrón de asociación similar al de la RNAPII (Figuras 45A y 48B).

Por otra parte, resultados publicados muy recientemente apoyan nuestros argumentos. En primer lugar, Kaplan et al., (2012) han demostrado que ciertas mutaciones en Rpb1, situadas en el dominio trigger loop del centro activo, implicado directamente en la selección del TSS y en el mantenimiento de la fidelidad de la polimerasa, se correlacionan directamente con defectos en la tasa de la elongación y con la resistencia o sensibilidad a 6AU y MPA. Así, mutantes englobados por estos autores en la categoría de mutantes GOF ( Gain $\underline{\text { Of }}$ Function), tienen polimerasas rápidas, es decir, con altas tasas de elongación, seleccionan el TSS aguas arriba y presentan sensibilidad a MPA. Por otro lado, los mutantes de pérdida de función o LOF (L Loss $\underline{O f}$ Function) presentan una tasa de elongación de la polimerasa reducida, selección del TSS aguas abajo y resistencia en placa a la droga MPA, además de una expresión constitutiva del gen IMD2 en ausencia de inducción. Estos efectos son similares a los que hemos mostrado para el mutante $s u b 1 \Delta$, que es resistente a MPA (Koyama et al., 
2008) y a 6AU en medio sólido (Figuras 20, 29 y 52) y en el que la inducción del gen IMD2 puede ser una consecuencia de la utilización del TSS aguas abajo, probablemente debido a una polimerasa más lenta, como lo demuestran los ensayos de TRO.

En segundo lugar, el trabajo realizado en el laboratorio del Dr. Krogan (comunicación personal) muestra que la deleción de $S U B 1$ suprime los fenotipos de un mutante del trigger loop de Rpb1 (E1103G) y exacerba los fenotipos de otro mutante en este mismo dominio (F1086S). Estas dos mutaciones de Rpb1 fueron previamente caracterizadas como GOF y LOF, respectivamente. Así la mutación E1103G causa sensibilidad a MPA y 6AU, un incremento en la tasa de elongación (Kaplan et al., 2012; Malagon et al., 2006) y un desplazamiento aguas arriba del sitio de inicio de la transcripción de $I M D 2$, mientras que la mutación F1086S causa resistencia al MPA, tasa de elongación reducida y un cambio en el TSS aguas abajo (Kaplan et al., 2012). Es decir, la deleción de SUB1 suprime defectos provocados por polimerasa rápidas, probablemente al ralentizar sus tasas, mientras que exacerba los defectos de las polimerasa lentas, al disminuir aún más las tasas de elongación. Por lo tanto, es posible que Sub1, a través de su asociación con el factor TFIIB, pueda participar en la selección de TSS. No obstante, la asociación de Sub1 con la secuencia codificante del gen IMD2, dependiente de transcripción, sugiere asimismo que Sub1 podría estar regulando su elongación, modulando la tasa de elongación de la polimerasa. Por otro lado, no podemos descartar que, si Sub1 regula la expresión del gen IMD2, es posible que las células sub1 $\Delta$ tengan una concentración intracelular de nucleótidos más baja, de manera que Sub1 podría afectar a la elongación de la transcripción de forma indirecta a través de su efecto sobre la transcripción del gen IMD2. Sin embargo, nuestros resultados indican que el efecto de Sub1 en la elongación es más general y nos decantamos por un modelo en el que Sub1 influye en la transición iniciación-elongación y, en consecuencia, en la elongación, probablemente a través de su interacción con el factor de elongación Spt5 durante las fases tempranas de la elongación.

\subsubsection{Sub1 está ligado funcionalmente al factor de elongación Spt5}

Spt5 es un factor de transcripción asociado al complejo de elongación, que se recluta durante la transición iniciación-elongación y que no está presente en el PIC (Mayer et al., 2010). Mediante estudios estructurales, se ha demostrado que Spt5, a través de su dominio NGN, proporciona estabilidad al híbrido DNA-RNA en el centro activo de la polimerasa, contribuyendo al mantenimiento de la burbuja de transcripción 
(Klein et al., 2011; Martinez-Rucobo et al., 2011). Por su parte, como ya hemos visto, se ha descrito recientemente que Sub1 es un componente del PIC, asociado fuertemente a los promotores génicos y localizado en una región adyacente al área de formación de la burbuja de transcripción (Rosonina et al., 2009; Sikorski et al., 2011). Adicionalmente, nosotros hemos demostrado que también está presente a lo largo de las secuencias codificantes de los genes durante la transcripción activa. Puesto que tanto Spt5 como Sub1 se unen a la burbuja de transcripción abierta, se asocian a la cromatina durante la transición iniciación-elongación y, además, las células subl $\Delta$ muestran una disminución de la densidad de polimerasa en regiones codificantes, es posible que Sub1, de forma redundante, favorezca la asociación de Spt5 con la RNAPII durante la transición iniciación-elongación, promoviendo de este modo la elongación de la transcripción. De acuerdo con esta hipótesis, los niveles de Spt5 asociados con Rpb1 se encuentran reducidos en un mutante $\operatorname{subl\Delta }$, especialmente en un doble mutante spt5194 subl $\Delta$. Esto es consistente con el hecho de que la mutación spt5-194 se localiza en el dominio NGN, mediante el cual Spt5 se une directamente a la polimerasa y a Spt4 (Guo et al., 2008; Klein et al., 2011; Martinez-Rucobo et al., 2011). Además, la mutación spt5-194 también altera la asociación Spt4-Spt5 (Guo et al., 2008). Este hecho podría explicar los defectos de crecimiento observados en los dobles mutantes spt5

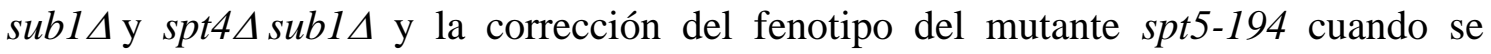
sobre-expresa $S U B 1$.

La transición iniciación-elongación se vuelve irreversible tras la asociación del complejo Spt4/5, ya que mantiene la burbuja de transcripción y evita la liberación del RNA del centro activo de la polimerasa (Klein et al., 2011; Martinez-Rucobo et al., 2011). Durante la iniciación, la asociación de Spt5 a la RNAPII está impedida por la presencia del factor TFIIE, asociado a la misma región del dominio clamp (Chen et al., 2007). Curiosamente, Sub1 interacciona genéticamente con TFIIE y se ha propuesto que colaboraría con TFIIE y TFIIH en el mantenimiento del complejo abierto durante la iniciación (Sikorski et al., 2011). Una posibilidad es que durante esta etapa, Sub1 colabore con TFIIE y otros componentes del PIC (por ejemplo, TFIIB) y evite la entrada al complejo de Bur1 y Spt4/5 y, posteriormente, durante la transición iniciaciónelongación, contribuya a la estabilidad de la asociación Spt5-Rpb1 y a la tasa de elongación de la RNAPII. El cambio de la función de Sub1 de iniciación a elongación podría regularse en función de su estatus de fosforilación. Además, hay que tener en 
cuenta que Sub1 regula la fosforilación de la RNAPII y de Spt5, fosforilaciones que son necesarias para promover la elongación de la transcripción (Buratowski, 2009; Liu et al., 2009; Zhou et al., 2009). Aunque los resultados de los ensayos de actividad in vitro para Bur1 en el mutante sub1 $\Delta$ sugieren que Sub1 desempeña un efecto negativo sobre la actividad de esta quinasa, es posible que éste se limite a un momento específico del ciclo de transcripción en el que la actividad de Bur1 debe estar inhibida (y por lo tanto, la fosforilación de Spt5) como, por ejemplo, durante la pre-iniciación, consistente con el hecho de que Bur1 no se encuentra asociado al PIC (Liu et al., 2004), ni tampoco Spt5 (Mayer et al., 2010). De este modo, es posible que eventos de fosforilación específicos de la RNAPII (Buratowski, 2009), de Spt5 (Liu et al., 2009; Zhou et al., 2009) y de Sub1 (Ge et al., 1994; Henry et al., 1996; Jonker et al., 2006b) ocurran de manera simultánea $\mathrm{y}$, en último término, regulen la transición iniciación-elongación y, en consecuencia, la elongación de la transcripción.

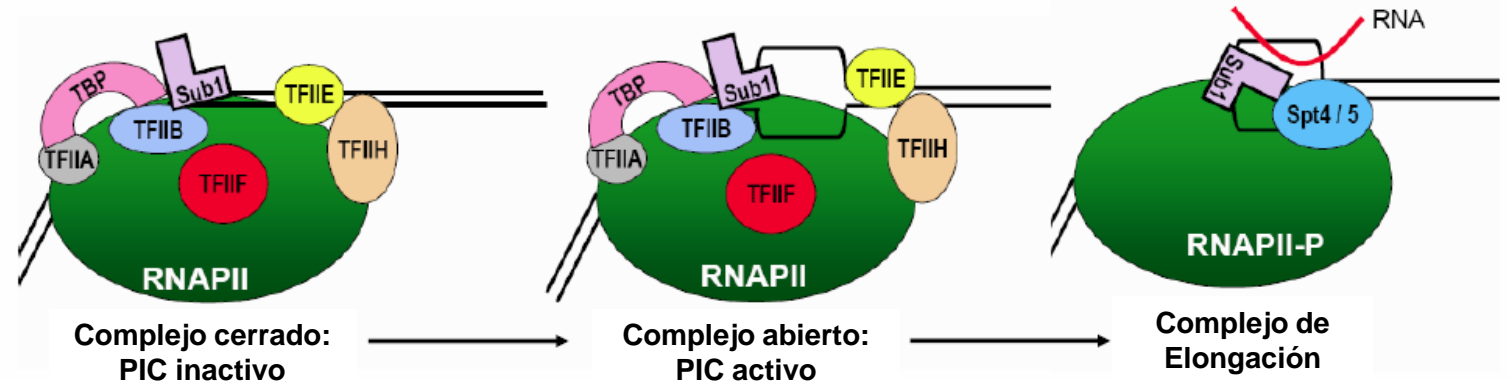

Figura 60. Sub1 es un componente integral del PIC y, además, interacciona con Spt4/5 en el complejo de elongación. Modelo que muestra cómo Sub1, durante la pre-iniciación, podría cooperar con TFIIB y TFIIE en la formación del complejo abierto y la activación subsiguiente del PIC; y como durante la transición iniciación-elongación, probablemente tras ser fosforilado y sufrir un cambio conformacional, saldría del PIC, momento en el que Spt4/5 se reclutaría a la burbuja de transcripción, tras desplazar a TFIIE. En este punto Sub1 se asociaría a Spt4/5, estabilizando su interacción con la RNAPII y promoviendo la estabilidad del complejo de elongación. Imagen modificada de (Sikorski et al., 2011).

\subsection{4. ¿Cómo un componente del PIC puede ser a la vez un factor de elongación?}

En este trabajo hemos demostrado que Sub1 influye en la elongación de la transcripción. Sin embargo, los niveles más altos de Sub1 se encuentran asociados a los promotores génicos y a las regiones 5' adyacentes, y van disminuyendo hacia 3'. Es posible que el intercambio de factores de iniciación, por factores de elongación, suponga un cambio conformacional en el complejo de transcripción, que dificulte la detección por ChIP de Sub1 en las secuencias codificantes y 3' y favorezca la detección de otros factores. Sikorski et al. (2011) recientemente han propuesto que Sub1 compite con la proteína de unión a DNA Rfa1 por la asociación a la cromatina. Según estos 
autores, durante la transcripción, Sub1 se asocia esencialmente a las regiones promotoras, a las que Rfa1 sólo se puede asociar en ausencia de Sub1, mientras que, por el contrario, Rfa1 se asocia principalmente a las secuencias codificantes (Sikorski et al., 2011). Sin embargo, es posible que Sub1, tras su fosforilación, vea reducida su capacidad de unión al DNA, como se ha demostrado in vitro (Ge et al., 1994; Henry et al., 1996; Jonker et al., 2006b) y que, en este estado, se una de forma más débil a las secuencias codificantes, permitiendo la asociación de Rfa1. De hecho, la interacción genética descrita para $S U B 1$ y RFAl, en la que la deleción de $S U B 1$ incrementa el fenotipo de un mutante rfal (Sikorski et al., 2011), sugiere una función cooperativa entre ambas proteínas, por lo que las dos podrían estar uniéndose a las regiones codificantes de un modo no-competitivo y consistente con el hecho de que ambas están ligadas genética y funcionalmente a Bur1 (Figuras 20-23; (Clausing et al., 2010). Argumentos similares pueden explicar las diferencias en el patrón de asociación a la cromatina de Sub1 y Spt5.

Por otro lado, existe la posibilidad de que en el caso de los genes de expresión constitutiva como PMA1, la mayor parte de moléculas de Sub1 se encuentren asociadas a los promotores y que solamente una pequeña fracción se localice en las regiones codificantes, mientras que la participación de Sub1 en la elongación podría ser más relevante en aquellos genes cuya transcripción dependa directamente de este factor, como es el caso del gen IMD2. En este sentido, el complejo Ccr4-Not1 se ha descrito recientemente como un auténtico factor de elongación, que solamente se asocia in vivo a las secuencias codificantes de algunos genes inducibles y dependiente de la transcripción. Además, se ha demostrado que este complejo interacciona con la RNAPII y con los complejos de elongación in vitro, afecta a la tasa de elongación y estimula que la polimerasa reanude la transcripción tras las pausas (Kruk et al., 2011).

Tal y como sugieren nuestros datos, y los de otros laboratorios, sobre la función de Sub1, éste podría favorecer la formación del PIC, a través de su interacción con TFIIB y TFIIE (Henry et al., 1996; Knaus et al., 1996; Sikorski et al., 2011), y la elongación, promoviendo la asociación de Spt5 con la RNAPII durante la transición iniciación-elongación. El complejo Spt4/5 se asocia a la RNAPII a través de la interacción que establece Spt5 con el dominio clamp de Rpb1 (Klein et al., 2011; Martinez-Rucobo et al., 2011). Este dominio es un módulo multifuncional que, por un lado, controla el acceso del dsDNA al centro activo durante la iniciación de la 
transcripción y, por otro, participa en la separación del híbrido RNA-DNA en el extremo de la burbuja de transcripción durante la elongación. Para ello, el clamp adopta dos conformaciones estructurales distintas: la conformación abierta en la que el dsDNA accede al centro activo y la conformación cerrada en la que el ssDNA se posiciona en el centro activo y se favorece la procesividad de la polimerasa (Cramer, 2002a, 2004; Cramer et al., 2000, 2001; Gnatt et al., 2001). Curiosamente, Rpb7 se asocia a Rpb1 a través de la interacción con el dominio clamp, restringiendo su conformación al estado cerrado (Armache et al., 2005; Bushnell and Kornberg, 2003; Choder, 2004). Por su parte, Sub1, se recluta a la cromatina de manera dependiente de Rpb4/7, se asocia a ambos complejos, Spt4/5 y Rpb4/7, y se encuentra relacionado, al menos genéticamente, con el dominio clamp.

Sorprendentemente los complejos Spt4/5 y Rpb4/7 comparten numerosas analogías funcionales, aunque hasta la fecha no se haya demostrado una relación directa entre ambos. Por ejemplo, en arqueas se ha demostrado que las subunidades homólogas de Rpb4/7, E/F, favorecen la procesividad de la polimerasa durante la elongación, garantizando la estabilidad del híbrido DNA-RNA en el centro activo, con un mecanismo similar al descrito para Spt4/5. Este mecanismo implica, entre otros factores, la interacción con el dominio clamp y con la cadena no molde del DNA (revisado por (Grohmann and Werner, 2010). Por otro lado, trabajos independientes han demostrado que ambos complejos promueven el reclutamiento co-transcripcional de proteínas de unión a RNA implicadas en la localización, traducción y/o degradación de mRNAs en el citoplasma, participando en la coordinación de eventos que regulan la expresión génica (Harel-Sharvit et al., 2010; Shen et al., 2010). Asimismo, han sido relacionados con la supresión de una ruta de reparación de daño a DNA acoplada a transcripción (Ding et al., 2010; Li and Smerdon, 2002; Tatum et al., 2011) y recientemente se ha demostrado por ensayo de doble híbrido, una interacción entre Spt5 y Rpa43, una subunidad de la RNAPI, homóloga de Rpb7 (Beckouet et al., 2011).

Teniendo en cuenta todos estos datos, es posible que el mecanismo de regulación por el que Sub1 forma parte del PIC, modula la fosforilación del CTD y afecta a la tasa de elongación, implique la asociación funcional de Sub1 con Rpb4/7 y el dominio clamp. Además, dependiendo de la etapa de la transcripción, podría ejercer su función a través de factores específicos, factores que se asocian directamente al dominio clamp, como TFIIE y Spt5 (Figura 61). 


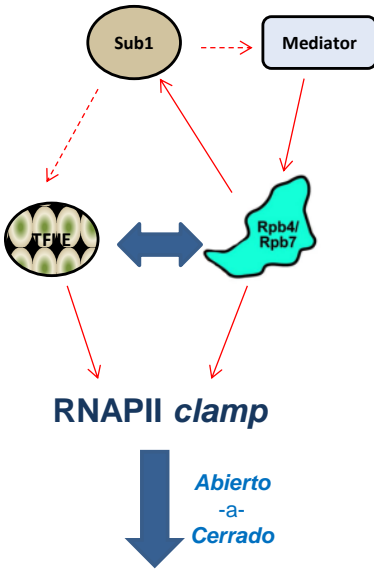

Formación burbuja de transcripción dsDNA $\rightarrow$ ssDNA

INICIACIÓN

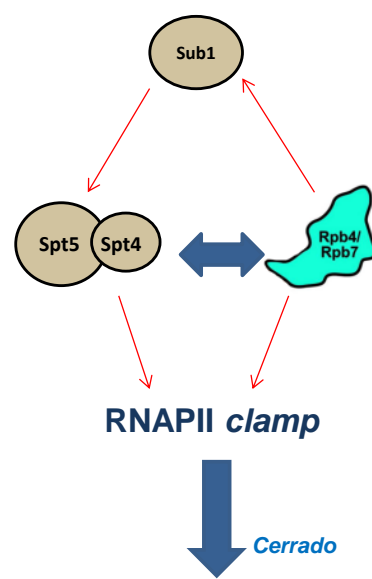

Estimulación de la elongación Aumento Procesividad

ELONGACIÓN

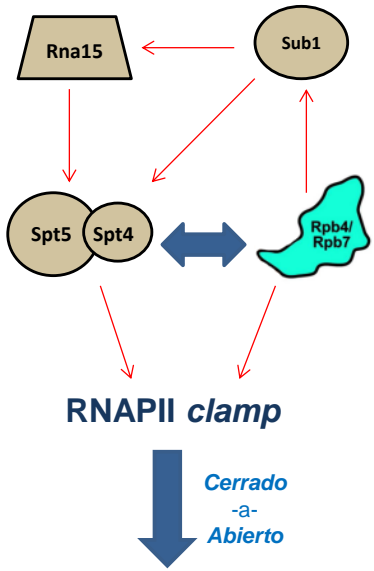

Estimulación de la terminación

Figura 61. Modelo de la interrelación durante todo el ciclo de transcripción de Sub1 con Rpb4/7, el dominio clamp y varios factores de transcripción y procesamiento. Durante la iniciación, Rpb4/7 y el factor TFIIE interaccionan con el dominio clamp de la RNAPII y participan en la formación del complejo abierto, garantizando la estabilidad de la burbuja de transcripción. Rpb4/7, por su parte, recluta a Sub1 a la burbuja de transcripción donde podría cooperar con TFIIE (Sikorski et al., 2011). Asimismo, Sub1 podría favorecer el reclutamiento del Mediador (Srb10) por Rpb4/7 (Figura 17 y (Cai et al., 2010). Tras la activación del PIC, el complejo de transcripción sufre un cambio conformacional que permite la salida de TFIIE y, en su lugar, la incorporación de Spt $4 / 5$ al clamp (Grohmann et al., 2011; Larochelle et al., 2012), garantizando su conformación cerrada y promoviendo la procesividad de la polimerasa (Hirtreiter et al., 2010; Klein et al., 2011; Martinez-Rucobo et al., 2011). En este punto, Sub1 interaccionaría con Spt $4 / 5$ favoreciendo su asociación estable con Rpb1 e influyendo en la tasa de elongación de la polimerasa (Figura 50). Por último, Sub1 y Spt4/5 participarían en el reclutamiento de factores de terminación como Rna15 (Calvo and Manley, 2001, 2005; Mayer et al., 2012b), probablemente desde el promotor o regiones de la secuencia codificante cercanas. En esta etapa, se desconoce el papel de Rpb4/7, aunque en arqueas estimula la terminación dependiente de secuencias ricas en U (revisado por (Grohmann and Werner, 2011). Las flechas con línea contínua indican interacción física/co-purificación mientras que las líneas discontínuas indican interacción genética.

Una posibilidad es que Sub1 tenga efectos sobre la estabilidad de interacciones que se establecen a nivel del dominio clamp durante la iniciación y la elongación temprana, por ejemplo, cooperando con los GTFs (por ejemplo, TFIIE) en la preiniciación-iniciación y con Spt4/5 en la elongación. Esta hipótesis viene apoyada por el hecho de que la deleción de $S U B 1$ es letal en combinación con la mutación del clamp rpb1-L1397S (Figura 28). En este sentido, conviene recordar que durante la iniciación, el factor TFIIE contribuye a la formación del complejo abierto y al mantenimiento de la estabilidad de la burbuja de transcripción, gracias a su interacción con el clamp, cuya movilidad contribuye a modular (Chen et al., 2007; Kim et al., 2000; Naji et al., 2007; Werner and Weinzierl, 2005). En arqueas, se ha propuesto que el factor homólogo a TFIIE, TFE podría reclutarse al complejo de transcripción vía las subunidades E/F (Rpb4/7) de la polimerasa o bien podría modificar la conformación de la polimerasa a través de E/F (revisado por (Grohmann and Werner, 2011). Además, en estos 
organismos se ha descrito que TFE compite con Spt4/5 por el acceso al clamp durante la iniciación (Grohmann et al., 2011) y que una vez desplazado, Spt4/5, junto con E/F, contribuirían a la procesividad de la polimerasa (Grohmann and Werner, 2011). Por su parte, Sikorski et al (2011) plantearon la hipótesis de que Sub1, como componente integral del PIC, podría cooperar con TFIIE en el mantenimiento de la estabilidad de la burbuja durante la preiniciación (Sikorski et al., 2011) y, en base a nuestros resultados, podría impedir la entrada de Bur1 y su actividad y, en consecuencia, la fosforilación de Spt5. Asimismo, tras la iniciación y la salida del TFIIE del PIC, Sub1 podría participar en el intercambio de este factor por el complejo Spt4/5, contribuyendo de este modo a la transición iniciación-elongación.

\subsubsection{Sub1 funciona durante todo el ciclo de transcripción. Un modelo de trabajo}

A continuación, proponemos un modelo que explica la función de Sub1 a lo largo de todo el ciclo de transcripción (Figura 62).

Sub1 se reclutaría a los promotores a través de su dominio de unión a DNA y de su asociación con el dímero Rpb4/7, anclado al núcleo de la polimerasa mediante interacción con el clamp (Armache et al., 2003; Bushnell and Kornberg, 2003). Durante la pre-iniciación, Sub1 ayudaría a mantener el PIC en conformación estable pero inactiva, contribuyendo a la estabilización de la burbuja de transcripción junto con el factor TFIIE (Sikorski et al., 2011), asociado también al dominio clamp de Rpb1 (Grohmann et al., 2011) y/o inhibiría el reclutamiento y la actividad quinasa de Kin28, requerida para fosforilar a la RNAPII en Ser5 y reclutar las enzimas de capping (Buratowski, 2009; Komarnitsky et al., 2000). De acuerdo con el hecho de que Rpb4/7 recluta al complejo Mediador (Cai et al., 2010), es posible que la interacción entre Sub1 y Rpb4/7 influya en dicho reclutamiento y por ende en el de Srb10. Una situación similar podría ocurrir para Fcp1 (Calvo and Manley, 2005).

Durante la iniciación, la fosforilación de Sub1 podría reducir su capacidad de unión a DNA (Ge et al., 1994; Henry et al., 1996; Jonker et al., 2006b), aliviando su efecto represor sobre Kin28, facilitando el escape del promotor (Henry et al., 1996; Knaus et al., 1996; Sikorski et al., 2011), la salida de TFIIB (Henry et al., 1996; Knaus et al., 1996) y el reclutamiento de la maquinaria de capping. Durante la transición iniciación-elongación, en el complejo de transcripción se intercambian los factores de iniciación por los de elongación (Pokholok et al., 2002), reclutándose entonces Spt4/5, que desplaza a TFIIE, e interacciona con el clamp (Grohmann et al., 2011; Klein et al., 
2011; Martinez-Rucobo et al., 2011) y con el complejo de capping (Pei and Shuman, 2002). En concordancia con esta hipótesis, Larochelle et al (2012) han demostrado que, en células humanas, la actividad de $\mathrm{Cdk} 7$ (yKin28) promueve la disociación de TFIIE y el reclutamiento del complejo DSIF (ySpt4/5) a la cromatina.

Después, Bur1 fosforila a Spt5 (Liu et al., 2009; Zhou et al., 2009) y a la RNAPII para promover la fosforilación por Ctk1 (Qiu et al., 2009), el complejo de capping se libera y se activa la elongación productiva (Buratowski, 2009). En ese contexto, Sub1 fosforilado se asociaría a Spt4/5 durante la elongación temprana y contribuiría de manera redundante a estabilizar su interacción con el clamp, tal vez estabilizando la unión de Rpb4/7 a este dominio, favoreciendo su conformación cerrada, disminuyendo los tiempos de pausa e influyendo de este modo en la tasa de elongación. En cuanto a la fosfatasa Fcp1, ésta viaja con la polimerasa, asociada a ella a través de Rpb1 y de Rpb4/7 (Cho et al., 2001; Kimura et al., 2002; Suh et al., 2005) y defosforila los residuos de Ser2 en regiones 3' génicas (Cho et al., 2001). En ausencia de SUB1 la unión de Rpb4/7 al clamp podría ser menos estable, lo que contribuiría al menor reclutamiento de Fcp1 y al menor reciclaje de la RNAPII observado en el mutante sub1 $\Delta$ (Calvo and Manley, 2005).

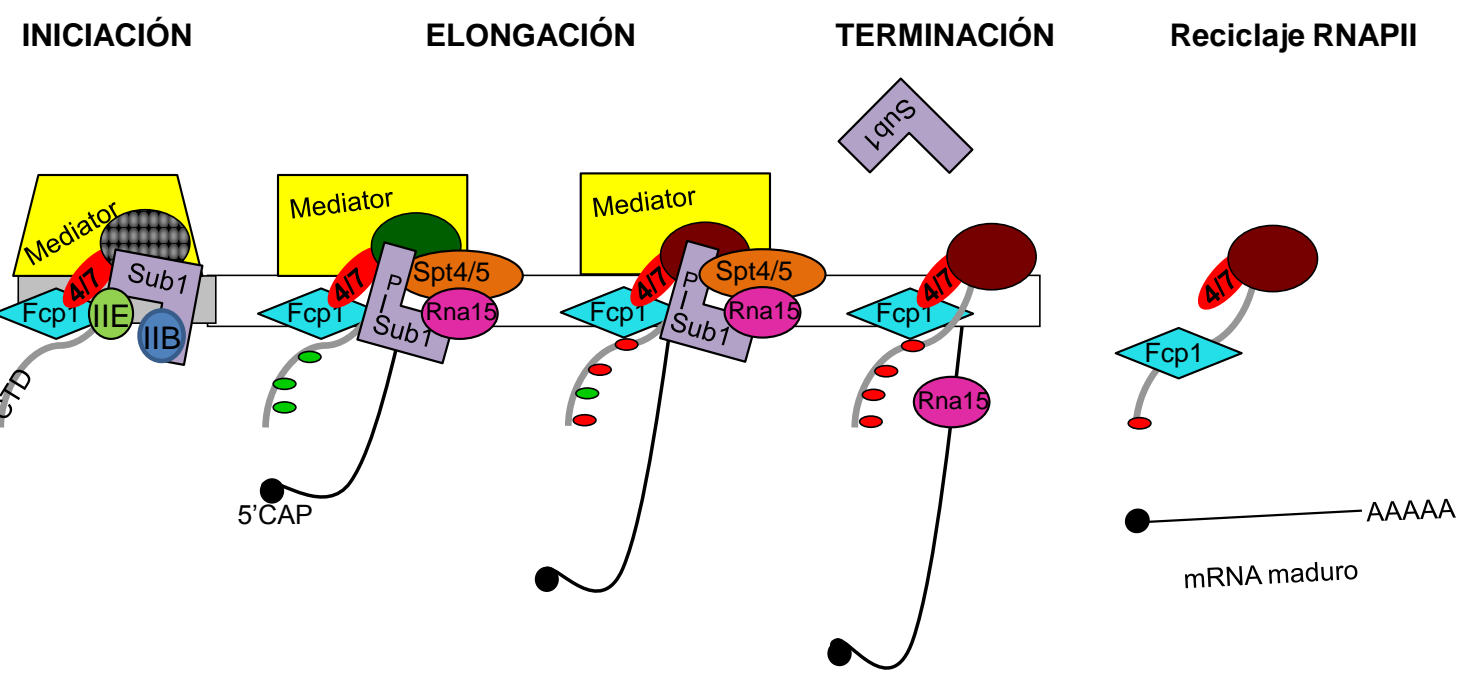

Figura 62. Regulación de la transcripción de la RNAPII por el factor Sub1. Modelo hipotético de la función de Sub1 a lo largo de un ciclo de transcripción. Durante la iniciación Rpb4/7 reclutarían al complejo de transcripción a Sub1, al complejo Mediador (Srb10) y a Fcp1. Tras la activación del PIC, se disociarían los factores TFIIB y TFIIE, a la par que se reclutaría Spt4/5. En este momento, Sub1 y Spt4/5 podrían participar en el reclutamiento cooperativo de Rna15. Durante la elongación temprana, tiene lugar la fosforilación en Ser5 (verde) y el capping, acoplado también a la función de Spt4/5 y de Sub1. Según la RNAPII avanza por la secuencia codificante, se fosforila progresivamente en Ser2 (rojo), primero por Bur1, que también fosforilará a Spt5, y después por Ctk1. Al llegar a las secuencias de terminación, Sub1 y Spt4/5 se disocian del complejo. En este punto, Rna15 participa en la formación del extremo 3' del mRNA y se produce la disociación de la RNAPII, que es defosforilada por Fcp1, para ser reciclada y poder reiniciar un nuevo ciclo de transcripción. Durante la transición de iniciación a elongación, es posible que Sub1 se fosforile, cambiando su conformación, y que se defosforile cuando alcance las regiones 3', durante la transición elongación-terminación. 
Por último, Sub1 y Spt4/5 podrían participar de forma conjunta en el procesamiento del extremo 3' de los mRNAs. Así, tanto Sub1 como Spt4/5 interaccionan con el factor de terminación/poliadenilación Rna15 (componente del complejo CFI), y son necesarios para su reclutamiento (Calvo and Manley, 2001, 2005; Lindstrom et al., 2003; Mayer et al., 2012b). En ausencia de Sub1, además de producirse inestabilidad en la interacción Spt5-RNAPII, también podría producirse una alteración del reclutamiento y de la función del complejo CFI. De hecho, Calvo y Manley (2001) propusieron un modelo en el que Sub1 podría ejercer un papel antiterminador, impidiendo la terminación prematura de los transcritos al inhibir la función de Rna15. Así, mostraton que la deleción de $S U B 1$ corrige los defectos en terminación del mutante rna15-1. Es problable entonces que la deleción de $S U B 1$, que da lugar, por un lado, a un incremento en la fosforilación en Ser2 del CTD, marca necesaria para el reclutamiento de Rna15 y, por otro, a un descenso de la tasa de elongación, sea un contexto favorable para suprimir los defectos en terminación de una proteína Rna15 mutante (Calvo and Manley, 2001), como lo es para corregir los defectos en splicing del mutante spt5-194 (Figura 55), al disminuir la tasa de síntesis de la polimerasa.

Un posible modelo para la función de Sub1 durante la terminación podría implicar un nuevo cambio de conformación de Sub1 y de su localización en el complejo de transcripción. Así, por ejemplo, su defosforilación, coincidiendo con la defosforilación de la polimerasa, podría aliviar la inhibición sobre la función terminadora de Rna15. (Calvo and Manley, 2001). Al mismo tiempo, esta defosforilación podría promover la salida de Sub1 del complejo, desestabilizando la interacción Spt4/5-RNAPII y provocando la terminación (Mayer et al., 2012b). De este modo, Sub1, no solamente contribuiría a la transición iniciación-elongación, sino que también lo haría en la transición elongación-terminación, participando en la regulación de la transcripción de la RNAPII desde la formación del PIC hasta la terminación. 


\section{Conclusiones}


1.-El factor de transcripción Sub1 de S. cerevisiae regula globalmente la fosforilación de la RNAPII durante todo el ciclo de transcripción:

1.1.-Sub1 favore la función de la quinasa de pre-iniciación Srb10, e inhibe la función de las quinasas de iniciación, Kin28, y elongación, Bur1 y Ctk1.

1.2.-Sub1 modula la fosforilación del CTD en Ser5, modulando la función de la quinasa Kin28, sin afectar a priori, a su defosforilación.

1.3.-Sub1 modula los niveles de Ser2P, ya que regula tanto su fosforilación por Ctk1, como su defosforilación por Fcp1.

1.4.-Hemos aportado evidencias que sugieren que Sub1 podría modular la fosforilación de la RNAPII a través de su interacción con Rpb4/7.

2.-Sub1 regula la elongación de la transcripción:

2.1.-Sub1 se asocia a lo largo de toda la secuencia génica, de manera dependiente de transcripción, e influye en el reclutamiento de la RNAPII.

2.3.-Sub1 se asocia con el complejo Spt4/5 e influye en su interacción con la RNAPII y, en consecuencia, en la tasa de elongación de la RNAPII. 
Para la realización de esta tesis doctoral se ha utilizado como organismo de estudio la levadura Saccharomyces cerevisiae. La bacteria Escherichia coli se ha utilizado como herramienta de biología molecular en experimentos de clonación, amplificación de plásmidos y producción de proteínas recombinantes.

\subsection{Cepas}

\subsubsection{Cepas de Saccharomyces cerevisiae}

La mayoría de las estirpes utilizadas, exceptuando algunas cedidas por otros laboratorios, se construyeron en los fondos genéticos W303 (Mat a/ $\alpha$ ade2-1 his 311,15 leu2-3,112 trp1-1 ura3-1, (Thomas and Rothstein, 1989) y BY4741/BY4742

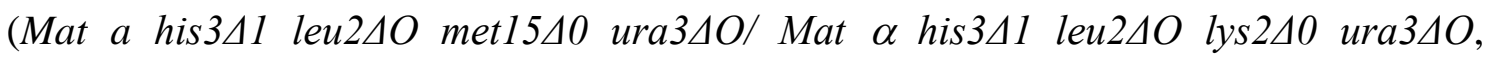
(Brachmann et al., 1998). Las cepas utilizadas se especifican en la Tabla 3.

\subsubsection{Cepas de Escherichia coli}

Todos los experimentos con la bacteria $E$. coli se realizaron con la cepa DH5 $\alpha$ (F- endAl gyr96 hsdR17 DlacU169 (f80lacZ4M15) recAl relAl supE44-thi-1 (Hanahan, 1983), a excepción de los ensayos de expresión de la proteína His-Spt5 recombinante, que se utilizó la cepa BL21 (DE3) [F- omp T hsd $\mathrm{S}\left(\mathrm{r}_{\mathrm{B}}^{-}, \mathrm{m}_{\mathrm{B}}^{-}\right.$) gal dcm, גDE3 (lacI lacUV5-T7 gene 1 ind1 sam7 nin5) (Studier and Moffatt, 1986)].

\subsection{Medios de Cultivo}

\subsubsection{Medios de cultivo para levaduras}

-Medio rico YEPD: $1 \%$ de extracto de levadura, $2 \%$ de bacto-peptona y $2 \%$ de glucosa.

-Medio rico YEPD+KAN: $1 \%$ de extracto de levadura, $2 \%$ de bacto-peptona y $2 \%$ de glucosa, suplementado con $100 \mu \mathrm{g} / \mathrm{ml}$ de disulfato de G418.

-Medio rico YEPGal: $1 \%$ de extracto de levadura, 2\% de bacto-peptona y 2\% de galactosa.

-Medio rico YEPRaf: $1 \%$ de extracto de levadura, 2\% de bacto-peptona y $2 \%$ de rafinosa.

-Medio completo SC: 0,67\% de bases nitrogenadas (YNB) sin aminoácidos, 2\% de glucosa y 0,2\% de dropout mix selectivo. El dropout mix es una combinación de 
suplementos, como aminoácidos y algunas bases nitrogenadas, entre otros componentes, excepto el/los suplemento/s de selección de la/s auxotrofía/s correspondiente/s.

\begin{tabular}{|ll|ll|}
\hline & \multicolumn{2}{c|}{ Dropout mix } & \\
\hline Adenina & $0,5 \mathrm{~g}$ & Leucina & $10,0 \mathrm{~g}$ \\
Alanina & $2,0 \mathrm{~g}$ & Lisina & $2,0 \mathrm{~g}$ \\
Arginina & $2,0 \mathrm{~g}$ & Metionina & $2,0 \mathrm{~g}$ \\
Asparragina & $2,0 \mathrm{~g}$ & Ácido para-aminobenzoico & $2,0 \mathrm{~g}$ \\
Ácido aspártico & $2,0 \mathrm{~g}$ & Fenilalanina & $2,0 \mathrm{~g}$ \\
Cisteína & $2,0 \mathrm{~g}$ & Prolina & $2,0 \mathrm{~g}$ \\
Glutamina & $2,0 \mathrm{~g}$ & Serina & $2,0 \mathrm{~g}$ \\
Ácido glutámico & $2,0 \mathrm{~g}$ & Treonina & $2,0 \mathrm{~g}$ \\
Glicina & $2,0 \mathrm{~g}$ & Triptófano & $2,0 \mathrm{~g}$ \\
Histidina & $2,0 \mathrm{~g}$ & Tirosina & $2,0 \mathrm{~g}$ \\
Inositol & $2,0 \mathrm{~g}$ & Uracilo & $2,0 \mathrm{~g}$ \\
Isoleucina & $2,0 \mathrm{~g}$ & Valina & $2,0 \mathrm{~g}$ \\
\hline
\end{tabular}

-Medio pre-esporulación Pre-SPO: 0,5\% de extracto de levadura, 0,6\% de bases nitrogenadas (YNB) con aminoácidos, 0,5\% de bacto-peptona, 1\% de acetato potásico, y $1,02 \%$ de biftalato potásico, $\mathrm{pH}$ ajustado a 5.5 con $\mathrm{NaOH}$ saturado.

-Medio de esporulación SPO: $1 \%$ de acetato potásico, 0,1\% de extracto de levadura y $0,05 \%$ de glucosa.

Cuando fue necesario, los medios se suplementaron con los aminoácidos apropiados, en función de las auxotrofías de las cepas utilizadas y en las siguientes proporciones: $3 \mathrm{ml} / 1$ ó 0,1 ml/placa de histidina- $\mathrm{HCl} 100 \mathrm{mM}, 10 \mathrm{ml} / \mathrm{l}$ ó 0,2 ml/placa de isoleucina-valina $50 \mathrm{mM}, 20 \mathrm{ml} / \mathrm{l}$ ó $0,2 \mathrm{ml} /$ placa de leucina $100 \mathrm{mM}$, y $10 \mathrm{ml} / \mathrm{l}$ ó 0,1 $\mathrm{ml} /$ placa de triptófano $40 \mathrm{mM}$. En el caso de las cepas auxótrofas para uracilo y adenina, los medios se suplementaron con las siguientes concentraciones: $10 \mathrm{ml} / \mathrm{l}$ ó 0,25 $\mathrm{ml} /$ placa de uracilo $20 \mathrm{mM}$, y $15 \mathrm{ml} / 1$ ó $0,2 \mathrm{ml} /$ placa de adenina $10 \mathrm{mM}$.

La preparación de los medios se llevó a cabo utilizando agua destilada. En el caso de medios de cultivo sólidos, además, se añadió agar en una concentración final del 2\%.

\subsubsection{Medios de cultivo para bacterias}

-Medio rico LB: $0,5 \%$ de extracto de levadura, $1 \%$ de bacto-triptona y $1 \%$ de $\mathrm{NaCl}$. 
-Medio rico LB+Amp: $0,5 \%$ de extracto de levadura, $1 \%$ de bacto-triptona y $1 \%$ de $\mathrm{NaCl}$, suplementado con ampicilina sódica a una concentración final de $100 \mu \mathrm{g} / \mathrm{ml}$, añadida tras el autoclavado.

La preparación de los medios se llevó a cabo utilizando agua destilada. En el caso de medios de cultivo sólidos, se añadió agar a una concentración final del $2 \%$.

\subsection{Condiciones de crecimiento}

Los cultivos de levadura en medio líquido se incubaron a $28^{\circ} \mathrm{C}$, excepto en los casos especificados, y con una agitación de $250 \mathrm{rpm}$. El crecimiento se controló midiendo la absorbancia en el espectrofotómetro a $600 \mathrm{~nm}$, trabajándose siempre con cultivos en fase exponencial, salvo que se especifique lo contrario. En medio sólido, las temperaturas de incubación fueron de $25^{\circ} \mathrm{C}, 28^{\circ} \mathrm{C}, 30^{\circ} \mathrm{C}, 32^{\circ} \mathrm{C}, 34^{\circ} \mathrm{C}$ y $37^{\circ} \mathrm{C}$, según se indique.

Las bacterias se incubaron a $37^{\circ} \mathrm{C}$, salvo que se indique lo contrario.

\subsection{Técnicas Genéticas}

\subsubsection{Transformación de Saccharomyces cerevisiae}

Para la transformación de levaduras se siguió el protocolo descrito por (Gietz et al., 1995), modificado según (Amberg, 2005), siguiendo la técnica del acetato de litio. Las células competentes se obtuvieron a partir de cultivos incubados en YEPD hasta una $\mathrm{DO}_{600 \mathrm{~nm}}$ de $1,0 \quad\left(\sim 2 \times 10^{7}\right.$ células $\left./ \mathrm{ml}\right)$. Se utilizaron $5 \mathrm{ml}$ de cultivo por transformación y las concentraciones de DNA variaron desde $100 \mathrm{ng}$ hasta 1-2 $\mu \mathrm{g}$, según las necesidades de los experimentos. Para la selección de los transformantes las células se plaquearon en medios SC selectivos. En el caso de la selección para la resistencia a kanamicina, las células se incubaron 2 horas en YEPD a $28^{\circ} \mathrm{C}$ en agitación, previamente a su plaqueo en YEPD con G418 a una concentración final de $100 \mu \mathrm{g} / \mathrm{ml}$.

\subsubsection{Modificación génica en levaduras}

Las cepas originales de esta tesis se construyeron por métodos genéticos de cruzamientos o por reemplazamiento génico, en el caso de tratarse de un gen no esencial, usando la técnica descrita por (Longtine et al., 1998). El reemplazamiento génico permite la deleción de un gen o la adición de un epítopo en un solo paso. Se utilizan varios plásmidos que contienen distintos marcadores de selección (TRP1, 
his5+, $\mathrm{kan}^{r}$ ) y/o distintos epítopos (HA, MYC, Flag, GST, (Tabla 4), como molde para una reacción de PCR. En la reacción se utilizaron como cebadores oligonucleótidos que anillan a la vez en el gen diana que se quiere modificar y en el plásmido molde. El DNA amplificado se utiliza para transformar las levaduras. Los reemplazamientos se comprobaron por PCR, usando cebadores externos a la zona reemplazada y que detectan el marcador génico utilizado para tal propósito. En el caso de la adición de epítopos, se utilizó un cebador interno al marcador de selección adyacente al epítopo y otro interno al gen diana.

\subsubsection{Conjugación, esporulación y análisis de tétradas}

Se utilizaron técnicas genéticas convencionales descritas en (Amberg, 2005) para la obtención de cepas diploides, para su esporulación y para la disección de ascas. Las cepas parentales se cruzaron mezclándolas en YEPD sólido e incubando a $28^{\circ} \mathrm{C}$ durante 5-7 horas. Los diploides generados se aislaron mediante selección de marcadores o micromanipulando los zigotos. Para la esporulación, los diploides se crecieron durante 24 horas en medio de Pre-SPO a $28^{\circ} \mathrm{C}$, previo a su incubación en medio SPO durante 34 días. Las ascas se diseccionaron usando un micromanipulador (Singer Instruments), tras el tratamiento con glusulasa (dilución 1:10 PerkinElmer), durante 30 minutos a temperatura ambiente. La segregación de los diferentes genes se analizó determinando los fenotipos de las ascosporas y se verificó para cada uno de ellos independientemente, mediante réplica en los medios selectivos apropiados e incubando las placas en las condiciones que cada marcador requiriese.

\subsubsection{Transformación de Escherichia coli}

Las células competentes de E. coli fueron preparadas por el personal técnico del Instituto de Biología Funcional y Genómica, siguiendo el protocolo descrito por (Kushner, 1978). Para transformarlas, se mezclaron 25-100 $\mu \mathrm{l}$ de células competentes con 100 pg-10 ng de DNA, y se incubaron en hielo durante 20 minutos. A continuación, se sometieron a un choque térmico de 2 minutos a $37^{\circ} \mathrm{C}$. Tras ello, se añadieron $400 \mu \mathrm{l}$ de $\mathrm{LB}$ y se incubaron a $37^{\circ} \mathrm{C}$ durante 1 hora. Las células se recogieron por centrifugación y se sembraron en LB+Amp.

\subsection{Plásmidos}

En la Tabla 4 se detallan los plásmidos que se emplearon para obtener módulos de integración con los que se transformaron células de levadura, construir mutantes de 
deleción o etiquetar proteínas. Además, se recogen los plásmidos de expresión para la producción de las proteínas recombinantes usadas en los ensayos de actividad quinasa, los plásmidos utilizados para el ensayo GLAM y los empleados para las demás construcciones llevadas a cabo en el transcurso de este trabajo.

\subsection{Métodos de manipulación y Análisis de Ácidos Nucleicos}

\subsubsection{Aislamiento de DNA y RNA}

\subsubsection{Aislamiento de DNA plasmídico de E. coli}

Para la obtención de DNA plasmídico a pequeña escala se utilizó el sistema comercial Nucleospin ${ }^{\circledR}$ Ready-to-use system for fast purification of nucleic acids de Macherey-Nagel, siguiendo las instrucciones del fabricante.

\subsubsection{Aislamiento de DNA genómico de levadura}

La obtención de DNA genómico de levadura se realizó a partir de cultivos de 5ml de YEPD crecidos a $28^{\circ} \mathrm{C}$ durante toda la noche según (Amberg, 2005). Las células se recogieron por centrifugación y se lavaron con agua estéril. Al sedimento de células se añadieron $200 \mu \mathrm{l}$ de tampón de lisis (tritón X-100 2\%, SDS 1\%, NaCl 100 mM, Tris$\mathrm{HCl} 10 \mathrm{mM}$ pH8.0, EDTA $1 \mathrm{mM}$ ), $200 \mu \mathrm{l}$ de fenol:cloroformo:alcohol isoamílico (25:24:1) y $200 \mu \mathrm{l}$ de perlas de vidrio de $45 \mu \mathrm{m}$. La mezcla se agitó en el vórtex durante 4 minutos. Seguidamente, se añadieron $200 \mu \mathrm{lde}$ TE (Tris-HCl 10 mM, EDTA 1 mM a $\mathrm{pH}$ 8.0) y se centrifugó a temperatura ambiente durante 5 minutos a $13.200 \mathrm{rpm}$. Se recogió la fase acuosa en un tubo nuevo, se añadieron 2,5 volúmenes de etanol 96\% (v/v) frío y se centrifugó a $4^{\circ} \mathrm{C}$ durante 5 minutos a $13.200 \mathrm{rpm}$. Se eliminó el sobrenadante por aspiración y el precipitado se resuspendió en $400 \mu \mathrm{l}$ de TE 1X. Posteriormente, se añadieron $3 \mu \mathrm{l}$ de RNasa A [10 mg/ml] y se incubó a $37^{\circ} \mathrm{C}$ durante 15 minutos. Finalmente, se añadieron $10 \mu \mathrm{l}$ de acetato amónico $4 \mathrm{M}$ y $1 \mathrm{ml}$ de etanol 96\% (v/v) frío, se mezcló por inversión y se centrifugó a 13.200 rpm durante 5 minutos a $4^{\circ} \mathrm{C}$. El sobrenadante se eliminó y el DNA precipitado se lavó con etanol al 70\% (v/v). El DNA genómico se resuspendió en TE estéril y se guardó a $-20^{\circ} \mathrm{C}$ hasta su utilización en los ensayos correspondientes.

\subsubsection{Aislamiento de RNA total de levadura}

El ARN total de S. cerevisiae se preparó según el protocolo descrito por (Schmitt et al., 1990). Las células se recogieron por centrifugación y se lavaron con agua estéril. 
Se resuspendieron después en $200 \mu \mathrm{l}$ de tampón AE (NaAc 50 mM, EDTA 10 mM, pH 5.2), a los que se añadió $1 / 10$ del volumen de SDS 10\%. A esta mezcla se añadieron posteriormente 1,2 volúmenes de fenol ácido saturado calentado a $65^{\circ} \mathrm{C}$. Durante 5 minutos, la muestra se sometió a intervalos de 20 segundos de agitación en el vórtex, seguidos de 20 segundos de incubación a $65^{\circ} \mathrm{C}$, tras lo cual, se congeló en hielo seco y seguidamente se centrifugó a temperatura ambiente durante 10 minutos a $8.000 \mathrm{rpm}$. Con la fase acuosa recuperada a un tubo nuevo, se repitió la extracción con fenol ácido caliente. Seguidamente, se realizó una nueva extracción con fenol ácido:cloroformo:alcohol isoamílico (25:24:1). El RNA se precipitó con 1/10 del volumen de NaAc 3 M pH 5.2 y 2 volúmenes de etanol 96\% (v/v) frío. Se incubó en hielo seco durante al menos 20 minutos y se centrifugaron a $4^{\circ} \mathrm{C}$, durante 20 minutos a $13.200 \mathrm{rpm}$. El RNA se lavó con etanol 70\% (v/v) y se resuspendió en $50 \mu \mathrm{l}$ de agua. La concentración de RNA se determinó por espectrofotometría en un equipo Nanodrop, analizando la absorbancia a $260 \mathrm{~nm}$. La integridad del RNA se comprobó por electroforesis en geles de agarosa teñidos con bromuro de etidio ( $\mathrm{EtBr}$ ). El agua destilada y todas las soluciones acuosas utilizadas fueron previamente tratadas con DEPC al 0,1\% y autoclavadas.

\subsubsection{Electroforesis de ácidos nucleicos}

La separación de fragmentos de DNA se realizó mediante electroforesis en geles de agarosa. Dependiendo del tamaño de las moléculas a separar, se usaron geles de concentración de agarosa variable (0,8\%-2\% p/v) en tampón TAE (Tris-acetato $40 \mathrm{mM}$, EDTA $1 \mathrm{mM})$ y conteniendo $\operatorname{EtBr}(0,5 \mu \mathrm{g} / \mathrm{ml})$. A las muestras se les añadió tampón de carga 6X (azul de bromofenol 0,25\% (p/v), xilen cianol 0,25\% (p/v), glicerol $30 \%$ $(\mathrm{v} / \mathrm{v}))$. Las separaciones electroforéticas se realizaron a voltaje constante (50-120V) en tampón TAE. Para visualizar el DNA mediante iluminación con luz UV, se utilizó el equipo Gel Doc XR (Bio-Rad) equipado con una cámara CCD para la captura de imágenes. Los tamaños de las moléculas se estimaron por comparación con el marcador de peso molecular $1 \mathrm{~Kb}$ Plus DNA ladder (Invitrogen).

Para la electroforesis de RNA, se prepararon geles de agarosa de una concentración 1,8\%-2,0\% en tampón TAE y con $\operatorname{EtBr}(0,5 \mu \mathrm{g} / \mathrm{ml})$, en los que se cargaron $2 \mu \mathrm{g}$ del RNA extraído. Las condiciones de electroforesis fueron voltaje constante (70-110V), durante aproximadamente 40 minutos. En este caso, se prestó 
especial cuidado con el lavado de las cubetas de electroforesis, que se trataron previamente con SDS $1 \%(\mathrm{p} / \mathrm{v})$.

\subsubsection{Reacción en cadena de la polimerasa (PCR) y transcripción reversa (RT)}

\subsubsection{PCR}

Para la realización de PCRs de forma rutinaria en el laboratorio, se utilizaron dos polimerasas. La polimerasa Expand High Fidelity PCR System (Roche), para la amplificación con alta fidelidad de módulos de integración utilizados en la construcción de cepas; la polimerasa KapaTaq Ready Mix DNA polymerase (Kapa Biosystems) para la amplificación desde DNA genómico purificado, cDNA o incluso directamente desde una pequeña cantidad de biomasa de células (o colonias aisladas) de $S$. cerevisiae, para la comprobación de cepas y otros procedimientos frecuentes. Ambas enzimas se usaron según las recomendaciones del fabricante. En el caso de las PCRs usando como molde directamente la biomasa de la levadura, las colonias se calentaron en un microondas durante 2 minutos a la máxima potencia. Las amplificaciones se realizaron en un termociclador T Personal (Biometra). La longitud de los ciclos de extensión y la temperatura de anillamiento fue variable, dependiendo del tamaño del fragmento a amplificar y de la temperatura de fusión o temperatura de melting (Tm) de los oligonucleótidos, respectivamente.

\subsubsection{PCR cuantitativa ( $q$ PCR)}

Las qPCRs para el análisis del DNA purificado en los experimentos de Inmunoprecipitación de cromatina (ChIP) correspondientes al estudio de las CTDquinasas se realizaron con un termociclador de PCR a tiempo real 7300 Real time PCR System (Applied Biosystems). Las qPCRs correspondientes al estudio de la elongación transcripcional se realizaron con el equipo CFX96 Real-time System (Bio-rad).

Para la reacción de PCR se utilizaron los reactivos del paquete comercial SYBR® Premix Ex Taq ${ }^{\mathrm{TM}}$ (Perfect Real Time, (Takara), siguiendo las instrucciones del fabricante y los requerimientos específicos de cada termociclador. El fluorocromo intercalante utilizado para la cuantificación del DNA de las muestras es el SYBR® Green. En las reacciones llevadas a cabo en el sistema 7300 Real time PCR System (Applied Biosystems), se utiliza como referencia pasiva el fluorocromo ROX. La reacción tipo constó de 1 ciclo de 30 segundos a $95^{\circ} \mathrm{C}, 40$ ciclos $\left(5\right.$ segundos a $95^{\circ} \mathrm{C}$ para la desnaturalización, y 31 segundos a $60^{\circ} \mathrm{C}$ para el anillamiento y la extensión), y 
un ciclo de disociación, propia de cada equipo utilizado, para comprobar la obtención de un único producto de amplificación en la reacción.

Para poder cuantificar es necesario realizar una recta patrón, representando el ciclo umbral de amplificación exponencial $(\mathrm{Ct})$, frente a la cantidad relativa de DNA. La recta se compone de 5 diluciones seriadas de 10 en 10 a partir de una muestra de DNA total. Para las cuantificaciones de los experimentos de ChIP se utilizó el DNA total correspondiente a una muestra INPUT. El primer punto suele ser una dilución 1/10 del INPUT. A cada punto de esta recta se le otorga un valor arbitrario a partir de los cuales el equipo estimará la cantidad de DNA presente en las muestras problema. Para el análisis de datos se utilizaron los programas 7300 System SDS software versión 1.4 (Applied Biosystems) y Bio-Rad CFX Manager 2.0 (Bio-Rad).

\subsubsection{Transcripción reversa o retrotranscripción (RT)}

Para la síntesis de cDNA, se trataron $2 \mu \mathrm{g}$ de RNA total con DNasa I (1 U/ $\mu \mathrm{l}$, Invitrogen), siguiendo las recomendaciones del fabricante, y de ellos, se utilizaron 400 ng para la reacción de RT con el kit comercial PrimeScript ${ }^{\mathrm{TM}}$ RT Enzyme (Takara).

\subsubsection{Marcaje in vivo de RNA naciente por RNA polimerasa II elongante (Transcriptional run-on ó TRO)}

Los ensayos de run-on se realizaron según los protocolos descritos previamente (Calvo and Manley, 2001; Rodriguez-Gil et al., 2010).

\subsubsection{Run-on y extracción de RNA}

Las células se crecieron en $25 \mathrm{ml}$ de medio rico YEPGal a $28^{\circ} \mathrm{C}$ hasta alcanzar una D. $\mathrm{O}_{600 \mathrm{~nm}}$ de 0.3-0.4. Los cultivos se recogieron por centrifugación a $3.000 \mathrm{rpm}$ durante 5 minutos a temperatura ambiente. Para su permeabilización, el sedimento de células se resuspendió en $5 \mathrm{ml}$ de sarcosil $0,5 \%(\mathrm{p} / \mathrm{v})$ y se volvió a centrifugar a temperatura ambiente a 3.000 rpm otros 5 minutos. Después, las células se transfirieron a un tubo de 1,5 ml, usando $1 \mathrm{ml}$ de sarcosil $0,5 \%(\mathrm{p} / \mathrm{v})$ y se volvieron a centrifugar hasta retirar completamente el sobrenadante. La transcripción se realizó resuspendiendo las células en $60 \mu \mathrm{l}$ de agua destilada estéril y añadiendo $79 \mu \mathrm{l}$ de mezcla de transcripción: $60 \mu \mathrm{l}$ de tampón de transcripción 2,5X (Tris- $\mathrm{HCl} 50 \mathrm{mM}, \mathrm{pH}$ 7.7, KCl $500 \mathrm{mM}, \mathrm{MgCl}_{2} 80 \mathrm{mM}$ ); $8 \mu \mathrm{l}$ de una mezcla de rNTPs, $10 \mathrm{mM}$ cada uno; $3 \mu \mathrm{lde}$ DTT 0,1 M; y $8 \mu \mathrm{lde}{ }^{\alpha 32} \mathrm{rUTP} 3000 \mathrm{Ci} / \mathrm{mmol}$. La mezcla de reacción se incubó durante 5 
minutos a $30^{\circ} \mathrm{C}$. La reacción se paró con $800 \mu \mathrm{l}$ de agua DEPC fría y se centrifugaron las células para eliminar los nucleótidos no incorporados. Finalmente, se aisló el RNA total según el método descrito en el apartado 6.6.1.3.

\subsubsection{Hibridación, exposición y análisis}

El RNA marcado se utilizó para hibridar una membrana de nylon que contenía 8 sondas de DNA fijadas mediante slot blot y correspondientes a: 6 regiones de $300 \mathrm{pb}$ de secuencia conocida del gen $Y L R 454 w$, situada la primera de todas en el ATG y el resto separadas entre sí por una distancia de $1 \mathrm{~Kb}$; DNA bacteriano, como control negativo; y rDNA 18S, como control positivo. Estas sondas se amplificaron por PCR y se purificaron utilizando el kit comercial GFX ${ }^{\mathrm{TM}} P C R$ DNA and Gel Band Purification Kit (GE Healthcare).

Antes de la hibridación de la membrana, el RNA se fragmentó añadiendo $25 \mu \mathrm{l}$ de $\mathrm{NaOH}$ 0,2 $\mathrm{N}$ e incubándolo durante 5 minutos en hielo. Posteriormente se neutralizó con igual cantidad de $\mathrm{HCl} 0,2 \mathrm{~N}$. Tras haber pre-hibridado la membrana durante 1 hora a $65^{\circ} \mathrm{C}$ en una solución que contenía $\mathrm{Na}_{2} \mathrm{HPO}_{4}$ 0,5 M, EDTA $1 \mathrm{mM}$ y SDS 7\% (p/v), ( $\mathrm{pH}$ 7.2) se realizó la hibridación con el RNA marcado e hidrolizado en $3 \mathrm{ml}$ de la misma solución durante 24 horas a $65^{\circ} \mathrm{C}$. Después de la hibridación, se realizaron dos lavados de 20 minutos a $65^{\circ} \mathrm{C}$ con una solución que contenía SSC1X y SDS $0,1 \%(\mathrm{p} / \mathrm{v})$. Las membranas se expusieron durante 24 horas a $-80^{\circ} \mathrm{C}$, utilizando películas de autorradiografía. La señal radiactiva se capturó en pantallas radiosensibles (BAS-IP MS2040; Fujifilm), que se escanearon en un sistema Phosphorimager, Personal Molecular Imager (Bio-Rad). Las imágenes se analizaron y cuantificaron con el programa QuantityOne v4.6.6. (Bio-rad). Los valores obtenidos para cada sonda individual se sustrajeron del valor correspondiente al control negativo y se relativizaron respecto del control positivo. El valor obtenido se normalizó a su vez frente al valor correspondiente a la sonda ATG.

\subsubsection{Fijación de sondas de DNA mediante slot blot}

Una membrana de Nylon Nytran Super Charge (Schleider\&Schuell BioScience) de tamaño adecuado se colocó dentro de un dispositivo Hybri-Slot (Whatman Biometra), que contiene dos filas de doce pocillos en línea. En ocho de estos pocillos se cargaron $500 \mu \mathrm{l}$ de una solución tampón SCC $6 \mathrm{X}(\mathrm{NaCl} 3 \mathrm{M}$, citrato sódico 0,3 M, pH 7.0 ajustado con $\mathrm{NaOH}$ ), que se hizo pasar a través de la membrana mediante una 
bomba de vacío conectada al dispositivo de slot blot. Seguidamente, se repitió este mismo paso para las muestras de DNA (100 ng de DNA con SSC 6X en un volumen final de $400 \mu \mathrm{l}$, desnaturalizado en un baño a $100^{\circ} \mathrm{C}$, durante 10 minutos). Tras ello, la membrana se retiró del dispositivo y se embebió en solución de desnaturalización $(\mathrm{NaCl}$ 1,5 M, NaOH 0,5 M) a temperatura ambiente durante 10 minutos, e inmediatamente después se transfirió a una solución de neutralización $(\mathrm{NaCl} 1 \mathrm{M}$, Tris- $\mathrm{HCl}$ 0,5 M, pH 7.0) y se incubó otros 5 minutos. La membrana se dejó secar sobre papel Whatman $3 M$ y se irradió con $1200 \mathrm{~J} / \mathrm{m}^{2}$ de luz UV en una cámara Stratalinker (Stratagene) para la inmovilización del DNA.

\subsection{Oligonucleótidos}

En la Tabla 5 se detallan los oligonucleótidos utilizados para llevar a cabo las PCR cuantitativas de los experimentos de ChIP y RT-PCR, así como los utilizados para la síntesis de las sondas de los TRO.

\subsection{Métodos de Manipulación y Análisis de Proteínas}

\subsubsection{Obtención de extractos proteicos y cuantificación de proteínas}

En todos los casos se trabajaron con extractos proteicos en condiciones nativas. Se prepararon, salvo en los casos especificados, en tampón de lisis que contiene HEPESKOH 20 mM pH 7.6, acetato potásico 200 mM, glicerol 10\% (v/v) y EDTA 1 mM. La lisis celular se llevó a cabo en tampón de lisis con inhibidores de proteasas y fosfatasas (cóctel de inhibidores de proteasas (Sigma) dilución 1/10, PMSF 10 mM, NaF 10 mM, ortovanadato sódico $20 \mathrm{mM}$ ), usando perlas de vidrio de $45 \mu \mathrm{m}$ y un sistema Fast Prep. En el caso de las purificaciones TAP y de los ensayos de co-inmunoprecipitación, la rotura celular se realizó también por lisis mecánica en nitrógeno líquido usando un sistema Freezer/Mill 6770 (Spex Sample Prep). La cuantificación de la concentración de proteínas en los extractos se estimó a partir de la medida de absorbancia a $280 \mathrm{~nm}$ realizada en equipo de espectrofotometría Nanodrop 1000 (Thermo scientific). 


\subsubsection{Inmunoprecipitaciones y co-inmunoprecipitaciones de proteínas}

Para los ensayos de inmunoprecipitación y co-inmunoprecipitación de proteínas, los extractos totales de proteínas, en primer lugar, se incubaron durante 1 hora a $4^{\circ} \mathrm{C}$ con $20 \mu \mathrm{l}$ de proteína A-sefarosa (Amersham) equilibrada en tampón de lisis para su clarificación. Esta incubación se realizó para evitar en la medida de lo posible las uniones inespecíficas. Posteriormente, se llevó a cabo una centrifugación para recuperar los sobrenadantes a un tubo nuevo. La inmunoprecipitación se realizó por incubación de $50 \mu \mathrm{g}-5 \mathrm{mg}$ de extractos proteicos clarificados (en función de los niveles de expresión celulares de la proteína y de la calidad del anticuerpo) con el anticuerpo específico (concentración variable; normalmente $1 \mu \mathrm{g}$ de anticuerpo por $1 \mathrm{mg}$ de proteínas) y $20 \mu \mathrm{l}$ de proteína A-sefarosa equilibrada en tampón de lisis. La incubación se realizó a $4^{\circ} \mathrm{C}$ en un tiempo variable de 2-3 horas a toda la noche. Posteriormente se llevaron a cabo lavados sucesivos de las inmunoprecipitaciones con tampón de lisis sin inhibidores y se analizaron mediante Western Blot.

\subsubsection{Análisis por Western Blot}

En todos los casos, el análisis de proteínas por Western Blot se realizó en condiciones desnaturalizantes, utilizando geles de poliacrilamida en presencia de SDS (SDS-PAGE) (Laemmli, 1970). Las muestras se desnaturalizaron mediante dilución en tampón de carga Laemmli e incubándolas durante 5 minutos a $100^{\circ} \mathrm{C}$. La electroforesis se realizó a voltaje constante (70-120V), usando un tampón de carrera que contiene Tris-base $25 \mathrm{mM}$, glicina $250 \mathrm{mM}$ y SDS $0,1 \%(\mathrm{p} / \mathrm{v})$. Las proteínas se transfirieron a membranas de PVDF (Millipore) por electrotransferencia húmeda a 200mA, durante 2 horas en frío. El tampón de transferencia contiene Tris-base $50 \mathrm{mM}$, glicina $380 \mathrm{mM}$ y metanol 10\% (v/v). La membrana se bloqueó con leche en polvo 5\% (p/v) en tampón PBS ( $\mathrm{NaCl} 137 \mathrm{mM}, \mathrm{Na}_{2} \mathrm{HPO}_{4} 10 \mathrm{mM}, \mathrm{KH}_{2} \mathrm{PO}_{4} 10 \mathrm{mM}, \mathrm{KCl} 2,7 \mathrm{mM}, \mathrm{pH}$ 7.4), por incubación a temperatura ambiente durante 30 minutos-1 hora. El anticuerpo primario se diluyó en una solución con leche en polvo $1 \%$ (p/v) y Tween-20 0,05\% (v/v) en PBS. El tiempo de incubación con el anticuerpo primario varió en función de las características particulares de cada anticuerpo (desde 1 hora a temperatura ambiente a toda la noche a $4^{\circ} \mathrm{C}$ ). La membrana se lavó tres veces con PBS1X durante 5 minutos. El anticuerpo secundario se diluyó en la misma solución utilizada para diluir el primario. La incubación se realizó a temperatura ambiente durante 30 minutos, seguida de 3 lavados de 5 minutos con PBS1X. Para la detección quimioluminiscente se utilizó el 
sistema Pierce ${ }^{\circledR}$ ECL Western Blotting Substrate (Thermo scientific) siguiendo las instrucciones del fabricante. Los anticuerpos se detallan en la Tabla 6.

\subsubsection{Purificación por afinidad en tándem o Purificación TAP}

El protocolo de TAP (Tandem Affinity Purification) es una purificación en serie mediante cromatografía de afinidad de una proteína etiquetada con el epítopo TAP. Esta técnica permite la identificación de proteínas que se unen físicamente a la proteína marcada o al complejo del que forma parte la proteína marcada. En esta tesis hemos llevado a cabo la purificación de Sub1-TAP según el protocolo descrito por (Rigaut et al., 1999) y modificado según (Rodriguez-Navarro et al., 2004).

Las células se crecieron en 21 de medio rico YEPD a $28^{\circ} \mathrm{C}$ hasta alcanzar una D. O $_{600 \mathrm{~nm}}$ de 2,4-2,6, tras lo cual se recogieron por centrifugación y se lavaron con agua destilada fría. Los extractos proteicos se prepararon en un tampón de lisis que contenía $\mathrm{NaCl}$ 0,1 M, Tris-HCl 50 mM pH 7.5, $\mathrm{MgCl}_{2}$ 1,5 mM, y NP40 0,15\% (v/v), cóctel de inhibidores de proteasas (Sigma) dilución 1/10, PMSF 10 mM, NaF 10 mM, y DTT 1 mM, utilizando el sistema Freezer/Mill 6770 (Spex Sample Prep). Tras eliminar los restos celulares por centrifugación, los extractos se incubaron durante 1 hora a $4^{\circ} \mathrm{C}$ con $400 \mu \mathrm{l}$ de IgG sepharose 6 Fast Flow (GE-Healthcare) equilibrada en tampón de lisis. En este paso, la IgG se une a la Proteína A presente en el epítopo TAP. Por centrifugación se eliminaron los extractos sobrantes y posteriormente se lavó la resina de IgG con tampón de lisis. El epítopo TAP contiene una secuencia de corte para la proteasa TEV. La digestión con la proteasa TEV (Invitrogen) se llevó a cabo en un volumen final de $150 \mu \mathrm{l}$ de tampón de lisis sin inhibidores, DTT 0,5 mM y EDTA 0,5 $\mathrm{mM}$, durante 2 horas en agitación débil $(750 \mathrm{rpm})$ a $16^{\circ} \mathrm{C}$. Tras la digestión, las proteínas purificadas, separadas de la resina de $\mathrm{IgG}$, se recuperaron por centrifugación a un tubo nuevo, para incubarse después con calmodulina acoplada a una matriz de sefarosa (Calmodulin Sepharosa 4B, GE Healthcare), en presencia de $\mathrm{CaCl}_{2} 2 \mathrm{mM}$ y DTT $1 \mathrm{mM}$, durante 1 hora a $4^{\circ} \mathrm{C}$. La elución de las proteínas acopladas a la calmodulina se realizó en 3 pasos sucesivos, consistentes en incubaciones de 10 minutos a $37^{\circ} \mathrm{C}$ en agitación con $350 \mu \mathrm{l}$ de tampón de elución (Tris-HCl $10 \mathrm{mM}$, pH8,0, EGTA $10 \mathrm{mM}, \mathrm{NaCl} 50 \mathrm{mM}$ ). Del volumen final obtenido, se separaron dos partes: una correspondiente al 10\% de la purificación y otra al 90\% restante. Para concentrar el purificado, ambas se precipitaron con TCA (ácido tricloroacético) a una concentración final del $10 \%$, durante toda la noche a $4^{\circ} \mathrm{C}$. El precipitado se lavó con acetona al $100 \%$ 
fría y se centrifugó a $4^{\circ} \mathrm{C}$, durante 30 minutos a $13.200 \mathrm{rpm}$. Tras lo cual se retiró el sobrenadante y el precipitado se dejó secar a temperatura ambiente. La fracción correspondiente al $10 \%$ se resuspendió en tampón de carga Laemmli y se utilizó para comprobar la calidad de la purificación por Western Blot. La fracción del 90\% se digirió con tripsina en el Servicio de Proteómica del Hospital Universitario de Salamanca y se analizó mediante espectrometría de trampa iónica (Nano-ESI ion-trap mass spectrometer Esquire 3000 plus, Bruker Daltonics) en el Servicio de Proteómica del Centro Nacional de Biotecnología (CNB, CSIC, Madrid). Los péptidos secuenciados se contrastaron con aquéllos presentes en las bases de datos Swiss-Prot y NCBInr.

\subsubsection{Inmunoprecipitación de cromatina o ChIP}

Los experimentos de inmunoprecipitación de cromatina (ChIP) se realizaron siguiendo el protocolo descrito en (Keogh et al., 2003) y (Calvo and Manley, 2005).

\subsubsection{Preparación y fijación del cultivo}

Se utilizaron células procedentes de cultivos en medio rico YEPD que se crecieron hasta una D. $600 \mathrm{~nm}$ de 0.5-0.6 a $28^{\circ} \mathrm{C}$. Para las ChIP de Sbr10-Myc, los cultivos se crecieron según describieron (Larschan and Winston, 2005). Las células se incubaron en YEPRaf a $28^{\circ} \mathrm{C}$ hasta D.O $600 \mathrm{~nm}$ de 1.0, se centrifugaron, se retiró el medio sobrenadante y el sedimento celular se lavó con medio YEP sin fuente de carbono. Finalmente, la mitad de las células se transfirieron a medio fresco YEPRaf y la otra mitad a medio YEPGal y se incubaron durante 20 minutos a $28^{\circ} \mathrm{C}$, para permitir la inducción de los genes GAL. En las ChIP correspondientes a los estudios de elongación, utilizando el gen largo YLR454w bajo el promotor GAL1, los cultivos se crecieron directamente en YEPGal a $28^{\circ} \mathrm{C}$ hasta una D. 600nm $_{6}$ de 0.5-0.6. Para las ChIP de Rpb1 o Sub1-HA en presencia de 6AU, las células se crecieron en medio SC sin uracilo hasta una D.O $600 \mathrm{~nm}$ de 0.5 , momento en el que el cultivo se dividió en dos partes y se añadió la droga a una concentración de $100 \mu \mathrm{g} / \mathrm{ml}$ a una de ellas. Ambas mitades se incubaron durante 1 hora más a $28^{\circ} \mathrm{C}$.

Para unir covalentemente las proteínas al DNA, las células se fijaron por tratamiento con formaldehido al 1\%, durante 20 minutos en agitación a temperatura ambiente. La fijación se detuvo por adición de glicina a una concentración final de 360 $\mathrm{mM}$, incubándose 5 minutos más. Por último, se centrifugó a $5.000 \mathrm{rpm}$ durante 5 minutos a $4^{\circ} \mathrm{C}$ y las células se lavaron dos veces con tampón TBS frío (Tris-HCl $20 \mathrm{mM}$ pH 7.6, y $\mathrm{NaCl} 150 \mathrm{mM}$ ) y una vez con tampón de lisis FA (HEPES-KOH 100 mM, 
NaCl 300 mM, EDTA 2 mM, Tritón x-100 2\% (v/v), deoxicolato sódico 0,2\% (p/v), SDS $0,1 \%(\mathrm{p} / \mathrm{v})$. En este punto, las células se congelaron a $-80^{\circ} \mathrm{C}$ o se procedió a la preparación de los extractos y la fragmentación del DNA.

\subsubsection{Preparación del extracto celular y fragmentación del DNA}

Las células se resuspendieron en $500 \mu \mathrm{l}$ de tampón de lisis con inhibidores de proteasas (cóctel de inhibidores (Sigma) dilución 1/10, PMSF $10 \mathrm{mM}$ ) y fosfatasas ( NaF $10 \mathrm{mM}$, ortovanadato sódico $20 \mathrm{mM}$ ). A continuación, se añadió un volumen de bolitas de vidrio de $45 \mu \mathrm{m}$ similar al volumen de sedimento celular y se lisaron las células en un sistema Fast Prep, realizando 5 pulsos de 30 segundos a velocidad 4,5 K, dejando las células 1 minuto en hielo entre pulso y pulso. Posteriormente se eliminaron las bolitas por centrifugación. Se añadió $1 \mathrm{ml}$ más de tampón de lisis con inhibidores al lisado celular y se sonicó en un sistema Bioruptor TM (Diagenode) hasta obtener fragmentos de DNA de un tamaño 300-500 pb. A continuación, se centrifugó a 13.200 rpm durante 10 minutos a $4^{\circ} \mathrm{C}$, para eliminar los restos celulares y se transfirió el sobrenadante a un tubo nuevo. Se añadió sarcosil a una concentración final 1\% (p/v) y se cuantificó la concentración de proteínas.

\subsubsection{Inmunoprecipitación}

De manera estándar, inmunoprecipitamos $20 \mathrm{mg}$ de proteínas, usando para ello el anticuerpo específico requerido en cada experimento concreto y $20 \mu \mathrm{l}$ de proteína Asefarosa (Amersham), equilibrada con tampón de lisis y bloqueada con ssDNA de salmón (2 mg/ml). Tomamos 1/10 del volumen a inmunoprecipitar, como muestra control de DNA total (INPUT). Las inmunoprecipitaciones se realizaron en primer lugar incubando los extractos durante 3-4 horas a $4^{\circ} \mathrm{C}$ en agitación suave con el anticuerpo, añadiendo después la proteína A y el ssDNA e incubando toda la noche. Tras la incubación, se realizaron dos lavados sucesivos de la resina con $1400 \mu \mathrm{l}$ de tampón de lisis, un lavado con $1400 \mu \mathrm{l}$ tampón de lisis con $\mathrm{NaCl}$ a $500 \mathrm{mM}$, un lavado con $1400 \mu \mathrm{l}$ tampón de LiCl (Tris-HCl 10 mM pH 8,0, LiCl 250 mM, NP-40 0,5\% (v/v), deoxicolato sódico 0,5\% (p/v), EDTA $1 \mathrm{mM}$ ) y un lavado con $1400 \mu \mathrm{l}$ de TE. A todos los lavados les siguió una centrifugación en frío a $5000 \mathrm{rpm}$ durante 30". Después del último lavado, la resina se resuspendió en $100 \mu \mathrm{l}$ de TE con $20 \mu \mathrm{g}$ de RNasa A, para digerir el RNA. En este punto, las muestras INPUT también se trataron con RNAsa A. Posteriormente, las proteínas se eluyeron de la resina mediante dos incubaciones 
sucesivas con $250 \mu \mathrm{l}$ de tampón de elución $\left(\mathrm{NaHCO}_{3}\right.$ 0,1 M, SDS 1\% (p/v), durante 15 minutos a temperatura ambiente y en agitación. Eluciones que se juntaron en un mismo tubo. El volumen de las muestras INPUT se ajustó hasta $500 \mu$ l añadiendo tampón de elución.

\subsubsection{Procesamiento del INPUT y del PRECIPITADO}

Para revertir la fijación y separar las proteínas del DNA, las muestras se incubaron durante 6 horas a $65^{\circ} \mathrm{C}$. Tras ello, se digirieron las proteínas añadiendo $25 \mu \mathrm{lde}$ Tris$\mathrm{HCl}, 10 \mu \mathrm{l}$ de EDTA 0,5 M pH 8.0 y $20 \mu \mathrm{g}$ de proteinasa $\mathrm{K}$ e incubando a $37^{\circ} \mathrm{C}$ durante 1 hora. Se realizó una extracción con $500 \mu \mathrm{l}$ de fenol:cloroformo:alcohol isoamílico (25:24:1), utilizando columnas Phase-lock (5-Prime) y por centrifugación a temperatura ambiente durante 5 minutos. La fase acuosa se recuperó a un tubo nuevo y se precipitó durante toda la noche a $-20^{\circ} \mathrm{C}$ con $1 / 10$ del volumen de acetato sódico $0,3 \mathrm{M}$ pH 5.2, más 2,5 volúmenes de etanol 96\% (v/v) y $1 \mu \mathrm{l}$ de glicógeno (Roche). Las muestras se centrifugaron a $13.200 \mathrm{rpm}$ durante $30-40$ minutos a $4^{\circ} \mathrm{C}$ y el precipitado correspondiente se lavó con etanol 70\% (v/v). El precipitado se secó por centrifugación en vacío y se resuspendió en $100 \mu \mathrm{l}$ de TE. Por último, se realizó una purificación del DNA utilizando el producto comercial GFX ${ }^{\mathrm{TM}} P C R$ DNA and Gel Band Purification Kit (GE Healthcare), quedando las muestras de DNA resuspendidas en $70 \mu$ del tampón de elución. Se utilizó $1 \mu \mathrm{l}$ de una dilución 1/20 de las muestras INPUT y $1 \mu$ lirectamente de los precipitados para llevar a cabo las qPCRs.

\subsubsection{Anticuerpos}

Los anticuerpos usados en esta tesis se describen en la Tabla 6.

\subsubsection{Expresión de proteínas recombinantes desde Escherichia coli}

Dos proteínas recombinantes, GST-CTD y rSpt5-His, se expresaron y purificaron para usarse como sustrato en las reacciones de actividad quinasa in vitro.

\section{Expresión de la proteína GST-CTD.}

Transformamos E. coli DH5 $\alpha$ con un vector de expresión pGEX-4-T1 que contenía el CTD de S. cerevisiae marcado con el epítopo GST (Tabla 4, (Barilla et al., 2001). Los transformantes se crecieron en medio $\mathrm{LB}$ a $37^{\circ} \mathrm{C}$ hasta que el cultivo alcanzó una D.O.600nm de 0.6. Después, la inducción de la expresión se llevó a cabo añadiendo al cultivo isopropil- $\beta$-D-tiogalactósido (IPTG) a una concentración final de 0,5 mM e 
incubándolo a $30^{\circ} \mathrm{C}$ durante 16 horas. La proteína GST-CTD se purificó por cromatografía de afinidad utilizando bolitas de glutation-sefarosa (glutathione Sepharose 4B, Amersham), siguiendo las indicaciones del proveedor.

\section{Expresión de la proteína rSpt5-His.}

Transformamos E. coli BL21 (DE3) con un vector de expresión pET21a que contenía el gen SPT5 marcado con 6 Histidinas en su extremo N-terminal (Tabla 4 (Liu et al., 2009). Los transformantes se crecieron a $37^{\circ} \mathrm{C}$ hasta una D.O $600 \mathrm{~nm}$ de 0.4-0.5. Después se indujo la expresión con IPTG a una concentración final de $1 \mathrm{mM}$ y el cultivo se incubó durante 3-4 horas a $37^{\circ} \mathrm{C}$. La proteína se purificó mediante cromatografía de afinidad utilizando un sistema de Ni-sefarosa (Protein A HP SpinTrap $^{\mathrm{TM}}$, GE Healthcare), de acuerdo con las instrucciones del fabricante.

\subsection{Ensayos de Actividades Enzimáticas}

\subsubsection{Ensayos de actividad quinasa in vitro}

Las células se crecieron en medio rico YEPD, a $28^{\circ} \mathrm{C}$, hasta una D. $\mathrm{O}_{600 \mathrm{~nm}}$ de 0.6. Se recogieron por centrifugación, se lavaron y se suspendieron en tampón de lisis (HEPES-KOH 20 mM, pH 7.6, acetato potásico 200 mM, glicerol 10\% (v/v) y EDTA 1 $\mathrm{mM}$ ), con inhibidores de proteasas (cóctel de inhibidores de proteasas (Sigma) dilución 1/10, PMSF $10 \mathrm{mM}$ ) y fosfatasas ( $\mathrm{NaF} 10 \mathrm{mM}$, ortovanadato sódico $20 \mathrm{mM}$ ). Se añadió un volumen similar al sedimento celular de bolitas de vidrio y se llevó a cabo la lisis en un sistema Fast Prep. Posteriormente, se eliminaron las bolitas de vidrio por centrifugación y el lisado celular se centrifugó de nuevo a $4^{\circ} \mathrm{C}$ durante $10-20$ minutos a $13.200 \mathrm{rpm}$, tras lo cual se recuperó el sobrenadante. Se inmunoprecipitaron las quinasas utilizando $150 \mu \mathrm{g}$ de proteínas e incubándolas con 0.75-1 $\mu \mathrm{l}$ de anticuerpo específico anti-HA ó anti-Myc, unido previamente a proteína A-sefarosa (Amershan), durante 1.5-2 horas en agitación suave. Tras la incubación, se realizaron tres lavados con tampón de lisis y dos lavados con tampón quinasa (HEPES-KOH 20 mM, pH 7,6, acetato magnésico 7,5 mM, acetato potásico $100 \mathrm{mM}$, glicerol 2\% (v/v). Por último, los inmunoprecipitados se resuspendieron en $25 \mu \mathrm{l}$ de tampón quinasa con ATP a una concentración final de 2,5 mM y se incubaron con $30 \mathrm{ng}$ de proteína recombinante GST-CTD o 100 ng de 6xHIS-Spt5, durante 30 minutos a $30^{\circ} \mathrm{C}$. La reacción se paró por adición de $25 \mu$ de tampón de carga Laemmli 2X (Sigma) y el producto de la reacción se analizó por Western Blot, utilizando los anticuerpos correspondientes. 


\subsubsection{Ensayo de actividad fosfatasa ácida y cálculo de ratio GLAM}

El ensayo de actividad fosfatasa ácida y el cálculo de los ratio GLAM (gene lenght-dependent accumulation of $m R N A$ ) se llevaron a cabo tal y como se describe en (Morillo-Huesca et al., 2006). Las células se crecieron a $28^{\circ} \mathrm{C}$ en medio SC con galactosa $2 \%(\mathrm{p} / \mathrm{v})$, como fuente de carbono, hasta una D.O.600nm de 0.4. Las células se recogieron por centrifugación, se lavaron con agua y se resuspendieron en 1,5 $\mathrm{ml}$ de agua. El ensayo se llevó a cabo con $30 \mu \mathrm{l}$ de la suspensión celular, añadiendo $70 \mu \mathrm{l}$ de agua , $350 \mu \mathrm{l}$ de tampón acetato sódico (acetato sódico $70 \mathrm{mM}, \mathrm{pH} 4.0$ ) y $50 \mu \mathrm{l}$ de paranitrofenilfosfato (pNPP) a $5 \mathrm{mg} / \mathrm{ml}$, como sustrato de la reacción. La mezcla se incubó a $37^{\circ} \mathrm{C}$, durante 10 minutos. La reacción se detuvo añadiendo $100 \mu \mathrm{l}$ de TCA al $25 \%$ (v/v). Posteriormente, se añadieron $600 \mu \mathrm{l}$ de $\mathrm{Na}_{2} \mathrm{CO}_{3}$ saturado $(\sim 3 \mathrm{M})$ y se midió la absorbancia a $405 \mathrm{~nm}$ en un espectrofotómetro. Las unidades de actividad fosfatasa ácida se calcularon a través de la fórmula siguiente:

Actividad fosfatasa ácida $=\left(D^{2} \cdot O_{405 m} \times 0,066\right) /(D . O .600 \mathrm{~nm} \times \mathrm{V} \mathrm{x} \mathrm{t})$

Siendo: 0,066: factor de corrección; D.O.600nm: D.O.600nm de una dilución 1/5 de la suspensión de células en 1,5 $\mathrm{ml}$ de volumen; $\mathbf{V}$ : volumen de células utilizado en el ensayo, en $\mathrm{ml}$ (en nuestro caso, 0,03 ml) t: tiempo de reacción, en minutos (en nuestro caso, 10 minutos).

Los ratio GLAM se determinaron calculando la actividad fosfatasa ácida en cepas que contenían los plásmidos con las construcciones de PHO5 correspondientes (pSCh202, pSCh212, pSCh209) y el plásmido vacío (YCplac33), (Tabla 4). Este último se utilizó para cuantificar la actividad fosfatasa ácida endógena, que se restó a la actividad derivada de las construcciones mencionadas. A partir de la media obtenida de al menos tres experimentos diferentes, se calcularon los cocientes de actividad fosfatasa ácida entre las distintas unidades transcripcionales largas (correspondientes a las construcciones pSCh212 y pSCh209) y la unidad transcripcional más corta.

\subsection{Antibióticos, Drogas, Inhibidores y Enzimas}

\subsubsection{Antibióticos}

-Ampicilina, Amp (Apollo): antibiótico $\beta$-lactámico que inhibe la división celular de E.coli impidiendo la síntesis de la pared celular. Se utiliza para seleccionar células bacterianas que lleven un plásmido con el marcador de resistencia correspondiente. 
-G418, geneticina ${ }^{\circledR}$ (Apollo): antibiótico aminoglicosídico. Bloquea la síntesis de proteínas interfiriendo con la función de la subunidad $80 \mathrm{~S}$ del ribosoma eucariota (Jimenez and Davies, 1980). Se usa para seleccionar y mantener células eucariotas que lleven el gen de E.coli de resistencia a Kanamicina (Kan).

\subsubsection{Drogas e inhibidores}

-6-Azauracilo (6AU) (Sigma): inhibidor de la inosina 5'-monofosfato deshidrogenasa (IMPDH), enzima que participa en la ruta de síntesis de nucleótidos de guanina. Este compuesto se usa para testar defectos en la etapa de elongación de la transcripción.

-Isopropil- $\beta$-D-tiogalactósido (IPTG) (Apollo): compuesto químico que se usa para inducir la expresión de proteínas bajo el control del promotor lac.

-Cóctel de inhibidores de proteasas (Sigma): mezcla de distintos inhibidores de proteasas de serinas, de cisteínas, metaloproteasas, y proteasas ácidas.

-Dietil-dicarbonato (DEPC) (Sigma): inactivador de la RNasa A.

-Phenylmethanesulfonyl fluoride (PMSF) (Sigma): inhibidor de proteasas de serinas y de cisteínas.

-Fluoruro sódico (NaF) (Simga): inhibidor de fosfatasas de serina y treonina.

-Ortovanadato sódico (Sigma): inhibidor de tirosina-fosfatasas.

\subsubsection{Enzimas y otros reactivos}

-DNasa I (Invitrogen): digiere DNA de cadenas sencilla y doble hasta oligodeoxyribonucleótidos con un fosfato 5' libre.

-Endonuclesas de restricción (Fermentas): endonucleasas de DNA con dianas específicas de secuencia.

-Polimerasas termostables de DNA: Expand High Fidelity PCR System (Roche), PCRs que requieren alta fidelidad de la secuencia amplificada, y KapaTaq Ready Mix DNA polymerase (Kapa Biosystems).

-PrimeScript ${ }^{\text {TM }}$ RT reagent Kit (Perfect Real Time, Takara): mezcla de reactivos para la reacción de retrotranscripción.

-SYBR ${ }^{\circledR}$ Premix Ex Taq ${ }^{\text {TM }}$ (Perfect Real Time, Takara): combinación de reactivos para la realización de PCR cuantitativa

-TEV proteasa (Invitrogen): proteasa recombinante del virus del grabado del tabaco (TEV), específica de sitio, purificada de E.coli. Corta entre los aminoácidos Gln y Gly 
de la secuencia Glu-Asn-Leu-Tyr-Phe-Gln-Gly presente en el epítopo TAP utilizado en el etiquetado y purificación de proteínas (Rigaut et al., 1999)

-RNasa A (Sigma): nucleasa que degrada RNA de cadena sencilla.

-Proteinasa K (5-Prime): endoproteinasa inespecífica capaz de degradar proteínas hasta el nivel de aminoácidos.

-Glusulasa (PerkinElmer): digestión de las paredes celulares de las ascosporas.

-Calmodulin Sepharosa 4B (GE Healthcare): calmodulina conjugada covalentemente a una matriz de sefarosa.

-IgG sepharose 6 Fast Flow (GE Healthcare): Inmunoglobulina G humana conjugada covalentemente a una matriz de sefarosa con afinidad por la Proteína A.

-Proteína A sefarosa (Amersham): se une a la región constante (Fc) de la cadena pesada de las inmunoglobulinas $\operatorname{IgG}$, IgA e $\operatorname{IgM}$. Se utiliza en los ensayos de inmunoprecipitación. 
Tabla 3. Lista de cepas de Saccharomyces cerevisiae

\begin{tabular}{|c|c|c|}
\hline Cepa & Genotipo & Fuente \\
\hline OCSC154 & Mat $\alpha$ ade2-1 ade3-22 can1-100 his3-11,15 ura3-1 kin28::LEU2 [HAKIN28 TRP CEN] sub1::URA3 & Este trabajo \\
\hline OCSC166 & Mat $\alpha$ ade2-1 his 3-11,15 leu2-3,112 trp1-1 ura3-1 sub1::URA3 & Este trabajo \\
\hline OCSC261 & Mat $\alpha$ ade2-1 his 3-11,15 leu2-3,112 trp1-1 ura3-1 srb10::KAN & Este trabajo \\
\hline OCSC264 & Mat $\alpha$ ade2-1 his 3-11,15 leu2-3,112 trp1-1 ura3-1 srb10::KAN sub1::URA3 & Este trabajo \\
\hline OCSC267 & Mat $\alpha$ ade2-1 his 3-11,15 leu2-3,112 trp1-1 ura3-1 ADH1-SUB1 & Este trabajo \\
\hline OCSC268 & Mat $\alpha$ ade2-1 his 3-11,15 leu2-3,112 trp1-1 ura3-1 srb10::KAN sub1::URA3 ADH1-SUB1 & Este trabajo \\
\hline OCS570 & Mat a his3 2200 leu2-3,112 ura3-52 ceg1 1 1::his3 [HACEG1 LEU CEN] sub1::URA3 & Este trabajo \\
\hline OCSC157 & 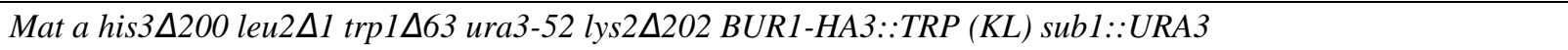 & Este trabajo \\
\hline OCSC301 & 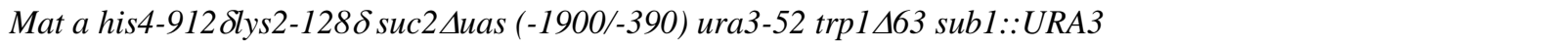 & Este trabajo \\
\hline OCSC303 & 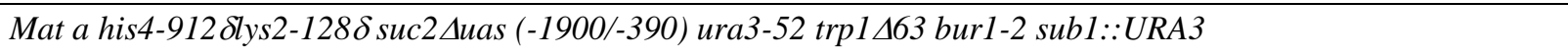 & Este trabajo \\
\hline ERYM356 & Mat a ura3-52 lys2-801 ${ }^{\text {amber }}$ ade2-101 ${ }^{\text {ochre }}$ trp1- $\Delta 63$ his3-delta200 leu2- $\triangle 1$ CTK -6HA::TRP1 (KL) & Este trabajo \\
\hline ERYM357 & 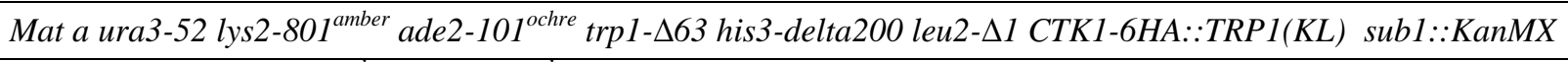 & Este trabajo \\
\hline OCSC1077 & $\begin{array}{l}\text { Mat a ura3-52 lys2-801 }{ }^{\text {amber }} \text { ade } 2-101^{\text {ochre }} \text { trp1- } \triangle 63 \text { his3-delta200 leu2- } \triangle 1 \text { CTK -6HA::TRP1 (KL) SRB10- } \\
13 \text { MYC::HIS3 }\end{array}$ & Este trabajo \\
\hline OCSC1078 & 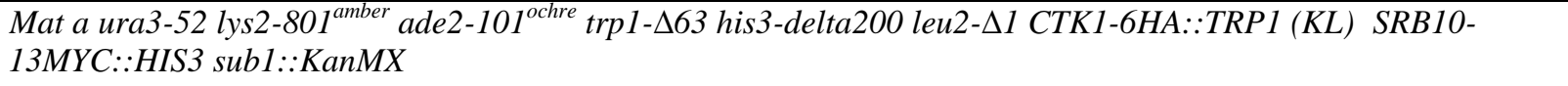 & Este trabajo \\
\hline OCSC1323 & Mat $\alpha$ ade2-1 his4-260 leu2-3,112 trp1-289 ura3-1 CDC5-3HA ::KanMX sub1::URA3 & Este trabajo \\
\hline OCSC181 & Mat a his3 $\Delta 200$ leu $2 \Delta 1$ trp $1 \Delta 63$ ura3-52 lys- $128 \delta$ spt5-194 subl::URA3 & Este trabajo \\
\hline OCSC810 & Mat a his3 $\Delta 200$ leu $2 \Delta 1$ trp1 $\Delta 63$ ura3-52 lys- $128 \delta$ spt5-194 ADH1-SUB1 & Este trabajo \\
\hline OCSC203 & 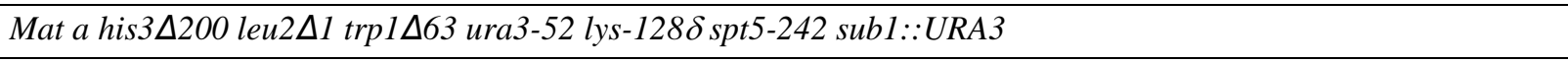 & Este trabajo \\
\hline OCSC1412 & Mat a ade2-1 his 3-11,15 leu2-3,112 trp1-1 ura3-1 Sub1-TAP::TRP1 & Este trabajo \\
\hline OCSC1725 & Mat a ade2-1 his 3-11,15 leu2-3,112 trp1-1 ura3-1 Sub1-TAP::TRP1 Rpb7-3HA::KanMX & Este trabajo \\
\hline OCSC2004 & Mat a ade2-1 his 3-11,15 leu2-3,112 trp1-1 ura3-1 rpb4::HIS3 pRS316 & Este trabajo \\
\hline OCSC2005 & Mat a ade2-1 his 3-11,15 leu2-3,112 trp1-1 ura3-1 rpb4::HIS3 sub1::URA3 & Este trabajo \\
\hline OCSC2007 & Mat a ade2-1 his 3-11,15 leu2-3,112 trp1-1 ura3-1 rpb4::HIS3 ADH1-SUB1 & Este trabajo \\
\hline
\end{tabular}




\begin{tabular}{|c|c|c|}
\hline OCSC1434 & Mat a ade2-1 his 3-11,15 leu2-3,112 trp1-1 ura3-1 Sub1-6HA::TRP1 & Este trabajo \\
\hline OCSC2002 & Mat a ade2-1 his 3-11,15 leu2-3,112 trp1-1 ura3-1 Sub1-6HA::TRP1 rpb4::KanMX & Este trabajo \\
\hline OCSC1524 & 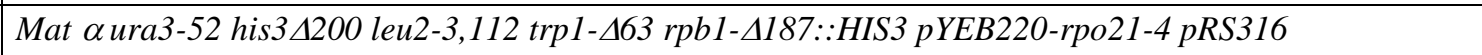 & Este trabajo \\
\hline OCSC1526 & Mat $\alpha$ ura3-52 his34200 leu2-3,112 trp1-463 rpb1-4187::HIS3 pYEB220-rpo21-4 sub1::URA3 & Este trabajo \\
\hline OCSC1436 & Mat a ade2-1 his 3-11,15 leu2-3,112 trp1-1 ura3-1 Spt5-FLAG::kanMX6 Sub1-6HA::TRP1 & Este trabajo \\
\hline OCSC1437 & Mat a ade2-1 his 3-11,15 leu2-3,112 trp1-1 ura3-1 Spt5-FLAG::kanMX6 & Este trabajo \\
\hline OCSC1739 & Mat a ade2-1 his 3-11,15 leu2-3,112 trp1-1 ura3-1 sub1::KAN pRS314 pRS316 & Este trabajo \\
\hline OCSC1740 & Mat a ade2-1 his 3-11,15 leu2-3,112 trp1-1 ura3-1 sub1::URA3 [Sub1-6HA::TRP1 HIS3 CEN] pRS316 & Este trabajo \\
\hline OCSC1601 & Mat a, his $3 \Delta 1$ leu $2 \Delta O$ met $15 \Delta O$ ura $3 \Delta O$ pRS316 & Este trabajo \\
\hline OCSC1602 & 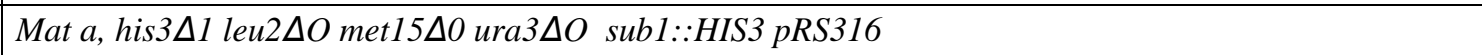 & Este trabajo \\
\hline OCSC1768 & 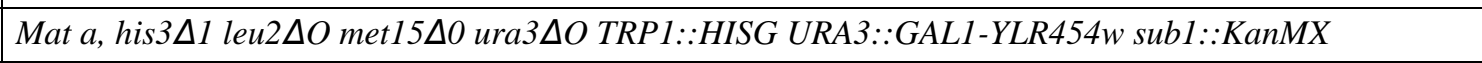 & Este trabajo \\
\hline OCSC1947 & 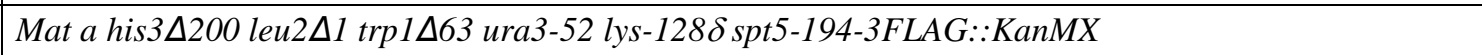 & Este trabajo \\
\hline OCSC1948 & 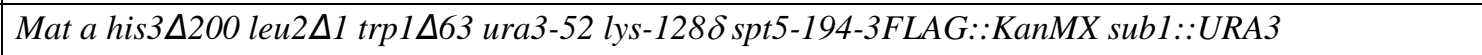 & Este trabajo \\
\hline OCSC175 & Mat $\alpha$ ade2-1 can1-100 his3-11,15 leu2,3 trp1-1 ura3-1 spt4::URA3 sub1::KanMX & Este trabajo \\
\hline OCSC1958 & Mat a, ade2-1 his3-11,15 leu2-3,112 trp1-1 ura3-1 can1-100 SUA7-13MYC::TRP1 pRS316 & Este trabajo \\
\hline YSB756 & Mat $\alpha$ ade2-1 ade3-22 can1-100 his3-11,15 ura3-1 kin28::LEU2 [HAKIN28 TRP CEN] & S. Buratowski \\
\hline YSB609 & Mat $\alpha$ ade2-1 ade3-22 can1-100 his3-11,15 ura3-1 kin28::LEU2 [HAkin28-K36A TRP CEN] & S. Buratowski \\
\hline YSB595 & Mat $\alpha$ ade2-1 ade3-22 can1-100 his3-11,15 ura3-1 kin28::LEU2 [HAkin28-T162A TRP CEN] & S. Buratowski \\
\hline YSB786 & Mat a his3 $\triangle 200$ leu2-3,112 ura3-52 ceg1 $\triangle 1::$ his3 [HACEG1 LEU CEN] & S. Buratowski \\
\hline YSB770 & 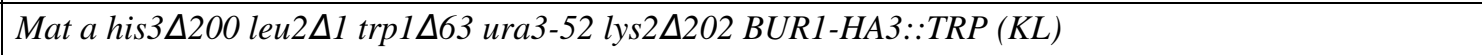 & S. Buratowski \\
\hline YSB1021 & 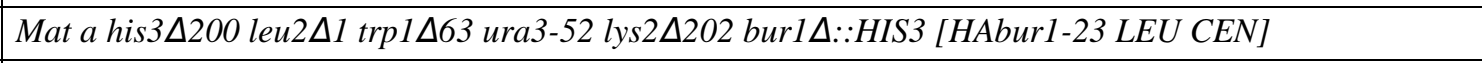 & S. Buratowski \\
\hline F243 & Mat a thr4 & M. Tamame \\
\hline F244 & Mat $\alpha$ thr4 & M. Tamame \\
\hline GY458 & 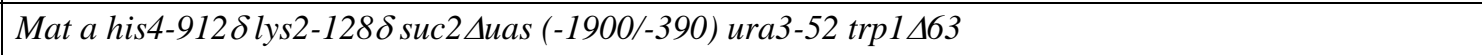 & G. Prelich \\
\hline GY170 & 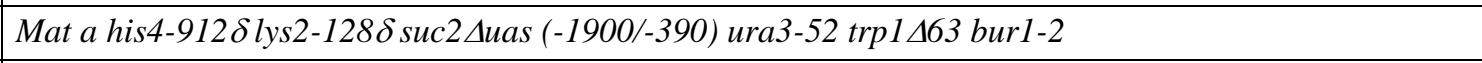 & G. Prelich \\
\hline YP655 & Mat $\alpha$ ade2-1 his4-260 leu2-3,112 trp1-289 ura3-1 CDC5-3HA ::KanMX & P. San Segundo \\
\hline MGSC339 & Mat $\alpha$ ade2-1 can1-100 his3-11,15 leu2,3 trp1-1 ura3-1 spt4::URA3 & A. Aguilera \\
\hline
\end{tabular}




\begin{tabular}{|c|c|c|}
\hline GHY1027 & 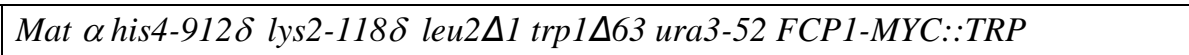 & G. Hartzog \\
\hline GHY94 & 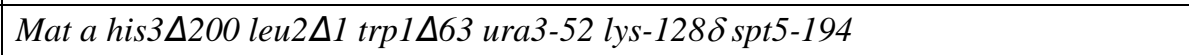 & G. Hartzog \\
\hline GHY828 & 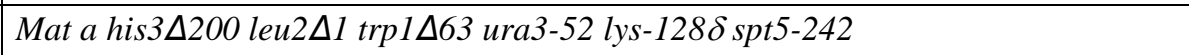 & G. Hartzog \\
\hline D711-13B & 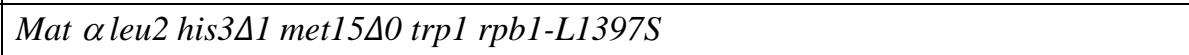 & (Kwapisz et al., 2008b) \\
\hline YFN117 & Mat $\alpha$ ura3-52 his34200 leu2-3,112 trp1-463 rpb1-4187::HIS3 pYEB220-rpo21-4 & F. Navarro \\
\hline GYLR-3A & 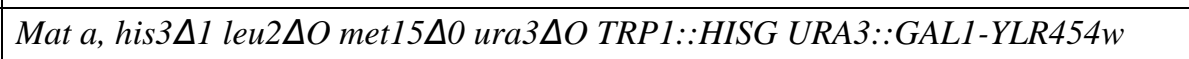 & (Jimeno-Gonzalez et al., 2010) \\
\hline PAY220 & Mat a, ade2-1 his3-11,15 leu2-3,112 trp1-1 ura3-1 can1-100 SUA7-13MYC::TRP1 & P. Alepuz \\
\hline
\end{tabular}


Tabla 4. Lista de plásmidos. Se índica una breve descripción del uso de cada plásmido y su fuente.

\begin{tabular}{|c|c|c|}
\hline Plásmido & Descripción & Fuente \\
\hline pFA6a-KanMX6 & Integración del marcador KanMX6 para delecionar genes & (Longtine et al., 1998) \\
\hline pYM3 & Integración de 6 copias del epítopo HA con marcador TRP1 de Kluyveromyces lactis & (Knop et al., 1999) \\
\hline $\begin{array}{l}\text { pFA6a-GST- } \\
\text { KanMX6 }\end{array}$ & Integración del epítopo GST con marcador KanMX6 & (Longtine et al., 1998) \\
\hline $\begin{array}{l}\text { pFA6a-13Myc- } \\
\text { His3MX6 }\end{array}$ & Integración de 13 copias del epítopo Myc con marcador His3MX6 (his5+ de Schizosaccharomyces pombe) & (Longtine et al., 1998) \\
\hline $\begin{array}{l}\text { pFa6a-3xFLAG- } \\
\text { KanMX6 }\end{array}$ & Integración de 3 copias del epítopo FLAG con marcador KanMX6 & $\begin{array}{c}\text { (Funakoshi and } \\
\text { Hochstrasser, 2009) }\end{array}$ \\
\hline pBS1479 & Integración del epítopo TAP con marcador TRPl de Kluyveromyces lactis & (Rigaut et al., 1999) \\
\hline YCplac33 & Vector de clonación centromérico con marcador $U R A 3$ & (Gietz and Sugino, 1988) \\
\hline pSCh202 & Plásmido centromérico con marcador $U R A 3$ que contiene la ORF del gen $P H O 5$ bajo control del promotor GAL1 & $\begin{array}{l}\text { (Morillo-Huesca et al., } \\
\text { 2006) }\end{array}$ \\
\hline pSCh212 & pSCh202 con la región codificante del gen PHO5 fusionado a la región 3'-UTR del lacZ de E.coli & $\begin{array}{l}\text { (Morillo-Huesca et al., } \\
\text { 2006) }\end{array}$ \\
\hline pSCh209-LAC4 & pSCh202 con la región codificante del gen PHO5 fusionado a la región 3'-UTR del gen LAC4 de Kluyveromyces lactis & $\begin{array}{l}\text { (Morillo-Huesca et al., } \\
\text { 2006) }\end{array}$ \\
\hline pRS316 & Vector de clonación centromérico con marcador $U R A 3$ & (Sikorski y Hieter 1989) \\
\hline pRS314 & Vector de clonación centromérico con marcador $L E U 2$ & (Sikorski y Hieter 1989) \\
\hline pRS313 & Vector de clonación centromérico con marcador HIS3 & (Sikorski y Hieter 1989) \\
\hline pDM366 & $\begin{array}{l}\text { Plásmido } 2 \mu \text { que contiene la } O R F \text { del gen } U R A 3 \text { flanqueado por secuencias repetitivas hisG, flanqueadas a su vez por } \\
\text { secuencias } 5 \text { ' y 3' del gen } S U B 1 \text {. Utilizado en la construcción de cepas } s u b 1 \Delta:: U R A 3\end{array}$ & (Knaus et al., 1996) \\
\hline pO23 & $\begin{array}{l}\text { Vector de clonación centromérico } U R A 3 \text {, que contiene el gen } S U B 1 \text { marcado con el epítopo FLAG bajo el promotor } \\
A D H 1 \text {. }\end{array}$ & J.L. Manley \\
\hline His6-rSpt5 & Vector de expresión pET21a que contiene el gen SPT5 marcado con 6 Histidinas en su extremo N-terminal & (Liu et al., 2009) \\
\hline pGST-CTD & Vector de expresión pGEX-4-T1 que contiene el CTD de $S$. cerevisiae marcado con el epítopo GST. & (Barilla et al., 2001) \\
\hline pOC2 & $\begin{array}{l}\text { Vector de clonación centromérico que contiene el gen } S U B 1 \text { bajo su propio promotor con marcador HIS3, etiquetado con } \\
6 \mathrm{HA} \text { en su extremo C-Terminal, y con marcador de selección TRP1 }\end{array}$ & Este trabajo \\
\hline
\end{tabular}


Tabla 5. Oligonucleótidos. Se detalla la secuencia y la utilidad de cada cebador.

\begin{tabular}{|c|c|c|}
\hline Oligonucleótido & Secuencia & Utilidad \\
\hline$A C T 1(-376)$ & TACCCGCCACGCGTTTTTTTCTTT & qPCR \\
\hline ACT1 (-120) & GGTTTGAGTAGAAAGGGGAAGGAAGA & qPCR \\
\hline$A C T 1(+1)$ & ATGGATTCTGAGGTTGCTGCTTTGG & qPCR \\
\hline$A C T 1(+300)$ & GTCCCAGTTGGTGACAATACCGT & qPCR \\
\hline$A C T 1(+757)$ & GTATTGTTTTGGATTCCGGTGATGGTGTTA & qPCR \\
\hline$A C T 1(+1015)$ & ATTGAAGAAGATTGAGCAGCGGTTTG & qPCR \\
\hline$A D H 1$ (-235) & TTCCTTCCTTCATTCACGCACACT & qPCR \\
\hline$A D H 1(-13)$ & GTTGATTGTATGCTTGGTATAGCTTG & qPCR \\
\hline$A D H I(+146)$ & ACGCTTGGCACGGTGACTG & qPCR y RT-PCR \\
\hline$A D H 1(+372)$ & ACCGTCGTGGGTGTAACCAGA & qPCR y RT-PCR \\
\hline GAL1 (-556) & ATATGTTGTGGAAATGTAAAGAGCC & qPCR \\
\hline GAL1 (-276) & TACTGCCAATTTTTCCTCTTCATAAC & qPCR \\
\hline GAL1-YLR454w (-194) & CTGGGGTAATTAATCAGCGAAGCGATG & qPCR \\
\hline$Y L R 454 w(+35)$ & CACTTGTACAGTAGAACATTAATCGGAAAC & qPCR \\
\hline$Y L R 454 w(+392)$ & CGCAATTAGTCAACAACGATATCACGATTG & qPCR y T-RO \\
\hline YLR454w (+605) & CCTACTTGAAGTCCATCCTTCAGAGG & qPCR \\
\hline YLR454w (+945) & CAATACCAACAGGTTCAGAAATGAGATGC & qPCR y T-RO \\
\hline YLR454w (+1147) & GAGAGAACAAATTGGTTTCGCCAAATATCG & qPCR \\
\hline YLR454w (+1986) & CATATCATCCACCCTAGGTGCTAGGTCGG & qPCR y T-RO \\
\hline YLR454w (+2199) & GAGCTGACCAGACCTAACCATAGTAGCGTG & qPCR \\
\hline YLR454w (+4069) & AGATATTACTCG TTGTTCGTGC CCAG & qPCR y T-RO \\
\hline YLR454w (+4268) & TCCCAAAACCCTAGTTTAACAGAAG & qPCR \\
\hline YLR454w (+5904) & CGTACTGTTGAAATGGAACGAGGACGC & qPCR \\
\hline YLR454w (+6074) & ATCGCTTCCATACTCGTTGTATCATCAGTC & qPCR \\
\hline YLR454w (+7701) & GAGGGTCACA GATCTATTAC TTGCCC & qPCR \\
\hline YLR454w (+7850) & GTTGTGAGTTGCTTCAGTGGTGAAGTG & qPCR \\
\hline$Y L R 454 w(+1)$ & ATGTTCTACTGTACAAGTGGC & T-RO \\
\hline YLR454w (+350) & CCCCATTGAGCCAGTATTGTG & T-RO \\
\hline$Y L R 454 w(+1284)$ & CGGACAAGAGGACGTAAAGACTTTAATG & T-RO \\
\hline$Y L R 454 w(+2281)$ & GTTCCAAAGATGATTTACCTCTGTCGC & T-RO \\
\hline$Y L R 454 w(+4348)$ & AGCATATAGGGACTTTTTGC & T-RO \\
\hline$Y L R 454 w(+6259)$ & CACAAGCTTCTGGATTTTCCAGGGA & T-RO \\
\hline$Y L R 454 w(+7580)$ & GAGATCAAGTGATTATATGATCGTTGAAG & T-RO \\
\hline$Y L R 454 w(+7845)$ & ATGGCTCCGTGTAGGAATTATAAGTTGTG & $\mathrm{T}-\mathrm{RO}$ \\
\hline Intergénico CVII 5' & TCCGTAAAACCAGTAACAAGCA & $\mathrm{qPCR}$ \\
\hline Intergénico CVII 3' & ACTTTTCAATTTGCGCTTCC & $\mathrm{qPCR}$ \\
\hline$I M D 2(-352)$ & TCTCGAAGAAAGCGGAAAAA & qPCR \\
\hline IMD2 (-195) & AGCCCACGAAACTGAGAAAA & qPCR \\
\hline$I M D 2(+274)$ & TGGGTGGTATCGGTTTCATT & qPCR \\
\hline$I M D 2(+488)$ & CCCACCAACTTTGCATTTCT & qPCR \\
\hline
\end{tabular}




\begin{tabular}{|c|c|c|}
\hline$I M D 2(+1265)$ & CGCCATGCAAAAGACTGGTA & qPCR \\
\hline IMD2 (+1371) & GTCAACGACAGCACCGGAG & qPCR \\
\hline $\operatorname{KIN} 28(+310)$ & CAGATATTAAGGCATGG & RT-PCR \\
\hline $\operatorname{KIN} 28(+533)$ & CCAAACAACAATTCTGG & RT-PCR \\
\hline PDR5 (+188) & CCAACAAAAGTGATGCTCAGTC & qPCR \\
\hline PDR5 (+483) & CAGCCCACTTTTTAGGATTTTG & qPCR \\
\hline$P G K 1(-131)$ & GGTCAATGCAAGAAATAC & qPCR \\
\hline PGK1 (-31) & TACTTCCTTGATGATCTG & qPCR \\
\hline$P G K 1(+275)$ & CACCTTCTTGAACGACTGTGTC & qPCR \\
\hline$P G K 1(+404)$ & AAAGAGCTCAATTCGTGTCTG & qPCR \\
\hline PGK1 (+1091) & TAACACCGTCATCATTGGT & qPCR \\
\hline$P G K 1(+1205)$ & CAACACCTGGCAATTCCTT & qPCR \\
\hline PHO5 (+78) & CGATGTCGACAAGATTG & RT-PCR \\
\hline PHO5 (+563) & GATGTTGAATTGGTCAC & RT-PCR \\
\hline PMA1 (-370) & GGTACCGCTTATGCTCCCCTCCAT & qPCR \\
\hline PMA1 (-90) & CTTTTGAATGTGTGTATAAAAGAGAG & qPCR \\
\hline PMA1 (+168) & CGACGACGAAGACAGT GATAACG; & qPCR \\
\hline PMA1 (+376) & ATTGAATTGGACCGACGAAAAACAT AAC & qPCR \\
\hline PMA1 (+584) & AAGTCGTCCCAGGTGATATTTTGCA & $\mathrm{qPCR}$ \\
\hline PMA1 (+807) & AACGAAAGTGTTGTCACCGGTAGC & qPCR \\
\hline PMA1 (+1010) & GTTTGCCAGCTGTCGTTACCACCAC & qPCR \\
\hline PMA1 (+1235) & GCAGC CAAACAAGCAGTCAACATCAAG & qPCR \\
\hline PMA1 (+2018) & CTATTATTGA TGCTTTGAAGACCTCCAG & qPCR \\
\hline PMA1 (+2290) & TGCCCAAAATAATAGACATACCCCATAA & qPCR \\
\hline PMA1 (+2552) & ATATTGTTACTGTCGTCCGTGTCTGGAT & qPCR \\
\hline PMA1 (+2757) & ATTAGGTTTCCTTTTCGTGTTGAGTAGA & qPCR \\
\hline PYK1 (-327) & GAATGCTTGTGATGTCT TCCAAGT & qPCR \\
\hline PYK1 (-23) & TGATTGGTGTCTTGTAAATAGAAACA & qPCR \\
\hline PYKl (+195) & CAACGCCAGAAAGTCCGAAGAA & qPCR \\
\hline$P Y K 1(+358)$ & GTACATGATCTTGTCGTCACAAGC & qPCR \\
\hline PYK1 (-750) & CGACGAAATCTTGAAGGTCACTG & qPCR \\
\hline PYKl (+938) & GCTCTGGTTGGTCTTGGGTTGTA & qPCR \\
\hline PYK1 (+1040) & CTATGGCTGAAACCGCTGTCATTG & qPCR \\
\hline PYK1 (+1267) & CAGCTCTTGGGCATCTGGTAAC & qPCR \\
\hline $\operatorname{SRB10}(+631)$ & GTCGAGAATTGCACAAC & RT-PCR \\
\hline$S R B 10(+775)$ & GTATCATCCTTTTTTCGG & RT-PCR \\
\hline$S U B 1(+1)$ & CATGCCATGGGTATGTCATATTACAACAGG & RT-PCR \\
\hline SUBI $(+861)$ & CATGCCATGGGTTTATTCTTCTTCACTTAT & RT-PCR \\
\hline YEF3 (-255) & GCACGTGAAAAAGAAACGTTTTTAATG & qPCR \\
\hline YEF3 (-123) & GATGTTACCATTCAAGAAAGAAGCGAC & qPCR \\
\hline$Y E F 3(+878)$ & TCTTGGGTAAATTGTTGCCAGG & qPCR \\
\hline$Y E F 3(+1188)$ & GTGCAAGAAGATAGTCATGTATGGGGTG & qPCR \\
\hline$Y E F 3(+2813)$ & GATTCTTTGGGTGCTTTGTCTAAGGC & qPCR \\
\hline
\end{tabular}




\begin{tabular}{|l|l|c|}
\hline$Y E F 3(+3019)$ & CGGCAATCTTGTTACCCATAGC & qPCR \\
\hline$R P B 1(+4406)$ & CGTCACACCATACAGTAACG & RT-PCR \\
\hline$R P B 1(+5170)$ & GTTCGTCTTGCTTTGGAGAATA & RT-PCR \\
\hline$R P B 4(+1)$ & ATGAATGTTTCTACATC & RT-PCR \\
\hline$R P B 4(+647)$ & TTAATAGAGTGTTTCTAG & RT-PCR \\
\hline $18 S(+1274)$ & CATGGCCGTTCTTAGTTGGT & RT-PCR \\
\hline $18 S(+1403)$ & ATTGCCTCAAACTTCCATCG & RT-PCR \\
\hline
\end{tabular}


Tabla 6. Lista de anticuerpos primarios y secundarios. Se detalla la especificidad, el origen y la fuente de los anticuerpos primarios. Para los anticuerpos secundarios se muestra la especificidad, las enzimas conjugadas con cada anticuerpo y la fuente.

\begin{tabular}{|c|c|c|c|}
\hline \multicolumn{4}{|c|}{ Anticuerpos primarios } \\
\hline Proteína & Origen & Epítopo & Fuente \\
\hline Rpb1 (8WG16) & Ratón & $\begin{array}{l}\text { Dominio C-terminal de la subunidad Rpb1 de } \\
\text { la RNAPII (CTD) }\end{array}$ & Covance \\
\hline Rpb1 (CTD4H8) & Ratón & Ser5 fosforilada del CTD & Milipore \\
\hline Rpb1 (ab5095) & Conejo & Policlonal frente a la Ser2 fosforilada del CTD & Abcam \\
\hline Rpb3 (1Y26) & Ratón & Subunidad Rpb3 de la RNAPII & Neoclone \\
\hline Rpb4 (2Y14) & Ratón & Subunidad Rpb4 de la RNAPII & Neoclone \\
\hline PGK (22C5) & Ratón & 3-Fosfoglicerato quinasa (PGK) & Mol.Probes \\
\hline TAP & Conejo & $\begin{array}{l}\text { SSGALDYDIPTTASENLYFQ } \\
\text { (extremo C-terminal del epítopo TAP tras ser } \\
\text { cortado con la proteasas TEV) }\end{array}$ & $\begin{array}{c}\text { Open } \\
\text { Biosystems }\end{array}$ \\
\hline FLAG (M5) & Ratón & DYKDDDDK & Sigma \\
\hline HA (12CA5) & Ratón & YPYDVPDYA & Roche \\
\hline c-MYC (9E10) & Ratón & $\begin{array}{l}\text { Aminoácidos } 408-439 \text { del extremo C- terminal } \\
\text { de la proteína c-Myc humana }\end{array}$ & Santa Cruz \\
\hline Spt5 (yN-20) & Cabra & $\begin{array}{l}\text { Policlonal frente al extremo N-terminal de la } \\
\text { proteína Spt5 de } S \text {. cerevisiae }\end{array}$ & Santa Cruz \\
\hline \multicolumn{4}{|c|}{ Anticuerpos secundarios } \\
\hline Especificidad & & Conjugación & Fuente \\
\hline Ratón & & Peroxidasa & Sigma \\
\hline Conejo & & Peroxidasa & Sigma \\
\hline Cabra & & Peroxidasa & Sigma \\
\hline $\begin{array}{l}\text { Proteína A, región Fc de la } \\
\text { Hc de } \operatorname{IgG}, \operatorname{IgA} \text { e IgM }\end{array}$ & & Peroxidasa & Sigma \\
\hline
\end{tabular}


Adams, M.D., Rudner, D.Z., and Rio, D.C. (1996). Biochemistry and regulation of premRNA splicing. Curr Opin Cell Biol 8, 331-339.

Ahn, S.H., Keogh, M.C., and Buratowski, S. (2009). Ctk1 promotes dissociation of basal transcription factors from elongating RNA polymerase II. EMBO J 28, 205212.

Ahn, S.H., Kim, M., and Buratowski, S. (2004). Phosphorylation of serine 2 within the RNA polymerase II C-terminal domain couples transcription and 3 ' end processing. Mol Cell 13, 67-76.

Akhtar, M.S., Heidemann, M., Tietjen, J.R., Zhang, D.W., Chapman, R.D., Eick, D., and Ansari, A.Z. (2009). TFIIH kinase places bivalent marks on the carboxyterminal domain of RNA polymerase II. Mol Cell 34, 387-393.

Akoulitchev, S., Chuikov, S., and Reinberg, D. (2000). TFIIH is negatively regulated by cdk8-containing mediator complexes. Nature 407, 102-106.

Alexandru, G., Uhlmann, F., Mechtler, K., Poupart, M.A., and Nasmyth, K. (2001). Phosphorylation of the cohesin subunit Scc1 by Polo/Cdc5 kinase regulates sister chromatid separation in yeast. Cell 105, 459-472.

Allison, L.A., Moyle, M., Shales, M., and Ingles, C.J. (1985). Extensive homology among the largest subunits of eukaryotic and prokaryotic RNA polymerases. Cell $42,599-610$.

Allison, L.A., Wong, J.K., Fitzpatrick, V.D., Moyle, M., and Ingles, C.J. (1988). The Cterminal domain of the largest subunit of RNA polymerase II of Saccharomyces cerevisiae, Drosophila melanogaster, and mammals: a conserved structure with an essential function. Mol Cell Biol 8, 321-329.

Amberg, D.B., D; and Strathern, JN (2005). Methods in Yeast Genetics: A Cold Spring Harbor Laboratory Course Manual

Ansari, A., and Hampsey, M. (2005). A role for the CPF 3 '-end processing machinery in RNAP II-dependent gene looping. Genes Dev 19, 2969-2978.

Archambault, J., Chambers, R.S., Kobor, M.S., Ho, Y., Cartier, M., Bolotin, D., Andrews, B., Kane, C.M., and Greenblatt, J. (1997). An essential component of a C-terminal domain phosphatase that interacts with transcription factor IIF in Saccharomyces cerevisiae. Proc Natl Acad Sci U S A 94, 14300-14305.

Archambault, J., Jansma, D.B., Kawasoe, J.H., Arndt, K.T., Greenblatt, J., and Friesen, J.D. (1998). Stimulation of transcription by mutations affecting conserved regions of RNA polymerase II. J Bacteriol 180, 2590-2598.

Arigo, J.T., Eyler, D.E., Carroll, K.L., and Corden, J.L. (2006). Termination of cryptic unstable transcripts is directed by yeast RNA-binding proteins Nrd1 and Nab3. Mol Cell 23, 841-851. 
Armache, K.J., Kettenberger, H., and Cramer, P. (2003). Architecture of initiationcompetent 12-subunit RNA polymerase II. Proc Natl Acad Sci U S A 100, 69646968.

Armache, K.J., Mitterweger, S., Meinhart, A., and Cramer, P. (2005). Structures of complete RNA polymerase II and its subcomplex, Rpb4/7. J Biol Chem 280, 7131-7134.

Artsimovitch, I., and Landick, R. (2000). Pausing by bacterial RNA polymerase is mediated by mechanistically distinct classes of signals. Proc Natl Acad Sci U S A 97, 7090-7095.

Awrey, D.E., Weilbaecher, R.G., Hemming, S.A., Orlicky, S.M., Kane, C.M., and Edwards, A.M. (1997). Transcription elongation through DNA arrest sites. A multistep process involving both RNA polymerase II subunit RPB9 and TFIIS. J Biol Chem 272, 14747-14754.

Baillat, D., Hakimi, M.A., Naar, A.M., Shilatifard, A., Cooch, N., and Shiekhattar, R. (2005). Integrator, a multiprotein mediator of small nuclear RNA processing, associates with the C-terminal repeat of RNA polymerase II. Cell 123, 265-276.

Banerjee, S., Kumar, B.R., and Kundu, T.K. (2004). General transcriptional coactivator PC4 activates p53 function. Mol Cell Biol 24, 2052-2062.

Barilla, D., Lee, B.A., and Proudfoot, N.J. (2001). Cleavage/polyadenylation factor IA associates with the carboxyl-terminal domain of RNA polymerase II in Saccharomyces cerevisiae. Proc Natl Acad Sci U S A 98, 445-450.

Bartkowiak, B., and Greenleaf, A.L. (2011). Phosphorylation of RNAPII: To P-TEFb or not to P-TEFb? Transcription 2, 115-119.

Bartkowiak, B., Liu, P., Phatnani, H.P., Fuda, N.J., Cooper, J.J., Price, D.H., Adelman, K., Lis, J.T., and Greenleaf, A.L. (2010). CDK12 is a transcription elongationassociated CTD kinase, the metazoan ortholog of yeast Ctk1. Genes Dev 24, 2303-2316.

Baskaran, R., Chiang, G.G., Mysliwiec, T., Kruh, G.D., and Wang, J.Y. (1997). Tyrosine phosphorylation of RNA polymerase II carboxyl-terminal domain by the Abl-related gene product. J Biol Chem 272, 18905-18909.

Baskaran, R., Dahmus, M.E., and Wang, J.Y. (1993). Tyrosine phosphorylation of mammalian RNA polymerase II carboxyl-terminal domain. Proc Natl Acad Sci U S A 90, 11167-11171.

Baskaran, R., Escobar, S.R., and Wang, J.Y. (1999). Nuclear c-Abl is a COOH-terminal repeated domain (CTD)-tyrosine (CTD)-tyrosine kinase-specific for the mammalian RNA polymerase II: possible role in transcription elongation. Cell Growth Differ 10, 387-396. 
Bataille, A.R., Jeronimo, C., Jacques, P.E., Laramee, L., Fortin, M.E., Forest, A., Bergeron, M., Hanes, S.D., and Robert, F. (2012). A universal RNA polymerase II CTD cycle is orchestrated by complex interplays between kinase, phosphatase, and isomerase enzymes along genes. Mol Cell 45, 158-170.

Beckouet, F., Mariotte-Labarre, S., Peyroche, G., Nogi, Y., and Thuriaux, P. (2011). Rpa43 and its partners in the yeast RNA polymerase I transcription complex. FEBS Lett 585, 3355-3359.

Beyer, A.L., and Osheim, Y.N. (1988). Splice site selection, rate of splicing, and alternative splicing on nascent transcripts. Genes Dev 2, 754-765.

Birse, C.E., Minvielle-Sebastia, L., Lee, B.A., Keller, W., and Proudfoot, N.J. (1998). Coupling termination of transcription to messenger RNA maturation in yeast. Science 280, 298-301.

Blazek, D., Kohoutek, J., Bartholomeeusen, K., Johansen, E., Hulinkova, P., Luo, Z., Cimermancic, P., Ule, J., and Peterlin, B.M. (2011). The Cyclin K/Cdk12 complex maintains genomic stability via regulation of expression of DNA damage response genes. Genes Dev 25, 2158-2172.

Borggrefe, T., Davis, R., Erdjument-Bromage, H., Tempst, P., and Kornberg, R.D. (2002). A complex of the Srb8, $-9,-10$, and -11 transcriptional regulatory proteins from yeast. J Biol Chem 277, 44202-44207.

Bortvin, A., and Winston, F. (1996). Evidence that Spt6p controls chromatin structure by a direct interaction with histones. Science 272, 1473-1476.

Bouchoux, C., Hautbergue, G., Grenetier, S., Carles, C., Riva, M., and Goguel, V. (2004). CTD kinase I is involved in RNA polymerase I transcription. Nucleic Acids Res 32, 5851-5860.

Brachmann, C.B., Davies, A., Cost, G.J., Caputo, E., Li, J., Hieter, P., and Boeke, J.D. (1998). Designer deletion strains derived from Saccharomyces cerevisiae S288C: a useful set of strains and plasmids for PCR-mediated gene disruption and other applications. Yeast 14, 115-132.

Brannan, K., and Bentley, D.L. (2012). Control of Transcriptional Elongation by RNA Polymerase II: A Retrospective. Genet Res Int 2012, 170173.

Brawerman, G. (1981). The Role of the poly(A) sequence in mammalian messenger RNA. CRC Crit Rev Biochem 10, 1-38.

Bregman, D.B., Du, L., van der Zee, S., and Warren, S.L. (1995). Transcriptiondependent redistribution of the large subunit of RNA polymerase II to discrete nuclear domains. J Cell Biol 129, 287-298.

Brill, S.J., and Sternglanz, R. (1988). Transcription-dependent DNA supercoiling in yeast DNA topoisomerase mutants. Cell 54, 403-411. 
Brodsky, A.S., and Silver, P.A. (2000). Pre-mRNA processing factors are required for nuclear export. RNA 6, 1737-1749.

Brown, C.E., and Sachs, A.B. (1998). Poly(A) tail length control in Saccharomyces cerevisiae occurs by message-specific deadenylation. Mol Cell Biol 18, 65486559.

Buratowski, S. (2003). The CTD code. Nat Struct Biol 10, 679-680.

Buratowski, S. (2005). Connections between mRNA 3' end processing and transcription termination. Curr Opin Cell Biol 17, 257-261.

Buratowski, S. (2009). Progression through the RNA polymerase II CTD cycle. Mol Cell 36, 541-546.

Bushnell, D.A., and Kornberg, R.D. (2003). Complete, 12-subunit RNA polymerase II at 4.1-A resolution: implications for the initiation of transcription. Proc Natl Acad Sci U S A 100, 6969-6973.

Cadena, D.L., and Dahmus, M.E. (1987). Messenger RNA synthesis in mammalian cells is catalyzed by the phosphorylated form of RNA polymerase II. J Biol Chem $262,12468-12474$.

Cai, G., Imasaki, T., Takagi, Y., and Asturias, F.J. (2009). Mediator structural conservation and implications for the regulation mechanism. Structure 17, 559567.

Cai, G., Imasaki, T., Yamada, K., Cardelli, F., Takagi, Y., and Asturias, F.J. (2010). Mediator head module structure and functional interactions. Nat Struct Mol Biol 17, 273-279.

Calvo, O., and Garcia, A. (2012). RNA Polymerase II Phosphorylation and Gene Expression Regulation. Protein Phosphorylation in Human Health (Ed.), ISBN: 978-953-51-0737-8, InTech.

Calvo, O., and Manley, J.L. (2001). Evolutionarily conserved interaction between CstF64 and PC4 links transcription, polyadenylation, and termination. Mol Cell 7, 1013-1023.

Calvo, O., and Manley, J.L. (2005). The transcriptional coactivator PC4/Sub1 has multiple functions in RNA polymerase II transcription. EMBO J 24, 1009-1020.

Carles, C., Treich, I., Bouet, F., Riva, M., and Sentenac, A. (1991). Two additional common subunits, $\mathrm{ABC} 10$ alpha and $\mathrm{ABC} 10$ beta, are shared by yeast RNA polymerases. J Biol Chem 266, 24092-24096.

Carlson, M. (1997). Genetics of transcriptional regulation in yeast: connections to the RNA polymerase II CTD. Annu Rev Cell Dev Biol 13, 1-23.

Cismowski, M.J., Laff, G.M., Solomon, M.J., and Reed, S.I. (1995). KIN28 encodes a C-terminal domain kinase that controls mRNA transcription in Saccharomyces 
cerevisiae but lacks cyclin-dependent kinase-activating kinase (CAK) activity. Mol Cell Biol 15, 2983-2992.

Clark, T.A., Sugnet, C.W., and Ares, M., Jr. (2002). Genomewide analysis of mRNA processing in yeast using splicing-specific microarrays. Science 296, 907-910.

Clausing, E., Mayer, A., Chanarat, S., Muller, B., Germann, S.M., Cramer, P., Lisby, M., and Strasser, K. (2010). The transcription elongation factor Bur1-Bur2 interacts with replication protein $\mathrm{A}$ and maintains genome stability during replication stress. J Biol Chem 285, 41665-41674.

Clemente-Blanco, A., Sen, N., Mayan-Santos, M., Sacristan, M.P., Graham, B., Jarmuz, A., Giess, A., Webb, E., Game, L., Eick, D., et al. (2011). Cdc14 phosphatase promotes segregation of telomeres through repression of RNA polymerase II transcription. Nat Cell Biol 13, 1450-1456.

Collart, M.A., Tourkine, N., Belin, D., Vassalli, P., Jeanteur, P., and Blanchard, J.M. (1991). c-fos gene transcription in murine macrophages is modulated by a calcium-dependent block to elongation in intron 1. Mol Cell Biol 11, 2826-2831.

Comer, F.I., and Hart, G.W. (2001). Reciprocity between O-GlcNAc and O-phosphate on the carboxyl terminal domain of RNA polymerase II. Biochemistry 40, 78457852.

Conesa, C., and Acker, J. (2010). Sub1/PC4 a chromatin associated protein with multiple functions in transcription. RNA Biol 7, 287-290.

Coppola, J.A., Field, A.S., and Luse, D.S. (1983). Promoter-proximal pausing by RNA polymerase II in vitro: transcripts shorter than 20 nucleotides are not capped. Proc Natl Acad Sci U S A 80, 1251-1255.

Corden, J.L. (1990). Tails of RNA polymerase II. Trends Biochem Sci 15, 383-387.

Corden, J.L. (2007). Transcription. Seven ups the code. Science 318, 1735-1736.

Corden, J.L., Cadena, D.L., Ahearn, J.M., Jr., and Dahmus, M.E. (1985). A unique structure at the carboxyl terminus of the largest subunit of eukaryotic RNA polymerase II. Proc Natl Acad Sci U S A 82, 7934-7938.

Coulon, V., Veyrune, J.L., Tourkine, N., Vie, A., Hipskind, R.A., and Blanchard, J.M. (1999). A novel calcium signaling pathway targets the c-fos intragenic transcriptional pausing site. J Biol Chem 274, 30439-30446.

Cramer, P. (2002a). Common structural features of nucleic acid polymerases. Bioessays 24, 724-729.

Cramer, P. (2002b). Multisubunit RNA polymerases. Curr Opin Struct Biol 12, 89-97.

Cramer, P. (2004). RNA polymerase II structure: from core to functional complexes. Curr Opin Genet Dev 14, 218-226. 
Cramer, P., Armache, K.J., Baumli, S., Benkert, S., Brueckner, F., Buchen, C., Damsma, G.E., Dengl, S., Geiger, S.R., Jasiak, A.J., et al. (2008). Structure of eukaryotic RNA polymerases. Annu Rev Biophys 37, 337-352.

Cramer, P., Bushnell, D.A., Fu, J., Gnatt, A.L., Maier-Davis, B., Thompson, N.E., Burgess, R.R., Edwards, A.M., David, P.R., and Kornberg, R.D. (2000). Architecture of RNA polymerase II and implications for the transcription mechanism. Science 288, 640-649.

Cramer, P., Bushnell, D.A., and Kornberg, R.D. (2001). Structural basis of transcription: RNA polymerase II at 2.8 angstrom resolution. Science 292, 18631876.

Chambers, R.S., and Dahmus, M.E. (1994). Purification and characterization of a phosphatase from HeLa cells which dephosphorylates the C-terminal domain of RNA polymerase II. J Biol Chem 269, 26243-26248.

Chambers, R.S., and Kane, C.M. (1996). Purification and characterization of an RNA polymerase II phosphatase from yeast. J Biol Chem 271, 24498-24504.

Chan, C.L., and Landick, R. (1993). Dissection of the his leader pause site by base substitution reveals a multipartite signal that includes a pause RNA hairpin. J Mol Biol 233, 25-42.

Chanarat, S., Seizl, M., and Strasser, K. (2011). The Prp19 complex is a novel transcription elongation factor required for TREX occupancy at transcribed genes. Genes Dev 25, 1147-1158.

Chapman, R.D., Heidemann, M., Albert, T.K., Mailhammer, R., Flatley, A., Meisterernst, M., Kremmer, E., and Eick, D. (2007). Transcribing RNA polymerase II is phosphorylated at CTD residue serine-7. Science 318, 17801782.

Chapman, R.D., Heidemann, M., Hintermair, C., and Eick, D. (2008). Molecular evolution of the RNA polymerase II CTD. Trends Genet 24, 289-296.

Chapman, R.D., Palancade, B., Lang, A., Bensaude, O., and Eick, D. (2004). The last CTD repeat of the mammalian RNA polymerase II large subunit is important for its stability. Nucleic Acids Res 32, 35-44.

Chen, H.T., Warfield, L., and Hahn, S. (2007). The positions of TFIIF and TFIIE in the RNA polymerase II transcription preinitiation complex. Nat Struct Mol Biol 14, 696-703.

Chervitz, S.A., Hester, E.T., Ball, C.A., Dolinski, K., Dwight, S.S., Harris, M.A., Juvik, G., Malekian, A., Roberts, S., Roe, T., et al. (1999). Using the Saccharomyces Genome Database (SGD) for analysis of protein similarities and structure. Nucleic Acids Res 27, 74-78. 
Cheung, A.C., and Cramer, P. (2012). A movie of RNA polymerase II transcription. Cell 149, 1431-1437.

Chi, Y., Huddleston, M.J., Zhang, X., Young, R.A., Annan, R.S., Carr, S.A., and Deshaies, R.J. (2001). Negative regulation of Gcn4 and Msn2 transcription factors by Srb10 cyclin-dependent kinase. Genes Dev 15, 1078-1092.

Chiu, Y.L., Ho, C.K., Saha, N., Schwer, B., Shuman, S., and Rana, T.M. (2002). Tat stimulates cotranscriptional capping of HIV mRNA. Mol Cell 10, 585-597.

Cho, E.J., Kobor, M.S., Kim, M., Greenblatt, J., and Buratowski, S. (2001). Opposing effects of Ctk1 kinase and Fcp1 phosphatase at Ser 2 of the RNA polymerase II C-terminal domain. Genes Dev 15, 3319-3329.

Cho, E.J., Rodriguez, C.R., Takagi, T., and Buratowski, S. (1998). Allosteric interactions between capping enzyme subunits and the RNA polymerase II carboxy-terminal domain. Genes Dev 12, 3482-3487.

Cho, E.J., Takagi, T., Moore, C.R., and Buratowski, S. (1997). mRNA capping enzyme is recruited to the transcription complex by phosphorylation of the RNA polymerase II carboxy-terminal domain. Genes Dev 11, 3319-3326.

Choder, M. (2004). Rpb4 and Rpb7: subunits of RNA polymerase II and beyond. Trends Biochem Sci 29, 674-681.

Chu, Y., Simic, R., Warner, M.H., Arndt, K.M., and Prelich, G. (2007). Regulation of histone modification and cryptic transcription by the Bur1 and Paf1 complexes. EMBO J 26, 4646-4656.

Dahan, N., and Choder, M. (2012). The eukaryotic transcriptional machinery regulates mRNA translation and decay in the cytoplasm. Biochim Biophys Acta.

Darzacq, X., Shav-Tal, Y., de Turris, V., Brody, Y., Shenoy, S.M., Phair, R.D., and Singer, R.H. (2007). In vivo dynamics of RNA polymerase II transcription. Nat Struct Mol Biol 14, 796-806.

Das, C., Hizume, K., Batta, K., Kumar, B.R., Gadad, S.S., Ganguly, S., Lorain, S., Verreault, A., Sadhale, P.P., Takeyasu, K., et al. (2006). Transcriptional coactivator PC4, a chromatin-associated protein, induces chromatin condensation. Mol Cell Biol 26, 8303-8315.

Daulny, A., and Tansey, W.P. (2009). Damage control: DNA repair, transcription, and the ubiquitin-proteasome system. DNA Repair (Amst) 8, 444-448.

Davey, M., Hannam, C., Wong, C., and Brandl, C.J. (2000). The yeast peptidyl proline isomerases FPR3 and FPR4, in high copy numbers, suppress defects resulting from the absence of the E3 ubiquitin ligase TOM1. Mol Gen Genet 263, 520-526.

David, C.J., Boyne, A.R., Millhouse, S.R., and Manley, J.L. (2011). The RNA polymerase II C-terminal domain promotes splicing activation through recruitment of a U2AF65-Prp19 complex. Genes Dev 25, 972-983. 
David, C.J., and Manley, J.L. (2011). The RNA polymerase C-terminal domain: a new role in spliceosome assembly. Transcription 2, 221-225.

Davis, C.A., Grate, L., Spingola, M., and Ares, M., Jr. (2000). Test of intron predictions reveals novel splice sites, alternatively spliced mRNAs and new introns in meiotically regulated genes of yeast. Nucleic Acids Res 28, 1700-1706.

de la Mata, M., Alonso, C.R., Kadener, S., Fededa, J.P., Blaustein, M., Pelisch, F., Cramer, P., Bentley, D., and Kornblihtt, A.R. (2003). A slow RNA polymerase II affects alternative splicing in vivo. Mol Cell 12, 525-532.

Dermody, J.L., Dreyfuss, J.M., Villen, J., Ogundipe, B., Gygi, S.P., Park, P.J., Ponticelli, A.S., Moore, C.L., Buratowski, S., and Bucheli, M.E. (2008). Unphosphorylated SR-like protein Npl3 stimulates RNA polymerase II elongation. PLoS One 3, e3273.

Desmoucelles, C., Pinson, B., Saint-Marc, C., and Daignan-Fornier, B. (2002). Screening the yeast "disruptome" for mutants affecting resistance to the immunosuppressive drug, mycophenolic acid. J Biol Chem 277, 27036-27044.

Dettmann, A., Jaschke, Y., Triebel, I., Bogs, J., Schroder, I., and Schuller, H.J. (2010). Mediator subunits and histone methyltransferase Set2 contribute to Ino2dependent transcriptional activation of phospholipid biosynthesis in the yeast Saccharomyces cerevisiae. Mol Genet Genomics 283, 211-221.

Dichtl, B., Blank, D., Ohnacker, M., Friedlein, A., Roeder, D., Langen, H., and Keller, W. (2002). A role for SSU72 in balancing RNA polymerase II transcription elongation and termination. Mol Cell 10, 1139-1150.

Ding, B., LeJeune, D., and Li, S. (2010). The C-terminal repeat domain of Spt5 plays an important role in suppression of Rad26-independent transcription coupled repair. $\mathrm{J}$ Biol Chem 285, 5317-5326.

Dolinski, K., Muir, S., Cardenas, M., and Heitman, J. (1997). All cyclophilins and FK506 binding proteins are, individually and collectively, dispensable for viability in Saccharomyces cerevisiae. Proc Natl Acad Sci U S A 94, 1309313098.

Donner, A.J., Ebmeier, C.C., Taatjes, D.J., and Espinosa, J.M. (2010). CDK8 is a positive regulator of transcriptional elongation within the serum response network. Nat Struct Mol Biol 17, 194-201.

Drouin, S., Laramee, L., Jacques, P.E., Forest, A., Bergeron, M., and Robert, F. (2010). DSIF and RNA polymerase II CTD phosphorylation coordinate the recruitment of Rpd3S to actively transcribed genes. PLoS Genet 6, e1001173.

Dvir, A., Conaway, R.C., and Conaway, J.W. (1997). A role for TFIIH in controlling the activity of early RNA polymerase II elongation complexes. Proc Natl Acad Sci U S A 94, 9006-9010. 
Edwards, A.M., Kane, C.M., Young, R.A., and Kornberg, R.D. (1991). Two dissociable subunits of yeast RNA polymerase II stimulate the initiation of transcription at a promoter in vitro. J Biol Chem 266, 71-75.

Egloff, S., and Murphy, S. (2008a). Cracking the RNA polymerase II CTD code. Trends Genet 24, 280-288.

Egloff, S., and Murphy, S. (2008b). Role of the C-terminal domain of RNA polymerase II in expression of small nuclear RNA genes. Biochem Soc Trans 36, 537-539.

Egloff, S., O'Reilly, D., Chapman, R.D., Taylor, A., Tanzhaus, K., Pitts, L., Eick, D., and Murphy, S. (2007). Serine-7 of the RNA polymerase II CTD is specifically required for snRNA gene expression. Science 318, 1777-1779.

Egloff, S., Szczepaniak, S.A., Dienstbier, M., Taylor, A., Knight, S., and Murphy, S. (2010). The integrator complex recognizes a new double mark on the RNA polymerase II carboxyl-terminal domain. J Biol Chem 285, 20564-20569.

Egloff, S., Zaborowska, J., Laitem, C., Kiss, T., and Murphy, S. (2012). Ser7 phosphorylation of the CTD recruits the RPAP2 Ser5 phosphatase to snRNA genes. Mol Cell 45, 111-122.

El Kaderi, B., Medler, S., Raghunayakula, S., and Ansari, A. (2009). Gene looping is conferred by activator-dependent interaction of transcription initiation and termination machineries. J Biol Chem 284, 25015-25025.

Escobar-Henriques, M., Balguerie, A., Monribot, C., Boucherie, H., and DaignanFornier, B. (2001). Proteome analysis and morphological studies reveal multiple effects of the immunosuppressive drug mycophenolic acid specifically resulting from guanylic nucleotide depletion. J Biol Chem 276, 46237-46242.

Esnault, C., Ghavi-Helm, Y., Brun, S., Soutourina, J., Van Berkum, N., Boschiero, C., Holstege, F., and Werner, M. (2008). Mediator-dependent recruitment of TFIIH modules in preinitiation complex. Mol Cell 31, 337-346.

Espinoza, F.H., Farrell, A., Nourse, J.L., Chamberlin, H.M., Gileadi, O., and Morgan, D.O. (1998). Cak1 is required for Kin 28 phosphorylation and activation in vivo. Mol Cell Biol 18, 6365-6373.

Fabrega, C., Shen, V., Shuman, S., and Lima, C.D. (2003). Structure of an mRNA capping enzyme bound to the phosphorylated carboxy-terminal domain of RNA polymerase II. Mol Cell 11, 1549-1561.

Fish, R.N., and Kane, C.M. (2002). Promoting elongation with transcript cleavage stimulatory factors. Biochim Biophys Acta 1577, 287-307.

Fong, N., and Bentley, D.L. (2001). Capping, splicing, and 3' processing are independently stimulated by RNA polymerase II: different functions for different segments of the CTD. Genes Dev 15, 1783-1795. 
Fujinaga, K., Irwin, D., Huang, Y., Taube, R., Kurosu, T., and Peterlin, B.M. (2004). Dynamics of human immunodeficiency virus transcription: $\mathrm{P}-\mathrm{TEFb}$ phosphorylates $\mathrm{RD}$ and dissociates negative effectors from the transactivation response element. Mol Cell Biol 24, 787-795.

Fukuda, A., Nakadai, T., Shimada, M., Tsukui, T., Matsumoto, M., Nogi, Y., Meisterernst, M., and Hisatake, K. (2004). Transcriptional coactivator PC4 stimulates promoter escape and facilitates transcriptional synergy by GAL4VP16. Mol Cell Biol 24, 6525-6535.

Funakoshi, M., and Hochstrasser, M. (2009). Small epitope-linker modules for PCRbased C-terminal tagging in Saccharomyces cerevisiae. Yeast 26, 185-192.

Gaillard, H., Tous, C., Botet, J., Gonzalez-Aguilera, C., Quintero, M.J., Viladevall, L., Garcia-Rubio, M.L., Rodriguez-Gil, A., Marin, A., Arino, J., et al. (2009). Genome-wide analysis of factors affecting transcription elongation and DNA repair: a new role for PAF and Ccr4-not in transcription-coupled repair. PLoS Genet 5, e1000364.

Galbraith, M.D., Donner, A.J., and Espinosa, J.M. (2010). CDK8: a positive regulator of transcription. Transcription 1, 4-12.

Garcia-Lopez, M.C., Pelechano, V., Miron-Garcia, M.C., Garrido-Godino, A.I., Garcia, A., Calvo, O., Werner, M., Perez-Ortin, J.E., and Navarro, F. (2011). The conserved foot domain of RNA pol II associates with proteins involved in transcriptional initiation and/or early elongation. Genetics 189, 1235-1248.

Gavin, A.C., Bosche, M., Krause, R., Grandi, P., Marzioch, M., Bauer, A., Schultz, J., Rick, J.M., Michon, A.M., Cruciat, C.M., et al. (2002). Functional organization of the yeast proteome by systematic analysis of protein complexes. Nature 415, 141147.

Ge, H., and Roeder, R.G. (1994). Purification, cloning, and characterization of a human coactivator, PC4, that mediates transcriptional activation of class II genes. Cell $78,513-523$.

Ge, H., Zhao, Y., Chait, B.T., and Roeder, R.G. (1994). Phosphorylation negatively regulates the function of coactivator PC4. Proc Natl Acad Sci U S A 91, 1269112695.

Gemmill, T.R., Wu, X., and Hanes, S.D. (2005). Vanishingly low levels of Ess1 prolylisomerase activity are sufficient for growth in Saccharomyces cerevisiae. J Biol Chem 280, 15510-15517.

Ghosh, A., Shuman, S., and Lima, C.D. (2011). Structural insights to how mammalian capping enzyme reads the CTD code. Mol Cell 43, 299-310. 
Gibney, P.A., Fries, T., Bailer, S.M., and Morano, K.A. (2008). Rtr1 is the Saccharomyces cerevisiae homolog of a novel family of RNA polymerase IIbinding proteins. Eukaryot Cell 7, 938-948.

Gietz, R.D., Schiestl, R.H., Willems, A.R., and Woods, R.A. (1995). Studies on the transformation of intact yeast cells by the LiAc/SS-DNA/PEG procedure. Yeast $11,355-360$.

Gietz, R.D., and Sugino, A. (1988). New yeast-Escherichia coli shuttle vectors constructed with in vitro mutagenized yeast genes lacking six-base pair restriction sites. Gene 74, 527-534.

Gilmour, D.S., and Lis, J.T. (1986). RNA polymerase II interacts with the promoter region of the noninduced hsp70 gene in Drosophila melanogaster cells. Mol Cell Biol 6, 3984-3989.

Glover-Cutter, K., Kim, S., Espinosa, J., and Bentley, D.L. (2008). RNA polymerase II pauses and associates with pre-mRNA processing factors at both ends of genes. Nat Struct Mol Biol 15, 71-78.

Glover-Cutter, K., Larochelle, S., Erickson, B., Zhang, C., Shokat, K., Fisher, R.P., and Bentley, D.L. (2009). TFIIH-associated Cdk7 kinase functions in phosphorylation of C-terminal domain Ser7 residues, promoter-proximal pausing, and termination by RNA polymerase II. Mol Cell Biol 29, 5455-5464.

Gnatt, A.L., Cramer, P., Fu, J., Bushnell, D.A., and Kornberg, R.D. (2001). Structural basis of transcription: an RNA polymerase II elongation complex at $3.3 \mathrm{~A}$ resolution. Science 292, 1876-1882.

Gomez-Herreros, F., de Miguel-Jimenez, L., Millan-Zambrano, G., Penate, X., Delgado-Ramos, L., Munoz-Centeno, M.C., and Chavez, S. (2012). One step back before moving forward: regulation of transcription elongation by arrest and backtracking. FEBS Lett.

Govind, C.K., Qiu, H., Ginsburg, D.S., Ruan, C., Hofmeyer, K., Hu, C., Swaminathan, V., Workman, J.L., Li, B., and Hinnebusch, A.G. (2010). Phosphorylated Pol II CTD recruits multiple HDACs, including $\operatorname{Rpd} 3 \mathrm{C}(\mathrm{S})$, for methylation-dependent deacetylation of ORF nucleosomes. Mol Cell 39, 234-246.

Govind, C.K., Zhang, F., Qiu, H., Hofmeyer, K., and Hinnebusch, A.G. (2007). Gcn5 promotes acetylation, eviction, and methylation of nucleosomes in transcribed coding regions. Mol Cell 25, 31-42.

Green, S.R., and Johnson, A.D. (2004). Promoter-dependent roles for the Srb10 cyclindependent kinase and the Hdal deacetylase in Tup1-mediated repression in Saccharomyces cerevisiae. Mol Biol Cell 15, 4191-4202.

Grenetier, S., Bouchoux, C., and Goguel, V. (2006). CTD kinase I is required for the integrity of the rDNA tandem array. Nucleic Acids Res 34, 4996-5006. 
Grohmann, D., Nagy, J., Chakraborty, A., Klose, D., Fielden, D., Ebright, R.H., Michaelis, J., and Werner, F. (2011). The initiation factor TFE and the elongation factor Spt $4 / 5$ compete for the RNAP clamp during transcription initiation and elongation. Mol Cell 43, 263-274.

Grohmann, D., and Werner, F. (2010). Hold on!: RNA polymerase interactions with the nascent RNA modulate transcription elongation and termination. RNA Biol 7, 310-315.

Grohmann, D., and Werner, F. (2011). Cycling through transcription with the RNA polymerase F/E (RPB4/7) complex: structure, function and evolution of archaeal RNA polymerase. Res Microbiol 162, 10-18.

Groner, B., Hynes, N., and Phillips, S. (1974). Length heterogeneity in the poly (adenylic acid) region of yeast messenger ribonucleic acid. Biochemistry 13, 5378-5383.

Guidi, B.W., Bjornsdottir, G., Hopkins, D.C., Lacomis, L., Erdjument-Bromage, H., Tempst, P., and Myers, L.C. (2004). Mutual targeting of mediator and the TFIIH kinase Kin28. J Biol Chem 279, 29114-29120.

Guillamot, M., Manchado, E., Chiesa, M., Gomez-Lopez, G., Pisano, D.G., Sacristan, M.P., and Malumbres, M. (2011). Cdc14b regulates mammalian RNA polymerase II and represses cell cycle transcription. Sci Rep 1, 189.

Guo, M., Xu, F., Yamada, J., Egelhofer, T., Gao, Y., Hartzog, G.A., Teng, M., and Niu, L. (2008). Core structure of the yeast spt4-spt5 complex: a conserved module for regulation of transcription elongation. Structure 16, 1649-1658.

Haag, J.R., and Pikaard, C.S. (2011). Multisubunit RNA polymerases IV and V: purveyors of non-coding RNA for plant gene silencing. Nat Rev Mol Cell Biol 12, 483-492.

Hampsey, M. (1998). Molecular genetics of the RNA polymerase II general transcriptional machinery. Microbiol Mol Biol Rev 62, 465-503.

Hampsey, M., and Kinzy, T.G. (2007). Synchronicity: policing multiple aspects of gene expression by Ctk1. Genes Dev 21, 1288-1291.

Hampsey, M., Singh, B.N., Ansari, A., Laine, J.P., and Krishnamurthy, S. (2011). Control of eukaryotic gene expression: gene loops and transcriptional memory. Adv Enzyme Regul 51, 118-125.

Hanahan, D. (1983). Studies on transformation of Escherichia coli with plasmids. J Mol Biol 166, 557-580.

Harel-Sharvit, L., Eldad, N., Haimovich, G., Barkai, O., Duek, L., and Choder, M. (2010). RNA polymerase II subunits link transcription and mRNA decay to translation. Cell 143, 552-563. 
Hargreaves, D.C., Horng, T., and Medzhitov, R. (2009). Control of inducible gene expression by signal-dependent transcriptional elongation. Cell 138, 129-145.

Hartzog, G.A., Wada, T., Handa, H., and Winston, F. (1998). Evidence that Spt4, Spt5, and Spt6 control transcription elongation by RNA polymerase II in Saccharomyces cerevisiae. Genes Dev 12, 357-369.

Hausmann, S., and Shuman, S. (2002). Characterization of the CTD phosphatase Fcp1 from fission yeast. Preferential dephosphorylation of serine 2 versus serine 5. J Biol Chem 277, 21213-21220.

He, X., Khan, A.U., Cheng, H., Pappas, D.L., Jr., Hampsey, M., and Moore, C.L. (2003). Functional interactions between the transcription and mRNA 3' end processing machineries mediated by Ssu72 and Sub1. Genes Dev 17, 1030-1042.

Heidemann, M., Hintermair, C., Voss, K., and Eick, D. (2012). Dynamic phosphorylation patterns of RNA polymerase II CTD during transcription. Biochim Biophys Acta.

Hengartner, C.J., Myer, V.E., Liao, S.M., Wilson, C.J., Koh, S.S., and Young, R.A. (1998). Temporal regulation of RNA polymerase II by Srb10 and Kin28 cyclindependent kinases. Mol Cell 2, 43-53.

Henry, N.L., Bushnell, D.A., and Kornberg, R.D. (1996). A yeast transcriptional stimulatory protein similar to human PC4. J Biol Chem 271, 21842-21847.

Hintermair, C., Heidemann, M., Koch, F., Descostes, N., Gut, M., Gut, I., Fenouil, R., Ferrier, P., Flatley, A., Kremmer, E., et al. (2012). Threonine-4 of mammalian RNA polymerase II CTD is targeted by Polo-like kinase 3 and required for transcriptional elongation. EMBO J 31, 2784-2797.

Hiraga, K., Suzuki, K., Tsuchiya, E., and Miyakawa, T. (1993). Cloning and characterization of the elongation factor EF-1 beta homologue of Saccharomyces cerevisiae. EF-1 beta is essential for growth. FEBS Lett 316, 165-169.

Hirayoshi, K., and Lis, J.T. (1999). Nuclear run-on assays: assessing transcription by measuring density of engaged RNA polymerases. Methods Enzymol 304, 351362.

Hirose, Y., and Manley, J.L. (1998). RNA polymerase II is an essential mRNA polyadenylation factor. Nature 395, 93-96.

Hirose, Y., and Manley, J.L. (2000). RNA polymerase II and the integration of nuclear events. Genes Dev 14, 1415-1429.

Hirose, Y., Tacke, R., and Manley, J.L. (1999). Phosphorylated RNA polymerase II stimulates pre-mRNA splicing. Genes Dev 13, 1234-1239. 
Hirst, M., Kobor, M.S., Kuriakose, N., Greenblatt, J., and Sadowski, I. (1999). GAL4 is regulated by the RNA polymerase II holoenzyme-associated cyclin-dependent protein kinase SRB10/CDK8. Mol Cell 3, 673-678.

Hirtreiter, A., Damsma, G.E., Cheung, A.C., Klose, D., Grohmann, D., Vojnic, E., Martin, A.C., Cramer, P., and Werner, F. (2010). Spt4/5 stimulates transcription elongation through the RNA polymerase clamp coiled-coil motif. Nucleic Acids Res 38, 4040-4051.

Ho, C.K., and Shuman, S. (1999). Distinct roles for CTD Ser-2 and Ser-5 phosphorylation in the recruitment and allosteric activation of mammalian mRNA capping enzyme. Mol Cell 3, 405-411.

Hodges, P.E., McKee, A.H., Davis, B.P., Payne, W.E., and Garrels, J.I. (1999). The Yeast Proteome Database (YPD): a model for the organization and presentation of genome-wide functional data. Nucleic Acids Res 27, 69-73.

Holstege, F.C., Fiedler, U., and Timmers, H.T. (1997). Three transitions in the RNA polymerase II transcription complex during initiation. EMBO J 16, 7468-7480.

Holstege, F.C., Jennings, E.G., Wyrick, J.J., Lee, T.I., Hengartner, C.J., Green, M.R., Golub, T.R., Lander, E.S., and Young, R.A. (1998). Dissecting the regulatory circuitry of a eukaryotic genome. Cell 95, 717-728.

Howe, K.J., Kane, C.M., and Ares, M., Jr. (2003). Perturbation of transcription elongation influences the fidelity of internal exon inclusion in Saccharomyces cerevisiae. RNA 9, 993-1006.

Hsin, J.P., and Manley, J.L. (2012). The RNA polymerase II CTD coordinates transcription and RNA processing. Genes Dev 26, 2119-2137.

Hsin, J.P., Sheth, A., and Manley, J.L. (2011). RNAP II CTD phosphorylated on threonine-4 is required for histone mRNA 3' end processing. Science 334, 683686.

Hurt, E., Luo, M.J., Rother, S., Reed, R., and Strasser, K. (2004). Cotranscriptional recruitment of the serine-arginine-rich (SR)-like proteins Gbp2 and Hrb1 to nascent mRNA via the TREX complex. Proc Natl Acad Sci U S A 101, 18581862.

Hyle, J.W., Shaw, R.J., and Reines, D. (2003). Functional distinctions between IMP dehydrogenase genes in providing mycophenolate resistance and guanine prototrophy to yeast. J Biol Chem 278, 28470-28478.

Izban, M.G., and Luse, D.S. (1992). The RNA polymerase II ternary complex cleaves the nascent transcript in a 3'----5' direction in the presence of elongation factor SII. Genes Dev 6, 1342-1356.

Jaehning, J.A. (2010). The Paf1 complex: platform or player in RNA polymerase II transcription? Biochim Biophys Acta 1799, 379-388. 
Jasiak, A.J., Hartmann, H., Karakasili, E., Kalocsay, M., Flatley, A., Kremmer, E., Strasser, K., Martin, D.E., Soding, J., and Cramer, P. (2008). Genome-associated RNA polymerase II includes the dissociable Rpb4/7 subcomplex. J Biol Chem 283, 26423-26427.

Jenks, M.H., O'Rourke, T.W., and Reines, D. (2008). Properties of an intergenic terminator and start site switch that regulate IMD2 transcription in yeast. Mol Cell Biol 28, 3883-3893.

Jenuwein, T., and Allis, C.D. (2001). Translating the histone code. Science 293, 10741080.

Jiang, Y., Yan, M., and Gralla, J.D. (1996). A three-step pathway of transcription initiation leading to promoter clearance at an activation RNA polymerase II promoter. Mol Cell Biol 16, 1614-1621.

Jimenez, A., and Davies, J. (1980). Expression of a transposable antibiotic resistance element in Saccharomyces. Nature 287, 869-871.

Jimeno-Gonzalez, S., Gomez-Herreros, F., Alepuz, P.M., and Chavez, S. (2006). A gene-specific requirement for FACT during transcription is related to the chromatin organization of the transcribed region. Mol Cell Biol 26, 8710-8721.

Jimeno-Gonzalez, S., Haaning, L.L., Malagon, F., and Jensen, T.H. (2010). The yeast 5'-3' exonuclease Rat1p functions during transcription elongation by RNA polymerase II. Mol Cell 37, 580-587.

Jimeno, S., Rondon, A.G., Luna, R., and Aguilera, A. (2002). The yeast THO complex and mRNA export factors link RNA metabolism with transcription and genome instability. EMBO J 21, 3526-3535.

Jones, J.C., Phatnani, H.P., Haystead, T.A., MacDonald, J.A., Alam, S.M., and Greenleaf, A.L. (2004). C-terminal repeat domain kinase I phosphorylates Ser2 and Ser5 of RNA polymerase II C-terminal domain repeats. J Biol Chem 279, 24957-24964.

Jonker, H.R., Wechselberger, R.W., Boelens, R., Kaptein, R., and Folkers, G.E. (2006a). The intrinsically unstructured domain of PC4 modulates the activity of the structured core through inter- and intramolecular interactions. Biochemistry $45,5067-5081$.

Jonker, H.R., Wechselberger, R.W., Pinkse, M., Kaptein, R., and Folkers, G.E. (2006b). Gradual phosphorylation regulates PC4 coactivator function. FEBS J 273, 14301444.

Joshi, R.S., Pina, B., and Roca, J. (2012). Topoisomerase II is required for the production of long Pol II gene transcripts in yeast. Nucleic Acids Res. 
Juneau, K., Palm, C., Miranda, M., and Davis, R.W. (2007). High-density yeast-tiling array reveals previously undiscovered introns and extensive regulation of meiotic splicing. Proc Natl Acad Sci U S A 104, 1522-1527.

Justice, M.C., Hsu, M.J., Tse, B., Ku, T., Balkovec, J., Schmatz, D., and Nielsen, J. (1998). Elongation factor 2 as a novel target for selective inhibition of fungal protein synthesis. J Biol Chem 273, 3148-3151.

Kaldis, P., Sutton, A., and Solomon, M.J. (1996). The Cdk-activating kinase (CAK) from budding yeast. Cell $86,553-564$.

Kamenski, T., Heilmeier, S., Meinhart, A., and Cramer, P. (2004). Structure and mechanism of RNA polymerase II CTD phosphatases. Mol Cell 15, 399-407.

Kaplan, C.D., Jin, H., Zhang, I.L., and Belyanin, A. (2012). Dissection of Pol II trigger loop function and Pol II activity-dependent control of start site selection in vivo. PLoS Genet 8, e1002627.

Kaplan, C.D., Laprade, L., and Winston, F. (2003). Transcription elongation factors repress transcription initiation from cryptic sites. Science 301, 1096-1099.

Keller, W., and Minvielle-Sebastia, L. (1997). A comparison of mammalian and yeast pre-mRNA 3'-end processing. Curr Opin Cell Biol 9, 329-336.

Kellis, M., Patterson, N., Endrizzi, M., Birren, B., and Lander, E.S. (2003). Sequencing and comparison of yeast species to identify genes and regulatory elements. Nature $423,241-254$.

Kelly, W.G., Dahmus, M.E., and Hart, G.W. (1993). RNA polymerase II is a glycoprotein. Modification of the COOH-terminal domain by O-GlcNAc. J Biol Chem 268, 10416-10424.

Keogh, M.C., Cho, E.J., Podolny, V., and Buratowski, S. (2002). Kin28 is found within TFIIH and a Kin28-Ccl1-Tfb3 trimer complex with differential sensitivities to Tloop phosphorylation. Mol Cell Biol 22, 1288-1297.

Keogh, M.C., Podolny, V., and Buratowski, S. (2003). Bur1 kinase is required for efficient transcription elongation by RNA polymerase II. Mol Cell Biol 23, 70057018.

Kim, H., Erickson, B., Luo, W., Seward, D., Graber, J.H., Pollock, D.D., Megee, P.C., and Bentley, D.L. (2010). Gene-specific RNA polymerase II phosphorylation and the CTD code. Nat Struct Mol Biol 17, 1279-1286.

Kim, H.J., Jeong, S.H., Heo, J.H., Jeong, S.J., Kim, S.T., Youn, H.D., Han, J.W., Lee, H.W., and Cho, E.J. (2004a). mRNA capping enzyme activity is coupled to an early transcription elongation. Mol Cell Biol 24, 6184-6193.

Kim, J., Guermah, M., McGinty, R.K., Lee, J.S., Tang, Z., Milne, T.A., Shilatifard, A., Muir, T.W., and Roeder, R.G. (2009a). RAD6-Mediated transcription-coupled 
H2B ubiquitylation directly stimulates H3K4 methylation in human cells. Cell 137, 459-471.

Kim, M., Ahn, S.H., Krogan, N.J., Greenblatt, J.F., and Buratowski, S. (2004b). Transitions in RNA polymerase II elongation complexes at the 3 ' ends of genes. EMBO J 23, 354-364.

Kim, M., Suh, H., Cho, E.J., and Buratowski, S. (2009b). Phosphorylation of the yeast Rpb1 C-terminal domain at serines 2, 5, and 7. J Biol Chem 284, 26421-26426.

Kim, T., and Buratowski, S. (2009). Dimethylation of H3K4 by Set1 recruits the Set3 histone deacetylase complex to 5 ' transcribed regions. Cell 137, 259-272.

Kim, T.K., Ebright, R.H., and Reinberg, D. (2000). Mechanism of ATP-dependent promoter melting by transcription factor IIH. Science 288, 1418-1422.

Kimura, M., and Ishihama, A. (2004). Tfg3, a subunit of the general transcription factor TFIIF in Schizosaccharomyces pombe, functions under stress conditions. Nucleic Acids Res 32, 6706-6715.

Kimura, M., Suzuki, H., and Ishihama, A. (2002). Formation of a carboxy-terminal domain phosphatase (Fcp1)/TFIIF/RNA polymerase II (pol II) complex in Schizosaccharomyces pombe involves direct interaction between Fcp1 and the Rpb4 subunit of pol II. Mol Cell Biol 22, 1577-1588.

Kinzy, T.G., and Woolford, J.L., Jr. (1995). Increased expression of Saccharomyces cerevisiae translation elongation factor 1 alpha bypasses the lethality of a TEF5 null allele encoding elongation factor 1 beta. Genetics 141, 481-489.

Kireeva, M.L., and Kashlev, M. (2009). Mechanism of sequence-specific pausing of bacterial RNA polymerase. Proc Natl Acad Sci U S A 106, 8900-8905.

Kizer, K.O., Phatnani, H.P., Shibata, Y., Hall, H., Greenleaf, A.L., and Strahl, B.D. (2005). A novel domain in Set2 mediates RNA polymerase II interaction and couples histone H3 K36 methylation with transcript elongation. Mol Cell Biol 25, 3305-3316.

Klein, B.J., Bose, D., Baker, K.J., Yusoff, Z.M., Zhang, X., and Murakami, K.S. (2011). RNA polymerase and transcription elongation factor Spt4/5 complex structure. Proc Natl Acad Sci U S A 108, 546-550.

Knaus, R., Pollock, R., and Guarente, L. (1996). Yeast SUB1 is a suppressor of TFIIB mutations and has homology to the human co-activator PC4. EMBO J 15, 1933 1940.

Knop, M., Siegers, K., Pereira, G., Zachariae, W., Winsor, B., Nasmyth, K., and Schiebel, E. (1999). Epitope tagging of yeast genes using a PCR-based strategy: more tags and improved practical routines. Yeast 15, 963-972. 
Knuesel, M.T., Meyer, K.D., Bernecky, C., and Taatjes, D.J. (2009). The human CDK8 subcomplex is a molecular switch that controls Mediator coactivator function. Genes Dev 23, 439-451.

Kobor, M.S., Archambault, J., Lester, W., Holstege, F.C., Gileadi, O., Jansma, D.B., Jennings, E.G., Kouyoumdjian, F., Davidson, A.R., Young, R.A., et al. (1999). An unusual eukaryotic protein phosphatase required for transcription by RNA polymerase II and CTD dephosphorylation in S. cerevisiae. Mol Cell 4, 55-62.

Kohoutek, J., and Blazek, D. (2012). Cyclin K goes with Cdk12 and Cdk13. Cell Div 7, 12.

Kolodziej, P.A., Woychik, N., Liao, S.M., and Young, R.A. (1990). RNA polymerase II subunit composition, stoichiometry, and phosphorylation. Mol Cell Biol 10, 19151920.

Komarnitsky, P., Cho, E.J., and Buratowski, S. (2000). Different phosphorylated forms of RNA polymerase II and associated mRNA processing factors during transcription. Genes Dev 14, 2452-2460.

Komissarova, N., and Kashlev, M. (1997). RNA polymerase switches between inactivated and activated states By translocating back and forth along the DNA and the RNA. J Biol Chem 272, 15329-15338.

Kong, S.E., Kobor, M.S., Krogan, N.J., Somesh, B.P., Sogaard, T.M., Greenblatt, J.F., and Svejstrup, J.Q. (2005). Interaction of Fcp1 phosphatase with elongating RNA polymerase II holoenzyme, enzymatic mechanism of action, and genetic interaction with elongator. J Biol Chem 280, 4299-4306.

Kornberg, R.D. (2005). Mediator and the mechanism of transcriptional activation. Trends Biochem Sci 30, 235-239.

Kostrewa, D., Zeller, M.E., Armache, K.J., Seizl, M., Leike, K., Thomm, M., and Cramer, P. (2009). RNA polymerase II-TFIIB structure and mechanism of transcription initiation. Nature 462, 323-330.

Kouzarides, T. (2002). Histone methylation in transcriptional control. Curr Opin Genet Dev 12, 198-209.

Koyama, H., Sumiya, E., Nagata, M., Ito, T., and Sekimizu, K. (2008). Transcriptional repression of the IMD2 gene mediated by the transcriptional co-activator Sub1. Genes Cells 13, 1113-1126.

Kramer, A. (1996). The structure and function of proteins involved in mammalian premRNA splicing. Annu Rev Biochem 65, 367-409.

Kress, T.L., Krogan, N.J., and Guthrie, C. (2008). A single SR-like protein, Npl3, promotes pre-mRNA splicing in budding yeast. Mol Cell 32, 727-734. 
Krishnamurthy, S., Ghazy, M.A., Moore, C., and Hampsey, M. (2009). Functional interaction of the Ess1 prolyl isomerase with components of the RNA polymerase II initiation and termination machineries. Mol Cell Biol 29, 2925-2934.

Krishnamurthy, S., He, X., Reyes-Reyes, M., Moore, C., and Hampsey, M. (2004). Ssu72 Is an RNA polymerase II CTD phosphatase. Mol Cell 14, 387-394.

Krogan, N.J., Dover, J., Wood, A., Schneider, J., Heidt, J., Boateng, M.A., Dean, K., Ryan, O.W., Golshani, A., Johnston, M., et al. (2003a). The Paf1 complex is required for histone $\mathrm{H} 3$ methylation by COMPASS and Dot1p: linking transcriptional elongation to histone methylation. Mol Cell 11, 721-729.

Krogan, N.J., Kim, M., Ahn, S.H., Zhong, G., Kobor, M.S., Cagney, G., Emili, A., Shilatifard, A., Buratowski, S., and Greenblatt, J.F. (2002). RNA polymerase II elongation factors of Saccharomyces cerevisiae: a targeted proteomics approach. Mol Cell Biol 22, 6979-6992.

Krogan, N.J., Kim, M., Tong, A., Golshani, A., Cagney, G., Canadien, V., Richards, D.P., Beattie, B.K., Emili, A., Boone, C., et al. (2003b). Methylation of histone $\mathrm{H} 3$ by Set 2 in Saccharomyces cerevisiae is linked to transcriptional elongation by RNA polymerase II. Mol Cell Biol 23, 4207-4218.

Kruk, J.A., Dutta, A., Fu, J., Gilmour, D.S., and Reese, J.C. (2011). The multifunctional Ccr4-Not complex directly promotes transcription elongation. Genes Dev 25, 581593.

Kuehner, J.N., and Brow, D.A. (2008). Regulation of a eukaryotic gene by GTPdependent start site selection and transcription attenuation. Mol Cell 31, 201-211.

Kuehner, J.N., Pearson, E.L., and Moore, C. (2011). Unravelling the means to an end: RNA polymerase II transcription termination. Nat Rev Mol Cell Biol 12, 283-294.

Kulaeva, O.I., Hsieh, F.K., Chang, H.W., Luse, D.S., and Studitsky, V.M. (2012). Mechanism of transcription through a nucleosome by RNA polymerase II. Biochim Biophys Acta.

Kuras, L., and Struhl, K. (1999). Binding of TBP to promoters in vivo is stimulated by activators and requires Pol II holoenzyme. Nature 399, 609-613.

Kushner, S. (1978). An improve method for transformation Escherichia coli with ColE1 derived plasmids. In Genetic engineering, H.W.B.a.S. Nicosia, ed. (Amsterdam: Elsevier/North-Holland Biomedical Press), pp. 17-23.

Kwapisz, M., Beckouet, F., and Thuriaux, P. (2008a). Early evolution of eukaryotic DNA-dependent RNA polymerases. Trends Genet 24, 211-215.

Kwapisz, M., Wery, M., Despres, D., Ghavi-Helm, Y., Soutourina, J., Thuriaux, P., and Lacroute, F. (2008b). Mutations of RNA polymerase II activate key genes of the nucleoside triphosphate biosynthetic pathways. EMBO J 27, 2411-2421. 
Laemmli, U.K. (1970). Cleavage of structural proteins during the assembly of the head of bacteriophage T4. Nature 227, 680-685.

Lander, E.S., Linton, L.M., Birren, B., Nusbaum, C., Zody, M.C., Baldwin, J., Devon, K., Dewar, K., Doyle, M., FitzHugh, W., et al. (2001). Initial sequencing and analysis of the human genome. Nature 409, 860-921.

Landick, R. (2006). The regulatory roles and mechanism of transcriptional pausing. Biochem Soc Trans 34, 1062-1066.

Laribee, R.N., Krogan, N.J., Xiao, T., Shibata, Y., Hughes, T.R., Greenblatt, J.F., and Strahl, B.D. (2005). BUR kinase selectively regulates H3 K4 trimethylation and $\mathrm{H} 2 \mathrm{~B}$ ubiquitylation through recruitment of the PAF elongation complex. Curr Biol 15, 1487-1493.

Larochelle, S., Amat, R., Glover-Cutter, K., Sanso, M., Zhang, C., Allen, J.J., Shokat, K.M., Bentley, D.L., and Fisher, R.P. (2012). Cyclin-dependent kinase control of the initiation-to-elongation switch of RNA polymerase II. Nat Struct Mol Biol.

Larschan, E., and Winston, F. (2005). The Saccharomyces cerevisiae Srb8-Srb11 complex functions with the SAGA complex during Gal4-activated transcription. Mol Cell Biol 25, 114-123.

Lewis, J.D., and Izaurralde, E. (1997). The role of the cap structure in RNA processing and nuclear export. Eur J Biochem 247, 461-469.

Li, B., Carey, M., and Workman, J.L. (2007). The role of chromatin during transcription. Cell 128, 707-719.

Li, S., and Smerdon, M.J. (2002). Rpb4 and Rpb9 mediate subpathways of transcription-coupled DNA repair in Saccharomyces cerevisiae. EMBO J 21, 5921-5929.

Liao, S.M., Zhang, J., Jeffery, D.A., Koleske, A.J., Thompson, C.M., Chao, D.M., Viljoen, M., van Vuuren, H.J., and Young, R.A. (1995). A kinase-cyclin pair in the RNA polymerase II holoenzyme. Nature 374, 193-196.

Licatalosi, D.D., Geiger, G., Minet, M., Schroeder, S., Cilli, K., McNeil, J.B., and Bentley, D.L. (2002). Functional interaction of yeast pre-mRNA 3' end processing factors with RNA polymerase II. Mol Cell 9, 1101-1111.

Lindstrom, D.L., and Hartzog, G.A. (2001). Genetic interactions of Spt4-Spt5 and TFIIS with the RNA polymerase II CTD and CTD modifying enzymes in Saccharomyces cerevisiae. Genetics 159, 487-497.

Lindstrom, D.L., Squazzo, S.L., Muster, N., Burckin, T.A., Wachter, K.C., Emigh, C.A., McCleery, J.A., Yates, J.R., 3rd, and Hartzog, G.A. (2003). Dual roles for Spt5 in pre-mRNA processing and transcription elongation revealed by identification of Spt5-associated proteins. Mol Cell Biol 23, 1368-1378. 
Lis, J. (1998). Promoter-associated pausing in promoter architecture and postinitiation transcriptional regulation. Cold Spring Harb Symp Quant Biol 63, 347-356.

Listerman, I., Sapra, A.K., and Neugebauer, K.M. (2006). Cotranscriptional coupling of splicing factor recruitment and precursor messenger RNA splicing in mammalian cells. Nat Struct Mol Biol 13, 815-822.

Liu, X., Bushnell, D.A., Silva, D.A., Huang, X., and Kornberg, R.D. (2011). Initiation complex structure and promoter proofreading. Science 333, 633-637.

Liu, Y., Kung, C., Fishburn, J., Ansari, A.Z., Shokat, K.M., and Hahn, S. (2004). Two cyclin-dependent kinases promote RNA polymerase II transcription and formation of the scaffold complex. Mol Cell Biol 24, 1721-1735.

Liu, Y., Warfield, L., Zhang, C., Luo, J., Allen, J., Lang, W.H., Ranish, J., Shokat, K.M., and Hahn, S. (2009). Phosphorylation of the transcription elongation factor Spt5 by yeast Bur1 kinase stimulates recruitment of the PAF complex. Mol Cell Biol 29, 4852-4863.

Longtine, M.S., McKenzie, A., 3rd, Demarini, D.J., Shah, N.G., Wach, A., Brachat, A., Philippsen, P., and Pringle, J.R. (1998). Additional modules for versatile and economical PCR-based gene deletion and modification in Saccharomyces cerevisiae. Yeast 14, 953-961.

Lopez, P.J., and Seraphin, B. (1999). Genomic-scale quantitative analysis of yeast premRNA splicing: implications for splice-site recognition. RNA 5, 1135-1137.

Lotan, R., Bar-On, V.G., Harel-Sharvit, L., Duek, L., Melamed, D., and Choder, M. (2005). The RNA polymerase II subunit Rpb4p mediates decay of a specific class of mRNAs. Genes Dev 19, 3004-3016.

Lotan, R., Goler-Baron, V., Duek, L., Haimovich, G., and Choder, M. (2007). The Rpb7p subunit of yeast RNA polymerase II plays roles in the two major cytoplasmic mRNA decay mechanisms. J Cell Biol 178, 1133-1143.

Lu, H., Flores, O., Weinmann, R., and Reinberg, D. (1991). The nonphosphorylated form of RNA polymerase II preferentially associates with the preinitiation complex. Proc Natl Acad Sci U S A 88, 10004-10008.

Lu, K.P., Finn, G., Lee, T.H., and Nicholson, L.K. (2007). Prolyl cis-trans isomerization as a molecular timer. Nat Chem Biol 3, 619-629.

Lu, K.P., and Zhou, X.Z. (2007). The prolyl isomerase PIN1: a pivotal new twist in phosphorylation signalling and disease. Nat Rev Mol Cell Biol 8, 904-916.

Luse, D.S., and Jacob, G.A. (1987). Abortive initiation by RNA polymerase II in vitro at the adenovirus 2 major late promoter. J Biol Chem 262, 14990-14997. 
MacKellar, A.L., and Greenleaf, A.L. (2011). Cotranscriptional association of mRNA export factor Yra1 with C-terminal domain of RNA polymerase II. J Biol Chem 286, 36385-36395.

Malagon, F., Kireeva, M.L., Shafer, B.K., Lubkowska, L., Kashlev, M., and Strathern, J.N. (2006). Mutations in the Saccharomyces cerevisiae RPB1 gene conferring hypersensitivity to 6-azauracil. Genetics 172, 2201-2209.

Malik, S., Guermah, M., and Roeder, R.G. (1998). A dynamic model for PC4 coactivator function in RNA polymerase II transcription. Proc Natl Acad Sci U S A 95, 2192-2197.

Malone, E.A., Fassler, J.S., and Winston, F. (1993). Molecular and genetic characterization of SPT4, a gene important for transcription initiation in Saccharomyces cerevisiae. Mol Gen Genet 237, 449-459.

Mandal, S.S., Cho, H., Kim, S., Cabane, K., and Reinberg, D. (2002). FCP1, a phosphatase specific for the heptapeptide repeat of the largest subunit of RNA polymerase II, stimulates transcription elongation. Mol Cell Biol 22, 7543-7552.

Mandel, C.R., Bai, Y., and Tong, L. (2008). Protein factors in pre-mRNA 3'-end processing. Cell Mol Life Sci 65, 1099-1122.

Maniatis, T., and Reed, R. (2002). An extensive network of coupling among gene expression machines. Nature 416, 499-506.

Martens, C., Krett, B., and Laybourn, P.J. (2001). RNA polymerase II and TBP occupy the repressed CYC1 promoter. Mol Microbiol 40, 1009-1019.

Martin, M., Cho, J., Cesare, A.J., Griffith, J.D., and Attardi, G. (2005). Termination factor-mediated DNA loop between termination and initiation sites drives mitochondrial rRNA synthesis. Cell 123, 1227-1240.

Martinez-Rucobo, F.W., Sainsbury, S., Cheung, A.C., and Cramer, P. (2011). Architecture of the RNA polymerase-Spt $4 / 5$ complex and basis of universal transcription processivity. EMBO J 30, 1302-1310.

Mason, P.B., and Struhl, K. (2003). The FACT complex travels with elongating RNA polymerase II and is important for the fidelity of transcriptional initiation in vivo. Mol Cell Biol 23, 8323-8333.

Mason, P.B., and Struhl, K. (2005). Distinction and relationship between elongation rate and processivity of RNA polymerase II in vivo. Mol Cell 17, 831-840.

Masuda, S., Das, R., Cheng, H., Hurt, E., Dorman, N., and Reed, R. (2005). Recruitment of the human TREX complex to mRNA during splicing. Genes Dev 19, 1512-1517.

Mayer, A., Heidemann, M., Lidschreiber, M., Schreieck, A., Sun, M., Hintermair, C., Kremmer, E., Eick, D., and Cramer, P. (2012a). CTD tyrosine phosphorylation 
impairs termination factor recruitment to RNA polymerase II. Science 336, 1723 1725.

Mayer, A., Lidschreiber, M., Siebert, M., Leike, K., Soding, J., and Cramer, P. (2010). Uniform transitions of the general RNA polymerase II transcription complex. Nat Struct Mol Biol 17, 1272-1278.

Mayer, A., Schreieck, A., Lidschreiber, M., Leike, K., Martin, D.E., and Cramer, P. (2012b). The spt5 C-terminal region recruits yeast 3' RNA cleavage factor I. Mol Cell Biol 32, 1321-1331.

McCracken, S., Fong, N., Rosonina, E., Yankulov, K., Brothers, G., Siderovski, D., Hessel, A., Foster, S., Shuman, S., and Bentley, D.L. (1997a). 5'-Capping enzymes are targeted to pre-mRNA by binding to the phosphorylated carboxyterminal domain of RNA polymerase II. Genes Dev 11, 3306-3318.

McCracken, S., Fong, N., Yankulov, K., Ballantyne, S., Pan, G., Greenblatt, J., Patterson, S.D., Wickens, M., and Bentley, D.L. (1997b). The C-terminal domain of RNA polymerase II couples mRNA processing to transcription. Nature 385, 357-361.

Millhouse, S., and Manley, J.L. (2005). The C-terminal domain of RNA polymerase II functions as a phosphorylation-dependent splicing activator in a heterologous protein. Mol Cell Biol 25, 533-544.

Minvielle-Sebastia, L., Preker, P.J., and Keller, W. (1994). RNA14 and RNA15 proteins as components of a yeast pre-mRNA 3'-end processing factor. Science 266, 17021705 .

Mischo, H.E., Gomez-Gonzalez, B., Grzechnik, P., Rondon, A.G., Wei, W., Steinmetz, L., Aguilera, A., and Proudfoot, N.J. (2011). Yeast Sen1 helicase protects the genome from transcription-associated instability. Mol Cell 41, 21-32.

Missra, A., and Gilmour, D.S. (2010). Interactions between DSIF (DRB sensitivity inducing factor), NELF (negative elongation factor), and the Drosophila RNA polymerase II transcription elongation complex. Proc Natl Acad Sci U S A 107, 11301-11306.

Moore, M.J., Schwartzfarb, E.M., Silver, P.A., and Yu, M.C. (2006). Differential recruitment of the splicing machinery during transcription predicts genome-wide patterns of mRNA splicing. Mol Cell 24, 903-915.

Morillo-Huesca, M., Vanti, M., and Chavez, S. (2006). A simple in vivo assay for measuring the efficiency of gene length-dependent processes in yeast mRNA biogenesis. FEBS J 273, 756-769.

Morris, D.P., and Greenleaf, A.L. (2000). The splicing factor, Prp40, binds the phosphorylated carboxyl-terminal domain of RNA polymerase II. J Biol Chem 275, 39935-39943. 
Morris, D.P., Phatnani, H.P., and Greenleaf, A.L. (1999). Phospho-carboxyl-terminal domain binding and the role of a prolyl isomerase in pre-mRNA 3'-End formation. J Biol Chem 274, 31583-31587.

Mosley, A.L., Pattenden, S.G., Carey, M., Venkatesh, S., Gilmore, J.M., Florens, L., Workman, J.L., and Washburn, M.P. (2009). Rtr1 is a CTD phosphatase that regulates RNA polymerase II during the transition from serine 5 to serine 2 phosphorylation. Mol Cell 34, 168-178.

Moteki, S., and Price, D. (2002). Functional coupling of capping and transcription of mRNA. Mol Cell 10, 599-609.

Munoz, M.J., de la Mata, M., and Kornblihtt, A.R. (2010). The carboxy terminal domain of RNA polymerase II and alternative splicing. Trends Biochem Sci 35, 497-504.

Murray, S., Udupa, R., Yao, S., Hartzog, G., and Prelich, G. (2001). Phosphorylation of the RNA polymerase II carboxy-terminal domain by the Bur1 cyclin-dependent kinase. Mol Cell Biol 21, 4089-4096.

Murthi, A., Shaheen, H.H., Huang, H.Y., Preston, M.A., Lai, T.P., Phizicky, E.M., and Hopper, A.K. (2010). Regulation of tRNA bidirectional nuclear-cytoplasmic trafficking in Saccharomyces cerevisiae. Mol Biol Cell 21, 639-649.

Naji, S., Grunberg, S., and Thomm, M. (2007). The RPB7 orthologue E' is required for transcriptional activity of a reconstituted archaeal core enzyme at low temperatures and stimulates open complex formation. J Biol Chem 282, 1104711057.

Narita, T., Yamaguchi, Y., Yano, K., Sugimoto, S., Chanarat, S., Wada, T., Kim, D.K., Hasegawa, J., Omori, M., Inukai, N., et al. (2003). Human transcription elongation factor NELF: identification of novel subunits and reconstitution of the functionally active complex. Mol Cell Biol 23, 1863-1873.

Nechaev, S., and Adelman, K. (2011). Pol II waiting in the starting gates: Regulating the transition from transcription initiation into productive elongation. Biochim Biophys Acta 1809, 34-45.

Nedea, E., He, X., Kim, M., Pootoolal, J., Zhong, G., Canadien, V., Hughes, T., Buratowski, S., Moore, C.L., and Greenblatt, J. (2003). Organization and function of APT, a subcomplex of the yeast cleavage and polyadenylation factor involved in the formation of mRNA and small nucleolar RNA 3'-ends. J Biol Chem 278, 33000-33010.

Nelson, C., Goto, S., Lund, K., Hung, W., and Sadowski, I. (2003). Srb10/Cdk8 regulates yeast filamentous growth by phosphorylating the transcription factor Ste12. Nature 421, 187-190. 
Ng, H.H., Robert, F., Young, R.A., and Struhl, K. (2003). Targeted recruitment of Set1 histone methylase by elongating Pol II provides a localized mark and memory of recent transcriptional activity. Mol Cell 11, 709-719.

Ni, Z., Olsen, J.B., Guo, X., Zhong, G., Ruan, E.D., Marcon, E., Young, P., Guo, H., Li, J., Moffat, J., et al. (2011). Control of the RNA polymerase II phosphorylation state in promoter regions by CTD interaction domain-containing proteins RPRD1A and RPRD1B. Transcription 2, 237-242.

Ni, Z., Schwartz, B.E., Werner, J., Suarez, J.R., and Lis, J.T. (2004). Coordination of transcription, RNA processing, and surveillance by $\mathrm{P}-\mathrm{TEFb}$ kinase on heat shock genes. Mol Cell 13, 55-65.

O'Sullivan, J.M., Tan-Wong, S.M., Morillon, A., Lee, B., Coles, J., Mellor, J., and Proudfoot, N.J. (2004). Gene loops juxtapose promoters and terminators in yeast. Nat Genet 36, 1014-1018.

Ohkuni, K., and Yamashita, I. (2000). A transcriptional autoregulatory loop for KIN28CCL1 and SRB10-SRB11, each encoding RNA polymerase II CTD kinase-cyclin pair, stimulates the meiotic development of S. cerevisiae. Yeast 16, 829-846.

Orlicky, S.M., Tran, P.T., Sayre, M.H., and Edwards, A.M. (2001). Dissociable Rpb4Rpb7 subassembly of rna polymerase II binds to single-strand nucleic acid and mediates a post-recruitment step in transcription initiation. J Biol Chem 276, 10097-10102.

Orphanides, G., LeRoy, G., Chang, C.H., Luse, D.S., and Reinberg, D. (1998). FACT, a factor that facilitates transcript elongation through nucleosomes. Cell 92, 105-116.

Orphanides, G., Wu, W.H., Lane, W.S., Hampsey, M., and Reinberg, D. (1999). The chromatin-specific transcription elongation factor FACT comprises human SPT16 and SSRP1 proteins. Nature 400, 284-288.

Ostapenko, D., and Solomon, M.J. (2003). Budding yeast CTDK-I is required for DNA damage-induced transcription. Eukaryot Cell 2, 274-283.

Ostapenko, D., and Solomon, M.J. (2005). Phosphorylation by Cak1 regulates the Cterminal domain kinase Ctk1 in Saccharomyces cerevisiae. Mol Cell Biol 25, 3906-3913.

Pal, M., Ponticelli, A.S., and Luse, D.S. (2005). The role of the transcription bubble and TFIIB in promoter clearance by RNA polymerase II. Mol Cell 19, 101-110.

Palancade, B., and Bensaude, O. (2003). Investigating RNA polymerase II carboxylterminal domain (CTD) phosphorylation. Eur J Biochem 270, 3859-3870.

Palangat, M., and Landick, R. (2001). Roles of RNA:DNA hybrid stability, RNA structure, and active site conformation in pausing by human RNA polymerase II. J Mol Biol 311, 265-282. 
Palangat, M., Meier, T.I., Keene, R.G., and Landick, R. (1998). Transcriptional pausing at +62 of the HIV-1 nascent RNA modulates formation of the TAR RNA structure. Mol Cell 1, 1033-1042.

Patturajan, M., Schulte, R.J., Sefton, B.M., Berezney, R., Vincent, M., Bensaude, O., Warren, S.L., and Corden, J.L. (1998). Growth-related changes in phosphorylation of yeast RNA polymerase II. J Biol Chem 273, 4689-4694.

Pei, Y., and Shuman, S. (2002). Interactions between fission yeast mRNA capping enzymes and elongation factor Spt5. J Biol Chem 277, 19639-19648.

Perales, R., and Bentley, D. (2009). "Cotranscriptionality": the transcription elongation complex as a nexus for nuclear transactions. Mol Cell 36, 178-191.

Peterlin, B.M., and Price, D.H. (2006). Controlling the elongation phase of transcription with P-TEFb. Mol Cell 23, 297-305.

Phatnani, H.P., and Greenleaf, A.L. (2006). Phosphorylation and functions of the RNA polymerase II CTD. Genes Dev 20, 2922-2936.

Pinskaya, M., and Morillon, A. (2009). Histone H3 lysine 4 di-methylation: a novel mark for transcriptional fidelity? Epigenetics 4, 302-306.

Pittman, Y.R., Kandl, K., Lewis, M., Valente, L., and Kinzy, T.G. (2009). Coordination of eukaryotic translation elongation factor $1 \mathrm{~A}$ (eEF1A) function in actin organization and translation elongation by the guanine nucleotide exchange factor eEF1Balpha. J Biol Chem 284, 4739-4747.

Pokholok, D.K., Hannett, N.M., and Young, R.A. (2002). Exchange of RNA polymerase II initiation and elongation factors during gene expression in vivo. Mol Cell 9, 799-809.

Ponting, C.P. (2002). Novel domains and orthologues of eukaryotic transcription elongation factors. Nucleic Acids Res 30, 3643-3652.

Powell, W., and Reines, D. (1996). Mutations in the second largest subunit of RNA polymerase II cause 6-azauracil sensitivity in yeast and increased transcriptional arrest in vitro. J Biol Chem 271, 6866-6873.

Prelich, G. (2002). RNA polymerase II carboxy-terminal domain kinases: emerging clues to their function. Eukaryot Cell 1, 153-162.

Prelich, G., and Winston, F. (1993). Mutations that suppress the deletion of an upstream activating sequence in yeast: involvement of a protein kinase and histone $\mathrm{H} 3$ in repressing transcription in vivo. Genetics 135, 665-676.

Proudfoot, N.J. (2011). Ending the message: poly(A) signals then and now. Genes Dev $25,1770-1782$. 
Proudfoot, N.J., Furger, A., and Dye, M.J. (2002). Integrating mRNA processing with transcription. Cell 108, 501-512.

Qiu, H., Hu, C., Gaur, N.A., and Hinnebusch, A.G. (2012). Pol II CTD kinases Bur1 and Kin28 promote Spt5 CTR-independent recruitment of Paf1 complex. EMBO J 31, 3494-3505.

Qiu, H., Hu, C., and Hinnebusch, A.G. (2009). Phosphorylation of the Pol II CTD by KIN28 enhances BUR1/BUR2 recruitment and Ser2 CTD phosphorylation near promoters. Mol Cell 33, 752-762.

Qiu, H., Hu, C., Wong, C.M., and Hinnebusch, A.G. (2006). The Spt4p subunit of yeast DSIF stimulates association of the Paf1 complex with elongating RNA polymerase II. Mol Cell Biol 26, 3135-3148.

Quan, T.K., and Hartzog, G.A. (2010). Histone H3K4 and K36 methylation, Chd1 and Rpd3S oppose the functions of Saccharomyces cerevisiae Spt4-Spt5 in transcription. Genetics 184, 321-334.

Radonjic, M., Andrau, J.C., Lijnzaad, P., Kemmeren, P., Kockelkorn, T.T., van Leenen, D., van Berkum, N.L., and Holstege, F.C. (2005). Genome-wide analyses reveal RNA polymerase II located upstream of genes poised for rapid response upon $\mathrm{S}$. cerevisiae stationary phase exit. Mol Cell 18, 171-183.

Rajyaguru, P., She, M., and Parker, R. (2012). Scd6 targets eIF4G to repress translation: RGG motif proteins as a class of eIF4G-binding proteins. Mol Cell 45, 244-254.

Ramanathan, Y., Rajpara, S.M., Reza, S.M., Lees, E., Shuman, S., Mathews, M.B., and Pe'ery, T. (2001). Three RNA polymerase II carboxyl-terminal domain kinases display distinct substrate preferences. J Biol Chem 276, 10913-10920.

Ranuncolo, S.M., Ghosh, S., Hanover, J.A., Hart, G.W., and Lewis, B.A. (2012). Evidence of the involvement of O-GlcNAc-modified human RNA polymerase II CTD in transcription in vitro and in vivo. J Biol Chem 287, 23549-23561.

Rasmussen, E.B., and Lis, J.T. (1993). In vivo transcriptional pausing and cap formation on three Drosophila heat shock genes. Proc Natl Acad Sci U S A 90, 7923-7927.

Renner, D.B., Yamaguchi, Y., Wada, T., Handa, H., and Price, D.H. (2001). A highly purified RNA polymerase II elongation control system. J Biol Chem 276, 4260142609.

Rigaut, G., Shevchenko, A., Rutz, B., Wilm, M., Mann, M., and Seraphin, B. (1999). A generic protein purification method for protein complex characterization and proteome exploration. Nat Biotechnol 17, 1030-1032.

Riles, L., Shaw, R.J., Johnston, M., and Reines, D. (2004). Large-scale screening of yeast mutants for sensitivity to the IMP dehydrogenase inhibitor 6-azauracil. Yeast 21, 241-248. 
Rodriguez-Gil, A., Garcia-Martinez, J., Pelechano, V., Munoz-Centeno Mde, L., Geli, V., Perez-Ortin, J.E., and Chavez, S. (2010). The distribution of active RNA polymerase II along the transcribed region is gene-specific and controlled by elongation factors. Nucleic Acids Res 38, 4651-4664.

Rodriguez-Navarro, S., Fischer, T., Luo, M.J., Antunez, O., Brettschneider, S., Lechner, J., Perez-Ortin, J.E., Reed, R., and Hurt, E. (2004). Sus1, a functional component of the SAGA histone acetylase complex and the nuclear pore-associated mRNA export machinery. Cell 116, 75-86.

Rodriguez, C.R., Cho, E.J., Keogh, M.C., Moore, C.L., Greenleaf, A.L., and Buratowski, S. (2000). Kin28, the TFIIH-associated carboxy-terminal domain kinase, facilitates the recruitment of mRNA processing machinery to RNA polymerase II. Mol Cell Biol 20, 104-112.

Rondon, A.G., Jimeno, S., and Aguilera, A. (2010). The interface between transcription and mRNP export: from THO to THSC/TREX-2. Biochim Biophys Acta 1799, 533-538.

Rondon, A.G., Jimeno, S., Garcia-Rubio, M., and Aguilera, A. (2003). Molecular evidence that the eukaryotic THO/TREX complex is required for efficient transcription elongation. J Biol Chem 278, 39037-39043.

Rosonina, E., Willis, I.M., and Manley, J.L. (2009). Sub1 functions in osmoregulation and in transcription by both RNA polymerases II and III. Mol Cell Biol 29, 23082321 .

Rother, S., and Strasser, K. (2007). The RNA polymerase II CTD kinase Ctk1 functions in translation elongation. Genes Dev 21, 1409-1421.

Rougvie, A.E., and Lis, J.T. (1988). The RNA polymerase II molecule at the 5' end of the uninduced hsp70 gene of D. melanogaster is transcriptionally engaged. Cell $54,795-804$.

Roy, R., Adamczewski, J.P., Seroz, T., Vermeulen, W., Tassan, J.P., Schaeffer, L., Nigg, E.A., Hoeijmakers, J.H., and Egly, J.M. (1994). The MO15 cell cycle kinase is associated with the TFIIH transcription-DNA repair factor. Cell 79, 1093-1101.

Ruet, A., Sentenac, A., Fromageot, P., Winsor, B., and Lacroute, F. (1980). A mutation of the B220 subunit gene affects the structural and functional properties of yeast RNA polymerase B in vitro. J Biol Chem 255, 6450-6455.

Runner, V.M., Podolny, V., and Buratowski, S. (2008). The Rpb4 subunit of RNA polymerase II contributes to cotranscriptional recruitment of 3 ' processing factors. Mol Cell Biol 28, 1883-1891. 
Ruprich-Robert, G., and Thuriaux, P. (2010). Non-canonical DNA transcription enzymes and the conservation of two-barrel RNA polymerases. Nucleic Acids Res 38, 4559-4569.

Sampath, V., Balakrishnan, B., Verma-Gaur, J., Onesti, S., and Sadhale, P.P. (2008). Unstructured $\mathrm{N}$ terminus of the RNA polymerase II subunit Rpb4 contributes to the interaction of Rpb4.Rpb7 subcomplex with the core RNA polymerase II of Saccharomyces cerevisiae. J Biol Chem 283, 3923-3931.

Saunders, A., Core, L.J., and Lis, J.T. (2006). Breaking barriers to transcription elongation. Nat Rev Mol Cell Biol 7, 557-567.

Scafe, C., Chao, D., Lopes, J., Hirsch, J.P., Henry, S., and Young, R.A. (1990a). RNA polymerase II C-terminal repeat influences response to transcriptional enhancer signals. Nature 347, 491-494.

Scafe, C., Martin, C., Nonet, M., Podos, S., Okamura, S., and Young, R.A. (1990b). Conditional mutations occur predominantly in highly conserved residues of RNA polymerase II subunits. Mol Cell Biol 10, 1270-1275.

Schang, L.M., Hwang, G.J., Dynlacht, B.D., Speicher, D.W., Bantly, A., Schaffer, P.A., Shilatifard, A., Ge, H., and Shiekhattar, R. (2000). Human PC4 is a substratespecific inhibitor of RNA polymerase II phosphorylation. J Biol Chem 275, 60716074.

Schirmaier, F., and Philippsen, P. (1984). Identification of two genes coding for the translation elongation factor EF-1 alpha of S. cerevisiae. EMBO J 3, 3311-3315.

Schmitt, M.E., Brown, T.A., and Trumpower, B.L. (1990). A rapid and simple method for preparation of RNA from Saccharomyces cerevisiae. Nucleic Acids Res 18, 3091-3092.

Schneider, D.A., French, S.L., Osheim, Y.N., Bailey, A.O., Vu, L., Dodd, J., Yates, J.R., Beyer, A.L., and Nomura, M. (2006). RNA polymerase II elongation factors $\mathrm{Spt} 4 \mathrm{p}$ and Spt5p play roles in transcription elongation by RNA polymerase I and rRNA processing. Proc Natl Acad Sci U S A 103, 12707-12712.

Schroeder, S.C., Schwer, B., Shuman, S., and Bentley, D. (2000). Dynamic association of capping enzymes with transcribing RNA polymerase II. Genes Dev 14, $2435-$ 2440.

Schwartz, L.B., and Roeder, R.G. (1975). Purification and subunit structure of deoxyribonucleic acid-dependent ribonucleic acid polymerase II from the mouse plasmacytoma, MOPC 315. J Biol Chem 250, 3221-3228.

Selitrennik, M., Duek, L., Lotan, R., and Choder, M. (2006). Nucleocytoplasmic shuttling of the Rpb4p and Rpb7p subunits of Saccharomyces cerevisiae RNA polymerase II by two pathways. Eukaryot Cell 5, 2092-2103. 
Selth, L.A., Sigurdsson, S., and Svejstrup, J.Q. (2010). Transcript Elongation by RNA Polymerase II. Annu Rev Biochem 79, 271-293.

Serizawa, H., Makela, T.P., Conaway, J.W., Conaway, R.C., Weinberg, R.A., and Young, R.A. (1995). Association of Cdk-activating kinase subunits with transcription factor TFIIH. Nature 374, 280-282.

Shandilya, J., and Roberts, S.G. (2012). The transcription cycle in eukaryotes: From productive initiation to RNA polymerase II recycling. Biochim Biophys Acta $1819,391-400$.

Shaw, R.J., and Reines, D. (2000). Saccharomyces cerevisiae transcription elongation mutants are defective in PUR5 induction in response to nucleotide depletion. Mol Cell Biol 20, 7427-7437.

Sheffer, A., Varon, M., and Choder, M. (1999). Rpb7 can interact with RNA polymerase II and support transcription during some stresses independently of Rpb4. Mol Cell Biol 19, 2672-2680.

Shen, Z., St-Denis, A., and Chartrand, P. (2010). Cotranscriptional recruitment of She2p by RNA pol II elongation factor Spt4-Spt5/DSIF promotes mRNA localization to the yeast bud. Genes Dev 24, 1914-1926.

Shiekhattar, R., Mermelstein, F., Fisher, R.P., Drapkin, R., Dynlacht, B., Wessling, H.C., Morgan, D.O., and Reinberg, D. (1995). Cdk-activating kinase complex is a component of human transcription factor TFIIH. Nature 374, 283-287.

Shilatifard, A. (2008). Molecular implementation and physiological roles for histone H3 lysine 4 (H3K4) methylation. Curr Opin Cell Biol 20, 341-348.

Shilatifard, A., Conaway, R.C., and Conaway, J.W. (2003). The RNA polymerase II elongation complex. Annu Rev Biochem 72, 693-715.

Shuman, S. (2001). Structure, mechanism, and evolution of the mRNA capping apparatus. Prog Nucleic Acid Res Mol Biol 66, 1-40.

Sikorski, T.W., and Buratowski, S. (2009). The basal initiation machinery: beyond the general transcription factors. Curr Opin Cell Biol 21, 344-351.

Sikorski, T.W., Ficarro, S.B., Holik, J., Kim, T., Rando, O.J., Marto, J.A., and Buratowski, S. (2011). Sub1 and RPA associate with RNA polymerase II at different stages of transcription. Mol Cell 44, 397-409.

Simon, M., Seraphin, B., and Faye, G. (1986). KIN28, a yeast split gene coding for a putative protein kinase homologous to CDC28. EMBO J 5, 2697-2701.

Sims, R.J., 3rd, Rojas, L.A., Beck, D., Bonasio, R., Schuller, R., Drury, W.J., 3rd, Eick, D., and Reinberg, D. (2011). The C-terminal domain of RNA polymerase II is modified by site-specific methylation. Science 332, 99-103. 
Singh, B.N., and Hampsey, M. (2007). A transcription-independent role for TFIIB in gene looping. Mol Cell 27, 806-816.

Skaar, D.A., and Greenleaf, A.L. (2002). The RNA polymerase II CTD kinase CTDK-I affects pre-mRNA 3' cleavage/polyadenylation through the processing component Pti1p. Mol Cell 10, 1429-1439.

Somesh, B.P., Reid, J., Liu, W.F., Sogaard, T.M., Erdjument-Bromage, H., Tempst, P., and Svejstrup, J.Q. (2005). Multiple mechanisms confining RNA polymerase II ubiquitylation to polymerases undergoing transcriptional arrest. Cell 121, 913923.

Somesh, B.P., Sigurdsson, S., Saeki, H., Erdjument-Bromage, H., Tempst, P., and Svejstrup, J.Q. (2007). Communication between distant sites in RNA polymerase II through ubiquitylation factors and the polymerase CTD. Cell 129, 57-68.

Spain, M.M., and Govind, C.K. (2011). A role for phosphorylated Pol II CTD in modulating transcription coupled histone dynamics. Transcription 2, 78-81.

Spingola, M., Grate, L., Haussler, D., and Ares, M., Jr. (1999). Genome-wide bioinformatic and molecular analysis of introns in Saccharomyces cerevisiae. RNA 5, 221-234.

St-Pierre, B., Liu, X., Kha, L.C., Zhu, X., Ryan, O., Jiang, Z., and Zacksenhaus, E. (2005). Conserved and specific functions of mammalian ssu72. Nucleic Acids Res $33,464-477$.

Stegmeier, F., and Amon, A. (2004). Closing mitosis: the functions of the Cdc14 phosphatase and its regulation. Annu Rev Genet 38, 203-232.

Steiner, T., Kaiser, J.T., Marinkovic, S., Huber, R., and Wahl, M.C. (2002). Crystal structures of transcription factor NusG in light of its nucleic acid- and proteinbinding activities. EMBO J 21, 4641-4653.

Steinmetz, E.J., and Brow, D.A. (1996). Repression of gene expression by an exogenous sequence element acting in concert with a heterogeneous nuclear ribonucleoprotein-like protein, Nrd1, and the putative helicase Sen1. Mol Cell Biol 16, 6993-7003.

Steinmetz, E.J., and Brow, D.A. (2003). Ssu72 protein mediates both poly(A)-coupled and poly(A)-independent termination of RNA polymerase II transcription. Mol Cell Biol 23, 6339-6349.

Sterner, D.E., Lee, J.M., Hardin, S.E., and Greenleaf, A.L. (1995). The yeast carboxylterminal repeat domain kinase CTDK-I is a divergent cyclin-cyclin-dependent kinase complex. Mol Cell Biol 15, 5716-5724.

Stock, J.K., Giadrossi, S., Casanova, M., Brookes, E., Vidal, M., Koseki, H., Brockdorff, N., Fisher, A.G., and Pombo, A. (2007). Ring1-mediated 
ubiquitination of $\mathrm{H} 2 \mathrm{~A}$ restrains poised RNA polymerase II at bivalent genes in mouse ES cells. Nat Cell Biol 9, 1428-1435.

Strahl, B.D., and Allis, C.D. (2000). The language of covalent histone modifications. Nature 403, 41-45.

Strasser, K., Masuda, S., Mason, P., Pfannstiel, J., Oppizzi, M., Rodriguez-Navarro, S., Rondon, A.G., Aguilera, A., Struhl, K., Reed, R., et al. (2002). TREX is a conserved complex coupling transcription with messenger RNA export. Nature 417, 304-308.

Studier, F.W., and Moffatt, B.A. (1986). Use of bacteriophage T7 RNA polymerase to direct selective high-level expression of cloned genes. J Mol Biol 189, 113-130.

Suh, M.H., Meyer, P.A., Gu, M., Ye, P., Zhang, M., Kaplan, C.D., Lima, C.D., and Fu, J. (2010). A dual interface determines the recognition of RNA polymerase II by RNA capping enzyme. J Biol Chem 285, 34027-34038.

Suh, M.H., Ye, P., Zhang, M., Hausmann, S., Shuman, S., Gnatt, A.L., and Fu, J. (2005). Fcp1 directly recognizes the C-terminal domain (CTD) and interacts with a site on RNA polymerase II distinct from the CTD. Proc Natl Acad Sci U S A 102, 17314-17319.

Sun, Z.W., and Hampsey, M. (1996). Synthetic enhancement of a TFIIB defect by a mutation in SSU72, an essential yeast gene encoding a novel protein that affects transcription start site selection in vivo. Mol Cell Biol 16, 1557-1566.

Svejstrup, J.Q. (2003). Rescue of arrested RNA polymerase II complexes. J Cell Sci $116,447-451$.

Svejstrup, J.Q. (2007). Contending with transcriptional arrest during RNAPII transcript elongation. Trends Biochem Sci 32, 165-171.

Swanson, M.S., Malone, E.A., and Winston, F. (1991). SPT5, an essential gene important for normal transcription in Saccharomyces cerevisiae, encodes an acidic nuclear protein with a carboxy-terminal repeat. Mol Cell Biol 11, 4286.

Swanson, M.S., and Winston, F. (1992). SPT4, SPT5 and SPT6 interactions: effects on transcription and viability in Saccharomyces cerevisiae. Genetics 132, 325-336.

Taatjes, D.J. (2010). The human Mediator complex: a versatile, genome-wide regulator of transcription. Trends Biochem Sci 35, 315-322.

Tan-Wong, S.M., French, J.D., Proudfoot, N.J., and Brown, M.A. (2008). Dynamic interactions between the promoter and terminator regions of the mammalian BRCA1 gene. Proc Natl Acad Sci U S A 105, 5160-5165.

Tan, Q., Prysak, M.H., and Woychik, N.A. (2003). Loss of the Rpb4/Rpb7 subcomplex in a mutant form of the Rpb6 subunit shared by RNA polymerases I, II, and III. Mol Cell Biol 23, 3329-3338. 
Tatum, D., Li, W., Placer, M., and Li, S. (2011). Diverse roles of RNA polymerase IIassociated factor 1 complex in different subpathways of nucleotide excision repair. J Biol Chem 286, 30304-30313.

Tavenet, A., Suleau, A., Dubreuil, G., Ferrari, R., Ducrot, C., Michaut, M., Aude, J.C., Dieci, G., Lefebvre, O., Conesa, C., et al. (2009). Genome-wide location analysis reveals a role for Sub1 in RNA polymerase III transcription. Proc Natl Acad Sci U S A 106, 14265-14270.

Thiebaut, M., Kisseleva-Romanova, E., Rougemaille, M., Boulay, J., and Libri, D. (2006). Transcription termination and nuclear degradation of cryptic unstable transcripts: a role for the nrd1-nab3 pathway in genome surveillance. Mol Cell 23, 853-864.

Thomas, B.J., and Rothstein, R. (1989). Elevated recombination rates in transcriptionally active DNA. Cell 56, 619-630.

Thomas, M.C., and Chiang, C.M. (2006). The general transcription machinery and general cofactors. Crit Rev Biochem Mol Biol 41, 105-178.

Thompson, N.E., Steinberg, T.H., Aronson, D.B., and Burgess, R.R. (1989). Inhibition of in vivo and in vitro transcription by monoclonal antibodies prepared against wheat germ RNA polymerase II that react with the heptapeptide repeat of eukaryotic RNA polymerase II. J Biol Chem 264, 11511-11520.

Tietjen, J.R., Zhang, D.W., Rodriguez-Molina, J.B., White, B.E., Akhtar, M.S., Heidemann, M., Li, X., Chapman, R.D., Shokat, K., Keles, S., et al. (2010). Chemical-genomic dissection of the CTD code. Nat Struct Mol Biol 17, 11541161.

Valay, J.G., Simon, M., Dubois, M.F., Bensaude, O., Facca, C., and Faye, G. (1995). The KIN28 gene is required both for RNA polymerase II mediated transcription and phosphorylation of the Rpb1p CTD. J Mol Biol 249, 535-544.

van de Peppel, J., Kettelarij, N., van Bakel, H., Kockelkorn, T.T., van Leenen, D., and Holstege, F.C. (2005). Mediator expression profiling epistasis reveals a signal transduction pathway with antagonistic submodules and highly specific downstream targets. Mol Cell 19, 511-522.

Van Dyck, E., Foury, F., Stillman, B., and Brill, S.J. (1992). A single-stranded DNA binding protein required for mitochondrial DNA replication in S. cerevisiae is homologous to E. coli SSB. EMBO J 11, 3421-3430.

Vazquez-Novelle, M.D., Esteban, V., Bueno, A., and Sacristan, M.P. (2005). Functional homology among human and fission yeast Cdc14 phosphatases. J Biol Chem 280, 29144-29150. 
Venter, J.C., Adams, M.D., Myers, E.W., Li, P.W., Mural, R.J., Sutton, G.G., Smith, H.O., Yandell, M., Evans, C.A., Holt, R.A., et al. (2001). The sequence of the human genome. Science 291, 1304-1351.

Venters, B.J., Wachi, S., Mavrich, T.N., Andersen, B.E., Jena, P., Sinnamon, A.J., Jain, P., Rolleri, N.S., Jiang, C., Hemeryck-Walsh, C., et al. (2011). A comprehensive genomic binding map of gene and chromatin regulatory proteins in Saccharomyces. Mol Cell 41, 480-492.

Verma-Gaur, J., Rao, S.N., Taya, T., and Sadhale, P. (2008). Genomewide recruitment analysis of Rpb4, a subunit of polymerase II in Saccharomyces cerevisiae, reveals its involvement in transcription elongation. Eukaryot Cell 7, 1009-1018.

Viktorovskaya, O.V., Appling, F.D., and Schneider, D.A. (2011). Yeast transcription elongation factor Spt5 associates with RNA polymerase I and RNA polymerase II directly. J Biol Chem 286, 18825-18833.

Viladevall, L., St Amour, C.V., Rosebrock, A., Schneider, S., Zhang, C., Allen, J.J., Shokat, K.M., Schwer, B., Leatherwood, J.K., and Fisher, R.P. (2009). TFIIH and $\mathrm{P}-\mathrm{TEFb}$ coordinate transcription with capping enzyme recruitment at specific genes in fission yeast. Mol Cell 33, 738-751.

Vincent, O., Kuchin, S., Hong, S.P., Townley, R., Vyas, V.K., and Carlson, M. (2001). Interaction of the Srb10 kinase with Sip4, a transcriptional activator of gluconeogenic genes in Saccharomyces cerevisiae. Mol Cell Biol 21, 5790-5796.

Wada, T., Orphanides, G., Hasegawa, J., Kim, D.K., Shima, D., Yamaguchi, Y., Fukuda, A., Hisatake, K., Oh, S., Reinberg, D., et al. (2000). FACT relieves DSIF/NELF-mediated inhibition of transcriptional elongation and reveals functional differences between P-TEFb and TFIIH. Mol Cell 5, 1067-1072.

Wada, T., Takagi, T., Yamaguchi, Y., Ferdous, A., Imai, T., Hirose, S., Sugimoto, S., Yano, K., Hartzog, G.A., Winston, F., et al. (1998a). DSIF, a novel transcription elongation factor that regulates RNA polymerase II processivity, is composed of human Spt4 and Spt5 homologs. Genes Dev 12, 343-356.

Wada, T., Takagi, T., Yamaguchi, Y., Watanabe, D., and Handa, H. (1998b). Evidence that P-TEFb alleviates the negative effect of DSIF on RNA polymerase IIdependent transcription in vitro. EMBO J 17, 7395-7403.

Wang, D., Meier, T.I., Chan, C.L., Feng, G., Lee, D.N., and Landick, R. (1995). Discontinuous movements of DNA and RNA in RNA polymerase accompany formation of a paused transcription complex. Cell 81, 341-350.

Wang, W., Carey, M., and Gralla, J.D. (1992). Polymerase II promoter activation: closed complex formation and ATP-driven start site opening. Science 255, 450453. 
Wang, Z., and Roeder, R.G. (1998). DNA topoisomerase I and PC4 can interact with human TFIIIC to promote both accurate termination and transcription reinitiation by RNA polymerase III. Mol Cell 1, 749-757.

Wen, Y., and Shatkin, A.J. (1999). Transcription elongation factor hSPT5 stimulates mRNA capping. Genes Dev 13, 1774-1779.

Werner, F. (2012). A nexus for gene expression-molecular mechanisms of Spt5 and NusG in the three domains of life. J Mol Biol 417, 13-27.

Werner, F., and Grohmann, D. (2011). Evolution of multisubunit RNA polymerases in the three domains of life. Nat Rev Microbiol 9, 85-98.

Werner, F., and Weinzierl, R.O. (2005). Direct modulation of RNA polymerase core functions by basal transcription factors. Mol Cell Biol 25, 8344-8355.

Westover, K.D., Bushnell, D.A., and Kornberg, R.D. (2004). Structural basis of transcription: separation of RNA from DNA by RNA polymerase II. Science 303, 1014-1016.

Winston, F., Chaleff, D.T., Valent, B., and Fink, G.R. (1984). Mutations affecting Tymediated expression of the HIS4 gene of Saccharomyces cerevisiae. Genetics 107, 179-197.

Wintzerith, M., Acker, J., Vicaire, S., Vigneron, M., and Kedinger, C. (1992). Complete sequence of the human RNA polymerase II largest subunit. Nucleic Acids Res 20, 910.

Wong, C.M., Qiu, H., Hu, C., Dong, J., and Hinnebusch, A.G. (2007). Yeast cap binding complex impedes recruitment of cleavage factor IA to weak termination sites. Mol Cell Biol 27, 6520-6531.

Wood, A., Schneider, J., Dover, J., Johnston, M., and Shilatifard, A. (2003). The Paf1 complex is essential for histone monoubiquitination by the Rad6-Bre1 complex, which signals for histone methylation by COMPASS and Dot1p. J Biol Chem 278, 34739-34742.

Wood, A., Schneider, J., Dover, J., Johnston, M., and Shilatifard, A. (2005). The Bur1/Bur2 complex is required for histone $\mathrm{H} 2 \mathrm{~B}$ monoubiquitination by Rad6/Bre1 and histone methylation by COMPASS. Mol Cell 20, 589-599.

Woudstra, E.C., Gilbert, C., Fellows, J., Jansen, L., Brouwer, J., Erdjument-Bromage, H., Tempst, P., and Svejstrup, J.Q. (2002). A Rad26-Def1 complex coordinates repair and RNA pol II proteolysis in response to DNA damage. Nature 415, 929933.

Woychik, N.A., Liao, S.M., Kolodziej, P.A., and Young, R.A. (1990). Subunits shared by eukaryotic nuclear RNA polymerases. Genes Dev 4, 313-323. 
Wu, S.Y., and Chiang, C.M. (1998). Properties of PC4 and an RNA polymerase II complex in directing activated and basal transcription in vitro. J Biol Chem 273, $12492-12498$.

Wu, W.H., Pinto, I., Chen, B.S., and Hampsey, M. (1999). Mutational analysis of yeast TFIIB. A functional relationship between Ssu72 and Sub1/Tsp1 defined by allelespecific interactions with TFIIB. Genetics 153, 643-652.

Wu, X., Wilcox, C.B., Devasahayam, G., Hackett, R.L., Arevalo-Rodriguez, M., Cardenas, M.E., Heitman, J., and Hanes, S.D. (2000). The Ess1 prolyl isomerase is linked to chromatin remodeling complexes and the general transcription machinery. EMBO J 19, 3727-3738.

Xiang, K., Manley, J.L., and Tong, L. (2012). The yeast regulator of transcription protein Rtr1 lacks an active site and phosphatase activity. Nat Commun 3, 946.

Xiang, K., Nagaike, T., Xiang, S., Kilic, T., Beh, M.M., Manley, J.L., and Tong, L. (2010). Crystal structure of the human symplekin-Ssu72-CTD phosphopeptide complex. Nature 467, 729-733.

Xiao, T., Hall, H., Kizer, K.O., Shibata, Y., Hall, M.C., Borchers, C.H., and Strahl, B.D. (2003). Phosphorylation of RNA polymerase II CTD regulates H3 methylation in yeast. Genes Dev 17, 654-663.

Xiao, T., Kao, C.F., Krogan, N.J., Sun, Z.W., Greenblatt, J.F., Osley, M.A., and Strahl, B.D. (2005). Histone H2B ubiquitylation is associated with elongating RNA polymerase II. Mol Cell Biol 25, 637-651.

Xiao, T., Shibata, Y., Rao, B., Laribee, R.N., O'Rourke, R., Buck, M.J., Greenblatt, J.F., Krogan, N.J., Lieb, J.D., and Strahl, B.D. (2007). The RNA polymerase II kinase Ctk1 regulates positioning of a 5' histone methylation boundary along genes. Mol Cell Biol 27, 721-731.

Xu, Y.X., Hirose, Y., Zhou, X.Z., Lu, K.P., and Manley, J.L. (2003). Pin1 modulates the structure and function of human RNA polymerase II. Genes Dev 17, 27652776.

Xu, Y.X., and Manley, J.L. (2007). Pin1 modulates RNA polymerase II activity during the transcription cycle. Genes Dev 21, 2950-2962.

Yamada, T., Yamaguchi, Y., Inukai, N., Okamoto, S., Mura, T., and Handa, H. (2006). $\mathrm{P}-\mathrm{TEFb}$-mediated phosphorylation of hSpt5 C-terminal repeats is critical for processive transcription elongation. Mol Cell 21, 227-237.

Yamaguchi, Y., Inukai, N., Narita, T., Wada, T., and Handa, H. (2002). Evidence that negative elongation factor represses transcription elongation through binding to a DRB sensitivity-inducing factor/RNA polymerase II complex and RNA. Mol Cell Biol 22, 2918-2927. 
Yamaguchi, Y., Takagi, T., Wada, T., Yano, K., Furuya, A., Sugimoto, S., Hasegawa, J., and Handa, H. (1999). NELF, a multisubunit complex containing RD, cooperates with DSIF to repress RNA polymerase II elongation. Cell 97, 41-51.

Yan, M., and Gralla, J.D. (1997). Multiple ATP-dependent steps in RNA polymerase II promoter melting and initiation. EMBO J 16, 7457-7467.

Yao, S., and Prelich, G. (2002). Activation of the Bur1-Bur2 cyclin-dependent kinase complex by Cak1. Mol Cell Biol 22, 6750-6758.

Yeo, M., Lin, P.S., Dahmus, M.E., and Gill, G.N. (2003). A novel RNA polymerase II C-terminal domain phosphatase that preferentially dephosphorylates serine 5. J Biol Chem 278, 26078-26085.

Young, R.A. (1991). RNA polymerase II. Annu Rev Biochem 60, 689-715.

Yudkovsky, N., Ranish, J.A., and Hahn, S. (2000). A transcription reinitiation intermediate that is stabilized by activator. Nature 408, 225-229.

Zenklusen, D., Vinciguerra, P., Wyss, J.C., and Stutz, F. (2002). Stable mRNP formation and export require cotranscriptional recruitment of the mRNA export factors Yra1p and Sub2p by Hpr1p. Mol Cell Biol 22, 8241-8253.

Zhang, D.W., Mosley, A.L., Ramisetty, S.R., Rodriguez-Molina, J.B., Washburn, M.P., and Ansari, A.Z. (2012). Ssu72 phosphatase-dependent erasure of phospho-Ser7 marks on the RNA polymerase II C-terminal domain is essential for viability and transcription termination. J Biol Chem 287, 8541-8551.

Zhang, J., and Corden, J.L. (1991). Phosphorylation causes a conformational change in the carboxyl-terminal domain of the mouse RNA polymerase II largest subunit. J Biol Chem 266, 2297-2302.

Zhou, K., Kuo, W.H., Fillingham, J., and Greenblatt, J.F. (2009). Control of transcriptional elongation and cotranscriptional histone modification by the yeast BUR kinase substrate Spt5. Proc Natl Acad Sci U S A 106, 6956-6961.

Zhou, Q., Li, T., and Price, D.H. (2012). RNA polymerase II elongation control. Annu Rev Biochem 81, 119-143.

Zhu, B., Zheng, Y., Pham, A.D., Mandal, S.S., Erdjument-Bromage, H., Tempst, P., and Reinberg, D. (2005). Monoubiquitination of human histone H2B: the factors involved and their roles in HOX gene regulation. Mol Cell 20, 601-611. 
6-AU - 6-Azauracilo

A - Adenina

ATP - Adenosín trifosfato

C - Citosina

CAK - CDK Activating Kinase -

Quinasa activadora de Cdks

CDK - Cyclin Dependent Kinase -

Quinasa dependiente de ciclina

cDNA - DNA copia

ChIP - Chromatin Immunoprecipitation

- Inmunoprecipitación de Cromatina

ChIP on chip - Inmunoprecipitación de

Cromatina combinado con tecnología de microarray

Co-IP - Co-inmunoprecipitación

COMPASS - Complex Proteins

Associated with Set1p - Complejo de

Proteínas Asociadas con Set1p

CPF - Cleveage Polyadenylation

Factor - Factor de Corte y

Poliadenilación

CstF - Cleveage Stimulation Factor -

Factor de Estimulación del Corte

CTD - Carboxy-Terminal Domain -

Dominio Carboxilo-Terminal (referido

a Rpb1)

CUTs - Cryptic Unstable Transcripts -

Transcritos crípticos inestables

DO - Densidad Óptica

DEPC - Dietil-dicarbonato

DNA - Ácido Desoxirribonucleico

DNP - Ditipo No Parental

DP - Ditipo Parental
dsDNA - double strand DNA - DNA de

doble cadena

DSIF - DRB Sensitivity Inducing Factor

- Factor de inducción de la sensibilidad

a DRB

DTT - Ditiotreitol

EDTA - Ácido

etilendiaminotetraacético

EtBr - Bromuro de Etidio

FACT - Facilitates Chromatin

Transcription - Complejo que facilita la transcripción a través de la cromatina

G - Guanina

GLAM - Gene Lenght-dependent

Accumulation of mRNA - Acumulación de mensajeros dependiente de longitud génica

GOF - Gain Of Function - Ganancia de Función

GST - Glutation S Transferasa

GTF - General Transcription Factor -

Factor General de la Transcripción

GTP - Guanín trifosfato

HA - Hemaglutinina

HDACs - Histona de-acetilasa

IP - Inmunoprecipitación

IPTG - isopropil- $\beta$-D-tiogalactósido

Kb - Kilobase

LOF - Loss Of Function - Pérdida de

Función

ml - mililitro

mM - mimilimolar

MPA - micofenolato

mRNA - RNA mensajero 
NELF - Negative Elongation Factor -

Factor de Elongación Negativo

ng - nanogramo

nm - nanometro

nt - nucleótidos

NTPs - nucleótidos trifosfato

${ }^{\circ} \mathbf{C}$ - centígrado

ORF - Open Reading Frame - marco de lectura abierto

P-TEFb - Positive Transcription

Elongation Factor $b$ - Factor positivo de Elongación b

PAF - RNA polymerase II Associated

Factor - Factor Asociado a la RNAPII

PAP - PolyA polymerase - PoliA

polimerasa

pb - pares de bases

PBS - Phosphate Buffer Saline -

Tampón fosfato salino

PCR - Polymerase Chain Reaction -

Reacción en Cadena de la Polimerasa

PGK - 3-fosfoglicerato quinasa

PIC - Preinitiation Complex -

Complejo de preiniciación

Poly-A - Poliadeninas

pre-mRNA - RNA mensajero transcrito

primario

Pro - prolina

qPCR - Quantitative PCR - PCR

cuantitativa

RNA - Ácido Ribonucleico

RNAPI - RNA polimerasa I

RNAPII - RNA polimerasa II

RNAPIII - RNA polimerasa III
RNAPIV - RNA polimerasa IV

RNAPV - RNA polimerasa V

RNP - Ribonucleopartícula

RPA - Replication Protein A - Proteína

de Replicación A

rpm - revoluciones por minuto

rRNA - RNA ribosomal

RT-PCR - PCR acoplada a

Transcripción Reversa

RT-qPCR - Quantitative RT-PCR -

PCR cuantitativa acoplada a

Transcripción Reversa

SDS - Sodium dodecyl sulfate - Dodecil

sulfato sódico

Ser - Serina

Ser2 - Residuo/s de serina en posición 2 del heptapétido consenso del dominio CTD de Rpb1.

Ser5 - Residuo/s de serina en posición 5 del heptapétido consenso del dominio CTD de Rpb1.

Ser7- Residuo/s de serina en posición 7 del heptapétido consenso del dominio CTD de Rpb1.

Ser2P - Forma fosforilada de Ser2.

Ser5P - Forma fosforilada de Ser5.

Ser7P- Forma fosforilada de Ser7

siRNA small interference RNA - - RNA

pequeño de interferencia

SnoRNA - small nucleolar RNA - RNA

pequeño nucleolar

snRNA - small nuclear RNA - RNA

pequeño nuclear 
ssDNA - single strand DNA - DNA de

cadena sencilla

T - Timina

TAE - Tris/Acetato/EDTA

TAFs - Factores Asociados a TATA -

TATA Asocciated Factors

TAP - Purificación por Afinidad en

Tándem - Tandem Affinity Purification

TBE - Tris/Borato/EDTA

TBP - TATA Binding Protein - Proteína de unión a TATA

TCR-Transcription Coupled Repair -

Reparación Acoplada a la Transcripción

HATs - Acetil-transferasas de Histonas

TE - Tris/EDTA

Thr - Treonina

Tm - Melting Temperature -

Temperatura de anillamiento

TREX - Complejo de transporte de

mRNAs - Transcription Export

tRNA - RNA de transferencia

TRO - Transcriptional Run-On - Run-

On Transcripcional

TSS - Transcription Start Site - Sitio de Inicio de la Transcripción

Tyr - Tirosina

U - Unidades

U - Uracilo

UAS - Upstream Activating Sequence -

Secuencia de Activación aguas arriba

$\mu \mathrm{g}$ - microgramo

$\mu \mathbf{l}$ - microlitro

UTP - Uridin-trifosfato

UV - Ultravioleta
V - Voltios

$\boldsymbol{w t}$ - wild type - cepa silvestre 


\section{Anexos}




\title{
Sub1 Globally Regulates RNA Polymerase II C-Terminal Domain Phosphorylation ${ }^{\nabla}$
}

\author{
Alicia García, ${ }^{1}$ Emanuel Rosonina, ${ }^{2}$ James L. Manley, ${ }^{2}$ and Olga Calvo ${ }^{1 *}$ \\ Instituto de Microbiología Bioquímica, CSIC/Universidad de Salamanca, Campus Miguel de Unamuno s/n, Salamanca 37007, \\ Spain, ${ }^{1}$ and Department of Biological Sciences, Columbia University, New York, New York $10027^{2}$
}

Received 15 July 2010/Returned for modification 11 August 2010/Accepted 24 August 2010

\begin{abstract}
The transcriptional coactivator Sub1 has been implicated in several aspects of mRNA metabolism in yeast, such as activation of transcription, termination, and $3^{\prime}$-end formation. Here, we present evidence that Sub1 plays a significant role in controlling phosphorylation of the RNA polymerase II large subunit C-terminal domain (CTD). We show that $S U B 1$ genetically interacts with the genes encoding all four known CTD kinases, SRB10, KIN28, BUR1, and CTK1, suggesting that Sub1 acts to influence CTD phosphorylation at more than one step of the transcription cycle. To address this directly, we first used in vitro kinase assays, and we show that, on the one hand, $S U B 1$ deletion increased CTD phosphorylation by Kin28, Bur1, and Ctk1 but, on the other, it decreased CTD phosphorylation by Srb10. Second, chromatin immunoprecipitation assays revealed that $S U B 1$ deletion decreased Srb10 chromatin association on the inducible $G A L 1$ gene but increased Kin28 and Ctk1 chromatin association on actively transcribed genes. Taken together, our data point to multiple roles for Sub1 in the regulation of CTD phosphorylation throughout the transcription cycle.
\end{abstract}

A prominent feature of the largest subunit of RNA polymerase II (RNAP II), Rpb1, is the presence of a highly conserved carboxy-terminal domain (CTD) that has an essential role in transcription regulation in vivo $(12,17,54)$. Although the RNAP II CTD is not required for transcription in promoterindependent assays in vitro, it is essential in vivo (50), and it is required for efficient capping, splicing, and cleavage/polyadenylation of pre-mRNAs $(15,29,47)$. In fact, the CTD has been described as a platform that recruits RNA processing/ export and histone-modifying factors to the transcription complex, coupling mRNA metabolism to chromatin function $(8,54)$.

The CTD is characterized by repetition of the consensus heptapeptide sequence Tyr-Ser-Pro-Thr-Ser-Pro-Ser, ranging from 26 repeats in yeast to 52 in mammals, which is subjected to highly regulated phosphorylation $(14,15,47)$. Unphosphorylated RNAP II is mostly recruited to the preinitiation complex (PIC) (45), and hyperphosphorylated RNAP II is associated with initiation and elongation complexes (42). The CTD is phosphorylated on serine 5 of the heptapeptide repeat predominantly during promoter escape and early elongation, while serine 2 becomes phosphorylated principally during elongation $(16,38)$. In addition, it has recently been demonstrated that the CTD can be also phosphorylated on serine 7 $(3,13,25)$.

Phosphorylation of the CTD is achieved primarily by members of the cyclin-dependent kinase (CDK) family, which typically consist of a catalytic subunit and a regulatory cyclin subunit (47). In Saccharomyces cerevisiae, at least four Cdk

\footnotetext{
* Corresponding author. Mailing address: Instituto de Microbiología Bioquímica, CSIC/Universidad de Salamanca, Campus Miguel de Unamuno s/n, Salamanca 37007, Spain. Phone: 0034923294500, ext. 1936. Fax: 0034923224876. E-mail: ocalvo@usal.es.

${ }^{\nabla}$ Published ahead of print on 7 September 2010.
}

complexes, composed of Kin28-Ccl1-Tfb3, Srb10-Srb11, Ctk1Ctk2-Ctk3, and Bur1-Bur2, are able to phosphorylate the CTD, and all of them have a role in transcription regulation $(47,54)$. Srb10 (Cdk8 in higher eukaryotes) provides the kinase activity of the Mediator CDK8 module. Genetically, Srb10 has been found to act both positively and negatively in gene expression $(12,30)$. It has also been shown through in vitro studies to phosphorylate the CTD, on the one hand inactivating RNAP II prior to PIC formation (27) but, on the other, promoting transcription and formation of the scaffold complex (43). Kin28 (mammalian Cdk7), with Ccl1 and Tfb3, forms the transcription factor TFIIK subcomplex of the TFIIH initiation complex (reference 34 and references therein). Phosphorylation on Ser5 of the CTD by Kin28 is required for efficient cotranscriptional recruitment of $5^{\prime}$ capping enzymes and the placement of the 7-methyl guanosine cap on pre-mRNAs (38, 59 , 63), although it is not essential for transcription (31). $\mathrm{Kin} 28$, as well as $\mathrm{Cdk} 7$, can also phosphorylate the Ser7 residue of the CTD repeats $(3,25)$, and Cdk7 functions in promoterproximal pausing and, perhaps, termination by RNA polymerase II (25).

The phosphorylation of Ser2 is more complex. In mammalian and Drosophila cells, Cdk9/cyclinT, or P-TEFb, phosphorylates Ser2 and functions to promote transcription elongation (56). In S. cerevisiae, $\mathrm{P}-\mathrm{TEFb}$ activity is split between two separate complexes: the CTD kinase 1 complex (CTDK1), consisting of Ctk1, Ctk2, and Ctk3, and the Bur1/Bur2 complex $(16,71)$. Both complexes have been implicated in CTD phosphorylation during elongation. While Ctk1 is the main kinase for Ser2 phosphorylation (16), the specificity of the Bur1/Bur2 complex kinase is not yet clear. Murray et al. (49) examined the phosphorylation site specificity of Bur1 and showed that Bur1 associates primarily with Rpb1 and phosphorylates Ser5. However, it has been shown recently that Bur1/Bur2, in addition to phosphorylating Ser2 near promoters, also stimulates Ser2 
TABLE 1. Yeast strains

\begin{tabular}{|c|c|c|}
\hline Strain & Description & Source \\
\hline YSB756 & mat $\alpha$ ade2-1 ade3-22 can1-100 his3-11,15 ura3-1 kin28::LEU2 [KIN28-3×HA TRP CEN] & S. Buratowski \\
\hline OCSC154 & mat $\alpha$ ade2-1 ade3-22 can1-100 his3-11,15 ura3-1 kin28::LEU2 [KIN28-3×HA TRP CEN] sub1::URA3 & This study \\
\hline YSB609 & mat $\alpha$ ade2-1 ade3-22 can1-100 his3-11,15 ura3-1 kin28::LEU2 [kin28-K36A-3×HA TRP CEN] & S. Buratowski \\
\hline YSB776 & mata his3- $\Delta 200$ leu2- $\Delta 1$ trp1- $\Delta 63$ ura3-52 lys $2-\Delta 202$ SRB10-3 $\times \mathrm{HA}:: T R P$ & S. Buratowski \\
\hline OCSC159 & mata his3- $\Delta 200$ leu2- $\Delta 1$ trp1- $\Delta 63$ ura3-52 lys $2-\Delta 202$ SRB10-3 $\times \mathrm{HA}:: T R P$ sub1::URA3 & This study \\
\hline OCSC166 & mato ade2-1 his3-11,15 leu2-3,112 trp1-1 ura3-1 sub1::URA3 & This study \\
\hline OCSC261 & mat $\alpha$ ade2-1 his3-11,15 leu2-3,112 trp1-1 ura3-1 srb10::KAN & This study \\
\hline OCSC169 & mat $\alpha$ ade2-1 his3-11,15 leu2-3,112 trp1-1 ura3-1 srb10::KAN sub1::URA3 & This study \\
\hline OCSC267 & mato ade2-1 his3-11,15 leu2-3,112 trp1-1 ura3-1 ADH1-SUB1 & This study \\
\hline OCSC268 & mat $\alpha$ ade2-1 his3-11,15 leu2-3,112 trp1-1 ura3-1 srb10::KAN [ADH1-SUB1 LEU CEN] & This study \\
\hline YSB786 & mata his3- $\Delta 200$ leu2-3,112 ura3-52 ceg1- $\Delta 1:$ :his3 [CEG1-3×HA LEU CEN] & S. Buratowski \\
\hline OCS570 & 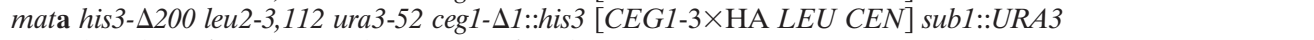 & This study \\
\hline YSB770 & 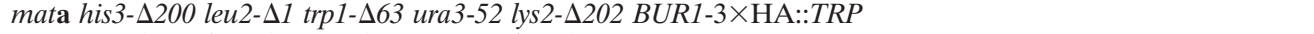 & S. Buratowski \\
\hline OCSC157 & 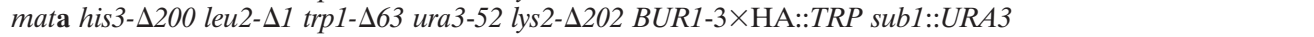 & This study \\
\hline OCSC560 & 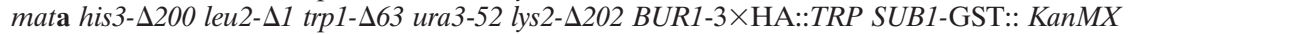 & This study \\
\hline YSB1021 & 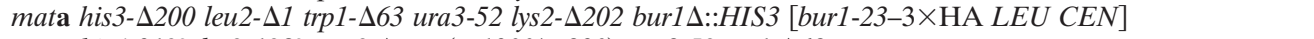 & S. Buratowski \\
\hline GY458 & 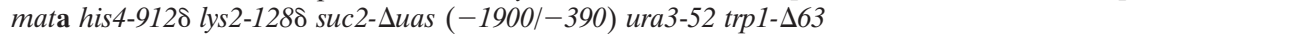 & G. Prelich \\
\hline OCSC301 & 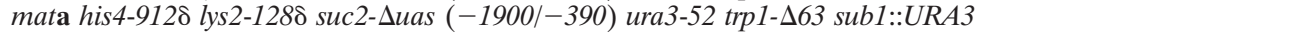 & This study \\
\hline GY170 & 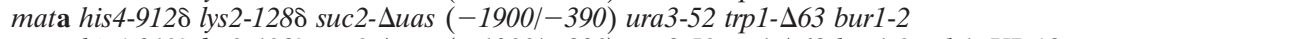 & G. Prelich \\
\hline OCSC303 & 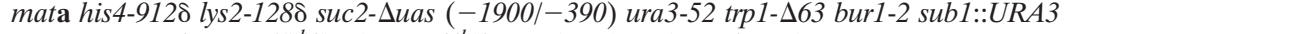 & This study \\
\hline ERYM356 & mata ura3-52 lys2-801 ${ }^{\text {amber }}$ ade2-101 ${ }^{\text {ochre }}$ trp1- $\Delta 63$ his3- $\Delta 200$ leu2- $\Delta 1$ CTK-6 $\times \mathrm{HA}:: T R P 1$ & This study \\
\hline ERYM357 & 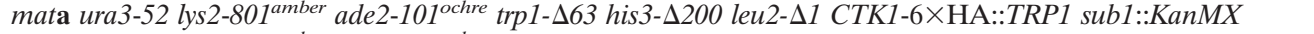 & This study \\
\hline OCSC558 & 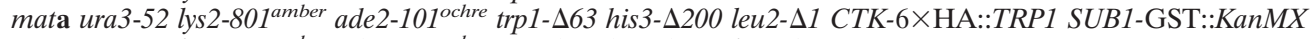 & This study \\
\hline OCSC1077 & 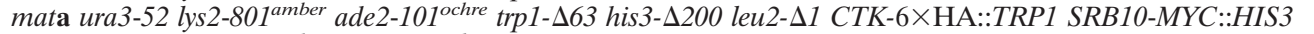 & This study \\
\hline OCSC1078 & 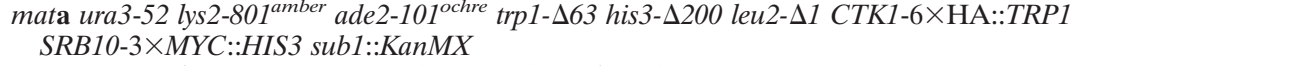 & This study \\
\hline OCSC1160 & mata ura3-52 lys801 ade2-101 trp- $\Delta 63$ his3- $\Delta 200$ leu2- $\Delta 1$ KIN28-6×HA::TRP1 & This study \\
\hline OCSC1168 & 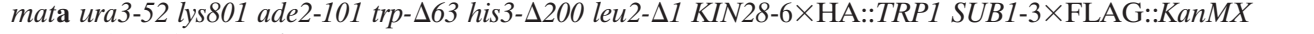 & This study \\
\hline YP655 & mato ade2-1 his4-260 leu2-3,112 trp1-289 ura3-1 CDC5-3×HA::KanMX & P. San Segundo \\
\hline OCSC1323 & mato ade2-1 his4-260 leu2-3,112 trp1-289 ura3-1 CDC5-3×HA::KanMX sub1::URA3 & This study \\
\hline
\end{tabular}

phosphorylation by Ctk1 during elongation (57). In addition, Bur1 phosphorylates the histone modifier Rad6/Bre1 $(69,70)$ and the carboxyl-terminal domain of the elongation factor Spt5, stimulating recruitment of the PAF1 elongation complex $(44,73)$.

Another factor involved in modulation of CTD phosphorylation in $S$. cerevisiae is Sub1. Sub1 was originally identified as a suppressor of TFIIB mutations and as a transcriptional stimulatory protein, homologous to human positive coactivator PC4 $(24,33,40,46,68)$, that physically interacts with TFIIB, arguing for a role as coactivator in transcription initiation by RNAP II $(28,37)$. In that sense, Rosonina et al. (60) showed that Sub1 contributes to the activation of osmoresponse genes during osmotic shock through the assembly or stabilization of promoter-associated complexes. On the other hand, Koyama et al. (39) proposed a role for Sub1 as a repressor of the inducible IMD2 gene. Sub1 has also been implicated in other aspects of mRNA metabolism, such as transcription termination and 3 '-end formation $(10,26)$. Moreover, several years ago, we described allele-specific interactions between SUB1 and both KIN28 and FCP1, which encodes the CTD phosphatase Fcp1. We showed that cells lacking Sub1 displayed decreased accumulation of Fcp1, altered RNAP II phosphorylation, and decreased cross-linking of RNAP II to transcribed genes (11). These results indicated that Sub1 has a role in RNAP II CTD phosphorylation and in transcription elongation.

Here, we present evidence that Sub1 indeed plays a universal role in CTD phosphorylation. We show that SUB1 genetically interacts with the genes encoding all four of the CTD kinases, SRB10, KIN28, BUR1, and CTK1, suggesting that Sub1 acts to influence CTD phosphorylation at more than one step of the transcription cycle. Supporting this view, we show first, by the results of in vitro kinase assays, that SUB1 deletion increases CTD phosphorylation by Kin28, Bur1, and Ctk1 but decreases CTD phosphorylation by Srb10, arguing for distinct roles of Sub1 in transcription preinitiation and elongation. Second, by the results of chromatin immunoprecipitation, we find that SUB1 deletion increases Kin28 and Ctk1 chromatin association while decreasing Srb10 chromatin association, in dicating that Sub1 is involved in regulating the association of these kinases with the transcriptional machinery. Taken together, our data point to multiple roles for Sub1 in the regulation of RNAP II CTD phosphorylation all along the transcription cycle.

\section{MATERIALS AND METHODS}

Yeast strains and media. The strains used in this study are listed in Table 1. Yeast strain construction and other genetic manipulations were performed by standard procedures (9). The $2 \%$ galactose and $2 \%$ raffinose media were prepared as described previously (41).

In vitro kinase assays. Cells were grown to an optical density at $600 \mathrm{~nm}$ $\left(\mathrm{OD}_{600}\right)$ of 0.8 , collected, washed, and suspended in lysis buffer (20 mM HEPES [pH 7.6], $200 \mathrm{mM}$ potassium acetate [KOAc], 10\% glycerol, and $1 \mathrm{mM}$ EDTA) (35) with protease and phosphatase inhibitors. Yeast whole-cell extracts were prepared by glass bead disruption of cells using a FastPrep system. Protein concentrations were determined, and $150 \mu \mathrm{g}$ was incubated with $15 \mu \mathrm{l}$ of 12CA5 (antihemagglutinin [anti-HA]) or anti-MYC antibody coupled to protein GSepharose for $2 \mathrm{~h}$ at $4^{\circ} \mathrm{C}$ to immunoprecipitate HA- and MYC-tagged kinases (Kin28, Srb10, Ctk1, and Bur1). The immunoprecipitates were washed three times with lysis buffer and twice with kinase buffer (20 mM HEPES [pH 7.6], 7.5 $\mathrm{mM} \mathrm{MgOAc}, 100 \mathrm{mM}$ KOAc, $2 \%$ glycerol). The beads were resuspended in 25 
A

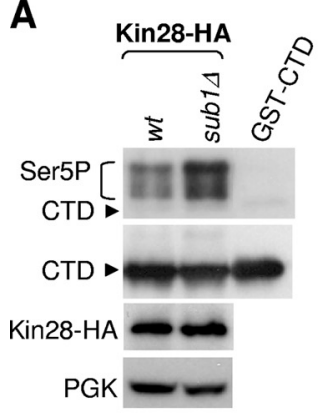

D

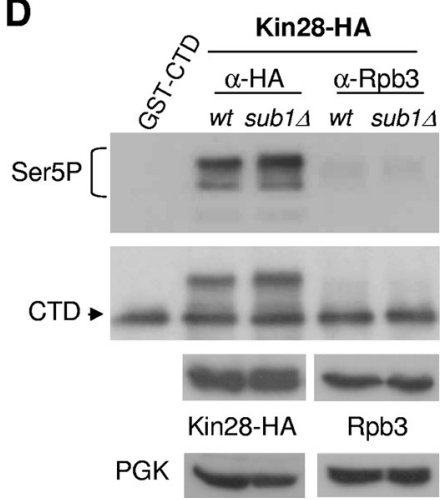

B

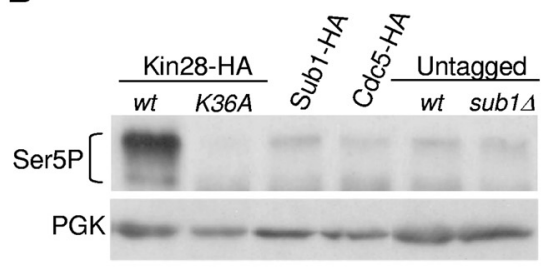

E

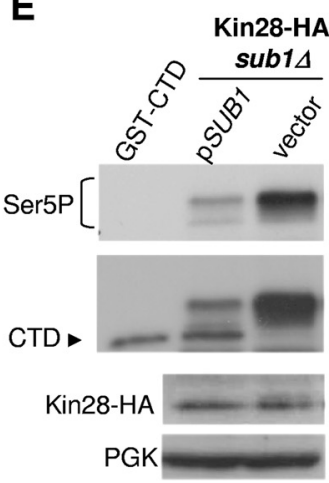

C

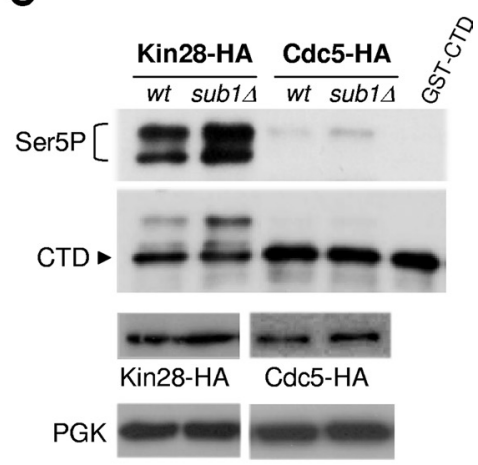

FIG. 1. SUB1 deletion increases Kin28 CTD kinase activity and Kin28 cross-linking to gene promoters. (A) In vitro kinase assay. Whole-cell extracts were prepared from wild-type (wt) and sub1s strains expressing HA-tagged Kin28. The epitope-tagged kinase complexes were immunoprecipitated with 12CA5-protein A beads, and kinase activity was assayed with $2.5 \mathrm{mM}$ ATP and recombinant GST-CTD as substrate. SDS-PAGE and immunoblot analysis were performed to analyze CTD phosphorylation, using the following antibodies: CTD4H8 (anti-CTD Ser5P), 8WG16 (anti-CTD), 12CA5 (anti-HA, for Kin28-HA), and PGK (anti-PGK, as total protein level control). (B) Whole-cell extracts were prepared from the following strains: tagged Kin28-HA (wt and kin28-K36A mutant), Sub1-HA, and Cdc5-HA strains and two nontagged strains (wt and sub1 $\Delta$ ). In vitro kinase assays were conducted as described for panel A, and CTD Ser5 phosphorylation analyzed with CTD4H8 antibody. (C) Whole-cell extracts were prepared from wt and sub1s strains expressing HA-tagged Cdc5, and in vitro kinase assays performed to analyze CTD Ser5P as described above. (D) In vitro kinase assay to analyze CTD Ser5 phosphorylation was performed using immunoprecipitated Kin28-HA and Rpb3 from wt and sub1 $\Delta$ Kin28-HA tagged strains. (E) Kin28-HA sub1 $\Delta$ cells were transformed with an empty plasmid (vector) or with a plasmid bearing $S U B 1$ (pSUB1) under the control of its own promoter. Kin28-HA was immunoprecipitated, kinase assays performed, and CTD Ser5P analyzed as described for panel $\mathrm{B}$.

$\mu \mathrm{l}$ of kinase buffer with $2.5 \mathrm{mM}$ ATP and incubated with $30 \mathrm{ng}$ of glutathione $S$-transferase (GST)-CTD for $30 \mathrm{~min}$ at $30^{\circ} \mathrm{C}$. The reaction mixtures were run and then electrophoresed on $8 \%$ SDS-polyacrylamide gels, transferred, and immunoblotted with the following antibodies: 8WG16 (nonphosphorylated CTD; Covance), CTD4H8 (phosphorylated CTD Ser5 [CTD Ser5P]; Millipore), or ab5095 (CTD Ser2P; Abcam).

ChIPs. The preparation of chromatin was performed as previously described $(11,35)$. For the Ser5P immunoprecipitations (IPs), CTD4H8 antibody was used and immunoprecipitation was performed as described in reference 11. PCR of purified chromatin was performed by quantitative real-time PCR with an ABI Prism 7000 detection system (Applied Biosystems), using SYBR Premix Ex Taq (Takara Bio, Inc.) and following the manufacturer's instructions. Four serial 10-fold dilutions of genomic DNA were amplified using the same reaction mixture as for the samples to construct the standard curves. All real-time PCRs were performed in quadruplicate and with at least three independent chromatin IPs (ChIPs). Quantitative analysis was carried out using the ABI Prism 7000 SDS software (version 1.2.3). The values obtained for the immunoprecipitated PCR products were compared to those of the total input, and the ratio of the value for each PCR product of transcribed genes to that of a nontranscribed region of chromosome VII was calculated. Numbers on the $y$ axis of graphs are detailed in the corresponding figure legends. ChIP assays of cells grown under conditions of galactose induction were performed as described previously (41).

RNA isolation and RT-PCR. Total RNA was extracted as described previously (62), and reverse transcription (RT)-PCR was performed using a PrimeScript RT reagent kit (Takara Bio, Inc.) following the manufacturer's instructions.

\section{RESULTS}

SUB1 deletion enhances both CTD Ser5 phosphorylation by Kin28 and its recruitment to gene promoters. We previously described a genetic interaction between SUB1 and KIN28 (11), suggesting that Sub1 influences CTD phosphorylation by Kin28. In order to study the significance of this genetic interaction, we followed two strategies. We first performed in vitro kinase assays to determine if Sub1 influences CTD phosphorylation by Kin28 and then carried out chromatin immunoprecipitation (ChIP) experiments to analyze whether Sub1 influences Kin28's association with gene promoters.

We first tested whether Sub1 affects Kin28 activity toward the CTD. HA-Kin28-containing complexes from SUB1 (wild type [wt]) and sub1s whole-cell extracts prepared from cells expressing HA-Kin28 in place of endogenous Kin28 were immunoprecipitated via the HA epitope tag and assayed in an in vitro IP kinase assay using as the substrate a GST-CTD fusion protein, as previously described (35). GST-CTD was incubated with no kinase or with HA-Kin28 immunoprecipitated from wt and sub1s cell extracts (Fig. 1A). Reaction mixtures were 
loaded onto an $8 \%$ SDS-PAGE gel and immunoblotted with CTD4H8 antibody, which recognizes CTD phosphorylation on Ser5 $(53,64)$, and with $8 \mathrm{~W} 16 \mathrm{G}$ antibody, which recognizes unphosphorylated CTD $(7,65)$. Equivalent IP of Kin28-HA was confirmed by Western blot assay using an anti-HA antibody. As shown by the results in Fig. 1A, Kin28-HA was active on GST-CTD in both wt and sub1 $\Delta$ cell IPs, since it efficiently phosphorylated the CTD on Ser5 as determined by immunoblotting. Strikingly, Kin28 activity in the IPs from sub1s cells was greater than its activity in those from wt cells. Since $S U B 1$ deletion did not affect total Kin28 levels (Fig. 1A, HA blot), this result suggests that Sub1 negatively influences Kin28 kinase activity.

In light of the above results and of additional related results described below, we wished to verify the specificity of the IP kinase assay. To this end, we performed a number of additional control experiments. First, we analyzed the extent of nonspecific background kinase activity by using extracts from strains expressing the following proteins for anti-HA IP: Kin28-HA (wt and Kin28-K36A, a mutant devoid of kinase activity [59]), Sub1-HA, Cdc5-HA (a non-CTD kinase functioning in mitosis and cytokinesis [5]), and two nontagged strains (wt and $s u b 1 \Delta$ ). As shown by the results in Fig. 1B, only wild-type Kin28-HA was able to phosphorylate GST-CTD efficiently. Thus, IPs of HA-Sub1, HA-Cdc5, or extracts not expressing a tagged protein contained no significant Ser5 kinase activity. Second, we immunoprecipitated the HA-tagged unrelated kinase Cdc5-HA from sub1 $\Delta$ as well as wt extracts and detected no Ser5 kinase activity in either case (Fig. 1C). Third, we analyzed the possibility that the kinase activities observed in wt and sub1s cell extracts could be due to other kinases that might coimmunoprecipitate with HA-Kin28, perhaps reflecting a bridging interaction with some other associated factor, such as RNAP II. For this purpose, we immunoprecipitated Kin28-HA and RNAP II (with anti-HA and Rpb3 antibodies, respectively) from wt and $s u b 1 \Delta \mathrm{Kin} 28-\mathrm{HA}$ extracts. GST-CTD kinase activity was observed only in the Kin28-HA IPs (Fig. 1D). Fourth, to provide further evidence that loss of Sub1 was indeed responsible for the observed effects on GST-CTD kinase activity, Kin28-HA sub1 $\Delta$ cells were transformed with an empty plasmid or with a plasmid bearing SUB1 under the control of its own promoter and IP kinase assays were performed as described above. As shown by the results in Fig. 1E, wild-type levels of kinase activity were restored when SUB1 was expressed from the low-copy-number plasmid in $s u b 1 \Delta$ cells, confirming that increased Kin28 kinase activity was in fact due to lack of Sub1. Finally, Sub1 did not coimmunoprecipitate with Kin28-HA (or with the three other CTD kinases analyzed below) when using extracts from wt cells (data not shown), indicating that its effects on kinase activity were indirect (see Discussion).

We next wished to determine whether Sub1 also affects Kin28 recruitment to gene promoters. We therefore analyzed the recruitment of Kin28 to the promoters of several constitutively transcribed genes, $A D H 1, A C T 1, P M A 1$, and $P Y K 1$, in the presence or absence of Sub1. For this purpose, we performed ChIP coupled with quantitative PCR (qPCR) with Kin28-HA-expressing wt and sub1s cells. Significantly, Kin28 cross-linking was increased at the promoter regions of all genes tested in the absence of Sub1 (Fig. 2A). The enrichment of
Kin28 at promoters in $s u b 1 \Delta$ cells compared to that in wt cells (considered $100 \%$ ) ranged from $125 \%$ at the $A D H 1$ promoter to $225 \%$ at the $A C T 1$ promoter. These data are in agreement with the observed increase of CTD phosphorylation in $s u b 1 \Delta$ cells shown previously (11). Taking into account that Sub1 negatively affects the recruitment of RNAP II $(11,60)$, as we have confirmed here for sub1s cells (data not shown), the $\mathrm{Kin} 28-\mathrm{HA} / \mathrm{Rpb} 1$ ratio was increased at promoter regions in sub1s cells compared to the ratio in wild-type cells (Fig. 2B). Hence, SUB1 deletion significantly enhanced the levels of Kin28 associated with the RNAP II transcriptional machinery. Taken together, our data support the idea that Sub1 associates with the transcription complex and modulates RNAP II CTD Ser5 phosphorylation by Kin28.

Promoter association of Ser5-phosphorylated RNAP II and the capping enzyme Ceg1 increases in $\operatorname{sub1\Delta }$ cells. Ser5 phosphorylation is strongest at the promoter regions of transcribed genes and diminishes downstream (38). We therefore tested whether increased Kin28 recruitment to promoters in $s u b 1 \Delta$ cells resulted in increased Ser5 CTD phosphorylation at the promoters of several genes. For this purpose, we performed ChIP on wt and sub1s cells with CTD4H8 and 8WG16 antibodies. As expected and as previously described (11), decreased RNAP II was detected at the promoters of $A C T 1$, $P M A 1$, and $P Y K 1$ genes in sub1D cells compared to the amounts in wt cells. However, Ser5P cross-linking in sub1 $\Delta$ cells increased significantly at $A C T 1-P$ and $P Y K 1-P$ and slightly at PMA1-P (Fig. 2C). Therefore, SUB1 deletion caused an increase in Ser5 phosphorylation associated with gene promoters relative to total RNAP II, in agreement with the observed increase in Kin28 activity and association with chromatin.

Kin28 phosphorylation of the CTD at Ser5 mediates cotranscriptional recruitment of the capping enzyme Ceg1 (e.g., see references 38,63 , and 67 ). We previously reported that SUB1 genetically interacts in an allele-specific manner with several kin28 mutants (kin28-T17D, kin28-K36D, and kin28T162D) (11). Interestingly, these interactions are comparable to interactions previously described between ceg1-250 and kin2 8 mutants (59). That is, the effects displayed by combining sub1s or ceg1-250 mutations with kin28 mutations resulted in similar phenotypes, ranging from lethality ( sub1 $\Delta$ kin $28-T 17 D$ and ceg1-250 kin28-T17D) to slight or no effect (sub1s kin28T162D and ceg1-250 kin28-T162D, respectively). Although we did not observe a genetic interaction between $s u b 1 \Delta$ and ceg1250 mutants (11), we hypothesized that due to the increased Kin28 activity and increased CTD Ser5P in sub1 $\Delta$ cells, Ceg1 recruitment to promoters could also be increased. To test this, ChIP analysis was performed with wt and sub1s cells expressing Ceg1-HA. As shown by the results in Fig. 2D, recruitment of the capping enzyme was in fact decreased in sub1s cells compared to the level in wt cells (Fig. 2D). However, if we compare Ceg1 and Rpb1 occupancies at promoters and calculate the Ceg1/Rpb1 ratio, considered to be 1.0 in wt cells, there was a slight increase in the Ceg1/Rpb1 ratio at the PYK1 (1:1.33) and $A C T 1$ (1:1.57) promoters in sub1 $\Delta$ cells (Fig. 2D, compare the results for Rpb1 and Ceg1-HA). Notably, in the case of PMA1, where the CTD Ser5P/Rpb1 ratio was 1.0, the Ceg1/Rpb1 ratio was also 1.0 ; in the case of $A C T 1$, where the CTD Ser5P/Rpb1 ratio was $>1$ (1.93), the Ceg1/Rpb1 ratio was also $>1$ (1.57), in agreement with a functional relationship 
A
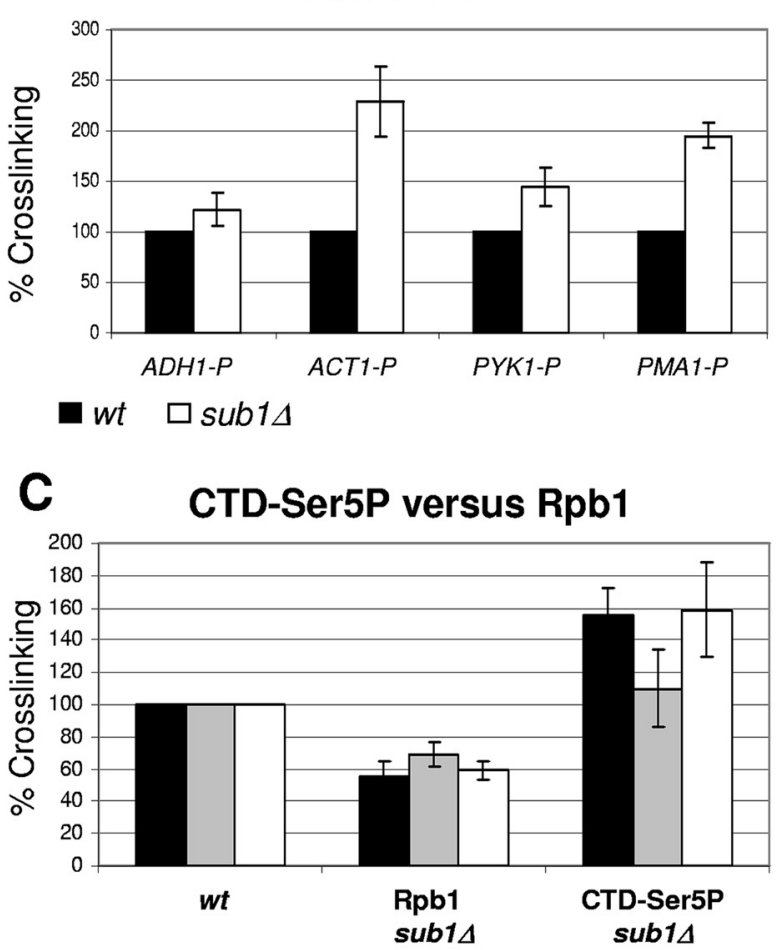

B

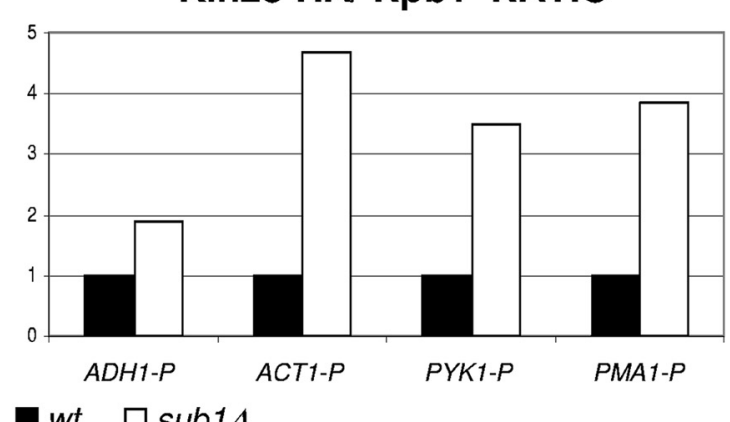

D

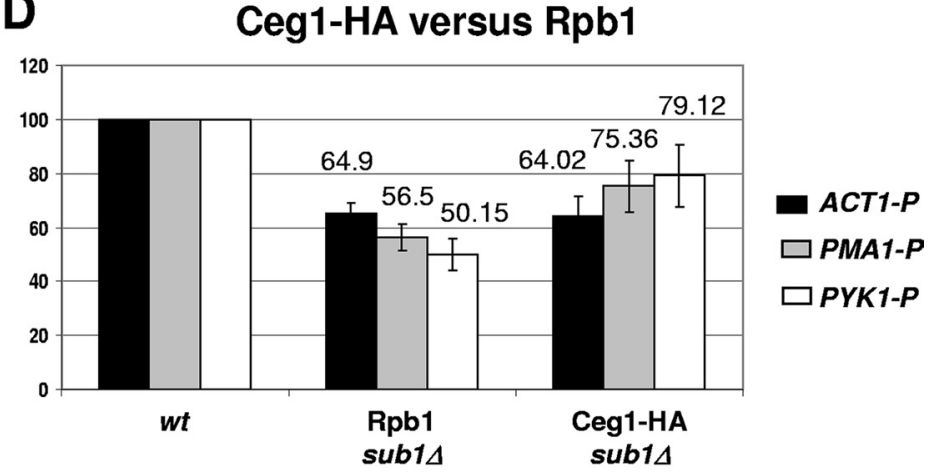

Chromatin IPs

FIG. 2. SUB1 deletion increases Kin28 and Rpb1 Ser5P cross-linking to gene promoters. ChIP analysis. ChIPs were performed on wt and sub1 $\Delta$ Kin 28 HA-tagged strains. (A) Kin28 binding to the promoters of four constitutively expressed genes, $A D H 1-P, A C T 1-P, P Y K 1-P$, and $P M A 1-P$, was examined by qRT-PCR, and quantifications (see Materials and Methods) were graphed. Numbers on the $y$ axis represent the percentages of Kin 28 cross-linked to gene promoters in sub1s cells relative to the levels in wt cells, where the level of cross-linking is considered to be $100 \%$. (B) Kin28-HA/Rpb1 ratio. Percentages of Kin28-HA and Rpb1 cross-linking for sub1s cells relative to the levels in wt cells were independently quantified, and the ratio was calculated and then graphed. (C) ChIP analysis of Rpb1 and CTD Ser5P was performed in wild-type (wt) and sub1s cells using 8WG16 (anti-Rpb1) and CTD4H8 (anti-CTD Ser5P) antibodies. Rpb1 and Rpb1 CTD Ser5P binding to promoters of $A C T 1, P Y K 1$, and PMA1 genes was analyzed by qRT-PCR, and the results graphed. Numbers on the $y$ axis represent the percentages of Rpb1 and Rpb1 CTD Ser5P cross-linked to gene promoters in sub1 $\Delta$ cells relative to the levels in wt cells, where the level of cross-linking is considered to be $100 \%$. (D) Occupancy of Rpb1 and Ceg1-HA at promoters of $A C T 1, P Y K 1$, and PMA1 genes was determined by ChIP in wt and sub1 cells using $8 \mathrm{WG} 16$ and HA antibodies. Numbers on the $y$ axis represent the percentages of Rpb1 and Ceg1-HA cross-linked to gene promoters in sub1 $\Delta$ cells relative to the levels in wt cells, where the level of cross-linking is considered $100 \%$. Error bars show standard deviations.

between Ser5 phosphorylation and Ceg1 capping enzyme recruitment.

SUB1 genetically interacts with $S R B 10$. To extend the above results, we next asked whether another CTD kinase, Srb10, might also be affected by Sub1, first by testing whether SUB1 and $S R B 10$ interact genetically. We examined the effects of both SUB1 deletion (sub1D) and SUB1 overexpression ( $A D H 1 S U B 1$ ) from the strong $A D H 1$ promoter on the growth of $s r b 10 \Delta$ cells, which display a growth defect at both 30 and $37^{\circ} \mathrm{C}$. Strikingly, the growth defect of $s r b 10 \Delta$ cells was partially suppressed by $S U B 1$ deletion and dramatically enhanced by $S U B 1$ overexpression, with the strongest effect at $37^{\circ} \mathrm{C}$ (Fig. $3 \mathrm{~A})$. We observed similar effects when we overexpressed SUB1 from a $G A L 1$-inducible promoter (data not shown). Although we have consistently observed, here (Fig. 3A) and elsewhere (11), that when Sub1 is overexpressed, cells tend to grow slightly more slowly than wt cells at $37^{\circ} \mathrm{C}$ and that $s u b 1 \Delta$ cells generally grow slightly faster than wt cells at this temperature, the effects of both deletion and overexpression of SUB1 on the $\operatorname{srb} 10 \Delta$ cells were much stronger than the effects observed on wt cells. This strong genetic interaction suggests that Sub1 also influences Srb10 kinase activity.

Sub1 positively influences Srb10 kinase activity and association with chromatin. We next performed in vitro IP kinase assays as described above to determine if $S U B 1$ deletion influences CTD phosphorylation by Srb10. For this purpose, we generated strains expressing Srb10-MYC in the wt or sub1s background, where we previously had HA tagged Ctk1 (see below). Srb10 has the capacity to phosphorylate the CTD on both Ser2 and Ser5 $(6,27,58)$. As shown by the results in Fig. $3 \mathrm{~B}$, the Srb10-MYC immunoprecipitated from wt and $s u b 1 \Delta$ cell extracts was active, since it phosphorylated the CTD on Ser5 and Ser2, as determined by immunoblotting with a monoclonal Ser5 antibody (CTD4H8) that specifically recognizes Ser5 phosphorylation (64) and a polyclonal Ser2 antibody (ab5095) that preferentially recognizes Ser2-phosphorylated, as well as unphosphorylated, CTD (57), respectively. However, in contrast to Kin28, the Srb10 kinase activity in $s u b 1 \Delta$ cells was significantly reduced compared to that in wt cells for both Ser5 and Ser2 phosphorylation (Fig. 3B). We also performed 

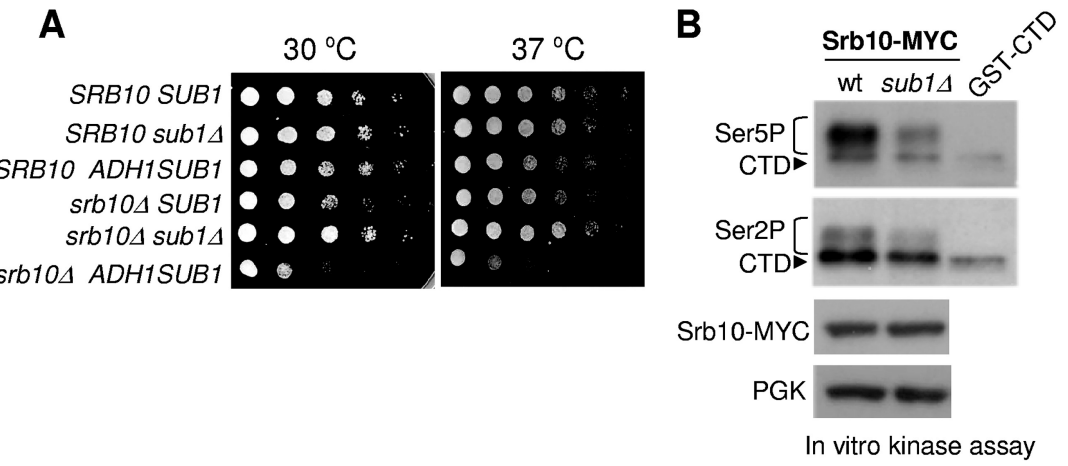

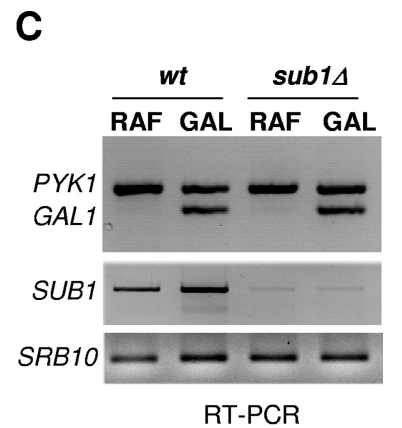

D

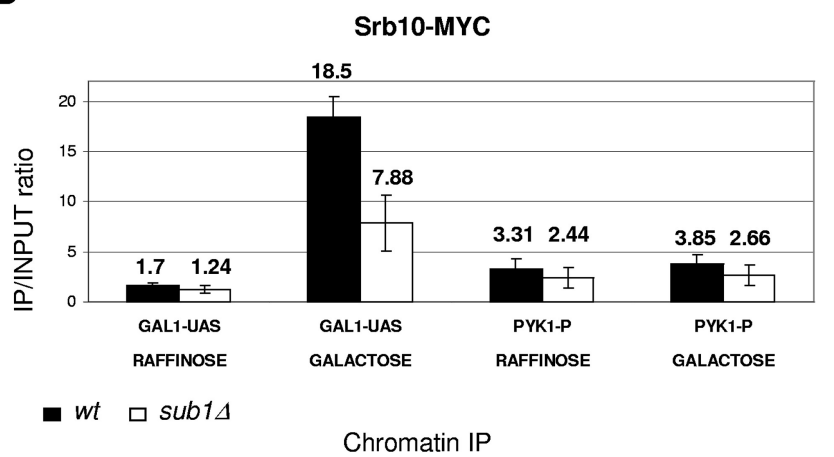

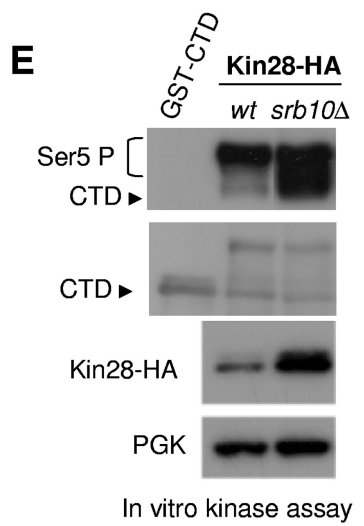

FIG. 3. SUB1 genetically interacts with $S R B 10$, and $S U B 1$ deletion negatively influences Srb10 kinase activity and association with active genes. (A) Genetic interaction between $S U B 1$ and $S R B 10$. SUB1 deletion partially suppresses the slow-growth phenotype of $s r b 10 \Delta$ cells and overexpression of $S U B 1$ enhances it, as shown by spot assay. To overexpress $S U B 1$, its open reading frame was cloned under the control of the $A D H 1$ promoter in a plasmid that was transformed into the srb10D strain (ADH1SUB1). Yeast strains with the indicated genotypes were spotted onto synthetic complete medium and grown at 30 and $37^{\circ} \mathrm{C}$ for 2 days. (B) Results of in vitro CTD kinase assay showing that $S U B 1$ deletion causes a decrease in CTD phosphorylation by Srb10. Whole-cell extracts were prepared from the wt and sub1 $\Delta$ strains expressing MYC-tagged Srb10, and in vitro kinase assay and CTD phosphorylation analysis were performed as described in the Fig. 1 legend. CTD Ser5 and Ser2 phosphorylation was analyzed using the following antibodies: CTD4H8 (anti-CTD Ser5P), ab5095 (anti-CTD Ser2P), 8WG16 (anti-CTD), anti-MYC antibody (Srb10 levels), and anti-PGK antibody (PGK levels, as control). (C) Induction of GAL1 transcription was monitored by RT-PCR. Total RNA was isolated from wt and sub1 $\Delta$ cells grown under noninducible ( $2 \%$ raffinose [RAF]) and inducible ( $2 \%$ galactose [GAL]) conditions. cDNA was synthesized, and PCR performed using specific primers for GAL1, PYK1, SUB1, and SRB10 genes. (D) ChIP analysis of Srb10 was conducted with wt and sub1 $\triangle$ cells grown in raffinose- or galactose-containing medium, using anti-MYC antibody. Srb10-MYC cross-linking to the promoter of PYK1 and to the upstream activating sequence of the GAL1 (UAS-GAL1) gene was analyzed by qRT-PCR. Quantifications of the results are shown in the graph, where numbers on the $y$ axis represent the ratio of the values obtained from specific primer products to the value for the negative control (intergenic region of chromosome VII), after normalizing to the results for the input controls. Error bars show standard deviations. (E) SRB10 deletion causes an increase in CTD Ser5 phosphorylation by Kin28, reflecting increased Kin28 levels in the srb10 cells. Whole-cell extracts were prepared from wt and srb10 $\Delta$ strains expressing HA-tagged Kin28, and in vitro kinase assays and CTD phosphorylation analysis were performed. CTD phosphorylation was analyzed using the following antibodies: CTD4H8 (anti-CTD Ser5P) and 8WG16 (anti-CTD). Kin28-HA and PGK levels were analyzed using 12CA5 (anti-HA) and anti-PGK, respectively.

IP kinase assays with Srb10-HA strains (data not shown). Both Srb10-MYC and Srb10-HA displayed decreased CTD phosphorylation when cells lacked Sub1. As SUB1 deletion did not affect the total Srb10 levels (Fig. 3B), our results indicate that Sub1, in contrast to its negative effect on Kin28, positively influences Srb10 kinase activity.

We next investigated whether Sub1 influences Srb10 association with chromatin. The Srb8-11 complex is known to be required for Gal4-dependent activation of GAL1 transcription (41). We therefore conducted ChIP experiments in cells grown both under conditions of GAL1 induction ( $2 \%$ galactose) and in noninducible conditions ( $2 \%$ raffinose). In addition, we extracted RNA to monitor GAL1 gene induction by RT-PCR. We also tested the expression of the constitutive gene $P Y K 1$ and of the SRB10 and SUB1 genes. As shown by the results in
Fig. 3C, as expected, GAL1 is only expressed in cells grown in galactose-containing medium, while $P Y K 1$ and $S R B 10$ are expressed similarly in both inducible and noninducible conditions. Unexpectedly, we detected an increase of SUB1 mRNA levels during galactose induction (Fig. 3C).

We next examined the effect of Sub1 on the association of Srb10 with the GAL1 and PYK1 promoters by ChIP. As expected, in wild-type cells, Srb10 was not present at the GAL1 promoter when cells were grown in raffinose medium but was rapidly and efficiently recruited when cells were transferred to galactose-containing medium (20 min of galactose induction). However, Srb10 recruitment was significantly decreased in the absence of Sub1 (Fig. 3D). In the case of PYK1, although Srb10 cross-linking to the promoter region was less efficient, it was also decreased in cells lacking Sub1 (Fig. 3D). These results 
A

sub1+/- ctk1+/-

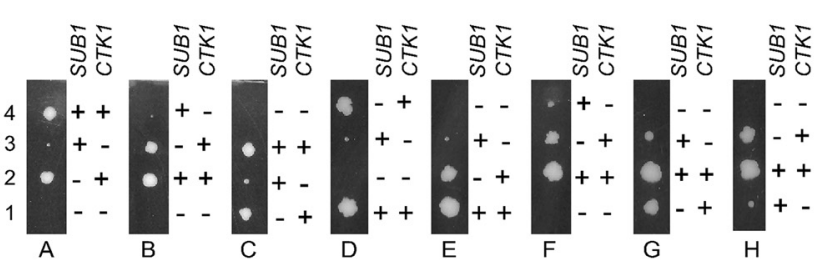

B

Ctk1-HA

wt sub1/ GST-CTD

$\underset{\text { CTD }}{\operatorname{Ser} 2 P}[$

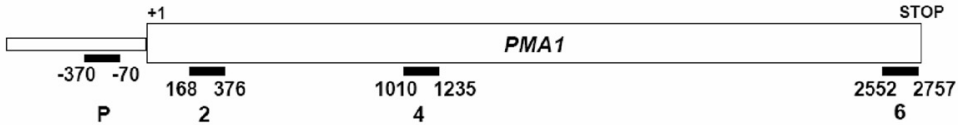

CTD

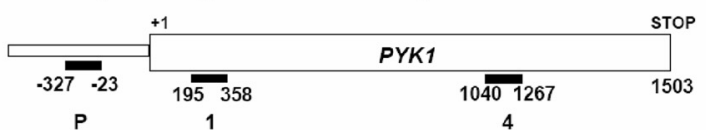

Ctk1-HA

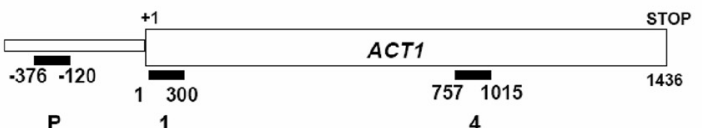

In vitro kinase assay

D
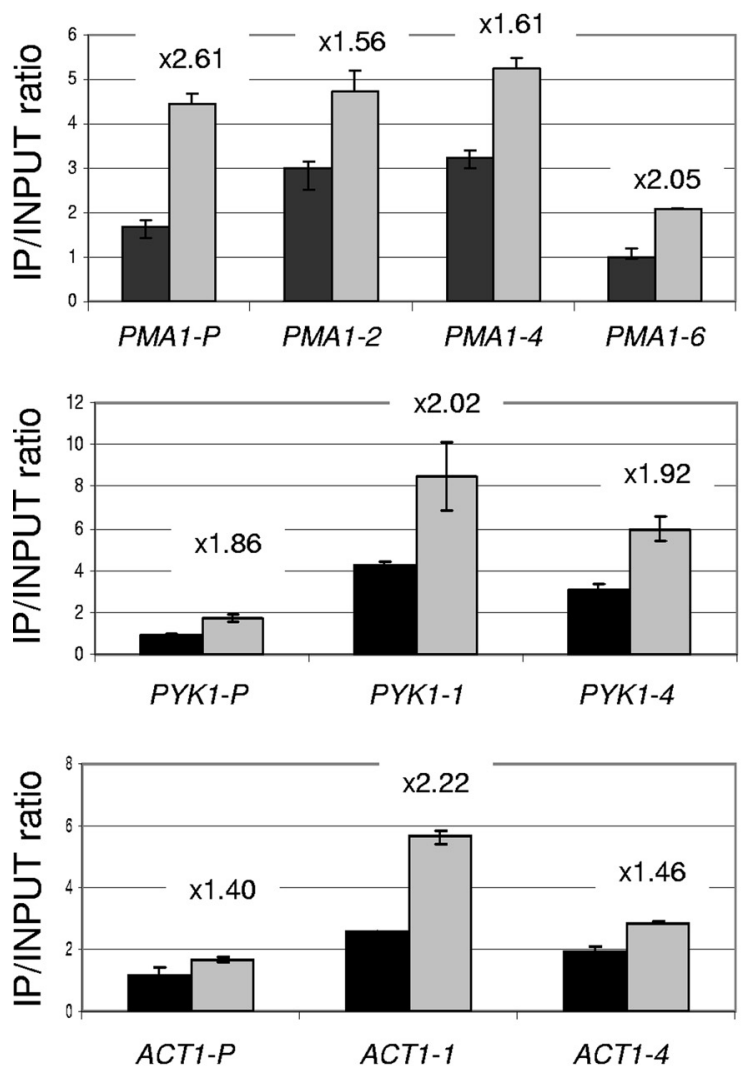

wt $\square$ sub1

Ctk1-HA
E
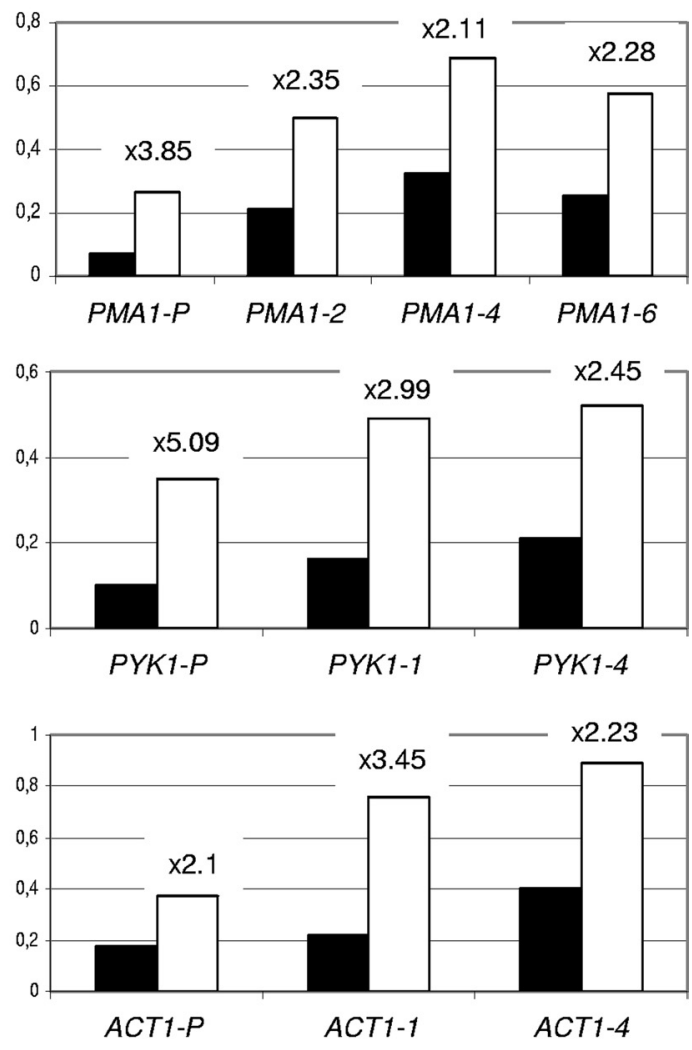

- wt $\square$ sub1A

\section{Chromatin IP}

FIG. 4. Sub1 influences recruitment and kinase activity of the elongation kinase Ctk1 during transcription. (A) sub1 $\Delta$ and $c t k 1 \Delta$ are synthetically lethal. A diploid yeast strain heterozygous for both SUB1 and CTK1 (sub1 ::URA3/SUB1 ctk1 $::$ kanMX/CTK1) was sporulated, and the meiotic progeny were separated by tetrad dissection and allowed to grow for 3 days. Thirteen tetrads were dissected, with nine showing a tetratype segregation pattern (eight of which are shown), and two showing a paternal ditype segregation pattern. The genotype of the resulting colonies was 
indicate that Sub1 positively influences Srb10 recruitment to the GAL1 and, to a lesser extent, $P Y K 1$ promoter, which agrees with the observed decrease of Srb10 kinase activity in $s u b 1 \Delta$ cells.

We next asked whether the effects of SUB1 deletion on Srb10 might contribute to the effects we observed on Kin28. Previous studies have shown that TFIIH is negatively regulated by CDK8-containing Mediator complexes in human cells (4) and that Srb10 inhibits KIN28 transcription in meiotic yeast cells (51). Extending these results, we observed that deletion of $S R B 10$ resulted in an increase in Kin28-HA levels and, as a consequence, an increase in Kin 28 activity, as analyzed by in vitro kinase assays (Fig. 3E). The effect of SRB10 deletion on Kin28 levels was specific, as we detected no changes in the levels of Sub1-HA, Ceg1-HA, or Ctk1-HA in srb10 $\Delta$ cells compared to their levels in wt cells (data not shown). Since Srb10 promoter recruitment and activity were reduced in $s u b 1 \Delta$ cells, this could explain, at least in part, how Kin28 recruitment and/or activity was enhanced (see Discussion).

subls and $c t k 1 \Delta$ mutations are synthetically lethal. We showed previously that SUB1 deletion results in increased levels of CTD Ser2 phosphorylation on RNAP II associated with chromatin (11). To extend this result, we performed genetic experiments to investigate whether $S U B 1$ also interacts with the gene encoding the elongating CTD Ser 2 kinase Ctk1. Although it is well established that Ser2 phosphorylation follows Ser5 phosphorylation, it is not yet clear whether Ser5 phosphorylation is required for subsequent Ser2 phosphorylation and transcriptional elongation. It has been suggested that CTD Ser5 phosphorylation by Kin28 does not affect the level of CTD Ser2 phosphorylation (16); however, CTD Ser5P is a preferential substrate for Ser2 phosphorylation by Ctk1 (32) and it has recently been suggested that Ser5 phosphorylation stimulates Ser2 phosphorylation by Bur1/Bur2 kinase (57).

We first examined whether $S U B 1$ genetically interacts with $C T K 1$. For this, we generated a diploid strain lacking one copy each of $S U B 1$ and $C T K 1$ and analyzed the meiotic progeny by tetrad dissection (Fig. 4A). As expected, haploid progeny lacking SUB1 showed no growth defect compared to the growth of the wt, whereas the growth of cells lacking CTK1 was significantly impaired. Significantly, however, in every case, meiotic progeny lacking both $C T K 1$ and $S U B 1$ were nonviable, indicating a synthetic lethal genetic interaction between these genes (Fig. 4A). This interaction, together with the genetic interactions with genes encoding other CTD kinases, suggests that Sub1 regulates phosphorylation of the CTD at multiple stages of the transcription cycle, including elongation.

Sub1 negatively regulates Ctk1 activity and recruitment. We previously analyzed total CTD Ser2 phosphorylation by ChIP and detected an increase on chromatin-associated RNAP II in the absence of SUB1 (11). In light of the results described above, this increase could be due to an inhibitory effect of Sub1 on Ctk1 recruitment and/or activity that is alleviated in $s u b 1 \Delta$ cells. To test these possibilities, we generated strains expressing Ctk1 with a C-terminal $6 \times \mathrm{HA}$ tag in the wt or $s u b 1 \Delta$ background. We then investigated whether Ctk1 kinase activity was also impaired in sub1 $1 \Delta$ cells, again using in vitro IP kinase assays. Indeed, Ctk1 kinase activity toward GST-CTD in IPs from $s u b 1 \Delta$ cells was increased compared to its level in the wt, as determined by Western blotting using the anti-Ser2P antibody (Fig. 4B). The Ctk1 levels, as measured by Western blotting with anti-HA antibody, were equivalent in the two IPs. We also verified the specificity of the Ser2 activity in the IPs by using extracts from two nontagged strains (wt and sub1 $\Delta$ ). The kinase activity in HA IPs from these strains was barely detectable compared to the Ctk1-6 $\times$ HA kinase activity (data not shown). Thus, we conclude that Sub1 negatively influences Ctk1 kinase activity.

The Ctk1-6×HA strains (wt and $s u b 1 \Delta$ ) that we analyzed were designed to also express Srb10-MYC. This allowed us to determine the effect of SUB1 deletion on Srb10 and Ctk1 kinase activity in the same cells, using a single cell extract. As shown in Fig. 3B and 4B, we observed a decrease in GST-CTD phosphorylation when Srb10-MYC was immunoprecipitated from sub1 $\Delta$ extracts (Fig. 3B) and an increase when Ctk1-HA was immunoprecipitated from the same extracts (Fig. 4B). These results confirm that Sub1 has a positive influence on Srb10 kinase activity, probably acting at the level of PIC formation, and a negative effect on Ctk1 activity, likely during transcription elongation.

We next examined the effect of Sub1 on the recruitment of Ctk1 to active genes. The Ctk1-6×HA association with three different genes was determined by ChIP (Fig. 4D). Compared to the levels in wt cells, we observed increases of $\sim 1.5$ - to 2.5 -fold in the levels of Ctk1-6×HA at the PMA1, PYK1, and $A C T 1$ genes in cells lacking Sub1. Considering that Sub1 negatively affects the recruitment of RNAP II $(11,60)$, as we have confirmed for $s u b 1 \Delta$ cells expressing Ctk1-6 $\times$ HA (data not shown), the Ctk1/Rpb1 ratio was increased in sub1 $\Delta$ cells from the promoter to the $3^{\prime}$ regions (Fig. $4 \mathrm{E}$ ). Thus, the deletion of SUB1 significantly increased the levels of Ctk1 associated with the RNAP II transcription machinery.

Together, our data indicate that the increased Ser2 phosphorylation observed in the absence of SUB1 is due to three factors: increased Ctk1 recruitment, increased Ctk1 kinase activity, and reduced Fcp1 phosphatase levels (11).

SUB1 deletion increases the elongation defects of burl mutants. Bur1 associates with nonphosphorylated Rpb1 and phosphorylates Ser5 and Ser2 of the CTD $(32,45)$. More recently, it has been shown that Bur1/Bur2 phosphorylates

inferred by growth or lack of growth on selective medium. Cells with a deletion of CTK1 alone show a slow-growth phenotype, as reported previously. (B) SUB1 deletion causes increased Ctk1 kinase activity. Whole-cell extracts were prepared from wt and sub1D strains with an HA-tagged Ctk1, and in vitro kinase assay was performed as described in the Fig. 1 legend to analyze CTD Ser2 phosphorylation, using anti-CTD Ser2P. (C) Schematic representation of the $A C T 1, P Y K 1$, and PMA1 genes. Numbers are nucleotide positions relative to start codon (+1), and black bars represent PCR products analyzed by ChIP. (D) Increased Ctk1-HA association with chromatin in cells lacking SUB1. ChIP for Ctk1-HA was performed in wt and sub1 $\Delta$ cells. Ctk1-HA association with PMA1, PYK1, and $A C T 1$ genes was analyzed by qRT-PCR, and quantifications were graphed (see Materials and Methods). (E) Ctk1-HA/Rpb1 ratio. Ctk1-HA and Rpb1 cross-linking were independently quantified in wt and sub1s cells, and then Ctk1/Rpb1 ratio was calculated and graphed. Error bars show standard deviations. 
A

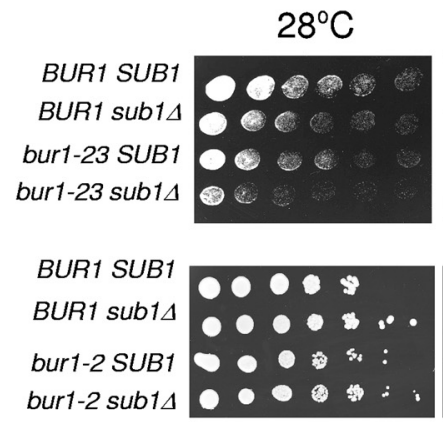

$37^{\circ} \mathrm{C}$

$50 \mu \mathrm{g} / \mathrm{ml} 6-\mathrm{AU}$
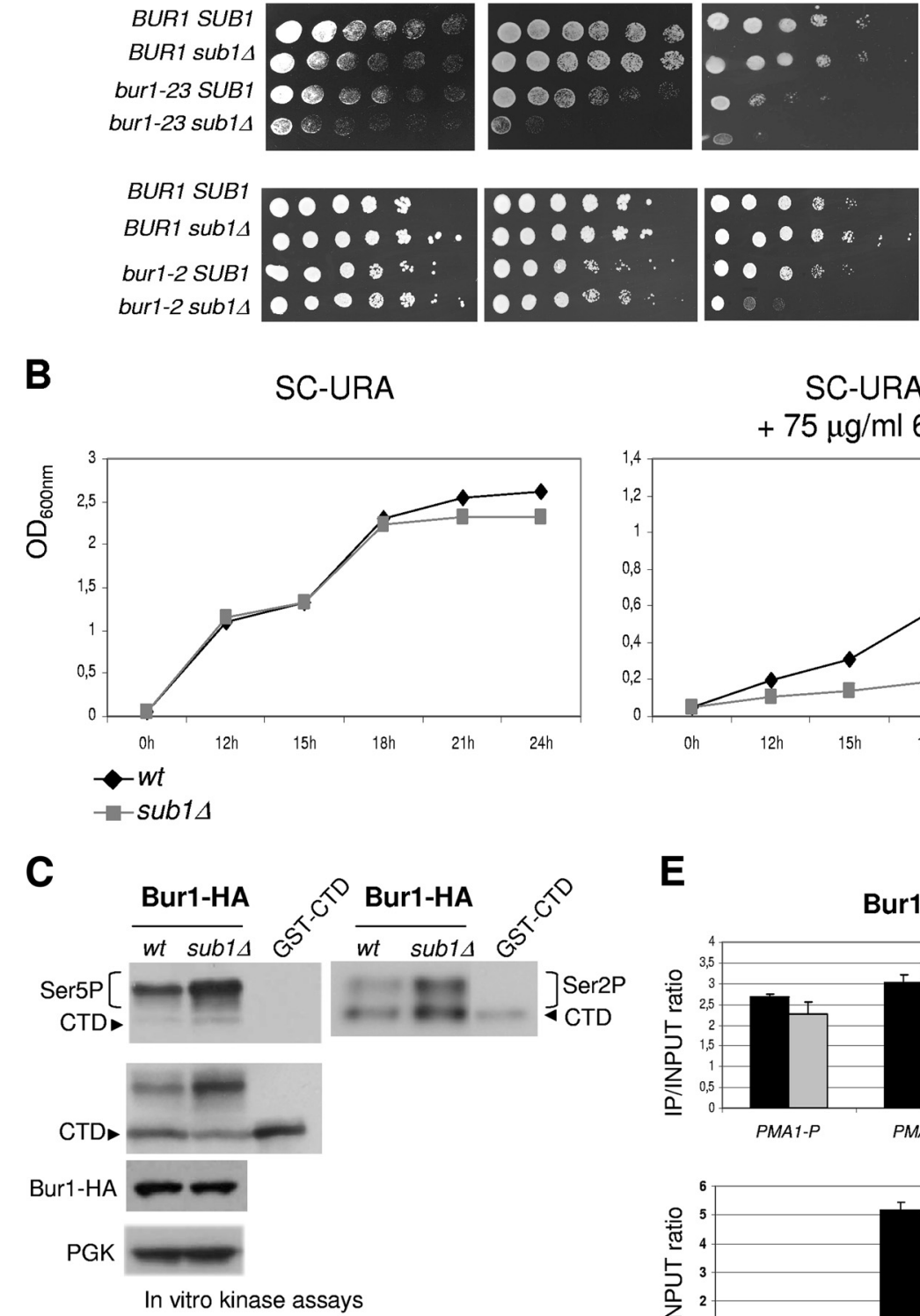

D

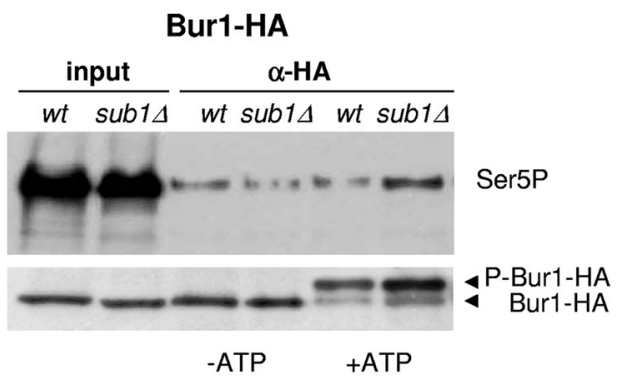

In vitro kinase assay and Co-IP

E

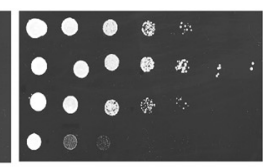

SC-URA

$+75 \mu \mathrm{g} / \mathrm{ml} 6 \mathrm{AU}$
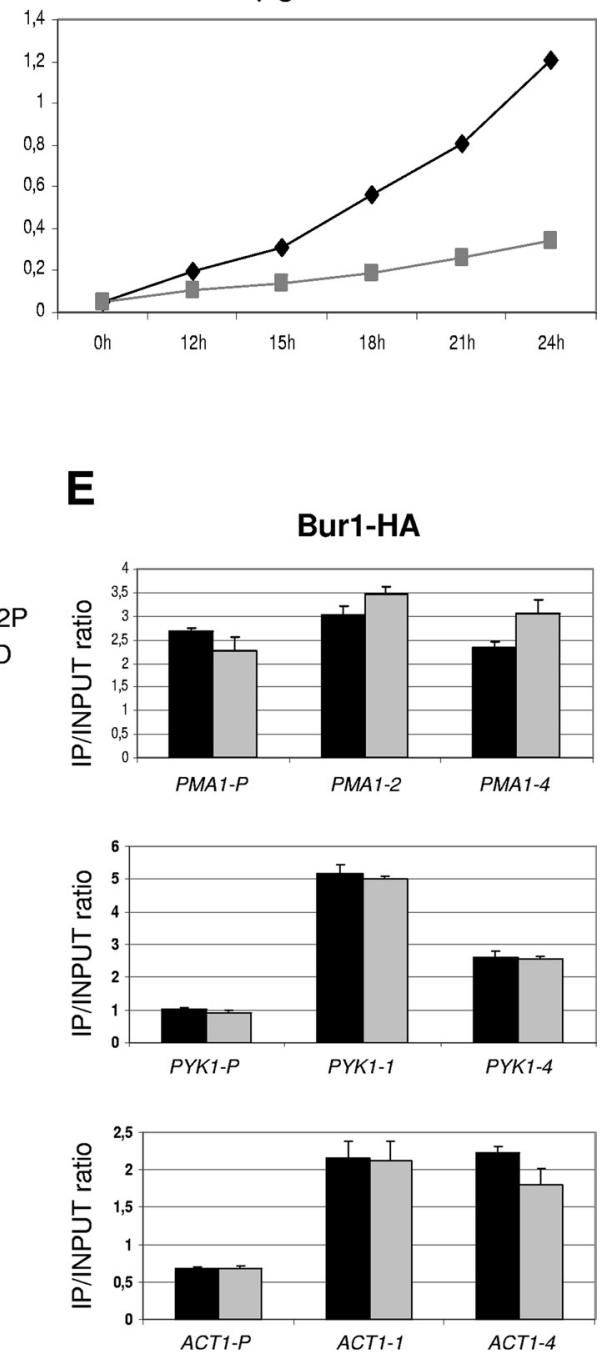

口 wt $\square$ sub1d

Chromatin IP

FIG. 5. Bur1 kinase recruitment and activity is also enhanced by deletion of SUB1. (A) SUB1 deletion increases the elongation defect of bur1 mutants. Phenotypic analysis of SUB1-BUR1 genetic interaction. SUB1 was deleted in a bur1-2 strain and in the isogenic wt strain. In the case of the bur1-23 mutant, we generated a diploid strain by crossing it with a sub1 $\Delta$ mutant. The diploid was sporulated, and the tetrads dissected and analyzed. The growth phenotype of one tetrad is shown. Yeast strains with the indicated genotypes were spotted on yeast extract-peptone-dextrose or synthetic complete (SC) medium containing $50 \mu \mathrm{g} / \mathrm{ml}$ of 6-azauracil (6-AU), and plates were incubated for 3 days. As shown, SUB1 deletion increases the growth and elongation defects of bur1-23 cells and the elongation defect of bur1-2 cells. (B) sub1 $1 \Delta$ cells are sensitive to 6 -AU in liquid medium. Growth curves of wt and sub1s strains in SC medium without or with $75 \mu \mathrm{g} / \mathrm{ml}$ of 6-AU. (C) Bur1 kinase activity is increased in sub1s mutant. In vitro kinase assay was performed as described in the Fig. 1 legend in wt and sub1s cells expressing an HA-tagged Bur1. CTD 
Ser2 near promoters and stimulates Ser2 phosphorylation by Ctk1 during transcription elongation (57). To complete our genetic study aimed at understanding the connection between Sub1 and CTD kinases, we next examined possible genetic interactions between $S U B 1$ and BUR1. For this purpose, we used two bur1 mutants, the bur1-2 and bur1-23 strains (35, 55, 72). Both bur1 mutations impair Bur1's in vitro kinase activity, while bur1-23 cells show defects in elongation efficiency as measured by ChIP, although cotranscriptional phosphorylation of CTD Ser5 and Ser2 was not strongly affected (35). The bur1-2 mutant shows an overall slow-growth phenotype, while burl-23 presents a more serious growth defect at $28^{\circ} \mathrm{C}$ and strong thermosensitivity at $37^{\circ} \mathrm{C}$. Both mutants are sensitive to 6-azauracil (6-AU), a drug commonly used to detect effects in elongation $(23,66)$.

We deleted SUB1 in wt and bur1-2 isogenic strains and analyzed the effect on growth phenotypes at 28 and $37^{\circ} \mathrm{C}$ and in medium containing 6-AU (Fig. 5A, bottom). In the case of bur1-23, we generated a diploid by crossing it with the $s u b 1 \Delta$ strain. The diploid was sporulated, and the tetrads dissected and analyzed. The growth phenotypes of one tetrad type are shown in Fig. 5A (top). $S U B 1$ deletion was found to exacerbate the 6-AU sensitivity of the bur1-2 mutant, as seen by increased sensitivity to the drug in bur1-2 sub1s cells compared to that of bur1-2 mutant cells. In the case of the bur1-23 mutant, SUB1 deletion strongly enhanced both the growth defect and sensitivity to 6-AU (Fig. 5A). Although $S U B 1$ deletion alone did not result in sensitivity to 6-AU in these assays (Fig. 5A and data not shown), sensitivity to the drug was detected when cells were grown in liquid medium (Fig. 5B). In any event, these data reveal a genetic interaction between $S U B 1$ and BUR1. Indeed, the fact that the bur1-2 sub1s double mutant only displayed a synthetic phenotype on 6-AU-containing medium likely indicates that $S U B 1$ deletion mainly affects bur1 elongation defects $(35,71)$.

SUB1 deletion alters Bur1 kinase activity. The genetic interaction of $S U B 1$ with BUR1 suggested that, similarly to Kin28, Srb10, and Ctk1, Sub1 may influence Bur1 kinase activity. Given that phosphorylation of the RNAP II CTD by Kin28 was reported to enhance Bur1/Bur2 recruitment and Ser2 CTD phosphorylation near promoters (57), it is possible that the increased Kin28 activity in $s u b 1 \Delta$ cells can lead to increased CTD phosphorylation by Bur1. On the other hand, Bur1 was observed to associate primarily with Rpb1 containing unphosphorylated CTD repeats and then to phosphorylate Rpb1 on Ser5 (49). Therefore, we decided to analyze both Ser5 and Ser 2 CTD phosphorylation by in vitro IP kinase assays with wt and sub1 $\Delta$ cells containing HA epitope-tagged Bur1, again using the GST-CTD fusion protein as the substrate. Significantly, the deletion of SUB1 resulted in increased Ser5 and
Ser2 phosphorylation in the Bur1-HA IPs (Fig. 5C). Consistent with the results of Murray et al. (49), Ser5 phosphorylation by Bur1 was more efficient than the Ser2 phosphorylation (Fig. $5 \mathrm{C}$, compare results for wt cells in left and right panels, respectively). It has been shown that Bur1 has the capacity for autophosphorylation and that Bur1 phosphorylation promotes CTD phosphorylation $(49,72)$. We therefore tested whether SUB1 deletion affects Bur1 autophosphorylation by immunoprecipitating Bur1-HA from wt and sub1s cell extracts and performing in vitro kinase assays with coimmunoprecipitating proteins. As shown by the results in Fig. 5D, top, Bur1 coimmunoprecipitated and phosphorylated Rpb1 and, consistent with the results obtained with GST-CTD, this phosphorylation was increased in sub1s extracts. Significantly, Bur1-HA autophosphorylation was also increased in the absence of Sub1 (Fig. 5D, bottom). Therefore, it is possible that increased CTD phosphorylation in sub1s cells is due to an increase of Bur1 kinase activation.

Like the cell cycle CDKs, with the exception of Srb10, transcriptional CDKs undergo activating phosphorylation within their T loops. Thus, previous studies demonstrated that Cak1 phosphorylates Kin28, Bur1, and Ctk1 within their T loops and stimulates their activities $(22,36,52,72)$. Therefore, we tested whether Cak1 levels were altered in the absence of SUB1. However, we did not detect any significant variation of Cak1 levels in sub1s cells compared to the level in wt cells, nor did we detect Cak1 coimmunoprecipitating with Sub1 (results not shown).

ChIP analysis of Bur1-HA performed in wt and sub1s cells showed no significant difference in total Bur1 cross-linked to genes (Fig. 5E). However, again if we consider that Rpb1 cross-linking is reduced in subl $\Delta$ cells (see above and reference $11)$, the Bur1-HA/Rpb1 ratio was slightly increased ( $\sim 1.2-$ to 2.0-fold [data not shown]). But in this case, increased recruitment could be an indirect effect due to increased Kin28 activity, because, as mentioned above, phosphorylation by Kin 28 enhances Bur1/Bur2 recruitment (57).

\section{DISCUSSION}

We have presented evidence that Sub1 influences RNAP II CTD phosphorylation via interactions with all four CTD kinases, Kin28, Srb10, Bur1, and Ctk1. These effects were observed both genetically and biochemically, including effects on kinase activity and/or recruitment to chromatin. Our results thus indicate that Sub1 can act throughout the transcription cycle as a general regulator of CTD phosphorylation. Below, we discuss the implications of Sub1's interactions with these kinases and how Sub1 can influence CTD phosphorylation and transcription by RNAP II.

phosphorylation was analyzed using anti-CTD Ser5P (CTD4H8, top left), anti-CDT Ser2P (ab5095, top right) and anti-nonphosphorylated CTD (8WG16) antibodies. Bur1-HA levels were tested with anti-HA antibody. For both Ser2P and Ser5P, we observe increased phosphorylation of the CTD in the absence of Sub1. (D) SUB1 deletion increases Bur1 autophosphorylation and Bur1/RNAP II-CTD interaction. Whole-cell extracts were prepared from wt and sub1 $\Delta$ Bur1-HA strains. Epitope-tagged kinase complexes were immunoprecipitated with 12CA5-protein A beads, and kinase activity with or without ATP was assayed. SDS-PAGE and immunoblot analysis were performed to analyze Bur1 autophosphorylation using HA antibody and CTD Ser5P/Bur1-HA coimmunoprecipitation using anti-Ser5P (CTD4H8) antibody. (E) SUB1 deletion slightly influences Bur1 association with coding gene regions compared to its influence on Rpb1 association. Bur1 occupancy at PMA1, PYK1, and ACT1 genes was assayed by ChIP in wt and sub1 cells. Graph shows qRT-PCR quantifications performed as described in the Fig. 4 legend. 
$w t$
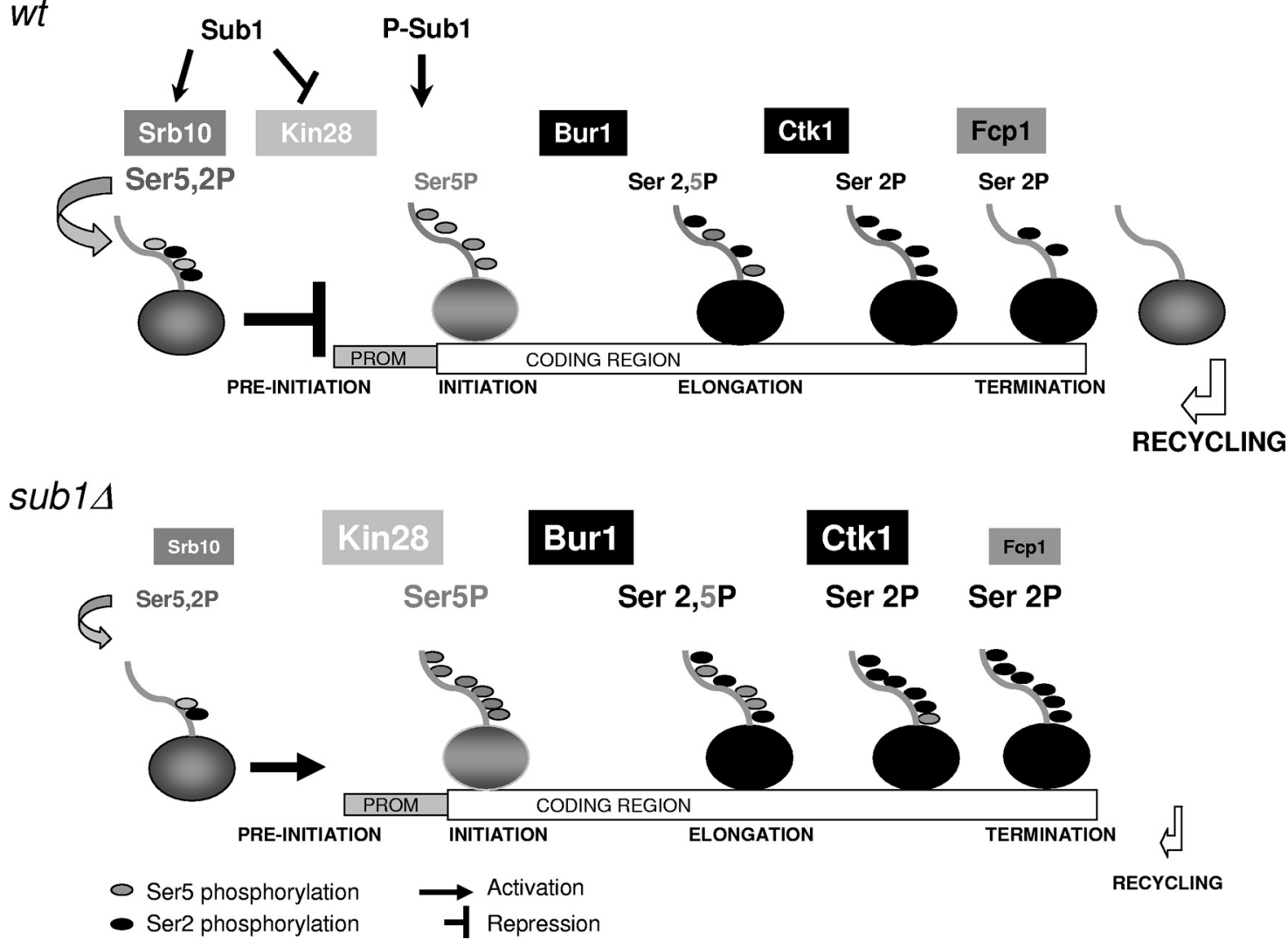

FIG. 6. Model showing how Sub1 might function to regulate RNAP II CTD phosphorylation. In wild-type cells, nonphosphorylated Sub1 joins the promoter (PROM) (possibly via TFIIB [see references 28, 37, and 60]), contacting the promoter via its DNA binding domain. At that point, Sub1 interacts with the CDK8 (Srb10) Mediator complex, helping to maintain the PIC in a stable but inactive conformation. Sub1 is then phosphorylated (possibly by the action of kinases at the PIC, similarly to PC4), losing its DNA binding capacity and promoting clearance of TFIIB $(26,35)$. The PIC next changes conformation such that Kin28 can be activated and, with the help of Srb10, promotes PIC dissociation into the scaffold complex, as well as the recruitment of elongating kinases Ctk1 and Bur1. In contrast, in sub1 cells, Srb10 activity and recruitment are decreased, while Kin28 recruitment and activity increase, in agreement with TFIIH being negatively regulated by CDK8-containing Mediator complexes $(4,51)$. As a result, Ser5P levels are increased, and consequently, Bur1 and Ctk1 association with chromatin is also enhanced (19, 57). Furthermore, in $s u b 1 \Delta$ cells, there is a reduction in Fcp1 phosphatase levels and its association with chromatin, which induces an additional increase in Ser2P, impairing RNAP II recycling after transcription termination. Thus, a decrease in RNAP II recruitment is observed in cells lacking Sub1 (11). Different font sizes in the figure labels indicate the increase or decrease of the corresponding CTD-modifying enzymes in sub1s versus wt cells.

Opposing effects of Sub1 on CTD phosphorylation during transcription initiation. It has been proposed that the timing of Srb10 and Kin28 activation can regulate transcription. Srb10 phosphorylates the CTD prior to PIC formation and inhibits transcription, while Kin28 promotes transcription by phosphorylating the CTD after PIC formation (27). However, Srb10, together with Kin28, can also promote transcription and contribute to PIC dissociation and scaffold complex formation (43). Here, we have shown that the presence of Sub1 has a negative effect on the growth of cells lacking Srb10. But our in vitro kinase assays showed that Sub1 positively influences CTD phosphorylation by Srb10, implying a negative effect on transcription inhibition according to Hengartner et al. (27). In contrast, we have detected additive effects on cell growth when combining mutations of KIN28, CTK1, and BUR1 with SUB1 deletion, consistent with a positive role of Sub1 in transcription (28) and with the fact that $s u b 1 \Delta$ decreases RNAP II recruitment to gene promoters (11). However, the results of our kinase and ChIP assays indicate a repressive role for Sub1 on
CTD phosphorylation by Kin28, Ctk1, and Bur1. How can these disparate results be reconciled?

In the absence of Kin28 activity, Srb10 activity is important to promote transcription (43). It is possible, then, that when SUB1 is overexpressed in srb10 $\Delta$ cells, Kin28 activity at the PIC is inhibited by Sub1, which in this case cannot be compensated by the action of Srb10. Therefore, PIC dissociation, scaffold complex formation, and consequently, transcription are impaired, giving rise to the observed growth defect. Altogether, our data are consistent with a negative role for Sub1 in transcription preinitiation, favoring Srb10 kinase activity and negatively influencing CTD phosphorylation by Kin28 (Fig. 6).

Sub1 also negatively affects Ctk1 association with chromatin. Recently, it has been suggested that Ctk1 contributes to scaffold maintenance, as it promotes the dissociation of basal transcription factors from elongating polymerase independent of its kinase activity (1). It is thus probable that, as suggested by in vitro studies for its human homolog PC4 (46), Sub1 has the capacity to repress transcription while promoting PIC forma- 
tion and, possibly, PIC dissociation into the scaffold complex through the action of CTD kinases, RNAP II, and TFIIB. In agreement with this, it has been suggested that Sub1 is a clearance factor, since it promotes the release of TFIIB from the promoter by disrupting the interaction between TFIIB and TATA-binding protein (37).

Additionally, PC4 transcription inhibition correlates with its ability to inhibit RNAP II phosphorylation by cdk-1, cdk-2, and cdk-7 in vitro (61). This inhibition is regulated by phosphorylation, as unphosphorylated PC4 displayed the kinase inhibitory activity, whereas phosphorylated PC4 was devoid of it. Sub1 is also likely regulated by phosphorylation, as it can be phosphorylated in vitro, regulating its capacity to bind DNA (28).

Sub1 influences CTD Ser5P and CTD Ser2P by different mechanisms. Our genetic and biochemical studies have provided evidence that Sub1 has opposing effects on CTD phosphorylation at the preinitiation step versus the initiation/elongation steps. Increased Ser5 phosphorylation in cells lacking SUB1 is the result of increased Kin28 recruitment and kinase activity. Although SUB1 deletion reduces the levels of the Ser2 phosphatase Fcp1 (11), we have not observed a similar effect for the Ser5 phosphatase Ssu72 (data not shown). In addition, we have observed no genetic interaction between SUB1 and the recently described RNAP II CTD Ser5 phosphatase RTR1 (48; data not shown). These results suggest that Sub1 influences Ser5 and Ser2 phosphorylation/dephosphorylation by different mechanisms.

Taken together, our data indicate that the increase in Ser2 phosphorylation observed in the absence of $S U B 1$ is due to as many as four distinct factors: (i) increased Ctk1 recruitment, probably due to the effects of Sub1 on PIC formation and/or dissociation of the scaffold complex; (ii) increased Ctk1 kinase activity and reduced Fcp1 phosphatase levels (11), in agreement with the fact that Fcp1 and Ctk1 play opposite roles in CTD Ser2 phosphorylation (16); (iii) the likelihood that some of the increase in Ser2 phosphorylation is due to the Ser5 phosphorylation increase, as CTD Ser5P is a preferential substrate for Ser2 phosphorylation by Ctk1 (32); and (iv) an increase in Bur1 kinase activity.

A model for Sub1 regulation of the CTD kinases. An important question concerns the mechanism(s) by which Sub1 influences the activity and chromatin recruitment of the four CTD kinases. Based on our results and those of previous studies, we propose that the Sub1-Srb10 connection provides the key to explaining the Sub1 effect on recruitment. Srb10 provides the kinase activity of the CDK8 (Srb8-11) module of Mediator, which plays negative roles in the recruitment of RNAP II and TFIIH. CDK8 sterically blocks Mediator interactions with RNAP II (20), and Mediator appears to play a critical role in PIC assembly at the level of TFIIH and TFIIE recruitment (21). In addition, TFIIH is negatively regulated by CDK8containing Mediator complexes in human cells (4), Srb10 inhibits KIN28 transcription in yeast (51), and we have observed that SRB10 deletion increases Kin28 levels and, as a consequence, Kin28-HA kinase activity. And finally, Sub1 is genetically and functionally linked to Mediator (18). Thus, Sub1 might influence CTD kinase recruitment via effects on the Mediator CDK8 complex. In fact, Sub1 has a positive role in promoting Srb10 recruitment to the inducible GAL1 gene, the transcription of which depends on the Srb8-11 and SAGA complexes (41).

Since Srb10 promoter recruitment and kinase activity were reduced in $s u b 1 \Delta$ cells, this might suggest that $S U B 1$ deletion should increase Kin28 levels. However, our results showed that Kin28 levels were in fact unaltered in cells lacking Sub1. One possibility is that the decrease in Srb10 activity and/or recruitment due to $S U B 1$ deletion is not sufficient to significantly affect KIN28 expression, as was observed with SRB10 deletion. The levels of Srb10 in sub1 $\Delta$ cells remained at wt levels, and this could be sufficient to maintain KIN28 expression at wt levels. However, the reduction in Srb10 kinase activity brought about by $S U B 1$ deletion could in turn affect Kin 28 activity. For example, if Srb10 phosphorylates Kin28 or its cyclin partner, as is the case in mammals (4), this could explain, at least in part, how $S U B 1$ deletion enhances Kin28 activity and/or promoter recruitment without increasing its levels.

It is possible, then, that in sub1s cells, Srb10's inhibitory effect on Kin28 is reduced, enhancing the recruitment of Kin28 and thereby enhancing the recruitment of Ctk1 subsequent to PIC formation. This idea is in agreement not only with the above-described studies indicating an evolutionarily conserved negative effect of Srb10/Cdk8 on Kin28 but also with recent work showing that Mediator CDK8 can interact with and recruit $\mathrm{P}-\mathrm{TEFb}$ to the transcriptional machinery in mammals (19). Increased Ctk1 activity, along with decreased Fcp1 levels (11), in sub1 $\Delta$ cells will then reduce RNAP II recycling and, as a result, its recruitment to gene promoters (Fig. 6) $(11,60)$.

Perhaps most strikingly, the results of our in vitro IP kinase assays indicate that, in addition to regulating the recruitment of CTD kinases, Sub1 affects CTD phosphorylation by influencing the activity of all four CTD kinases. We currently do not understand the biochemical basis for these effects. The altered kinase activities were not due to the absence of Sub1 in the $s u b 1 \Delta$ cell IPs because Sub1 did not immunoprecipitate with any of the CTD kinases in extracts from wt cells, indicating that Sub1 plays an indirect role in regulating the activities of the kinases. We also have found no evidence that Sub1 modifies CTD kinase activities by influencing posttranslational modifications of the kinases. We thus consider two possible explanations for the effects of Sub1 on the activities of the kinases. One is that Sub1 enhances the association (or dissociation) of an unidentified common regulator with the kinases, while the second is that Sub1 in some way influences kinase conformation and, thus, accessibility to the CTD. We are currently investigating these possibilities. In any case, the fact that Sub1 coordinates both the activities and recruitment to active genes of all four CTD kinases strongly supports an important role for Sub1 in regulating CTD phosphorylation throughout the transcription cycle.

\section{ACKNOWLEDGMENTS}

We thank S. Buratowski, G. Prelich, and P. San Segundo for yeast strains. O.C. thanks R. Jiménez for laboratory facilities and support and María Gómez for technical support on qPCR.

This work was supported by grants number BFU 2006-09041 and BFU 2009-07179 from the Spanish Ministerio de Ciencia e Innovación and SA012A08 from the Junta de Castilla y León to O.C. and a grant from the NIH to J.L.M. A.G. was supported by a fellowship from the Junta de Castilla y León. 


\section{REFERENCES}

1. Ahn, S. H., M. C. Keogh, and S. Buratowski. 2009. Ctk1 promotes dissociation of basal transcription factors from elongating RNA polymerase II EMBO J. 28:205-212.

2. Ahn, S. H., M. Kim, and S. Buratowski. 2004. Phosphorylation of serine 2 within the RNA polymerase II C-terminal domain couples transcription and $3^{\prime}$ end processing. Mol. Cell 13:67-76.

3. Akhtar, M. S., M. Heidemann, J. R. Tietjen, D. W. Zhang, R. D. Chapman, D. Eick, and A. Z. Ansari. 2009. TFIIH kinase places bivalent marks on the carboxy-terminal domain of RNA polymerase II. Mol. Cell 34:387-393.

4. Akoulitchev, S., S. Chuikov, and D. Reinberg. 2000. TFIIH is negatively regulated by cdk8-containing mediator complexes. Nature 407:102-106.

5. Alexandru, G., F. Uhlmann, K. Mechtler, M. A. Poupart, and K. Nasmyth. 2001. Phosphorylation of the cohesin subunit Scc1 by Polo/Cdc5 kinase regulates sister chromatid separation in yeast. Cell 105:459-472.

6. Borggrefe, T., R. Davis, H. Erdjument-Bromage, P. Tempst, and R. D. Kornberg. 2002. A complex of the Srb8, -9, -10, and -11 transcriptional regulatory proteins from yeast. J. Biol. Chem. 277:44202-44207.

7. Bregman, D. B., L. Du, S. van der Zee, and S. L. Warren. 1995. Transcription-dependent redistribution of the large subunit of RNA polymerase II to discrete nuclear domains. J. Cell Biol. 129:287-298.

8. Buratowski, S. 2005. Connections between mRNA $3^{\prime}$ end processing and transcription termination. Curr. Opin. Cell Biol. 17:257-261.

9. Burke, D., D. Dawson, and T. Stearns. 2000. Methods in yeast genetics. Cold Spring Harbor Laboratory Press, Cold Spring Harbor, NY.

10. Calvo, O., and J. L. Manley. 2001. Evolutionarily conserved interaction between CstF-64 and PC4 links transcription, polyadenylation, and termination. Mol. Cell 7:1013-1023.

11. Calvo, O., and J. L. Manley. 2005. The transcriptional coactivator PC4/Sub1 has multiple functions in RNA polymerase II transcription. EMBO J. 24: 1009-1020.

12. Carlson, M. 1997. Genetics of transcriptional regulation in yeast: connections to the RNA polymerase II CTD. Annu. Rev. Cell Dev. Biol. 13:1-23.

13. Chapman, R. D., M. Heidemann, T. K. Albert, R. Mailhammer, A. Flatley, M. Meisterernst, E. Kremmer, and D. Eick. 2007. Transcribing RNA polymerase II is phosphorylated at CTD residue serine-7. Science 318:17801782.

14. Chapman, R. D., M. Heidemann, C. Hintermair, and D. Eick. 2008. Molecular evolution of the RNA polymerase II CTD. Trends Genet. 24:289-296.

15. Cho, E. J. 2007. RNA polymerase II carboxy-terminal domain with multiple connections. Exp. Mol. Med. 39:247-254.

16. Cho, E. J., M. S. Kobor, M. Kim, J. Greenblatt, and S. Buratowski. 2001 Opposing effects of Ctk1 kinase and Fcp1 phosphatase at Ser 2 of the RNA polymerase II C-terminal domain. Genes Dev. 15:3319-3329.

17. Dahmus, M. E. 1996. Reversible phosphorylation of the C-terminal domain of RNA polymerase II. J. Biol. Chem. 271:19009-19012.

18. Dettmann, A., Y. Jaschke, I. Triebel, J. Bogs, I. Schroder, and H. J. Schuller. 2010. Mediator subunits and histone methyltransferase Set 2 contribute to Ino2-dependent transcriptional activation of phospholipid biosynthesis in the yeast Saccharomyces cerevisiae. Mol. Genet. Genomics 283:211-221.

19. Donner, A. J., C. C. Ebmeier, D. J. Taatjes, and J. M. Espinosa. 2010. CDK8 is a positive regulator of transcriptional elongation within the serum response network. Nat. Struct. Mol. Biol. 17:194-201.

20. Elmlund, H., V. Baraznenok, M. Lindahl, C. O. Samuelsen, P. J. Koeck, S. Holmberg, H. Hebert, and C. M. Gustafsson. 2006. The cyclin-dependent kinase 8 module sterically blocks Mediator interactions with RNA polymerase II. Proc. Natl. Acad. Sci. U. S. A. 103:15788-15793.

21. Esnault, C., Y. Ghavi-Helm, S. Brun, J. Soutourina, N. Van Berkum, C. Boschiero, F. Holstege, and M. Werner. 2008. Mediator-dependent recruitment of TFIIH modules in preinitiation complex. Mol. Cell 31:337-346.

22. Espinoza, F. H., A. Farrell, J. L. Nourse, H. M. Chamberlin, O. Gileadi, and D. O. Morgan. 1998. Cak1 is required for Kin28 phosphorylation and activation in vivo. Mol. Cell. Biol. 18:6365-6373.

23. Exinger, F., and F. Lacroute. 1992. 6-Azauracil inhibition of GTP biosynthesis in Saccharomyces cerevisiae. Curr. Genet. 22:9-11.

24. Ge, H., and R. G. Roeder. 1994. Purification, cloning, and characterization of a human coactivator, $\mathrm{PC} 4$, that mediates transcriptional activation of class II genes. Cell 78:513-523.

25. Glover-Cutter, K., S. Larochelle, B. Erickson, C. Zhang, K. Shokat, R. P. Fisher, and D. L. Bentley. 2009. TFIIH-associated Cdk7 kinase functions in phosphorylation of C-terminal domain Ser7 residues, promoter-proximal pausing, and termination by RNA polymerase II. Mol. Cell. Biol. 29:54555464.

26. He, X., A. U. Khan, H. Cheng, D. L. Pappas, Jr., M. Hampsey, and C. L. Moore. 2003. Functional interactions between the transcription and mRNA $3^{\prime}$ end processing machineries mediated by Ssu72 and Sub1. Genes Dev. 17:1030-1042

27. Hengartner, C. J., V. E. Myer, S. M. Liao, C. J. Wilson, S. S. Koh, and R. A Young. 1998. Temporal regulation of RNA polymerase II by Srb10 and Kin28 cyclin-dependent kinases. Mol. Cell 2:43-53.

28. Henry, N. L., D. A. Bushnell, and R. D. Kornberg. 1996. A yeast transcrip- tional stimulatory protein similar to human PC4. J. Biol. Chem. 271:2184221847

29. Hirose, Y., and J. L. Manley. 2000. RNA polymerase II and the integration of nuclear events. Genes Dev. 14:1415-1429.

30. Holstege, F. C., E. G. Jennings, J. J. Wyrick, T. I. Lee, C. J. Hengartner, M. R. Green, T. R. Golub, E. S. Lander, and R. A. Young. 1998. Dissecting the regulatory circuitry of a eukaryotic genome. Cell 95:717-728.

31. Hong, S. W., S. M. Hong, J. W. Yoo, Y. C. Lee, S. Kim, J. T. Lis, and D. K. Lee. 2009. Phosphorylation of the RNA polymerase II C-terminal domain by TFIIH kinase is not essential for transcription of Saccharomyces cerevisiae genome. Proc. Natl. Acad. Sci. U. S. A. 106:14276-14280.

32. Jones, J. C., H. P. Phatnani, T. A. Haystead, J. A. MacDonald, S. M. Alam, and A. L. Greenleaf. 2004. C-terminal repeat domain kinase I phosphorylates Ser2 and Ser5 of RNA polymerase II C-terminal domain repeats. J. Biol. Chem. 279:24957-24964.

33. Kaiser, K., G. Stelzer, and M. Meisterernst. 1995. The coactivator p15 (PC4) initiates transcriptional activation during TFIIA-TFIID-promoter complex formation. EMBO J. 14:3520-3527.

34. Keogh, M. C., E. J. Cho, V. Podolny, and S. Buratowski. 2002. Kin28 is found within TFIIH and a Kin28-Ccl1-Tfb3 trimer complex with differential sensitivities to T-loop phosphorylation. Mol. Cell. Biol. 22:1288-1297.

35. Keogh, M. C., V. Podolny, and S. Buratowski. 2003. Bur1 kinase is required for efficient transcription elongation by RNA polymerase II. Mol. Cell. Biol. 23:7005-7018

36. Kimmelman, J., P. Kaldis, C. J. Hengartner, G. M. Laff, S. S. Koh, R. A. Young, and M. J. Solomon. 1999. Activating phosphorylation of the Kin28p subunit of yeast TFIIH by Cak1p. Mol. Cell. Biol. 19:4774-4787.

37. Knaus, R., R. Pollock, and L. Guarente. 1996. Yeast SUB1 is a suppressor of TFIIB mutations and has homology to the human co-activator PC4. EMBO J. 15:1933-1940.

38. Komarnitsky, P., E. J. Cho, and S. Buratowski. 2000. Different phosphorylated forms of RNA polymerase II and associated mRNA processing factors during transcription. Genes Dev. 14:2452-2460.

39. Koyama, H., E. Sumiya, M. Nagata, T. Ito, and K. Sekimizu. 2008. Transcriptional repression of the IMD2 gene mediated by the transcriptional co-activator Sub1. Genes Cells 13:1113-1126.

40. Kretzschmar, M., K. Kaiser, F. Lottspeich, and M. Meisterernst. 1994. A novel mediator of class II gene transcription with homology to viral immediate-early transcriptional regulators. Cell 78:525-534.

41. Larschan, E., and F. Winston. 2005. The Saccharomyces cerevisiae Srb8Srb11 complex functions with the SAGA complex during Gal4-activated transcription. Mol. Cell. Biol. 25:114-123.

42. Laybourn, P. J., and M. E. Dahmus. 1990. Phosphorylation of RNA polymerase IIA occurs subsequent to interaction with the promoter and before the initiation of transcription. J. Biol. Chem. 265:13165-13173.

43. Liu, Y., C. Kung, J. Fishburn, A. Z. Ansari, K. M. Shokat, and S. Hahn. 2004. Two cyclin-dependent kinases promote RNA polymerase II transcription and formation of the scaffold complex. Mol. Cell. Biol. 24:1721-1735.

44. Liu, Y., L. Warfield, C. Zhang, J. Luo, J. Allen, W. H. Lang, J. Ranish, K. M. Shokat, and S. Hahn. 2009. Phosphorylation of the transcription elongation factor Spt5 by yeast Bur1 kinase stimulates recruitment of the PAF complex. Mol. Cell. Biol. 29:4852-4863.

45. Lu, H., O. Flores, R. Weinmann, and D. Reinberg. 1991. The nonphosphorylated form of RNA polymerase II preferentially associates with the preinitiation complex. Proc. Natl. Acad. Sci. U. S. A. 88:10004-10008.

46. Malik, S., M. Guermah, and R. G. Roeder. 1998. A dynamic model for PC4 coactivator function in RNA polymerase II transcription. Proc. Natl. Acad. Sci. U. S. A. 95:2192-2197.

47. Meinhart, A., T. Kamenski, S. Hoeppner, S. Baumli, and P. Cramer. 2005. A structural perspective of CTD function. Genes Dev. 19:1401-1415.

48. Mosley, A. L., S. G. Pattenden, M. Carey, S. Venkatesh, J. M. Gilmore, L. Florens, J. L. Workman, and M. P. Washburn. 2009. Rtr1 is a CTD phosphatase that regulates RNA polymerase II during the transition from serine 5 to serine 2 phosphorylation. Mol. Cell 34:168-178.

49. Murray, S., R. Udupa, S. Yao, G. Hartzog, and G. Prelich. 2001. Phosphorylation of the RNA polymerase II carboxy-terminal domain by the Bur1 cyclin-dependent kinase. Mol. Cell. Biol. 21:4089-4096.

50. Nonet, M., D. Sweetser, and R. A. Young. 1987. Functional redundancy and structural polymorphism in the large subunit of RNA polymerase II. Cell 50:909-915.

51. Ohkuni, K., and I. Yamashita. 2000. A transcriptional autoregulatory loop for KIN28-CCL1 and SRB10-SRB11, each encoding RNA polymerase II CTD kinase-cyclin pair, stimulates the meiotic development of S. cerevisiae. Yeast 16:829-846.

52. Ostapenko, D., and M. J. Solomon. 2005. Phosphorylation by Cak1 regulates the C-terminal domain kinase Ctk1 in Saccharomyces cerevisiae. Mol. Cell. Biol. 25:3906-3913.

53. Patturajan, M., R. J. Schulte, B. M. Sefton, R. Berezney, M. Vincent, O. Bensaude, S. L. Warren, and J. L. Corden. 1998. Growth-related changes in phosphorylation of yeast RNA polymerase II. J. Biol. Chem. 273:4689-4694.

54. Phatnani, H. P., and A. L. Greenleaf. 2006. Phosphorylation and functions of the RNA polymerase II CTD. Genes Dev. 20:2922-2936. 
55. Prelich, G., and F. Winston. 1993. Mutations that suppress the deletion of an upstream activating sequence in yeast: involvement of a protein kinase and histone H3 in repressing transcription in vivo. Genetics 135:665-676.

56. Price, D. H. 2000. P-TEFb, a cyclin-dependent kinase controlling elongation by RNA polymerase II. Mol. Cell. Biol. 20:2629-2634.

57. Qiu, H., C. Hu, and A. G. Hinnebusch. 2009. Phosphorylation of the Pol II CTD by KIN28 enhances BUR1/BUR2 recruitment and Ser2 CTD phosphorylation near promoters. Mol. Cell 33:752-762.

58. Ramanathan, Y., S. M. Rajpara, S. M. Reza, E. Lees, S. Shuman, M. B. Mathews, and T. Pe'ery. 2001. Three RNA polymerase II carboxyl-terminal domain kinases display distinct substrate preferences. J. Biol. Chem. 276: 10913-10920.

59. Rodriguez, C. R., E. J. Cho, M. C. Keogh, C. L. Moore, A. L. Greenleaf, and S. Buratowski. 2000. Kin28, the TFIIH-associated carboxy-terminal domain kinase, facilitates the recruitment of mRNA processing machinery to RNA polymerase II. Mol. Cell. Biol. 20:104-112.

60. Rosonina, E., I. M. Willis, and J. L. Manley. 2009. Sub1 functions in osmoregulation and in transcription by both RNA polymerases II and III. Mol Cell. Biol. 29:2308-2321.

61. Schang, L. M., G. J. Hwang, B. D. Dynlacht, D. W. Speicher, A. Bantly, P. A Schaffer, A. Shilatifard, H. Ge, and R. Shiekhattar. 2000. Human PC4 is a substrate-specific inhibitor of RNA polymerase II phosphorylation. J. Biol Chem. 275:6071-6074.

62. Schmitt, M. E., T. A. Brown, and B. L. Trumpower. 1990. A rapid and simple method for preparation of RNA from Saccharomyces cerevisiae. Nucleic Acids Res. 18:3091-3092.

63. Schroeder, S. C., B. Schwer, S. Shuman, and D. Bentley. 2000. Dynamic association of capping enzymes with transcribing RNA polymerase II. Genes Dev. 14:2435-2440.

64. Stock, J. K., S. Giadrossi, M. Casanova, E. Brookes, M. Vidal, H. Koseki, N. Brockdorff, A. G. Fisher, and A. Pombo. 2007. Ring1-mediated ubiquitina- tion of $\mathrm{H} 2 \mathrm{~A}$ restrains poised RNA polymerase II at bivalent genes in mouse ES cells. Nat. Cell Biol. 9:1428-1435.

65. Thompson, N. E, T. H. Steinberg, D. B. Aronson, and R. R. Burgess. 1989 Inhibition of in vivo and in vitro transcription by monoclonal antibodies prepared against wheat germ RNA polymerase II that react with the heptapeptide repeat of eukaryotic RNA polymerase II. J. Biol. Chem. 264:1151111520.

66. Uptain, S. M., C. M. Kane, and M. J. Chamberlin. 1997. Basic mechanisms of transcript elongation and its regulation. Annu. Rev. Biochem. 66:117-172.

67. Valay, J. G., M. Simon, M. F. Dubois, O. Bensaude, C. Facca, and G. Faye. 1995. The KIN28 gene is required both for RNA polymerase II mediated transcription and phosphorylation of the Rpb1p CTD. J. Mol. Biol. 249:535544.

68. Werten, S., G. Stelzer, A. Goppelt, F. M. Langen, P. Gros, H. T. Timmers, P. C. Van der Vliet, and M. Meisterernst. 1998. Interaction of PC4 with melted DNA inhibits transcription. EMBO J. 17:5103-5111.

69. Wood, A., J. Schneider, J. Dover, M. Johnston, and A. Shilatifard. 2005. The Bur1/Bur2 complex is required for histone H2B monoubiquitination by Rad6/Bre1 and histone methylation by COMPASS. Mol. Cell 20:589-599.

70. Wood, A., and A. Shilatifard. 2006. Bur1/Bur2 and the Ctk complex in yeast: the split personality of mammalian P-TEFb. Cell Cycle 5:1066-1068.

71. Yao, S., A. Neiman, and G. Prelich. 2000. BUR1 and BUR2 encode a divergent cyclin-dependent kinase-cyclin complex important for transcription in vivo. Mol. Cell. Biol. 20:7080-7087.

72. Yao, S., and G. Prelich. 2002. Activation of the Bur1-Bur2 cyclin-dependent kinase complex by Cak1. Mol. Cell. Biol. 22:6750-6758.

73. Zhou, K., W. H. Kuo, J. Fillingham, and J. F. Greenblatt. 2009. Control of transcriptional elongation and cotranscriptional histone modification by the yeast BUR kinase substrate Spt5. Proc. Natl. Acad. Sci. U. S. A. 106:69566961. 


\title{
RNA Polymerase II Phosphorylation and Gene Expression Regulation
}

\author{
Olga Calvo and Alicia García \\ Additional information is available at the end of the chapter
}

http://dx.doi.org/10.5772/48490

\section{Introduction}

RNA polymerases (RNAPs) are among the most important cellular enzymes. They are present in all living organisms from Bacteria and Archaea to Eukarya and are responsible for DNA-dependent transcription. Although in Bacteria and Archaea there is only one RNAP, Eukarya possess up to three RNAPs in animals (I, II and III) and five in plants (IV and V) [1-2]. All of the RNAPs are evolutionarily related and have common structural and functional properties. The minimally conserved structural organization is represented by the bacterial enzyme, which contains only 4 subunits $\left(\alpha, \alpha^{\prime}, \beta, \beta^{\prime}\right)$, whereas Archaea and Eukarya RNAPs are composed of 12 subunits (Rpb1-Rpb12) [3]. In prokaryotes, one RNAP transcribes all of the genes into all of the RNAs, however, in eukaryotes, this is achieved by three RNAPs. RNAPI transcribes genes that encode for $18 \mathrm{~S}$ and $28 \mathrm{~S}$ ribosomal RNAs; RNAPIII transcribes short genes, such as tRNAs and 5S ribosomal RNA, and RNAPII transcribes all protein-coding genes and genes for small noncoding RNAs (e.g., small nuclear RNAs (snRNAs) that are involved in splicing). The largest catalytic subunits of all three eukaryotic polymerases share homology among themselves and with the largest subunit of bacterial polymerase [4]. Solely the largest subunit of RNAPII (Rpb1) contains an unusual evolutionarily conserved carboxy-terminal domain (CTD) [5], which is subjected to numerous post-translational modifications of extraordinary importance in gene expression regulation [6-8].RNAPII transcription plays a central role in gene expression and is highly regulated at many steps, such as initiation, elongation and termination. Furthermore, phosphorylation of the Rpb1 CTD is known to regulate all of the transcription steps and coordinate these steps with other nuclear events. Prior to mRNA biosynthesis, RNAPII proceeds through several steps, such as promoter recognition, preinitiation complex (PIC) assembly, open complex formation, initiation and promoter escape. This sequence of events is initiated by the binding of gene-specific activators and coactivators, which results in the recruitment of basal transcription machinery (i.e., general transcription factors (GTFs): 
TFIIA, TFIIB, TFIID, TFIIE, TFIIF, and TFIIH) and RNAPII to promoters [9-11]. Basal transcription factors position RNAPII on promoters to form the PIC but also function at later steps, such as promoter melting and initiation site selection. Thereafter, initiation proceeds, and RNAPII leaves the promoter during promoter clearance and proceeds into processive transcript elongation. Finally, when the gene has been fully transcribed, transcriptional termination occurs, and RNAPII is released and recycled to reinitiate a new round of transcription [12-14].

During its passage across a gene, RNAPII must overcome challenges. Initially, the polymerase needs to escape from the promoter, and the synthesis of the pre-mRNAs must be tightly coupled to its subsequent processing (i.e., capping, splicing, and polyadenylation). Then, initiation factors must be exchanged for elongation factors [15], which are thought to increase the transcription rate and RNAPII processivity. In fact, recently, there has been an extraordinary increase in the number of proteins known to influence transcription elongation by avoiding transcriptional arrest, facilitating chromatin passage and mRNA processing [16-21], allowing mRNA packaging into a mature ribonucleoprotein (mRNP) and controlling mRNP quality and mRNA export [13, 22-28]. Therefore, the discovery of all of these factors has provided further evidence that the elongation phase is also highly regulated in eukaryotic cells and strictly coordinated with other nuclear processes [12-14].

\section{RNAPII CTD phosphorylation: The CTD code}

During the last two decades, gene expression studies have provided further evidence that many steps in gene expression, originally considered distinct and independent, are, in fact, highly coordinated, linked and regulated in a complex web of connections [29-30]. The central coordinator that directs this regulatory network (i.e., from transcription initiation to termination and with pre-mRNA processing) in combination with many other nuclear functions is RNAPII, and the carboxy-terminal domain (CTD) of its largest subunit is of remarkable importance. CTD phosphorylation regulates and coordinates the entire transcription cycle with pre-mRNA processing, mRNA transport and with chromatin remodeling and modification [13]. The CTD, therefore, has a critical integrating role in essentially all of the mRNA biogenesis steps, thus, it is subject to a dynamic regulation during the transcription cycle (i.e., [21, 31-32]). Therefore, RNAPII phosphorylation is one of the key processes in the regulation of transcription specifically and gene expression in general; consequently, deciphering the mechanisms that underlie RNAPII phosphorylation regulation has become one of the most studied issues in the field of gene expression.

RNAPII is comprised of 12 subunits (Rpb1-12) that are structurally and functionally conserved from yeast to mammals [33-34]. In 1985, the largest subunit of RNAPII, Rpb1, from mouse and Saccharomyces cerevisiae, was cloned [4,35], and its sequence revealed that it contained a highly conserved carboxy-terminal domain (CTD). This domain has been extensively studied since then and, although it is a simple repetition in tandem of the heptapeptide consensus sequence Tyr1-Ser2-Pro3-Thr4-Ser5-Pro6-Ser7 (YSPTSPS); Figure 1), the CTD has an extremely complex functionality. The consensus sequence is present in 
animals, plants, yeast, and in many protists [5, 36-37], and it has been hypothesized that the CTD structure has originated through amplifications of a repetitive DNA sequence and that the number of repeats appears directly correlated with genomic complexity (Figure 1A; [38]). For example, mouse and human CTDs contain 52 repeats [35, 39-40]; the Drosophila CTD contains 45 repeats [41]; 25-27 repeats are found in the yeast CTD (Figure 1A; [4]); and 15 repeats are found in protozoan CTDs $[5,38]$. Although the CTD is completely dispensable for in vitro transcription, it is required for efficient RNA processing [17, 42]. In fact, the CTD is essential for cell viability because its deletion is lethal in mice, Drosophila and yeast, and partial truncations or site-specific mutations cause specific growth defects $[5,42]$.

\section{Human \\ RNAPII-CTD}

$\begin{array}{llll}\text { YSPTSPA } & 28 & \text { YSPTSPS } \\ \text { YEPRSPG } & 29 & \text { YSPTSPS } \\ \text { YTPQSPS } & 30 & \text { YSPTSPS } \\ \text { YSPTSPS } & 31 & \text { YSPSSPR } \\ \text { YSPTSPS } & 32 & \text { YTPQSPT } \\ \text { YSPTSPN } & 33 & \text { YTPSSPS } \\ \text { YSPTSPS } & 34 & \text { YSPSSPS } \\ \text { YSPTSPS } & 35 & \text { YSPTSPK } \\ \text { YSPTSPS } & 36 & \text { YTPTSPS } \\ 0 & \text { YSPTSPS } & 37 & \text { YSPSSPE } \\ 1 & \text { YSPTSPS } & 38 & \text { YTPTSPK } \\ 2 & \text { YSPTSPS } & 39 & \text { YSPTSPK } \\ 3 & \text { YSPTSPS } & 40 & \text { YSPTSPK } \\ 4 & \text { YSPTSPS } & 41 & \text { YSPTSPT } \\ 15 & \text { YSPTSPS } & 42 & \text { YSPTTPK } \\ 6 & \text { YSPTSPS } & 43 & \text { YSPTSPT } \\ 17 & \text { YSPTSPS } & 44 & \text { YSPTSPV } \\ 8 & \text { YSPTSPS } & 45 & \text { YTPTSPK } \\ 9 & \text { YSPTSPS } & 46 & \text { YSPTSPT } \\ 0 & \text { YSPTSPS } & 47 & \text { YSPTSPK } \\ 1 & \text { YSPTSPS } & 48 & \text { YSPTSPT } \\ 2 & \text { YSPTSPN } & 49 & \text { YSPTSPKGST } \\ 23 & \text { YSPTSPN } & 50 & \text { YSPTSPG } \\ 24 & \text { YTPTSPS } & 51 & \text { YSPTSPT } \\ 25 & \text { YSPTSPS } & 52 & \text { YSLTSPAISPDDSDEEN } \\ 26 & \text { YSPTSPN } & & \\ 27 & \text { YTPTSPN } & & \end{array}$

\section{Saccharomyces cerevisiae RNAPII-CTD}

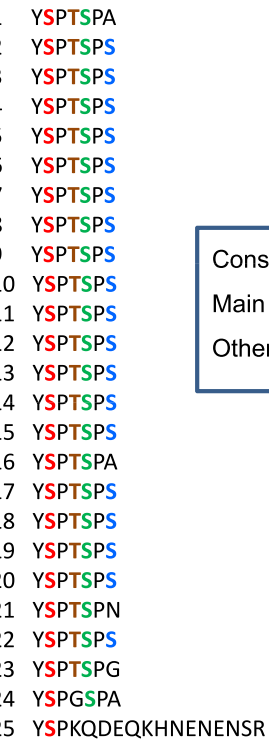

Consensus sequence: $\quad \mathbf{Y}_{1} \mathbf{S}_{2} \mathbf{P}_{3} \mathbf{T}_{4} \mathbf{S}_{5} \mathbf{P}_{6} \mathbf{S}_{7}$

Main phosphorylation sites: $Y_{1} S_{2} P_{3} T_{4} S_{5} P_{6} S_{7}$ Other phosphorylation sites: $\mathrm{Y}_{1} \mathrm{~S}_{2} \mathrm{P}_{3} \mathrm{~T}_{4} \mathrm{~S}_{5} \mathrm{P}_{6} \mathrm{~S}_{7}$

Figure 1. Human and Saccharomyces cerevisiae Rpb1-CTDs.

Original studies showed that two RNAPII forms can be differentiated in SDS-PAGE gels because of the different mobility of Rpb1 [43]. These two forms were termed RNAPIIA and RNAPIIO, and they differ in the extent of CTD phosphorylation. RNAPIIA is hypophosphorylated [44], and RNAPIIO is hyperphosphorylated [45]. Moreover, both forms, IIA and IIO, are functionally distinct because the IIA form is preferentially recruited to the promoter and associated with preinitiation complexes [46], whereas RNAPIIO functions during elongation, is highly phosphorylated [44] and thus requires dephosphorylation to stimulate its recruitment into the PIC complexes and to reinitiate a new round of transcription [47]. We currently know that this earlier two-step transcription cycle 
model that is based on the two RNAPII forms is overly simple. Different phosphorylated forms of RNAPII are specific and characteristic of the different steps that occur during the transcription cycle [48], and the correct progression of RNAPII through the transcription cycle is dependent on changes in the CTD phosphorylation status. Differential CTD phosphorylation promotes the exchange of initiation and elongation factors during promoter clearance [15], the exchange of elongation and 3 '-end processing factors at termination [49], as well as RNAPII recycling [50] and, moreover, links pre-mRNA processing and other nuclear events with transcription [17, 42]. Therefore, the CTD phosphorylation cycle is very complex. It is widely known that the three serines (i.e., Ser2, Ser5, and Ser7) [7, 51], the tyrosine [52-53] and the threonine [54] in each repeat can be phosphorylated. Additionally, both proline residues can be isomerized by a prolyl isomerase [55]. Moreover, glycosylation of serines and threonine can also occur [8], and in human cells, the CTD can be methylated at some of the degenerate repeat sites [56]. The multitude of possible CTD modifications, especially Ser phosphorylations, in combination with the numerous repetitions, gives rise to a wide range of variations (i.e., phosphorylation patterns) that have been termed the "CTD code" (Figure 2) [6-8].

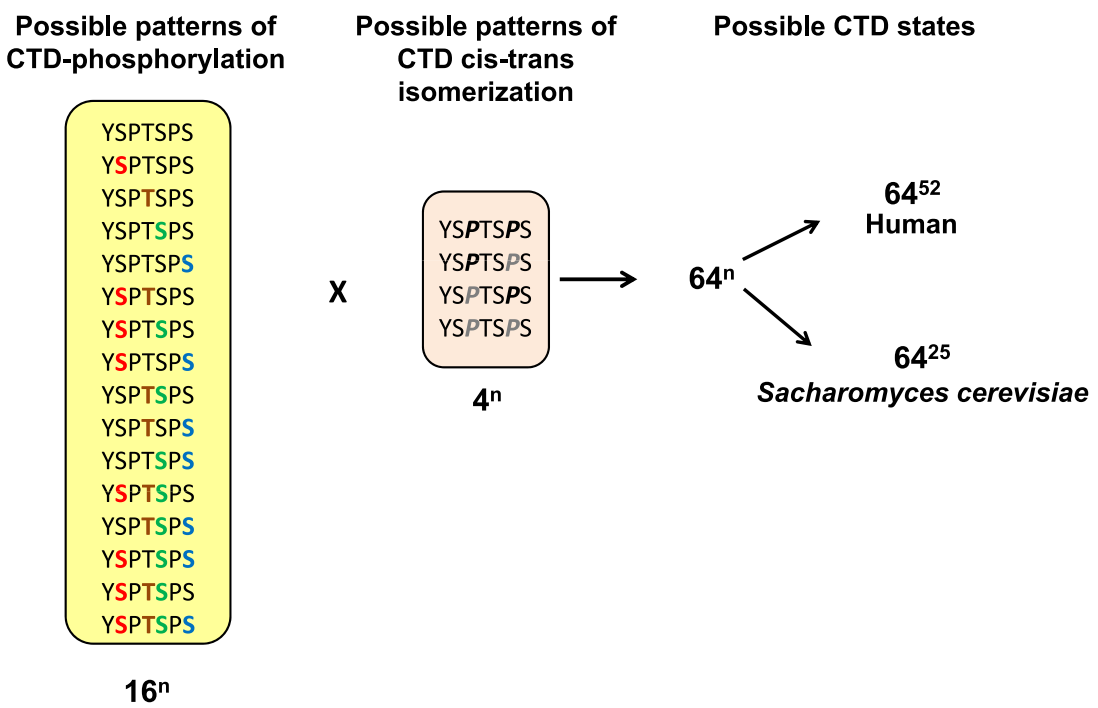

Figure 2. The CTD Code. Only Ser (S) and Thr (T) phosphorylation sites have been considered. CTD glycosylation has not been considered [57] because this modification is mutually exclusive of phosphorylation [8]. n: number of consensus repetitions.

The RNAPII CTD code determines and coordinates the timely sequential recruitment of required specific factors during the transcription cycle. Therefore, the CTD functions as a scaffold that coordinates mRNA biogenesis, such as transcription initiation [58], promoter clearance [59], elongation [60], and termination [31, 61-62], as well as RNA processing [17, $21,30]$ and snRNA and snoRNA gene expression [63-65] by recruiting the appropriate set of factors when required during active transcription. These factors recognize CTD 
phosphorylation patterns either indirectly or directly by contacting phosphorylated residues. Among the CTD-associated factors are export and histone modifier factors and DNA repair factors [21].

\subsection{Ser2P and Ser5P, and to a lesser extent, Ser7P, are the main determinants of the CTD code}

To determine precisely which serine residues are phosphorylated in a particular repeat has been challenging because of the numbers of phospho-acceptor amino acid residues and consensus motif repetitions (Figure 1). However, studies involving chromatin immunoprecipitation with specific monoclonal antibodies have provided evidence that differential phosphorylation of the Ser residues coincides with the temporal and spatial recruitment of different factors [8, 32, 48, 66-67]. In fact, these antibodies have been largely used to decipher and characterize the role of CTD phosphorylation during the transcription cycle and in gene expression regulation $[8,32,68]$. Antibodies that selectively recognize either Ser2 or Ser5 phosphorylation (i.e., Ser2P or Ser5P, respectively) were the first residues to be described [66]; phosphorylation of these two residues has been extensively studied, and they have been considered as the two main determinants of the CTD code [6]. It is widely known that CTD phosphorylation switch from Ser5 to Ser2 during the course of transcription and is subject to a dynamic regulation during the whole transcription cycle [69-71]. The level of Ser5 phosphorylation peaks early in the transcription cycle and remains constant or decreases as RNAPII progresses to the 3' end of the gene (Figure 3); [48, 67, 72]). In contrast, Ser2 phosphorylation is the predominant modification in the coding and $3^{\prime}$-end gene regions and occurs simultaneously with productive elongation [31, 48, 73]. On the other hand, de-phosphorylation of Ser5 occurs during the initiation-elongation transition and throughout the entire elongation step, whereas Ser2 de-phosphorylation occurs at the end of transcription to recycle the polymerase and reinitiate a new round of transcription. Therefore, reversible phosphorylation/de-phosphorylation of the CTD plays a significant role in modulating the transcription cycle [31-32].

Most recently, the use of new anti-CTD monoclonal antibodies has demonstrated that Ser7, which is the most degenerate position of the CTD [41], can be phosphorylated during the transcription of snRNA genes and protein-coding genes [64, 68, 74]. Subsequently, this mark increases the complexity of the CTD code [7-8]. Ser7 phosphorylation is mediated by the same kinase [74-75], although, at least in Saccharomyces cerevisiae, Ser7P appears not to be dephosphorylated by the same Ser5 phosphatase (see below) [76].The first study on Ser7 phosphorylation provided further evidence that this modification is functionally important for transcription and processing of snRNAs $[8,64]$ and hypothesized that the CTD code could be gene-transcription dependent. In mammals, Ser7P peaks at the promoter region of snRNA genes but is enhanced toward the $3^{\prime}$ end of protein-coding genes [68]. Recent genome-wide distribution studies in yeast have provided further evidence that Ser7P in protein coding genes occurs early during transcription initiation and is maintained during the entire transcription cycle. In fact, Ser7P is not only maintained, but it is also generated de novo during transcription elongation. Additionally, it has been hypothesized that Ser7 phosphorylation could facilitate elongation and suppress cryptic transcription [77]. 


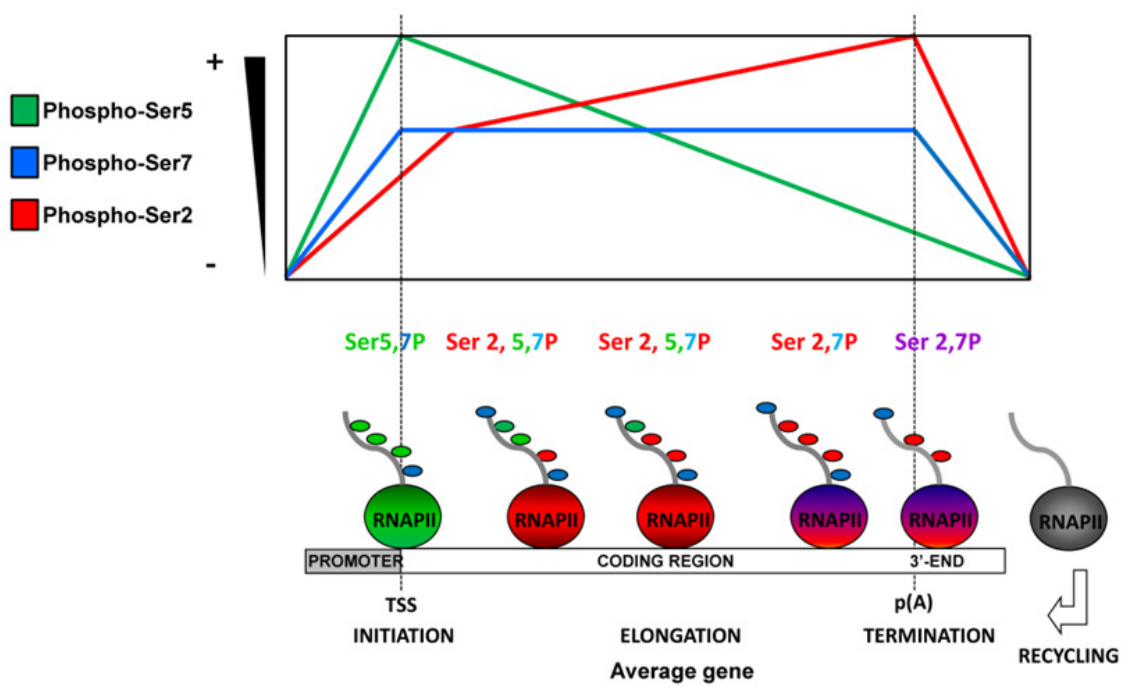

Figure 3. RNAPII CTD phosphorylation profile in Sacharomyces cerevisiae. During transcription initiation and promoter escape RNAPII CTD is phosphorylated on Ser5 (Ser5P) [48, 78]. Concurrently, Ser7 is phosphorylated (Ser7P), establishing a bivalent mark at both protein-coding and noncoding genes [74-76]. Shortly after promoter dissociation, Ser5P is rapidly removed while phosphorylated Ser2 (Ser2P) and Ser7P continue to accumulate [70,77]. Finally, all CTD marks are rapidly removed at the end of transcription, and the hypophosphorylated RNAPII (in grey) is ready to assemble into the preinitiation complex and re-initiate transcription [73, 79-80]. Small circles represent phosphorylated serine residues (green cirlces for Ser5P, blue circles for Ser7P and red circles for Ser2P). Differently colored big circles represent the distinct phosphorylated forms of RNAPII during initiation, elongation and termination. TSS: transcription start site; $\mathrm{p}(\mathrm{A})$ : polyadenylation site.

\subsection{Tyrosine 1 and Threonine 4 can also be phosphorylated}

Tyrosine 1 (Tyr1) is evolutionarily conserved and present in all of the 52 repeats of the mammalian CTD, and in all of the 26-27 repeats of the yeast CTD. Although, it is well known that Tyr1 is susceptible to phosphorylation by tyrosine kinases in vivo [52-53] and that Tyr1 mutations are lethal in yeast [81], the function of this modification is unknown. Additionally, threonine 4 (Thr4) is also subjected to phosphorylation, at least in mammalian and in yeast cells [54, 82], and recently it has been demonstrated that phosphorylation of the Thr4 residues is required specifically for histone mRNA 3' end processing, which facilitates the recruitment of $3^{\prime}$ processing factors to histone genes, and is evolutionarily conserved from yeast to human [54].

In mammals, there is an important degeneracy at some positions in the CTD, mainly in most of the carboxy-terminal repeats. Thus, the last repeat of the CTD is followed by a conserved 10 amino acid extension (Figure 1; [5]) that contains a constitutive site for the casein kinase (CK) II site [83]. Though deletion of this extension results in degradation of the CT, and 
effects in transcription and pre-mRNA processing [83-84], mutation of the CKII target site does not affect RNAPII CTD stability. Additionally, this extension is required for the phosphorylation of Tyr1 by c-Abl in mammals and it has been suggested that Tyr1 phosphorylation could be involved in functions specific of these higher eukaryotes [85]. Finally, non-consensus residues, such as lysine and arginine, are also present in the CTD, and they could be potentially modified by acetylation, ubiquitylation, sumoylation (lysine residues) and methylation (lysine and arginine residues) [86]. Therefore, the possibilities of CTD modifications are enormous, and only some of the modifications have been demonstrated to influence, while interacting with numerous factors, different aspects of gene expression.

\section{Modifying enzymes: Kinases and phosphatases}

Most of what is known concerning CTD-protein interactions, and in particular RNAPII CTD modifying enzymes, is derived from animal and yeast models, especially Saccharomyces cerevisiae, since the consensus sequence and repetitive structure of the CTD in addition to the CTD-modifying enzymes are highly conserved across a wide range of organisms. A number of kinases and phosphatases that target the CTD have been described and extensively studied (Tables 1 and 2, and reference therein). Recent genomewide distribution studies of the CTD modifications in yeast have provided further evidence that complex interplay exists between these enzymes (i.e., kinases, phosphatases and isomerase), which coordinate a universal RNAPII CTD cycle [69]. These modifying enzymes alter specific serine residues within the CTD repeats and have distinct and specific functions along the transcription cycle. Although the catalytic mechanisms of CTD kinases and phosphatases are known, the basis for their specificity remains incompletely understood [87-88].

Below, in figure 4, we will highlight the most relevant features and functions of CTD kinases and phosphatases, with special emphasis on the budding yeast enzymes because extensive studies on RNAPII CTD phosphorylation have been performed on that organism, and most of these enzyme complexes are evolutionarily conserved.

\subsection{RNAPII CTD kinases}

The CTD is phosphorylated by members of the cyclin-dependent kinase (CDK) family, which usually consists of a catalytic and a cyclin subunit. Although CDKs are cell cycle regulators, several members of this family have direct functions in RNAPII activity regulation $[39,88]$. All these kinases are members of multiprotein transcription regulatory complexes and, in mammals, the best known are $\mathrm{Cdk} 7 / \mathrm{CycH}, \mathrm{Cdk} 8 / \mathrm{CycC}$ and $\mathrm{Cdk} 9 / \mathrm{CycT}$; recently, Cdk12/CycK has been characterized as a new CTD kinase [89]. These kinases are evolutionarily conserved, and the following four complexes with kinase activity have been identified in the well-known yeast model Saccharomyces cerevisae: Kin28/Ccl1, Srb10/Srb11, Bur1/Bur2 and Ctk1/Ctk2 (Table 1). 


\begin{tabular}{|c|c|c|c|}
\hline KINASES & SPECIFICITY & FUNCTION & REFERENCES \\
\hline $\begin{array}{l}\text { ySrb10 / Srb11 } \\
\text { hCdk8 / CycC }\end{array}$ & $\begin{array}{l}\text { CTD-Ser2 } \\
\text { CTD-Ser5 } \\
\text { Other substrates } \\
\text { Bdf1 and Taf2, Med2 } \\
\text { Gcn4, Msn2, Ste12, } \\
\text { Gal4 }\end{array}$ & $\begin{array}{l}\text { TFIIH inhibition } \\
\text { PIC inhibition / activation } \\
\text { Scaffold complex formation } \\
\text { SAGA-dependent transcription }\end{array}$ & [90-94] \\
\hline $\begin{array}{l}\text { yKin28 / Ccl1- } \\
\text { Tfb3 } \\
\text { hCdk7 / CycH }\end{array}$ & $\begin{array}{l}\text { CTD-Ser5 } \\
\text { CTD-Ser7 } \\
\text { Other substrates } \\
\text { Med4 } \\
\text { Rgr1/Med14 }\end{array}$ & $\begin{array}{l}\text { Promoter scape } \\
\text { Scaffold complex formation } \\
\text { Capping complex recruitment } \\
\text { Bur1 activity stimulation } \\
\text { Set1/COMPASS recruitment } \\
\text { Elongation factor Paf1C recruitment } \\
\text { SAGA complex recruitment } \\
\text { SnRNA 3' processing } \\
\text { Promoter-pausing } \\
\text { Gene looping }\end{array}$ & $\begin{array}{l}{[64,72,74-76,90,94-} \\
100]\end{array}$ \\
\hline $\begin{array}{l}\text { yBur1 / Bur2 } \\
\text { hCdk9 / CycT }\end{array}$ & $\begin{array}{l}\text { CTD-Ser2 } \\
\text { CTD-Ser5 } \\
\text { CTD-Ser7 } \\
\text { CTD-Thr4 } \\
\text { Other Substrates } \\
\text { hDSIF (ySpt5), } \\
\text { Rad6/Bre1 }\end{array}$ & $\begin{array}{l}\text { Ctk1 activity stimulation } \\
\text { Elongation } \\
\text { PAF complex recruitment } \\
\text { H3K4 methylation } \\
\text { H2B monoubiquitination } \\
\text { Histone genes } 3 \text { '-end processing }\end{array}$ & {$[54,99,101-104]$} \\
\hline $\begin{array}{l}\text { yCtk1 / Ctk2- } \\
\text { Ctk3 } \\
\text { hCdk12 / CycK }\end{array}$ & $\begin{array}{l}\text { CTD-Ser2 } \\
\text { Other Substrates } \\
\text { Rps2 }\end{array}$ & $\begin{array}{l}\text { RNAPII release from basal initiation } \\
\text { factors } \\
\text { 3'-processing factors recruitment } \\
\text { Transcription termination } \\
\text { Spt6 recruitment } \\
\text { H3K36 methylation } \\
\text { Translation elongation }\end{array}$ & {$[16,49,89,105-112]$} \\
\hline
\end{tabular}

Table 1. RNAPII CTD kinases. Mammalian and Saccharomyces cerevisiae kinases are shown. 
CTD-Phosphatases

CTD-Kinases

\section{Srb10/CDK8}

Ser5,2P

$$
\text { Ser5,7P Ser 2, 5,7P Ser 2, 5,7P }
$$

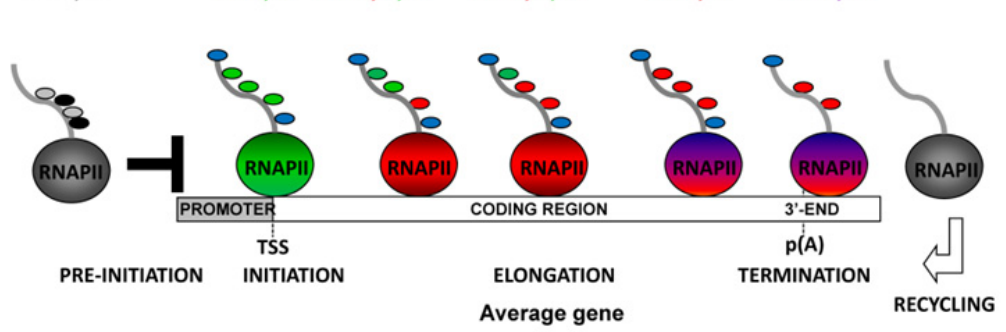

Figure 4. The levels of CTD phosphorylation are precisely modulated during the whole transcription cycle by the action of evolutionary conserved kinases and phosphatases. The level of Ser5 phosphorylation peaks early in the transcription cycle due to the action of Kin28 (Cdk7 in human) and remains constant or decreases as RNAPII progresses to the $3^{\prime}$ end of the gene [48, 67, 72]. In contrast, Ser2 phosphorylation is the predominant modification in the gene body and towards the $3^{\prime}$ end, and occurs concurrently with productive elongation $[31,48]$. Ctk1 is the principal kinase responsible for Ser2 phosphorylation in the body of the genes [16, 73]. In addition to Ctk1, the Bur1/Bur2 kinase complex phosphorylates Ser2 when RNAPII is near the promoter and stimulates Ser2 phosphorylation by Ctk1 during elongation [99]. Several CTD-phosphatases have been shown to specifically de-phosphorylate Ser5P (Ssu72 and Rtr1), Ser2P (Fcp1) and Ser7 (Ssu72) to promote the initiation-elongation transition, elongation, termination, and RNAPII recycling [50, 73, 79, 167, 182]. Srb10 was demonstrated to phosphorylate the RNAPII CTD prior to PIC assembly, negatively regulating transcription initiation [92].

\subsubsection{Pre-initiation and Initiation RNAPII CTD kinases}

\section{Cdk8/CycC and Srb10/Srb11}

Human Cdk8/CycC and yeast Srb10/Srb11 are part of the CDK-module of Mediator [113], a large complex of 25-30 proteins that is structured in 4 sub-complexes or modules that act as a molecular bridge between DNA-binding transcription factors and RNAPII [114-115]. Mediator is required for the expression of nearly all RNAPII transcribed genes [116]. Cdk8/Srb10 is part of the CDK-module (Cdk8, cyclin C, MED12 and MED13 in mammals; Srb8, 9, 10 and 11 in yeast), which dynamically associates with Mediator [93, 117]. Although Cdk8/Srb10 can phosphorylate Ser2 and Ser5 of the CTD repeats in vitro [90, 92-94, 109, 113], the in vivo relevance of $\mathrm{Cdk} 8 / \mathrm{Srb} 10$ remains to be defined. In fact, several studies have provided evidence that Srb10/11 can have both negative [116] and positive [118] effects on gene expression in vivo. Srb10 was demonstrated to phosphorylate the RNAPII CTD prior to PIC assembly, negatively regulating transcription initiation (Figure 4; [92]). Notably, human $\mathrm{Cdk} 8$ represses transcription via phosphorylation and inactivation of the cyclin $\mathrm{H}$ subunit of 
TFIIH, which is the Cdk7 partner [90]. However, subsequent work showed that Srb10 functions in association with Kin28 (hCdk7) to promote RNAPII re-initiation [94]. Following PIC formation and an initial round of transcription, it is thought that subsequent rounds of RNAPII binding and promoter clearance are facilitated via a "scaffold complex" that is composed of a subset of Mediator subunits and GTFs (except TFIIB and TFIIF) that remains bound at the promoter [119]. Therefore, Kin28 and Srb10 have overlapping positive functions in promoting transcription and in the formation of the scaffold complex [94]. Srb10 phosphorylates two subunits of the general transcription factor TFIID (Bdf1 and Taf2) at the PIC; however, the role of these phosphorylation events has not yet been defined. Moreover, Srb10 phosphorylates and inactivates some transcription factors [120-122] by triggering their nuclear export or degradation [123-124] and phosphorylates and enhances the activity of others (Table 1). In summary, the in vivo relevance of RNAPII phosphorylation by $\mathrm{Cdk} 8 / \mathrm{Srb} 10$ and its role in gene expression have yet to be elucidated.

$\mathrm{Cdk7/CycH}$ and Kin28/Ccl1-Tfb3

The Cdk7/cyclin $\mathrm{H}$ complex in mammals and its homolog in Sacharomyces cerevisiae, Kin28/Ccl1, are part of the TFIIH general transcription factor. In yeast, Kin28 is found associated with a third subunit (Tfb3) to form a trimer, called TFIIK (Kin28-Ccl1-Tfb3) within TFIIH [125]. Mammalian Cdk7 was isolated as a RNAPII CTD kinase that possesses Cdk-activating kinase (CAK) activity [126-128], whereas in yeast, Kin28 lacks this activity [129]. The CAK activity is fulfilled by a different kinase, Cak1 [130-131]. Cdk7 and Kin28 are both essential for cell viability [132], and the in vivo function of Kin28 has been extensively studied in yeast. Cdk7/Kin28 is the primary kinase that phosphorylates the CTD within a transcription initiation complex (Figure 4). Cdk7/Kin28 has been demonstrated to phosphorylate both Ser5 and Ser7 in vitro and in vivo [72, 74-76, 92]. Phosphorylation on Ser5 by Cdk7/Kin28 is thought to disrupt the stable interactions between the CTD and PIC components, thereby permitting the polymerase to release from the promoter and commence productive transcript elongation [92, 133-134]. Ser5 phosphorylation by Cdk7/Kin28 is required for the recruitment of the mRNA-capping complex [72, 135-137] and nuclear cap-binding complex (CBC) [100] to nascent transcripts and for co-transcriptional recruitment of elongation factor Paf1C [138], histone H3-lysine 4 methyltransferase complex (SET1/COMPASS) [98], and histone acetyltransferase complex SAGA [97].

Additionally, yeast Kin28 phosphorylates two subunits of Mediator (i.e., Med4 and Rgr1/Med14), and although the functionally of these modifications is unknown, it has been demonstrated that Mediator significantly enhances the phosphorylation of RNAPII CTD by Kin28 [94, 96]. In fact, in vitro assembly of TFIIH into a pre-initiation complex requires Mediator [139], and following transcription initiation, phosphorylation of Ser5 by Kin28 parallels with the release of Mediator from the CTD of RNAPII as promoter clearance occurs [80].

As discussed above, in yeast, Kin28 and Srb10 have overlapping functions in promoting transcription, PIC dissociation and subsequent scaffold complex formation [94]. Genetic analysis has provided further evidence that Kin28 and Srb10 are not redundant because only 
Kin28 is essential for growth, and Srb10 is much less processive in terms of phosphorylation than Kin28 [140]. It is clear that Kin28 is the primary kinase responsible for the high level of phosphorylation of RNAPII during initiation [48, 67, 94, 141]. In fact, one essential role of Kin28 that Srb10 does not have is the stimulation of pre-mRNA processing. However, what appears clear, at least in yeast, is that PIC dissociation is dependent on the kinase activities of Kin28 and Srb10. Additionally, another function of RNAPII CTD Ser5 phosphorylation by Kin28 is the enhancement of Bur1/Bur2 recruitment and Ser2 CTD phosphorylation near the promoters [99]. Moreover, it has recently been demonstrated that TFIIH kinase places bivalent marks on the CTD, thereby phosphorylating Ser7 during transcription initiation [74-75].

\subsubsection{RNAPII CTD elongating kinases \\ Cdk9/CycT and Cdk12/CycK}

Eukaryotic organisms possess many factors that regulate transcriptional elongation; among these factors is Cdk9 kinase, which is the catalytic subunit of the positive transcription elongation factor $\mathrm{b}(\mathrm{P}-\mathrm{TEFb})$ that controls the elongation phase of transcription by RNAPII in mammals and Drosophila melanogaster [12]. Cdk9 is the major Ser2 kinase, but it also contributes to Ser5 phosphorylation in vitro and in vivo during the initiation-elongation transition and the polymerase release of promoter-proximal pausing [109, 142]. Cdk9 activity is also required for efficient coupling of transcription with pre-mRNA processing [108]. Additionally, very recently, it has been shown that Thr4 is phosphorylated by Cdk9 [54].

In higher eukaryotes, the transcription factor $\mathrm{P}-\mathrm{TEFb}$ not only regulates CTD phosphorylation, but it also inhibits the action of transcriptional repressors and is required for the association of several elongation factors with the transcribing polymerase. P-TEFb also targets DRB sensitivity-inducing factor (DSIF) and negative elongation factor (NELF) [142-144] (Table 1). Thus, P-TEFb promotes transcription by the following two different mechanisms: inhibiting the action of transcriptional repressors and phosphorylating the CTD during transcription elongation. Until recently, it was believed that Cdk9 was the only CTD Ser2 kinase in higher eukaryotes. In fact, Cdk9 can reconstitute the activity of both $S$. cerevisiae Ser2 CTD kinases, Bur1 and Ctk1. However, it has recently been demonstrated that Drosophila have one ortholog of yeast Ctk1, Cdk12, whereas humans have two, Cdk12 and Cdk13; only Cdk12 has been clearly demonstrated to be an elongating CTD kinase [89, 145]. Notably and similarly, fission yeast Schizosaccharomyces pombe has the following two Ser2 elongating kinases: Lsk1 (ScCtk1) and Cdk9 (ScBur1) [146].

\section{Bur1/Bur2}

Bur1 kinase and its cyclin, Bur2, form an essential CDK in S. cerevisiae involved in transcription elongation [147-148]. Although Bur1 and Ctk1 kinase complexes appear to functionally reconstitute the activity of $\mathrm{P}-\mathrm{TEFb}$ in yeast [149], Bur1 is more related in sequence and functionally to mammalian P-TEFb than Ctk1 [147, 149], and as we have discussed, it is clear that $\mathrm{Cdk} 12$ is the functional equivalent of yeast Ctk1 $[89,145]$. Bur1 can phosphorylate Ser2 
and Ser5 [99, 147, 150] [151], and although it was first demonstrated to show some preference for Ser5 and to be less active than Ctk1 or Kin28 [147], later studies provided evidence that Bur1 interacts with the RNAPII CTD and phosphorylates at Ser2. In fact, Bur1 phosphorylates elongating RNAPII molecules that have been previously phosphorylated at Ser5 and are located near the promoter during early transcription elongation (Figure 4, and [99]. Thus, it has been hypothesized that Bur1/Bur2 is recruited to RNAPII, whose repeats are phosphorylated on Ser5 to enhance phosphorylation on Ser2 by Ctk1. Consistent with it, Bur1 produces the Ser2 phosphorylated residues that remains when Ctk1 is inactivated [152]. Bur1 also stimulates transcription elongation as its mammalian homologue P-TEFb [150, 152], and mutations on BUR1 cause sensitivity to drugs that are known to affect transcription elongation (e.g., 6-azauracil) $[147,150]$. More recently, a chemical-genomic analysis has provided further evidence that Bur1 also phosphorylates Ser7 in the body of the genes [77].

Bur1 shares another function with the mammalian and Schizosaccharomyces pombe Cdk9 [142, 153]. Bur1 kinase activity is important for the in vivo phosphorylation of the elongation factor Spt5 (mammalian DSIF) [102, 154]. Spt5 contains a carboxy-terminal domain that consists of approximately 15 repeats (CTR) that are similar to the RNAPII CTD [102], which is subject to phosphorylation. The Spt5-CTR is required for efficient elongation by RNAPII and for chromatin modifications in transcribed regions (see below). Thus, Spt5 phosphorylation mediates, at least in part, Bur1 kinase roles on transcription elongation and histone modifications [154].

\section{Ctk1/Ctk2-Ctk3}

Ctk1 was originally identified as the kinase subunit of the yeast CTDK-I complex that catalyzes phosphorylation of the RNAPII CTD [155]. Ctk2 is the cyclin, and the Ctk3 function remains unknown. Ctk1 is the principal kinase that is responsible for CTD-Ser2P during transcription elongation, which is coincident with reduced Ser5P [73, 156]. Although Ctk1 is not directly involved in transcription elongation [16, 18, 157], it associates with RNAPII throughout elongation [49], and the kinase activity of Ctk1 is required for the association of polyadenylation and termination factors [16] and histone modification factors [158]. Additionally, Ctk1 interacts genetically as well as biochemically with the TREX complex [159], which couples transcription elongation to mRNA export [160]. Moreover, Ctk1 promotes the dissociation of basal transcription factors from elongating RNAPII, early during transcription, however, kinase activity is not required [105].

In addition to its functions in transcribing gene coding proteins, Ctk1 is involved in RNAPI transcription, interacts with RNAPI in vivo [161], and it is required for the integrity of the rDNA tandem array [162]. All of these studies suggest that Ctk1 might participate in the regulation of distinct nuclear transcriptional machineries. Additionally, it has been demonstrated that Ctk1 is required for DNA damage-induced transcription [163], and notably, that Ctk1 has a role in the fidelity of translation elongation in the cytoplasm [110, 164].

\subsection{RNAPII CTD phosphatases}

Dynamic de-phosphorylation of Ser2P and Ser5P make a significant contribution to changes in CTD phosphorylation patterns during the transcription cycle and is essential for RNAPII 
recycling [8, 31]. Dephosphrylation is achieved by several CTD phosphatases (Table 2). Initially, only one phosphatase was identified, Fcp1, which is required for Ser2P dephosphorylation, transcription elongation and RNAPII recycling to initiate new rounds of transcription [47, 165]. Two other CTD phosphatase were later identified in yeast, Ssu72, a component of the mRNA 3' end processing machinery [79, 88, 166] and Rtr1 [167]. In mammals, in addition to Fcp1, there are other CTD phosphatases, i.e., the small phosphatase SCP1 [168] and RPAP2, which is the human homolog of Rtr1 [169]. Briefly, Fcp1 dephosphorylates Ser2P [73]; Ssu72 dephosphorylates Ser5P and Ser7P [50, 69]; and Rtr1 in yeast and SCP1 in mammals specifically dephosphorylate Ser5P [79, 167-168].

\section{Rtr1 / RPAP2}

Chromatin immunoprecipitation studies have provided further evidence that the increase in Ser2P occurs as transcription progresses through the gene and follows Ser5P dephosphorylation. Rtr1 in yeast was identified as the RNAPII CTD phosphatase driven the Ser5-Ser2P transition at the $5^{\prime}$ regions of the transcribed genes. Rtr1 genetically interacts with the RNAPII machinery, and Rtr1 deletion provokes global Ser5P accumulation in whole-cell extracts and Ser5P association throughout the coding regions [167, 171]. RPAP2 was identified in a systematic analysis carried out to determine the composition and organization of the soluble RNAPII machinery [169], and as in the case of Rtr1, Ser5P levels increase in vivo when RPAP2 is knocked down. Additionally, RPAP2 depletion affects snRNA gene expression as it does mutations of the Ser7 residue [64]. In fact, Ser7P recruits the 3 '-end processing Integrator complex and RPAP2 to drive Ser5 de-phosphorylation of RNAPII CTD during the transcription of snRNA genes [170, 183]. Recently, a model has been proposed in which RPAP2 recruitment to snRNA genes through CTD-Ser7P triggers a cascade of events that are critical for proper gene expression [170].

\begin{tabular}{|l|l|l|l|}
\hline PHOSPHATASES & SPECIFICITY & \multicolumn{1}{|c|}{ FUNCTION } & REFERENCES \\
\hline $\begin{array}{l}\text { yRtr1 } \\
\text { hRpap2 }\end{array}$ & CTD-Ser5P & $\begin{array}{l}\text { Promote Ser5P to Ser2P transition } \\
\text { Association of Integrator with snRNA genes }\end{array}$ & [167, 169-171] \\
\hline $\begin{array}{l}\text { ySsu72 } \\
\text { hSsu72 }\end{array}$ & $\begin{array}{l}\text { CTD-Ser5P, } \\
\text { Ser7P } \\
\text { CTD-Ser5P }\end{array}$ & $\begin{array}{l}\text { Transcription initiation/elongation } \\
\text { Transcription termination and 3'-end processing } \\
\text { Facilitate Fcp1 activity } \\
\text { Gene looping and RNAPII recycling }\end{array}$ & $\begin{array}{l}{[50,69,79,166,172-} \\
176]\end{array}$ \\
\hline y/h Fcp1 & CTD-Ser2P & $\begin{array}{l}\text { Positive regulator of RNAPII transcription } \\
\text { Transcription elongation } \\
\text { Transcription termination and RNAPII } \\
\text { recycling }\end{array}$ & $\begin{array}{l}{[47,73,165,177-} \\
182]\end{array}$ \\
\hline hSCP1 & CTD-Ser5P & $\begin{array}{l}\text { Transition from initiation / capping to processive } \\
\text { transcript elongation. }\end{array}$ & {$[168]$} \\
\hline
\end{tabular}

Table 2. RNAPII CTD phosphatases. Human and Saccharomyces cerevisiae phosphatases are shown. 


\section{Ssu72}

Ssu72 was first described as a Ser5P phosphatase and recently as a Ser7P phosphatase [50, 69]. In fact, Ssu72 was originally identified as functionally interacting with the general transcription factor TFIIB [184-185]. Afterward, it was demonstrated that Ssu72 is part of the cleavage and polyadenylation factor $(\mathrm{CPF})$ with a role at the $3^{\prime}$-end of genes [166, 175]. In fact, Ssu72 is crucial for transcription-coupled $3^{\prime}$-end processing and termination of proteincoding genes [175, 186-187]. Later, Ssu72 was characterized as a Ser5P phosphatase [79] and a potential tyrosine phosphatase [188] and, most recently, it has been demonstrated that Ssu72 is also a Ser7 phosphatase [50,69]. A genome-wide distribution analysis of Ssu72 has demonstrated two peaks of association (Figure 4): a low peak at the $5^{\prime}$-end of genes and a higher peak at the cleavage and polyadenylation site or immediately after it [50]. In agreement with it, Ssu72 dephosphorylates RNAPII CTD following cleavage and polyadenylation and recycles the terminating RNAPII, giving rise to a hypophosphorylated polymerase. In fact, inactivation of Ssu72 leads to the accumulation of Ser7P marks that avoids RNAPII recruitment to the PIC, and therefore inhibits transcription initiation, which results in cell death [50]. In other words, Ssu72 is critical for transcription termination, 3'end processing and RNAPII recycling to restart a new round of transcription. Additionally, it has been shown that Ssu72 has a function in gene looping [172]. In a screen looking for mammalian retinoblastoma tumor suppressors, a human homolog of yeast Ssu72 was identified. As in yeast, mammalian Ssu72 associates with TFIIB and the yeast cleavage/polyadenylation factor Pta1, and exhibits intrinsic phosphatase activity [176]. The crystal complex structure that is formed by human symplekin (Pta1 in yeast), hSsu72 and a CTD phosphopeptide has been elucidated, and hSsu72 was demonstrated to have a function in coupling transcription to pre-mRNA 3'-end processing [187].

Fcp 1 / SCP1

Fcp1 was the first discovered CTD phosphatase and is highly conserved among eukarya [177, 189-191]. It directly de-phosphorylates RNAPII, and its activity is stimulated in vitro by TFIIF and inhibited by TFIIB [73, 177-178]. Fcp1 is essential for cell viability and for transcription in yeast [177-178] and preferentially dephosphorylates Ser2P [73, 192]. Fcp1 has two essential domains: an FCP homologous domain near the amino-terminus and a downstream BRCA1 carboxy-terminal (BRCT) domain [87]. Higher eukaryotes have additional small CTD phosphatases (SCPs) that contain only the FCPH domain characteristic of the Fcp1 proteins. However, SCP1 preferentially catalyzes Ser5P de-phosphorylation and is especially active on RNAPII molecules that have been phosphorylated by TFIIH [168].

Gene transcription is decreased in cells lacking Fcp1 function, and fcp1 mutants exhibited a general accumulation of hyperphosphorylated RNAPII in whole-cell extracts, and specifically in the gene coding regions [178]. Fcp1 also has the ability to stimulate RNAPII transcript elongation in vitro independent of its phosphatase activity [182], which suggests that it associates with and modulates elongating RNAPII. In agreement with this, chromatin immunoprecipitation studies have demonstrated that Fcp1 associates with the promoter and coding region of active genes in vivo [73]. Recent genome-wide studies have provided 
further evidence that Fcp1 associates with genes from promoter to 3 '-end regions, showing the highest association of Fcp1 with the cleavage and polyadenylation site. This association occurs after Bur1 and Ctk1 have dissociated, which permits Fcp1 to completely dephosphorylate all the remaining Ser2P residues ([50], Figure 4). Fcp1 is also responsible for de-phosphorylation of RNAPII following its release from DNA [165]. Fcp1 association with genes at the cleavage polyadenylation site overlaps with Ssu72 association, whereas this overlapping does not exist at the $5^{\prime}$ and coding regions (Figure 4). This fact indicates that CTD de-phosphorylation may be coupled at the $3^{\prime}$-ends, and it has been hypothesized that Ssu72 activity may be important for Fcp1 function, thereby coupling Ser2P dephosphorylation to the removal of Ser5P and Ser7P [69].

\section{Other factors influencing RNAPII CTD phosphorylation}

Although many factors can have effects on CTD phosphorylation, we will highlight the following two that we believe are of significant relevance: the prolyl isomerases hPin $1 / \mathrm{yEss} 1$ and the structure of the RNAPII itself. In addition, we will describe the role of ySub1 in CTD phosphorylation, because it has been extensively studied by us.

\section{1. hPin1 / yEss1}

The CTD can adopt either cis- or trans-conformations, which can significantly affect its modification, especially its phosphorylation. Peptidyl prolyl isomerases (PPIases) are enzymes that accelerate the rates of rotation about the peptide bond preceding proline and are important for protein folding and regulation of dynamic cellular processes [193-194]. Pin1 in mammals and Ess1 in S. cerevisiae are RNAPII CTD PPIases. Phosphorylated Ser2 and Ser5 match with the pSer-Pro sequence that is recognized by Pin1, and the CTD appears to be its principal target of regulation [195-196]. Pin1 has specificity for phosphorylated Ser/Thr-Pro sequences, and it modulates RNAPII activity during cell cycle at least in part by regulating RNAPII CTD phosphorylation levels [195]. Yeast Ess1 physically interacts with the CTD [55, 197], and it preferentially binds and isomerizes in vitro Ser5P residues [198]. Although Pin1 stimulates RNAPII CTD hyperphosphorylation, which results in transcription repression and inhibition of mRNA splicing [195-196], in vivo studies have proposed that Ess1 promotes RNAPII CTD de-phosphorylation. In any case, both isomerases have important functions in transcription. Therefore, initiation-elongation transition is inhibited by Pin1 [196], whereas Ess1 affects multiple steps, such as initiation, elongation, 3 '-end processing, and termination [197, 199-201]. In fact, it has been demonstrated that Ess1 promotes Ssu72-dependent function by creating the CTD structural conformation that is recognized by Ssu72 [202], and recently it has been confirmed that isomerization is a key regulator of RNAPII CTD de-phosphorylation at the end of genes [69].

\subsection{RNAPII structure and Rpb1-CTD localization}

The structure of the complete 12-subunit RNAPII (Rpb1-12) is known [203-204]. Rpb4 and $\mathrm{Rpb} 7$ subunits form a conserved sub-complex that is conserved in all three eukaryotic RNA 
polymerases and archaea RNAP [205-206]. Crystal structures of the Rpb4/7 heterodimer in the context of the complete RNAPII complex localized it in the proximity of the Rpb1-CTD $[203,207]$, and biochemical and genetic studies suggest that Rpb4/7 might have a function in the recruitment of some CTD-binding proteins to transcribing RNAPII. Moreover, it is possible that this sub-complex, Rpb4/7, would regulate the access of CTD modifying enzymes during the whole transcription cycle [203, 207, 209-212]. Actually, structural studies have provided further evidence that the CTD extends from the RNAPII core enzyme near the RNA exit channel [204], where it is ideally located to bind and be affected by the action of a multitude of factors, among them kinases, phosphatases and isomerases. In fact, in yeast, the isopropylisomerase Ess1 and the phosphatase Fcp1 are associated with Rpb7 and Rpb4, respectively [55, 87, 208].

\subsection{The ssDNA binding protein Sub1 as a general regulator of transcription}

Sub1 is an ssDNA binding protein that has been implicated in several steps of mRNA metabolism, such as initiation, transcription termination and $3^{\prime}$-end processing [186, 213215]. Sub1 was originally described as a transcriptional stimulatory protein that is homologous to the human positive coactivator PC4, which physically interacts with activators and components of the RNAPII basal transcription machinery [216-220]. Sub1 genetically and physically interacts with TFIIB [214-215, 221], and several functions have been proposed for Sub1 that include stimulating PIC recruitment and promoter escape. In fact, most recently, using a quantitative proteomic screen to identify promoter-bound PIC components, Sub1 was identified as a functional PIC component that is associated with RNAPII complexes [225]. In addition, we have recently demonstrated that Sub1 globally regulates RNAPII CTD phosphorylation (Figure 5, [222]) and that it is a bona fide elongation factor that influences transcription elongation rates (García and Calvo, unpublished results). Although it has been broadly studied, and several functions have been hypothesized for Sub1 [213, 215, 222-225]; however, the exact mechanism by which Sub1 functions in transcription remains unclear. Sub1 globally regulates RNAPII-CTD phosphorylation during the entire transcription cycle by modulating, albeit differentially, the activity and recruitment of CTD modifying enzymes [222, 224]. We have proposed a model showing how Sub1 might function to globally regulate RNAPII CTD phosphorylation (Figure 5). In wild-type cells (wt), non-phosphorylated Sub1 joins the promoter (possibly via TFIIB; [214215, 221]), contacting the promoter via its DNA binding domain. At that point, Sub1 interacts with the Cdk8-Mediator complex, helping to maintain the PIC in a stable but inactive conformation. Sub1 is then phosphorylated (possibly by the action of kinases at the PIC, similarly to PC4, its human homolog), losing its DNA binding capacity and promoting clearance of TFIIB [214-215, 226]. The PIC next changes conformation such that Kin28 can be activated, and with the help of Srb10 promotes PIC dissociation into the scaffold complex as well as the recruitment of elongating kinases Ctk1 and Bur1. In contrast, in the absence of Sub1 (sub1 4$)$, Srb10 activity and recruitment are decreased, while Kin28 recruitment and activity increases, in agreement with TFIIH being negatively regulated by Cdk8-containing Mediator complexes [90, 227]. As a result, Ser5P levels are increased, and consequently Bur1 and Ctk1 association with chromatin is also enhanced $[99,228]$. Furthermore, in sub1 $\Delta$ cells 
there is a reduction on Fcp1 phosphatase levels and its association with chromatin, which induces an additional increase in Ser2P, impairing RNAPII recycling after transcription termination. Thus, a decrease in RNAPII recruitment is observed in cells lacking Sub1 [224]. Additionally, Sub1 also influences Spt5 elongation factor phosphorylation by Bur1 (García and Calvo, unpublished results). We currently do not understand the biochemical basis for these effects. We have not found evidence that Sub1 associates with any of the CTD kinases or evidence that Sub1 influences the CTD kinase activities by influencing post-translational modifications of the kinases. Therefore, we currently consider two possible explanations for the effects of Sub1 on the activities of the CTD kinases. One explanation is that Sub1 enhances the association (or dissociation) of an unidentified, common regulator with the kinases, whereas the other is that Sub1 in some manner influences kinase accessibility to the CTD.

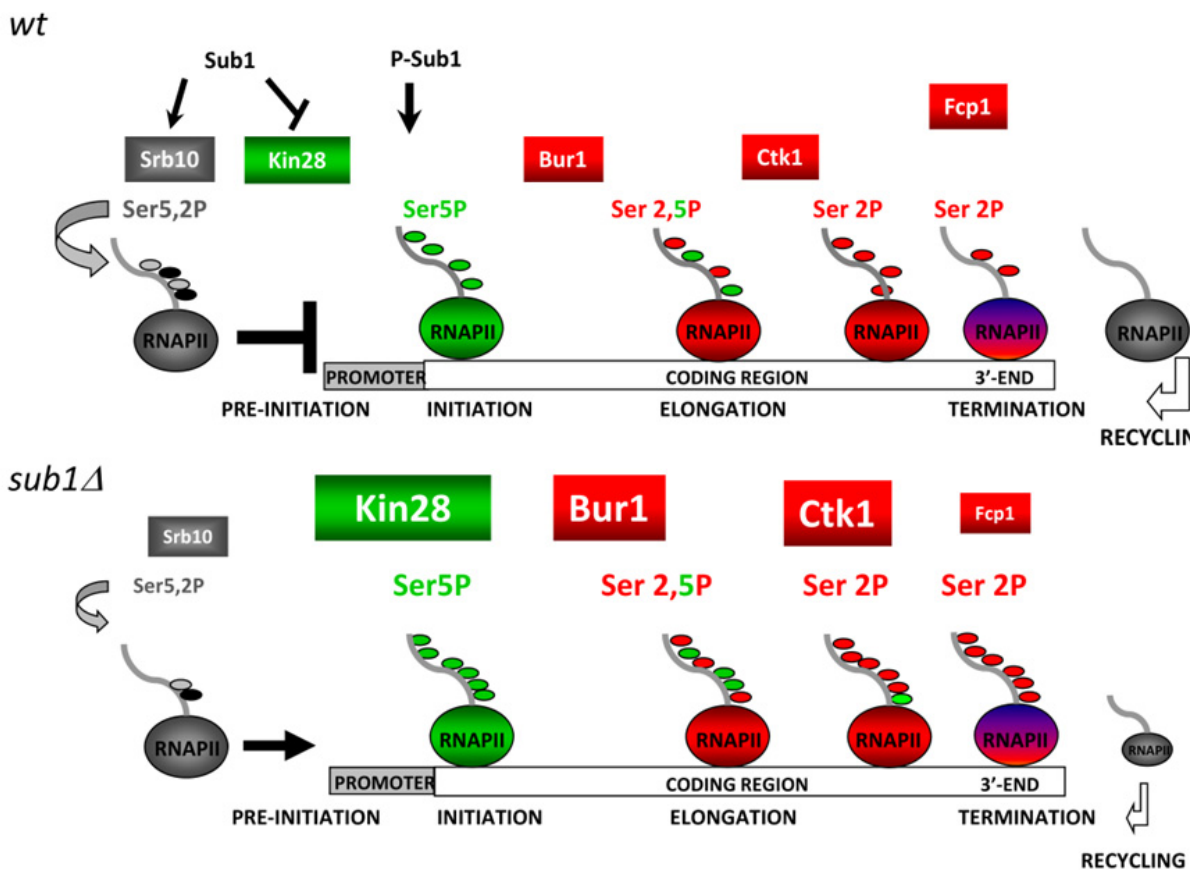

Figure 5. Model showing how Sub1 might function to globally regulate RNAPII CTD phosphorylation [222]. Different font sizes in the figure text indicate the increase or decrease of the corresponding CTD modifying enzymes in sub1 $\Delta$ versus $w t$ cells.

\section{RNAPII CTD phosphorylation and pre-mRNA processing}

The CTD is an unordered structure that extends from the RNAPII core enzyme, near the RNA exit channel [204, 209]. This localization is convenient to interact with a plethora of factors, such as the CTD-modifying enzymes and binding factors involved in distinct 
nuclear processes, for example, components of the RNA processing machinery [32, 88]. Furthermore, its length and the ability to adopt numerous conformations permit it to interact with different factors at the same time [31-32], and it is currently clear that these interactions depends on the CTD phosphorylation patterns during the transcription cycle [8, 21].

As transcription progresses the nascent RNA is capped to protect the $5^{\prime}$ end, intron sequences are removed, and a polyadenylated tail is added to the $3^{\prime}$ end. Coupling mRNA processing to transcription increases processing efficiency and allows multiple regulatory pathways to guarantee that only correctly modified mRNAs are exported. For more than a decade, numerous studies have provided evidence that the CTD serves as a scaffold for the assembly of an enormous variety of protein complexes to coordinate not only transcription of non-coding and protein-coding genes [8, 58-62, 64-65], but also pre-mRNA processing [21, 31-32]: capping [42, 135, 137], splicing [229], and 3'-end cleavage and polyadenylation [42]. All of these functions are achieved through the recognition and reading of the CTD code during the transcription cycle [6-8, 31]. Thus, co-transcriptional CTD-mediated processing of nascent RNA plays a crucial role in both recruitment of RNA processing machineries and regulation of their activities. Indeed, a functional CTD is not required for in vitro transcription by RNAPII, but it is essential for efficient pre-mRNA processing [42, 230-231].

\section{Capping}

The capping reaction consists in the addition of an inverted 7-methylguanosine cap to the first RNA residue by a 5'-5' triphosphate bridge. It is a characteristic of all RNAPII transcripts and is added to the $5^{\prime}$-end of nascent transcripts when they are only 25-50 bases long. The capping complex contains the following three enzymatic activities: RNA 5'triphosphatase, guanylyl transferase and RNA (guanine-7) methyltransferase [17, 67]. In yeast, these activities are achieved by three enzymes (i.e., Cet1, Ceg1 and Abd1, respectively), whereas in metazoans, these activities are performed by two enzymes (i.e., HCE and MT) because guanylyl transferase and RNA 5'-triphosphatase are two functionally domains of HCE protein [17]. Following Ser5 phosphorylation by TFIIH, the mRNA capping complex binds directly and specifically to Ser5P residues through the Ceg1 subunit in yeast or the guanylyl transferase domain in metazoans [48, 67, 78, 95, 137]. Furthermore, phosphorylated CTD interaction with the capping complex allosterically stimulates the capping enzyme activity and in response, enhances early transcription [136, 232]. Because the CTD is located near the RNA exit channel, its interaction with the capping complex permits its positioning for rapid processing of the mRNA $5^{\prime}$-end as the nascent transcript emerges from the polymerase. This is thought to protect the RNA from degradation and promote RNAPII to proceed into productive transcription elongation. In fact, by coupling capping and early transcription, only capped RNA will be elongated [67, 136, 232-233].

\section{3'-end processing}

Not only capping and transcription are linked at the $5^{\prime}$-end regions of protein coding-genes, but also polyadenylation and transcription termination at the $3^{\prime}$-end regions. In brief, $3{ }^{\prime}$-end 
processing consists of the following two-step reaction: endonucleolytic cleavage of the premRNA and subsequent addition of a poly(A) tail [17]. Both enzymatic reactions require a functional CTD [42, 230]. In fact, deletion of the CTD or absence of CTD phosphorylation negatively affects 3 '-end processing [16, 30, 106, 157, 234]. Furthermore, the CTD binds $3^{\prime}-$ end processing factors and stimulates cleavage/polyadenylation in vivo and in vitro [42, 230]. The cleavage is achieved by a complex that consists of CstF, CPSF, CF1, and CF2 in higher eukaryotes and CF1A, CF1B, and CFII in yeast, whereas the polyadenylation reaction is performed by a poly(A) polymerase in both cases [17] . Cleavage/polyadenylation factors CPSF and CstF can specifically bind to CTD affinity columns and are copurified with RNAPII [42]. In yeast, several 3'-end factors preferentially binds phosphorylated CTD [72, 106-107, 235]. Furthermore, yeast 3 '-end processing factors are recruited depending on Ser2 phosphorylation by Ctk1 when RNAPII reaches the 3 '-end regions of the transcribed genes. Therefore, regulation of CTD phosphorylation as the polymerase transcribes facilitates coordination of the assembly of the 3 '-end processing machinery with transcription [16]. Additionally, the polyadenylation signals are required for proper transcription termination in mammals and yeast [236-237]. In fact, Rtt103, which is a $3^{\prime}$-end mRNA processing factor, interacts with the CTD phosphorylated on Ser2 and recruits a 5'-3' RNA exonuclease, thereby promoting the release of RNAPII from the DNA [238-239]. In summary, Ser5 phosphorylation by TFIIH kinase (Kin28/Cdk7) is required to recruit the RNA-capping machinery to RNAPII [48, 67, 72], whereas Ser2 phosphorylation is required for the recruitment of $3^{\prime}$-end processing complexes and for transcription termination [16, 30, 106, 238-239] (Figure 7). However, it is unknown whether phosphorylation of Ser5 and Ser2 of all of the repeats or only some of the repeats is required to enhance capping and cleavage/polyadenylation, respectively.

Ser7 phosphorylation has been functionally related with 3 '-end processing of snRNA in higher eukaryotes. Human snRNA genes, contrary to protein-coding genes, are not polyadenylated, and instead of a poly(A) signal, they contain a conserved $3^{\prime}$ box RNAprocessing element that is recognized by the snRNA gene-specific Integrator RNA $3^{\prime}$ endprocessing complex. This complex binds to RNAPII CTD and links transcription and $3^{\prime}$-end processing [63-64, 240-241]. Therefore, in metazoans, Ser7P, in combination with Ser2P, is a major determinant for the recruitment of the Integrator complex to snRNA genes during its transcription [64, 240-241]. In yeast, the Integrator-like complex recruitment depends on Ser7 phosphorylation, the promoter elements and the specialized PIC that binds those elements [74]. After promoter escape, the RNA processing complex travels with the elongating phosphorylated polymerase up to the $3^{\prime}$-end box at the end of the snRNA transcription unit, where it associates with the nascent transcript in a co-transcriptionaldependent manner.

\section{Splicing}

As in the case of capping and cleavage/polyadenylation, a number of studies performed in vivo and in vitro during the last decades have demonstrated the existence of a functional interaction between the transcriptional machinery and the splicing apparatus [21, 242]. However, this functional interaction and the underlying mechanism are less accurately 
understood. The most complex pre-mRNA processing reaction is splicing, which is carried out by a large complex, the spliceosome, consisting of at least 150 protein components and five snRNAs [242]. The first indication of a coupling between transcription and splicing came from studies demonstrating that truncation of the CTD severely altered splicing in vitro [42]. Later it was shown that the CTD directly affects splicing, and that a phosphorylated CTD is required for the efficient splicing reaction [231, 243]. These data provided evidence that an elongating RNAPII with phosphorylated CTD is an active component of the splicing reaction. A number of physical links between the phosphorylated CTD and the splicing apparatus have been established, and chromatin immunoprecipitation analysis have shown that the direct binding of the splicing machinery to the nascent RNA is responsible in a large part for the co-transcriptional splicing in yeast and mammals [244245]. Hyperphosphorylated, but not hypophosphorylated RNAPII, has been found associated with splicing factors and detected in active spliceosomes [246-248]. For instance, in yeast, the splicing factor Prp40 binds to phosphorylated CTD [249]; in mammals, Spt6 binds selectively to the CTD-Ser2P [112], and the spliceosome-associated protein CA150 interacts with phosphorylated CTD while interacting with the SF1 splicing factor [250-251]. Therefore, all these studies led to the idea that the phosphorylated CTD acts as a scaffold, binding multiple splicing factors, and directly enhancing the spliceosome assembly. Corroborating this idea, a recent study identified a splicing factor, U2AF65, that interacts directly with the CTD to activate splicing and likely plays a role in spliceosome assembly $[242,252]$. Another recent study provided evidence that coupling transcription and splicing through CTD phosphorylation can be a regulatory point in the control of gene expression. For instance, it has been described that a set of inducible genes can be actively transcribed by RNAPII phosphorylated on Ser5, but not on Ser2, under non-inducing conditions, giving rise to a full length unspliced transcript. However, after induction, Cdk9 is recruited, phosphorylates the CTD on Ser2 and the generated transcript is properly spliced [253]. This fact strongly implicates Ser2P as a key in the integration of splicing and transcription. In addition to constitutive splicing, functional links between the CTD and alternative splicing have also been provided [86]. Thus, it has been suggested that the CTD may regulate the choice of alternative exons by increasing the local concentration of splicing factors [229], and that possibility participate in the physical modulation of alternative splicing.

\section{RNAPII CTD phosphorylation coordinates transcription to other nuclear processes}

\subsection{Coupling the CTD code and the histone code}

The nucleosome is the basic element of chromatin and consists of a histone octamer composed of two copies of histone 2A (H2A), H2B, H3 and H4, wrapped by 146 bp of DNA [254]. The histones carry numerous post-translational modifications, and some of these are associated with transcription. In fact, a general view is that histone post-translational modifications draw parallel with either positive or negative transcriptional states. Numerous discoveries have led to the idea that such modifications regulate transcription 
either directly by causing structural changes to chromatin (e.g., histone acetylation) or indirectly by recruiting protein complexes (e.g., histone methylation) [255-257]. Therefore, chromatin not only plays an essential role in packaging the DNA, but also in regulating gene expression. Most histone modifications reside in their amino- and carboxy-terminal tails, and a few of them in their globular domains. As in the case of CTD phosphorylation, where Ser5P triggers Ser2 phosphorylation, some histone modifications mark the deposition of another, thus creating a complex epigenetic signal code, the "histone code", that governs chromatin organization and DNA-dependent processes such as transcription. Therefore, the histone code is responsible for an active or inactive chromatin state with respect to transcription, because it coordinates the recruitment of various chromatin modifying and remodeling complexes to regulate chromatin structure and, consequently, transcription [258-259]. Because this review focuses on RNAPII CTD phosphorylation, only certain histone modifications, which are functionally related to the CTD code and transcription, will be discussed. There are excellent reviews that discuss all the histone modifications and their roles in different nuclear processes [255, 258, 260-261].

Lysine is a key substrate residue because it undergoes many exclusive modifications important for transcription regulation (i.e., acetylation, methylation, ubiquitination and SUMOylation [255, 261]. The lysine residues can be mono-, di- or trimethylated, and each level of modification can result in distinct biological effects. In brief, with respect to transcription, acetylation activates and sumoylation appears to be repressive, and both modifications may mutually interfere. On the other hand, methylation can have distinct effects; thus, lysine 4 in histone $\mathrm{H} 3$ (H3K4me3) is trimethylated at the $5^{\prime}$-ends of genes during activation, whereas trimethylation of $\mathrm{H} 3 \mathrm{~K} 9$ occurs in transcriptionally silent regions. Arginine residues of $\mathrm{H} 3$ and $\mathrm{H} 4$ can also be mono- or dimethylated, which activate transcription. Serine/threonine phosphorylation of $\mathrm{H} 3$ in specific sites also marks activated transcription, and ubiquitination of $\mathrm{H} 2 \mathrm{~B}$ and $\mathrm{H} 2 \mathrm{~A}$ are associated with active and repressed transcription, respectively (reviewed by [255-257]. All histone modifications are removable by specific enzymes (e.g., histone deacetylases (HDACs), phosphatases, and ubiquitin proteases ([255-257], and references therein). In fact HDACs play important regulatory roles during active transcription [262].

Methylation of H3K4 and K36 are the most well characterized histone modifications with roles in active transcription [263], and whose functions are directly linked to RNAPII CTD phosphorylation (Figure 6). H3K4 is methylated by the Set1/COMPASS complex, while K36 is mediated by the Set2 complex. The profile of H3K4 tri-methylation (H3K4me3) strongly correlates with the distribution pattern of the RNAPII CTD-Ser5P. It is mainly found around the transcriptional start site (TSS) contributing to transcription initiation, elongation and RNA processing [264]. Set1 recruitment and H3K4 tri-methylation usually peaks at the promoter and 5' region of a gene, depending on Kin28/Cdk7 activity (Figure 7) and Paf1 complex, a RNAPII-associated complex [265], and contributes to transcription initiation, elongation and RNA processing [264] [98]. H3K4 mono and di-methylation tend to expand along the coding regions compared to try-methylation. On the other hand, H3K36 methylation by Set 2 is observed across the entire coding region with an increase toward the 
3'-ends of actively transcribed genes. Ctk1 also regulates H3K4 methylation [158, 266]. Thereby, differently phosphorylated CTD by Kin28 and Ctk1 is responsible for the characteristic distribution of $\mathrm{H} 3 \mathrm{~K} 4$ tri-methylation in the coding region [158]. In contrast to Set1, the recruitment of Set2 and H3K36 methylation depends on a CTD-Ser2P/Ser5P double mark (Figure 6), and therefore, on Ctk1 kinase activity [158, 266]. Interestingly, the other Ser2 kinase complex, Bur1/2, also promotes Set2 recruitment and assists H3-K36 methylation, particularly at the $5^{\prime}$ ends of genes and is required for the histone $2 \mathrm{~B}$ ubiquitination activity of the Rad6/Bre1 complex [101, 103, 152].

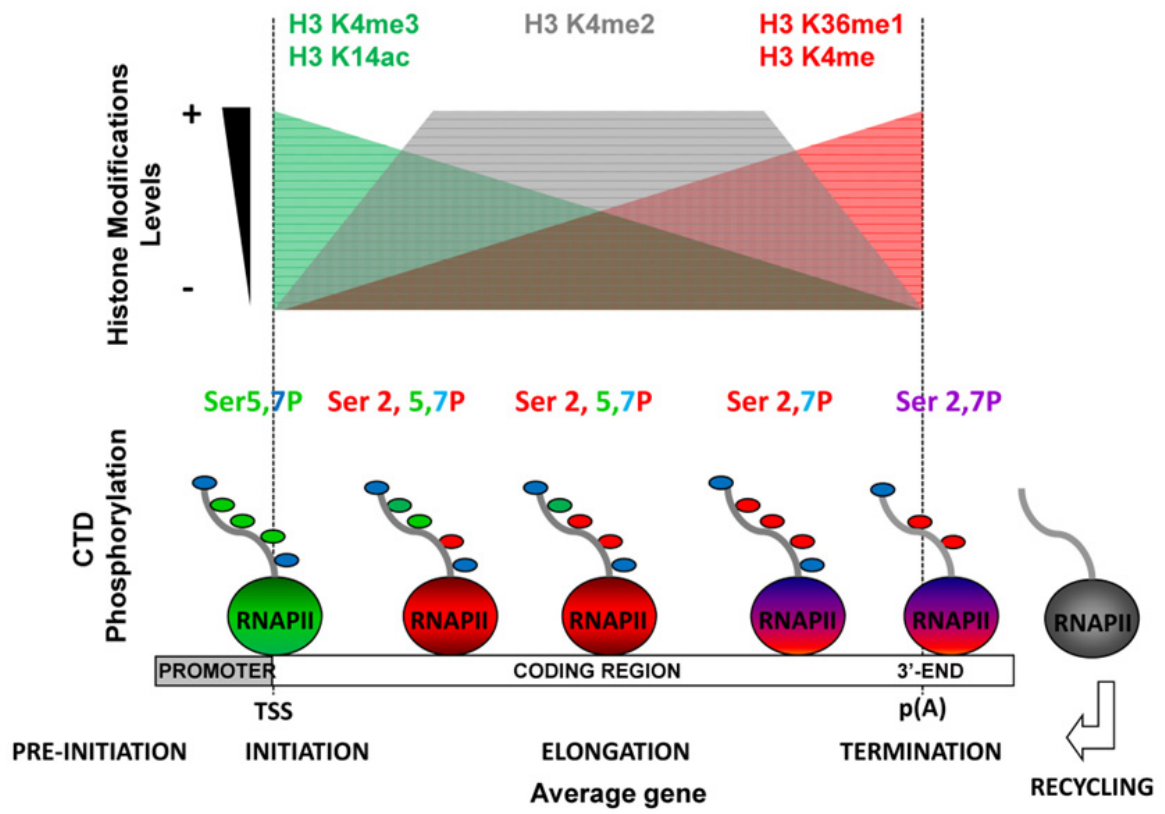

Figure 6. Histone H3 tri-, di-, and mono-methylation and acetylation during RNAPII transcription in $S$. cerevisiae.

$\mathrm{H} 3$ acetylation / deacetylation is also relevant during active transcription. Thus, histone acetyl and deacetyl transferase complexes (HAT and HDACs, respectively) are recruited to the transcriptional machinery during elongation through the interaction with RNAPII. Indeed, they modulate histone occupancy in the coding regions of actively transcribed genes, and this depends on CTD phosphorylation status [267-268]. HAT acetylates nucleosomes promoting nucleosomes eviction and allowing RNAPII to pass through. Afterward, the nucleosomes are immediately reassembled behind the polymerase and HDACs are co-transcriptionally recruited to rapidly and efficiently deacetylate the reassembled nucleosomes behind the polymerase. Altogether, this avoids cryptic transcription and maintains active transcription [262]. Methylation of histone H3 by Set1 and Set2 is required for deacetylation of nucleosomes in coding regions by the histone 
deacetylase complexes (HDACs) Set3C and $\operatorname{Rpd} 3 C(S)$, respectively. HDACs' recruitment is triggered by $\mathrm{H} 3 \mathrm{~K} 4$ methylation at promoters and within coding regions to restrict hyperactetylated histones to promoters and to maintain transcription activity. Set1H3K4me2 can be recognized by two different HDACs, RPD3S or SET3C [264]. The Set1SET3C pathway preferentially affects actively transcribed genes with promoters configured for efficient initiation/re-initiation [269]. In contrast, Set1-RPD3S pathway is active at loci subjected to cryptic and weak transcription encompassing repressed promoters of coding genes. Related to this, phosphorylation of the CTD by Kin28/Cdk7 is important for the initial recruitment of the Rpd3S and Set3 HDACs to coding sequences ([268], Figure 7). In fact, it has been reported that Set3C and $\operatorname{Rpd} 3 \mathrm{C}(\mathrm{S})$ are co-transcriptionally recruited in the absence of Set1 and Set2, but stimulated by the CTD kinase Kin28/Cdk7. Hence, the Rpd3C(S) and Set3C co-transcriptional recruitment is stimulated by CTD Ser5P to achieve the deacetylation of $\mathrm{H} 3$ residues. This, together with evidence that the RNAPII CTD recruits additional chromatin modifying complexes, histone chaperones and elongation factors, suggest that phosphorylated RNAPII is crucial in coordinating the activities of the many factors required for regulating histone dynamics and consequently transcription elongation at actively transcribing genes ([262], and references therein).

\subsection{Transport}

In addition to the complexes involved in mRNA processing, several other proteins bind to the RNAs as soon as their $5^{\prime}$-end emerges from the RNAPII, packaging them into a messenger ribonucleoparticle (mRNP). This set of interactions of packaging and export factors play a dual function of protecting the RNA from degradation and preparing it to be exported. Although interactions between the CTD and many mRNA processing factors have been characterized, this is not the case for mRNA packaging and export factors. However, packaging and export seems to be also coupled to transcription through RNAPII CTD interactions because defects in transcription elongation, splicing, and 3 '-end processing affect export [270]. In yeast, mRNA export is linked to transcription through the TREX (transcription export) complex, which is composed of the THO complex (Tho2, Hpr1, Mft1, and Thp2) and the evolutionally conserved RNA export proteins, Sub2 (UAP56 in human) and Yra1 (REF/Aly in human), and a novel protein termed Tex1 [271-272]. Deletions of the individual THO components causes defects on transcription, transcription-dependent hyper-recombination, and on mRNA export [160, 273]. In addition, the Sub2/Yra1 complex is directly recruited to the actively transcribed regions via the THO complex [272, 274]. Although it has been shown that the TREX complex and Ctk1 are functionally related [159], recruitment of the TREX complex to transcribed genes is not dependent on Ctk1 in yeast [16], and the association of the human TREX complex to transcript might be coupled to transcription indirectly through splicing [275]. Then, the potential role of the CTD and CTD phosphorylation in this process remains unclear, however in a very recent study, the mRNA export factor Yra1 was identified as a CTD phosphorylated-binding protein [276]. Then, this study provides strong support for the idea that the phosphorylated CTD is directly involved in the cotranscriptional recruitment of export factors to active genes. In summary, many 
aspects of the mRNA metabolism from the 5' capping to the export occur cotranscriptionally and are coordinated through transcription, with the RNAPII CTD and its phosphorylation being the main coordinator in most cases (Figure 7).

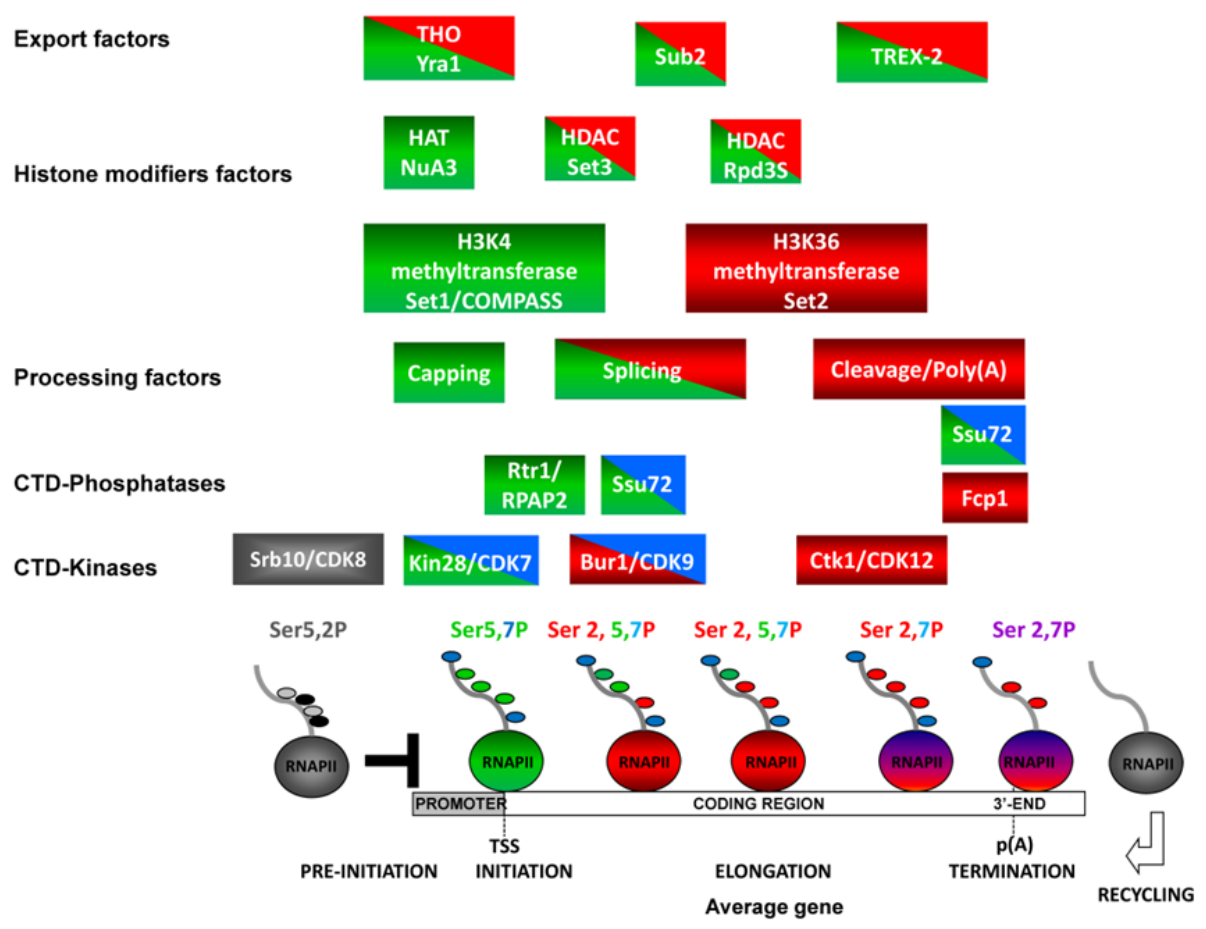

Figure 7. RNAPII CTD phosphorylation/ de-phosphorylation is co-transcriptionally connected and coordinated with other nuclear processes: pre-mRNA processing; histone modifications and mRNA export. The main complexes required for co-transcriptional processes occurring during the expression of a regular protein coding-gene are shown. See text for details.

\section{RNAPII CTD phosphorylation and transcription regulation}

The levels of CTD phosphorylation/de-phosphorylation are precisely modulated during the entire transcription cycle, which regulates the association of many important factors with initiating and elongating RNAPII, such as transcription and pre-mRNA processing factors, chromatin modifiers and mRNA export factors [21]. The interplay of all of these factors is essential to regulating transcription and, consequently, gene expression. Subsequently, in a regular protein-coding gene, the following set of coordinated nuclear events must occur for it to be properly transcribed in a functional mRNA before it is exported to the cytoplasm and translated (Figure 7). Unphosphorylated RNAPII is recruited to the pre-initiation complex (PIC); then, after its binding to the promoters, it is phosphorylated on Ser5 by yKin28 (hCdk7). Ser5 phosphorylation is required for RNAPII dissociation from the PIC and 
consequently promotes transcription initiation. Simultaneously, Ser5 phosphorylation targets capping and splicing factor recruitment, the Set1 methyltransferase complex, and the Set3C and Rpd3S histone deacetylase complexes. During early elongation, Ser5P levels are decreased, whereas Ser2P levels increase due to the kinase activity of yBur1 (hCdk9) near the promoters, and by the kinase activity of yCtk1 (hCdk12) at the forward coding and 3'ends, which leads to the recruitment of the histone methyltransferase Set2 and the activation of the Rpd3S complex, which prevents cryptic transcription within the genes. When RNAPII arrives at and recognizes the termination site, the $3^{\prime}$-end-processing factors that are associated with the CTD achieve cleavage and polyadenylation of the nascent mRNA, which also requires proper phosphorylation of the polymerase. During the termination process, the CTD is de-phosphorylated by Ssu72 and Fcp1, and the polymerase is recycled to initiate a new round of transcription. All along the gene, packaging and export factors (TREX complexes) are incorporated into the transcriptional machinery protecting the transcript from degradation and preparing it for export to the cytoplasm.

\section{Therapeutic potential}

Cellular differentiation, morphogenesis, development and adaptability of all organisms are subjected to proper gene expression and, therefore, variations in gene regulation can have profound effects on protein function, challenging the viability of the organisms. Currently, it is clear that RNAPII phosphorylation has an important role on gene expression, and therefore, in all the processes mentioned above. Consequently, over the last decade CTD phosphorylation has attracted the attention of biomedical research, especially due to the fact that the CTD kinase Cdk9 has been involved in several physiological cell processes, whose deregulation may be associated with cancer, and also due to the fact that Cdk9 activity is required for human immunodeficiency virus type 1 (HIV-1) replication. Related to it, many studies have shown the enormous potential of Cdk9 kinase inhibition as a treatment of several kinds of tumors, HIV infection, and cardiac hypertrophy.

The human immunodeficiency virus type 1 (HIV-1) requires host cell factors for all steps of the viral replication, among them the transcription elongation factor P-TEFb. Transcription of HIV-1 viral genes is achieved by host RNAPII and is induced by a viral trans-activator protein, Tat. When bound to the TAR viral RNA region, Tat activates HIV-1 transcription by early recruiting of host transcriptional activators including $\mathrm{P}-\mathrm{TEFb}$, which phosphorylates RNAPII CTD promoting viral transcript elongation [280]. Thus, treatment with drugs that inhibit Cdk9, such as flavopiridol, has been used as a retroviral therapy on AIDS patients [281]. Therefore, from the point of view of basic research, the study of the functions of Cdk9 and RNAPII CTD phosphorylations are of great interest in understanding the mechanisms that regulate HIV replication, which consequently lead to progress on AIDS biomedical research. Further evidence has been provided of a deregulated Cdk9 function in several tumors such as lymphoma, neuroblastoma, primary neuroectodermal tumor, rhabidomiosarcoma or prostate cancer [282-284]. The Cdk9 inhibition by chemotherapeutic agents, such as flavopiridol or CY-202, has shown to reduce transcription in malignant cells, 
mainly affecting the short half-lives RNAs. Most of these RNAs code for anti-apoptotic proteins, for instance onco-protein Mcl-1, which is necessary in tumor proliferation maintenance. Unfortunately, they only have a modest activity in patients although promising studies continue at present [285]. Cardiac hypertrophy consists of an increased size of cardiomyocytes, associated to some cardiac diseases as hypertension or diminished heart function. Hypertrophy is a physiological response to a stress stimulus that results in an increase of the cell size, and that may eventually produce a heart failure. Increased cell size produces increased mRNAs transcription, which requires Cdk9 activity. Thus, it has been shown that therapy with Cdk9 inhibitors benefits patients with cardiovascular disorders [286].

\title{
9. Concluding remarks
}

The primary function of the RNAPII CTD phosphorylation in eukaryotes is the integration of transcription with distinct nuclear processes. Thus, CTD phosphorylation operates as a fine-tuning regulatory mechanism during the whole transcription cycle and is consequently of extraordinary importance for proper gene expression. Since the late 1980's, an overwhelming number of laboratories have tried to decipher the mechanism underlying the creation of a CTD code and how this code is translated during transcription to coordinate mRNA processing, export and chromatin modifications. Although great progress has been achieved, most recently due to wide-genomic analysis techniques, a number of issues remained unsolved. For instance, it is very challenging to determine the exact phosphorylation state of specific residues within specific repeats during each step of transcription, as well as to determine the exact number of repeats that are phosphorylated within the CTD at every step of transcription, and how this is related to CTD specific roles in gene expression. Moreover, it needs to be determined if phosphorylation of the repeats with non-consensus sequences is regulated in the same manner as the consensus repeats, and if this is achieved by the same set of CTD modifying enzymes. In addition, other residues such as lysine and arginine can be potentially modified; therefore, further increasing the complexity of the CTD, and suggesting that if they are transcriptionally modified, may further elucidate the CTD functions or discover new ones. Finally, detailed understanding of RNAPII CTD phosphorylation is very relevant and will add insight into the processes that alter gene expression, such as HIV infection and cancer, and will help to investigate if other human CTD modifying enzymes, in addition to Cdk9, may be good candidates for therapy. In conclusion, research has made much progress, but further progress is still needed, and the new massive techniques in genomics and proteomics will help to advance complete understanding much faster.

\section{Author details}

\author{
Olga Calvo and Alicia García \\ Instituto de Biología Funcional y Genómica, Consejo Superior de Investigaciones Científicas I \\ Universidad de Salamanca, Spain
}




\section{Acknowledgement}

This work was supported by a grant from the Spanish Ministerio de Ciencia e Innovación (BFU 2009-07179) to OC. AG was supported by a fellowship from the Junta de Castilla y León. The IBFG acknowledges support from "Ramón Areces Foundation".

\section{References}

[1] Jun SH, Reichlen MJ, Tajiri M, Murakami KS (2011) Archaeal RNA polymerase and transcription regulation. Crit Rev Biochem Mol Biol. 46: 27-40.

[2] Werner F, Grohmann D (2011) Evolution of multisubunit RNA polymerases in the three domains of life. Nat Rev Microbiol. 9: 85-98.

[3] Grohmann D, Werner F (2011) Cycling through transcription with the RNA polymerase F/E (RPB4/7) complex: structure, function and evolution of archaeal RNA polymerase. Res Microbiol. 162: 10-18.

[4] Allison LA, Moyle M, Shales M, Ingles CJ (1985) Extensive homology among the largest subunits of eukaryotic and prokaryotic RNA polymerases. Cell. 42: 599-610.

[5] Corden JL (1990) Tails of RNA polymerase II. Trends Biochem Sci. 15: 383-387.

[6] Buratowski S (2003) The CTD code. Nat Struct Biol. 10: 679-680.

[7] Corden JL (2007) Transcription. Seven ups the code. Science. 318: 1735-1736.

[8] Egloff S, Murphy S (2008) Cracking the RNA polymerase II CTD code. Trends Genet. 24: 280-288.

[9] Hahn S, Young ET (2011) Transcriptional regulation in Saccharomyces cerevisiae: transcription factor regulation and function, mechanisms of initiation, and roles of activators and coactivators. Genetics. 189: 705-736.

[10] Sikorski TW, Buratowski S (2009) The basal initiation machinery: beyond the general transcription factors. Curr Opin Cell Biol. 21: 344-351.

[11] Thomas MC, Chiang CM (2006) The general transcription machinery and general cofactors. Crit Rev Biochem Mol Biol. 41: 105-178.

[12] Saunders A, Core LJ, Lis JT (2006) Breaking barriers to transcription elongation. Nat Rev Mol Cell Biol. 7: 557-567.

[13] Selth LA, Sigurdsson S, Svejstrup JQ (2010) Transcript Elongation by RNA Polymerase II. Annu Rev Biochem. 79: 271-293.

[14] Shilatifard A, Conaway RC, Conaway JW (2003) The RNA polymerase II elongation complex. Annu Rev Biochem. 72: 693-715.

[15] Pokholok DK, Hannett NM, Young RA (2002) Exchange of RNA polymerase II initiation and elongation factors during gene expression in vivo. Mol Cell. 9: 799-809.

[16] Ahn SH, Kim M, Buratowski S (2004) Phosphorylation of serine 2 within the RNA polymerase II C-terminal domain couples transcription and 3' end processing. Mol Cell. 13: 67-76.

[17] Hirose Y, Manley JL (2000) RNA polymerase II and the integration of nuclear events. Genes Dev. 14: 1415-1429.

[18] Mason PB, Struhl K (2005) Distinction and relationship between elongation rate and processivity of RNA polymerase II in vivo. Mol Cell. 17: 831-840. 
[19] Orphanides G, Reinberg D (2000) RNA polymerase II elongation through chromatin. Nature. 407: 471-475.

[20] Orphanides G, Reinberg D (2002) A unified theory of gene expression. Cell. 108: 439451.

[21] Perales R, Bentley D (2009) "Cotranscriptionality": the transcription elongation complex as a nexus for nuclear transactions. Mol Cell. 36: 178-191.

[22] Carmody SR, Wente SR (2009) mRNA nuclear export at a glance. J Cell Sci. 122: 19331937.

[23] Chanarat S, Seizl M, Strasser K (2011) The Prp19 complex is a novel transcription elongation factor required for TREX occupancy at transcribed genes. Genes Dev. 25: 1147-1158.

[24] Gonzalez-Aguilera C, Tous C, Babiano R, de la Cruz J, Luna R, Aguilera A (2011) Nab2 functions in the metabolism of RNA driven by polymerases II and III. Mol Biol Cell. 22: 2729-2740.

[25] Iglesias N, Stutz F (2008) Regulation of mRNP dynamics along the export pathway. FEBS Lett. 582: 1987-1996.

[26] Komili S, Silver PA (2008) Coupling and coordination in gene expression processes: a systems biology view. Nat Rev Genet. 9: 38-48.

[27] Kruk JA, Dutta A, Fu J, Gilmour DS, Reese JC (2011) The multifunctional Ccr4-Not complex directly promotes transcription elongation. Genes Dev. 25: 581-593.

[28] Svejstrup JQ (2007) Elongator complex: how many roles does it play? Curr Opin Cell Biol. 19: 331-336.

[29] Maniatis T, Reed R (2002) An extensive network of coupling among gene expression machines. Nature. 416: 499-506.

[30] Proudfoot NJ, Furger A, Dye MJ (2002) Integrating mRNA processing with transcription. Cell. 108: 501-512.

[31] Buratowski S (2009) Progression through the RNA polymerase II CTD cycle. Mol Cell. 36: 541-546.

[32] Phatnani HP, Greenleaf AL (2006) Phosphorylation and functions of the RNA polymerase II CTD. Genes Dev. 20: 2922-2936.

[33] Cramer P (2002) Multisubunit RNA polymerases. Curr Opin Struct Biol. 12: 89-97.

[34] Cramer P (2002) Common structural features of nucleic acid polymerases. Bioessays. 24: 724-729.

[35] Corden JL, Cadena DL, Ahearn JM, Jr., Dahmus ME (1985) A unique structure at the carboxyl terminus of the largest subunit of eukaryotic RNA polymerase II. Proc Natl Acad Sci U S A. 82: 7934-7938.

[36] Liu P, Greenleaf AL, Stiller JW (2008) The essential sequence elements required for RNAPII carboxyl-terminal domain function in yeast and their evolutionary conservation. Mol Biol Evol. 25: 719-727.

[37] Liu P, Kenney JM, Stiller JW, Greenleaf AL (2010) Genetic organization, length conservation, and evolution of RNA polymerase II carboxyl-terminal domain. Mol Biol Evol. 27: 2628-2641.

[38] Chapman RD, Heidemann M, Hintermair C, Eick D (2008) Molecular evolution of the RNA polymerase II CTD. Trends Genet. 24: 289-296. 
[39] Prelich G (2002) RNA polymerase II carboxy-terminal domain kinases: emerging clues to their function. Eukaryot Cell. 1: 153-162.

[40] Wintzerith M, Acker J, Vicaire S, Vigneron M, Kedinger C (1992) Complete sequence of the human RNA polymerase II largest subunit. Nucleic Acids Res. 20: 910.

[41] Allison LA, Wong JK, Fitzpatrick VD, Moyle M, Ingles CJ (1988) The C-terminal domain of the largest subunit of RNA polymerase II of Saccharomyces cerevisiae, Drosophila melanogaster, and mammals: a conserved structure with an essential function. Mol Cell Biol. 8: 321-329.

[42] McCracken S, Fong N, Yankulov K, Ballantyne S, Pan G, Greenblatt J, Patterson SD, Wickens M, Bentley DL (1997) The C-terminal domain of RNA polymerase II couples mRNA processing to transcription. Nature. 385: 357-361.

[43] Schwartz LB, Roeder RG (1975) Purification and subunit structure of deoxyribonucleic acid-dependent ribonucleic acid polymerase II from the mouse plasmacytoma, MOPC 315. J Biol Chem. 250: 3221-3228.

[44] Cadena DL, Dahmus ME (1987) Messenger RNA synthesis in mammalian cells is catalyzed by the phosphorylated form of RNA polymerase II. J Biol Chem. 262: 1246812474.

[45] Zhang J, Corden JL (1991) Phosphorylation causes a conformational change in the carboxyl-terminal domain of the mouse RNA polymerase II largest subunit. J Biol Chem. 266: 2297-2302.

[46] Lu H, Flores O, Weinmann R, Reinberg D (1991) The nonphosphorylated form of RNA polymerase II preferentially associates with the preinitiation complex. Proc. Natl. Acad. Sci. U S A. 88: 10004-10008.

[47] Cho H, Kim TK, Mancebo H, Lane WS, Flores O, Reinberg D (1999) A protein phosphatase functions to recycle RNA polymerase II. Genes Dev. 13: 1540-1552.

[48] Komarnitsky P, Cho EJ, Buratowski S (2000) Different phosphorylated forms of RNA polymerase II and associated mRNA processing factors during transcription. Genes Dev. 14: 2452-2460.

[49] Kim M, Ahn SH, Krogan NJ, Greenblatt JF, Buratowski S (2004) Transitions in RNA polymerase II elongation complexes at the 3' ends of genes. EMBO J. 23: 354-364.

[50] Zhang DW, Mosley AL, Ramisetty SR, Rodriguez-Molina JB, Washburn MP, Ansari AZ (2012) Ssu72 Phosphatase-dependent Erasure of Phospho-Ser7 Marks on the RNA Polymerase II C-terminal Domain Is Essential for Viability and Transcription Termination. J Biol Chem. 287: 8541-8551.

[51] Palancade B, Bensaude O (2003) Investigating RNA polymerase II carboxyl-terminal domain (CTD) phosphorylation. Eur J Biochem. 270: 3859-3870.

[52] Baskaran R, Chiang GG, Mysliwiec T, Kruh GD, Wang JY (1997) Tyrosine phosphorylation of RNA polymerase II carboxyl-terminal domain by the Abl-related gene product. J Biol Chem. 272: 18905-18909.

[53] Baskaran R, Dahmus ME, Wang JY (1993) Tyrosine phosphorylation of mammalian RNA polymerase II carboxyl-terminal domain. Proc Natl Acad Sci U S A. 90: 1116711171.

[54] Hsin JP, Sheth A, Manley JL (2011) RNAPII CTD phosphorylated on threonine-4 is required for histone mRNA 3' end processing. Science. 334: 683-686. 
[55] Wu X, Wilcox CB, Devasahayam G, Hackett RL, Arevalo-Rodriguez M, Cardenas ME, Heitman J, Hanes SD (2000) The Ess1 prolyl isomerase is linked to chromatin remodeling complexes and the general transcription machinery. EMBO J. 19: 3727-3738.

[56] Sims RJ, 3rd, Rojas LA, Beck D, Bonasio R, Schuller R, Drury WJ, 3rd, Eick D, Reinberg D (2011) The C-terminal domain of RNA polymerase II is modified by site-specific methylation. Science. 332: 99-103.

[57] Kelly WG, Dahmus ME, Hart GW (1993) RNA polymerase II is a glycoprotein. Modification of the COOH-terminal domain by O-GlcNAc. J Biol Chem. 268: 1041610424.

[58] Kim YJ, Bjorklund S, Li Y, Sayre MH, Kornberg RD (1994) A multiprotein mediator of transcriptional activation and its interaction with the C-terminal repeat domain of RNA polymerase II. Cell. 77: 599-608.

[59] Corden JL (1993) RNA polymerase II transcription cycles. Curr Opin Genet Dev. 3: 213218.

[60] Corden JL, Patturajan M (1997) A CTD function linking transcription to splicing. Trends Biochem Sci. 22: 413-416.

[61] Gudipati RK, Villa T, Boulay J, Libri D (2008) Phosphorylation of the RNA polymerase II C-terminal domain dictates transcription termination choice. Nat Struct Mol Biol. 15: 786-794.

[62] Vasiljeva L, Kim M, Mutschler H, Buratowski S, Meinhart A (2008) The Nrd1-Nab3Sen1 termination complex interacts with the Ser5-phosphorylated RNA polymerase II C-terminal domain. Nat Struct Mol Biol. 15: 795-804.

[63] Egloff S, Murphy S (2008) Role of the C-terminal domain of RNA polymerase II in expression of small nuclear RNA genes. Biochem Soc Trans. 36: 537-539.

[64] Egloff S, O'Reilly D, Chapman RD, Taylor A, Tanzhaus K, Pitts L, Eick D, Murphy S (2007) Serine-7 of the RNA polymerase II CTD is specifically required for snRNA gene expression. Science. 318: 1777-1779.

[65] Jacobs EY, Ogiwara I, Weiner AM (2004) Role of the C-terminal domain of RNA polymerase II in U2 snRNA transcription and 3' processing. Mol Cell Biol. 24: 846-855.

[66] Patturajan M, Schulte RJ, Sefton BM, Berezney R, Vincent M, Bensaude O, Warren SL, Corden JL (1998) Growth-related changes in phosphorylation of yeast RNA polymerase II. J Biol Chem. 273: 4689-4694.

[67] Schroeder SC, Schwer B, Shuman S, Bentley D (2000) Dynamic association of capping enzymes with transcribing RNA polymerase II. Genes Dev. 14: 2435-2440.

[68] Chapman RD, Heidemann M, Albert TK, Mailhammer R, Flatley A, Meisterernst M, Kremmer E, Eick D (2007) Transcribing RNA polymerase II is phosphorylated at CTD residue serine-7. Science. 318: 1780-1782.

[69] Bataille AR, Jeronimo C, Jacques PE, Laramee L, Fortin ME, Forest A, Bergeron M, Hanes SD, Robert F (2012) A universal RNA polymerase II CTD cycle is orchestrated by complex interplays between kinase, phosphatase, and isomerase enzymes along genes. Mol Cell. 45: 158-170.

[70] Kim H, Erickson B, Luo W, Seward D, Graber JH, Pollock DD, Megee PC, Bentley DL (2010) Gene-specific RNA polymerase II phosphorylation and the CTD code. Nat Struct Mol Biol. 17: 1279-1286. 
[71] Mayer A, Lidschreiber M, Siebert M, Leike K, Soding J, Cramer P (2010) Uniform transitions of the general RNA polymerase II transcription complex. Nat Struct Mol Biol. 17: 1272-1278.

[72] Rodriguez CR, Cho EJ, Keogh MC, Moore CL, Greenleaf AL, Buratowski S (2000) Kin28, the TFIIH-associated carboxy-terminal domain kinase, facilitates the recruitment of mRNA processing machinery to RNA polymerase II. Mol Cell Biol. 20: 104-112.

[73] Cho EJ, Kobor MS, Kim M, Greenblatt J, Buratowski S (2001) Opposing effects of Ctk1 kinase and Fcp1 phosphatase at Ser 2 of the RNA polymerase II C-terminal domain. Genes Dev. 15: 3319-3329.

[74] Akhtar MS, Heidemann M, Tietjen JR, Zhang DW, Chapman RD, Eick D, Ansari AZ (2009) TFIIH kinase places bivalent marks on the carboxy-terminal domain of RNA polymerase II. Mol Cell. 34: 387-393.

[75] Glover-Cutter K, Larochelle S, Erickson B, Zhang C, Shokat K, Fisher RP, Bentley DL (2009) TFIIH-associated Cdk7 kinase functions in phosphorylation of C-terminal domain Ser7 residues, promoter-proximal pausing, and termination by RNA polymerase II. Mol Cell Biol. 29: 5455-5464.

[76] Kim M, Suh H, Cho EJ, Buratowski S (2009) Phosphorylation of the yeast Rpb1 Cterminal domain at serines 2, 5, and 7. J Biol Chem. 284: 26421-26426.

[77] Tietjen JR, Zhang DW, Rodriguez-Molina JB, White BE, Akhtar MS, Heidemann M, Li X, Chapman RD, Shokat K, Keles S, Eick D, Ansari AZ (2010) Chemical-genomic dissection of the CTD code. Nat Struct Mol Biol. 17: 1154-1161.

[78] Ghosh A, Shuman S, Lima CD (2011) Structural insights to how mammalian capping enzyme reads the CTD code. Mol Cell. 43: 299-310.

[79] Krishnamurthy S, He X, Reyes-Reyes M, Moore C, Hampsey M (2004) Ssu72 Is an RNA polymerase II CTD phosphatase. Mol Cell. 14: 387-394.

[80] Svejstrup JQ, Li Y, Fellows J, Gnatt A, Bjorklund S, Kornberg RD (1997) Evidence for a mediator cycle at the initiation of transcription. Proc Natl Acad Sci U S A. 94: 6075-6078.

[81] West ML, Corden JL (1995) Construction and analysis of yeast RNA polymerase II CTD deletion and substitution mutations. Genetics. 140: 1223-1233.

[82] Zhang J, Corden JL (1991) Identification of phosphorylation sites in the repetitive carboxyl-terminal domain of the mouse RNA polymerase II largest subunit. J Biol Chem. 266: 2290-2296.

[83] Chapman RD, Palancade B, Lang A, Bensaude O, Eick D (2004) The last CTD repeat of the mammalian RNA polymerase II large subunit is important for its stability. Nucleic Acids Res. 32: 35-44.

[84] Fong N, Bird G, Vigneron M, Bentley DL (2003) A 10 residue motif at the C-terminus of the RNA pol II CTD is required for transcription, splicing and 3' end processing. EMBO J. 22: 4274-4282.

[85] Baskaran R, Escobar SR, Wang JY (1999) Nuclear c-Abl is a COOH-terminal repeated domain (CTD)-tyrosine (CTD)-tyrosine kinase-specific for the mammalian RNA polymerase II: possible role in transcription elongation. Cell Growth Differ. 10: 387-396.

[86] Munoz MJ, de la Mata M, Kornblihtt AR (2010) The carboxy terminal domain of RNA polymerase II and alternative splicing. Trends Biochem Sci. 35: 497-504. 
[87] Kamenski T, Heilmeier S, Meinhart A, Cramer P (2004) Structure and mechanism of RNA polymerase II CTD phosphatases. Mol Cell. 15: 399-407.

[88] Meinhart A, Kamenski T, Hoeppner S, Baumli S, Cramer P (2005) A structural perspective of CTD function. Genes Dev. 19: 1401-1415.

[89] Bartkowiak B, Liu P, Phatnani HP, Fuda NJ, Cooper JJ, Price DH, Adelman K, Lis JT, Greenleaf AL (2010) CDK12 is a transcription elongation-associated CTD kinase, the metazoan ortholog of yeast Ctk1. Genes Dev. 24: 2303-2316.

[90] Akoulitchev S, Chuikov S, Reinberg D (2000) TFIIH is negatively regulated by cdk8containing mediator complexes. Nature. 407: 102-106.

[91] Hallberg M, Polozkov GV, Hu GZ, Beve J, Gustafsson CM, Ronne H, Bjorklund S (2004) Site-specific Srb10-dependent phosphorylation of the yeast Mediator subunit Med2 regulates gene expression from the 2-microm plasmid. Proc Natl Acad Sci U S A. 101: 3370-3375.

[92] Hengartner CJ, Myer VE, Liao SM, Wilson CJ, Koh SS, Young RA (1998) Temporal regulation of RNA polymerase II by Srb10 and Kin28 cyclin-dependent kinases. Mol Cell. 2: 43-53.

[93] Larschan E, Winston F (2005) The Saccharomyces cerevisiae Srb8-Srb11 complex functions with the SAGA complex during Gal4-activated transcription. Mol Cell Biol. 25: 114-123.

[94] Liu Y, Kung C, Fishburn J, Ansari AZ, Shokat KM, Hahn S (2004) Two cyclin-dependent kinases promote RNA polymerase II transcription and formation of the scaffold complex. Mol Cell Biol. 24: 1721-1735.

[95] Fabrega C, Shen V, Shuman S, Lima CD (2003) Structure of an mRNA capping enzyme bound to the phosphorylated carboxy-terminal domain of RNA polymerase II. Mol Cell. 11: 1549-1561.

[96] Guidi BW, Bjornsdottir G, Hopkins DC, Lacomis L, Erdjument-Bromage H, Tempst P, Myers LC (2004) Mutual targeting of mediator and the TFIIH kinase Kin28. J Biol Chem. 279: 29114-29120.

[97] Govind CK, Zhang F, Qiu H, Hofmeyer K, Hinnebusch AG (2007) Gen5 promotes acetylation, eviction, and methylation of nucleosomes in transcribed coding regions. Mol Cell. 25: 31-42.

[98] Ng HH, Robert F, Young RA, Struhl K (2003) Targeted recruitment of Set1 histone methylase by elongating Pol II provides a localized mark and memory of recent transcriptional activity. Mol Cell. 11: 709-719.

[99] Qiu H, Hu C, Hinnebusch AG (2009) Phosphorylation of the Pol II CTD by KIN28 enhances BUR1/BUR2 recruitment and Ser2 CTD phosphorylation near promoters. Mol Cell. 33: 752-762.

[100] Wong CM, Qiu H, Hu C, Dong J, Hinnebusch AG (2007) Yeast cap binding complex impedes recruitment of cleavage factor IA to weak termination sites. Mol Cell Biol. 27: 6520-6531.

[101] Laribee RN, Krogan NJ, Xiao T, Shibata Y, Hughes TR, Greenblatt JF, Strahl BD (2005) BUR kinase selectively regulates $\mathrm{H} 3 \mathrm{~K} 4$ trimethylation and $\mathrm{H} 2 \mathrm{~B}$ ubiquitylation through recruitment of the PAF elongation complex. Curr Biol. 15: 1487-1493. 
[102] Liu Y, Warfield L, Zhang C, Luo J, Allen J, Lang WH, Ranish J, Shokat KM, Hahn S (2009) Phosphorylation of the transcription elongation factor Spt5 by yeast Bur1 kinase stimulates recruitment of the PAF complex. Mol Cell Biol. 29: 4852-4863.

[103] Wood A, Schneider J, Dover J, Johnston M, Shilatifard A (2005) The Bur1/Bur2 complex is required for histone $\mathrm{H} 2 \mathrm{~B}$ monoubiquitination by Rad6/Bre1 and histone methylation by COMPASS. Mol Cell. 20: 589-599.

[104] Zhou Z, Lin IJ, Darst RP, Bungert J (2009) Maneuver at the transcription start site: Mot1p and NC2 navigate TFIID/TBP to specific core promoter elements. Epigenetics. 4: $1-4$.

[105] Ahn SH, Keogh MC, Buratowski S (2009) Ctk1 promotes dissociation of basal transcription factors from elongating RNA polymerase II. EMBO J. 28: 205-212.

[106] Licatalosi DD, Geiger G, Minet M, Schroeder S, Cilli K, McNeil JB, Bentley DL (2002) Functional interaction of yeast pre-mRNA 3' end processing factors with RNA polymerase II. Mol Cell. 9: 1101-1111.

[107] Meinhart A, Cramer P (2004) Recognition of RNA polymerase II carboxy-terminal domain by 3'-RNA-processing factors. Nature. 430: 223-226.

[108] Ni Z, Schwartz BE, Werner J, Suarez JR, Lis JT (2004) Coordination of transcription, RNA processing, and surveillance by P-TEFb kinase on heat shock genes. Mol Cell. 13: 55-65.

[109] Ramanathan Y, Rajpara SM, Reza SM, Lees E, Shuman S, Mathews MB, Pe'ery T (2001) Three RNA polymerase II carboxyl-terminal domain kinases display distinct substrate preferences. J Biol Chem. 276: 10913-10920.

[110] Rother S, Strasser K (2007) The RNA polymerase II CTD kinase Ctk1 functions in translation elongation. Genes Dev. 21: 1409-1421.

[111] Wood A, Shukla A, Schneider J, Lee JS, Stanton JD, Dzuiba T, Swanson SK, Florens L, Washburn MP, Wyrick J, Bhaumik SR, Shilatifard A (2007) Ctk complex-mediated regulation of histone methylation by COMPASS. Mol Cell Biol. 27: 709-720.

[112] Yoh SM, Cho H, Pickle L, Evans RM, Jones KA (2007) The Spt6 SH2 domain binds Ser2-P RNAPII to direct Iws1-dependent mRNA splicing and export. Genes Dev. 21: 160-174.

[113] Liao SM, Zhang J, Jeffery DA, Koleske AJ, Thompson CM, Chao DM, Viljoen M, van Vuuren HJ, Young RA (1995) A kinase-cyclin pair in the RNA polymerase II holoenzyme. Nature. 374: 193-196.

[114] Kornberg RD (2005) Mediator and the mechanism of transcriptional activation. Trends Biochem Sci. 30: 235-239.

[115] Taatjes DJ (2010) The human Mediator complex: a versatile, genome-wide regulator of transcription. Trends Biochem Sci. 35: 315-322.

[116] Holstege FC, Jennings EG, Wyrick JJ, Lee TI, Hengartner CJ, Green MR, Golub TR, Lander ES, Young RA (1998) Dissecting the regulatory circuitry of a eukaryotic genome. Cell. 95: 717-728.

[117] Knuesel MT, Meyer KD, Bernecky C, Taatjes DJ (2009) The human CDK8 subcomplex is a molecular switch that controls Mediator coactivator function. Genes Dev. 23: 439451. 
[118] Carlson M (1997) Genetics of transcriptional regulation in yeast: connections to the RNA polymerase II CTD. Annu. Rev. Cell Dev. Biol. 13: 1-23.

[119] Yudkovsky N, Ranish JA, Hahn S (2000) A transcription reinitiation intermediate that is stabilized by activator. Nature. 408: 225-229.

[120] Hirst M, Kobor MS, Kuriakose N, Greenblatt J, Sadowski I (1999) GAL4 is regulated by the RNA polymerase II holoenzyme-associated cyclin-dependent protein kinase SRB10/CDK8. Mol Cell. 3: 673-678.

[121] Vincent O, Kuchin S, Hong SP, Townley R, Vyas VK, Carlson M (2001) Interaction of the Srb10 kinase with Sip4, a transcriptional activator of gluconeogenic genes in Saccharomyces cerevisiae. Mol Cell Biol. 21: 5790-5796.

[122] Galbraith MD, Donner AJ, Espinosa JM (2010) CDK8: a positive regulator of transcription. Transcription. 1: 4-12.

[123] Chi Y, Huddleston MJ, Zhang X, Young RA, Annan RS, Carr SA, Deshaies RJ (2001) Negative regulation of Gcn4 and Msn2 transcription factors by Srb10 cyclin-dependent kinase. Genes Dev. 15: 1078-1092.

[124] Nelson C, Goto S, Lund K, Hung W, Sadowski I (2003) Srb10/Cdk8 regulates yeast filamentous growth by phosphorylating the transcription factor Ste12. Nature. 421: 187190.

[125] Keogh MC, Cho EJ, Podolny V, Buratowski S (2002) Kin28 is found within TFIIH and a Kin28-Ccl1-Tfb3 trimer complex with differential sensitivities to T-loop phosphorylation. Mol Cell Biol. 22: 1288-1297.

[126] Roy R, Adamczewski JP, Seroz T, Vermeulen W, Tassan JP, Schaeffer L, Nigg EA, Hoeijmakers JH, Egly JM (1994) The MO15 cell cycle kinase is associated with the TFIIH transcription-DNA repair factor. Cell. 79: 1093-1101.

[127] Serizawa H, Makela TP, Conaway JW, Conaway RC, Weinberg RA, Young RA (1995) Association of Cdk-activating kinase subunits with transcription factor TFIIH. Nature. 374: 280-282.

[128] Shiekhattar R, Mermelstein F, Fisher RP, Drapkin R, Dynlacht B, Wessling HC, Morgan DO, Reinberg D (1995) Cdk-activating kinase complex is a component of human transcription factor TFIIH. Nature. 374: 283-287.

[129] Cismowski MJ, Laff GM, Solomon MJ, Reed SI (1995) KIN28 encodes a C-terminal domain kinase that controls mRNA transcription in Saccharomyces cerevisiae but lacks cyclin-dependent kinase-activating kinase (CAK) activity. Mol Cell Biol. 15: 2983-2992.

[130] Espinoza FH, Farrell A, Nourse JL, Chamberlin HM, Gileadi O, Morgan DO (1998) Cak1 is required for Kin28 phosphorylation and activation in vivo. Mol Cell Biol. 18: 6365-6373.

[131] Kaldis P, Sutton A, Solomon MJ (1996) The Cdk-activating kinase (CAK) from budding yeast. Cell. 86: 553-564.

[132] Simon M, Seraphin B, Faye G (1986) KIN28, a yeast split gene coding for a putative protein kinase homologous to CDC28. EMBO J. 5: 2697-2701.

[133] Akoulitchev S, Makela TP, Weinberg RA, Reinberg D (1995) Requirement for TFIIH kinase activity in transcription by RNA polymerase II. Nature. 377: 557-560. 
[134] Jiang Y, Yan M, Gralla JD (1996) A three-step pathway of transcription initiation leading to promoter clearance at an activation RNA polymerase II promoter. Mol Cell Biol. 16: 1614-1621.

[135] Cho EJ, Takagi T, Moore CR, Buratowski S (1997) mRNA capping enzyme is recruited to the transcription complex by phosphorylation of the RNA polymerase II carboxyterminal domain. Genes Dev. 11: 3319-3326.

[136] Ho CK, Shuman S (1999) Distinct roles for CTD Ser-2 and Ser-5 phosphorylation in the recruitment and allosteric activation of mammalian mRNA capping enzyme. Mol Cell. 3: 405-411.

[137] McCracken S, Fong N, Rosonina E, Yankulov K, Brothers G, Siderovski D, Hessel A, Foster S, Shuman S, Bentley DL (1997) 5'-Capping enzymes are targeted to pre-mRNA by binding to the phosphorylated carboxy-terminal domain of RNA polymerase II. Genes Dev. 11: 3306-3318.

[138] Qiu H, Hu C, Wong CM, Hinnebusch AG (2006) The Spt4p subunit of yeast DSIF stimulates association of the Paf1 complex with elongating RNA polymerase II. Mol Cell Biol. 26: 3135-3148.

[139] Ranish JA, Yudkovsky N, Hahn S (1999) Intermediates in formation and activity of the RNA polymerase II preinitiation complex: holoenzyme recruitment and a postrecruitment role for the TATA box and TFIIB. Genes Dev. 13: 49-63.

[140] Borggrefe T, Davis R, Erdjument-Bromage H, Tempst P, Kornberg RD (2002) A complex of the Srb8, $-9,-10$, and -11 transcriptional regulatory proteins from yeast. J Biol Chem. 277: 44202-44207.

[141] Valay JG, Simon M, Dubois MF, Bensaude O, Facca C, Faye G (1995) The KIN28 gene is required both for RNA polymerase II mediated transcription and phosphorylation of the Rpb1p CTD. J Mol Biol. 249: 535-544.

[142] Wada T, Takagi T, Yamaguchi Y, Watanabe D, Handa H (1998) Evidence that P-TEFb alleviates the negative effect of DSIF on RNA polymerase II-dependent transcription in vitro. EMBO J. 17: 7395-7403.

[143] Wada T, Orphanides G, Hasegawa J, Kim DK, Shima D, Yamaguchi Y, Fukuda A, Hisatake K, Oh S, Reinberg D, Handa H (2000) FACT relieves DSIF/NELF-mediated inhibition of transcriptional elongation and reveals functional differences between PTEFb and TFIIH. Mol Cell. 5: 1067-1072.

[144] Yamaguchi Y, Takagi T, Wada T, Yano K, Furuya A, Sugimoto S, Hasegawa J, Handa H (1999) NELF, a multisubunit complex containing RD, cooperates with DSIF to repress RNA polymerase II elongation. Cell. 97: 41-51.

[145] Bartkowiak B, Greenleaf AL (2011) Phosphorylation of RNAPII: To P-TEFb or not to PTEFb? Transcription. 2: 115-119.

[146] Viladevall L, St Amour CV, Rosebrock A, Schneider S, Zhang C, Allen JJ, Shokat KM, Schwer B, Leatherwood JK, Fisher RP (2009) TFIIH and P-TEFb coordinate transcription with capping enzyme recruitment at specific genes in fission yeast. Mol Cell. 33: 738751.

[147] Keogh MC, Podolny V, Buratowski S (2003) Bur1 kinase is required for efficient transcription elongation by RNA polymerase II. Mol Cell Biol. 23: 7005-7018. 
[148] Yao S, Neiman A, Prelich G (2000) BUR1 and BUR2 encode a divergent cyclindependent kinase-cyclin complex important for transcription in vivo. Mol Cell Biol. 20: 7080-7087.

[149] Wood A, Shilatifard A (2006) Bur1/Bur2 and the Ctk complex in yeast: the split personality of mammalian P-TEFb. Cell Cycle. 5: 1066-1068.

[150] Murray S, Udupa R, Yao S, Hartzog G, Prelich G (2001) Phosphorylation of the RNA polymerase II carboxy-terminal domain by the Bur1 cyclin-dependent kinase. Mol Cell Biol. 21: 4089-4096.

[151] Lindstrom DL, Hartzog GA (2001) Genetic interactions of Spt4-Spt5 and TFIIS with the RNA polymerase II CTD and CTD modifying enzymes in Saccharomyces cerevisiae. Genetics. 159: 487-497.

[152] Chu Y, Simic R, Warner MH, Arndt KM, Prelich G (2007) Regulation of histone modification and cryptic transcription by the Bur1 and Paf1 complexes. EMBO J. 26: 4646-4656.

[153] Pei Y, Shuman S (2003) Characterization of the Schizosaccharomyces pombe Cdk9/Pch1 protein kinase: Spt5 phosphorylation, autophosphorylation, and mutational analysis. J Biol Chem. 278: 43346-43356.

[154] Zhou K, Kuo WH, Fillingham J, Greenblatt JF (2009) Control of transcriptional elongation and cotranscriptional histone modification by the yeast BUR kinase substrate Spt5. Proc. Natl. Acad. Sci. U S A. 106: 6956-6961.

[155] Sterner DE, Lee JM, Hardin SE, Greenleaf AL (1995) The yeast carboxyl-terminal repeat domain kinase CTDK-I is a divergent cyclin-cyclin-dependent kinase complex. Mol Cell Biol. 15: 5716-5724.

[156] Jones JC, Phatnani HP, Haystead TA, MacDonald JA, Alam SM, Greenleaf AL (2004) C-terminal repeat domain kinase I phosphorylates Ser2 and Ser5 of RNA polymerase II C-terminal domain repeats. J Biol Chem. 279: 24957-24964.

[157] Skaar DA, Greenleaf AL (2002) The RNA polymerase II CTD kinase CTDK-I affects pre-mRNA 3' cleavage/polyadenylation through the processing component Pti1p. Mol Cell. 10: 1429-1439.

[158] Xiao T, Shibata Y, Rao B, Laribee RN, O'Rourke R, Buck MJ, Greenblatt JF, Krogan NJ, Lieb JD, Strahl BD (2007) The RNA polymerase II kinase Ctk1 regulates positioning of a 5' histone methylation boundary along genes. Mol Cell Biol. 27: 721-731.

[159] Hurt E, Luo MJ, Rother S, Reed R, Strasser K (2004) Cotranscriptional recruitment of the serine-arginine-rich (SR)-like proteins Gbp2 and Hrb1 to nascent mRNA via the TREX complex. Proc Natl Acad Sci U S A. 101: 1858-1862.

[160] Jimeno S, Rondon AG, Luna R, Aguilera A (2002) The yeast THO complex and mRNA export factors link RNA metabolism with transcription and genome instability. EMBO J. 21: 3526-3535.

[161] Bouchoux C, Hautbergue G, Grenetier S, Carles C, Riva M, Goguel V (2004) CTD kinase I is involved in RNA polymerase I transcription. Nucleic Acids Res. 32: 58515860.

[162] Grenetier S, Bouchoux C, Goguel V (2006) CTD kinase I is required for the integrity of the rDNA tandem array. Nucleic Acids Res. 34: 4996-5006. 
[163] Ostapenko D, Solomon MJ (2003) Budding yeast CTDK-I is required for DNA damageinduced transcription. Eukaryot Cell. 2: 274-283.

[164] Hampsey M, Kinzy TG (2007) Synchronicity: policing multiple aspects of gene expression by Ctk1. Genes Dev. 21: 1288-1291.

[165] Kong SE, Kobor MS, Krogan NJ, Somesh BP, Sogaard TM, Greenblatt JF, Svejstrup JQ (2005) Interaction of Fcp1 phosphatase with elongating RNA polymerase II holoenzyme, enzymatic mechanism of action, and genetic interaction with elongator. J Biol Chem. 280: 4299-4306.

[166] Dichtl B, Blank D, Ohnacker M, Friedlein A, Roeder D, Langen H, Keller W (2002) A role for SSU72 in balancing RNA polymerase II transcription elongation and termination. Mol Cell. 10: 1139-1150.

[167] Mosley AL, Pattenden SG, Carey M, Venkatesh S, Gilmore JM, Florens L, Workman JL, Washburn MP (2009) Rtr1 is a CTD phosphatase that regulates RNA polymerase II during the transition from serine 5 to serine 2 phosphorylation. Mol Cell. 34: 168-178.

[168] Yeo M, Lin PS, Dahmus ME, Gill GN (2003) A novel RNA polymerase II C-terminal domain phosphatase that preferentially dephosphorylates serine 5. J Biol Chem. 278: 26078-26085.

[169] Jeronimo C, Forget D, Bouchard A, Li Q, Chua G, Poitras C, Therien C, Bergeron D, Bourassa S, Greenblatt J, Chabot B, Poirier GG, Hughes TR, Blanchette M, Price DH, Coulombe B (2007) Systematic analysis of the protein interaction network for the human transcription machinery reveals the identity of the 7SK capping enzyme. Mol Cell. 27: 262-274.

[170] Egloff S, Zaborowska J, Laitem C, Kiss T, Murphy S (2012) Ser7 phosphorylation of the CTD recruits the RPAP2 Ser5 phosphatase to snRNA genes. Mol Cell. 45: 111-122.

[171] Gibney PA, Fries T, Bailer SM, Morano KA (2008) Rtr1 is the Saccharomyces cerevisiae homolog of a novel family of RNA polymerase II-binding proteins. Eukaryot Cell. 7: 938-948.

[172] Ansari A, Hampsey M (2005) A role for the CPF 3'-end processing machinery in RNAPII-dependent gene looping. Genes Dev. 19: 2969-2978.

[173] Ganem C, Devaux F, Torchet C, Jacq C, Quevillon-Cheruel S, Labesse G, Facca C, Faye $G$ (2003) Ssu72 is a phosphatase essential for transcription termination of snoRNAs and specific mRNAs in yeast. EMBO J. 22: 1588-1598.

[174] Pappas DL, Jr., Hampsey M (2000) Functional interaction between Ssu72 and the Rpb2 subunit of RNA polymerase II in Saccharomyces cerevisiae. Mol Cell Biol. 20: 8343-8351.

[175] Steinmetz EJ, Brow DA (2003) Ssu72 protein mediates both poly(A)-coupled and poly(A)-independent termination of RNA polymerase II transcription. Mol Cell Biol. 23: 6339-6349.

[176] St-Pierre B, Liu X, Kha LC, Zhu X, Ryan O, Jiang Z, Zacksenhaus E (2005) Conserved and specific functions of mammalian ssu72. Nucleic Acids Res. 33: 464-477.

[177] Archambault J, Chambers RS, Kobor MS, Ho Y, Cartier M, Bolotin D, Andrews B, Kane CM, Greenblatt J (1997) An essential component of a C-terminal domain phosphatase that interacts with transcription factor IIF in Saccharomyces cerevisiae. Proc Natl Acad Sci U S A. 94: 14300-14305. 
[178] Kobor MS, Archambault J, Lester W, Holstege FC, Gileadi O, Jansma DB, Jennings EG, Kouyoumdjian F, Davidson AR, Young RA, Greenblatt J (1999) An unusual eukaryotic protein phosphatase required for transcription by RNA polymerase II and CTD dephosphorylation in S. cerevisiae. Mol Cell. 4: 55-62.

[179] Licciardo P, Ruggiero L, Lania L, Majello B (2001) Transcription activation by targeted recruitment of the RNA polymerase II CTD phosphatase FCP1. Nucleic Acids Res. 29: 3539-3545.

[180] Lin PS, Dubois MF, Dahmus ME (2002) TFIIF-associating carboxyl-terminal domain phosphatase dephosphorylates phosphoserines 2 and 5 of RNA polymerase II. J Biol Chem. 277: 45949-45956.

[181] Lin PS, Marshall NF, Dahmus ME (2002) CTD phosphatase: role in RNA polymerase II cycling and the regulation of transcript elongation. Prog Nucleic Acid Res Mol Biol. 72: 333-365.

[182] Mandal SS, Cho H, Kim S, Cabane K, Reinberg D (2002) FCP1, a phosphatase specific for the heptapeptide repeat of the largest subunit of RNA polymerase II, stimulates transcription elongation. Mol Cell Biol. 22: 7543-7552.

[183] Ni Z, Olsen JB, Guo X, Zhong G, Ruan ED, Marcon E, Young P, Guo H, Li J, Moffat J, Emili A, Greenblatt JF (2011) Control of the RNA polymerase II phosphorylation state in promoter regions by CTD interaction domain-containing proteins RPRD1A and RPRD1B. Transcription. 2: 237-242.

[184] Sun ZW, Hampsey M (1996) Synthetic enhancement of a TFIIB defect by a mutation in SSU72, an essential yeast gene encoding a novel protein that affects transcription start site selection in vivo. Mol Cell Biol. 16: 1557-1566.

[185] Wu WH, Pinto I, Chen BS, Hampsey M (1999) Mutational analysis of yeast TFIIB. A functional relationship between Ssu72 and Sub1/Tsp1 defined by allele-specific interactions with TFIIB. Genetics. 153: 643-652.

[186] He X, Khan AU, Cheng H, Pappas DL, Jr., Hampsey M, Moore CL (2003) Functional interactions between the transcription and mRNA 3' end processing machineries mediated by Ssu72 and Sub1. Genes Dev. 17: 1030-1042.

[187] Xiang K, Nagaike T, Xiang S, Kilic T, Beh MM, Manley JL, Tong L (2010) Crystal structure of the human symplekin-Ssu72-CTD phosphopeptide complex. Nature. 467: 729-733.

[188] Meinhart A, Silberzahn T, Cramer P (2003) The mRNA transcription/processing factor Ssu72 is a potential tyrosine phosphatase. J Biol Chem. 278: 15917-15921.

[189] Chambers RS, Dahmus ME (1994) Purification and characterization of a phosphatase from HeLa cells which dephosphorylates the C-terminal domain of RNA polymerase II. J Biol Chem. 269: 26243-26248.

[190] Chambers RS, Kane CM (1996) Purification and characterization of an RNA polymerase II phosphatase from yeast. J Biol Chem. 271: 24498-24504.

[191] Kimura M, Ishihama A (2004) Tfg3, a subunit of the general transcription factor TFIIF in Schizosaccharomyces pombe, functions under stress conditions. Nucleic Acids Res. 32: 6706-6715. 
[192] Hausmann S, Shuman S (2002) Characterization of the CTD phosphatase Fcp1 from fission yeast. Preferential dephosphorylation of serine 2 versus serine 5. J Biol Chem. 277: 21213-21220.

[193] Lu KP, Finn G, Lee TH, Nicholson LK (2007) Prolyl cis-trans isomerization as a molecular timer. Nat Chem Biol. 3: 619-629.

[194] Lu KP, Zhou XZ (2007) The prolyl isomerase PIN1: a pivotal new twist in phosphorylation signalling and disease. Nat Rev Mol Cell Biol. 8: 904-916.

[195] Xu YX, Hirose Y, Zhou XZ, Lu KP, Manley JL (2003) Pin1 modulates the structure and function of human RNA polymerase II. Genes Dev. 17: 2765-2776.

[196] Xu YX, Manley JL (2007) Pin1 modulates RNA polymerase II activity during the transcription cycle. Genes Dev. 21: 2950-2962.

[197] Morris DP, Phatnani HP, Greenleaf AL (1999) Phospho-carboxyl-terminal domain binding and the role of a prolyl isomerase in pre-mRNA 3'-End formation. J Biol Chem. 274: 31583-31587.

[198] Gemmill TR, Wu X, Hanes SD (2005) Vanishingly low levels of Ess1 prolyl-isomerase activity are sufficient for growth in Saccharomyces cerevisiae. J Biol Chem. 280: 1551015517.

[199] Hani J, Schelbert B, Bernhardt A, Domdey H, Fischer G, Wiebauer K, Rahfeld JU (1999) Mutations in a peptidylprolyl-cis/trans-isomerase gene lead to a defect in 3'-end formation of a pre-mRNA in Saccharomyces cerevisiae. J Biol Chem. 274: 108-116.

[200] Wilcox CB, Rossettini A, Hanes SD (2004) Genetic interactions with C-terminal domain (CTD) kinases and the CTD of RNA Pol II suggest a role for ESS1 in transcription initiation and elongation in Saccharomyces cerevisiae. Genetics. 167: 93-105.

[201] Wu X, Rossettini A, Hanes SD (2003) The ESS1 prolyl isomerase and its suppressor BYE1 interact with RNA pol II to inhibit transcription elongation in Saccharomyces cerevisiae. Genetics. 165: 1687-1702.

[202] Krishnamurthy S, Ghazy MA, Moore C, Hampsey M (2009) Functional interaction of the Ess1 prolyl isomerase with components of the RNA polymerase II initiation and termination machineries. Mol Cell Biol. 29: 2925-2934.

[203] Armache KJ, Kettenberger H, Cramer P (2003) Architecture of initiation-competent 12subunit RNA polymerase II. Proc Natl Acad Sci U S A. 100: 6964-6968.

[204] Cramer P, Bushnell DA, Kornberg RD (2001) Structural basis of transcription: RNA polymerase II at 2.8 angstrom resolution. Science. 292: 1863-1876.

[205] Grohmann D, Klose D, Klare JP, Kay CW, Steinhoff HJ, Werner F (2010) RNA-binding to archaeal RNA polymerase subunits F/E: a DEER and FRET study. J Am Chem Soc. 132: 5954-5955.

[206] Young RA (1991) RNA polymerase II. Annual Review of Biochemistry. 60: 689-715.

[207] Bushnell DA, Kornberg RD (2003) Complete, 12-subunit RNA polymerase II at 4.1-A resolution: implications for the initiation of transcription. Proc Natl Acad Sci U S A. 100: 6969-6973.

[208] Kimura M, Suzuki H, Ishihama A (2002) Formation of a carboxy-terminal domain phosphatase (Fcp1)/TFIIF/RNA polymerase II (pol II) complex in Schizosaccharomyces pombe involves direct interaction between Fcp1 and the Rpb4 subunit of pol II. Mol Cell Biol. 22: 1577-1588. 
[209] Armache KJ, Mitterweger S, Meinhart A, Cramer P (2005) Structures of complete RNA polymerase II and its subcomplex, Rpb4/7. J Biol Chem. 280: 7131-7134.

[210] Cai G, Imasaki T, Takagi Y, Asturias FJ (2009) Mediator structural conservation and implications for the regulation mechanism. Structure. 17: 559-567.

[211] Cai G, Imasaki T, Yamada K, Cardelli F, Takagi Y, Asturias FJ (2010) Mediator head module structure and functional interactions. Nat Struct Mol Biol. 17: 273-279.

[212] Sampath V, Balakrishnan B, Verma-Gaur J, Onesti S, Sadhale PP (2008) Unstructured $\mathrm{N}$ terminus of the RNA polymerase II subunit Rpb4 contributes to the interaction of Rpb4.Rpb7 subcomplex with the core RNA polymerase II of Saccharomyces cerevisiae. J Biol Chem. 283: 3923-3931.

[213] Calvo O, Manley JL (2001) Evolutionarily conserved interaction between CstF-64 and PC4 links transcription, polyadenylation, and termination. Mol Cell. 7: 1013-1023.

[214] Henry NL, Bushnell DA, Kornberg RD (1996) A yeast transcriptional stimulatory protein similar to human PC4. J Biol Chem. 271: 21842-21847.

[215] Knaus R, Pollock R, Guarente L (1996) Yeast SUB1 is a suppressor of TFIIB mutations and has homology to the human co-activator PC4. EMBO J. 15: 1933-1940.

[216] Ge H, Roeder RG (1994) Purification, cloning, and characterization of a human coactivator, PC4, that mediates transcriptional activation of class II genes. Cell. 78: 513523.

[217] Kaiser K, Stelzer G, Meisterernst M (1995) The coactivator p15 (PC4) initiates transcriptional activation during TFIIA-TFIID-promoter complex formation. EMBO J. 14: 3520-3527.

[218] Kretzschmar M, Kaiser K, Lottspeich F, Meisterernst M (1994) A novel mediator of class II gene transcription with homology to viral immediate-early transcriptional regulators. Cell. 78: 525-534.

[219] Malik S, Guermah M, Roeder RG (1998) A dynamic model for PC4 coactivator function in RNA polymerase II transcription. Proc. Natl. Acad. Sci. U S A. 95: 2192-2197.

[220] Werten S, Stelzer G, Goppelt A, Langen FM, Gros P, Timmers HT, Van der Vliet PC, Meisterernst M (1998) Interaction of PC4 with melted DNA inhibits transcription. EMBO J. 17: 5103-5111.

[221] Rosonina E, Willis IM, Manley JL (2009) Sub1 functions in osmoregulation and in transcription by both RNA polymerases II and III. Mol Cell Biol. 29: 2308-2321.

[222] Garcia A, Rosonina E, Manley JL, Calvo O (2010) Sub1 globally regulates RNA polymerase II C-terminal domain phosphorylation. Mol Cell Biol. 30: 5180-5193.

[223] Calvo O, Manley JL (2003) Strange bedfellows: polyadenylation factors at the promoter. Genes Dev. 17: 1321-1327.

[224] Calvo O, Manley JL (2005) The transcriptional coactivator PC4/Sub1 has multiple functions in RNA polymerase II transcription. EMBO J. 24: 1009-1020.

[225] Sikorski TW, Ficarro SB, Holik J, Kim T, Rando OJ, Marto JA, Buratowski S (2011) Sub1 and RPA Associate with RNA Polymerase II at Different Stages of Transcription. Mol Cell. 44: 397-409.

[226] Ge H, Zhao Y, Chait BT, Roeder RG (1994) Phosphorylation negatively regulates the function of coactivator PC4. Proc Natl Acad Sci U S A. 91: 12691-12695. 
[227] Ohkuni K, Yamashita I (2000) A transcriptional autoregulatory loop for KIN28-CCL1 and SRB10-SRB11, each encoding RNA polymerase II CTD kinase-cyclin pair, stimulates the meiotic development of S. cerevisiae. Yeast. 16: 829-846.

[228] Donner AJ, Ebmeier CC, Taatjes DJ, Espinosa JM (2010) CDK8 is a positive regulator of transcriptional elongation within the serum response network. Nat. Struct. Mol. Biol. 17: 194-201.

[229] de la Mata M, Kornblihtt AR (2006) RNA polymerase II C-terminal domain mediates regulation of alternative splicing by SRp20. Nat Struct Mol Biol. 13: 973-980.

[230] Hirose Y, Manley JL (1998) RNA polymerase II is an essential mRNA polyadenylation factor. Nature. 395: 93-96.

[231] Hirose Y, Tacke R, Manley JL (1999) Phosphorylated RNA polymerase II stimulates pre-mRNA splicing. Genes Dev. 13: 1234-1239.

[232] Cho EJ, Rodriguez CR, Takagi T, Buratowski S (1998) Allosteric interactions between capping enzyme subunits and the RNA polymerase II carboxy-terminal domain. Genes Dev. 12: 3482-3487.

[233] Kim HJ, Jeong SH, Heo JH, Jeong SJ, Kim ST, Youn HD, Han JW, Lee HW, Cho EJ (2004) mRNA capping enzyme activity is coupled to an early transcription elongation. Mol Cell Biol. 24: 6184-6193.

[234] Fong N, Bentley DL (2001) Capping, splicing, and 3' processing are independently stimulated by RNA polymerase II: different functions for different segments of the CTD. Genes Dev. 15: 1783-1795.

[235] Barilla D, Lee BA, Proudfoot NJ (2001) Cleavage/polyadenylation factor IA associates with the carboxyl-terminal domain of RNA polymerase II in Saccharomyces cerevisiae. Proc Natl Acad Sci U S A. 98: 445-450.

[236] Bauren G, Belikov S, Wieslander L (1998) Transcriptional termination in the Balbiani ring 1 gene is closely coupled to 3'-end formation and excision of the 3'-terminal intron. Genes Dev. 12: 2759-2769.

[237] Birse CE, Minvielle-Sebastia L, Lee BA, Keller W, Proudfoot NJ (1998) Coupling termination of transcription to messenger RNA maturation in yeast. Science. 280: 298301.

[238] Kim M, Krogan NJ, Vasiljeva L, Rando OJ, Nedea E, Greenblatt JF, Buratowski S (2004) The yeast Rat1 exonuclease promotes transcription termination by RNA polymerase II. Nature. 432: 517-522.

[239] West S, Gromak N, Proudfoot NJ (2004) Human 5' --> 3' exonuclease Xrn2 promotes transcription termination at co-transcriptional cleavage sites. Nature. 432: 522-525.

[240] Baillat D, Hakimi MA, Naar AM, Shilatifard A, Cooch N, Shiekhattar R (2005) Integrator, a multiprotein mediator of small nuclear RNA processing, associates with the C-terminal repeat of RNA polymerase II. Cell. 123: 265-276.

[241] Egloff S, Szczepaniak SA, Dienstbier M, Taylor A, Knight S, Murphy S (2010) The integrator complex recognizes a new double mark on the RNA polymerase II carboxylterminal domain. J Biol Chem. 285: 20564-20569.

[242] David CJ, Boyne AR, Millhouse SR, Manley JL (2011) The RNA polymerase II Cterminal domain promotes splicing activation through recruitment of a U2AF65-Prp19 complex. Genes Dev. 25: 972-983. 
[243] Millhouse S, Manley JL (2005) The C-terminal domain of RNA polymerase II functions as a phosphorylation-dependent splicing activator in a heterologous protein. Mol Cell Biol. 25: 533-544.

[244] Listerman I, Sapra AK, Neugebauer KM (2006) Cotranscriptional coupling of splicing factor recruitment and precursor messenger RNA splicing in mammalian cells. Nat Struct Mol Biol. 13: 815-822.

[245] Moore MJ, Schwartzfarb EM, Silver PA, Yu MC (2006) Differential recruitment of the splicing machinery during transcription predicts genome-wide patterns of mRNA splicing. Mol Cell. 24: 903-915.

[246] Kim E, Du L, Bregman DB, Warren SL (1997) Splicing factors associate with hyperphosphorylated RNA polymerase II in the absence of pre-mRNA. J Cell Biol. 136: 19-28.

[247] Mortillaro MJ, Blencowe BJ, Wei X, Nakayasu H, Du L, Warren SL, Sharp PA, Berezney R (1996) A hyperphosphorylated form of the large subunit of RNA polymerase II is associated with splicing complexes and the nuclear matrix. Proc Natl Acad Sci U S A. 93: 8253-8257.

[248] Yuryev A, Patturajan M, Litingtung Y, Joshi RV, Gentile C, Gebara M, Corden JL (1996) The C-terminal domain of the largest subunit of RNA polymerase II interacts with a novel set of serine/arginine-rich proteins. Proc Natl Acad Sci U S A. 93: 6975-6980.

[249] Morris DP, Greenleaf AL (2000) The splicing factor, Prp40, binds the phosphorylated carboxyl-terminal domain of RNA polymerase II. J Biol Chem. 275: 39935-39943.

[250] Carty SM, Goldstrohm AC, Sune C, Garcia-Blanco MA, Greenleaf AL (2000) Proteininteraction modules that organize nuclear function: FF domains of CA150 bind the phosphoCTD of RNA polymerase II. Proc Natl Acad Sci U S A. 97: 9015-9020.

[251] Goldstrohm AC, Albrecht TR, Sune C, Bedford MT, Garcia-Blanco MA (2001) The transcription elongation factor CA150 interacts with RNA polymerase II and the premRNA splicing factor SF1. Mol Cell Biol. 21: 7617-7628.

[252] David CJ, Manley JL (2011) The RNA polymerase C-terminal domain: a new role in spliceosome assembly. Transcription. 2: 221-225.

[253] Hargreaves DC, Horng T, Medzhitov R (2009) Control of inducible gene expression by signal-dependent transcriptional elongation. Cell. 138: 129-145.

[254] Luger K (2003) Structure and dynamic behavior of nucleosomes. Curr Opin Genet Dev. 13: 127-135.

[255] Berger SL (2007) The complex language of chromatin regulation during transcription. Nature. 447: 407-412.

[256] Cho EJ (2007) RNA polymerase II carboxy-terminal domain with multiple connections. Exp. Mol. Med. 39: 247-254.

[257] Hampsey M, Reinberg D (2003) Tails of intrigue: phosphorylation of RNA polymerase II mediates histone methylation. Cell. 113: 429-432.

[258] Jenuwein T, Allis CD (2001) Translating the histone code. Science. 293: 1074-1080.

[259] Strahl BD, Allis CD (2000) The language of covalent histone modifications. Nature. 403: 41-45.

[260] Kouzarides T (2007) SnapShot: Histone-modifying enzymes. Cell. 128: 802.

[261] Kouzarides T (2007) Chromatin modifications and their function. Cell. 128: 693-705. 
[262] Spain MM, Govind CK (2011) A role for phosphorylated Pol II CTD in modulating transcription coupled histone dynamics. Transcription. 2: 78-81.

[263] Kouzarides T (2002) Histone methylation in transcriptional control. Curr Opin Genet Dev. 12: 198-209.

[264] Pinskaya M, Morillon A (2009) Histone H3 lysine 4 di-methylation: a novel mark for transcriptional fidelity? Epigenetics. 4: 302-306.

[265] Krogan NJ, Dover J, Wood A, Schneider J, Heidt J, Boateng MA, Dean K, Ryan OW, Golshani A, Johnston M, Greenblatt JF, Shilatifard A (2003) The Paf1 complex is required for histone $\mathrm{H} 3$ methylation by COMPASS and Dot1p: linking transcriptional elongation to histone methylation. Mol Cell. 11: 721-729.

[266] Kizer KO, Phatnani HP, Shibata Y, Hall H, Greenleaf AL, Strahl BD (2005) A novel domain in Set2 mediates RNA polymerase II interaction and couples histone H3 K36 methylation with transcript elongation. Mol Cell Biol. 25: 3305-3316.

[267] Drouin S, Laramee L, Jacques PE, Forest A, Bergeron M, Robert F (2010) DSIF and RNA polymerase II CTD phosphorylation coordinate the recruitment of Rpd3S to actively transcribed genes. PLoS Genet. 6: e1001173.

[268] Govind CK, Qiu H, Ginsburg DS, Ruan C, Hofmeyer K, Hu C, Swaminathan V, Workman JL, Li B, Hinnebusch AG (2010) Phosphorylated Pol II CTD recruits multiple HDACs, including $\operatorname{Rpd} 3 \mathrm{C}(\mathrm{S})$, for methylation-dependent deacetylation of ORF nucleosomes. Mol Cell. 39: 234-246.

[269] Kim T, Buratowski S (2009) Dimethylation of H3K4 by Set1 recruits the Set3 histone deacetylase complex to 5' transcribed regions. Cell. 137: 259-272.

[270] Brodsky AS, Silver PA (2000) Pre-mRNA processing factors are required for nuclear export. RNA. 6: 1737-1749.

[271] Rondon AG, Jimeno S, Aguilera A (2010) The interface between transcription and mRNP export: from THO to THSC/TREX-2. Biochim Biophys Acta. 1799: 533-538.

[272] Strasser K, Masuda S, Mason P, Pfannstiel J, Oppizzi M, Rodriguez-Navarro S, Rondon AG, Aguilera A, Struhl K, Reed R, Hurt E (2002) TREX is a conserved complex coupling transcription with messenger RNA export. Nature. 417: 304-308.

[273] Rondon AG, Jimeno S, Garcia-Rubio M, Aguilera A (2003) Molecular evidence that the eukaryotic THO/TREX complex is required for efficient transcription elongation. J Biol Chem. 278: 39037-39043.

[274] Zenklusen D, Vinciguerra P, Wyss JC, Stutz F (2002) Stable mRNP formation and export require cotranscriptional recruitment of the mRNA export factors Yra1p and Sub2p by Hpr1p. Mol Cell Biol. 22: 8241-8253.

[275] Masuda S, Das R, Cheng H, Hurt E, Dorman N, Reed R (2005) Recruitment of the human TREX complex to mRNA during splicing. Genes Dev. 19: 1512-1517.

[276] MacKellar AL, Greenleaf AL (2011) Cotranscriptional association of mRNA export factor Yra1 with C-terminal domain of RNA polymerase II. J Biol Chem. 286: 3638536395.

[277] Krogan NJ, Kim M, Tong A, Golshani A, Cagney G, Canadien V, Richards DP, Beattie BK, Emili A, Boone C, Shilatifard A, Buratowski S, Greenblatt J (2003) Methylation of histone $\mathrm{H} 3$ by Set2 in Saccharomyces cerevisiae is linked to transcriptional elongation by RNA polymerase II. Mol Cell Biol. 23: 4207-4218. 
[278] Lunde BM, Reichow SL, Kim M, Suh H, Leeper TC, Yang F, Mutschler H, Buratowski S, Meinhart A, Varani G (2010) Cooperative interaction of transcription termination factors with the RNA polymerase II C-terminal domain. Nat Struct Mol Biol. 17: 11951201.

[279] Stewart M (2010) Nuclear export of mRNA. Trends Biochem Sci. 35: 609-617.

[280] Ammosova T, Berro R, Jerebtsova M, Jackson A, Charles S, Klase Z, Southerland W, Gordeuk VR, Kashanchi F, Nekhai S (2006) Phosphorylation of HIV-1 Tat by CDK2 in HIV-1 transcription. Retrovirology. 3: 78.

[281] Coley W, Kehn-Hall K, Van Duyne R, Kashanchi F (2009) Novel HIV-1 therapeutics through targeting altered host cell pathways. Expert Opin Biol Ther. 9: 1369-1382.

[282] Bellan C, De Falco G, Lazzi S, Micheli P, Vicidomini S, Schurfeld K, Amato T, Palumbo A, Bagella L, Sabattini E, Bartolommei S, Hummel M, Pileri S, Tosi P, Leoncini L, Giordano A (2004) CDK9/CYCLIN T1 expression during normal lymphoid differentiation and malignant transformation. J Pathol. 203: 946-952.

[283] Lee DK, Duan HO, Chang C (2001) Androgen receptor interacts with the positive elongation factor P-TEFb and enhances the efficiency of transcriptional elongation. $\mathrm{J}$ Biol Chem. 276: 9978-9984.

[284] Simone C, Giordano A (2007) Abrogation of signal-dependent activation of the cdk9/cyclin T2a complex in human RD rhabdomyosarcoma cells. Cell Death Differ. 14: 192-195.

[285] Shapiro GI (2006) Cyclin-dependent kinase pathways as targets for cancer treatment. J Clin Oncol. 24: 1770-1783.

[286] Krystof V, Chamrad I, Jorda R, Kohoutek J (2010) Pharmacological targeting of CDK9 in cardiac hypertrophy. Med Res Rev. 30: 646-666. 


\title{
Sub1 associates with Spt5 and influences RNA polymerase II transcription elongation rate
}

\author{
Alicia García, Alejandro Collin, and Olga Calvo \\ Instituto de Biología Funcional y Genómica, Consejo Superior de Investigaciones Científicas/Universidad \\ de Salamanca, 37007 Salamanca, Spain
}

\begin{abstract}
The transcriptional coactivator Sub1 has been implicated in several steps of mRNA metabolism in yeast, such as the activation of transcription, termination, and $3^{\prime}$-end formation. In addition, Sub1 globally regulates RNA polymerase II phosphorylation, and most recently it has been shown that it is a functional component of the preinitiation complex. Here we present evidence that Sub1 plays a significant role in transcription elongation by RNA polymerase II (RNAPII). We show that SUB1 genetically interacts with the gene encoding the elongation factor Spt5, that Sub1 influences Spt5 phosphorylation of the carboxy-terminal domain of RNAPII largest subunit by the kinase Bur1, and that both Sub1 and Spt5 copurify in the same complex, likely during early transcription elongation. Indeed, our data indicate that Sub1 influences Spt5-Rpb1 interaction. In addition, biochemical and molecular data show that Sub1 influences transcription elongation of constitutive and inducible genes and associates with coding regions in a transcription-dependent manner. Taken together, our results indicate that Sub1 associates with Spt5 and influences Spt5-Rpb1 complex levels and consequently transcription elongation rate.
\end{abstract}

\begin{abstract}
Monitoring Editor
William P. Tansey

Vanderbilt University
\end{abstract}

Received: Apr 30, 2012

Revised: Aug 27, 2012

Accepted: Sep 6, 2012

\section{INTRODUCTION}

Transcription by RNA polymerase II (RNAPII) can be divided into the following steps: RNAPII recruitment to gene promoters and the assembly of the preinitiation complex (PIC) and promoter clearance, initiation, elongation, and termination. For many years, the coordinated recruitment of the transcriptional machinery to form the PIC has been considered to be the principal step for the regulation of transcription. However, recent data show that the elongation phase is also highly regulated in eukaryotic cells and strictly coordinated with other nuclear processes, such as remodeling, DNA repair, recombination, and replication. In fact, in addition to the basal elongation factors, a number of factors involved in mRNA

This article was published online ahead of print in MBoC in Press (http://www .molbiolcell.org/cgi/doi/10.1091/mbc.E12-04-0331) on September 12, 2012 Address correspondence to: Olga Calvo (ocalvo@usal.es).

Abbreviations used: 6AU, 6-azauracil; ChIP, chromatin immunoprecipitation; CTD, carboxy-terminal domain; GLAM, gene-length-dependent mRNA accumulation; MPA, mycophenolic acid; PIC, preinitiation complex; RNAPII, RNA polymerase II; Sub1-HA, Sub1-hemagglutinin; TAP, tandem affinity purification; TRO, transcriptional run on; TSS, transcription start site.

(C) 2012 García et al. This article is distributed by The American Society for Cell Biology under license from the author(s). Two months after publication it is available to the public under an Attribution-Noncommercial-Share Alike 3.0 Unported Creative Commons License (http://creativecommons.org/licenses/by-nc-sa/3.0).

"ASCB ${ }^{\circledR}$," "The American Society for Cell Biology ${ }^{\circledR}$," and "Molecular Biology of the Cell ${ }^{\circledR}$ " are registered trademarks of The American Society of Cell Biology. processing, chromatin modification, remodeling, and mRNA export are also recruited during transcription elongation (reviewed in (Shilatifard et al., 2003; Saunders et al., 2006; Selth et al., 2010). In Saccharomyces cerevisiae, these factors include the basal elongation factors TFIIS and the Spt4/Spt5 complex, the chromatin assembly factor Spt16/Pob3 (known as FACT in higher eukaryotes), and the polymerase-associated factor (PAF) complex (Shilatifard et al., 2003; Saunders et al., 2006; Selth et al., 2010). Spt5 (NusG in bacteria) is the only RNA polymerase-associated factor that is conserved in all living organisms (Vassylyev et al., 2002; Korkhin et al., 2009; Grohmann and Werner, 2011). It contains a conserved NGN domain that stimulates transcription elongation and RNAP processivity (Burova et al., 1995; Chen et al., 2009). In the case of Eukarya and Archaea, this domain binds to the RNAP and Spt4 to form the Spt4/5 elongation complex (Guo et al., 2008; Hirtreiter et al., 2010; Klein et al., 2011; Martinez-Rucobo et al., 2011).

Transcription elongation is regulated not only by elongation factors but also by the phosphorylation of the carboxy-terminal domain (CTD) of the largest subunit of RNAPII. Phosphorylation of the CTD by CTD-modifying enzymes occurs predominantly on the Ser-2 and Ser-5 residues (Sims et al., 2004; Saunders et al., 2006). The level of Ser-5 phosphorylation peaks early in the transcription cycle due to the action of Kin28 and remains constant or decreases as RNAPII progresses to the $3^{\prime}$ end of the gene (Komarnitsky et al., 2000; 
Rodriguez et al., 2000; Schroeder et al., 2000). In contrast, Ser-2 phosphorylation is the predominant modification in the body and toward the $3^{\prime}$ end of the gene and occurs concurrently with productive elongation (Komarnitsky et al., 2000; Buratowski, 2009). Ctk1 is the principal kinase responsible for Ser-2 phosphorylation, which is important for the recruitment of the histone methyltransferase Set2 and the association of the polyadenylation and termination factors with RNAPII (Cho et al., 2001; Ahn et al., 2004). In addition to Ctk1, the Bur1/Bur2 kinase complex phosphorylates Ser-2 when RNAPII is near the promoter and stimulates Ser-2 phosphorylation by Ctk1 during elongation (Qiu et al., 2009). Bur1 also phosphorylates the histone modifier Rad6/Bre1 (Wood et al., 2005) and the carboxylterminal domain of the elongation factor Spt5, which stimulates the recruitment of the PAF1 elongation complex (Liu et al., 2009; Zhou et al., 2009). In addition, we recently showed that the transcriptional coactivator Sub1 globally regulates RNAPII-CTD phosphorylation during the entire transcription cycle through the action of all CTD kinases (Garcia et al., 2010), suggesting that it might also have a role in transcription elongation.

Sub1 has been implicated in several steps of mRNA metabolism, including initiation, transcription termination, and 3 '-end processing (Henry et al., 1996; Knaus et al., 1996; Calvo and Manley, 2001; He et al., 2003). It was originally described as a transcriptional stimulatory protein that is homologous to the human positive coactivator PC4 (Ge and Roeder, 1994; Kaiser et al., 1995; Malik et al., 1998). Sub1 genetically and physically interacts with TFIIB (Henry et al., 1996; Knaus et al., 1996), and most recently it has been reported that Sub1 is a PIC component (Sikorski et al., 2011). In addition, Sub1 contributes to the activation of osmoresponse genes during osmotic shock (Rosonina et al., 2009) and to the regulation of IMD2 gene expression (Koyama et al., 2008). Moreover, it has been suggested that Sub1 might have a role in transcription elongation based on the following observations: 1) Sub1 function is linked to CTD elongation kinases (Calvo and Manley, 2005; Garcia et al., 2010); 2) SUB1 genetically interacts with FCP1, which encodes the Ser-2 CTD phosphatase Fcp1 (Calvo and Manley, 2005); 3) cells lacking Sub1 display decreased accumulation of Fcp1, altered RNAPII phosphorylation, and decreased cross-linking of RNAPII to transcribed genes (Calvo and Manley, 2005).

Here we present evidence that Sub1 plays a role in transcription elongation. We show that SUB1 genetically interacts with SPT5. Sub1 regulates Spt5 phosphorylation by the CTD kinase Bur1, and both Sub1 and Spt5 copurify in the same complex, likely during early transcription elongation. Indeed, our data indicate that Sub1 influences Spt5-Rpb1 levels. We also show that Sub1 promotes transcription elongation of constitutive and inducible genes and that it associates with coding regions in a transcription-dependent manner. Taken together, our results indicate that Sub1 associates with Spt5 and influences Spt5-Rpb1 complex levels and consequently transcription elongation rates.

\section{RESULTS}

\section{Sub1 influences the efficiency of transcription elongation of long transcripts}

We previously presented evidence suggesting that Sub1 could indirectly influence transcription elongation via its effects on the association of RNAPII with chromatin during active transcription and on the phosphorylation of the RNAPII CTD (Calvo and Manley, 2005; Garcia et al., 2010). Therefore we first investigated whether Sub1 indeed is able to influence transcription elongation, using several different strategies: we studied elongation efficiency by the genelength-dependent mRNA accumulation (GLAM) assay, IMD2 gene expression by real-time quantitative PCR (RT-qPCR), RNAPII association with constitutive and regulated genes by chromatin immunoprecipitation (ChIP), and levels of active elongation-competent polymerase by transcriptional run-on (TRO) assay.

The GLAM assay specifically detects defects in elongation and is used to measure the efficiency of gene-length-dependent mRNA accumulation (Morillo-Huesca et al., 2006). The wild-type (wt) and sub1 $\Delta$ strains were transformed with three plasmids containing transcription units of different lengths, with the same PHO5 coding sequences under control of the GAL1 promoter and variable 3' untranslated sequences (Figure $1 \mathrm{~A}$ ). The ratios of acid phosphatase activity for the long transcripts versus the short transcripts (GLAM ratios) were calculated for each strain (Figure 1C). We also analyzed the spt5-194 mutant, as a positive control for elongation defects, and the corresponding wt strain. As shown in Figure 1B (left), the GLAM ratio for spt5-194 was dramatically reduced compared with the wt ratio, consistent with its function as an elongation factor. Similar values have been reported for other elongation factor mutants, such as spt4 $\Delta$, and for PAF1 complex mutants (Morillo-Huesca et al., 2006; Gaillard et al., 2009). Of interest, the GLAM ratio for sub1 $1 \Delta$ cells was also significantly reduced (Figure $1 \mathrm{C}$, left) but to a lesser extent than in spt5-194 cells (Figure 1B, left). The genelength-dependent defect observed with spt5-194 and sub1 $\Delta$ cells was further confirmed by RT-PCR assays performed with cDNA generated from spt5-194, sub1 $\Delta$, and the two corresponding wt strains bearing the different transcription units or an empty plasmid as a mock control (Figure 1, B and C, right). Our results showed that PHO5 expression decreased in both spt5-194 and sub1 $1 \Delta$ cells when expressed as long transcription units containing either the lac $Z$ or LAC4 3' untranslated sequences but was not affected when PHO5 was transcribed from the short transcription unit.

\section{Sub1 promotes transcription elongation and associates with coding regions}

The IMD2 gene encodes a rate-limiting enzyme in the de novo synthesis of GTP (IMP dehydrogenase 2), and its expression is increased by treatment with the GTP-depleting drugs mycophenolic acid (MPA) and 6-azauracil (6AU; Shaw and Reines, 2000; EscobarHenriques et al., 2001). Although their mechanism is not well understood (Jenks et al., 2008; Kuehner and Brow, 2008), these compounds have been widely used to identify proteins involved in transcription elongation (Shaw and Reines, 2000; Desmoucelles et al., 2002; Riles et al., 2004). In fact, mutations in several of the genes encoding components of the transcriptional elongation machinery confer sensitivity to $6 \mathrm{AU}$ in $\mathrm{S}$. cerevisiae due to the resulting inability to induce IMD2 transcription (Shaw and Reines, 2000; Riles et al., 2004). IMD2 transcription is regulated by the selection of different start sites. Upstream starts sites lead to short, noncoding transcripts that are prematurely terminated and degraded in noninducing conditions, whereas a downstream start is selected upon nucleotide limitation, leading to IMD2 induction (Jenks et al., 2008; Kuehner and Brow, 2008).

It has been proposed that Sub1 represses IMD2 gene expression upon binding to the promoter in noninduced conditions (Koyama et al., 2008), in which only upstream short, noncoding transcripts are synthesized and IMD2 is not transcribed. In fact, deletion of SUB1 increases the expression of IMD2 in normal growth conditions, whereas its expression is avoided in wt cells (Koyama et al., 2008). However, Sub1 effects on IMD2 expression may be explained in part by a mechanism involving transcription start site selection (TSS), consistent with recent data showing that SUB1 deletion alters TSS selection (N. Krogan, personal communication). Thus, in the absence of 


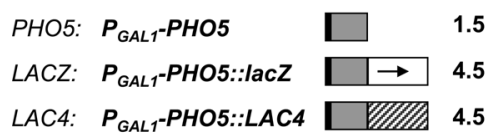

B

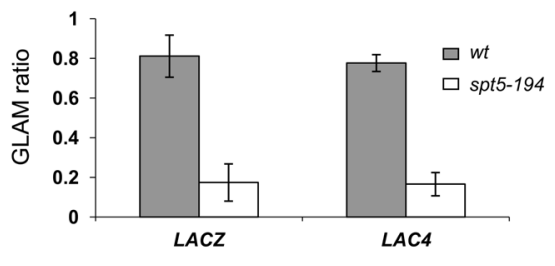

Transcription unit

C

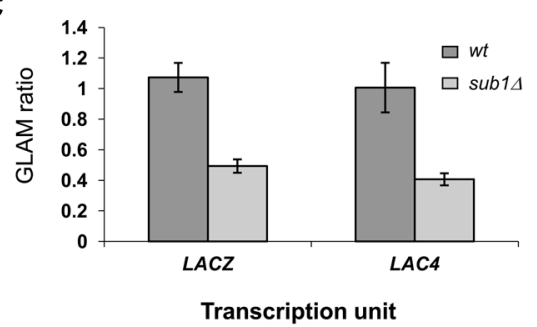

GLAM assay
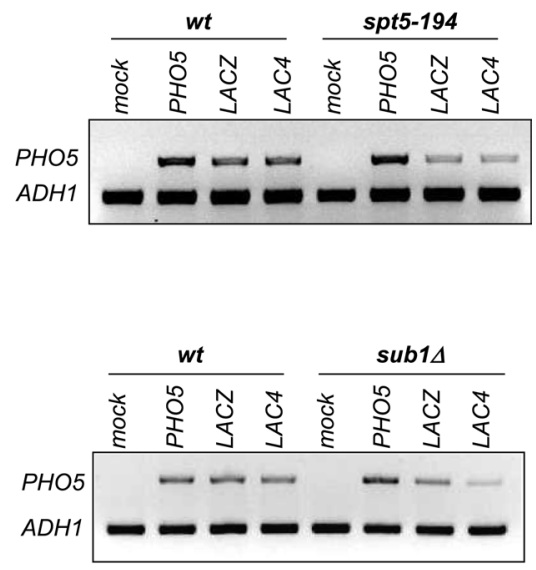

we cannot rule out that this effect on bur1 cells can be gene specific because we did not analyze IMD2 expression levels in the bur1 and bur1sub1 $1 \Delta$ cells. In any case, our data suggest that full expression of the IMD2 gene after 6AU induction may be influenced by Sub1 function, and in addition to its involvement in TSS selection, when bound to the promoter in noninduced conditions and when short transcripts from the IMD2 promoter are being transcribed, Sub1 might also have a role farther downstream during IMD2 elongation after induction.

To investigate further whether Sub1 participates in transcription elongation, we analyzed the association of Sub1-hemagglutinin (HA) with the IMD2 and PMA1 promoters and coding regions in the presence or absence of 6AU. As shown in Figure 2B, and as previously reported, Sub1-HA associated with the PMA1 and IMD2 promoters under normal growth conditions (Calvo and Manley, 2005; Koyama et al., 2008). The association of Sub1-HA with the IMD2 coding region was near the lower limit of detection in the absence of 6AU (Figure 2B, left), and it was almost undetectable in the $3^{\prime}$-end region. Conversely, Sub1-HA was found to be associated with the constitutively transcribed PMA1 gene from the promoter to the $3^{\prime}$-end regions (Figure 2, B, right, and D; Calvo and Manley, 2005; Sikorski et al., 2011). Curiously, we observed that after 6AU treatment, Sub1-HA association with the IMD2 promoter increased (Figure 2B, left; note that the graphs are presented on a

Sub1 in noninduced conditions, transcription from the downstream start site may be preferred, resulting in constitutive IMD2 expression. This explains why sub1 $1 \Delta$ cells are resistant to MPA or 6AU treatment in solid media (Koyama et al., 2008; Garcia et al., 2010). However, we observed that sub1 $1 \Delta$ cells have reduced growth in liquid media containing 6AU and that the SUB1 deletion conferred high sensitivity to 6AU when combined with two bur1 mutations (Garcia et al., 2010). These data suggest that Sub1 could also have a role during transcription elongation. Indeed, recently it was shown that Rpb1 mutations in the trigger loop cause sensitivity or resistance to MPA, which correlates with a shift to upstream or downstream IMD2 start sites and with increased or reduced elongation rates, respectively (Kaplan et al., 2012).

Therefore we first decided to analyze IMD2 expression in wt and sub1 $\Delta$ cells in the presence or absence of 6AU. As shown in Figure 2A (left), IMD2 expression increased by more than 10-fold in sub1 $1 \Delta$ cells compared with wt cells in normal growth conditions. When cells were treated with 6AU, IMD2 mRNA levels increased significantly in wt cells as expected but did not further increase in sub1D cells (Figure 2A, left). This is more evident when we calculated the $+6 \mathrm{AU} /-6 \mathrm{AU}$ ratios (Figure 2A, right). Then, this result indicates that Sub1 effect on IMD2 expression is epistatic to 6AU activation. In addition, the lack of further activation of IMD2 by 6AU in sub1 $\Delta$ cells is in agreement with the fact that these cells are sensitive to 6AU when grown in liquid media and that the SUB1 deletion enhanced the 6AU sensitivity of bur1 mutants (Garcia et al., 2010). However, logarithmic scale), whereas its association with the PMA1 promoter decreased (Figure 2B, right). In addition, we detected an increase in the association of Sub1-HA with IMD2 coding and the $3^{\prime}$-end regions of $\sim 4$ and 6.5 times, respectively, above the background levels in the noninduced conditions (Figure 2B, left) and a decrease in the association with the PMA $15^{\prime}$-coding regions (Figure $2 \mathrm{~B}$, right).

We also analyzed the association of TFIIB (Sua7) with chromatin as a negative control (Figure $2 \mathrm{C}$ ) because TFIIB is a well-characterized PIC component with no role in transcription elongation and close genetic and functional connections with Sub1 (Knaus et al., 1996; Wu et al., 1999; Rosonina et al., 2009). For this purpose, we used a TFIIB-MYC strain for ChIP assays. As expected, TFIIB only associates efficiently with the IMD2 promoter region regardless of 6AU treatment, although a slight increase in TFIIB association above background was observed at the 3 '-end after induction, possibly due to its role in gene looping (Singh and Hampsey, 2007). In the case of the PMA1 gene, both Sub1 and TFIIB associate with the promoter, but only Sub1 shows an association that is significantly above background with coding regions (Figure 2D). These results provide strong evidence that Sub1 plays a role in IMD2 transcription elongation under induction conditions and may also have a role during transcription elongation of the constitutive PMA1 gene.

We next analyzed Sub1 association with the long transcription unit of the YLR454 gene (8 kb), which is expressed under the control of the GAL1 promoter (Mason and Struhl, 2005). The purpose of this experiment was to provide evidence that the signal over the 
A

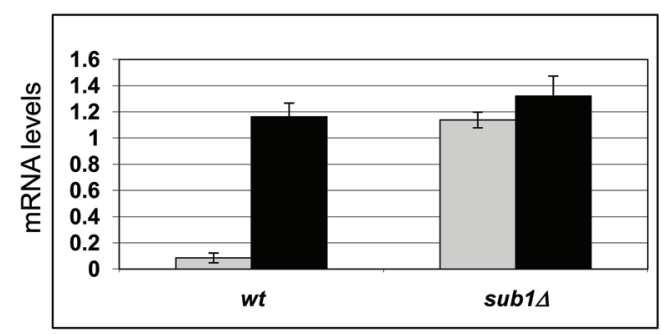

$\square-6 \mathrm{AU} \square+6 \mathrm{AU}$

\section{RT-qPCR}

B

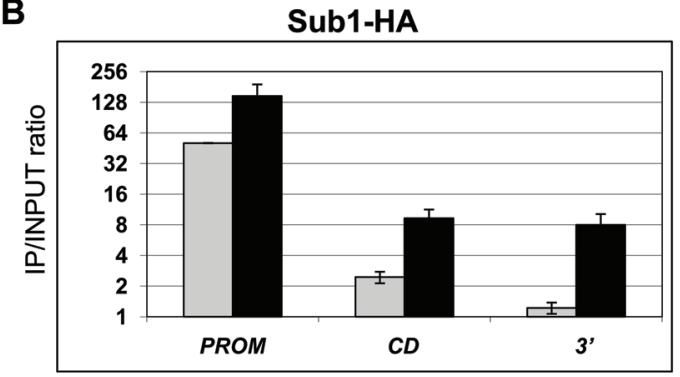

$\square-6 \mathrm{AU} \quad+6 \mathrm{AU}$

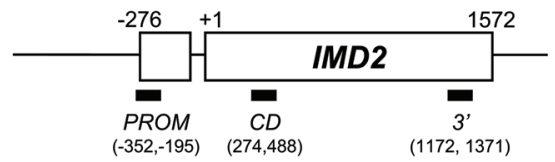

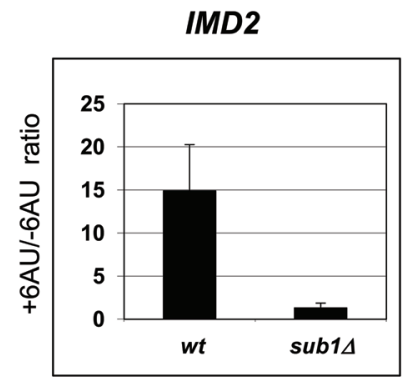

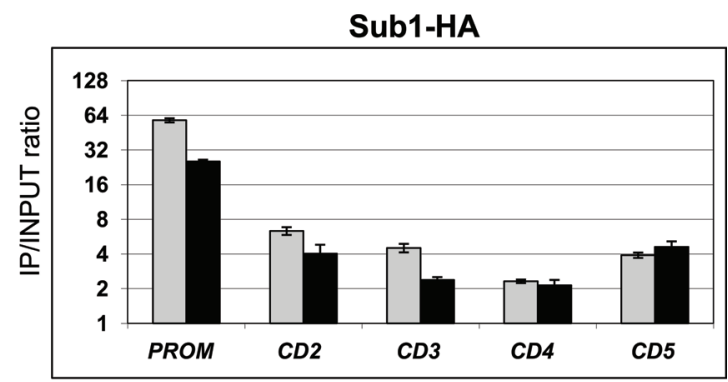

$\square-6 \mathrm{AU} \quad \square+6 \mathrm{AU}$

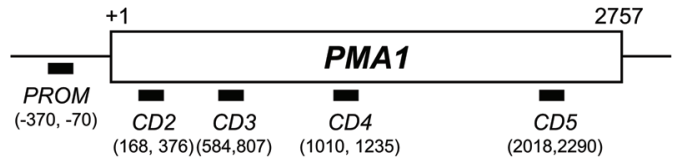

Chromatin IP

C

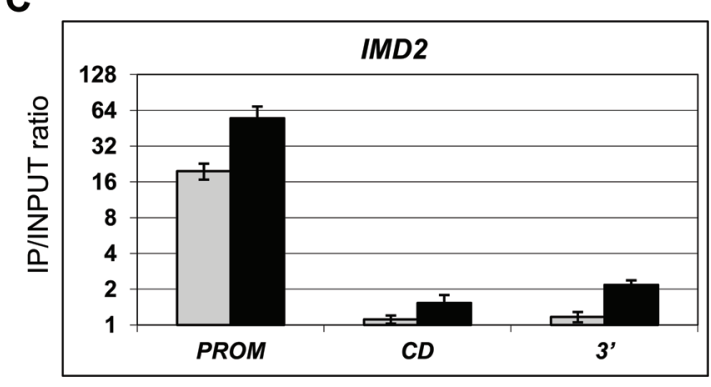

$\square-6 \mathrm{AU} \square+6 \mathrm{AU}$
D

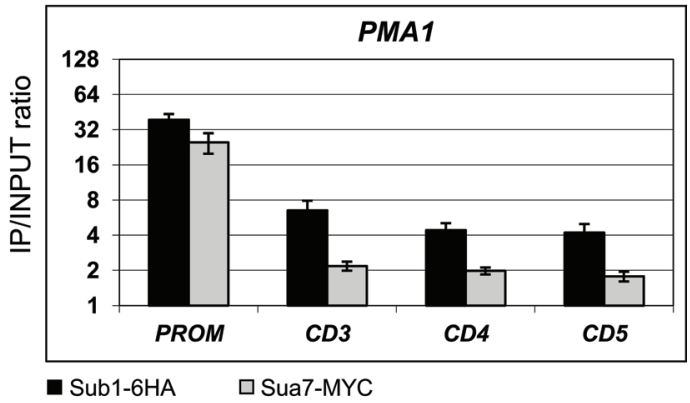

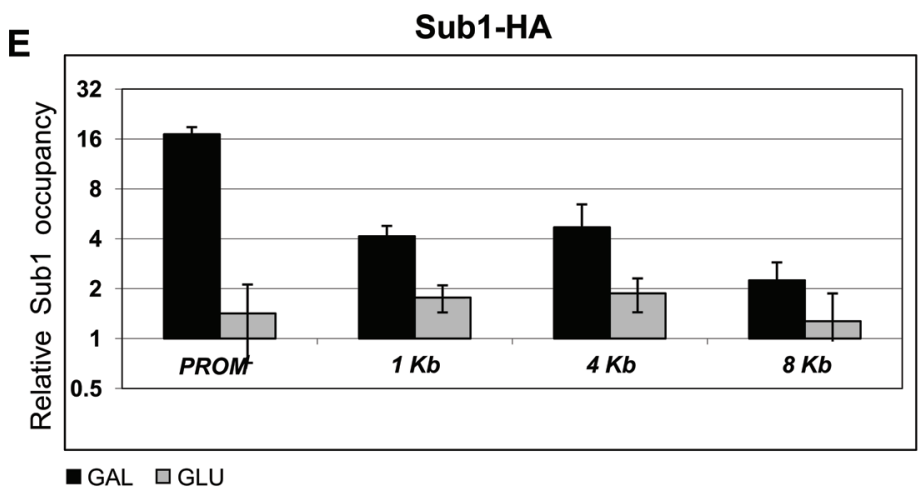

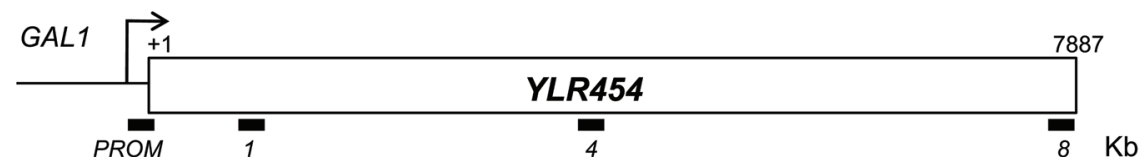


$\mathbf{F}$

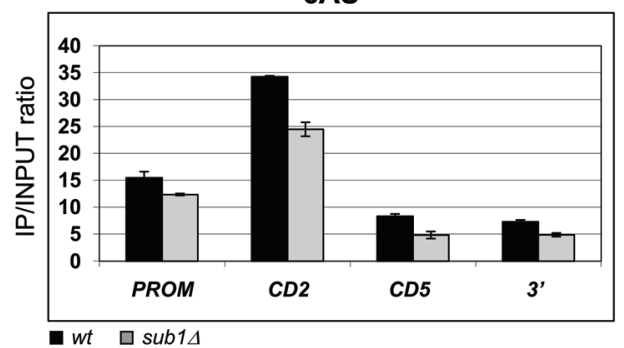

Rpb1

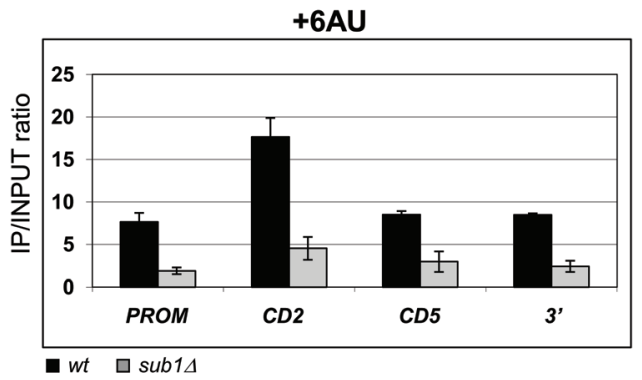

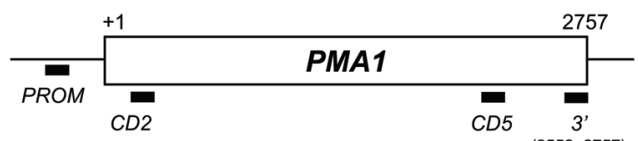

G

$-6 A U$

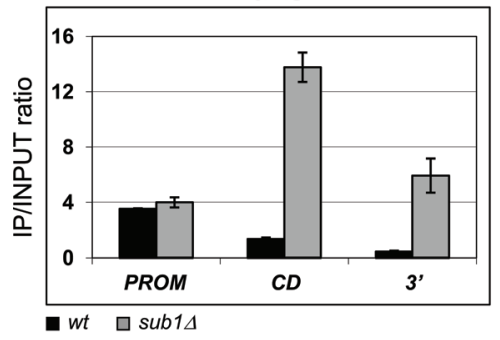

$+6 \mathrm{AU}$
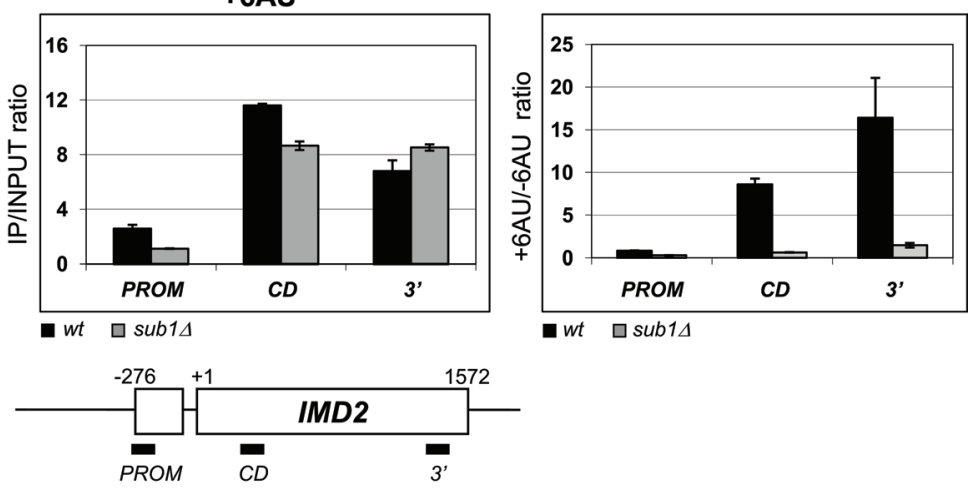

wt $\square$ sub14

Chromatin IP

FIGURE 2: Sub1 promotes transcription elongation, associates with coding regions, and influences Rpb1 association to chromatin during transcription elongation. (A) RT-qPCR analysis of the IMD2 gene. Total RNA was isolated from wt and sub1 $1 \Delta$ cells grown in SC-URA with or without $50 \mu \mathrm{g} / \mathrm{ml}$ 6AU. cDNA synthesis was performed and coupled with qPCR. IMD2 expression values were normalized to the 18S rRNA values and graphed. The relative levels of the IMD2 mRNA in sub1 $\Delta$ vs. wt cells are shown. (B) ChIP analysis of Sub1-HA was performed in the wt strain using an anti-HA antibody. Cross-linking to the IMD2 (left) and PMA1 (right) promoter and coding regions in the presence or absence of $100 \mu \mathrm{g} / \mathrm{ml}$ of 6AU was analyzed by qPCR. Quantifications of the results are shown in the graph, where the numbers on the $y$-axis represent the ratio of the values obtained from specific primer products to the negative control (intergenic region of chromosome VII) and normalized to the input controls. A schematic representation of the IMD2 and PMA1 genes is shown below the corresponding graph; the PCR primers pairs corresponding to the promoter and coding regions at the specified positions are indicated. In the case of the IMD2 gene, the upstream white box represents the promoter transcribed region leading to short, noncoding transcripts (Jenks et al., 2008). (C) ChIP assay to analyze the Sua7-MYC association with the IMD2 gene as in B. (D) ChIP analysis of the Sub1-HA and Sua7-MYC association with the PMA1 gene. (E) Sub1-HA occupancy during galactose induction and after $4 \mathrm{~min}$ of glucose treatment. A schematic representation of the GAL1-YLR454 gene; the PCR primers pairs corresponding to the promoter and coding regions at the specified positions are indicated. (F) Rpb1 occupancy at the promoter and coding regions of the PMA1 gene was assayed by ChIP in wt and sub1 $1 \Delta$ cells in the presence or absence of $100 \mu \mathrm{g} / \mathrm{ml}$ of 6AU with the 8 WG16 antibody. Real-time qPCR quantifications were graphed as described. (G) Rpb1 occupancy at the promoter (left) and coding (middle) regions of the IMD2 gene assayed as in F. Right, the +6AU/-6AU ratio. Rpb1 cross-linking to promoter and coding regions was independently quantified in wt and sub1 $1 \Delta$ cells, and the $+6 \mathrm{AU} /-6 \mathrm{AU}$ ratio was then calculated and graphed.

genes is meaningful and not due to a decrease in the strong promoter signal over distance as a consequence of the average chromatin shearing ( -300 base pairs). In addition, by analysis of the Sub1 association with a long gene, the coding region signal can be separated from a promoter signal due to any tandem-oriented downstream gene near the $3^{\prime}$-end region. As shown in Figure 2E, Sub1-HA associates with coding regions during galactose induction and disassociates after glucose-mediated transcriptional repression. The Sub1 association with chromatin remains significant as far as $4 \mathrm{~kb}$ downstream from the promoter, whereas its association with the most 3 '-end is slightly above background. It is worth noting that most yeast genes are $\sim 1.5-2 \mathrm{~kb}$ long, and genes as long as YLR454 are rarely found in S. cerevisiae. Nonetheless, this result provides further evidence that Sub1 associates with at least the coding regions of average size and even longer genes (e.g., $P M A 1)$ in $S$. cerevisiae and further supports the hypothesis that Sub1 may have a role during transcription elongation.

We also investigated whether Sub1 has a role in transcription elongation by analyzing Rpb1 occupancy from the promoter to 3'end regions of the IMD2 and PMA1 genes in both wt and sub1D cells in the presence or absence of 6AU. We (Calvo and Manley, 2005; Garcia et al., 2010) and others (Rosonina et al., 2009; Sikorski et al., 2011) have already reported that there is decreased association of RNAPII with the chromatin of constitutively transcribed genes 
in the promoter and coding regions in cells lacking Sub1. Here we extended our study to the IMD2 gene, regulated by guanine nucleotide levels. In agreement with our previous data, we observed a reduction in the association of Rpb1 with the PMA1 gene in sub1 $1 \Delta$ cells compared with wt cells when grown under normal conditions, and this reduction was further enhanced with 6AU treatment (Figure 2F). Rpb1 association with the coding and $3^{\prime}$-end regions of the IMD2 gene was undetectable in wt cells, as expected, in accordance with IMD2 repression in normal growth conditions (Figure 2G, left). However, after 6AU treatment, Rpb1 was efficiently recruited to IMD2 coding regions. The opposite was observed when we analyzed Rpb1 association with the IMD2 gene in sub1 $1 \Delta$ cells (Figure $2 \mathrm{G}$, middle). That is, an increase of Rpb1 association with the coding regions of IMD2 in noninduced conditions and a reduction after induction was observed. However, this reduction is not further enhanced at the $3^{\prime}$-end regions. In any case, the Rpb1 ChIP data completely paralleled the IMD2 expression levels (Figure 2A) because there was a decrease in the association of Rpb1 with the IMD2 gene along with a reduction of IMD2 mRNA after 6AU treatment in sub1D cells compared with wt cells. In fact, when we calculated the $+6 \mathrm{AU} /-6 \mathrm{AU}$ ratio of Rpb1 association (Figure $2 \mathrm{G}$, right), we clearly observed a dramatic reduction along the entire gene in sub1 $1 \Delta$ cells compared with wt cells.

In summary, our results indicate that the reduction in nucleotide levels after 6AU treatment causes transcription elongation to become more dependent on the presence of Sub1. This is supported by the fact that Sub1-HA associates with the IMD2 coding regions during transcription elongation and the fact that Rpb1 association to chromatin is reduced in sub1 $1 \Delta$ cells during transcription elongation after induction. Taken together, our data support the hypothesis that Sub1 influences transcription elongation, although they do not definitively indicate that Sub1 plays a direct role in that process. In fact, as SUB1 deletion affects IMD2 expression, and thus nucleotide levels could be lower in sub1 $\Delta$ cells, suggesting the possibility that the effect of Sub1 on transcription elongation could be indirect through IMD2.

\section{Sub1 influences RNAPII transcription elongation rate}

Mason and Struhl (2005) developed an assay to measure two distinct aspects of the elongation process: the rate of transcription and the processivity of RNAPII. They showed that for RNAPII processivity, mutations on the well-known transcription elongation factors fall into three categories: 1) mutations that reduce RNAPII processivity; 2) mutations that reduce processivity only in the presence of $6 \mathrm{AU}$; and 3) mutations that do not affect processivity. Transcription factors with roles in transcription elongation have subsequently been described (Chanarat et al., 2011; Gonzalez-Aguilera et al., 2011; Kruk et al., 2011). For example, the Ccr4-Not complex belongs to a new category because mutations on the subunits of Crc4-Not cause increased RNAPII processivity and reduced elongation rate (Kruk et al., 2011). Furthermore, a mutation on the Spt5 elongation factor (spt5-242) affects the transcription elongation rate without affecting processivity (Quan and Hartzog, 2010). We used the same assay as Mason and Struhl (2005) to measure the level of RNAPII association with various positions within the $8 \mathrm{~kb}$ of the GAL1-YLR454 fusion gene, inducible by galactose in wt and sub1 $1 \Delta$ cells (Figure 3A). Our data showed that, as in the case of the PMA1 gene, RNAPII levels are decreased from the promoter to the $3^{\prime}$ end in sub1 $1 \Delta$ cells when compared with wt cells (Figure 3B). However, the decrease of Rpb1 density in the $3^{\prime}$-end regions is significantly less pronounced than at the promoter. This finding suggests that the absence of Sub1 does not cause a processivity defect. Next, we analyzed the relative Rpb1 occupancy along the GAL1-YLR454 gene as previously described (Mason and Struhl, 2005) to study RNAPII processivity (Figure 3C). Surprisingly, deletion of SUB1 resulted in either no effect or a slight increase of Rpb1 association downstream of the promoter and along the gene. We then analyzed whether the decrease of Rpb1 density from promoter to $3^{\prime}$-end regions (Figure 3B) was due to the slowed progression of RNAPII across the gene. We analyzed the relative Rpb1 association to chromatin after repressing transcription of the GAL1-YLR454 gene with glucose for 4 min (Mason and Struhl, 2005; Quan and Hartzog, 2010). All regions examined in the sub1 $\Delta$ mutant showed significantly higher RNAPII occupancy than in wt cells (Figure 3D). This result is similar to what was described for the spt5-242 mutation, which affects the elongation rate without affecting processivity (Quan and Hartzog, 2010). These results support the hypothesis that elongation of RNAPII across the gene is impaired in sub1 1 , resulting in more RNAPII association within the body of the gene after the last wave of transcription.

ChIP assays measure the levels of polymerases associated with chromatin during active transcription (Mason and Struhl, 2005). However, ChIP does not specifically distinguish the active, elongation-competent form of the polymerase, for instance, from arrested or paused polymerase (Hirayoshi and Lis, 1999; Rodriguez-Gil et al., 2010). However, the TRO assay enables measurement of the density of actively transcribing RNA polymerases by labeling nascent premRNA (Birse et al., 1998; Hirayoshi and Lis, 1999; Rodriguez-Gil et al., 2010). We therefore used TRO to study the distribution of transcriptionally competent polymerases along the GAL1-YLR454 gene in wt and sub1s cells. We designed 300-base pair probes distributed along the gene (Figure 4A) and performed TRO. A representative slot blot filter and quantification of three independent experiments are shown in Figure 4, B and C, respectively. We observed that active RNAPII is significantly decreased in sub1 $1 \Delta$ cells when compared with wt cells and that this decrease is stronger in the $5^{\prime}$ region of the YLR454 gene (Figure 4B). This result agrees with the ChIP experiments (Figure 3B). However, when we analyzed the relative levels of active RNAPII along the gene with respect to the $5^{\prime}$ region (ATG; Figure 4 C), we observed a significant reduction of active polymerase in sub1 $1 \Delta$ cells. This result indicates that the higher occupancy of Rpb1 along the GAL1-YLR454 gene observed by ChIP in the absence of Sub1 (Figure 3D) corresponds to inactive, arrested polymerases that most likely cannot efficiently resume transcription. Taken together, the data presented here show that Sub1 influences transcription elongation.

\section{Sub1 is genetically linked to the Spt4/Spt5 elongation complex}

We just showed that SUB1 deletion causes transcription elongation rate defects similar to those displayed by the spt5-242 mutant (Quan and Hartzog, 2010). In addition, our previous work showed a functional connection between Sub1 and the CTD-elongation kinase Bur1 (Calvo and Manley, 2005; Garcia et al., 2010). We then decided to investigate whether Sub1 is genetically and functionally linked to the essential elongation factor Spt5, which is also phosphorylated by Bur1 (Liu et al., 2009; Zhou et al., 2009). Spt5 associates with Spt4, and the Spt4/5 complex is required for efficient elongation by RNAPII (Hartzog et al., 1998; Wada et al., 1998). We first performed genetic studies using two spt5 mutants—spt5-194 and spt5-242which impair RNAPII transcription elongation: spt5-194 grows slowly at $37^{\circ} \mathrm{C}$ and has very moderate sensitivity to $6 \mathrm{AU}$, whereas spt5-242 is cold sensitive and not sensitive to 6AU (Winston et al., 1984; Swanson et al., 1991; Swanson and Winston, 1992; Hartzog et al., 1996, 1998). In contrast, sub1s cells grow normally and are not 


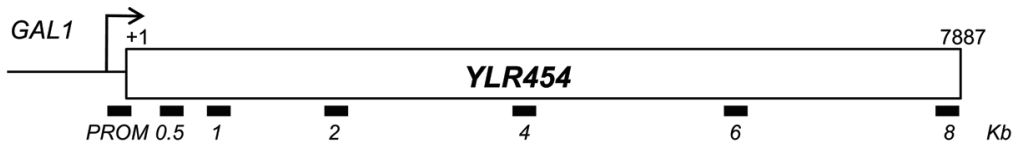

B

Rpb1

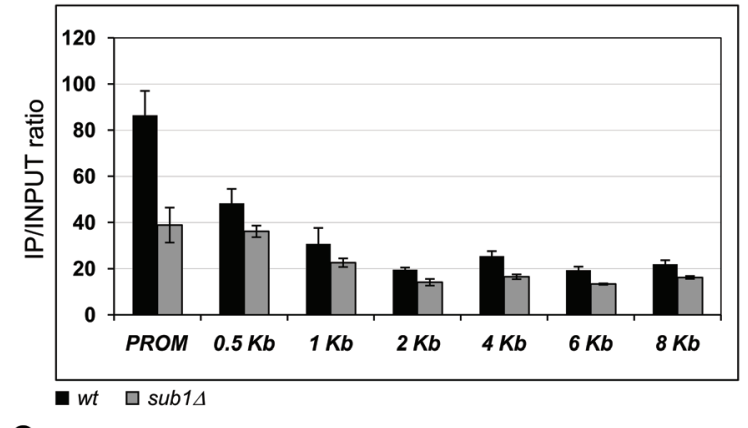

C
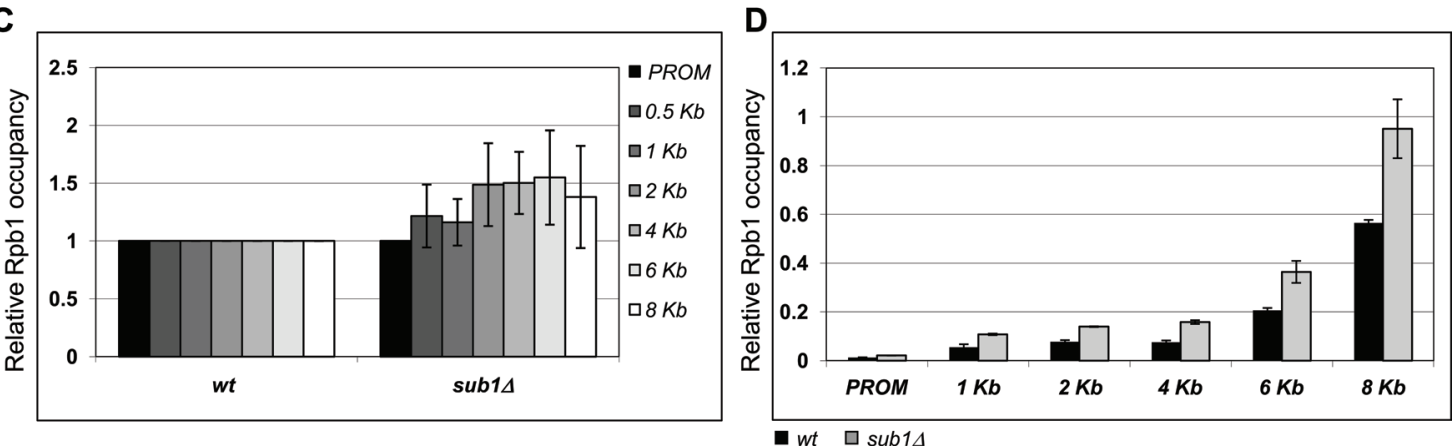

FIGURE 3: Deletion of SUB1 leads to transcription elongation rate defects. (A) A schematic representation of the GAL1-YLR454 gene. PCR primer pairs corresponding to the promoter and coding region at the specified positions are indicated. (B) Total Rpb1 occupancy at the promoter and coding regions of the GAL1-YLR454 gene was assayed by ChIP, using 8WG16 antibody in wt and sub1 $\Delta$ galactose-induced cells. Quantifications of qPCR were graphed as described in Figure 2. (C) Measurement of RNAPII processivity. Relative Rpb1 occupancy at the GAL1-YLR454 gene in $w t$ and sub1 $\Delta$ cells at the indicated positions after inducing conditions. The qPCR values were first normalized to the values at the promoter $(P)$ and then with respect to the wt cells values, taken as 1, for each probe as previously described (Mason and Struhl, 2005). (D) Measurement of the elongation rate as described in Mason and Struhl (2005). Relative Rpb1 occupancy of galactose-induced cells in wt and sub1 1 cells along the GAL1-YLR454 gene after 4 min of glucose treatment (glucose/galactose ratio). Increased association of RNAPII with the coding region in the sub1 $\Delta$ cells results in reduced polymerase dissociation after the last wave of transcription, leading to an elongation rate defect.

sensitive to 6AU in solid media (Figure 5, A and C; Garcia et al.,

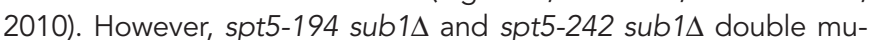
tants both have increased temperature-sensitive growth defects at 37 and $28^{\circ} \mathrm{C}$, respectively, and are highly sensitive to 6AU (Figure $5 A)$. Overexpression of SUB1 suppresses the growth defects of the spt5-194 mutant (Figure 5B), although not entirely. In fact, overexpression of SUB1 in wt cells causes a slight growth defect, as already reported (Calvo and Manley, 2001). Subsequently, we also tested whether Sub1 is genetically linked to Spt4. As shown in Figure 5C, combining the SUB1 deletion with the temperature-sensitive mutant spt4 $\Delta$ results in a very strong synthetic growth defect and extreme 6AU sensitivity. Therefore Sub1 is genetically linked to both Spt4 and Spt5, suggesting that Sub1 might be functionally linked to the Spt4/Spt5 elongation complex.

\section{Deletion of SUB1 enhances Spt5 phosphorylation by Bur1 but not its recruitment to chromatin}

We next tested whether Sub1 affects Spt5 phosphorylation by Bur1, because it has been shown that Bur1 phosphorylates the carboxyterminal domain of Spt5, thereby stimulating the recruitment of PAF (Liu et al., 2009) and histone-modifying proteins (Zhou et al., 2009) to the elongation complex. HA-Bur1-containing complexes were immunoprecipitated (IPed) from wt and sub1 $1 \Delta$ whole-cell extracts prepared from cells expressing HA-Bur1 via the HA epitope tag. IP products were subjected to an in vitro IP kinase assay, with or without the addition of ATP (Garcia et al., 2010), using a recombinant hexahistidine (6HIS)-Spt5 protein (rSpt5; Liu et al., 2009) as the substrate. Immunoblotting with the phosphospecific anti-Spt5-P antibody (Liu et al., 2009; Figure 6A, top) and an antibody that recognizes the Nterminal region of Spt5 (Figure 6A, bottom) showed that Bur1 activity was higher in sub1 $\Delta$ than in wt cells. As a control, equivalent IP of Bur1-HA was confirmed by Western blot using an anti-HA antibody (Figure 6A, right). To extend these results, we performed an in vitro kinase assay as a positive control for Bur1-HA kinase activity. We tested the ability of Bur1-HA IPed from wt and sub1 $1 \Delta$ strains and Bur1-23-HA (with reduced kinase activity) IPed from bur1-23 cells (Keogh et al., 2003) to phosphorylate the glutathione S-transferase (GST)-CTD fusion protein on Ser-5. As shown in Figure 6B, Bur1-HA IPed from wt and sub1 $1 \Delta$ cell extracts was fully active because it efficiently phosphorylated GST-CTD as determined by immunoblotting. In addition, Bur1 activity was greater in sub1 $1 \Delta$ cell extracts than in wt cells, as previously reported (Garcia et al., 2010), and there was also a significant reduction in the phosphorylation of GST-CTD in the bur123 cell extracts, which is in agreement with previous work (Keogh 


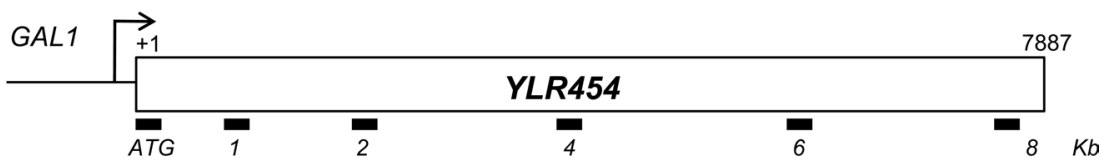

B

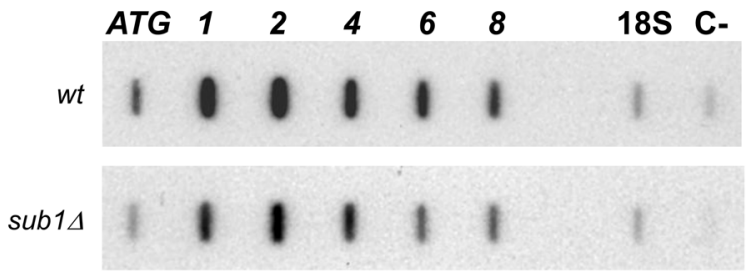

C

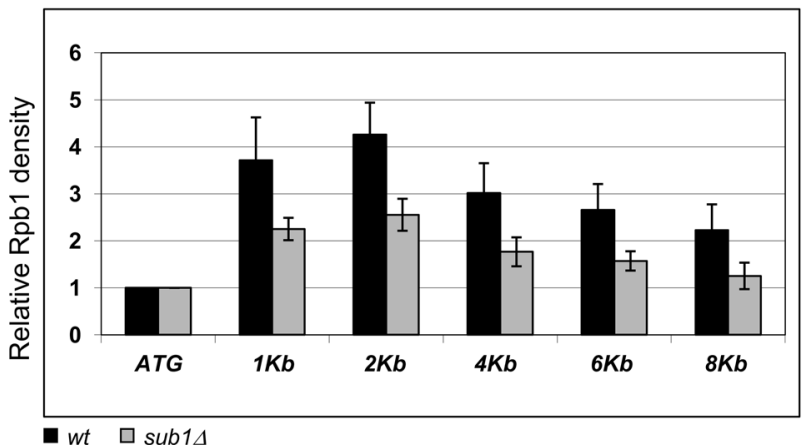

FIGURE 4: Active elongation-competent RNAPII is decreased in sub1 cells. (A) Diagram of the GAL1-YLR454 gene. Locations of the probes used in the TRO analysis are indicated. (B) TRO of wt and sub1 $1 \Delta$ cells growing in galactose-containing medium. (C) Quantitation of blot hybridizations. Hybridization signals were quantitated by Phosphorlmager analysis. The bacteria DNA background signal (C-) was subtracted from each probe, and, after normalization for $18 \mathrm{~S}$ rRNA signal, the results were normalized to the ATG probe, which was fixed at 1. of the tested genes (unpublished data). Taken together, our data support the idea that Sub1 associates with the transcription complex and modulates the phosphorylation of the CTDs of Rpb1 (Garcia et al., 2010) and Spt5.

The exact mechanisms by which Sub1 influences Bur1 kinase activity remain unknown. One possibility is that the effects of Sub1 on Bur1 activity may be indirect, through Kin28, because SUB1 deletion increases Kin28 recruitment and activity (Garcia et al., 2010) and Kin28 promotes Bur1 kinase recruitment and Spt5 phosphorylation (Qiu et al., 2009, 2012). Another possibility is through replication protein RPA, because both Sub1 and Bur1 have been genetically and functionally linked to RPA. The Bur1/2 complex interacts with RPA and maintains genome stability during replication stress (Clausing et al., 2010). In contrast, the Rfa1 subunit of RPA seems to compete with Sub1 for chromatin binding to promoter regions (Sikorski et al., 2011). Indeed, Rfa1 is able to associate with promoter regions during active transcription only in the absence of Sub1. The increased Rfa1 association in sub1 $1 \Delta$ cells could then enhance Bur1 recruitment (because they both directly interact) and therefore kinase activity. However, Bur1 recruitment is not altered when Sub1 is lacking (Garcia et al., 2010). Nevertheless, we cannot rule out that Sub1 may indirectly influence Bur1 kinase activity during transcription elongation through Rfa1. et al., 2003). Taken together, these results show that Sub1 negatively influences Bur1 kinase activity toward the CTDs of both Spt5 and RNAPII (Figure 6, A and B; Garcia et al., 2010).

In light of the forgoing results, we next tested the extent of Bur1HA-specific kinase activity on the CTD of Spt5 in our assays using extracts from wt and sub1 $1 \Delta$ strains expressing another kinase, such as Ctk1-HA (Garcia et al., 2010). In addition, we also tested the activity of the Bur1-23-HA mutant kinase with rSpt5. As shown in Figure 6C, only wild-type Bur1-HA (from wt and sub1 $1 \Delta$ cell extracts) was able to phosphorylate the Spt5 CTD efficiently, which is consistent with previous work (Zhou et al., 2009), and Spt5 phosphorylation was greater in the absence of Sub1.

We next determined whether Sub1 also affects Spt5 recruitment to gene promoters. Genome-wide occupancy profiles for yeast transcription factors showed that elongation factors are recruited to the transcriptional machinery during a $5^{\prime}$ transition that occurs $\sim 150$ nucleotides downstream of the transcription start site (Mayer et al., 2010). We therefore analyzed the recruitment of Spt5 to the $5^{\prime}$ coding region of several constitutively transcribed genes $(A D H 1$, PYK 1, PMA1, and PDR5) between +150 to +400 nucleotides downstream of the transcription start site in the presence or absence of Sub1. For this purpose, we performed ChIP coupled with qPCR using wt and sub1 $1 \Delta$ cells expressing Spt5-FLAG. As shown in Figure 6D, the SUB1 deletion did not affect the association of Spt5 with the $5^{\prime}$ coding region of the genes tested. We obtained the same result when we analyzed the association of Spt5 to the middle and $3^{\prime}$-end

\section{SUB1 deletion suppresses the splicing defect of a spt5-194 mutation}

It has been shown that the transcription elongation rate influences splicing (de la Mata et al., 2003; Howe et al., 2003; Shukla and Oberdoerffer, 2012). Thus RNAPII mutants that slow transcription or cells treated with MPA and 6AU display increased exon inclusion (Howe et al., 2003). Because Sub1 influences the transcription elongation rate, we decided to test whether SUB1 deletion also affects splicing.

Spt5 has been implicated in pre-mRNA processing because unspliced pre-mRNAs accumulate in spt5 mutants (Lindstrom et al., 2003; Xiao et al., 2005). Therefore we analyzed splicing of the RPL26

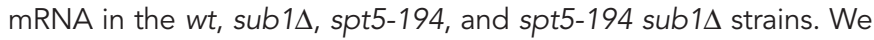
isolated RNA from all four strains and performed RT-PCR to analyze the levels of the unspliced and mature RPL26A mRNA (Figure 6E; Lindstrom et al., 2003). We also analyzed the expression of PYK1, which does not contain introns. As shown in Figure 6E, the levels of mature and unspliced RPL26 pre-mRNA were similar in wt and sub1 $1 \Delta$ cells. However, there was a large increase in the level of unspliced RPL26 pre-mRNA in the spt5-194 mutant, which is consistent with previous work (Lindstrom et al., 2003). Of interest, when the SUB1 deletion was combined with the spt5-194 mutation, there was a significant reduction in the accumulation of unspliced RPL26. This result is consistent with a reduction of the transcription elongation rate in sub1 $\Delta$ cells (Figure 3 ) and in agreement with the fact that elongation rates influences splicing (de la Mata et al., 2003; Howe 
A
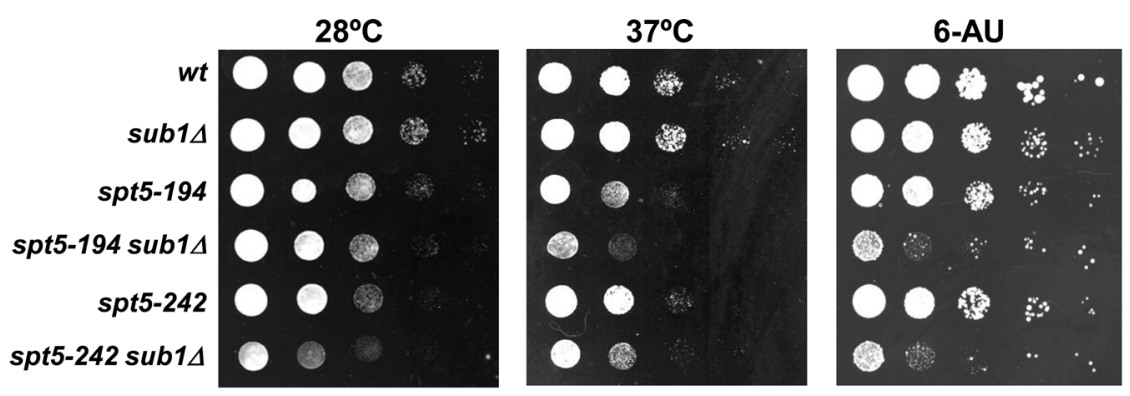

$75 \mu \mathrm{g} / \mathrm{ml}$
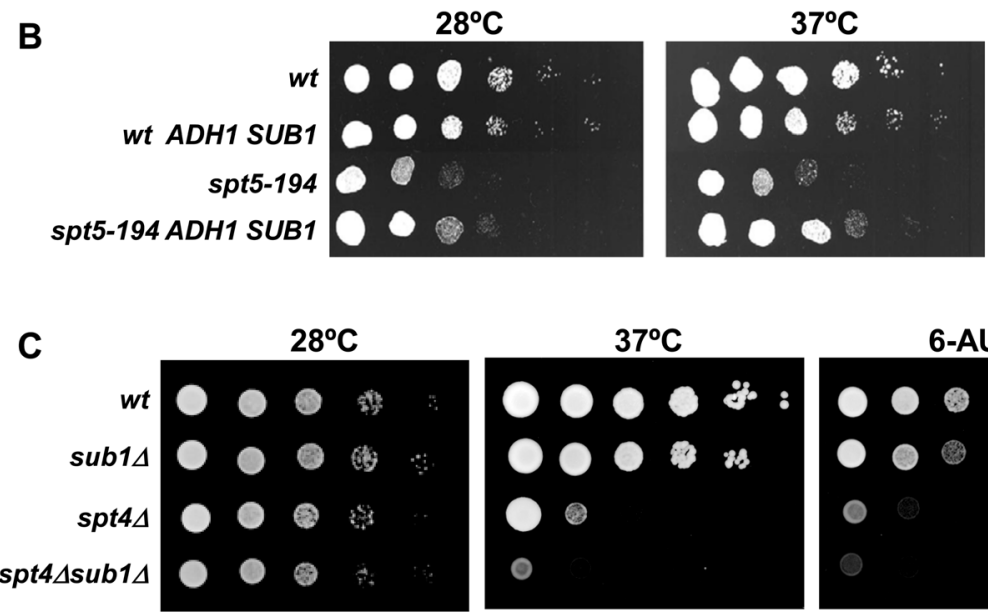

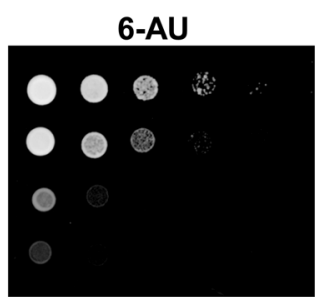

$25 \mu \mathrm{g} / \mathrm{ml}$

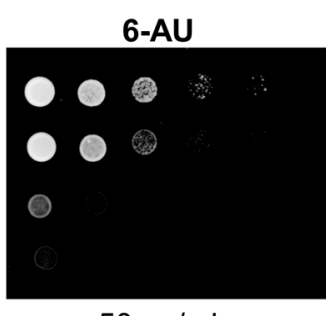

$50 \mu \mathrm{g} / \mathrm{ml}$

FIGURE 5: Sub1 is genetically linked to Spt5. Genetic interaction between SUB1, SPT5, and SPT4. (A) SUB1 deletion enhances the growth defects of spt5-194 and spt5-242 and causes 6AU sensitivity to them, and (B) overexpression of SUB1 suppresses spt5-194 growth phenotypes. To overexpress SUB1, its open reading frame was cloned under the control of the ADH1 promoter (ADH1SUB1). (C) SUB1 deletion enhances the growth thermosensitivity and 6AU sensitivity of spt $4 \Delta$ mutant. Yeast strains with the indicated genotypes were spotted onto SC-URA and SC-URA media with 75,50 , or $25 \mu \mathrm{g} / \mathrm{ml}$ of $6 \mathrm{AU}$ and grown at 28 or $37^{\circ} \mathrm{C}$ for $2-3 \mathrm{~d}$.

et al., 2003). Similarly, N. Krogan and colleagues (personal communication) observed that slow RNAPII mutations or SUB1 deletion enhance splicing.

\section{Sub1 and Spt5 copurify early during transcription elongation}

Lindstrom et al. (2003) affinity purified Spt5-FLAG from yeast extracts and used mass spectrometry to identify a large number of proteins involved in transcription and pre-mRNA processing, including Sub1. Nevertheless, the copurification of these two proteins was not further confirmed. Therefore we performed a tandem affinity purification (TAP) assay to investigate whether Spt5 copurified with Sub1-TAP and subsequently confirmed our results by colP. We first purified Sub1-TAP from yeast extracts (Rodriguez-Navarro et al., 2004), and we used an isogenic strain lacking the TAP tag (mock) as a control for nonspecific purification. Purified samples from both strains (Sub1-TAP and mock) were analyzed with a polyclonal anti-Spt5 antibody (Figure 7A). In accordance with previous work (Lindstrom et al., 2003), Spt5 associated with Sub1-TAP, indicating that Sub1 and Spt5 might be part of the same complex. We also confirmed the copurification by IP experiments. We performed an anti-HA IP assay using whole-cell extracts from the Sub1-HA and the double-tagged Sub1-HA/Spt5-FLAG strains. We used the Spt5FLAG strain as a negative control for the anti-HA IP. As expected, Sub1 was efficiently IPed from the Sub1-HA and Sub1-HA/Spt5FLAG cell extracts (anti-HA immunodetection in Figure 7B, bottom, lanes 2 and 3, respectively). We immunoblotted the same membrane with anti-FLAG antibody and only a fraction of Spt5-FLAG colPed with Sub1-HA, as shown in Figure 7B (middle, lane 3). Then, It is possible that Sub1 associates with Spt5 in a transient manner. Consistent with this hypothesis, when we analyzed the association of Spt5-FLAG and Sub1-HA with the chromatin of several actively transcribed genes ( $P Y K 1$ in Figure $7 C$ and $A D H 1, P G K 1, P M A 1$ and YEF3 in Supplemental Figure S1) we observed an increase in the association of Sub1-HA with the promoter regions, which rapidly declined downstream of the promoters but was maintained at a lower level throughout the $3^{\prime}$ end of the genes (Figure 7C; Nedea et al., 2003; Rosonina et al., 2009; Sikorski et al., 2011). In contrast, the association of Spt5-FLAG with the middle and 3' regions of the open reading frames increased (Figure $7 \mathrm{C}$ and Supplemental Figure S1; see Mayer et al., 2010). Thus there is a small region, -150-400 nucleotides downstream of the transcription start site (Figure 7C), where Spt5 and Sub1 might directly or indirectly interact as part of the same complex during early elongation. Alternatively, Sub1 might be less efficiently detected by ChIP in coding regions due to conformational changes occurring in the elongation apparatus that weaken the ability of Sub1 to bind to DNA but permit interaction with the Spt4/Spt5 complex (see Discussion).

\section{Deletion of SUB1 affects Spt5-Rpb1 interaction}

Several lines of evidence suggested that Spt4/5 association with Rpb1 could be altered in sub1 $\Delta$. First, there is genetic interaction of 
A

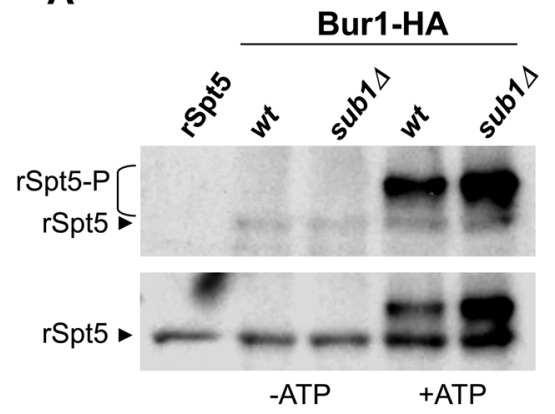

Kinase assay

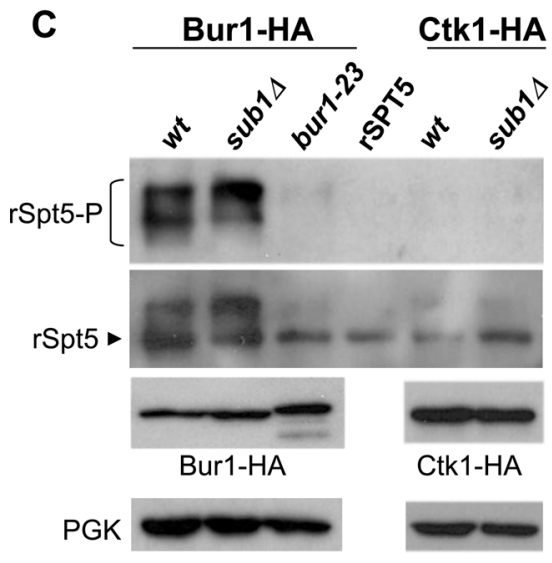

Kinase assay
B

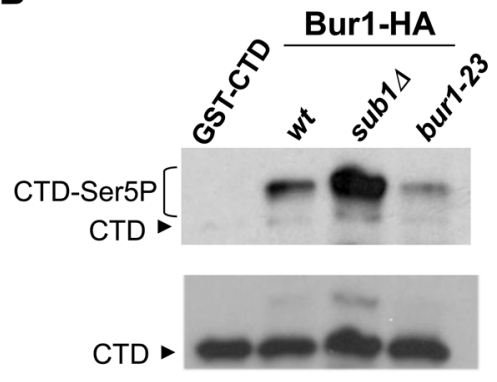

Kinase assay

D

Spt5-Flag

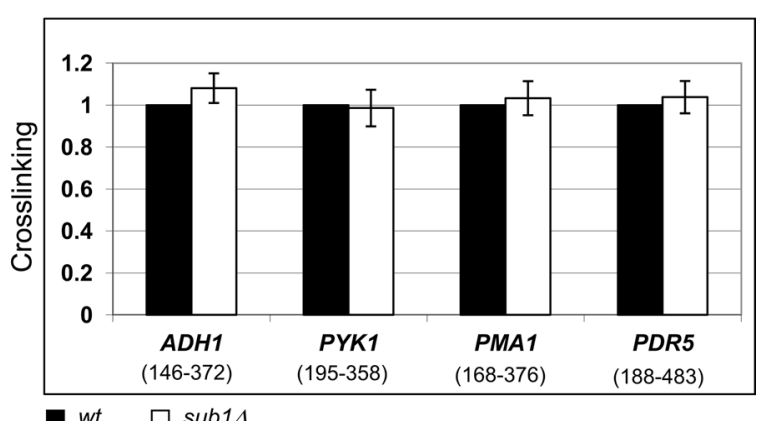

Chromatin IP

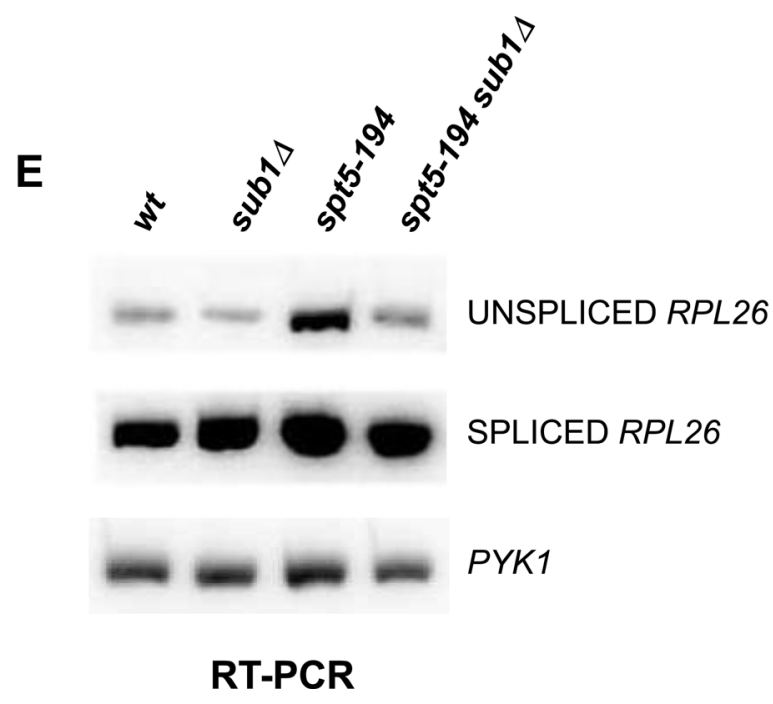

FIGURE 6: Deletion of SUB1 enhances Spt5 phosphorylation by Bur 1 but not its recruitment to the $5^{\prime}$ regions of genes. (A) In vitro kinase assay. WCEs were prepared from wt and sub1 $1 \Delta$ strains expressing HA-tagged Bur1. The HA-tagged kinase complexes were IPed with 12CA5-protein A beads, and kinase activity was assayed using recombinant 6HIS-Spt5 as substrate. SDS-PAGE and immunoblot analysis were performed to analyze Spt5 phosphorylation using the following antibodies: anti-P Spt5 (Liu et al., 2009), anti-Spt5, 12CA5 (anti-HA for Bur1-HA), and anti-PGK (for total protein level control). (B) WCEs were prepared from the Bur1-HA (wt and bur1-23 mutant) and Bur1-HA sub1 $1 \Delta$ strains. In vitro kinase assays were conducted as described but using recombinant GST-CTD as substrate, and CTD Ser-5 phosphorylation was analyzed with the CTD4H8 (anti-CTD Ser5P) and 8WG16 (anti-CTD) antibodies. (C) WCEs were prepared from the wt and sub1 $1 \Delta$ strains expressing HA-tagged Bur1 and Ctk1 and from bur1-23-HA mutant cells. In vitro kinase assays were performed to analyze Spt5 phosphorylation as described. (D) ChIP analyses were performed in the wt and sub1 $1 \Delta$ strains expressing Spt5-FLAG. Spt5 binding to the $5^{\prime}$ region (the nucleotide position relative to the start codon is shown between brackets) of four constitutively expressed genes-ADH1, PYK1, PMA1, and PDR5-was examined by $\mathrm{qPCR}$, 


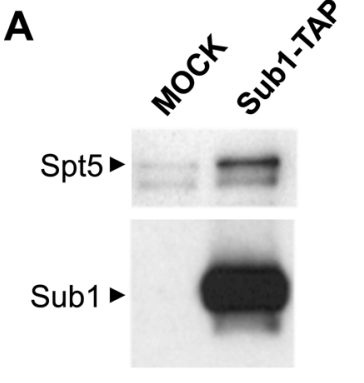

TAP purification

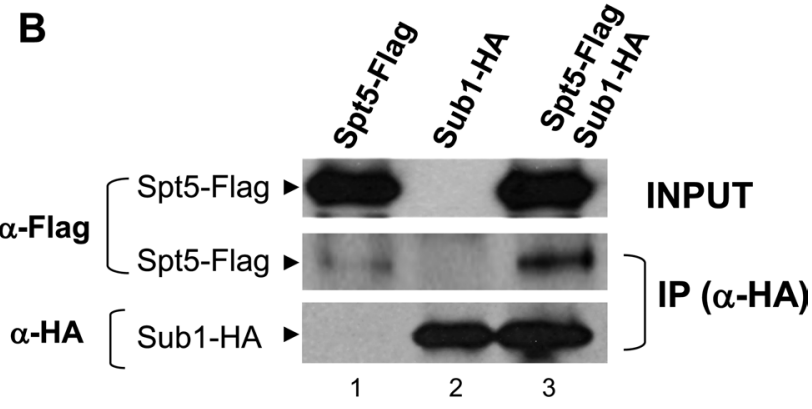

Coimmunoprecipitation
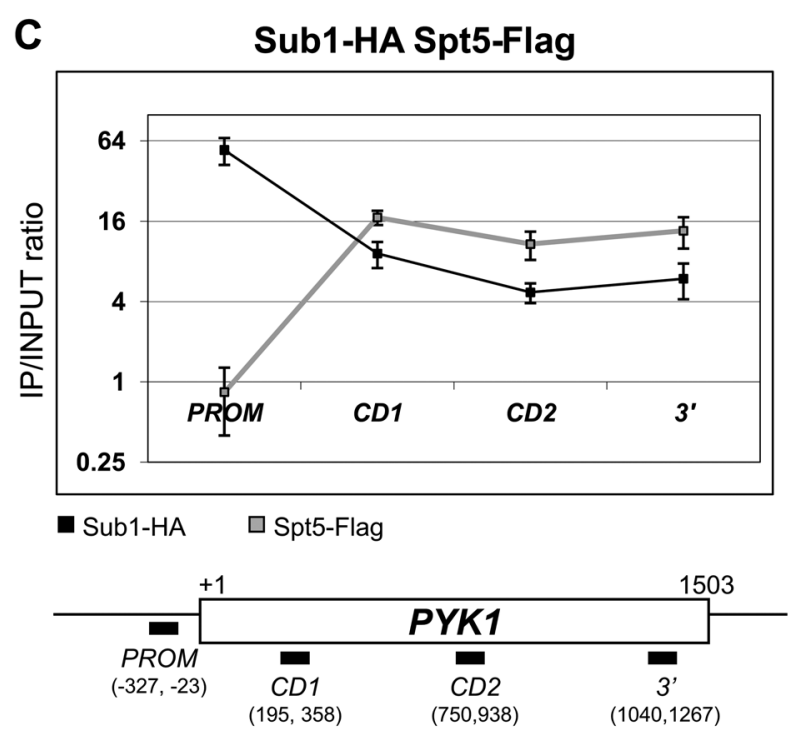

\section{Chromatin IP}

FIGURE 7: Sub1 and Spt5 copurify during early transcription elongation. (A) Spt5 copurifies with Sub1-TAP. Tandem affinity purification was performed with a yeast strain expressing Sub1-TAP, and purified extracts were analyzed by Western blot using a polyclonal anti-Spt5 antibody. An isogenic strain lacking the TAP tag was used as a control for nonspecific purification (mock). (B) Spt5-FLAG coimmunoprecipitates with Sub1-HA. WCEs were prepared from the strains Spt5-FLAG, Sub1-HA, and Sub1-HA/Spt5-FLAG, and anti-HA IPs were carried out. After extensive washing, inputs and IPs were analyzed by Western blotting. The upper and middle membranes were immunoblotted with anti-FLAG and the lower membrane with anti-HA. (C) ChIP analysis of Spt5 and Sub1 was conducted in the double-tagged Spt5-FLAG/Sub1-HA strain using anti-FLAG and anti-HA antibodies, respectively. Spt5-FLAG and Sub1-HA crosslinking to the promoter, coding, and $3^{\prime}$ regions of the PYK1 gene was analyzed by $\mathrm{qPCR}$, and the quantifications of the results are graphed as described in Figure 2. A schematic representation of the PYK1 gene is shown; the numbers indicate the nucleotide position relative to the start codon $(+1)$, and the bars above the genes represent the PCR products analyzed by ChIP.

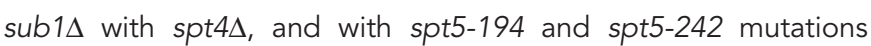
located in the NGN domain (Figure 5). The spt5-194 mutation disrupts Spt4-Spt5 interaction (Guo et al., 2008), and spt5-242

mutation causes elongation rate defects (Quan and Hartzog, 2010). Second, the NGN domain is required to interact with Rpb1 (Klein et al., 2011; Martinez-Rucobo et al., 2011) and overexpression of Sub1 partially suppresses spt5-194 growth defects. Third, the levels of active elongating polymerase are reduced in sub1 $\Delta$ cells (Figure $4, B$ and C). Therefore we decided to investigate the interaction of Spt5 with Rpb1 in wt, sub14, spt5-194, and spt5-194 sub1 $\Delta$ cells expressing Spt5-FLAG proteins. We IPed Spt5-FLAG from whole-cell extracts and analyzed the Rpb1 levels by Western blot analysis. As shown in Figure $8 \mathrm{~A}$ (inputs), the levels of Spt5 protein were unaffected in sub1s and spt5-194 cells when compared with wt cells but were slightly decreased in spt5-194 sub1/ double-mutant cells. This was not due to an effect of SUB1 deletion on SPT5 transcription, as revealed by the RT-PCR experiments (Figure 8B), but it may be an indication that Spt5 is more unstable in the double-mutant cells. When we analyzed the Spt5-FLAG IPs, we observed less Rpb1-Spt5 complex in sub1 $\Delta$ and spt5-194 cells. Furthermore, this defect is significantly enhanced in the case of the spt5-194 sub1s double mutant, in which levels of the Rpb1-Spt5 complex were greatly reduced. To corroborate this result, we next IPed Rpb1 and analyzed the levels of colPed Spt5-FLAG (Figure 8C). Similar levels of Rpb1 were IPed from wt, sub14, spt5-194, and spt5-194sub14 strains. However, slightly less Spt5 associated with Rpb1 in sub1 $\Delta$ compared with wt cells, and in the case of spt5-194 cells, the amount of Spt5 colPed with Rbp1 was significantly reduced. Moreover, this reduction was extraordinarily enhanced in the spt5194 sub1 $1 \Delta$ cells, in which Spt5 was almost undetectable.

Thus our results suggest that Sub1 might help to maintain appropriate levels of Spt5 protein levels, directly or indirectly increasing its stability, and with special significance in the spt5-194 background. This is consistent with the essential nature of Spt5, with the requirement of a functional NGN domain for the Spt5-Rpb1 interaction, and with the fact that overexpression of SUB1 suppresses spt5-194 growth defects. Taken together, our data indicate that Sub1 influences the

and quantifications were graphed (see Materials and Methods). The numbers on the $y$-axis represent the association of Spt5 with the $5^{\prime}$ regions of genes in sub1 $\Delta$ cells relative to wt cells, in which cross-linking is considered 1. (E) RT-PCR analysis of the spliced and unspliced forms of the RPL26 gene. RNA was prepared from wt, sub1 1 , spt5-194, and spt5-194sub1 $\Delta$ cells. Unspliced pre-mRNAs were specifically amplified using one primer from intron sequences and another from the second exon as previously described (Lindstrom et al., 2003). Another pair of primers was used to amplify the spliced RPL26 mRNA. As a loading control, PYK1, which does not contain introns, was also analyzed by RT-PCR. All PCRs were performed using ${ }^{32} \mathrm{P}-\mathrm{dCTP}$, and the PCR products were run on an $8 \%$ polyacrylamide gel. 


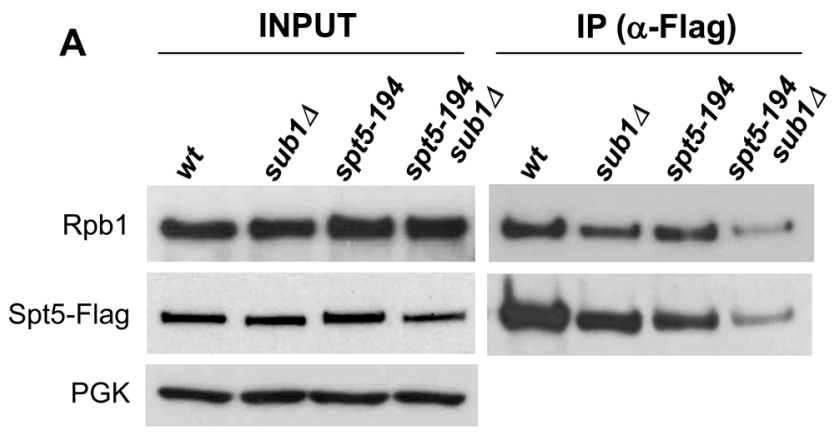

B

\section{Coimmunoprecipitation}

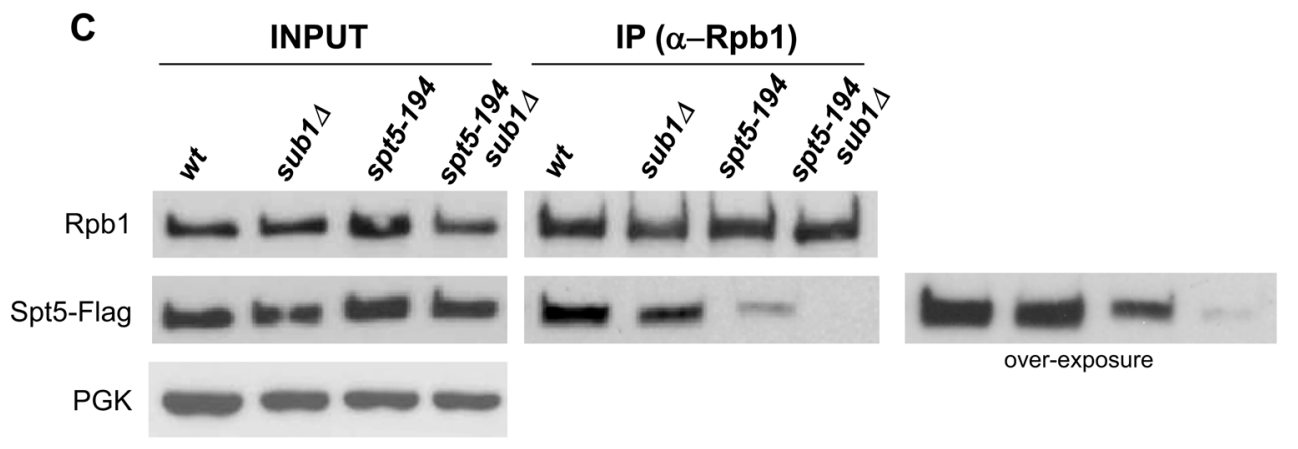

\section{Coimmunoprecipitation}

FIGURE 8: Deletion of SUB1 negatively affects the Spt5-Rpb1 interaction. (A) ColP of Spt5-Rpb1. WCEs of wt, sub1 spt5-194, and spt5-194sub1 $1 \Delta$ expressing the corresponding Spt5-FLAG and Spt5-194-FLAG proteins were used to perform anti-FLAG IPs. Western blots of the inputs and IPs were analyzed with anti-Rpb1 (top), anti-FLAG (middle), and anti-PGK (bottom). The ColP was performed at least three times, and a representative experiment is shown. (B) RT-PCR analysis of the SPT5 gene. 18S rRNA was used as loading control. PCR products were run on an ethidium bromidestained gel. (C) ColP of Spt5-Rpb1 as in A, but the IPs were performed with anti-Rpb1 (8WG16). Western blots of the inputs and IPs were also analyzed using the same antibodies as in A.

interaction of Spt5 with Rpb1, consistent with all our demonstration that Sub1 influences transcription elongation.

\section{DISCUSSION}

Over the past several years, there has been an extraordinary increase in the number of proteins known to influence transcription elongation (Selth et al., 2010). Many of these proteins do not directly affect transcription elongation (Mason and Struhl, 2005), although they possess some of the criteria used to define them as elongation factors. These criteria include the ability to travel with elongating RNAPII and associate in vivo with coding regions in a transcriptiondependent manner (e.g., Krogan et al., 2002; Pokholok et al., 2002; Mason and Struhl, 2003; Kruk et al., 2011). One important characteristic of a transcription elongation defect is the reduced association of RNAPII with transcribed regions from $5^{\prime}$ to $3^{\prime}$ ends, which may be a consequence of a defect in the elongation rate, processivity, or both (Mason and Struhl, 2005; Quan and Hartzog, 2010; Chanarat et al., 2011; Kruk et al., 2011). Here we provided new insight into this process by showing that Sub1, a PIC component, associates with the Spt5 elongation factor and influences transcription elongation rate.

\section{Sub1 affects transcription elongation efficiency and elongation rate}

We presented data showing a reduced elongation efficiency of long transcripts in sub1s cells by the GLAM assay. However, we cannot conclude from this assay alone whether a factor is involved directly in elongation, since mutations in factors involved in premRNA processing also show reduced GLAM ratios (Morillo-Huesca et al., 2006; Gaillard et al., 2009). In addition, ChIP analysis showed that in the sub1 $\Delta$ mutant RNAPII association to chromatin was reduced, although measurement of in vivo processivity showed that the relative RNAPII association with chromatin is not altered or very slightly increased in sub1 $\Delta$ cells. On the other hand, we observed a higher density of RNAPII after the last wave of transcription by ChIP in the absence of Sub1, indicating an elongation rate defect, which results in a decrease of active, competent elongating polymerase measured by TRO. Thus it is possible that the polymerase recruited to the promoter in sub1 $1 \Delta$ cells is slower than in wild-type cells or does not efficiently resume transcription after transient stalling or arrest. Moreover, the role of Sub1 in the transcription elongation rate is further supported by data demonstrating that SUB1 deletion suppresses spt5-194 splicing defects, which is consistent with the fact that elongation rates influence the splicing and selection of alternative splice sites (de la Mata et al., 2003; Howe et al., 2003).

The elongation rate defect has been also described for an Rpb2 mutation (Mason and Struhl, 2005), for Ccr4-Not elongation complex mutants (Kruk et al., 2011), and for the spt5-242 mutation (Quan and Hartzog, 2010). Therefore, given that the Spt5/Spt4 complex affects RNAPII processivity and elongation rate (Mason 
and Struhl, 2005; Quan and Hartzog, 2010) and Sub1 appears to influence levels of an Rpb1-Spt5 complex, this provides an explanation for the defects in the polymerase elongation rates observed in sub1 $\Delta$ cells during transcription elongation. However, we cannot rule out that the Sub1 role in elongation may also derive from a promoter role and/or from a function in gene looping due to its close functional link with TFIIB (Knaus et al., 1996; Wu et al., 1999; Rosonina et al., 2009). Although different from TFIIB, Sub1 associates not only with promoters, but also with coding regions.

\section{Sub1 is functionally linked to the elongation factor Spt5}

Spt5 is present in the elongation complex but is not detected in the PIC. It is recruited to the transcriptional machinery during the initiation-elongation transition (Mayer et al., 2010), and structural studies recently showed that the conserved Spt5 NGN domain locks the nucleic acids in the polymerase cleft and maintains the transcription bubble (Martinez-Rucobo et al., 2011). It was recently reported that Sub1 is a PIC component that localizes at the promoter, where DNA must be unwound for transcription (Sikorski et al., 2011), and we showed that it remains associated with coding regions during active transcription. Because Spt5 and Sub1 bind to open transcription bubbles (Klein et al., 2011; MartinezRucobo et al., 2011; Sikorski et al., 2011) and are associated with chromatin during early transcription elongation, and sub1 $1 \Delta$ cells display reduced levels of RNAPII occupancy in coding regions, it is possible that Sub1 could redundantly help Spt5 associate with RNAPII during the initiation-elongation transition and positively promote transcription elongation. In agreement with this, Spt5 levels associated with Rpb1 are slightly reduced in sub1s cells, and this defect is significantly enhanced in the double mutant spt5-194 sub1 1 . This is consistent with the fact that the spt5-194 mutation is located in the NGN domain of Spt5, which directly binds to Rpb1 and Spt4 (Klein et al., 2011; Martinez-Rucobo et al., 2011). In addition, the spt5-194 mutation interrupts Spt4-Spt5 binding (Guo et al., 2008). This could explain the growth defects displayed by the spt 5 sub $1 \Delta$ and spt $4 \Delta$ sub $1 \Delta$ double mutants and the correction of the spt5-194 growth defects by overexpressing SUB1.

Based on structural studies, it has been proposed that the initiation-elongation transition may become irreversible after Spt4/5 binding because Spt4/5 maintains the transcription bubble and prevents RNA release (Martinez-Rucobo et al., 2011). On the other hand, it has been proposed that initiation factors, such as TFIIE, that bind to overlapping sites on the polymerase clamp domain (Chen et al., 2007) will likely avoid premature binding of Spt4/5 during initiation and therefore Spt5 phosphorylation. It is interesting that Sub1 has also been genetically linked to TFIIE, and it has been suggested that Sub1 could help TFIIE and TFIIH to maintain the open complex (Sikorski et al., 2011). It is possible that Sub1 cooperates with TFIIE as a PIC component, where Bur1 and Spt5 entry is avoided, and with Spt5 as an elongation factor to maintain the transcription bubble, depending on Sub1 phosphorylation status. In particular, Sub1 could function with Spt5 to help stabilize the Rpb1-Spt5 elongation complex and increase elongation rate. Furthermore, Sub1 regulates RNAPII and Spt5 phosphorylation, as shown here and previously (Garcia et al., 2010), which is required to promote transcription elongation (Buratowski, 2009; Liu et al., 2009; Zhou et al., 2009). Conversely, the effect of Sub1 on in vitro phosphorylation appears to indicate a negative effect. It is possible that these negative effects are limited in vivo to a specific time at which phosphorylation by Bur1 should be inhibited, for example, during preinitiation (Bur1 is not detected in the PIC complexes; Liu et al., 2004; Garcia et al., 2010), thus blocking Bur1 kinase activity and Spt5 recruitment and phosphorylation as well.

Our results are consistent with recently proposed models for Sub1 function in which Sub1 is recruited to promoters and helps to maintain the PIC in a stable but inactive conformation, possibly by helping TFIIE (Sikorski et al., 2011) and/or inhibiting Kin28 recruitment and activity (Garcia et al., 2010), required to phosphorylate RNAPII-CTD on Ser-5 and to recruit capping enzymes (Komarnitsky et al., 2000; Buratowski, 2009). During transcription initiation, the phosphorylation of Sub1 would reduce its DNA-binding capacity (Ge et al., 1994; Henry et al., 1996; Jonker et al., 2006), alleviate kinase inhibitory effects, and facilitate promoter clearance (Henry et al., 1996; Knaus et al., 1996; Sikorski et al., 2011) and capping enzymes recruitment (Garcia et al., 2010). During the initiationelongation transition, initiation factors are exchanged by elongation factors (Pokholok et al., 2002) and Spt4/Spt5 complex is recruited, binding the polymerase (e.g., Martinez-Rucobo et al., 2011) and the capping complex (Pei and Shuman, 2002). Thereafter, Bur1 phosphorylates Spt5 and RNAPII-CTDSer5P on Ser-2 to promote extensive phosphorylation by Ctk1 farther downstream in coding and 3'-end regions (Qiu et al., 2009), the capping complex is released, and productive transcription elongation is triggered (reviewed by Buratowski, 2009). In that context, our data indicate that Sub1 joins the early elongation complex containing Spt4/Spt5 and influences transcription elongation, most likely by stabilizing Spt5-Rpb1 association with DNA. This could help to decrease the time that this complex is paused immediately after the initiation-elongation transition and positively influences the transcription elongation rate. Moreover, extensive and specific phosphorylation events targeting RNAPII (e.g., Buratowski, 2009), Spt5 (Liu et al., 2009; Zhou et al., 2009), and Sub1 (Ge et al., 1994; Henry et al., 1996; Jonker et al., 2006) could take place simultaneously and ultimately regulate the initiation-elongation transition and therefore transcription elongation.

\section{Sub1 associates predominantly with promoters as a PIC component but also with coding regions as an elongation factor}

If Sub1 associates with the Spt5 elongation factor and has a role during transcription elongation, why is Sub1 found associated predominantly with the promoter and 5' coding regions? One possibility is that conformational changes occur in the elongation apparatus that may weaken the ability of Sub1 to bind to DNA or may interfere with detection by ChIP in the middle and $3^{\prime}$ ends of genes. It has been proposed that Sub1 competes with the more abundant single-strand DNA (ssDNA)-binding protein Rfa1, which participates in transcription elongation and was purified with Sub1 in the PIC (Sikorski et al., 2011). In fact, Rfa1 associates with promoters in the absence of Sub1, whereas its association with coding regions is Sub1 independent. Because the in vitro ability of phospho-Sub1/ PC4 to bind to DNA is reduced, thus allowing it to escape from promoters (Ge et al., 1994; Henry et al., 1996; Jonker et al., 2006), it is possible that phosphorylated Sub1 will be less strongly associated with coding regions where Rfa1 ssDNA-binding affinity is increased (Sikorski et al., 2011). Alternatively, in coding regions these two proteins could be bound to DNA in a noncompetitive manner. In fact, a SUB1 and RFA1 genetic interaction suggests some cooperative function (Sikorski et al., 2011), and both have been genetically and functionally linked to Bur1 function (Clausing et al., 2010; Garcia et al., 2010). Another possibility is that the majority of Sub1 is associated with promoter regions, and only a small pool of Sub1 
participates in transcription elongation of constitutively transcribed genes (e.g., PMA1), whereas its participation could be very relevant for genes whose transcription directly depend on it (e.g., IMD2). For instance, the Ccr4-Not1 complex has been recently described as a bone fide elongation factor, but it is recruited only to several induced genes (Kruk et al., 2011). In any case, there is ample evidence demonstrating that Sub1 is recruited to promoters and associates in a transcription-dependent manner with coding regions as part of the transcription elongation complex, at least during early elongation. This is strongly supported by the fact that Sub1 associates with the Spt4/Spt5 elongation complex and influences transcription elongation rate.

\section{MATERIALS AND METHODS Yeast strains and media}

The strains used in this study are listed in Supplemental Table S1. Yeast strain construction and other genetic manipulations were performed following standard procedures (Burke et al., 2000).

\section{In vitro kinase assays}

To analyze GST-CTD and 6HIS-Spt5 phosphorylation, we performed in vitro kinase assays as previously described (Garcia et al., 2010). Cells were grown to an $\mathrm{OD}_{600}$ of 0.8 , collected, washed, and suspended in lysis buffer (20 mM 4-(2-hydroxyethyl)-1-piperazineethanesulfonic acid [HEPES], $\mathrm{pH}$ 7.6, $200 \mathrm{mM} \mathrm{KOAc,} \mathrm{10 \%}$ glycerol, 1 mM EDTA; Keogh et al., 2003) containing protease and phosphatase inhibitors. Yeast whole-cell extracts were prepared by glass bead cell disruption using a FastPrep system. Protein concentrations were determined, and $150 \mu \mathrm{g}$ were incubated with $15 \mu$ of protein G-Sepharose-coupled 12CA5 (anti-HA) antibody for $2 \mathrm{~h}$ at $4^{\circ} \mathrm{C}$ to immunoprecipitate Bur1-HA. The immunoprecipitates were washed three times with lysis buffer and twice with kinase buffer (20 mM HEPES, pH 7.6, 7.5 mM MgOAc, $100 \mathrm{mM}$ KOAc, $2 \%$ glycerol). The beads were resuspended in $25 \mu \mathrm{l}$ of kinase buffer with $2.5 \mathrm{mM}$ of ATP and incubated with $30 \mathrm{ng}$ of GST-CTD or $100 \mathrm{ng}$ of $\mathrm{rSpt} 5$ for $30 \mathrm{~min}$ at $30^{\circ} \mathrm{C}$. The following antibodies were used: 8WG16 (nonP-CTD; Covance, Berkeley, CA); CTD4H8 (CTD-Ser5P; Millipore, Billerica, MA); anti-Spt5 (yN-20; Santa Cruz Biotechnology, Santa Cruz, CA), and a phospho-specific anti-Spt5-P antibody (a gift from S. Hahn [Fred Hutchinson Cancer Research Center]; Liu et al., 2009). Bur1-HA and Bur1-23-HA are C-terminal tagged; however, Bur1-HA is expressed from a chromosomal copy and Bur1-23-HA from a centromeric plasmid (pRS315), both under the control of their own promoters (a gift from S. Buratowski [Harvard Medical School]; see Supplemental Table S1).

\section{Chromatin immunoprecipitation}

Chromatin purification, immunoprecipitation, RT-qPCR amplification, and data analysis were performed as described previously (Garcia et al., 2010). Briefly, PCR of purified chromatin, following immunoprecipitation, was performed by RT-qPCR with a CFX96 Detection System (Bio-Rad, Hercules, CA), using SYBR Premix Ex Taq (Takara Bio, Otsu, Japan) and following manufacturer's instructions. Four serial 10-fold dilutions of genomic DNA were amplified using the same reaction mixture as the samples to construct the standard curves. All real-time PCRs were performed in triplicate and with at least three independent ChIPs. Quantitative analysis was carried out using the CFX96 Manager Software, version 0.2.1. The values obtained for the IPed PCR products were compared with those of the total input, and the ratio of the values from each PCR product from transcribed genes to a nontranscribed region of CVII was calculated.
Numbers on the $y$-axis of the graphs are detailed in the corresponding figure legend. ChIP analysis to study elongation rate and processivity was performed as described (Mason and Struhl, 2005). Briefly, to study processivity, yeast cells were grown in rich medium with $2 \%$ raffinose as the carbon source at $28^{\circ} \mathrm{C}$ to an $\mathrm{OD}_{600}$ of 0.5 , followed by galactose induction for $2.5 \mathrm{~h}$. To study the elongation rate, we treated the galactose-induced cells with glucose at a final concentration of $5 \%$ for $4 \mathrm{~min}$. ChIP was performed three times with the 8WG16 antibody using chromatin from three independently grown cultures. To represent RNAPII processivity in wild-type and mutant cells, the data are expressed as the ratio of RNAPII occupancy in each strain relative to the promoter position followed by the normalization of each value to the corresponding position in wild-type strain, which was set to 1 . To represent the elongation rate, the RNAPII association with chromatin after 4 min of glucose treatment was normalized to RNAPII association under galactose induction conditions at every region tested in the wild-type and sub1 $1 \Delta$ cells.

\section{Transcriptional run on}

Twenty-five milliliters of culture at an $\mathrm{OD}_{600}$ of $0.3-4$ growing at $30^{\circ} \mathrm{C}$ and induced with $2 \%$ galactose was permeabilized and nascent RNA labeled with [ $\alpha{ }^{32}$ P]UTP for $5 \mathrm{~min}$ at $30^{\circ} \mathrm{C}$ as described (Birse et al., 1998; Calvo and Manley, 2001). After partial hydrolysis, RNA was hybridized directly to filter immobilized YLR454 probes. Hybridization signals were quantitated by Phosphorlmager analysis (Personal Molecular Imager; Bio-Rad). Each experiment was performed at least three times.

\section{RNA isolation and RT-PCR}

Total RNA was extracted as previously described (Schmitt et al., 1990), and RT-qPCR was performed using the PrimeScript RT Reagent Kit (Takara Bio), following the manufacturer's instructions. All qPCRs were performed in triplicate with at least three independent cDNA samples.

\section{6-Azauracil induction}

Cells were grown in synthetic complete (SC) media without uracil to an $\mathrm{OD}_{600}$ of 0.5 . They were then split into two cultures, and 6AU was added to one of the cultures to a final concentration of 50 or $100 \mu \mathrm{g} / \mathrm{ml}$. Both cultures were incubated for $1 \mathrm{~h}$, collected, washed, and resuspended in the appropriate buffer to isolate RNA. RT-qPCR was performed as described.

\section{GLAM assay}

The GLAM assay was carried out as in Morillo-Huesca et al. (2006) with cells grown to mid-log phase in selective synthetic medium lacking uracil with $2 \%$ galactose. Acidic phosphatase activity was measured at least twice in cells grown in three to four independently induced cultures for each strain. The mean values and standard deviations are represented in the corresponding figures.

\section{TAP purification, immunoprecipitation, and Western blot analysis}

Purification of Sub1-TAP was performed as described (RodriguezNavarro et al., 2004). Sub1-6HA IP was performed as follows: cells expressing Sub1-6HA were grown on rich medium to an $\mathrm{OD}_{600}$ of 1.0, harvested, washed with water, and resuspended in $250 \mu \mathrm{l}$ of lysis buffer (10 mM HEPES-KOH at pH 7.5, $140 \mathrm{mM} \mathrm{NaC1,} 1 \mathrm{mM}$ EDTA, 10\% glycerol, 0.1\% NP-40, 1 mM phenylmethylsulfonyl fluoride (PMSF), and a cocktail of protease inhibitors). Cell lysis was achieved at $4^{\circ} \mathrm{C}$ using a FastPrep System. The clarified whole-cell 
extracts (WCEs) were IPed for $2 \mathrm{~h}$ at $4^{\circ} \mathrm{C}$ with anti-HA antibody coupled to protein A-Sepharose. The IPs were extensively washed (lysis buffer with 0.5\% NP-40) and subsequently resuspended in SDSPAGE sample buffer. Western blot analysis was performed using the appropriate antibodies. A similar protocol was followed for Spt5FLAG IP, although it was performed overnight at $4{ }^{\circ} \mathrm{C}$ using antiFLAG antibody.

\section{ACKNOWLEDGMENTS}

We thank G. Hartzog, S. Buratowski, A. Aguilera, and F. Estruch for yeasts strains; S. Hahn for the recombinant Spt5 and anti-P-Spt5 antibodies; and L. Warfield for technical support. We thank S. Chavez, A. Rodríguez, and G. Millán for strains, plasmids, and technical support with the GLAM and TRO assays. We also thank N. Krogan for sharing data. We especially thank J. L. Manley for helpful comments on the manuscript, and also F. Navarro and N. J. Proudfoot. This work was supported by a grant from the Spanish Ministerio de Ciencia e Innovación (BFU 2009-07179) to O.C. A.G. was supported by a fellowship from the Junta de Castilla y León. The Instituto de Biología Funcional y Genómica acknowledges support from the Ramón Areces Foundation.

\section{REFERENCES}

Ahn SH, Kim M, Buratowski S (2004). Phosphorylation of serine 2 within the RNA polymerase II C-terminal domain couples transcription and $3^{\prime}$ end processing. Mol Cell 13, 67-76.

Birse CE, Minvielle-Sebastia L, Lee BA, Keller W, Proudfoot NJ (1998). Coupling termination of transcription to messenger RNA maturation in yeast. Science 280, 298-301.

Buratowski S (2009). Progression through the RNA polymerase II CTD cycle. Mol Cell 36, 541-546.

Burke D, Dawson D, Stearns T (2000). Methods in Yeast Genetics, Cold Spring Harbor, NY: Cold Spring Harbor Laboratory Press.

Burova E, Hung SC, Sagitov V, Stitt BL, Gottesman ME (1995). Escherichia coli NusG protein stimulates transcription elongation rates in vivo and in vitro. J Bacteriol 177, 1388-1392.

Calvo O, Manley JL (2001). Evolutionarily conserved interaction between CstF-64 and PC4 links transcription, polyadenylation, and termination. Mol Cell 7, 1013-1023.

Calvo O, Manley JL (2005). The transcriptional coactivator PC4/Sub1 has multiple functions in RNA polymerase II transcription. EMBO J 24, 1009-1020.

Chanarat S, Seizl M, Strasser K (2011). The Prp19 complex is a novel transcription elongation factor required for TREX occupancy at transcribed genes. Genes Dev 25, 1147-1158.

Chen H, Contreras X, Yamaguchi Y, Handa H, Peterlin BM, Guo S (2009). Repression of RNA polymerase II elongation in vivo is critically dependent on the C-terminus of Spt5. PLoS One 4, e6918.

Chen HT, Warfield L, Hahn S (2007). The positions of TFIIF and TFIIE in the RNA polymerase II transcription preinitiation complex. Nat Struct Mol Biol 14, 696-703.

Cho EJ, Kobor MS, Kim M, Greenblatt J, Buratowski S (2001). Opposing effects of Ctk1 kinase and Fcp1 phosphatase at Ser 2 of the RNA polymerase II C-terminal domain. Genes Dev 15, 3319-3329.

Clausing E, Mayer A, Chanarat S, Muller B, Germann SM, Cramer P, Lisby $M$, Strasser K (2010). The transcription elongation factor Bur1-Bur2 interacts with replication protein $A$ and maintains genome stability during replication stress. J Biol Chem 285, 41665-41674.

de la Mata M, Alonso CR, Kadener S, Fededa JP, Blaustein M, Pelisch F, Cramer P, Bentley D, Kornblihtt AR (2003). A slow RNA polymerase II affects alternative splicing in vivo. Mol Cell 12, 525-532.

Desmoucelles C, Pinson B, Saint-Marc C, Daignan-Fornier B (2002). Screening the yeast "disruptome" for mutants affecting resistance to the immunosuppressive drug, mycophenolic acid. J Biol Chem 277, 27036-27044

Escobar-Henriques M, Balguerie A, Monribot C, Boucherie $\mathrm{H}_{\text {, }}$ Daignan-Fornier B (2001). Proteome analysis and morphological studies reveal multiple effects of the immunosuppressive drug mycophenolic acid specifically resulting from guanylic nucleotide depletion. J Biol Chem 276, 46237-46242.
Gaillard H et al. (2009). Genome-wide analysis of factors affecting transcription elongation and DNA repair: a new role for PAF and Ccr4-not in transcription-coupled repair. PLoS Genet 5, e1000364.

Garcia A, Rosonina E, Manley JL, Calvo O (2010). Sub1 globally regulates RNA polymerase II C-terminal domain phosphorylation. Mol Cell Biol $30,5180-5193$

Ge H, Roeder RG (1994). Purification, cloning, and characterization of a human coactivator, $\mathrm{PC} 4$, that mediates transcriptional activation of class Il genes. Cell 78, 513-523.

Ge H, Zhao Y, Chait BT, Roeder RG (1994). Phosphorylation negatively regulates the function of coactivator PC4. Proc Natl Acad Sci USA 91, 12691-12695.

Gonzalez-Aguilera C, Tous C, Babiano R, de la Cruz J, Luna R, Aguilera A (2011). Nab2 functions in the metabolism of RNA driven by polymerases II and III. Mol Biol Cell 22, 2729-2740.

Grohmann D, Werner F (2011). Cycling through transcription with the RNA polymerase F/E (RPB4/7) complex: structure, function and evolution of archaeal RNA polymerase. Res Microbiol 162, 10-18.

Guo M, Xu F, Yamada J, Egelhofer T, Gao Y, Hartzog GA, Teng M, Niu L (2008). Core structure of the yeast spt4-spt5 complex: a conserved module for regulation of transcription elongation. Structure 16, 1649-1658.

Hartzog GA, Basrai MA, Ricupero-Hovasse SL, Hieter P, Winston F (1996). Identification and analysis of a functional human homolog of the SPT4 gene of Saccharomyces cerevisiae. Mol Cell Biol 16, 2848-2856.

Hartzog GA, Wada T, Handa H, Winston F (1998). Evidence that Spt4, Spt5, and Spt6 control transcription elongation by RNA polymerase II in Saccharomyces cerevisiae. Genes Dev 12, 357-369.

He X, Khan AU, Cheng H, Pappas DL Jr, Hampsey M, Moore CL (2003). Functional interactions between the transcription and mRNA 3' end processing machineries mediated by Ssu72 and Sub1. Genes Dev 17, 1030-1042.

Henry NL, Bushnell DA, Kornberg RD (1996). A yeast transcriptional stimulatory protein similar to human PC4. J Biol Chem 271, 21842-21847.

Hirayoshi K, Lis JT (1999). Nuclear run-on assays: assessing transcription by measuring density of engaged RNA polymerases. Methods Enzymol 304, 351-362.

Hirtreiter A, Damsma GE, Cheung AC, Klose D, Grohmann D, Vojnic E, Martin AC, Cramer P, Werner F (2010). Spt4/5 stimulates transcription elongation through the RNA polymerase clamp coiled-coil motif. Nucleic Acids Res 38, 4040-4051.

Howe KJ, Kane CM, Ares M, Jr (2003). Perturbation of transcription elongation influences the fidelity of internal exon inclusion in Saccharomyces cerevisiae. RNA 9, 993-1006.

Jenks MH, O'Rourke TW, Reines D (2008). Properties of an intergenic terminator and start site switch that regulate IMD2 transcription in yeast. Mol Cell Biol 28, 3883-3893.

Jonker HR, Wechselberger RW, Pinkse M, Kaptein R, Folkers GE (2006). Gradual phosphorylation regulates PC4 coactivator function. FEBS J $273,1430-1444$

Kaiser K, Stelzer G, Meisterernst M (1995). The coactivator p15 (PC4) initiates transcriptional activation during TFIIA-TFIID-promoter complex formation. EMBO J 14, 3520-3527.

Kaplan CD, Jin H, Zhang IL, Belyanin A (2012). Dissection of Pol II trigger loop function and Pol II activity-dependent control of start site selection in vivo. PLoS Genet 8, e1002627.

Keogh MC, Podolny V, Buratowski S (2003). Bur1 kinase is required for efficient transcription elongation by RNA polymerase II. Mol Cell Biol 23, 7005-7018.

Klein BJ, Bose D, Baker KJ, Yusoff ZM, Zhang X, Murakami KS (2011). RNA polymerase and transcription elongation factor Spt $4 / 5$ complex structure. Proc Natl Acad Sci USA 108, 546-550.

Knaus R, Pollock R, Guarente L (1996). Yeast SUB1 is a suppressor of TFIIB mutations and has homology to the human co-activator PC4. EMBO J 15, 1933-1940.

Komarnitsky P, Cho EJ, Buratowski S (2000). Different phosphorylated forms of RNA polymerase II and associated mRNA processing factors during transcription. Genes Dev 14, 2452-2460.

Korkhin Y, Unligil UM, Littlefield O, Nelson PJ, Stuart DI, Sigler PB, Bell SD, Abrescia NG (2009). Evolution of complex RNA polymerases: the complete archaeal RNA polymerase structure. PLoS Biol 7, e102.

Koyama H, Sumiya E, Nagata M, Ito T, Sekimizu K (2008). Transcriptional repression of the IMD2 gene mediated by the transcriptional co-activator Sub1. Genes Cells 13, 1113-1126.

Krogan NJ, Kim M, Ahn SH, Zhong G, Kobor MS, Cagney G, Emili A, Shilatifard A, Buratowski S, Greenblatt JF (2002). RNA polymerase II 
elongation factors of Saccharomyces cerevisiae: a targeted proteomics approach. Mol Cell Biol 22, 6979-6992.

Kruk JA, Dutta A, Fu J, Gilmour DS, Reese JC (2011). The multifunctional Ccr4-Not complex directly promotes transcription elongation. Genes Dev 25, 581-593.

Kuehner JN, Brow DA (2008). Regulation of a eukaryotic gene by GTPdependent start site selection and transcription attenuation. Mol Cell 31, 201-211.

Lindstrom DL, Squazzo SL, Muster N, Burckin TA, Wachter KC, Emigh CA, McCleery JA, Yates JR 3rd, Hartzog GA (2003). Dual roles for Spt5 in pre-mRNA processing and transcription elongation revealed by identification of Spt5-associated proteins. Mol Cell Biol 23, 1368-1378.

Liu Y, Kung C, Fishburn J, Ansari AZ, Shokat KM, Hahn S (2004). Two cyclindependent kinases promote RNA polymerase II transcription and formation of the scaffold complex. Mol Cell Biol 24, 1721-1735.

Liu Y, Warfield L, Zhang C, Luo J, Allen J, Lang WH, Ranish J, Shokat KM, Hahn S (2009). Phosphorylation of the transcription elongation factor Spt5 by yeast Bur 1 kinase stimulates recruitment of the PAF complex. Mol Cell Biol 29, 4852-4863.

Malik S, Guermah M, Roeder RG (1998). A dynamic model for PC4 coactivator function in RNA polymerase II transcription. Proc Natl Acad Sci USA 95, 2192-2197.

Martinez-Rucobo FW, Sainsbury S, Cheung AC, Cramer P (2011). Architecture of the RNA polymerase-Spt $4 / 5$ complex and basis of universal transcription processivity. EMBO J 30, 1302-1310.

Mason PB, Struhl K (2003). The FACT complex travels with elongating RNA polymerase II and is important for the fidelity of transcriptional initiation in vivo. Mol Cell Biol 23, 8323-8333.

Mason PB, Struhl K (2005). Distinction and relationship between elongation rate and processivity of RNA polymerase II in vivo. Mol Cell 17, 831-840.

Mayer A, Lidschreiber M, Siebert M, Leike K, Soding J, Cramer P (2010). Uniform transitions of the general RNA polymerase II transcription complex. Nat Struct Mol Biol 17, 1272-1278.

Morillo-Huesca M, Vanti M, Chavez S (2006). A simple in vivo assay for measuring the efficiency of gene length-dependent processes in yeast mRNA biogenesis. FEBS J 273, 756-769.

Nedea E, He X, Kim M, Pootoolal J, Zhong G, Canadien V, Hughes T, Buratowski S, Moore CL, Greenblatt J (2003). Organization and function of APT, a subcomplex of the yeast cleavage and polyadenylation factor involved in the formation of mRNA and small nucleolar RNA 3 '-ends. J Biol Chem 278, 33000-33010.

Pei Y, Shuman S (2002). Interactions between fission yeast mRNA capping enzymes and elongation factor Spt5. J Biol Chem 277, 19639-19648.

Pokholok DK, Hannett NM, Young RA (2002). Exchange of RNA polymerase II initiation and elongation factors during gene expression in vivo. Mol Cell 9, 799-809.

Qiu H, Hu C, Gaur NA, Hinnebusch AG (2012). Pol II CTD kinases Bur1 and Kin28 promote Spt5 CTR-independent recruitment of Paf1 complex. EMBO J 31, 3494-3505.

Qiu H, Hu C, Hinnebusch AG (2009). Phosphorylation of the Pol II CTD by KIN28 enhances BUR1/BUR2 recruitment and Ser2 CTD phosphorylation near promoters. Mol Cell 33, 752-762.

Quan TK, Hartzog GA (2010). Histone H3K4 and K36 methylation, Chd1 and Rpd3S oppose the functions of Saccharomyces cerevisiae Spt4-Spt5 in transcription. Genetics 184, 321-334.

Riles L, Shaw RJ, Johnston M, Reines D (2004). Large-scale screening of yeast mutants for sensitivity to the IMP dehydrogenase inhibitor 6-azauracil. Yeast 21, 241-248.

Rodriguez CR, Cho EJ, Keogh MC, Moore CL, Greenleaf AL, Buratowski $\mathrm{S}$ (2000). Kin28, the TFIIH-associated carboxy-terminal domain kinase, facilitates the recruitment of mRNA processing machinery to RNA polymerase II. Mol Cell Biol 20, 104-112.
Rodriguez-Gil A, Garcia-Martinez J, Pelechano V, Munoz-Centeno Mde L, Geli V, Perez-Ortin JE, Chavez S (2010). The distribution of active RNA polymerase II along the transcribed region is gene-specific and controlled by elongation factors. Nucleic Acids Res 38, 4651-4664.

Rodriguez-Navarro S, Fischer T, Luo MJ, Antunez O, Brettschneider S, Lechner J, Perez-Ortin JE, Reed R, Hurt E (2004). Sus1, a functional component of the SAGA histone acetylase complex and the nuclear pore-associated mRNA export machinery. Cell 116, 75-86.

Rosonina E, Willis IM, Manley JL (2009). Sub1 functions in osmoregulation and in transcription by both RNA polymerases II and III. Mol Cell Biol 29, 2308-2321.

Saunders A, Core LJ, Lis JT (2006). Breaking barriers to transcription elongation. Nat Rev Mol Cell Biol 7, 557-567.

Schmitt ME, Brown TA, Trumpower BL (1990). A rapid and simple method for preparation of RNA from Saccharomyces cerevisiae. Nucleic Acids Res 18, 3091-3092.

Schroeder SC, Schwer B, Shuman S, Bentley D (2000). Dynamic association of capping enzymes with transcribing RNA polymerase II. Genes Dev $14,2435-2440$

Selth LA, Sigurdsson S, Svejstrup JQ (2010). Transcript elongation by RNA polymerase II. Annu Rev Biochem 79, 271-293.

Shaw RJ, Reines D (2000). Saccharomyces cerevisiae transcription elongation mutants are defective in PUR5 induction in response to nucleotide depletion. Mol Cell Biol 20, 7427-7437.

Shilatifard A, Conaway RC, Conaway JW (2003). The RNA polymerase II elongation complex. Annu Rev Biochem 72, 693-715.

Shukla S, Oberdoerffer S (2012). Co-transcriptional regulation of alternative pre-mRNA splicing. Biochim Biophys Acta 1819, 673-683.

Sikorski TW, Ficarro SB, Holik J, Kim T, Rando OJ, Marto JA, Buratowski $S$ (2011). Sub1 and RPA associate with RNA polymerase II at different stages of transcription. Mol Cell 44, 397-409.

Sims RJ 3rd, Belotserkovskaya R, Reinberg D (2004). Elongation by RNA polymerase II: the short and long of it. Genes Dev 18, 2437-2468.

Singh BN, Hampsey M (2007). A transcription-independent role for TFIIB in gene looping. Mol Cell 27, 806-816.

Swanson MS, Malone EA, Winston F (1991). SPT5, an essential gene important for normal transcription in Saccharomyces cerevisiae, encodes an acidic nuclear protein with a carboxy-terminal repeat. Mol Cell Biol 11, 3009-3119.

Swanson MS, Winston F (1992). SPT4, SPT5 and SPT6 interactions: effects on transcription and viability in Saccharomyces cerevisiae. Genetics 132, 325-336.

Vassylyev DG, Sekine S, Laptenko O, Lee J, Vassylyeva MN, Borukhov S, Yokoyama S (2002). Crystal structure of a bacterial RNA polymerase holoenzyme at 2.6 A resolution. Nature 417, 712-719.

Wada T et al. (1998). DSIF, a novel transcription elongation factor that regulates RNA polymerase II processivity, is composed of human Spt4 and Spt5 homologs. Genes Dev 12, 343-356.

Winston F, Chaleff DT, Valent B, Fink GR (1984). Mutations affecting Tymediated expression of the HIS4 gene of Saccharomyces cerevisiae. Genetics 107, 179-197.

Wood A, Schneider J, Dover J, Johnston M, Shilatifard A (2005). The Bur1/ Bur2 complex is required for histone H2B monoubiquitination by Rad6/ Bre1 and histone methylation by COMPASS. Mol Cell 20, 589-599.

Wu WH, Pinto I, Chen BS, Hampsey M (1999). Mutational analysis of yeast TFIIB. A functional relationship between Ssu72 and Sub1/Tsp1 defined by allele-specific interactions with TFIIB. Genetics 153, 643-652.

Xiao Y, Yang YH, Burckin TA, Shiue L, Hartzog GA, Segal MR (2005). Analysis of a splice array experiment elucidates roles of chromatin elongation factor Spt4-5 in splicing. PLoS Comput Biol 1, e39.

Zhou K, Kuo WH, Fillingham J, Greenblatt JF (2009). Control of transcriptional elongation and cotranscriptional histone modification by the yeast BUR kinase substrate Spt5. Proc Natl Acad Sci USA 106, 6956-6961. 